\title{
Análisis integrado de factores genéticos, bióticos y abióticos para la formulación de una nueva hipótesis sobre la etiología del "mal del ciprés"
}

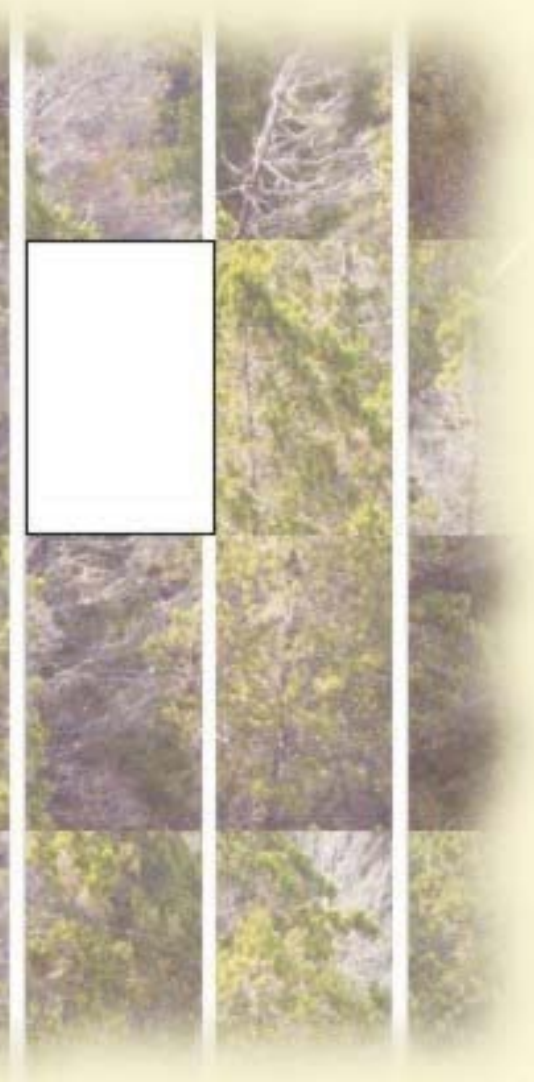

\author{
Verónica A. El Mujtar \\ Tesis Doctoral \\ La Plata, 2009
}


El presente trabajo de Tesis, para optar al grado de Doctor de la Facultad de Ciencias Exactas, ha sido realizado en el Instituto de Biotecnología y Biología Molecular (IBBM-CONICET-CCT La Plata) del Departamento de Ciencias Biológicas de la Facultad de Ciencias Exactas de la Universidad Nacional de La Plata, bajo la dirección del Dr. Oscar Grau, la codirección del Dr. Leonardo A. Gallo y el asesoramiento del Dr. Víctor Romanowski. 
Bqca. Verónica A. El Mujtar

Tesista

Dr. Oscar Grau

Director (IBBM)

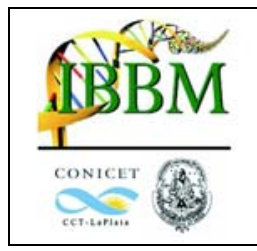

Dr. Leonardo A. Gallo

Codirector (INTA)

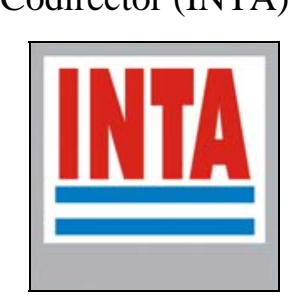

Dr. Víctor Romanowski

Asesor (IBBM) 
porque me enseñó a trocar

dificultades por desafios

y a saber que siempre

Fay una expficación

para aqueffo que no entendemos

porque simbofiza ef núcleo de Sa famifia

que me mima y contiene

en cadapaso

porque es fefiz con mis fogros

y es findo verfa sonreír 


\section{華 Marce}

por todo fo que no es necesario escribir

porque parte de esto surgió

una tarde de mates, de espasdas as $\mathscr{T}_{i} f_{t r i}$

mientras soñábamos ef futuro

$y$ Sos sueños

siempre nos ayudan

a ser mejores 


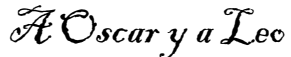
ÁLeo y a $\mathcal{O}_{\text {scar }}$

por ef afecto, Sa confianza y ef respeto pifares sobre fos que es mucho más simple aventurarse a construir 


\section{Agradecimientos}

Son muchas las personas que colaboraron conmigo en el trabajo de tesis, espero haber sido capaz de demostrarles mi agradecimiento a lo largo del tiempo porque seguramente estas hojas y estas líneas no van a ser suficientes para retribuir todo el apoyo que recibí de cada una de ellas. La lista es extensa, creo recordar a todos, si olvido a alguien será totalmente involuntario.

Quiero agradecerle:

a Oscar (Oscar Grau), mi director, el afecto de todos estos años. Elijo esa palabra, porque da cuenta de lo demás. Sin el afecto, el apoyo, la confianza y el esfuerzo se reducen apenas a gestos. Desde el afecto, son realidades concretas y palpables de lo que su presencia significó para mí. Gracias jefe, por estar siempre, por rescatar mis aciertos y ayudar a corregir mis errores, por escuchar mi parloteo constante, por atender mis demandas, por comprender mis rabietas, por ver las diferencias a través del cristal del afecto y encontrar la manera de descubrir nuevos caminos juntos.

a Leo (Leonardo Gallo), mi codirector, por construir un espacio basado en la confianza y el afecto donde las diferencias tienen un lugar, donde es posible contrastar realidades y verdades, donde lo que vale no es la perfección sino la entrega. Un lugar donde uno y otro descubre capacidades e incapacidades, trastocando de a poco las segundas en las primeras. Quiero agradecerle por la estadía de postgrado en Bordeaux, que fue mi primer experiencia fuera del país. Durante ese tiempo aprendí de genética, de otra cultura, de otras formas de vida, pero fundamentalmente aprendí mucho sobre mí. Gracias por ese viaje. Agradecer a Leo es agradecer a su familia, principalmente a María Rosa y Lilén. Gracias por el tiempo que mis estadías en Bariloche pudieron restarle a los encuentros de familia. Gracias por tener siempre pronta una palabra de aliento y una sonrisa.

a ambos, Oscar y Leo, por rescatar en mí a la persona, por ver más allá de mis defectos, por brindarme la libertad necesaria para poder construir e investigar con creatividad. Gracias por permitirme disfrutar de lo que hago, por construir vínculos más que tesis de doctorado, por valorar lo humano por encima de lo científico.

a Victor Romanowski, mi asesor, por el apoyo de tantas y tantas oportunidades, por darme la posibilidad de avanzar cuando muchas puertas parecían cerradas. Gracias por la confianza depositada en mi trabajo y en mí.

a Marce (Marcelo Perdomo) por la infinita paciencia con que tomó cada uno de los pedidos y respondió a cada una de mis preguntas, por ser mis ojos en el bosque, por dedicar tiempo de descanso a los muestreos, por avanzar codo a codo conmigo y por enseñarme el valor de los objetivos. Gracias por acompañarme en esta etapa, por superar todas las dificultades y tener siempre una sonrisa dispuesta y una mirada reflexiva sobre las cosas.

a Selma (Selma Gago Zachert) porque el azar me dejó en la mesada de su laboratorio y no podría haber elegido mejor lugar. Gracias por enseñarme las maravillas de la biología molecular, los secretos y las respuestas que puede contener un experimento negativo si se lo 
mira bien. Gracias por las innumerables charlas, las deliciosas recetas y las incontables cervezas compartidas. Gracias por mostrarme que el saber es más valioso cuando se acompaña de buenos sentimientos. Gracias por la amistad que no conoce de distancias.

a Silvia (Silvia Moya), por compartir conmigo los buenos momentos y los difíciles, por estar y permitirme estar, por tener siempre un espíritu calmo ante las demandas urgentes, por dibujar sonrisas con su ternura, por hacer que todo sea más fácil. A Enrique, Lulú, Caro y Enriquito, porque Silvia no es ella sin su familia, y lo que da surge de lo que recibe.

a Ernesto Andenmatten porque cuando empecé a interesarme por el mal del ciprés me brindó el espacio y el apoyo necesarios para comenzar la búsqueda bibliográfica, los viajes de reconocimiento y el encuentro con quienes habian trabajado antes en el tema. Gracias por la confianza y el respeto con que todos mis pedidos fueron siempre considerados, por el interés en mi trabajo, por el cariño y el tiempo dedicados. A todo el equipo (presente y pasado) del Campo Forestal General San Martín (EEA-INTA), Gustavo Basil, Federico Letourneau, Nicolás De Agostini, Nicolás Hanek y Paula (Vicky) Klasmer por alentar el trabajo, aportar ideas, compartir computadoras, mates y encuentros que hicieron más placenteras mis estadías en El Bolsón. A Doña Irma por el cariño de cada momento.

a toda la gente de la Unidad de Genética Ecológica y Mejoramiento Forestal del Instituto Nacional de Tecnología Agropecuaria (INTA-Bariloche) por la calidez con que me reciben en cada viaje. A Mario Pastorino y Paula Marchelli por responder preguntas, aportar ideas y estar siempre atentos a las demandas. Gracias Mario por la respuesta a mis extensos mails; vos, siempre claro, ordenado, preciso. Gracias por los muestreos en San Ramón, las charlas y el tiempo dedicado. Gracias Paula por los almuerzos interrumpidos con los comentarios sobre sitios de muestreo, marcadores moleculares y programas de análisis. A Carolina Moreno y María Marta Azpillicueta porque no hay nada como la dinámica de Caro, ni el entusiasmo de María; gracias por los mates, cafés, cervezas y charlas que siempre me hacen sentir querida. Gracias a Alejandro Aparicio por coordinar y llevar adelante los ensayos de transferencia, por mantener las plantas y ocuparse de las fotos y tantas otras cosas. Gracias Ale por el apoyo, la franqueza y el afecto. A Verónica Arana, Matías Milleron, Carolina Soliani, Alejandro Martinez, Fernanda Izquierdo, Sebastiān Zuki, Abel Martinez, Georgina Sola, Fernando Barbero y a toda la comunidad INTA-Bariloche por hacer mis viajes siempre agradables. A Guillermina Dalla Salda, María Elena Fernandez, Javier Gyenge y Tomás Schlichter por dedicar parte de su tiempo para conversar sobre el trabajo realizado.

a Alina Greslebin, por el cariño y la calidez con que se brinda, por estar siempre dispuesta al encuentro y a las nuevas ideas, por el diálogo científico y las charlas de la vida. Gracias por compartir conmigo tantas tardes, viajes y salidas de campo. Gracias a Carlos, Male, Maru y Carlitos, por acompañar esos encuentros, aprender con nosotras y enseñarme mucho. Gracias por escuchar una y mil veces, las charlas de Phytophthora, pulgones y cipreses. Gracias Alina por el esfuerzo, el entusiasmo y las ganas que pones y transmitís en lo que haces. Gracias a Ludmila La Manna, Gabriel Loguercio, Florencia Urretavizcacha, Pía Floria y a toda la gente del CIEFAP con quien comparti charlas y recorridas en Esquel. Gracias a la familia Berwin por permitir el ingreso a la propiedad y por la amabilidad con que respondieron las preguntas, sonrisa mediante, mate de por miedo. 
a Juli (Julieta Covelli) por el tiempo de trabajo juntas entre pulgones de patas blancas y negras, por las colectas de campo, las PCRs y la buena onda de siempre. Juli, fue mi primer experiencia en formación de recursos humanos, espero que haya sido tan gratificante para ella como lo fue para mí. Gracias Juli, por aportar al orden del laboratorio, al desarrollo de los experimentos y al trabajo en un ambiente agradable y divertido.

a Miguel Ángel Delfino (MAD), Elliot Kitajima, Marcelo (Tito) Barrera e Ignacio Mundo por los trabajos realizados en colaboración. MAD gracias por las sonrisas, la diversión y todas las ocurrencias, nadie más que vos pierde un bolso verde seco en un bosque de ciprés! Gracias Elliot por el entusiasmo con que emprendes cada trabajo. Gracias por los discos, particularmente el de Elis, y por la feijoada, la caipirinha y la amabilidad de cada encuentro. Gracias Tito, por el esfuerzo dedicado y las charlas. Mi agradecimiento a la gente del LISEA, Juan, Juje, Sarita, Marcelo porque cada visita es un encuentro con amigos.

a toda la gente que respondió a mis pedidos de información y dedicó parte de su tiempo a conversar conmigo. De Argentina: Mónica Mermoz, Susana Seijas, Carla Pozzi y Adolfo Moretti de Parques Nacionales; Javier Grosfeld, Adriana Rovere, Andrea Relva, Cecilia Núñez y Laura Suárez de la Universidad Nacional del Comahue; Marcelo Rey y Jorge Cuevas del Servicio de Prevención y Lucha contra Incendios Forestales; Darío Schauman y María Canale del Servicio Forestal Andino; Carlos Merg del Centro de Pronósticos Patagónico; Beatriz Fant de Fundación Bariloche, Javier Ayesa del laboratorio de Teledetección-SIG (INTA-Bariloche) y Noga Zelener del Instituto de Biotecnología (INTACastelar). De Chile: Ivăn Quiroz-Marchant (Instituto Forestal, INFOR), Ángelo Sartori y Aída Baldini (Corporación Nacional Forestal, CONAF), Carlos Le Quesne (Universidad Austral de Chile), Marco Peña (Laboratorio de Teledetección aplicada al medioambiente) y Roberto Rodríguez Ríos (Universidad de Concepción).

a Adolfo Moretti, por gestionar mi recorrida en Isla Victoria y responder a todos los pedidos. Gracias por la hospitalidad y la cálida bienvenida de cada viaje. Gracias también a Pato por la tarde de sol, las charlas, y las reuniones.

a Mariano Amoroso con quien compartí en más de una oportunidad la casita de Huéspedes en El Bolsón. Gracias por las numerosas charlas sobre el mal del ciprés, el intercambio de bibliografía y el aporte de otra visión sobre el tema.

a María Havrylenko quien no solo respondió a mi curiosidad sobre el primer reporte del mal del ciprés realizado por su padre y sobre sus propios trabajos en el tema, sino que me enseñó la belleza de una tarde de té. Gracias por mostrarme cómo momentos simples y cotidianos pueden volverse entrañables. Gracias por el fluido intercambio y la alegría de cada uno de tus mails.

a Pablo Rosso, quien desde Estados Unidos y Alemania, respondió preguntas y más preguntas, enriqueció observaciones y aportó comentarios siempre interesantes.

a Ceci (Zanek) por las ... tantas... noches de cervezas y buenos platos. Gracias por permitir que el mal del ciprés se metiera en las cenas, por apoyar, contener y divertir con tus 
comentarios, por construir un espacio donde el encuentro es posible. Gracias por la buena compañía!

a los virus verdes, actuales y pasados, por todo lo aprendido juntos, principalmente a Edu que supo ver más allá de mi espíritu gruñón.

a toda la gente del IBBM que a lo largo de estos años me enseñó a mirar no sólo hacia fuera, a reconocer los errores propios, valorar los aciertos ajenos y entender que cada uno encuentra siempre su lugar. Gracias a Mónica por enseñarme los secretos del DGGE, y a Eugenita por compartir conmigo el aprendizaje, a Mario por facilitarme el equipo necesario y a Daniel (El Negro) porque siempre uno encuentra en él a un amigo, con quien se puede charlar de ciencia y de la vida.

a mi mamá, porque lo bueno que hay en mí se lo debo a ella, al amor, los valores y principios con que me educó siempre (lo malo es sólo porque soy mala alumna); y en mamá a toda la familia, Abel, mis hermanas (Vale, Vane, Majo, Lu), cuñados (Javi, Migue, César, Juan), sobrinos (Nico, Guille, Facu y Marco), mi tía Rosa (Tipi), la super abuela Sole, mis primos y sus lindas familias (Fer, Rochi, Santi y Agus; Fede, Maria, Cata y la pancita!!). A todos gracias por estar, por entender las ausencias en tiempos de trabajo intenso, gracias por la contención, por el afecto, por la paz de los abrazos y los mimos!!!

a mis queridos, Cati y Cachi, por el inmenso cariño y apoyo de todos estos años, por estar siempre cerca, por hacerme parte de su familia, y acompañar los momentos difíciles y el cambio. Gracias por el lugar que tengo en ustedes, gracias por el lugar que tienen en mí.

a mis amigos de hoy y siempre, Diego, Juan, Marce, Laura, Rodolfo, Laura, Selma gracias por estar en cada momento.

\section{Mi reconocimiento,}

a la Facultad de Ciencias Exactas de la Universidad Nacional de La Plata por posibilitarme realizar el Doctorado dentro del ámbito de la Institución.

a la Universidad Nacional de La Plata y la Agencia Nacional de Promoción Científica y Tecnológica por las becas otorgadas.

al Campo Forestal General San Martín del Instituto Nacional de Tecnología Agropecuaria por permitir el desarrollo del presente trabajo en los bosques de $A$. chilensis bajo su gestión. 


\section{RESUMEN DEL TRABAJO DE TESIS}

El desarrollo de un trabajo de investigación en sistemas naturales plantea el desafío de avanzar en el conocimiento sorteando la dificultad de la falta de control sobre un conjunto de factores que pueden afectar las variables en estudio.

La presente tesis tuvo como objetivo general el análisis simultáneo del mismo grupo de individuos desde diversos aspectos a fin de avanzar en la identificación de la etiología del o de los procesos actualmente englobados bajo la denominación mal del ciprés.

El empleo de un diseño de muestreo pareado, basado en la selección de individuos que difieren en los síntomas aéreos y presentan valores similares de altura total, DAP, posición sociológica y nivel de competencia, demostró ser robusto para la identificación de diferencias entre individuos con y sin síntomas del mal del ciprés.

La aplicación del sistema de marcadores moleculares RGA permitió identificar diferencias genéticas entre grupos de plantas sintomáticas y asintomáticas para mal del ciprés, establecer la existencia de estructuración genética entre áreas de bosque de $A$. chilensis ubicadas al del Norte y Sur de la región de El Bolsón e identificar 25 marcadores RGA candidatos para futuros estudios de genotipicación y análisis funcional. Según la bibliografía disponible este sería el primer trabajo en el que se aplica la técnica RGA para detectar diferencias genéticas en un patosistema de etiología desconocida.

En el transcurso de la tesis se abordó la caracterización de agentes bióticos asociados al mal del ciprés y se evalúo su rol en el desarrollo de la mortalidad, descartándose la acción de bacterias endógenas de xilema de A. chilensis, áfidos del género Cinara (Curtis) y P. austrocedrae como agentes causales del mal del ciprés. Estos dos últimos grupos de agentes estarían involucrados en el desarrollo de los nuevos síntomas aéreos (enrojecimiento del follaje) reportados en A. chilensis en las últimas décadas. Los métodos de diagnóstico desarrollados en relación con los agentes bióticos aportan un conjunto de ensayos moleculares de detección e identificación que permitirán un rápido avance en las investigaciones futuras en relación a la sanidad de los bosques de $A$. chilensis. 
El empleo de los pares seleccionados en un análisis dendrocronológico permitió identificar patrones de crecimiento diferencial entre plantas con y sin síntomas de mal del ciprés y establecer la asociación entre el inicio del decaimiento del crecimiento anual de los árboles sintomáticos con eventos climáticos extremos (sequías).

Los análisis realizados sobre individuos femeninos y masculinos, permitieron establecer que el mal del ciprés afecta con mayor frecuencia a los individuos femeninos y que esta diferencia estaría determinada por una susceptibilidad diferencial de los individuos femeninos a la sequía.

Considerando el análisis conjunto de la información generada a lo largo de la tesis se planteó una nueva hipótesis para el mal del ciprés según la cual la mortalidad diferencial de árboles sería consecuencia de una susceptibilidad diferencial a la cavitación.

La hipótesis de cavitación se ajusta al modelo etiológico de origen radical y explica las modificaciones fisiológicas que derivan en la aparición de los síntomas aéreos, internos y subterráneos, siendo estos últimos consecuencia de la acción secundaria de organismos saprofitos o patógenos sobre individuos previamente debilitados. La hipótesis predice además el patrón de distribución y el patrón ecológico del mal del ciprés, se corresponde con la susceptibilidad diferencial a la sequía establecida para los individuos femeninos y permite plantear una nueva interpretación de la asociación entre las condiciones de micrositio y el desarrollo del mal del ciprés. 
INDICE

Pág.

ÍNDICE

ÍNDICE DE TABLAS $\quad$ ix

ÍNDICE DE FIGURAS

ÍNDICE DE GRÁFICOS $\quad$ XV

$\begin{array}{lr}\text { ABREVIATURAS } & \text { Xvii }\end{array}$

INTRODUCCIÓN GENERAL - MORTALIDAD DE ÁRBOLES EN SISTEMAS

BOSCOSOS NATURALES

CAPITULO I - MAL DEL CIPRÉS: UNA ENFERMEDAD COMPLEJA DE ETIOLOGÍA DESCONOCIDA

1.- CARACTERÍSTICAS GENERALES, HIPÓTESIS E INTERROGANTES EN RELACIÓN AL MAL DEL CIPRÉS

1.1.- SÍNTOMAS Y DESARROLLO DEL MAL DEL CIPRÉS A NIVEL DE INDIVIDUO 10

1.1.1.- Síntomas aéreos o de copa 10

$\begin{array}{ll}\text { 1.1.2.- Síntomas subterráneos o de raíz } & 13\end{array}$

$\begin{array}{ll}\text { 1.1.3.- Síntomas generales } & 15\end{array}$

1.2.- DISTRIBUCIÓN DEL MAL DEL CIPRÉS A NIVEL DE BOSQUE 17

1.3.- CUANTIFICACIÓN DEL MAL DEL CIPRÉS 19

1.4.- PATRÓN ECOLÓGICO DEL MAL DEL CIPRÉS 20

1.5.- AGENTES Y MODELOS ETIOLÓGICOS PROPUESTOS 21

2.- AUSTROCEDRUS CHILENSIS: CARACTERÍSTICAS GENERALES DE LA ESPECIE AFECTADA POR EL MAL DEL CIPRÉS 26

2.1.- DISTRIBUCIÓN Y SUPERFICIE DE LOS BOSQUES DE $A$. CHILENSIS 26

2.2.- TIPOS FORESTALES Y DISTRIBUCIÓN ECOLÓGICA DE LOS BOSQUES DE $A$. CHILENSIS 27

2.3.- CARACTERÍSTICAS GENERALES Y ADAPTACIONES MORFOLÓGICAS DE $A$. CHILENSIS 29

2.4.- IMPORTANCIA DE LOS BOSQUES DE $A$. CHILENSIS Y PRINCIPALES DISTURBIOS 31

2.5.- ESTADO SANITARIO DE LOS BOSQUES DE A. CHILENSIS 32

3.- OBJETIVO GENERAL DE LA TESIS Y ASPECTOS A INVESTIGAR EN RELACIÓN CON EL MAL DEL CIPRÉS

3.1.- CARACTERIZACIÓN GENÉTICA

3.2.- Agentes BiÓticos 34

3.2.1.- Phytophthora austrocedrae 34

3.2.2.- Áfidos del género Cinara 34

3.2.3.- Bacterias endógenas de xilema $\quad 34$ 
3.3.- PATRONES DE CRECIMIENTO Y ASOCIACIÓN CON CLIMA

CAPITULO II - SELECCIÓN DE PARES DE PLANTAS ASINTOMÁTICAS Y SINTOMÁTICAS EN SECTORES DE BOSQUE CON PATRÓN DESAGREGADO DEL MAL DEL CIPRÉS

1.- INTRODUCCIÓN 39

2.- MATERIALES Y METODOS 40

2.1.- ÁREA DE MUESTREO 40

2.2.- MUESTREO PAREADO 43

2.2.1.- Estado sanitario 43

2.2.2.- Descriptores básicos 44

A-Altura total y diámetro a altura de pecho 44

B-Posición sociológica 44

C-Competencia 45

3.- RESULTADOS Y DISCUSIÓN

3.1.- MUESTREO PAREADO

3.1.1.- Estado sanitario

3.1.2.- Descriptores básicos

A-Altura total y diámetro a altura de pecho 47

B-Posición sociológica

C-Competencia

4.- CONCLUSIONES

CAPITULO III - CARACTERIZACIÓN GENÉTICA DE INDIVIDUOS SINTOMÁTICOS Y ASINTOMÁTICOS PARA MAL DEL CIPRÉS

INTERROGANTES $\quad 55$

HIPÓTESIS Y PREDICCIONES

$\begin{array}{ll}\text { 1.- INTRODUCCIÓN } & 57\end{array}$

2.- MATERIALES Y MÉTODOS $\quad 63$

2.1.- MATERIAL VEGETAL $\quad 63$

2.2.- EXTRACCIÓN DE DNA Y AMPLIFICACIÓN POR PCR 64

2.3.- ANÁLISIS DE LOS DATOS $\quad 65$

3.- RESULTADOS $\quad 69$

3.1.- UTILIDAD DEL SISTEMA DE MARCADORES RGA EN LA CARACTERIZACIÓN DE LA ESPECIE A. CHILENSIS

3.2.- CARACTERIZACIÓN DE LA VARIABILIDAD GENÉTICA EN PARES DE INDIVIDUOS ASINTOMÁTICOS Y SINTOMÁTICOS CON DISTRIBUCIÓN DESAGREGADA 
3.3- CARACTERIZACIÓN GENÉTICA DE POBLACIONES DE A. CHILENSIS PROVENIENTES DE BOSQUES MÉSICOS AFECTADOS POR MAL DEL CIPRÉS (EL BOLSÓN) Y BOSQUES XÉRICOS NO AFECTADOS (SAN RAMÓN)

3.3.1.- San Ramón vs. poblaciones Asintomática y Sintomática para mal del ciprés provenientes de la región de EL Bolsón

3.3.2.- San Ramón vs. poblaciones EB_N y EB_S provenientes de la región de El Bolsón

4.- DISCUSION Y CONCLUSIONES

4.1.- UTILIDAD DEL SISTEMA DE MARCADORES MULTILOCUS RGA EN LA CARACTERIZACIÓN DE LA ESPECIE A. CHILENSIS

4.2.- VARIABILIDAD GENÉTICA EN LA ESPECIE A. CHILENSIS

4.2.1- Comparación del sistema RGA con otros sistemas de marcadores moleculares

CAPITULO IV - EL ROL DE PHYTOPHTHORA AUSTROCEDRAE EN EL MAL DEL CIPRÉS

$\begin{array}{ll}\text { INTERROGANTE } & 89\end{array}$

HIPÓTESIS Y PREDICCIONES $\quad 89$

$\begin{array}{ll}\text { 1.- INTRODUCCIÓN } & 91\end{array}$

2.- MATERIALES Y METODOS 93

2.1.- EnSAYO PAREAdO: MOdELO 1

2.2.- ENSAYO EN PARCELAS: MODELO 2

3.- RESULTADOS Y DISCUSIÓN 94

3.1.- ENSAYO PAREADO: MODELO 1

3.2.- ENSAYO EN PARCELAS: MODELO 2

$\begin{array}{lr}\text { 4.- DISCUSION } & 102\end{array}$

5.- CONCLUSIONES 110

CAPITULO V - RELACIÓN ENTRE EL MAL DEL CIPRÉS Y ÁFIDOS DEL GÉNERO CINARA

INTERROGANTE

HIPÓTESIS Y PREDICCIONES 111

1.- INTRODUCCIÓN 113

2.- MATERIALES Y MÉTODOS 119

2.1.- ASOCIACIÓN ENTRE EL MAL DEL CIPRÉS Y LA PRESENCIA DE ÁFIDOS DEL GÉNERO CINARA 
2.2.- DESARROLLO DE UN MÉTODO MOLECULAR DE IDENTIFICACIÓN DE LAS ESPECIES

C. CUPRESSI Y C. TUJAFILINA

2.2.1- Recolección de muestras e identificación morfológica

119

2.2.2- Amplificación por PCR y secuenciación

2.2.3- Método de identificación molecular (PCR-RFLP)

2.3.- DisTRIBUCIÓN DE LAS ESPECIES C. CUPRESSI Y C. TUJAFILINA SEGÚN ESTADO SANITARIO DEL HUÉSPED

3.- RESULTADOS

3.1.- ASOCIACIÓN ENTRE EL MAL DEL CIPRÉS Y LA PRESENCIA DE ÁFIDOS DEL GÉNERO CINARA

3.2.- DESARROLLO DE UN MÉTODO MOLECULAR (PCR-RFLP) DE IDENTIFICACIÓN DE LAS ESPECIES C. CUPRESSI Y C. TUJAFILINA

3.3.- DISTRIBUCIÓN DE LAS ESPECIES C. CUPRESSI Y C. TUJAFILINA SEGÚN ESTADO SANITARIO DEL HUÉSPED

4.- DISCUSIÓN

5.- CONCLUSIONES

\section{CAPITULO VI - RELACIÓN ENTRE EL MAL DEL CIPRÉS Y BACTERIAS}

ENDÓGENAS PRESENTES EN XILEMA DE $\boldsymbol{A}$. CHILENSIS 133

INTERROGANTES

HIPÓTESIS Y PREDICCIONES

1.- INTRODUCCIÓN 135

2.- MATERIALES Y MÉTODOS 140

2.1.- DETECCIÓN DE BACTERIAS EN XILEMA DE $A$. CHILENSIS MEDIANTE LA AMPLIFICACIÓN POR PCR DEL GEN 16S rRNA

2.2.- CARACTERIZACIÓN MEDIANTE DGGE DE LA DIVERSIDAD DE LA REGIÓN V3 DEL GEN 16S rRNA AMPLIFICADA DESDE XILEMA DE $A$. CHILENSIS 141

3.- RESULTADOS Y DISCUSIÓN

3.1.- DETECCIÓN DE BACTERIAS EN XILEMA DE $A$. CHILENSIS MEDIANTE LA AMPLIFICACIÓN POR PCR DEL GEN 16S rRNA

3.2.- CARACTERIZACIÓN MEDIANTE DGGE DE LA DIVERSIDAD DE LA REGIÓN V3 DEL GEN 16S rRNA AMPLIFICADA DESDE XILEMA DE $A$. CHILENSIS

3.2.1-Caracterización de las poblaciones bacterianas de xilema en individuos de la especie $A$. chilensis

3.2.2- Caracterización de las poblaciones bacterianas de xilema en pooles de individuos de la especie $A$. chilensis 


\section{CAPITULO VII -PATRONES DE CRECIMIENTO Y FACTORES ABIÓTICOS}

ASOCIADOS AL MAL DEL CIPRÉS

INTERROGANTES 155

HIPÓTESIS Y PREDICCIONES 155

1.- INTRODUCCIÓN 157

2.- MATERIALES Y MÉTODOS 161

2.1.- CRECIMIENTO RADIAL DE INDIVIDUOS SINTOMÁTICOS Y ASINTOMÁTICOS PARA MAL DEL CIPRÉS Y ASOCIACIÓN CON CLIMA

2.2.- ANÁLISIS DEL EFECTO PREDISPONENTE DEL SITIO

2.3.- CARACTERIZACIÓN DE PATRONES DE CRECIMIENTO DE ÁREAS CON MAYOR Y MENOR $\begin{array}{ll}\text { INCIDENCIA DEL MAL DEL CIPRÉS } & 161\end{array}$

3.- RESULTADOS Y DISCUSIÓN 162

3.1.- CRECIMIENTO RADIAL DE INDIVIDUOS SINTOMÁTICOS Y ASINTOMÁTICOS PARA MAL DEL CIPRÉS Y ASOCIACIÓN CON CLIMA

3.2.- ANÁLISIS DEL EFECTO PREDISPONENTE DEL SITIO

3.3.- CARACTERIZACIÓN DE PATRONES DE CRECIMIENTO DE ÁREAS CON MAYOR Y MENOR INCIDENCIA DEL MAL DEL CIPRÉS

\section{CAPITULO VIII - SUSCEPTIBILIDAD DIFERENCIAL AL MAL DEL CIPRÉS ENTRE} INDIVIDUOS FEMENINOS Y MASCULINOS DE $\boldsymbol{A}$. CHILENSIS 171

$\begin{array}{ll}\text { INTERROGANTES } & 171\end{array}$

HIPÓTESIS Y PREDICCIONES 171

$\begin{array}{ll}\text { 1.- INTRODUCCIÓN } & 173\end{array}$

2.- MATERIALES Y MÉTODOS 175

2.1.- DIFERENCIAS EN LA RELACIÓN DE SEXOS EN GRUPOS DE INDIVIDUOS SINTOMÁTICOS Y ASINTOMÁTICOS PARA MAL DEL CIPRÉS

2.2.- DIFERENCIAS EN LOS PATRONES DE CRECIMIENTO ENTRE INDIVIDUOS FEMENINOS Y MASCULINOS DE LA ESPECIE $A$. CHILENSIS

3.- RESULTADOS Y DISCUSIÓN

3.1.- DIFERENCIAS EN LA RELACIÓN DE SEXOS EN GRUPOS DE INDIVIDUOS SINTOMÁTICOS Y ASINTOMÁTICOS PARA MAL DEL CIPRÉS 176

3.1.1.- Ensayo sobre pares 176

3.1.2.- Ensayo en parcelas 176

3.2.- DIFERENCIAS EN LOS PATRONES DE CRECIMIENTO ENTRE INDIVIDUOS FEMENINOS Y MASCULINOS DE LA ESPECIE $A$. CHILENSIS 178

4.- CONCLUSIONES 
CAPITULO IX - AVANCES EN EL CONOCIMIENTO SOBRE EL MAL DEL CIPRÉS Y NUEVA HIPÓTESIS SOBRE SU ETIOLOGÍA 185

1.- INTRODUCCIÓN 187

2.- APORTES DE LA INVESTIGACIÓN DESARROLLADA EN LA TESIS AL CONOCIMIENTO DEL MAL DEL CIPRÉS 190

2.1.- ESTRUCTURACIÓN NORTE-SUR 194

2.1.1- Glaciaciones Cuaternarias 195

2.1.2- Incendios $\quad 197$

2.1.3- Clima 197

2.1.4- Condiciones de sitio 197

2.1.5- Mal del ciprés 198

2.2.- PATRONES DE CRECIMIENTO Y MORTALIDAD EN $A$. CHILENSIS INTERPRETACIÓN FISIOLÓGICA DE LAS DIFERENCIAS DETECTADAS 199

3.- NUEVA HIPÓTESIS SOBRE EL ORIGEN DEL MAL DEL CIPRÉS 204

4.- EL MAL DEL CIPRÉS BAJO LA HIPÓTESIS DE CAVITACIÓN 206

CONCLUSIÓN DEL TRABAJO DE TESIS 211

$\begin{array}{lr}\text { BIBLIOGRÁFIA } & 213\end{array}$

$\begin{array}{ll}\text { ANEXOS } & 241\end{array}$

ANEXO 1 - INCIDENCIA Y DESARROLLO TEMPORAL DEL MAL DEL CIPRÉS 243

1.- INTRODUCCIÓN 243

2.- MATERIALES Y MÉTODOS 244

2.1-CARACTERIZACIÓN A NIVEL DE RODAL 245

2.1.1- Incidencia del mal del ciprés 245

2.1.2- Historia de aprovechamiento 245

2.2- CARACTERIZACIÓN A NIVEL DE PARCELA PERMANENTE 246

2.2.1- Análisis del desarrollo temporal del mal del ciprés 246

2.2.2- Distribución espacial de la mortalidad 247

2.3.-CARACTERIZACIÓN A NIVEL DE INDIVIDUO 247

2.3.1- Desarrollo temporal del mal del ciprés $\quad 247$

$\begin{array}{ll}\text { 3.- RESULTADOS Y DISCUSIÓN } & 248\end{array}$

3.1-CARACTERIZACIÓN A NIVEL DE RODAL 248

3.1.1- Incidencia del mal del ciprés 248

3.1.2- Historia de aprovechamiento 251

3.2- CARACTERIZACIÓN A NIVEL DE PARCELA PERMANENTE 253

3.2.1- Análisis del desarrollo temporal del mal del ciprés 253

3.2.2- Distribución espacial de la mortalidad 256 
3.3.-CARACTERIZACIÓN A NIVEL DE INDIVIDUO

3.3.1- Desarrollo temporal del mal del ciprés $\quad 258$

4.- CONCLUSIONES

258

5.- BIBLIOGRAFÍA

ANEXO 2- DISTANCIA GEOGRÁFICA ENTRE INDIVIDUOS DE UN PAR

ANEXO 3 - EXTRACCIÓN DE DNA TOTAL DESDE XILEMA DE A. CHILENSIS

ANEXO 5 - ANÁLISIS DE AGRUPAMIENTO DE INDIVIDUOS (STRUCTURE)

ANEXO 7 - DESARROLLO DE MÉTODOS MOLECULARES BASADOS EN PCR PARA LA DETECCIÓN E IDENTIFICACIÓN DE ESPECIES DEL GÉNERO PHYTOPHTHORA 273

1.- INTRODUCCIÓN 273

2.- MATERIALES Y MÉTODOS 275

2.1.- RECOLECCIÓN DE MUESTRAS Y EXTRACCIÓN DE DNA DESDE LESIONES NECRÓTICAS 275

2.2.- EXTRACCIÓN DE DNA DESDE CULTIVOS DE PHYTOPHTHORA SP 276

2.3.- DISEÑO DE PRIMERS 276

2.4.- AMPLIFICACIÓN DEL DNA EXTRAÍDO DESDE LESIONES NECRÓTICAS DE FLOEMA Y SECUENCIACIÓN DE LOS FRAGMENTOS AMPLIFICADOS 277

2.5.- ANÁLISIS IN SILICO 277

$\begin{array}{ll}\text { 2.6.- ENSAYOS RFLP } & 278\end{array}$

3.- RESULTADOS 278

3.1.- Desarrollo de un método molecular de DeteCción De P. aUSTROCEDRAE A PARTIR DE LESIONES NECRÓTICAS DE FLOEMA PRESENTES EN CUELLO Y RAÍZ 278

3.2.- DESARROLLO DE Un MÉTODO MOLECULAR DE IDENTIFICACIÓN DE ESPECIES DE PHYTOPHTHORA PRESENTES EN BOSQUES DE $A$. CHILENSIS

3.2.1-Análisis in silico $\quad 281$

3.2.2- Ensayos RFLP 283

4.- DISCUSION Y CONCLUSIONES 287

5.-BIBLIOGRAFÍA 289

ANEXO 8 - AMPLIFICACIÓN DEL GEN 16S rRNA 293 


\section{ANEXO 9 - SIGNIFICACIÓN DEL DENDROGRAMA DERIVADO DEL ANÁLISIS DE DGGE A NIVEL DE INDIVIDUO}

ANEXO 10 - ANÁLISIS COMPARATIVO DE DGGE SOBRE POOLES E INDIVIDUOS

El Mujtar V, Andenmatten E, 2007a. "Mal del ciprés": búsqueda de la causa más probable de daño mediante un análisis deductivo y comparativo. Bosque 28(1): 3-9.

El Mujtar V, Andenmatten E, 2007b. Análisis del "Mal del ciprés" mediante un "Modelo de Enfermedad": Vacíos de información y perspectivas. Revista de la Facultad de Agronomía de La Plata. 106(2): 119-133.

El Mujtar V, Covelli J, Delfino MA, Grau O, 2009. Molecular Identitication of Cinara cupressi and Cinara tujafilina (Hemiptera, Ahpididae). Environmental Entomology 38(2):505-512.

Mundo IA, El Mujtar VA, Perdomo HM, Gallo LA, Villalba R, Barrera MD. Austrocedrus chilensis growth decline in relation to drought events in northern Patagonia, Argentina. (Enviado) 


\section{INDICE DE TABLAS}

Pág.

Tabla II-1: Coordenadas geográficas, altitud e incidencia del mal del ciprés para cada uno de los sitios de muestreo.

Tabla II-2: Clasificación de estado sanitario aplicado a la selección de los pares de plantas sintomáticas / asintomáticas

Tabla II-3: Valor promedio y desvío estándar del DAP y la altura total según estado sanitario para cada sitio de muestreo y para el área de El Bolsón (EB).

Tabla II-4: Valores promedio del índice de competencia global, pasada y actual calculado para cada sitio de muestreo sobre el conjunto de los árboles y según categorías de estado sanitario.

Tabla III-1: Pares de primers utilizados en la caracterización genética de $A$. chilensis.

Tabla III-2: Número de marcadores RGA, totales y polimórficos.

Tabla III-3: Parámetros genéticos calculados a partir de las frecuencias alélicas estimadas para los marcadores obtenidos por RGA. SR: San Ramón. A: Asintomática. S: Sintomática.

Tabla III-4: Análisis molecular de la varianza y parámetros $\Phi$ determinados en base a los 43 marcadores polimórficos según organización jerárquica de las poblaciones en estudio.

SR: San Ramón. EB: EL Bolsón. A: Asintomática. S: Sintomática.

Tabla III-5: Matriz pareada de $\Phi_{\mathrm{PT}}$ calculada mediante análisis molecular de la varianza.

SR: San Ramón. A: Asintomática. S: Sintomática.

Tabla III-6: Parámetros genéticos calculados a partir de las frecuencias alélicas estimadas para los marcadores obtenidos por RGA. SR: San Ramón. EB_N: El Bolsón Norte. EB_S: El Bolsón Sur.

Tabla III-7: Análisis molecular de la varianza y parámetros $\Phi$ determinados en base a los 43 marcadores polimórficos según organización jerárquica de las poblaciones en estudio. SR: San Ramón. EB: El Bolsón. EB_N: El Bolsón Norte. EB_S: El Bolsón Sur.

Tabla III-8: Número de bandas, porcentaje de polimorfismo, variedades o poblaciones, especies y condiciones de amplificación, separación y detección reportadas para las combinaciones de primers utilizadas en la caracterización genética de $A$. chilensis mediante RGA.

Tabla III-9: Comparación de los parámetros de diversidad y diferenciación genética obtenidos para A. chilensis mediante el sistema RGA con los reportados para otros sistemas de marcadores moleculares en la misma especie y otras especies de la familia Cupressaceae.

Tabla V-1: Huésped, identificación morfológica y molecular de las especies de Cinara, haplotipos y números de acceso en Genbank de las secuencias clonadas.

Tabla VI-1: Valores de probabilidad del análisis de Chi cuadrado de la distribución de bandas de DGGE según grupos predefinidos: A vs. S, EB_N vs. EB_S y L5y6, R11, R18, R81 y L9y15.

Tabla VI-2: Valores de significación del dendrograma obtenido para el análisis de la diversidad de la región V3 del gen 16S rRNA en y entre áreas de muestreo (Figura VI-9).

Tabla VIII-1: Relación de sexos entre los grupos de individuos sintomáticos y asintomáticos para mal del ciprés en la región de El Bolsón. 
Tabla VIII-2: Relación de sexos entre los grupos de individuos sintomáticos y asintomáticos correspondientes al área norte y sur de El Bolsón.

Tabla A1-1: Superficie, pendiente, exposición y densidad de las parcelas permanentes analizadas y años en los que se efectuaron los correspondientes inventarios.

Tabla A1-2: Distribución de estados sanitarios para cada una de las áreas de muestreo según valores absolutos de frecuencia o volumen.

Tabla A1-3: Distribución porcentual de clases de tendencia para cada parcela permanente analizada. 253

Tabla A1-4: Número de árboles, por categoría e inventario, para la tendencia directa de desarrollo temporal en cada una de las parcelas permanentes.

Tabla A2-1: Distancia geográfica entre los individuos de cada uno de los pares asintomático / sintomático seleccionados para el desarrollo del trabajo de tesis.

Tabla A3-1: Extracción de DNA total para los 100 individuos seleccionados.

Tabla A4-1: Frecuencia del marcador RGA y frecuencias alélicas estimadas para los 43 marcadores polimórficos.

Tabla A5-1: Coeficientes de pertenencia a cada uno de los clusters inferidos en Structure de los 86 individuos caracterizados por RGA, clasificados según área de muestreo y estado sanitario.

Tabla A6-1: Reporte de la aplicación en otras especies de los primers utilizados en la caracterización genética de $A$. chilensis mediante RGA.

Tabla A7-1: Tamaños estimados y obtenidos para los fragmentos derivados del ensayo PCR-RFLP. 283

Tabla A8-1: Resultado de la amplificación del gen 16S rRNA desde muestras de DNA total obtenidas a partir de xilema de individuos de la especie $A$. chilensis.

Tabla A9-1: Valores de significación del dendrograma obtenido para el análisis de la diversidad de la región V3 del gen 16S rRNA entre individuos de $A$. chilensis (Figura VI-6, Capitulo VI). 


\section{INDICE DE FIGURAS}

Pág.

Figura I-1: Síntomas aéreos de mal del ciprés según se presentan en el bosque.

Figura I-2: Patrones de defoliación observados en bosques de $A$. chilensis.

Figura I-3: Lesiones necróticas producidas por P. austrocedrae en A. chilensis. 15

Figura I-4: Detalle de resinación en fuste de $A$. chilensis.

Figura I-5: Distribución del mal del ciprés a nivel de bosque.

Figura I-6: Clasificación por tipo de vitalidad, según características de copa y porcentaje de defoliación.

Figura I-7: Representación esquemática de los modelos $(\mathrm{M})$ etiológicos propuestos para el mal del ciprés y las relaciones entre ellos.

Figura I-8: Modelos etiológicos en relación a compartimentos fisiológicos.

Figura I-9: Principales tipos forestales de $A$. chilensis.

Figura I-10: Diversidad de copa en $A$. chilensis según condiciones de sitio y grado de competencia. 30

Figura I-11: Características de ramas y hojas en A. chilensis. 31

Figura II-1: Valle de El Bolsón, cordones montañosos y principales cursos de agua. 41

Figura II-2: Mapa de la zona de estudio mostrando la ubicación de los sitios de muestreo (L5y6, R11, R18, R81 y L9y15) y la localidad de El Bolsón.

Figura III-3: Sistema de marcadores moleculares multilocus RGA (resistance gene analogs).

Figura III-4: Perfil de amplificación obtenido para cada combinación de primers empleada en la caracterización con RGA.

Figura III-5 : Relación entre la frecuencia de cada marcador RGA y su correspondiente parámetro de diferenciación entre las poblaciones Asintomática y Sintomática $\left(\Phi_{\mathrm{PT}}\right)$.

Figura III-6: Particionamiento de los 86 individuos caracterizados por RGA obtenido para K=2, 3, 4 y 5 según el método de agrupamiento implementado en Structure.

Figura III-7 : Relación entre la frecuencia de los marcadores RGA y los parámetros de diferenciación $\Phi$ determinados para SR versus EB (A y S).

Figura III-8 : Relación entre la frecuencia de los marcadores RGA y los parámetros de diferenciación $\Phi$ determinados para SR versus EB (EB_N y EB_S).

Figura III-9: Perfiles de amplificación generados mediante la aplicación del sistema RGA en

A. chilensis.

Figura IV-1: Selección de individuos en muestreo pareado según porcentaje de defoliación.

Figura IV-2: Lesiones necróticas de floema, afectando gran porcentaje del cuello del árbol, y extendiéndose hacia el fuste.

Figura IV-3: Lesiones necróticas de floema limitadas en extensión y altura. 
Figura IV-4: Cambio de color de follaje y mortalidad súbita del árbol 28S.

Figura IV-5: Manifestaciones del cambio de color del follaje a nivel de bosque.

Figura IV-6: Presentación de síntomas aéreos a nivel de bosque.

Figura IV-7: Presencia de lesiones necróticas en el individuo P1 seleccionado por cambio de color en follaje con distribución central.

Figura IV-8: Presencia de lesiones necróticas en los individuos P3 y P4 seleccionados por cambio de color en follaje con distribución central.

Figura IV-9: Avance temporal del cambio de color de follaje.

Figura IV-10: Agregación de individuos con cambio de color de follaje (Panel superior) y detalle de las lesiones necróticas presentes en los individuos 2 y 4 (Panel inferior). 108

Figura IV-11: Agregación de individuos de distinto porte con cambio de coloración de follaje.

Figura V-1: Síntomas en follaje producidos por áfidos del género Cinara observados en bosques de A. chilensis en Chile.

Figura V-2: Colonias de C. cupressi detectadas en El Bolsón (Argentina).

Figura V-3: Síntomas en follaje producidos por áfidos del género Cinara observados en bosques de A. chilensis en región de El Bolsón (Argentina).

Figura V-4: Esquema de muestreo y procesamiento de las especies del género Cinara.

Figura V-5: Alineamiento de haplotipos de secuencia única de CO-I para especies de Cinara depositadas en GenBank.

Figura V-6: Perfiles de restricción de clones amplificados con primers COIS y COIA, digeridos con Hae III y separados por electroforesis en gel de agarosa $\%$ (TAE 1X).

Figura V-7: Amplicones obtenidos por PCR y perfiles de PCR-RFLP separados por electroforesis en gel de agarosa $2 \%$ (TAE $1 \mathrm{X}$ ).

Figura V-8: Aplicación del método de PCR-RFLP con base en el gen CO-I a pulgones obtenidos desde colonias aisladas en pares de plantas con y sin síntomas del mal del ciprés.

Figura VI-1: Representación esquemática de los dos modelos etiológicos evaluados.

Figura VI-2: A. Ubicación de la región variable V3 del gen 16S rRNA y estrategia de amplificación. B. Representación esquemática de la técnica de DGGE.

Figura VI-3: Ensayo de PCR para el gen 16S rRNA.

Figura VI-4: Amplificación por PCR con la combinación de primers fD1/rD1 sobre diluciones seriadas de DNA total extraído de xilema de $A$. chilensis.

Figura VI-5: Caracterización de la región V3 del gen 16S rRNA.

Figura VI-6: Diversidad de la región V3 del gen 16S rRNA a nivel de individuos.

Figura VI-7: Análisis comparativo de la diversidad de la región V3 del gen 16S rRNA en el R18.

Figura VI-8: Ordenamiento espacial de individuos (arriba) y bandas (abajo) según los dos primeros componentes del PCA.

Figura VI-9: Diversidad de la región V3 del gen 16S rRNA en y entre áreas y sitios de muestreo.

Figura VII-1: Cronologías promedio de árboles sintomáticos y asintomáticos para la región de El Bolsón. 
Figura VII-2: Cronologías de crecimiento promedio para el área norte y sur de El Bolsón.

Figura VIII-1: Conos masculinos (izquierda) y femeninos (derecha) de Austrocedrus chilensis.

Figura VIII-2: Cronologías promedio de árboles femeninos y masculinos para la región de El

Bolsón.

Figura VIII-3: Cronologías promedio de árboles femeninos y masculinos para el área norte de El

Bolsón (EB_N).

Figura VIII-4: Cronologías promedio de árboles femeninos y masculinos para el área sur de El

Bolsón (EB S).

Figura IX-1: Características que definen la estructuración norte-sur en la región de El Bolsón y principales factores que podrían determinar su origen.

Figura IX-2: Pisos altimétricos del área de estudio.

Figura IX-3: Relaciones teóricas, basadas en el marco hidráulico, entre la duración y la intensidad de la sequía, y los tres mecanismos hipotéticos de mortalidad.

Figura IX-4: Nueva hipótesis para explicar la etiología del mal del ciprés.

Figura A1-1: Mapa de la zona de estudio mostrando la ubicación de los sitios de muestreo (L5y6, R11, R18, R81 y L9y15) y la localidad de El Bolsón.

Figura A1-2: Representación esquemática de la caracterización de los sitios mediante el análisis en escala espacial (rodal, parcela permanente e individuo) y temporal.

Figura A7-1: Detección de P. austrocedrae mediante amplificación por PCR con primers específicos.

Figura A7-2: Detección de P. austrocedrae mediante amplificación por PCR con primers genéricos. 280

Figura A7-3: Impacto de la conservación de muestras en la detección de P. austrocedrae por PCR. 281

Figura A7-4: PCR-RFLP Combinación A.

Figura A7-5: PCR-RFLP Combinación B. 285

Figura A7-6: PCR-RFLP Combinación C. 285

Figura A7-7: PCR-RFLP Combinación A, análisis de la variabilidad intraespecífica. 287

Figura A10-1: Análisis comparativo de la diversidad de la región V3 del gen 16S rRNA en cada sitio de muestreo. B-R11, C-L5y6.

Figura A10-2: Análisis comparativo de la diversidad de la región V3 del gen 16S rRNA en cada sitio de muestreo. D-R81 y E-L9y15. 


\section{INDICE DE GRÁFICOS}

Pág.

Gráfico I-1: Evolución cronológica del reporte bibliográfico de los síntomas aéreos.

Gráfico I-2: Evolución cronológica del reporte bibliográfico del cambio de color del follaje.

Gráfico I-3: Evolución cronológica del reporte bibliográfico de los síntomas subterráneos o de raíz.

Gráfico II-1: Distribución de clases diamétricas para ambos estados sanitarios correspondiente al total de los individuos seleccionados.

Gráfico II-2: DAP de los 100 individuos seleccionados (eje principal) y diferencia relativa entre los individuos de cada par (eje secundario).

Gráfico II-3: Altura total de los 100 individuos seleccionados (eje principal) y diferencia relativa entre los individuos de cada par (eje secundario).

Gráfico II-4: Posición sociológica por código numérico según Bechtold (2003.

Gráfico II-5: Índice de competencia global, calculado en función de la competencia actual y pasada, para los individuos seleccionados.

Gráfico II-6: Índice de competencia pasada para los individuos seleccionados.

Gráfico IV-1: Distribución del porcentaje del cuello de cada individuo afectado por lesiones necróticas según estado sanitario para mal del ciprés y sitios de muestreo.

Gráfico IV-2: Porcentaje de individuos con lesiones necróticas según estado sanitario para mal del ciprés.

Gráfico IV-3: Distribución de árboles según síntomas aéreos para las parcelas del R11 y R18.

Gráfico IV-4: Correlación entre la incidencia de P. austrocedrae en un sitio (número de árboles con lesiones necróticas) y el número de individuos con síntomas aéreos de mal del ciprés (defoliación y amarillamiento) que presentan simultáneamente lesiones necróticas a nivel de cuello.

Gráfico IV-5: Distribución de los individuos afectados por P. austrocedrae entre clases sociológicas.

Gráfico V-1: Relación entre áfidos y estado sanitario según número total de pulgones adultos detectados.

Gráfico VII-1: Cambio relativo en el crecimiento promedio correspondiente a los períodos entre los eventos de sequía extremos de 1942-1943, 1962.

Gráfico VIII-1: Valores de la relación de sexo para las áreas norte (EB_N) y sur (EB_S) de la región de El Bolsón.

Gráfico A1-1: Incidencia de mal del ciprés para las categorías sintomático y muerto en cada una de las áreas de muestreo.

Gráfico A1-2: Distribución de individuos sintomáticos y muertos según clases diamétricas para cada una de las áreas de muestreo.

Gráfico A1-3: Volumen de madera extraído para cada una de las áreas de muestreo en el período 1987-2007. 
Gráfico A1-4: Distribución temporal del aprovechamiento forestal, en el período 1987-2007, para cada una de las áreas de muestreo.

Gráfico A1-5: Número de árboles afectados $(\mathrm{S}+\mathrm{M}+\mathrm{X})$, para la clase directa de desarrollo temporal en cada una de las parcelas permanentes.

Gráfico A1-6: Evolución del cambio de estado sanitario para cada parcela permanente.

Gráfico A1-7: Distribución espacial de la mortalidad en función del tiempo para las tres parcelas en estudio. En los ejes x e y, se indica la distancia en metros desde el centro de parcela. 


\section{ABREVIATURAS Y SIGLAS}

\begin{tabular}{|c|c|}
\hline A & Árbol Asintomático \\
\hline A- & Frecuencia del Alelo nulo \\
\hline $\mathrm{A}+$ & Frecuencia del Alelo marcador \\
\hline $\mathrm{AD}$ & Análisis Discriminante \\
\hline AFLP & Amplified Fragment Length Polymorphism \\
\hline Ais & Árbol Aislado \\
\hline AMOVA & Análisis Molecular de la Varianza \\
\hline AT & Altura Total \\
\hline $\mathrm{BC}$ & Buffer de Conservación \\
\hline BrEt & Bromuro de Etidio \\
\hline CAPS-STS & Cleaved Amplified Polymorphic Sequence-Sequence Tagged Site \\
\hline $\mathrm{CC}$ & Dominio coiled coil \\
\hline $\mathrm{CD}$ & Árbol Codominante \\
\hline $\mathrm{cm}$ & centímetros \\
\hline $\mathrm{cm}^{3}$ & centímetro(s) cúbico(s) \\
\hline $\mathrm{CO}-\mathrm{I}$ & Citocromo Oxidasa I \\
\hline $\mathrm{CO}-\mathrm{II}$ & Citocromo Oxidasa II \\
\hline CTAB & Hexadecyltrimethyl-ammonium bromide \\
\hline $\mathrm{D}$ & Árbol Dominante \\
\hline $\mathrm{DAC}$ & Diámetro a la altura del cuello del árbol \\
\hline DAP & Diámetro a la altura del pecho \\
\hline DGGE & Denaturing Gradient Gel Electroforesis \\
\hline DNA & Ácido 2' desoxirribonucleico \\
\hline dNTPs & 2'-deoxirribonucleósidos 5-trifosfato \\
\hline dUTP & 2'-deoxiuridine 5-trifosfato \\
\hline EB & El Bolsón \\
\hline EB_N & Área Norte de El Bolsón \\
\hline EB_S & Área Sur de El Bolsón \\
\hline EDTA & Ácido etilen diamino tetraacético \\
\hline $\mathrm{F}$ & Femenino \\
\hline FdUTP & 2'-deoxiuridine 5-trifosfato marcado con fluorescencia \\
\hline Fst & Índice de Fijación de Wright \\
\hline g & gramo(s) \\
\hline Genes R & Genes de resistencia a enfermedades \\
\hline
\end{tabular}




\begin{tabular}{|c|c|}
\hline Gst & Parámetro de variación genética de Nei \\
\hline h2 & Heredabilidad \\
\hline ha & hectárea \\
\hline $\mathrm{HCl}$ & Ácido clorhídrico \\
\hline $\mathrm{He}$ & Heterocigosidad esperada \\
\hline $\mathrm{Hj}$ & Heterocigosidad esperada bajo equilibrio de Hardy-Weinberg \\
\hline $\mathrm{Hj}(\mathrm{i})$ & Diversidad génica para el marcador i en la población j \\
\hline Ho & Heterocigosidad observada \\
\hline $\mathrm{H}-\mathrm{W}$ & Hardy-Weinberg \\
\hline I & Árbol Intermedio \\
\hline IFONA & Instituto Forestal Nacional \\
\hline IMOR(frec) & Incidencia del mal del ciprés basada en el número de árboles muertos \\
\hline IMOR(vol) & Incidencia del mal del ciprés basada en el volumen de árboles muertos \\
\hline IS & Índice de Shannon \\
\hline ISINT(frec) & Íncidencia del mal del ciprés basada en el número de árboles sintomáticos \\
\hline ISINT(vol) & Incidencia del mal del ciprés basada en el volumen de árboles sintomáticos \\
\hline ISSR & Inter Simple Sequence Repeat \\
\hline ITS & Internal Transcribed Spacer \\
\hline $\mathrm{KCl}$ & Cloruro de potasio \\
\hline Kinase & Domino de Kinasa \\
\hline $\mathrm{km}$ & kilómetro(s) \\
\hline L5y6 & Lotes 5 y 6 \\
\hline L9y15 & Lotes 9 y 15 \\
\hline LMRA & Loma del Medio Río Azul \\
\hline LRR & Dominio rico en repeticiones de leucina \\
\hline $\mathrm{m}$ & metro(s) \\
\hline M & Árbol muerto \\
\hline M & Masculino \\
\hline m.s.n.m & metros sobre el nivel del mar \\
\hline $\mathrm{m}^{3}$ & metro(s) cúbico(s) \\
\hline $\mathrm{Mb}$ & Megabases \\
\hline $\mathrm{MCMC}$ & Monte Carlo via Cadena de Markov \\
\hline $\mathrm{mg}$ & miligramo(s) \\
\hline $\mathrm{MgCl}_{2}$ & Cloruro de magnesio \\
\hline M-ID & Identificación morfológica \\
\hline $\min$ & minuto(s) \\
\hline
\end{tabular}




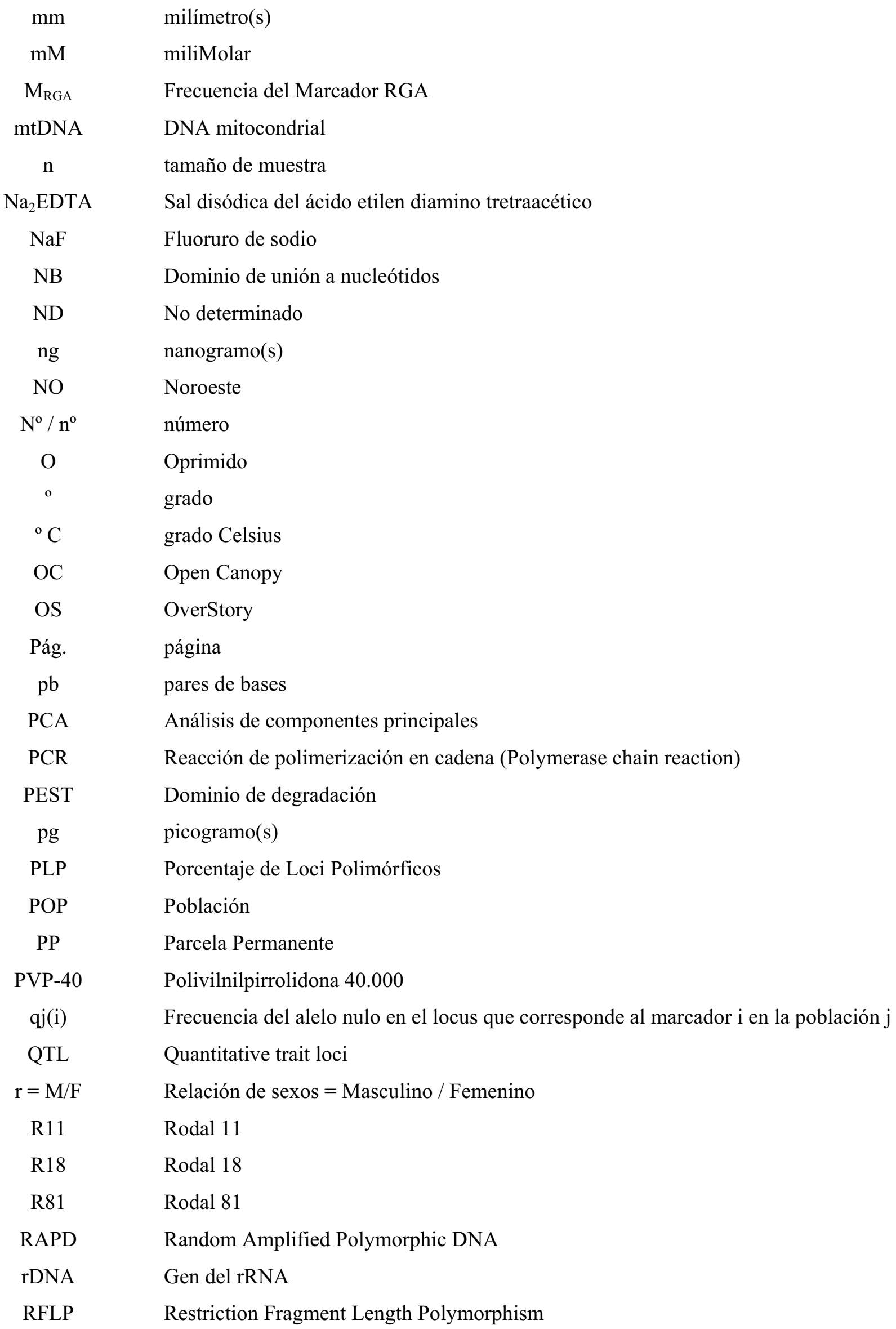

RAPD Random Amplified Polymorphic DNA

rDNA Gen del rRNA

RFLP Restriction Fragment Length Polymorphism 


\begin{tabular}{|c|c|}
\hline RGA & Resistance Gene Analogs \\
\hline $\mathrm{RME}$ & Dominio de endocitosis mediada por receptor \\
\hline RNA & Ácido ribonucléico \\
\hline RNasa & Ribonucleasa \\
\hline rRNA & RNA ribosomal \\
\hline $\mathrm{S}$ & Árbol Sintomático \\
\hline $\mathrm{s}$ & segundo(s) \\
\hline SP & Superstory \\
\hline SR & San Ramón \\
\hline $\mathrm{SSCP}$ & Single Strand Conformation Polymorphism \\
\hline TAE & Buffer Tris-Acetato-EDTA \\
\hline $\mathrm{TE}$ & Buffer Tris-EDTA \\
\hline TGGE & Temperature Gradient Gel Electrophoresis \\
\hline TIR & Dominio con homología a receptores Toll \\
\hline Tris & Tris-(hidroximetil)-aminometano \\
\hline tRNA & RNA de transferencia \\
\hline $\mathrm{U}$ & Unidad(es) \\
\hline US & Uperstory \\
\hline $\mathrm{V} 3$ & Región variable 3 del gen $16 \mathrm{~S}$ rRNA \\
\hline $\mathrm{V}_{\mathrm{AP}}$ & varianza entre poblaciones \\
\hline $\mathrm{V}_{\mathrm{AR}}$ & varianza entre regiones \\
\hline $\mathrm{V}_{\mathrm{WP}}$ & varianza dentro de las poblaciones \\
\hline $\mathrm{X}$ & Árbol aprovechado, caído o descalzado \\
\hline$\% \mathrm{p} / \mathrm{v}$ & Porcentaje peso en volumen \\
\hline$\% \mathrm{v} / \mathrm{v}$ & Porcentaje volumen en volumen \\
\hline$\mu \mathrm{g}$ & microgramo(s) \\
\hline$\mu l$ & microlitro(s) \\
\hline$\mu \mathrm{M}$ & microMolar \\
\hline$\Phi_{\mathrm{PR}}\left(\mathrm{Phi}_{\mathrm{PR}}\right)$ & diferenciación genética entre las poblaciones dentro de las regiones \\
\hline$\Phi_{\mathrm{PT}}\left(\mathrm{Phi}_{\mathrm{PT}}\right)$ & diferenciación genética entre poblaciones \\
\hline$\Phi_{\mathrm{RT}}\left(\mathrm{Phi}_{\mathrm{RT}}\right)$ & diferenciación genética entre las regiones \\
\hline
\end{tabular}


Quand Se mystère est trop impressionnant on n'ose pas désoféir.

$\mathscr{T}_{\text {tntoine de }}$ Paint-Exupéry

(Le $\mathscr{P}_{\text {etit }} \mathscr{P}_{\text {rince }}$ ) 
INTRODUCCIÓN GENERAL

MORTALIDAD DE ÁRBOLES EN SISTEMAS BOSCOSOS NATURALES 

La mortalidad de árboles es un fenómeno natural en los bosques nativos, cuyo conocimiento preciso es necesario para comprender la dinámica del sistema. Los bosques naturales son sistemas biológicos complejos expuestos durante su desarrollo y evolución a diversos tipos de disturbios (incendios, terremotos, enfermedades, sequías) que los apartan en forma constante de su condición de equilibrio.

Algunos de los procesos de mortalidad, como incendios o ataques por agentes bióticos (insectos, hongos patogénicos), son fáciles de caracterizar; siendo posible determinar el origen, la tasa de afectación, las condiciones que determinan su aparición y el impacto en el bosque.

Sin embargo, para otros procesos, la caracterización es compleja debido al desarrollo de la mortalidad en individuos de la misma especie que crecen en diversas condiciones ambientales, existiendo un importante desfasaje entre el momento del estrés que afecta a los individuos y la manifestación de los síntomas. Cuatro factores determinan mayormente las características de este tipo de procesos: ausencia de síntomas específicos, desarrollo lento y progresivo de la mortalidad, longevidad de las especies forestales y amplia distribución geográfica. Este tipo de procesos de mortalidad se engloba bajo la denominación general de "enfermedades de decaimiento".

Numerosos ejemplos de decaimiento en bosques nativos, se conocen desde mediados de siglo pasado y han sido informados desde distintos lugares del mundo. Inicialmente, estas enfermedades se asociaron y estudiaron en relación con dos procesos de escala global, la polución ambiental y el cambio climático. Sin embargo, aunque en algunos casos la asociación directa o indirecta pudo ser establecida (Schulze, 1989; Kandler e Innes, 1995; Ayres y Lombardero, 2000; Dale et al., 2000), para otros se determinó un origen biótico (Adams y Morehart, 1982; Beever et al., 1996) y en muchos la causa de la mortalidad continúa siendo incierta o ha sido únicamente explicada en términos del modelo de declinamiento forestal (Hennon y Shaw, 1997; Drohan et al., 2002; Niklasson et al., 2002; Bigler et al., 2006; Grodzki, 2007).

Las enfermedades de declinamiento, un caso particular de las enfermedades de decaimiento, son el resultado de la acción conjunta de tres tipos de factores que conducen al debilitamiento del vigor de los árboles (Manion, 1981). Los factores predisponentes son procesos de estrés de largo tiempo, como por ejemplo la polución ambiental, la competencia intra o interespecífica o las condiciones de sitio, que debilitan al árbol e incrementan su susceptibilidad a los factores desencadenantes o disparadores. Un factor desencadenante o disparador, corresponde a un estrés de corta duración, tal como un evento de sequía o el ataque por insectos defoliadores, que afecta 
de manera significativa el estado fisiológico del individuo y reduce en forma drástica su vigor. Dependiendo de la condición del árbol previa a la acción del factor disparador y de la intensidad del mismo, los árboles pueden superar el estrés y recuperar su vigor o permanecer en un estado de vigor disminuido. Los árboles que no recuperan el vigor, son susceptibles de ser afectados por los factores contribuyentes, tales como patógenos o agentes secundarios que continúan debilitando al árbol conduciendo finalmente a la muerte del mismo.

Ya sean enfermedades de decaimiento o declinamiento, el estudio de estos procesos de mortalidad constituye un gran desafío científico debido a que es necesario considerar numerosos aspectos y la interacción entre diversos agentes de daño que actúan en largos períodos de tiempo, a fin de poder establecer su etiología. Este tipo de enfermedades estimuló la investigación en diferentes disciplinas y el establecimiento de diversos programas de monitoreo a fin de evaluar el impacto de la polución ambiental, el cambio climático global y los estallidos de patógenos en la dinámica y la sanidad de los bosques (McLaughlin, 1998; Alexander y Palmer, 1999; Petriccione y Pompei, 2002; de Vries et al., 2003).

En Argentina, uno de los ejemplos más conocidos de enfermedad de decaimiento es el mal del ciprés, que se reportó por primera vez a mediados de la década del cuarenta. El mal del ciprés afecta a la especie nativa Austrocedrus chilensis (ciprés de la cordillera) y, a pesar de la intensa investigación desarrollada durante más de sesenta años, su etiología es aún desconocida. Actualmente se presenta en gran parte de la distribución natural de la especie y tiene importante impacto ecológico, económico, social y paisajístico.

El mal del ciprés se caracteriza por marchitamiento y defoliación progresivo del follaje, pudrición de raíces principales y muerte de árboles en pie. Las consecuencias de esta afección son muy importantes, tanto desde el punto de vista del manejo como de la conservación de una especie nativa. Los cambios que genera a nivel de la estructura y la dinámica natural de los bosques condicionan las posibilidades de manejo silvícola, siendo también significativas las alteraciones generadas desde el punto de vista ecológico y de paisaje.

El creciente deterioro de los bosques nativos de A. chilensis, la importante dispersión de la mortalidad y el desconocimiento de las causas y factores que condicionan su aparición hacen necesario un abordaje multidisciplinario para establecer la etiología de esta mortalidad.

Un intenso trabajo de investigación bibliográfica (El Mujtar y Andenmatten, 2007 a y b) permitió establecer que los datos existentes eran insuficientes para discriminar entre los diferentes grupos 
de agentes de daño. La falta de signos, la inespecificidad de los síntomas asociados con la mortalidad y la dificultad para establecer la asociación espacial y los patrones de dispersión o propagación obligan a considerar la participación de diferentes agentes de daño (bióticos, abióticos o combinaciones de ambos) en el desarrollo del proceso y a considerar el diseño de ensayos o experimentos lo suficientemente robustos como para responder a los numerosos y complejos interrogantes relacionados con el mal del ciprés.

El presente trabajo de tesis se enmarca en un proyecto de investigación orientado a cubrir parte de este vacío de información a través de la búsqueda y la caracterización de agentes de daño asociados con el mal del ciprés y el análisis de la diversidad genética en plantas sintomáticas y asintomáticas (PICT 25518, Agencia Nacional de Promoción Científica y Tecnológica).

El objetivo principal de la tesis es contribuir al conocimiento de la mortalidad de $A$. chilensis mediante un análisis general que aporte información sobre diversos aspectos en el mismo grupo de individuos a fin de avanzar en la identificación de la etiología del o de los procesos actualmente englobados bajo la denominación mal del ciprés. 



\section{CAPITULO I}

MAL DEL CIPRÉS

UNA ENFERMEDAD COMPLEJA DE ETIOLOGÍA DESCONOCIDA 

"En cuanto a la sintomatología, el mal mencionado carece de sintomas patológicos manifiestos y su origen, que podría ser fitopatológico -causado por hongos, bacterias o agentes ultramicroscópicos de tipo virus- o biológico-fisiogénico, no de orden patológico, no está fehacientemente determinado, por lo que desde la aparición de la calamidad hasta hoy lleva la denominación de "mal del ciprés".

El párrafo anterior fue extraído del Informe Histórico de los estudios realizados sobre el “mal del ciprés" de la Cordillera (Austrocedrus chilensis) publicado por Hranilovich (1988). Aunque Varsavsky et al. (1975) realizan la primera publicación científica sobre la mortalidad de ciprés; es Slavko Hranilovich quien señala la complejidad del problema y reseña los trabajos de investigación nacionales e internacionales desarrollados hasta ese momento. Es importante destacar que en dicha publicación, plasma el resultado de 35 años de observación, desde el momento del reporte de la mortalidad hasta la presentación del Informe Histórico y acuña el nombre "mal del ciprés" en base a la falta de conocimiento sobre la etiología del proceso.

El primer reporte de esta mortalidad, realizado por Demetrio Havrylenko, se remonta a mediados de la década del cuarenta, probablemente 1945, en Puerto Piedras Blancas, Isla Victoria, provincia de Neuquen. Sin embargo, no existen registros escritos de este reporte (María Havrylenko com. pers.) que se conoce a través de la publicación de Varsavsky et al. (1975) donde se lo menciona como comunicación personal con una referencia temporal aproximada. El segundo reporte, corresponde al año 1953 en cipresales adyacentes al Vivero Forestal General San Martín, Sección Golondrinas, al NO de la provincia de Chubut (Hranilovich, 1988). La aparición del problema, la evolución del mismo y las investigaciones realizadas pueden seguirse parcialmente a través de comunicaciones oficiales (Archivos Campo Forestal Gral. San MartínINTA Bariloche). Reportes posteriores, que figuran en los registros de la Administración de Parques Nacionales, dan cuenta de la detección de la mortalidad en el Lago Steffen en el año 1970 (Guardaparque Sección Inacayal) y en Villa La Angostura en el año 1972 (Guardaparque D. Williams) (Rosso, 1989).

\section{1.- CARACTERÍSTICAS GENERALES, HIPÓTESIS E INTERROGANTES EN RELACIÓN AL MAL DEL CIPRÉS}

La información que se detalla a continuación es el resultado de una revisión bibliográfica desarrollada a fin de establecer las características generales del mal del ciprés y conocer las hipótesis y modelos etiológicos propuestos para la mortalidad. 
Los datos recabados se emplearon, además, para conocer la evolución cronológica de cada uno de los aspectos analizados. Esta caracterización cronológica es útil para evaluar el progreso de la investigación y los cambios de modelos etiológicos derivados de la misma; sin embargo debe ser considerada teniendo en cuenta que se basa en la información disponible y que el mayor o menor grado de publicación de un grupo o línea de investigación puede influir en la tendencia observada.

\section{1.- SíNTOMAS Y DESARROLLO DEL MAL DEL CIPRÉS A NIVEL DE INDIVIDUO}

Las primeras referencias al mal del ciprés, lo describen como un marchitamiento o secamiento, acompañado de defoliación gradual que lleva a la muerte del árbol, mencionándose también el cambio de coloración del follaje y la presencia de pudriciones de raíz (Varsavsky et al., 1975; Merlo, 1985; Hranilovich, 1988). Havrylenko et al. (1989) realizan el primer análisis sistemático de la sintomatología señalando la ausencia de signos visibles y la falta de asociación entre el patrón de síntomas y afecciones conocidas. Los síntomas observados en individuos de ciprés de la cordillera afectados por mal del ciprés, pueden dividirse en tres grupos principales: aéreos o de copa, subterráneos o de raíz y generales.

\subsection{1.- Síntomas aéreos o de copa}

Los síntomas aéreos son secamiento (o secado), marchitamiento, cambio de color del follaje y defoliación. Este grupo comprende todos aquellos síntomas evidentes en la observación a campo y en conjunto se corresponde con la apreciación inicial de la mortalidad (Figura I-1).
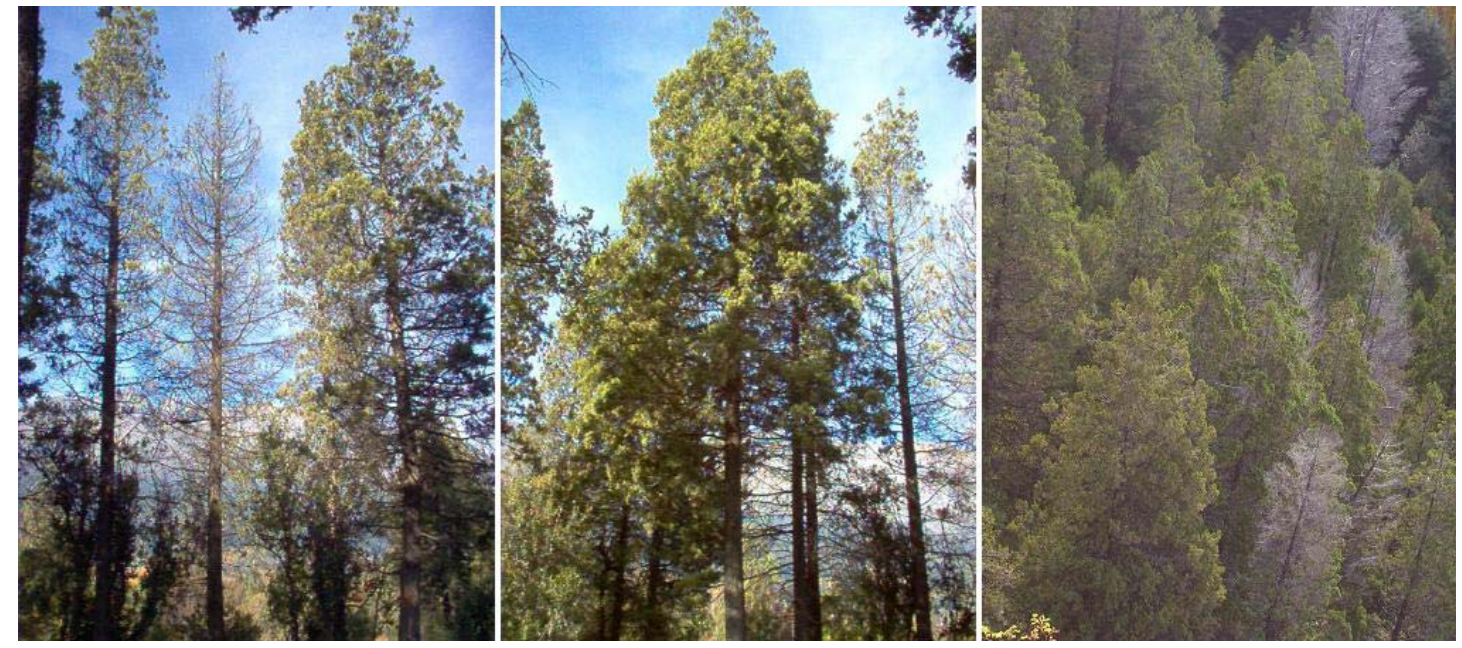

Figura I-1: Síntomas aéreos de mal del ciprés según se presentan en el bosque. Las imágenes muestran árboles con distinto grado de defoliación en comparación con árboles no afectados. 
El Gráfico I-1 presenta la evolución cronológica del reporte bibliográfico de este grupo de síntomas. La defoliación aparece como el síntoma reportado en forma más continua. Por el contrario, el término secamiento, fue utilizado sólo en las primeras descripciones (Hranilovich, 1964; Varsavksky et al., 1975; Hranilovich, 1988; Rosso et al., 1989). Marchitamiento y cambio de color del follaje, con una distribución relativamente constante en el tiempo, son reportados con menor frecuencia que la defoliación.

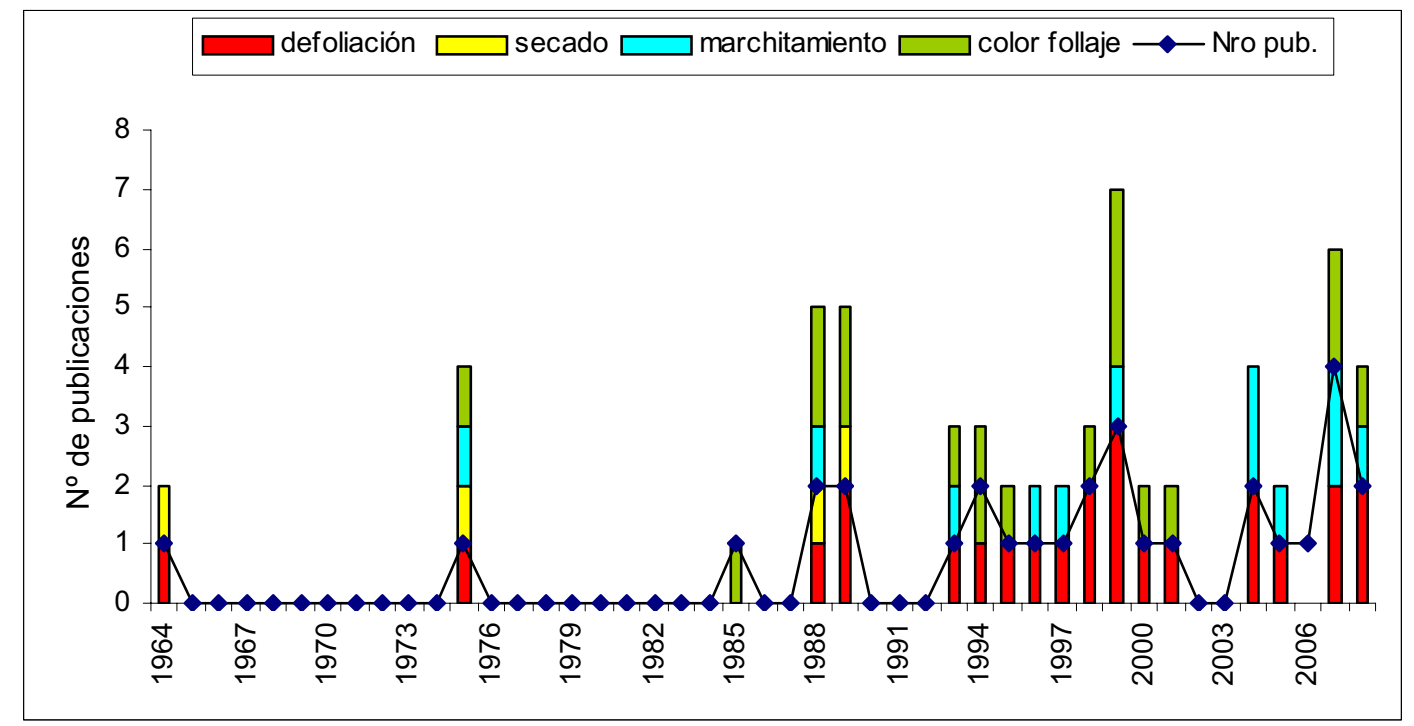

Gráfico I-1: Evolución cronológica del reporte bibliográfico de los síntomas aéreos. En ordenadas se representa el número de publicaciones que registra un determinado síntoma, el gráfico de línea representa el número total de publicaciones correspondiente a cada año.

Entre las descripciones utilizadas para indicar el cambio de color del follaje se encuentran amarillamiento, decoloración, clorosis, amarronamiento y follaje rojo. El amarillamiento es la descripción más ampliamente reportada (Gráfico I-2) y representa en gran medida la evolución del cambio de color del follaje registrada en la bibliografía. El término clorosis (Filip, 1995; Filip y Rosso, 1999) se emplea en asociación con amarillamiento, en tanto que decoloración se menciona sin ningún tipo de referencia (Havrylenko et al., 1989) o como un proceso gradual en que el color pasa de verde oliváceo y gris ceniciento al amarillo castaño opaco (Varsavsky et al., 1975).

El amarronamiento (Loguercio et al., 1999a; Hennon y Rajchenberg, 2000; La Manna et al., 2001; La Manna et al., 2008b), se menciona como etapa posterior al amarillamiento y previa a la caída foliar. La única excepción corresponde al reporte de Hennon y Rajchenberg (2000) donde se señala un amarronamiento rápido de todo el follaje en contraposición a la afección progresiva de la copa. Esta descripción de amarronamiento probablemente corresponda a la de follaje rojo (Filip, 1995; 
Fillip y Rosso, 1999) que se utilizó en forma inicial para indicar el cambio de coloración asociado a mortalidad rápida de árboles que puede o no estar ligada a defoliación (Greslebin y Hansen, 2007b; Floria y Greslebin, 2007).

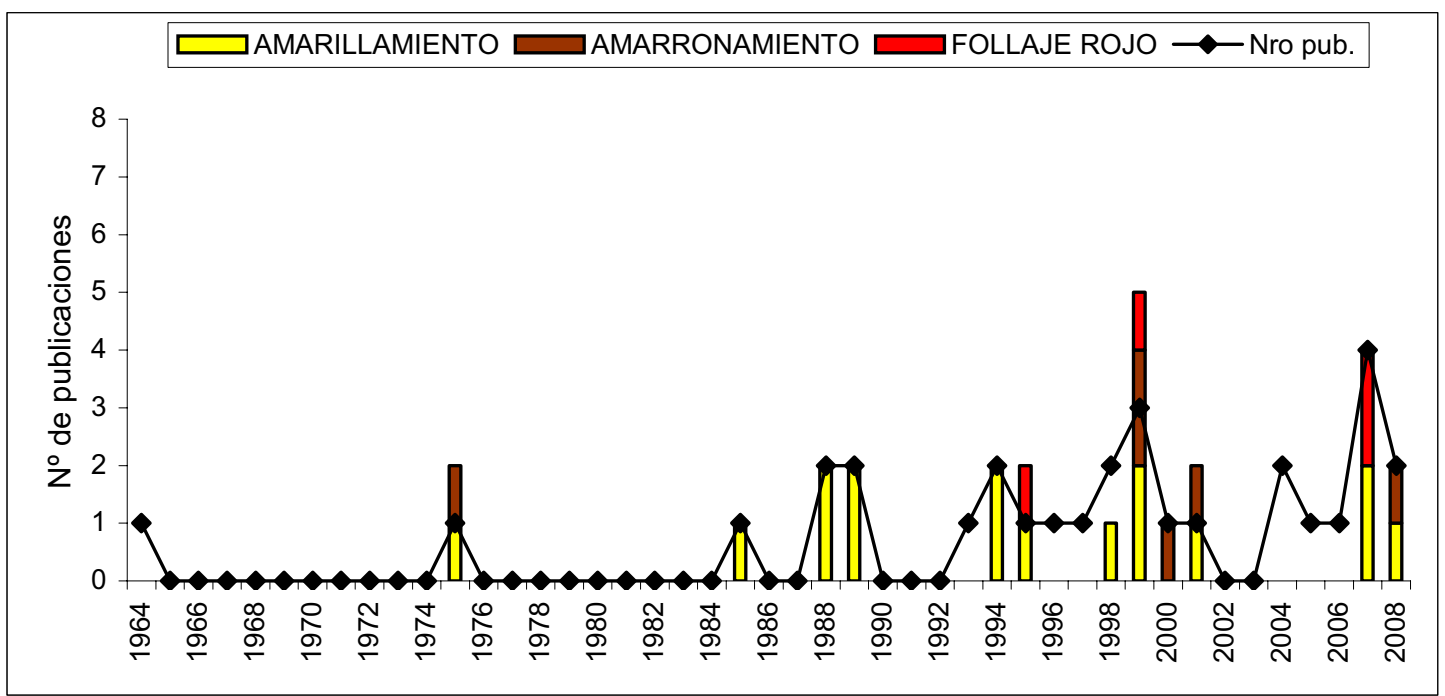

Gráfico I-2: Evolución cronológica del reporte bibliográfico del cambio de color del follaje. En ordenadas se representa el número de publicaciones que registra un determinado síntoma, el gráfico de línea representa el número total de publicaciones correspondiente a cada año. Amarillamiento incluye las descripciones clorosis y decoloración.

El patrón de desarrollo temporal a nivel de individuo se indica a través del marchitamiento y la defoliación. El marchitamiento se describe como progresivo en el 67\% de los casos (Rajchenberg y Cwielong, 1993; Rajchenberg et al., 1997; Loguercio et al., 1999a; La Manna y Rajchenberg, 2004a y b; Greslebin et al., 2005; Floria y Greslebin, 2007; La Manna et al. 2008a); en tanto que la defoliación se reporta como: progresiva (Barroetaveña y Rajchenberg, 1996; Hennon y Rajchenberg, 2000; La Manna et al., 2001, La Manna y Rajchenberg, 2004a y b; Greslebin et al., 2005; Greslebin y Hansen, 2007b; Floria y Greslebin, 2007; La Manna et al., 2008a y b), paulatina (Loguercio et al., 1998), gradual (Loguercio et al., 1999b; Filip y Rosso, 1999), parcial o total (Hranilovich, 1964; Rajchenberg y Cwielong, 1993; Rosso et al., 1994; Filip, 1995).

En el caso de la defoliación, también se caracteriza el patrón espacial como defoliación desde abajo (Varsavsky et al., 1975; Deschamps y Vizcarra Sánchez, 1988; Loguercio et al., 1999a) o de abajo-arriba y de dentro-afuera (Hennon y Rajchenberg, 2000). Havrylenko et al. (1989) describieron los patrones de defoliación observados en bosques de $A$. chilensis dividiéndolos en 5 clases principales: proximal en ramas inferiores, total en ramas inferiores, proximal generalizada, lateral y total (Figura I-2). 

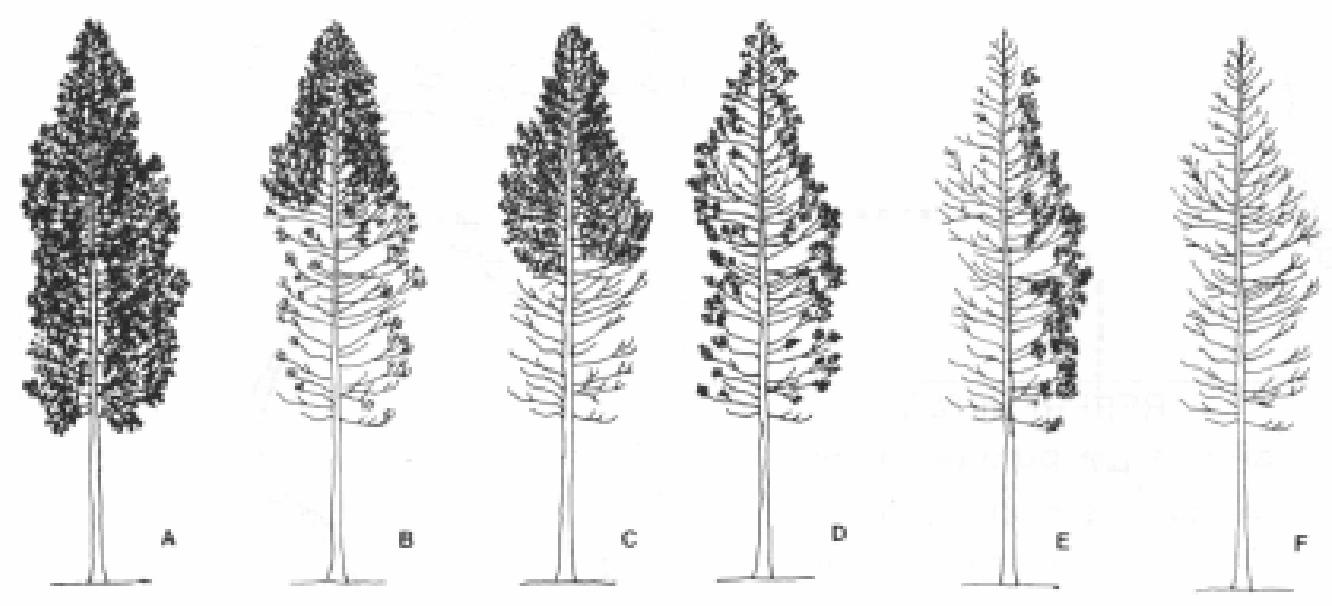

Figura I-2: Patrones de defoliación observados en bosques de A. chilensis. A: follaje completo. B: defoliación proximal. C: defoliación total en ramas inferiores. D: defoliación proximal generalizada. E: defoliación lateral. F: defoliación total. (Tomado de Havrylenko et al., 1989).

\subsection{2.- Síntomas subterráneos o de raíz}

Dentro de este grupo, se encuentran pudriciones, decaimientos y lesiones necróticas. Las pudriciones y lesiones necróticas pueden ser observadas también a nivel de cuello; sin embargo, se describen como síntomas subterráneos debido a que dicho hallazgo es siempre consecuencia de la afectación inicial de la raíz.

Dos tipos de pudriciones, cúbicas castañas y fibrilares blancas, se han reportado en forma simultánea o aislada sobre $A$. chilensis afectando albura y duramen (Varsavsky et al., 1975; Merlo, 1994; Havrylenko et al., 1989; Rajchenberg y Cwielong, 1993). En albura, Coniophora arida y Postia disecta, son responsables de las pudriciones castañas (83.3\% de los aislamientos) y Polyporus melanopus de las pudriciones blancas (3.8\% de los aislamientos); mientras que en duramen, una especie de la familia Hymenochaetaceae es responsable del 90.8\% de las pudriciones blancas céntricas o excéntricas (Barroetaveña y Rajchenberg, 1996).

El decaimiento o deterioro de raíz implica una pérdida de las características vitales de los tejidos como turgencia y coloración violácea de la corteza, coloración blanca en albura y rápida resinación ante el corte con cuchillo; que son reemplazadas por consistencia de corcho, coloración marrón opaca de la corteza, coloración beige, blanco ceniciento, amarillo-castaño o diversos tonos de marrón en albura, y resinación lenta o nula al corte con cuchillo (Loguercio y 
Rajchenberg, 2005). Sin embargo, este síntoma se reporta mayoritariamente sin una descripción detallada y como etapa previa al desarrollo de pudriciones.

En cuanto a las lesiones, Rosso et al. (1994) señalan necrosis de raíces finas y postulan la posible participación de agentes pitiáceos en el proceso; mientras que Filip (1995) menciona la presencia de tejido necrótico a nivel de cuello e indica la semejanza entre este tipo de lesiones y las producidas por Phytophthora lateralis en Chamaecyparis lawsoniana. Hennon y Rajchenberg (2000) describen el hallazgo de lesiones necróticas a nivel de cuello en algunos árboles, mencionando que la relación entre la presencia de estas lesiones y la muerte rápida de los mismos indicaría la existencia de hongos del género Phytophthora.

El reporte de pudriciones es relativamente constante desde el inicio de las investigaciones en mal del ciprés (Gráfico I-3). Por el contrario, el decaimiento de raíz y las lesiones necróticas (Gráfico I-3) comenzaron a reportarse a mediados de la década del noventa. La mayor frecuencia de reporte de lesiones necróticas en los últimos años (Gráfico I-3) se asocia al aislamiento de su agente causal, Phytophthora austrocedrae (Greslebin et al., 2007).

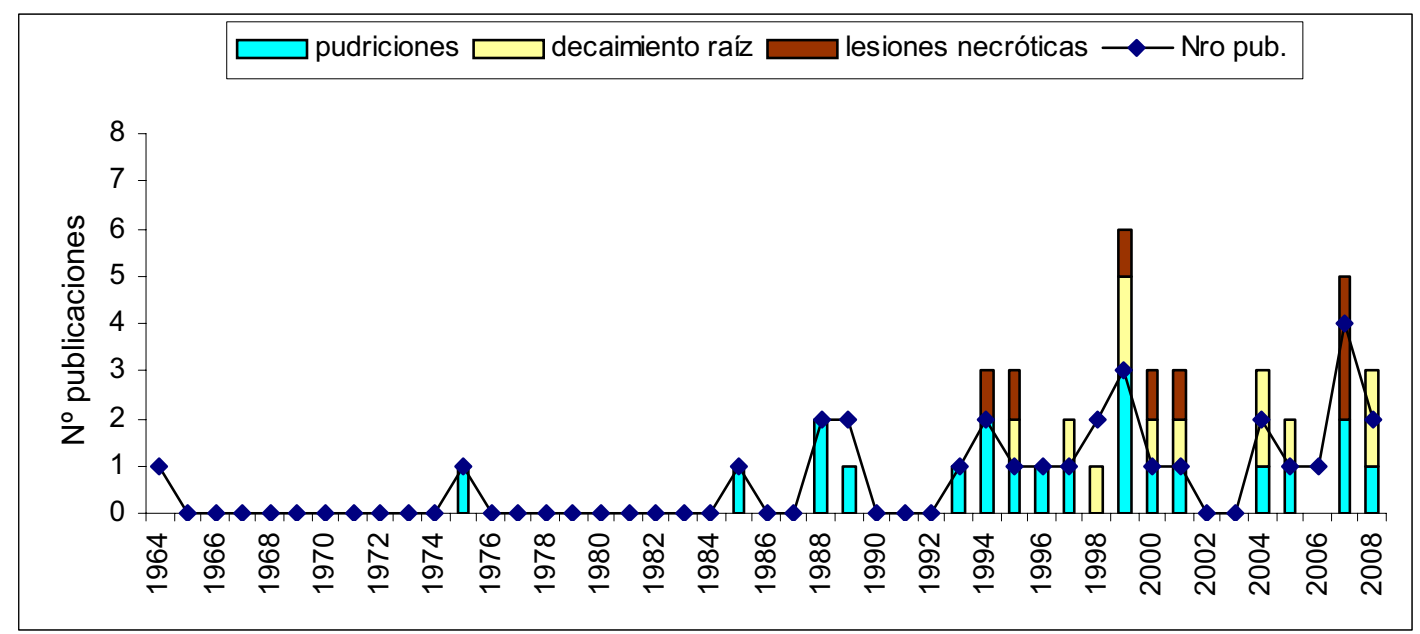

Gráfico I-3: Evolución cronológica del reporte bibliográfico de los síntomas subterráneos o de raíz. En ordenadas se representa el número de publicaciones que registra un determinado síntoma, el gráfico de línea representa el número total de publicaciones correspondiente a cada año.

Actualmente, las lesiones necróticas que afectan floema, se clasifican en tres grandes grupos: activas, inactivas y antiguas (Figura I-3). Las lesiones activas son húmedas al tacto y de color canela intenso; las inactivas secas y de color marrón oscuro; mientras que las antiguas, también de color marrón oscuro, se diferencian de las inactivas por su aspecto hundido y la presencia de tejido vivo que sobrecrece en los límites de la lesión (Floria, 2008). Las lesiones inactivas y 
antiguas son más frecuentemente detectadas que las lesiones activas, aunque las frecuencias relativas pueden variar con la época del año y los sitios (El Mujtar, obs. pers.; Greslebin, com. pers.).
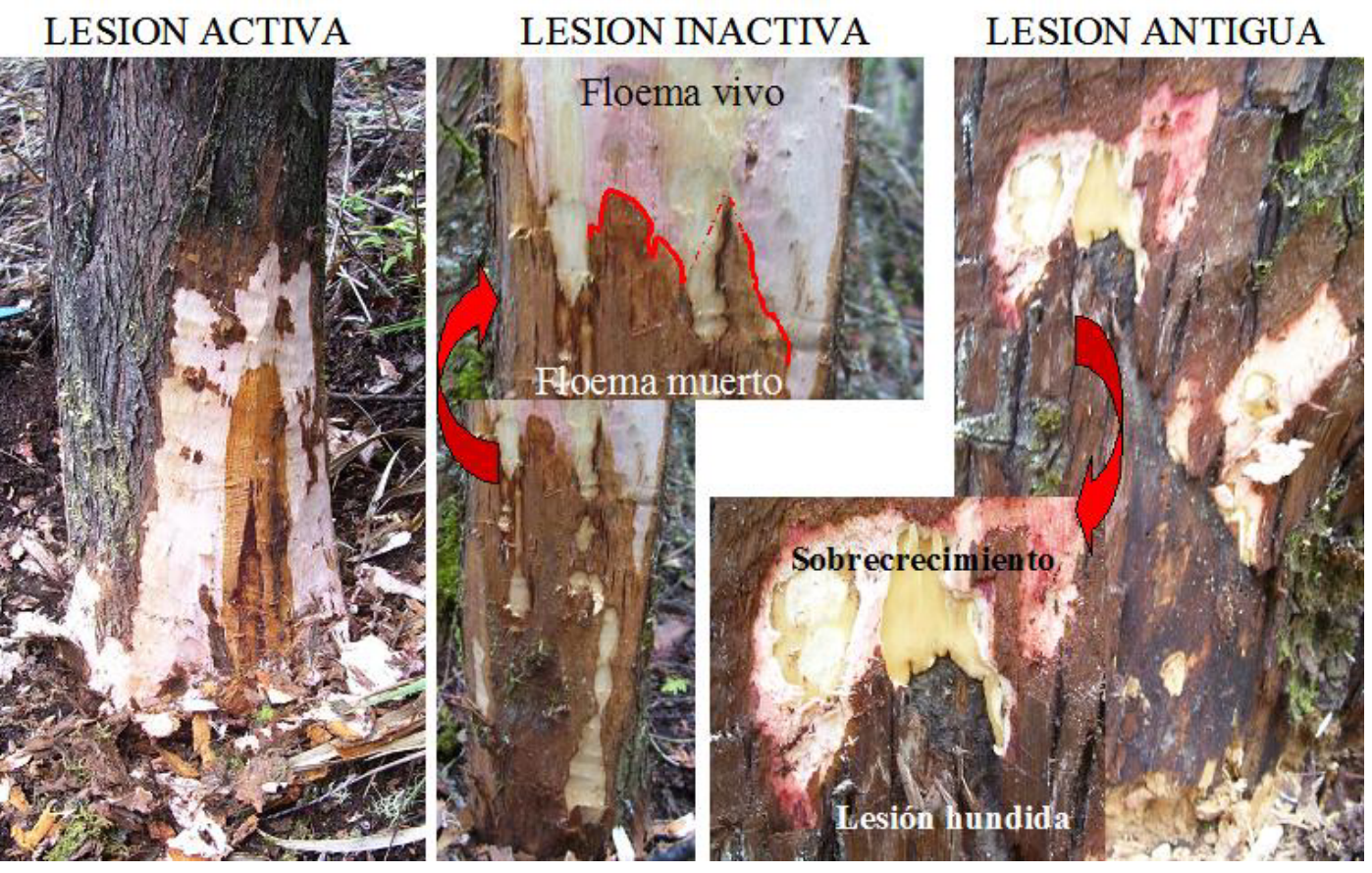

Figura I-3: Lesiones necróticas producidas por $P$. austrocedrae en A. chilensis. La coloración marrón de las lesiones contrasta con el color rosado del floema activo. Las flechas rojas señalan imágenes ampliadas mostrando en detalle el límite entre floema vivo y muerto en una lesión inactiva y la presencia de tejido vivo que crece por sobre el límite de una lesión antigua.

\subsection{3.- Síntomas generales}

Fructificación y resinación se encuentran dentro del grupo de síntomas generales. La fructificación ha sido escasamente reportada, y no existe acuerdo general sobre su inclusión en el conjunto de síntomas del mal del ciprés (Havrylenko et al., 1989; Rosso, 1989). Para la resinación se menciona presencia abundante y característica en la parte inferior del fuste (Merlo, 1985 y 1994; Rajchenberg y Cwielong, 1993; Rajchenberg et al., 1997) y cambio de las propiedades, pasando de color ambarino o ámbar translucida a blanca opaca (Varsavsky et al., 1975; Hranilovich, 1988). Havrylenko et al. (1989), por el contrario, la excluyen como síntoma por detectarla en individuos afectados y no afectados. Recientemente se describieron dos formas de resinación, localizada que hace referencia a la presencia de chorros de resina en puntos determinados del fuste, y difusa que indica gotas dispersas sin punto de salida definido (Floria y Greslebin, 2007). La resinación localizada (Figura I-4) presenta asociación positiva con el porcentaje de tejido afectado por lesiones necróticas en raíz y cuello del árbol (Floria y Greslebin, 2007). 

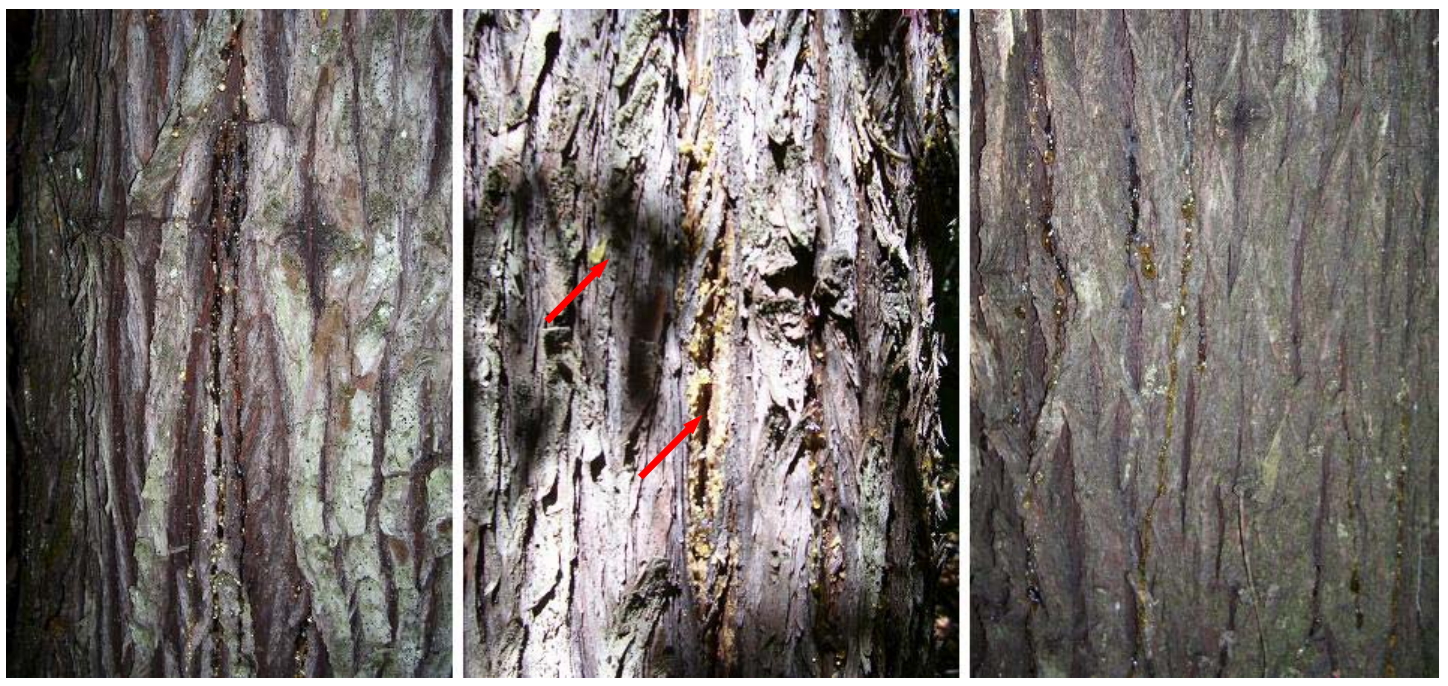

Figura I-4: Detalle de resinación en fuste de A. chilensis. En las imágenes de izquierda y derecha la resinación es color ámbar y translúcida. En la imagen del centro la resinación se observa en la grieta central y a su izquierda como grumos de resina blanca opaca (flechas rojas).

La caída de árboles por acción del viento se relaciona generalmente con el mal del ciprés. Sin embargo, desde los primeros reportes se señala que tanto árboles secos como verdes pueden ser volteados y que esta caída estaría en realidad asociada a la presencia de pudriciones (Varsavsky et al., 1975; Hranilovich, 1988; Deschamps y Vizcarra Sánchez, 1988; Havrylenko et al., 1989; Rajchenberg y Cwielong, 1993; Loguercio et al., 1999a). Por otro lado, se reporta que árboles afectados pueden permanecer luego de muertos largo tiempo en pie (Varsavsky et al., 1975; Hranilovich, 1988; La Manna y Rajchenberg, 2004b).

Además de los tres grupos de síntomas principales mencionados, se ha señalado que árboles de cualquier edad pueden ser afectados por mal del ciprés (Hranilovich, 1964; Varsavsky et al., 1975; Hranilovich, 1988; Havrylenko et al., 1989; Rosso et al., 1994; Loguercio et al., 1999a) o bien que la mortalidad es de carácter ontogénico (Merlo, 1985 y 1994; Deschamps y Vizcarra Sánchez, 1988). Sin embargo, no existen estudios que confirmen estas apreciaciones, en algunos casos se utiliza a la clase diamétrica como indicador de edad, mientras que en otros no se reporta el método utilizado para estimarla. En cuanto a clase diamétrica y posición sociológica, se señala que el mal del ciprés no está restringido a grupos definidos (Hranilovich, 1988; Rosso et al., 1994; Loguercio et al., 1999a; Filip y Rosso, 1999).

Aunque se han diferenciado dos tipos de mortalidad, progresiva y rápida (Filip y Rosso, 1999, Hennon y Rajchenberg, 2000), existen pocos trabajos que evalúen el desarrollo temporal a nivel de individuo o de bosque. Gran parte de la caracterización a nivel individual proviene de las 
observaciones del grado de afectación sobre el conjunto de ejemplares en un sitio (Varsavsky et al. 1975). Havrylenko et al. (1989) realizaron un seguimiento cuatrimestral de árboles durante un lapso de un año, estableciendo que los síntomas podían agravarse o mantenerse en el tiempo, variando los resultados obtenidos de acuerdo con el sitio. Calí (1996), a través de un estudio dendrocronológico en bosques de $A$. chilensis con presencia de mal del ciprés, determinó que la manifestación externa de la afección se correlaciona con una caída del crecimiento radial que comienza, por lo general, varios años antes que la sintomatología de la copa. Loguercio et al. (1998 y 1999a) mediante un estudio comparativo de crecimiento de pares de árboles dominantes con y sin síntomas de mal del ciprés establecieron que existen dos tipos de evolución temporal en la reducción del crecimiento: drástica (período de 5 a 25 años) y lenta (25 a 55 años).

\section{2.- DISTRIBUCIÓN DEL MAL DEL CIPRÉS A NIVEL DE BOSQUE}

Aunque los primeros reportes del mal del ciprés se remontan a 1945-1953, fue recién a fines de la década del ochenta que se iniciaron estudios de la distribución o dispersión de la mortalidad. Rosso (1989) definió tres niveles de análisis: macroescala o escala regional, que comprende el área de distribución de ciprés de la cordillera en Argentina y Chile; mesoescala, que se restringe a los límites de una población; y microescala, que contempla los individuos dentro de un área afectada por mal del ciprés. Mediante el establecimiento de 32 parcelas en el Parque Nacional Nahuel Huapi, realizó un análisis parcial a nivel de macroescala y caracterizó la distribución a nivel de mesoescala; en tanto que, utilizó 4 parcelas para determinar a nivel de microescala la disposición espacial de los árboles con síntomas respecto de los árboles sin síntomas de mal del ciprés.

La información recabada indica que la mortalidad presenta amplia dispersión dentro del Parque Nacional Nahuel Huapi, encontrándose zonas afectadas en la parte Norte (Lago Traful), centro (Isla Victoria, Llao-Llao, Lago Gutierrez, área urbana y suburbana de Bariloche, Cerro Campanario, Cerro Otto) y Sur (Lago Mascardi, Río Manso Inferior); aunque las mismas se hayan dispersas entre áreas de bosque sin síntomas de mal del ciprés. El tamaño y la forma de las parcelas es un indicador del tamaño de afección por mal del ciprés, mostrando que los parches varían entre 1.5 ha y 33 ha. A nivel de mesoescala, las parcelas presentan distribución homogénea de la mortalidad, pero no siempre reflejaron el estado sanitario general de la población, indicando que la mortalidad dentro de las poblaciones se presenta en grupos compactos o abiertos. Aplicando el método de cálculo de la segregación espacial de Pielou (1974) a parcelas con incidencias superiores a 25\%, se determinó que a nivel de microescala la disposición espacial sería agregada; es decir que el estado sanitario de un individuo no sería independiente del estado sanitario de su vecino más cercano (Rosso, 1989). 
El patrón espacial de árboles afectados a nivel de microescala indica agregación para una distancia de conexión definida ( 3 metros), aunque los valores de correlación varían de acuerdo con el nivel de incidencia y las condiciones ambientales de la parcela (Rosso et al., 1994). Los índices no serían significativos para altos valores de incidencia, dando segregación al azar. Sin embargo, es importante mencionar que en las parcelas empleadas la incidencia de la mortalidad no fue nunca inferior al 50\%. El patrón de agregación espacial entre individuos sintomáticos no ha sido establecido en sitios con incidencias inferiores al 50\%.

El mapeo de tres tipos de bosques de $A$. chilensis (bosque afectado por mal del ciprés, bosque asintomático denso y bosque asintomático ralo) mediante la aplicación de imágenes satelitales SPOT PAN y XS muestra que los parches con síntomas de defoliación y mortalidad no están agrupados ni limitados a un sector y que no hay evidencias de avance continuo y radial desde un centro de dispersión (La Manna et al., 2008b). La extensión de los parches de bosques con mal del ciprés o asintomático denso, varían entre 0.04-7.79 ha y 0.09-249.50 ha, respectivamente.

Las áreas afectadas por mal del ciprés se clasifican, por otra parte, según la observación visual de la distribución como agregadas o desagregadas (Figura I-5). Las primeras corresponden a zonas con síntomas claramente diferenciadas de las áreas asintomáticas que las rodean, mientras que en las desagregadas los árboles con síntomas se distribuyen uniformemente en un área (Shurtleff y Averre, 1997).
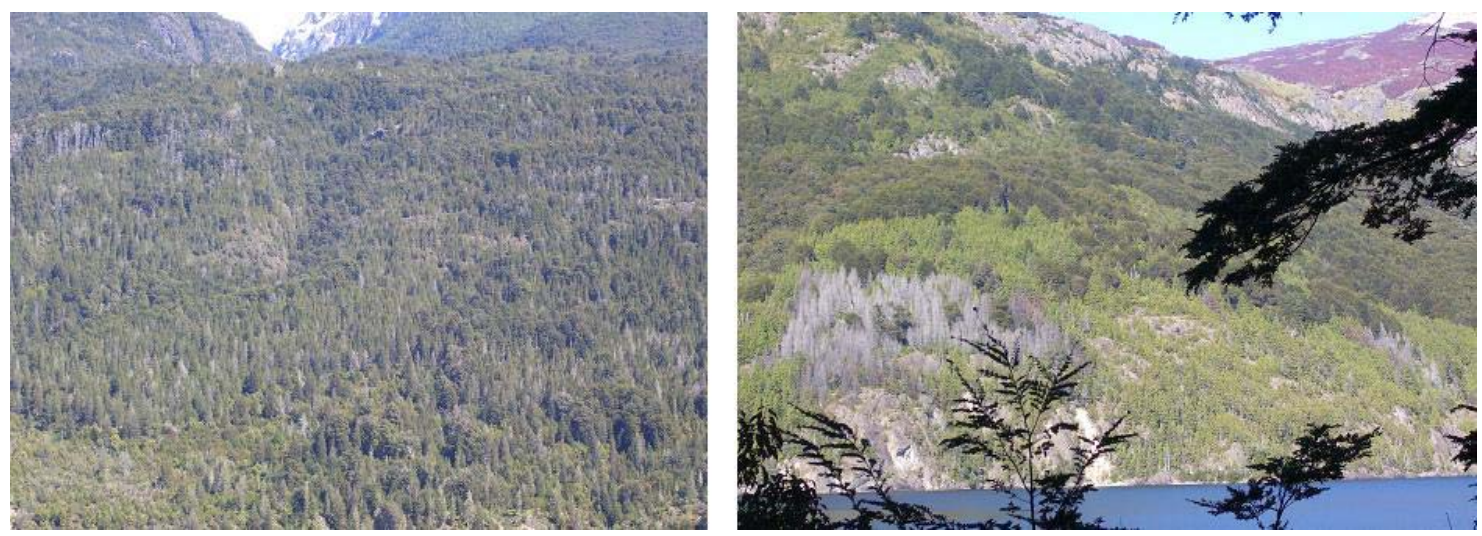

Figura I-5: Distribución del mal del ciprés a nivel de bosque. A la izquierda se observa el patrón desagregado con árboles sintomáticos dispersos entre árboles asintomáticos. A la derecha se observa el patrón agregado con árboles sintomáticos circunscriptos a un área bien definida. 


\section{3.- CUANTIFICACIÓN DEL MAL DEL CIPRÉS}

La cuantificación del mal del ciprés, al igual que su distribución, requiere un análisis en diferentes escalas. A nivel de individuo una sistematización de la intensidad de afectación fue establecida por Rajchenberg y Cwielong (1993), quienes propusieron una clasificación según seis estados de vitalidad de acuerdo con el porcentaje de defoliación y características de copa, corteza y hojas (Figura I-6). Esta clasificación asociada a defoliación gradual, se basa en el patrón de defoliación proximal generalizado (Figura I-2) propuesto por Havrylenko et al. (1989). Sin embargo, hasta el momento no se ha establecido un método objetivo para estimar el porcentaje de defoliación, y no existe acuerdo general sobre la forma de considerar la competencia al momento de determinar las características de la copa.

\begin{tabular}{|c|c|c|c|}
\hline \multicolumn{2}{|l|}{ Vitalidad } & Características & \% Defolis dión \\
\hline \multirow[t]{2}{*}{ Sano } & 0 & Copa oerrada & $0-10$ \\
\hline & 1 & Hojas verde intenso & $10-25$ \\
\hline \multirow[t]{2}{*}{ Enfermo } & 2 & $\begin{array}{l}\text { Cops abierta u hojas susentes en } \\
\text { el oentro del fuste, hojas verdes } 0 \\
\text { marchitadgs }\end{array}$ & $25 \cdot 60$ \\
\hline & 3 & $\begin{array}{l}\text { Cops abierts con hojas solamente } \\
\text { en el extemo de las ramas, hojas } \\
\text { verdes o marchitadas }\end{array}$ & \\
\hline \multirow[t]{2}{*}{ Muerto } & 4 & $\begin{array}{l}\text { Árbol muerto en pie } \\
\text { recientemente corteza inaltersds }\end{array}$ & 100 \\
\hline & 5 & $\begin{array}{l}\text { Árbol muerto en pie haœ } 2-3 \text { años } \\
\text { crtezs sgrietsda y } \\
\text { Iongitudinalmente hendida }\end{array}$ & 100 \\
\hline
\end{tabular}

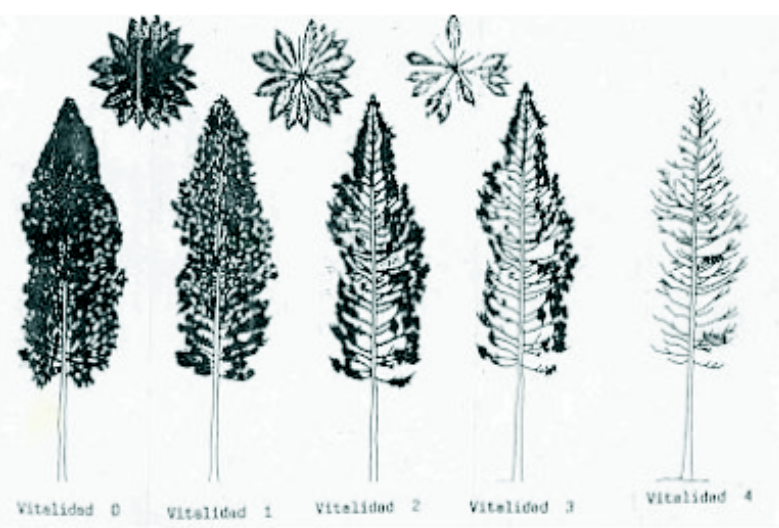

Figura I-6: Clasificación por tipo de vitalidad, según características de copa y porcentaje de defoliación. (Tomado de Rajchenberg y Cwielong, 1993).

A nivel de parcela o microescala, Rosso (1989) evaluó tres métodos para estimar la incidencia del mal del ciprés: recuento in situ de individuos con y sin síntomas, recuento con binoculares, y recuento sobre fotografías a color en base a la diferencia de coloración entre ambos estados sanitarios. Las mayores diferencias (2.21\% de desvío estándar) se dan entre los métodos de binoculares y/o fotografías y el método de recuento in situ. Los valores de incidencia en el área del Parque Nacional Nahuel Huapi variaron entre 5\% y 70\%; correspondiendo las parcelas de mayor afectación a Isla Victoria, Llao-Llao, área urbana de Bariloche (Av. Pioneros y Bustillo), Lagos Traful, Gutierrez y Mascardi. El método de recuento in situ fue utilizado por Calí (1996) quien estableció valores de incidencia de 73\% (Llao-Llao) y 50.5\% (Bahía Gutierrez) y Loguercio et al. (1998) que determinaron valores de incidencia en el rango de $28 \%$ a $86 \%$ para parcelas permanentes establecida en la Reserva Forestal Loma del Medio-Río Azul (Río Negro). 
El valor más frecuente de clase de vitalidad (Rajchenberg y Cwielong, 1993) y el porcentaje de área basal afectada, calculado como el porcentaje de área basal de ciprés en las clases de vitalidad 23 (enfermo) y 4-5 (muerto) respecto del área basal total de ciprés, son otros dos métodos que se utilizan para estimar la incidencia de mortalidad (La Manna, 2004; La Manna y Rajchenberg, 2004a; La Manna et al., 2008a; Loguercio et al., 1998 y 1999a). En un estudio de las características estructurales de los bosques de $A$. chilensis afectados por la mortalidad, se reportaron valores medios de incidencia (en \% de área basal) de 44.3\%, 50.4\% y 42.8\% no existiendo diferencias significativas en función de las estructuras de bosque determinadas (La Manna et al., 2006).

Los datos de incidencia a nivel de microescala muestran que, más allá de los métodos empleados para la estimación, el nivel de afectación es altamente variable con valores de incidencia que oscilan entre 5\% y $80 \%$. Es importante resaltar que en todos los estudios mencionados, la incidencia se calcula en base a la suma de los árboles con síntomas y árboles muertos asumiendo que la mortalidad es consecuencia directa de la presencia del mal del ciprés.

La primer cuantificación a nivel de macroescala corresponde a la zona del Valle 16 de Octubre (Chubut). El mapeo realizado por La Manna et al. (2008b) permitió establecer que la superficie de bosque afectada por mal del ciprés representa un $24 \%$ de la superficie total de bosque evaluada.

\section{4.- PATRón ECOLÓGico del MAL DEL CIPRÉS}

La presencia del mal del ciprés se reportó inicialmente asociada a sitios secos y húmedos, sobre suelos muy diversos, afectando individuos en diferentes exposiciones y en predios vírgenes o con algún tratamiento cultural o de aprovechamiento (Hranilovich, 1988). Sin embargo, mayor densidad y diversidad de especies arbóreas, precipitación superior a $900 \mathrm{~mm}$ anuales, pendiente poco pronunciada y suelos de tipo ándico con porcentajes de materia orgánica superior en los dos primeros estratos y $\mathrm{pH}$ ligeramente ácido fueron las condiciones ambientales más relevantes asociadas a parcelas con mal del ciprés en uno de los primeros estudios comparativos entre áreas con y sin mortalidad (Havrylenko et al., 1989). La relación entre precipitación, pendiente, altitud y exposición con la incidencia de mal del ciprés, fue evaluada mediante análisis uni, bi y multivariados (Baccalá et al., 1998) determinando la existencia de un patrón ecológico para la mortalidad. Los resultados indican que altas incidencias se asocian con sitios de alta precipitación (> a $1.700 \mathrm{~mm} /$ año) y moderadas a bajas altitudes (< a 875 m.s.n.m); en tanto que, bajas incidencias o ausencia de mortalidad se observan en zonas de menor precipitación o en combinaciones de elevadas altitudes, pronunciadas pendientes y moderada a baja precipitación. 
Altitud y precipitación presentan bajos valores de correlación, por lo que la asociación con altitud podría indicar un efecto de la temperatura en la ocurrencia de la mortalidad, mientras que la exposición no mostró ser una variable relevante.

El mal del ciprés se presenta en sitios con suelos de diversos orígenes. A nivel de micrositio no existen diferencias químicas entre suelos con o sin mortalidad, en tanto que las siguientes variables muestran diferencias significativas: pendiente, densidad del horizonte A, abundancia de características redoximórficas, humedad volumétrica al final de la estación seca y agua retenida a presión de 1 bar en el horizonte C (La Manna y Rajchenberg, 2004b). En lo que se refiere a micrositio pendientes más pronunciadas y menores densidades se asociaron a parcelas asintomáticas; en tanto que, las propiedades redoximórficas tendieron a ser más abundantes y cercanas a la superficie en las parcelas sintomáticas, al igual que el contenido de humedad al final de la estación seca y el agua retenida en el horizonte C. La mayor retención de agua se asoció a textura fina del suelo en las parcelas sintomáticas (La Manna y Rajchenberg 2004a). A pesar de este patrón general de correlación entre la presencia de mal del ciprés y condiciones de pobre drenaje se observan algunas excepciones como por ejemplo un sitio (Lago Futalaufquen) cuyo material original correspondió a depósitos volcánicos tamaño pumita, con mejor retención de agua que los suelos de ceniza (La Manna, 2004). La pedregosidad y la pendiente pronunciada del suelo serían las características de micrositio relacionadas, en este caso, con la aparición de la mortalidad.

El estudio de la relación entre el tipo de suelo y la estructura del bosque de $A$. chilensis evidenció la importancia del material parental y el grado de alofanización de la ceniza volcánica como determinante del tipo de estructura, aunque la historia de disturbio sería también un factor condicionante (La Manna et al., 2006). El mal del ciprés se presenta en distintos tipos de estructura no existiendo diferencias en los valores de incidencia calculados como porcentaje de área basal de ciprés afectada por la mortalidad. A nivel de sitio, la estructura de las parcelas con y sin síntomas corresponden en su mayoría al mismo tipo de estructura y no evidencian diferencias en altura dominante y área basal. Las diferencias de micrositio entre estas parcelas no parece determinar diferencias significativas en la estructura del bosque.

\section{5.- AGENTES Y MODELOS ETIOLÓGICOS PROPUESTOS}

La ausencia de signos relevantes (Havrylenko et al., 1989), la falta de especificidad de los síntomas aéreos asociados (El Mujtar y Andenmatten, 2007a y b) y la gran variabilidad de condiciones en que el mal del ciprés se desarrolla limitó la elucidación de la etiología del proceso. Rosso (1989) señaló 
que no existe correlación entre la presencia de patógenos foliares y los síntomas externos principales (amarillamiento y defoliación) postulando que éstos serían síntomas secundarios derivados de alteraciones en otra parte de la planta. La asociación entre el mal del ciprés y la presencia de pudriciones de raíz llevó a proponer un probable origen biótico para la mortalidad (Varsavsky et al. 1975; Hranilovich, 1988; Deschamps y Vizcarra Sánchez, 1988; Merlo,1985 y 1994) (MODELO 1, Figura I-7). Sin embargo, Havrylenko et al. (1989) señalaron que el hallazgo de diferentes pudriciones, castañas o blancas, en albura o duramen, y la existencia de árboles con síntomas aéreos y ausencia de pudriciones indicaría que las mismas son producidas por organismos xilófagos que atacan un sistema ya debilitado. Considerando, además, las condiciones ambientales asociadas al desarrollo de la mortalidad plantearon como posible agente causal a un organismo biótico presente en la rizosfera (MODELo 2, Figura I-7). Alternativamente, basándose en el carácter saprofítico de las especies responsables de las pudriciones castañas de albura asociadas al mal del ciprés y considerando el efecto de las condiciones de sitio determinadas (relieves poco pronunciados, escasa profundidad del horizonte A, presencia de un horizonte arcilloso), Rajchenberg y Cwielong (1993) propusieron un origen abiótico o combinado para el proceso (Modelo 3, Figura I-7). Con base en los resultados obtenidos mediante el análisis de autocorrelación espacial, la detección de necrosis en raíces finas, la presencia de lesiones necróticas en cuello y las condiciones ambientales asociadas, el probable origen biótico de la mortalidad se restringió a hongos pitiaceos (Rosso et al., 1994; Filip, 1995; Rajchenberg et al., 1997; Filip y Rosso, 1999) (MODELO 4, Figura I-7). La existencia de un patrón ecológico asociado con el mal del ciprés (Baccalá et al., 1998), la relación entre eventos climáticos cálidos-secos y el inicio de la caída en la tasa de crecimiento radial (Calí, 1996), las similitudes entre el mal del ciprés y la mortalidad que afecta a Chamaecyparis nootkatiensis (Hennon y Rajchenberg, 2000) y el aislamiento desde suelos y cursos de agua en bosques de $A$. chilensis de especies no patogénicas del género Phytophthora (Greslebin et al., 2005) sentaron las bases para considerar al mal del ciprés dentro del grupo de las enfermedades de declinamiento. La relación entre la ocurrencia de la mortalidad y las condiciones de micrositio determinantes de un drenaje impedido (texturas finas, presencia de rasgos redoximórficos a escasa profundidad, cercanía a cursos de agua) sirvieron de base para postular la acción del sitio como factor predisponente dentro de un modelo de declinamiento para el mal del ciprés (La Manna, 2004; La Manna y Rajchenber, 2004a y b) (MODElo 5, Figura I-7). Recientemente, Greslebin y Hansen (2007a y b) propusieron a la especie patogénica Phytophthora austrocedrae (Greslebin et al., 2007), aislada desde lesiones necróticas de floema, como agente causal del mal del ciprés (MODELO 6, Figura I-7). 


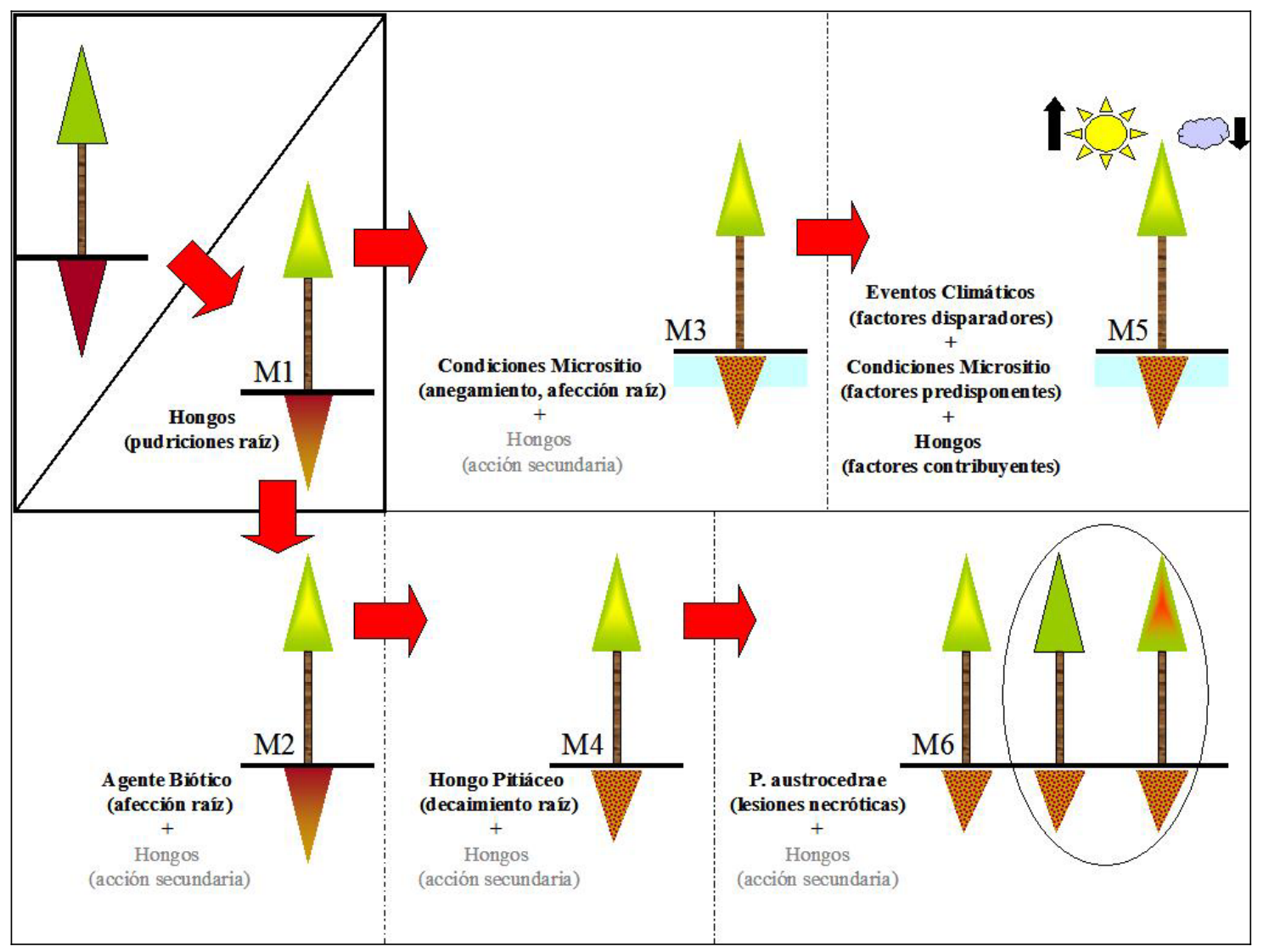

Figura I-7: Representación esquemática de los modelos (M) etiológicos propuestos para el mal del ciprés y las relaciones entre ellos. El árbol graficado en el vértice superior izquierdo representa las condiciones adecuadas de desarrollo. En negro se señalan los agentes primarios definidos para cada modelo, y en gris los agentes secundarios asociados. El óvalo negro en el M6, señala síntomas aéreos asociados al agente propuesto que no responden a la sintomatología clásica del mal del ciprés.

El Modelo 1 postuló que la defoliación y el amarillamiento son síntomas secundarios debidos a la alteración de las funciones biológicas de las raíces por efecto de las pudriciones. Las evaluaciones efectuadas mostraron que las pudriciones serían a su vez síntomas secundarios producidos por agentes xilófagos que afectan un sistema ya debilitado. El MODELO 2 postuló entonces, que el sistema es debilitado por un agente biótico de la rizosfera y que las condiciones ambientales asociadas son el resultado de los requerimientos para el desarrollo y la vehiculización del supuesto agente. El MoDELo 3, alternativamente, propuso un origen abiótico del debilitamiento debido a las condiciones de anoxia generadas por el drenaje impedido. Como las evidencias indicaron la ausencia de relación causal entre las condiciones de micrositio (anegamiento) y el desarrollo de la mortalidad, la asociación entre ambas se redujo a la acción como factor predisponente del proceso. El MODELo 5 incorporó la relación con eventos climáticos y postuló su participación como factores disparadores, completando así las características de una enfermedad de declinamiento. El MODELO 4, por su parte, acotó el origen 
a agentes bióticos específicos (pitiaceos) al incorporar la necrosis de raíces finas y el MODELO 6 lo ajustó completamente definiendo a una especie en particular como agente causal del proceso.

Cabe mencionar que los modelos planteados, si bien responden a los lineamientos generales de la investigación incorporando los conocimientos adquiridos y/o avanzando desde los más simples a los más complejos no han sido probados en forma completa. Por ejemplo, para el modelo de declinamiento, existe un importante cuerpo de información sobre la acción de condiciones de micrositio como posibles factores predisponentes, en tanto que los factores disparadores (climáticos) han sido evaluados, hasta el momento, únicamente en dos sitios y probados sólo en uno de ellos. Además, como se mencionó, existen áreas donde el origen de la mortalidad no se asocia con la acción predisponente de las condiciones de anegamiento, sino a un drenaje excesivo. Por otra parte, aunque la especie patogénica $P$. austrocedrae, propuesta como agente causal, ajusta el MoDELo 6 su participación no ha sido completamente demostrada; existiendo áreas con mal del ciprés en las cuales no se detecta la especie (Greslebin et al., 2007) e individuos con lesiones de P. austrocedrae que no responden a los síntomas aéreos definidos para el proceso. Árboles sin defoliación con numerosas e importantes lesiones necróticas a nivel de cuello, árboles defoliados con pocas o sin lesiones necróticas y árboles totalmente rojos o amarillo intenso que conservan gran parte de su follaje han sido reportados (Greslebin y Hansen, 2007b; Greslebin y Hansen, 2006). Para estos últimos se planteó mortalidad rápida (Filip, 1995; Filip y Rosso, 1999; Hennon y Rajchenberg, 2000; Greslebin y Hansen, 2006) en contraposición al desarrollo progresivo reportado para el mal del ciprés.

Todos los modelos etiológicos planteados en relación al mal del ciprés se basan en el supuesto de un origen radical del proceso y consideran que sea cual fuere el agente causal genera un desequilibrio entre los compartimentos aéreo y subterráneo de la planta, lo que conduce a estrés hídrico que sería en último término el responsable de la aparición de los síntomas aéreos (Modelo Ascendente, Figura I-8). Sin embargo, síntomas aéreos similares han sido descriptos en otras especies forestales, en cuyo caso el origen del proceso no es radical. El amarillamiento del olmo (Ulmus sp.) se caracteriza por pérdida de color y caída de hojas, que se acompaña por mortalidad previa de raíces finas (Sherald, 1999). En el caso del amarillamiento del fresno (Fraxinus sp.) los síntomas son inespecíficos y se confunden con los reportados para enfermedades causadas por factores ambientales (Roberts, 2004). Ambas enfermedades de amarillamiento son producidas por fitoplasmas, organismos procariotes sin pared celular verdadera, limitados a floema. Los marchitamientos vasculares, por otra parte, son producidos por bacterias que se multiplican dentro de los vasos del xilema o floema, causando muerte a 
distancia en las partes aéreas de la planta (Worral, 2005). En los amarillamientos producidos por fitoplasmas y los marchitamientos vasculares generados por bacterias, la afectación del compartimento de conducción lleva a un estado de estrés que determina la aparición de síntomas en la parte aérea y subterránea de la planta (MODELO MEDIO O DE DOBLE VÍA, Figura I-8).

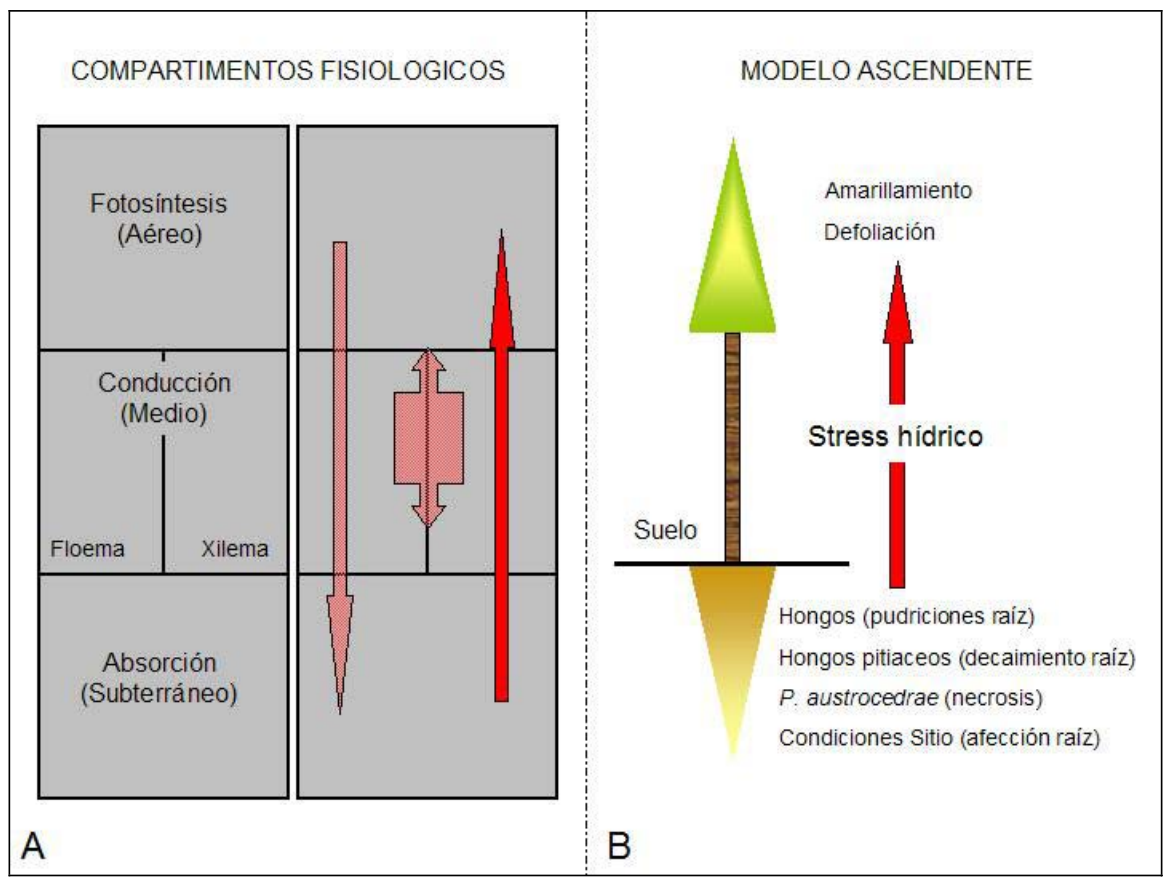

Figura I-8: Modelos etiológicos en relación a compartimentos fisiológicos. A- El modelo medio o de doble vía asienta en la afectación del compartimento de conducción; el modelo descendente en la afectación del compartimento aéreo; el modelo ascendente en la afectación del compartimento subterráneo. Flecha roja, indica modelo propuesto y evaluado. Flechas rojas translúcidas, modelos no contemplados en la investigación. B- Esquema general del modelo ascendente en el cual se basan los modelos etiológicos propuestos hasta el momento para el mal del ciprés.

Finalmente, aunque un origen a nivel del compartimento aéreo ha sido descartado en base a observaciones generales (Varsavsky, 1975; Rosso, 1989; Havrylenko et al., 1989), existe poca información sobre el efecto directo de agentes abióticos en la aparición de los síntomas de copa. Por otro lado, el impacto de insectos succionadores tampoco ha sido estudiado, a pesar de existir reportes de su presencia. En el declinamiento de Acer saccharum (Horsley et al., 2000) se demostró la existencia de fuerte correlación entre eventos de ataque por insectos y el estado sanitario, señalándose que el efecto de la defoliación en los carbohidratos estructurales de la planta (mayoritariamente reservas de almidón de las raíces) tendría un rol crítico en el vigor del árbol. La afección del compartimento aéreo, implica alteración o disminución global del proceso de fotosíntesis, lo que conduciría a una situación de estrés predisponiendo al ataque por organismos 
secundarios (MODELO DESCENDENTE, Figura I-8). En los compartimentos aéreo, subterráneo y medio, asientan funciones fisiológicas prioritarias para el crecimiento, mantenimiento y defensa de una planta; por tanto, el deterioro de cualquiera de ellos repercutirá necesariamente en los otros y en el vigor general.

Es importante destacar que la denominación mal del ciprés hace referencia a un síndrome complejo que nuclea eventos de mortalidad. En los sesenta años de investigación transcurridos, se han detectado situaciones particulares que señalarían orígenes diversos $\mathrm{o}$, al menos, condiciones de desarrollo diferentes. Dos características de micrositio han sido relacionadas con la mortalidad, drenaje impedido o excesivo. En tanto que se señalan dos tipos de desarrollo a nivel de individuo, progresivo y rápido; y dos formas de distribución de los individuos afectados, agregada y desagregada. En la actualidad se observan diferentes formas de asociación entre síntomas, detectándose árboles sin defoliación con importantes lesiones necróticas a nivel de cuello o raíz, árboles defoliados sin presencia de lesiones necróticas y árboles no defoliados con alteraciones del color de follaje (rojo o amarillo intenso).

Si bien, la mortalidad ha sido detectada en bosques con diferente tipo de estructura y afectando individuos de diversas clases diamétricas y posiciones sociológicas, es poco lo que se conoce sobre la incidencia de la mortalidad en función de la edad de los individuos y sobre la distinción entre la defoliación asociada al mal del ciprés y la apertura de copa derivada del proceso natural de competencia intra o inter-específica.

\section{2.- AUSTROCEDRUS CHILENSIS: CARACTERÍSTICAS GENERALES DE LA ESPECIE AFECTADA POR EL MAL DEL CIPRÉS}

Ciprés de la cordillera es el nombre común de una especie nativa de los bosques subantárticos de Argentina y Chile. Su nombre científico, Austrocedrus chilensis (D. Don) Pic. Serm. et Bizarri, fue acuñado en el año 1978 por Rodolpho Pichi-Sermoli y María Bizarri quienes la ubicaron dentro del género Austrocedrus, en la familia Cupresssaceae.

\section{1.- DISTRIBUCIÓN Y SUPERFICIE DE LOS BOSQUES DE $\boldsymbol{A}$. CHILENSIS}

La especie $A$. chilensis se distribuye a ambos lados de la cordillera de los Andes a lo largo de una franja discontinua de no más de $50 \mathrm{~km}$ de ancho, constituida por parches de bosque de tamaño variado, separados por grandes extensiones donde aparecen bosquetes o árboles aislados (Gallo et al., 2004). En Argentina el extremo Norte se encuentra en Huinganco-Cañada Molina 


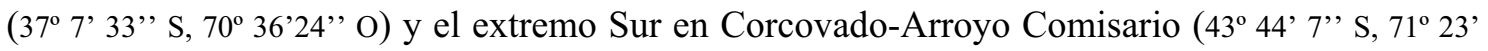
58" O) (Bran et al., 2004; Pastorino et al., 2006). En Chile se distribuye entre los $32^{\circ} 39^{\prime} \mathrm{S}$ y $\operatorname{los} 44^{\circ} \mathrm{S}$ (Schmithüsen, 1960; Schlegel, 1962). El extremo oriental se encuentra en Argentina, en El Cudío $\left(37^{\circ} 15^{\prime} 35^{\prime}\right.$ ' S, $\left.70^{\circ} 30^{\prime} 14^{\prime \prime} \mathrm{O}\right)$ (Pastorino et al., 2006), mientras que el extremo occidental se localizaría en Chile, entre los $37^{\circ} 30^{\prime} \mathrm{S}$ (Cordillera de Nahuelbuta) y los $40^{\circ} 20^{\prime} \mathrm{S}$ (Río Bueno) (Veblen y Schlegel, 1982).

De acuerdo con el Informe Regional Bosque Andino Patagónico del Primer Inventario Nacional de Bosques Nativos (Mendez y La Rocca, 2007), los bosques de ciprés de la cordillera se encuentran en la parte Norte del distrito de Bosque Caducifolio cubriendo 153.567 ha. Los bosques puros de ciprés ocupan una superficie de 51.922 ha representando el $33.8 \%$ de la superficie total; en tanto que las asociaciones forestales en las que ciprés constituye la especie dominante representan el 27.7\% (42.611 ha). La asociación ciprés-lenga (Nothofagus pumilio) cubre 7.995 ha y se restringe a la provincia de Neuquen, al igual que las asociaciones ciprés-radal (Lomatia hirsuta) con 11.966 ha y ciprés-ñire (Nothofagus antártica) con 8.357 ha. Por el contrario, la asociación ciprés-coihue (Nothofagus dombeyi) se encuentra en las provincias de Neuquen, Río Negro y Chubut, correspondiendo 14.293 ha a bosques con predominio de ciprés y 29.077 ha a bosques con predominio de coihue. Los bosques mixtos ciprés-coihue, aquellos en que no existe predomino de una especie sobre otra, cubren 12.516 ha entre las provincias de Neuquen y Chubut.

\section{2.- TIPOS FORESTALES Y DISTRIBUCIÓN ECOLÓGICA DE LOS BOSQUES DE $A$. CHILENSIS}

Los bosques de ciprés de la cordillera constituyen un "cinturón de frontera" entre dos regiones ecológicas bien definidas, los bosques húmedos de Nothofagus al Oeste y la estepa patagónica al Este. En la gran heterogeneidad ambiental, del gradiente O-E, han sido definidos cinco tipos forestales: mixto marginal, bosque mixto, bosque compacto, bosque marginal y marginal extremo (Dezzotti y Sancholuz, 1991; Pastorino y Gallo, 2002; Gallo et al., 2004).

El tipo forestal mixto marginal, se desarrolla en áreas con precipitación media anual superior a $2.000 \mathrm{~mm}$ y comprende pequeños bosquetes o individuos aislados de ciprés en afloramientos rocosos dentro de una matriz continua de $N$. dombeyi. En el bosque mixto (Figura I-9A), A. chilensis y Nothofagus sp. constituyen asociaciones boscosas, con una densidad media de ciprés de 460 individuos/ha, aunque su composición relativa disminuye hacia el Oeste. Estos bosques se encuentran en zonas con precipitación media anual entre 1.600 y $2.000 \mathrm{~mm}$. Los bosques compactos (Figura I-9B), son rodales puros de $A$. chilensis, con una densidad media de 798 individuos/ha, que desarrollan en áreas de precipitación media anual entre 900 y 1.600 mm; 
es en este tipo de bosque donde se observan los mejores fenotipos forestales de ciprés de la cordillera. Los bosques marginales (Figura I-9C), comprenden grupos de cipreses aislados, que crecen en colinas rocosas con precipitación media anual entre 600 y $900 \mathrm{~mm}$, conforman el ecotono con la estepa y tienen una densidad media de 268 individuos/ha. El tipo forestal marginal extremo, está representado por grupos de árboles centenarios, aislados en la cima de afloramientos rocosos, rodeados de una matriz de estepa, en áreas con precipitación media anual entre los 300 y $600 \mathrm{~mm}$. Este tipo forestal se caracteriza por la fisonomía xérica del hábitat en que desarrollan los individuos, muchos de los cuales son clonales (hasta 15 pies por individuo).

En los $1.230 \mathrm{~km}$ de su rango latitudinal, $A$. chilensis se desarrolla en un marcado gradiente de altitudes, suelos, temperaturas y precipitaciones. En Argentina el gradiente de precipitación media anual, en sentido Oeste-Este, va desde los $3.000 \mathrm{~mm}$ en la frontera con Chile a casi 300 $\mathrm{mm}$ en la estepa patagónica en una distancia de aproximadamente $100 \mathrm{~km}$; mientras que en Chile se observa un gradiente Norte-Sur que va desde $\operatorname{los} 300 \mathrm{~mm}$ a los $3.500 \mathrm{~mm}$ (Gallo et al., 2004).
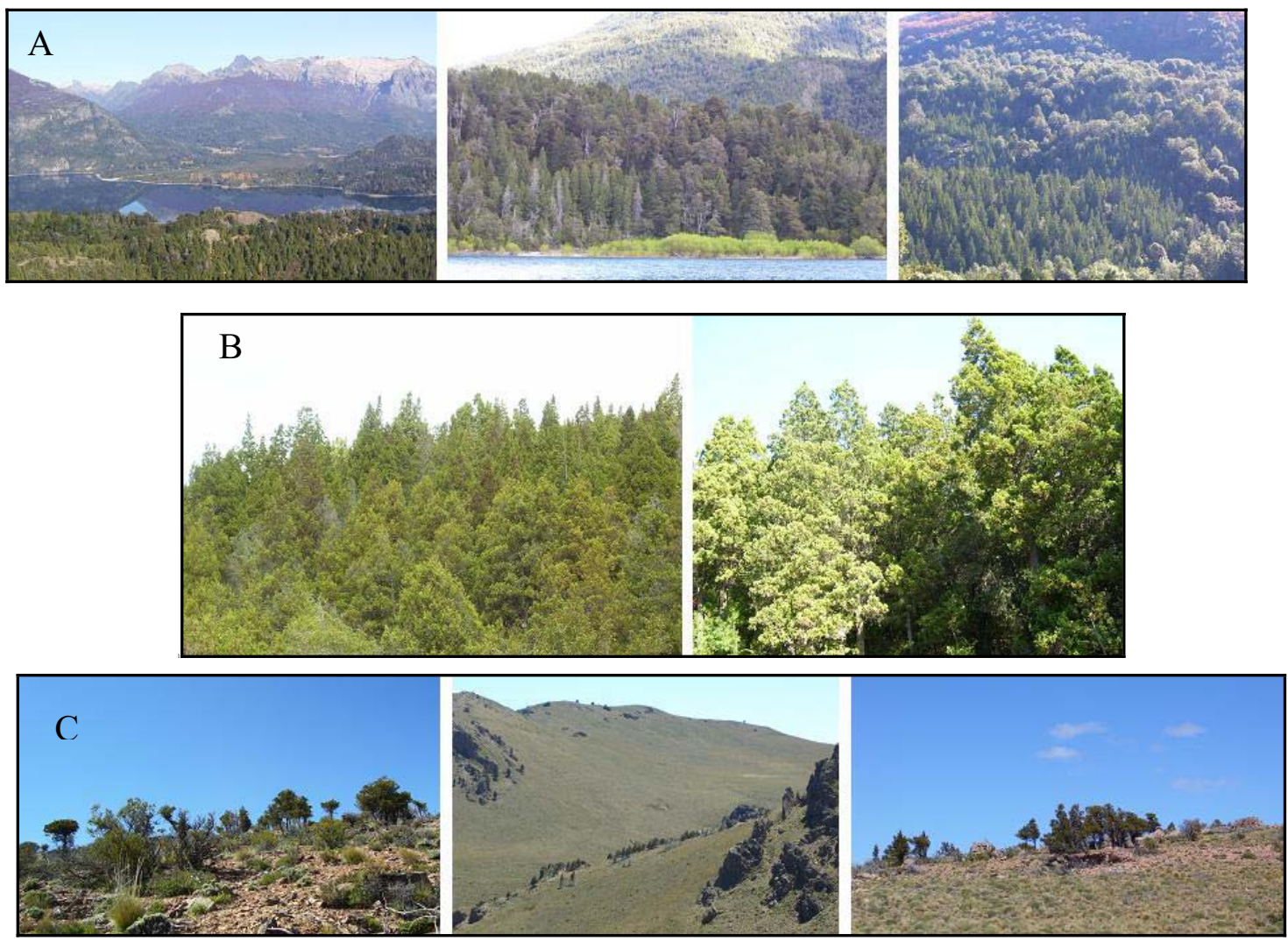

Figura I-9: Principales tipos forestales de A. chilensis. A- Bosque mixto. B- Bosque compacto. C- Bosque marginal. 
A. chilensis puede desarrollar en suelos de composición y profundidad variables, con texturas arenosas hasta arcillosas (Donoso 1982, 1993) y sobre lavas volcánicas (Donoso, 1993). En los Andes chilenos lo hace sobre suelos en general poco desarrollados, rocas graníticas o andesíticas, conglomerados volcánicos o granitos y muchas veces en depósitos de cenizas volcánicas que forman trumaos (Donoso et al., 2006). En Argentina los mejores bosques se encuentran sobre suelos alofánicos y profundos, pero también desarrolla sobre suelos rocosos y someros, o promontorios de tobas volcánicas (Tortorelli, 1956; Hueck, 1978; Gallo et al., 2004). Los bosque densos y puros de A. chilensis desarrollan sobre suelos de origen y características diversas, arcillosos que alternan exceso o falta de agua durante las distintas estaciones, volcánicos profundos con contenido adecuado de humedad, e incluso suelos vérticos con fuertes dificultades de enraizamiento, sistemas radicales superficiales y horizontales, y evidencias de anegamiento a escasa profundidad (La Manna, 2004).

\section{3.- CARACTERÍSTICAS GENERALES Y ADAPTACIONES MORFOLÓGICAS DE $A$. CHILENSIS}

Los individuos de ciprés de la cordillera se describen generalmente como ejemplares de copa cónica, angosta o piramidal, fuste recto, 20-25 m de altura. Sin embargo, las características de la copa, fuste, altura y diámetro varían de acuerdo con las condiciones de sitio (suelo y clima) y el grado de competencia en que los individuos se desarrollan. Árboles aislados poseen ramas verdes, vivas, que llegan incluso cerca del suelo (Figura I-10 A, B, C). Dentro del bosque las ramas inferiores se secan (Figura I-10 D, E, F), hasta unos dos tercios de la altura total, quedando retenidas en la planta. En lugares con exposición al viento a menudo se observa una copa unilateral denominada "en bandera"; mientras que en sitios con alta competencia puede darse desarrollo parcial de la copa (Figura I-10 F). La adaptación fenotípica de la especie en respuesta a fuertes vientos, alta competencia intra e interespecífica y/o alta precipitación nívea se manifiesta en la variación clinal Este-Oeste con individuos bajos de copa globosa en poblaciones marginales xéricas (Figura I-10 B), individuos de porte cónico en poblaciones mésicas (Figura I-10 A) y conicidad acentuada en poblaciones mixtas o en laderas empinadas a mayores alturas (Gallo et al., 2004).

A. chilensis se caracteriza por presentar ramitas comprimidas y hojas opuestas, decusadas y escuamiformes con bandas estomáticas blanquecinas (Figura I-11); siendo las hojas laterales más grandes, anquiladas y curvadas que las faciales (Dimitri, 1989). Existen diferencias de desarrollo entre ambos tipos de hojas, las laterales son comprimidas en su ancho, y las faciales (anteroposteriores) más pequeñas, imbricadas y cubiertas por las primeras (Grosfeld, 2002). 


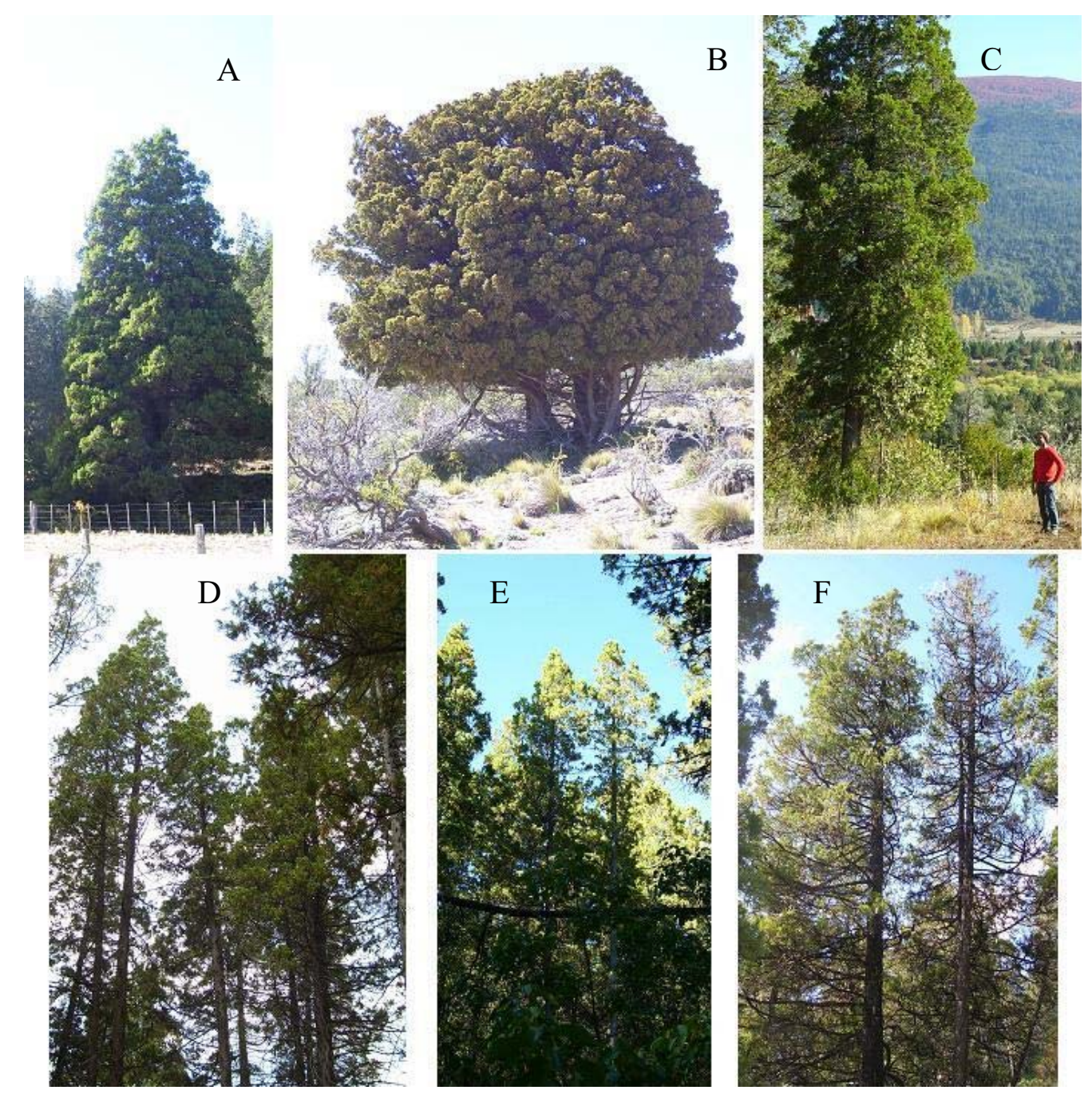

Figura I-10: Diversidad de copa en A. chilensis según condiciones de sitio y grado de competencia. A-C: Árboles aislados o con bajo nivel de competencia, desarrollan copa globosa o cónica, con ramas vivas cercanas al suelo. D-F: Árboles en competencia desarrollan copa con ramas inferiores secas, ramas vivas lejos del suelo, y en algunos casos copas incompletas.

Las características de las hojas cambian en respuesta a las condiciones de desarrollo, evidenciando otra forma de adaptación fenotípica en la especie. Plantas de sol y sombra presentan la misma descripción general pero varían en dimensiones y coloración de las hojas (Figura I-11), observándose una correlación negativa entre la intensidad lumínica y la distancia máxima entre hojas opuestas y una correlación positiva con el área foliar específica (Letourneau, 2006). Por otra parte, hacia las poblaciones más xéricas se observa disminución del tamaño de las hojas escuamiformes y aumento de la proporción ocupada por la banda estomática señalando una forma de respuesta a la pérdida de agua en condiciones ambientales extremas (Gallo et al., 2004). 


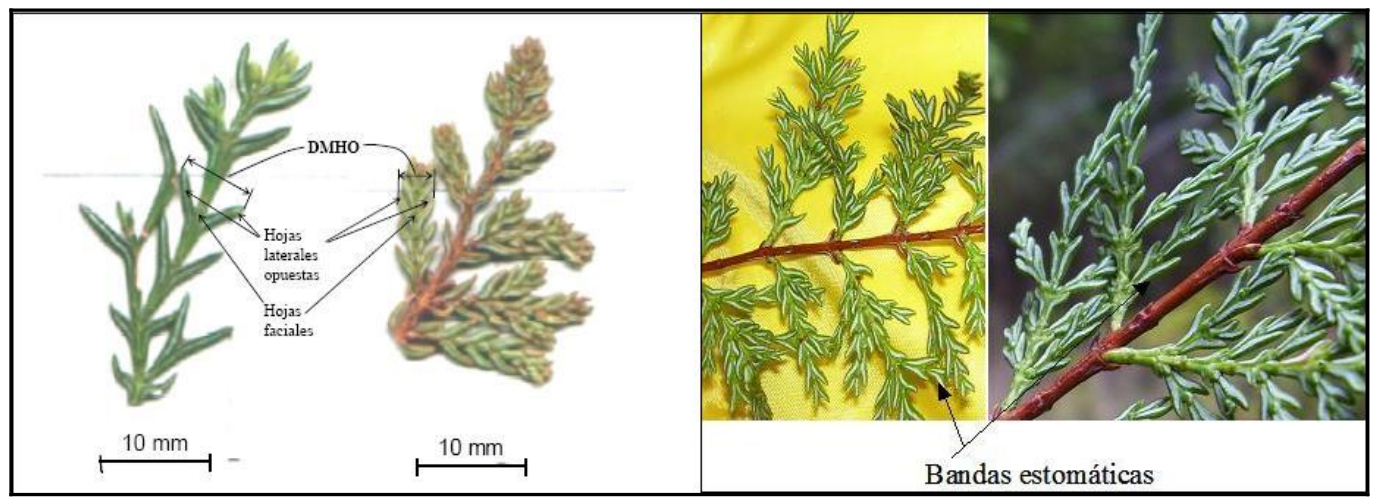

Figura I-11: Características de ramas y hojas en A. chilensis. En la imagen de la derecha se pueden apreciar, como líneas blancas, las bandas estomáticas. La imagen de la izquierda (tomada de Letourneau, 2006) muestra la adaptación fenotípica en hojas de sol (derecha) y sombra (izquierda) y la diferencia correspondiente en la distancia máxima entre hojas opuestas (DMHO).

\section{4.- IMPORTANCIA DE LOS BOSQUES DE $A$. CHILENSIS Y PRINCIPALES DISTURBIOS}

En Argentina los asentamientos humanos se encuentran altamente relacionados con los bosques de $A$. chilensis. Madera de buena calidad, leña y microambientes favorables determinaron en gran medida esta asociación, siendo la especie un importante recurso ecológico, social y paisajístico. La madera de ciprés de la cordillera es de textura fina, veteado suave, nudosa, de olor característico, con un peso específico de $0.45-0.50 \mathrm{~g} / \mathrm{cm}^{3}$, albura blanco amarillenta y duramen castaño ocráceo claro (Diaz-Vaz, 1985; Dimitri, 1989). Moderadamente durable, con una vida útil de 5 a 15 años en ausencia de tratamiento de preservación, fácil de trabajar, cepillar y encolar (Rodríguez, 2004). Actualmente se utiliza en revestimientos interiores y exteriores (casas y cabañas), en mueblería, artesanía y postes. Existe un importante mercado con precios que la ubican entre las más cotizadas de las coníferas comercializadas en Argentina. Su importancia económica se relaciona, por otra parte, con sus particularidades paisajísticas que hacen de las áreas en las que se distribuye puntos turísticos de relevancia nacional e internacional.

La explotación maderera con escaso manejo silvícola, los incendios forestales y el uso ganadero constituyen desde fines del siglo XIX los disturbios de origen antrópico más importantes que afectan la dinámica natural de los bosques de ciprés de la cordillera. A ellos se suma desde mediados de siglo XX el efecto de ramoneo por mamíferos introducidos desde Europa (ciervo rojo y ciervo dama), que modifica el proceso de regeneración por dinámica de claros. Entre los disturbios naturales se encuentran el fuego, los movimientos sísmicos, el viento y las condiciones climáticas; pudiendo estas últimas actuar en forma directa sobre el establecimiento o la mortalidad de individuos o indirectamente modificando la frecuencia o intensidad de otros disturbios (Veblen et al., 2005). 


\section{5.- ESTADO SANITARIO DE LOS BOSQUES DE $A$. CHILENSIS}

La sanidad de los bosques de $A$. chilensis es afectada por la presencia de enfermedades y plagas forestales (Donoso et al., 2006; Rajchenberg y Gomez, 2005).

Entre las primeras se encuentran:

- enfermedades de plántulas (descriptas en invernáculo), como el moho gris producido por Botrytis sp. o el damping off por Fusarium sp.

- enfermedades de fuste, del tipo de pudriciones de duramen debidas a una especie de la familia Hymenochaetaceae o de albura generadas por Aphylloporales

- enfermedades foliares, como la roya del ciprés que se presenta en áreas de bosque mixto y la afección por Lophodermiun sp.

- y enfermedades de raíz producidas por la recientemente descripta especie Phytophthora austrocedrae (Greslebin et al., 2007).

Entre las plagas se encuentran::

- insectos que atacan raíces produciendo mortalidad y pérdida de crecimiento, como Hylamorpha elegans, Phitoloema germani y Guemmophorus niger, frecuentes en vivero

- ácaros de la familia Tarsonemidae, que pueden producir daño en frutos, ramas y follaje de ciprés, dando origen a una típica formación en roseta

- $\quad$ en el orden Lepidoptera las familias Elachistidae y Tortricidae se alimentan de frutos y semillas, siendo Nanodacna austrocedrella la especie que produce mayor daño

- y barrenadores de tallo y raíz entre los que se encuentran Nyctelia sp., Sericoides glacialis y Anthaxia concinna.

Dos especies del género Cinara se describen entre los insectos succionadores que afectan ciprés, C. tujafilina y C. cupressi. En Chile, C. cupressi mostró gran capacidad de dispersión, adaptabilidad a climas y especies huéspedes, afectando los géneros Austrocedrus, Cupressus, Chamaecyparis, Juniperus y Thuja. La afección de A. chilensis por C. cupressi en Chile constituye el principal problema sanitario de la especie, con un porcentaje de mortalidad del $30 \%$ en sectores de la Cordillera de la VI Región (Holgmren, 2006). En Argentina C. cupressi afecta cipreses exóticos (Delfino y Binazi, 2005), pero no existen hasta el momento datos cuantitativos de afección ni dispersión en el área de distribución de ciprés de la cordillera.

El principal problema sanitario de los bosques de A. chilensis en Argentina es la presencia del denominado "mal del ciprés" cuya etiología continúa siendo desconocida. 


\section{3.- OBJETIVO GENERAL DE LA TESIS Y ASPECTOS A INVESTIGAR EN RELACIÓN CON EL MAL DEL CIPRÉS}

El análisis sistemático de toda la información recabada en la búsqueda bibliográfica fue útil para conocer en detalle las características generales del mal del ciprés y la evolución cronológica de cada uno de los síntomas reportados y de los modelos etiológicos propuestos en relación a la mortalidad. A su vez, este conocimiento permitió detectar algunos aspectos para los cuales no existe información previa y que ameritan el inicio de una investigación.

El mal del ciprés se presenta según dos patrones de distribución, agregado y desagregado. El patrón agregado, se asocia mayoritariamente a condiciones de sitio que determinarían la afectación de un grupo cercano de árboles. El patrón desagregado, por su parte, se interpreta en términos de diferencias genéticas entre los individuos dentro de un sitio, que determinarían una mayor resistencia o susceptibilidad al mal del ciprés. Sin embargo, hasta el momento del inicio del presente trabajo de tesis no existía ningún estudio sobre las diferencias genéticas entre individuos sintomáticos y asintomáticos. Entre los principales tipos forestales constituidos por A. chilensis, el mal del ciprés afecta únicamente los bosques húmedos mixtos y los bosques mésicos puros. La ausencia del mal del ciprés en bosques xéricos marginales se explica en función del patrón ecológico establecido para la mortalidad; esto es, alta precipitación, moderadas a bajas altitudes, pendientes poco pronunciadas. La influencia de la diversidad genética de la especie en el patrón de distribución no había sido considerada con anterioridad al desarrollo de la presente tesis, aunque la diferenciación genética entre poblaciones xéricas y mésicas (o húmedas) está sólidamente establecida.

Seis modelos etiológicos se propusieron para el mal del ciprés, avanzando desde los más simples a los más complejos e incorporando los conocimientos adquiridos. Actualmente existen dos modelos que se aplican como marco de referencia en las investigaciones realizadas. Uno contempla al mal del ciprés dentro de las enfermedades de declinamiento, y el otro considera que es una enfermedad de origen biótico producida por la especie patogénica $P$. austrocedrae. Hasta el momento ninguno de estos modelos fue probado en forma completa. Para el modelo de declinamiento, no se ha realizado nunca una investigación que evalúe factores predisponentes, disparadores y contribuyentes en el mismo grupo de individuos. El efecto disparador del clima se determinó sólo en un lugar. En cuanto a la acción predisponente del sitio, si bien la asociación entre las condiciones de pobre drenaje y la presencia del mal del ciprés está bien establecida, aún resta precisar la causa que determina dicha asociación. Por otra parte, la participación de $P$. austrocedrae no ha sido completamente demostrada; existiendo áreas con 
mal del ciprés en las cuales no se detecta la especie e individuos con lesiones de $P$. austrocedrae que no responden a los síntomas aéreos definidos para el proceso.

Modelos etiológicos alternativos, como la presencia de microorganismos (bacterias, fitoplasmas) en el sistema de conducción que determinen el estrés hídrico y el desbalance fisiológico de los individuos, o el impacto de insectos defoliadores que mediante alteración de la capacidad fotosintética de la copa afecten el balance entre el agua y el carbono, no han sido previamente considerados.

Entre los síntomas generales del mal del ciprés, la fructificación ha sido escasamente estudiada aunque refiere indirectamente a una afectación diferencial de sexos.

El objetivo principal de la tesis es contribuir al conocimiento de la mortalidad de $A$. chilensis mediante un análisis general que aporte información sobre diversos aspectos en el mismo grupo de individuos a fin de avanzar en la identificación de la etiología del o de los procesos actualmente englobados bajo la denominación mal del ciprés. El trabajo propuesto se orienta a responder algunos interrogantes relacionados con los siguientes aspectos aún no estudiados para el mal del ciprés:

\section{1.- CARACTERIZACIÓN GENÉTICA}

¿Existen diferencias genéticas entre individuos sintomáticos y asintomáticos?

¿Qué mecanismo genético determina el fenotipo: resistencia o susceptibilidad?

¿El patrón ecológico del mal del ciprés está determinado por las diferencias genéticas entre bosques mésicos y xéricos de $A$. chilensis?

\section{2.- AGENTES BIÓtICOS}

\subsection{1.- Phytophthora austrocedrae}

¿Cuál es el rol de $P$. austrocedrae en el mal del ciprés?

\subsection{2.- Áfidos del género Cinara}

¿Están los áfidos del género Cinara asociados al mal del ciprés?

¿Existe un impacto diferencial de Cinara cupressi entre individuos sintomáticos y asintomáticos?

\subsection{3.- Bacterias endógenas de xilema}

¿Existen bacterias en xilema de $A$. chilensis?

¿Están las bacterias de xilema asociadas al mal del ciprés? 


\section{3.- PATRONES DE CRECIMIENTO Y ASOCIACIÓN CON CLIMA}

¿Existen patrones de crecimiento diferenciales entre individuos sintomáticos y asintomáticos?

¿Estos patrones diferenciales tienen asociación con alguna variable climática?

\section{4.- SUSCEPTIBILIDAD DIFERENCIAL ENTRE SEXOS}

¿Son los individuos femeninos de A. chilensis más afectados que los individuos masculinos por el mal del ciprés?

¿Existen patrones de crecimiento diferenciales entre individuos femeninos y masculinos?

A pesar de la dificultad que plantea este tipo de investigación en sistemas biológicos altamente complejos, sometidos a diversas condiciones de estrés, en los cuales el estado sanitario resulta del balance o interacción entre impactos positivos y negativos diversos, la presentación del mal del ciprés en su forma desagregada ofrece un sistema de estudio adecuado para la investigación a desarrollar. Esta forma de distribución se caracteriza por presentar sectores de bosque que incluyen plantas sintomáticas y asintomáticas dentro de un ambiente que puede considerarse uniforme en sus características de microclima y micrositio. 



\section{CAPITULO II}

SELECCIÓN DE PARES DE PLANTAS ASINTOMÁTICAS Y SINTOMÁTICAS EN SECTORES DE BOSQUE CON PATRÓN DESAGREGADO DEL MAL DEL CIPRÉS 



\section{1.- INTRODUCCIÓN}

El "triángulo de enfermedad" es un modelo conceptual básico (Francl, 2001) que ilustra las condiciones necesarias para el establecimiento de una enfermedad; esto es, la interacción entre un huésped susceptible, un patógeno virulento y un ambiente favorable. La investigación desarrollada hasta el momento en el mal del ciprés señala que las condiciones de sitio influyen en el establecimiento de la mortalidad. Por tal motivo, para poder determinar la asociación entre el huésped y un posible agente de daño es necesario controlar la variación del ambiente. A pesar de la dificultad que plantea la investigación en sistemas biológicos altamente complejos, la presentación del mal del ciprés en su forma desagregada ofrece un sistema de estudio adecuado para la investigación a desarrollar. Esta forma de distribución se caracteriza por presentar plantas sintomáticas y asintomáticas dentro de un ambiente que puede considerarse uniforme en sus características de microclima y micrositio, permitiendo la selección de pares de plantas (caso/control) adecuados para estudios epidemiológicos.

La clasificación del estado sanitario de los individuos dentro de un bosque afectado por mal del ciprés se basa en la evaluación de síntomas inespecíficos como el grado de defoliación, amarillamiento y apertura de la copa. Las características de la copa en individuos de A. chilensis varían de acuerdo con el nivel de competencia experimentado durante el desarrollo. Individuos que crecen bajo intensa competencia desarrollan copas más abiertas y presentan menor vigor (Capitulo I), características que se confunden fácilmente con síntomas de mal del ciprés. Para evitar este tipo de incertezas en el presente trabajo de tesis se estableció un muestreo pareado de individuos que difieren en la sintomatología en tanto que comparten tamaño, posición sociológica y nivel de competencia. El diseño de pares planteado es útil para analizar las variables bajo estudio, en tanto que asegura mínima o nula variabilidad en el resto de los factores (microclima, micrositio, competencia, etc).

Estos pares de individuos caso/control (asintomático/sintomático) serán empleados a lo largo de todo el trabajo de tesis para establecer la asociación entre diferentes agentes de daño (bióticos y abióticos) y el mal del ciprés, y para determinar la influencia de la constitución genética de los individuos en la respuesta a este tipo de mortalidad. 


\section{2.- MATERIALES Y MÉTODOS}

\section{1.- ÁREA DE MUESTREO}

El segundo reporte bibliográfico sobre la ocurrencia del mal del ciprés tuvo lugar en el valle de El Bolsón. Sin embargo, sus bosques han sido escasamente incluidos en estudios etiológicos en comparación con los bosques del Parque Nacional Nahuel Huapi, Parque Nacional los Alerces y sus zonas de influencia.

Los bosques de $A$. chilensis que se desarrollan en el valle de El Bolsón fueron fuertemente afectados por los incendios de principio de siglo pasado generados para habilitar tierras para pastoreo y agricultura (Willis, 1914). Corresponden, en su gran mayoría, a bosques mésicos coetáneos y se encuentran entre las masas boscosas más importantes y extensas de la provincia de Río Negro (IFONA, 1986). La importancia de estos bosques, la falta de estudios específicos para el lugar y la presentación mayoritaria del mal del ciprés en su forma desagregada motivaron la elección de esta zona como área de muestreo.

El valle de El Bolsón, ubicado entre 200 y 400 m.s.n.m, está flanqueado por elevados cordones montañosos entre los que destacan Cerro Grande, Ventisquero, Hielo Azul, Lindo y Piltriquitrón. El gradiente de precipitación Oeste-Este, es modificado por la presencia de cordones montañosos paralelos a la cordillera de los Andes que separan el valle de la estepa. Como consecuencia, el área presenta un microclima benigno con valores de temperatura y precipitación superiores a los del resto de la región y escasos vientos entre los que predominan los de dirección Norte-Sur. Las precipitaciones se distribuyen de forma irregular a lo largo del año, mostrando un exceso de agua invernal (mayo-septiembre) y una deficiencia durante la temporada estival (diciembre-marzo) (Goya et al., 1995). El valor medio de precipitación anual es de 809 mm (período 1953-1989) (Krugliak, 1998), aunque existe un importante gradiente OesteEste. La temperatura media anual se encuentra alrededor de $\operatorname{los} 9^{\circ} \mathrm{C}$; $\sin$ embargo, a medida que aumenta la altitud disminuye la temperatura media y aumenta la amplitud térmica (Lanciotti y Cremona, 1999). Entre los cursos de agua que atraviesan la región, los más importantes son los ríos Azul y Quemquemtreu, que se unen al Sur de la localidad de El Bolsón y desembocan en el Lago Puelo. El Azul recibe el aporte de los ríos provenientes del Oeste, en tanto que el Quemquemtreu se alimenta de los ríos Repollos y Terneros y del arroyo del Medio (Figura II-1). La zona corresponde a un antiguo lecho lacunar de origen glaciario, con depósitos glacilacustres y glacifluviales; y fue sometida al efecto del vulcanismo (Seibert, 1982; Lanciotti y Cremona, 1999). Los suelos de la región corresponden al grupo de los Andisoles (Buamscha et al., 1998; La Manna, 2004). 

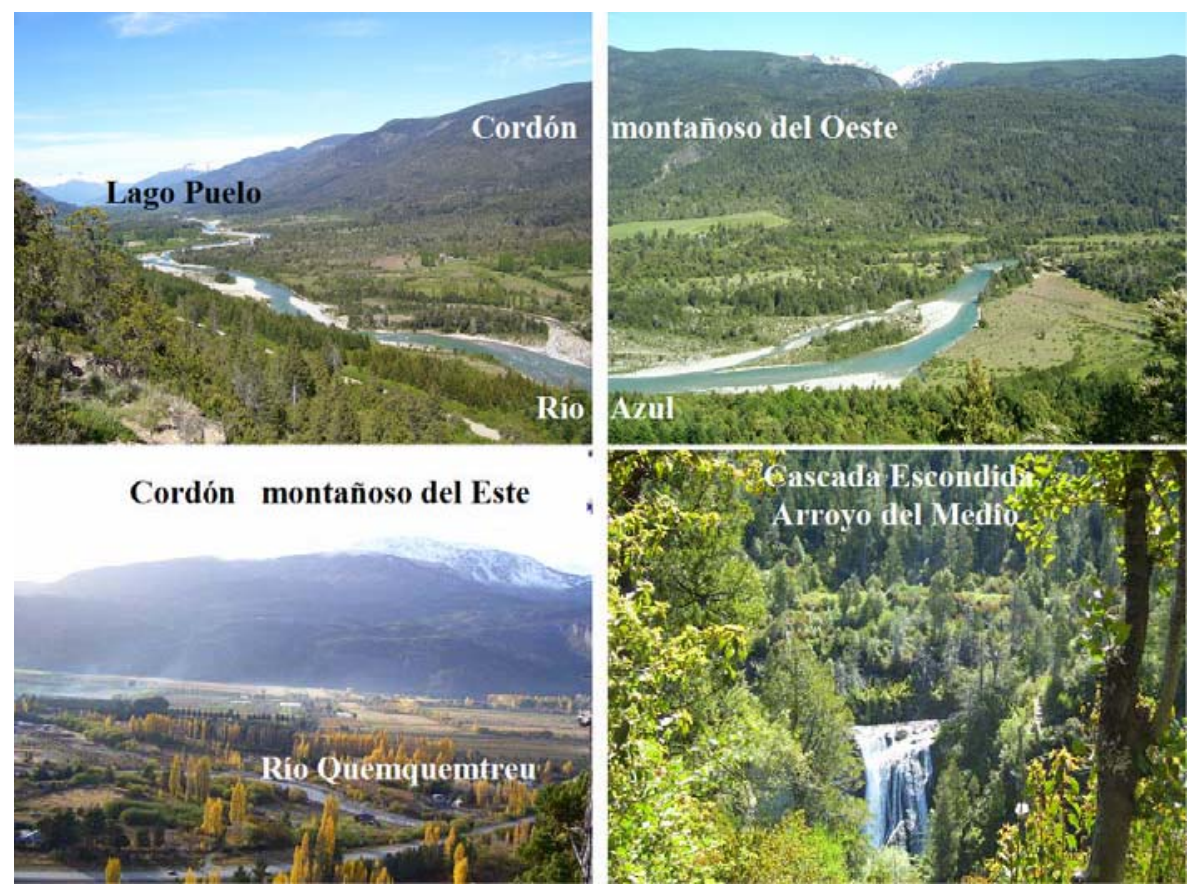

Figura II-1: Valle de El Bolsón, cordones montañosos y principales cursos de agua. Los ríos Azul y Quemquemtreu, corren entre los Cordones montañosos del Este y el Oeste, desembocando en el Lago Puelo. El Arroyo del Medio da origen a la Cascada Escondida que se ubica al Norte de la Reserva Forestal Loma del MedioRío Azul.

Para el desarrollo del presente trabajo de tesis, se seleccionaron cinco sectores de muestreo considerando que el mal del ciprés se reportó con mayor incidencia en el área Sur del valle de El Bolsón (Chauchard y Barnabá, 1986). Los sectores están ubicados, de Norte a Sur, en los siguientes sitios: Lotes $5 y 6$ (Reserva Forestal, Sección Los Repollos, Río Negro), Rodales 11 (R11), 18 (R18) y 81 (R81) (Reserva Forestal Loma del Medio-Río Azul, Río Negro) y Lotes 9y15 (Reserva Forestal, Sección El Puelo, Chubut) (Figura II-2, Tabla II-1). Aunque los Rodales 11 y 18 se ubican al Norte de la Reserva Forestal Loma del Medio-Río Azul (LMRA) en sectores cercanos; fueron elegidos debido a que presentan diferencias en exposición e impacto turístico. La distancia entre los sitios más alejados es inferior a los $12 \mathrm{~km}$.

La incidencia del mal del ciprés para cada sitio, estimada a partir del número de individuos sintomáticos reportados en el Plan de Ordenación del Cuartel Loma del Medio-Río Azul (Chauchard y Barnabá, 1986) y en el Inventario Forestal de los L5y6 y L9y15 (Chauchard, 1987), se presenta en la Tabla II-1. Sin embargo, debido a que la parte Sur del área de muestreo ha sido aprovechada en forma previa al desarrollo de los correspondientes inventarios (Chauchard y Barnabá, 1986) mediante la extracción de árboles muertos o muy afectados por mal del ciprés, los 
valores de incidencia deben ser considerados sólo como aproximados. La extracción de individuos en forma diferencial en los distintos sitios podría llevar a una evaluación incorrecta de la sanidad actual. La comparación del nivel de incidencia entre los sitios de muestreo y otros bosques de $A$. chilensis afectados por mal del ciprés, requiere determinar el impacto de las condiciones de desarrollo (competencia) en la mortalidad de los individuos. Estos análisis y evaluaciones del desarrollo temporal del mal del ciprés se presentan en el Anexo 1.

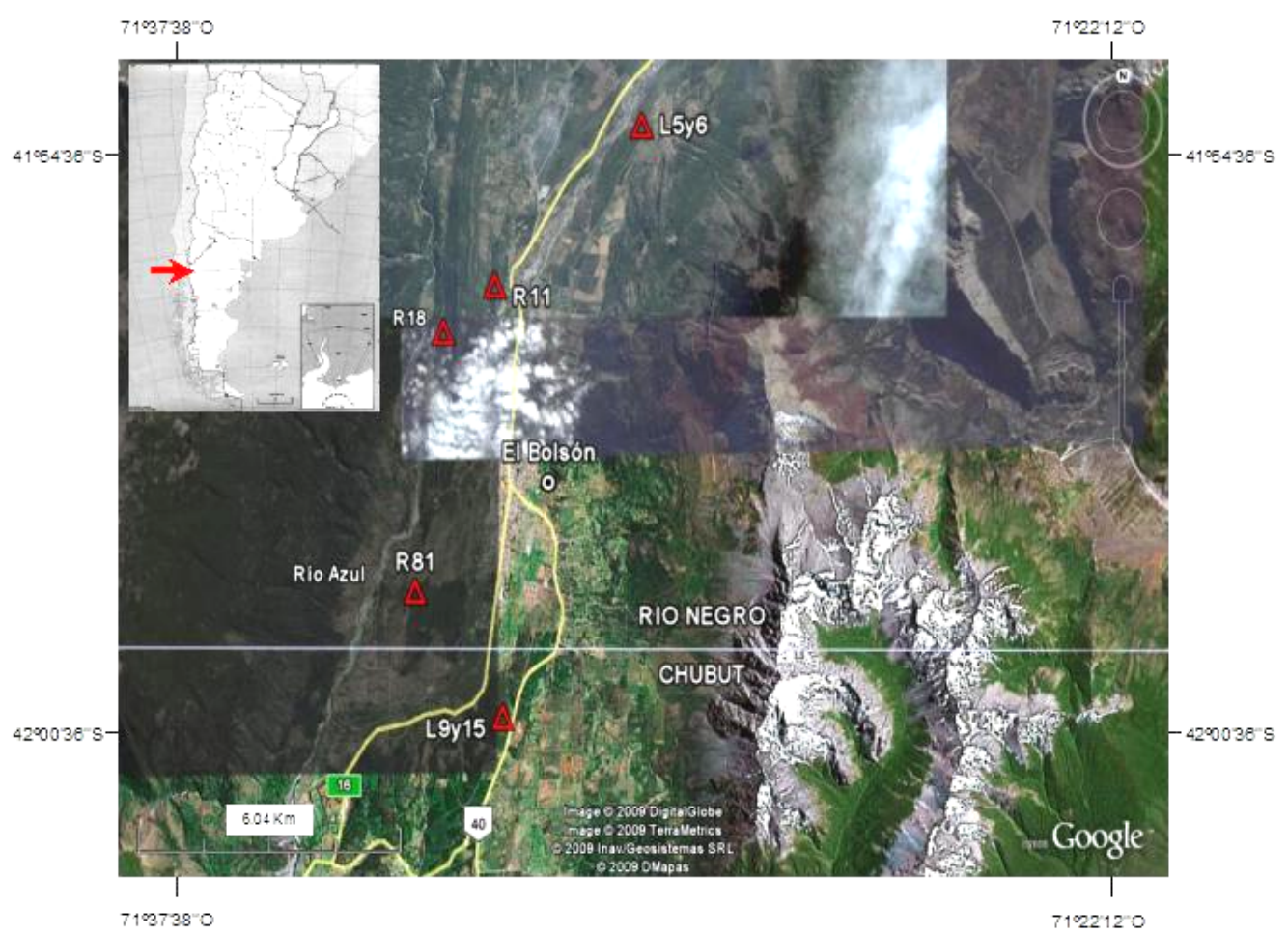

Figura II-2: Mapa de la zona de estudio mostrando la ubicación de los sitios de muestreo (L5y6, R11, R18, R81 y L9y15) y la localidad de El Bolsón. La línea gris indica el límite entre las provincias de Río Negro y Chubut. En el vértice superior izquierdo se ubica la zona de estudio en el mapa de Argentina (flecha roja).

\begin{tabular}{|c|c|c|c|c|}
\hline \multirow{2}{*}{$\begin{array}{l}\text { Sitio de } \\
\text { Muestreo }\end{array}$} & \multicolumn{2}{|c|}{ Coordenadas geográficas } & \multirow{2}{*}{$\begin{array}{c}\text { Altitud } \\
\text { (m.s.n.m) }\end{array}$} & \multirow{2}{*}{$\begin{array}{l}\text { Incidencia del } \\
\text { mal del ciprés }\end{array}$} \\
\hline & Latitud & Longitud & & \\
\hline Lotes $5 y 6$ & $41^{\circ} 54^{\prime} 19^{\prime \prime} \mathrm{S}$ & $71^{\circ} 30^{\prime} 01^{\prime \prime} \mathrm{O}$ & 482 & 1.44 \\
\hline Rodal 11 & $41^{\circ} 55^{\prime} 58^{\prime \prime} \mathrm{S}$ & $71^{\circ} 32^{\prime} 27^{\prime \prime} \mathrm{O}$ & 456 & 1.13 \\
\hline Rodal 18 & $41^{\circ} 56^{\prime} 27^{\prime \prime} \mathrm{S}$ & 71'33'19" O & 381 & 8.40 \\
\hline Rodal 81 & $41^{\circ} 59^{\prime} 08^{\prime \prime} \mathrm{S}$ & 71'³'47" O & 311 & 5.64 \\
\hline Lotes $9 \mathrm{y} 15$ & $42^{\circ} 00^{\prime} 27^{\prime \prime} \mathrm{S}$ & 71'32'19" O & 390 & 6.04 \\
\hline
\end{tabular}

Tabla II-1: Coordenadas geográficas, altitud e incidencia del mal del ciprés para cada uno de los sitios de muestreo. ${ }^{\text {a }}$ La incidencia estimada corresponde al porcentaje de individuos sintomáticos respecto del total de individuos en el sitio. 


\section{2.- MUESTREO PAREADO}

El diseño básico de muestreo consistió en la selección de 10 pares de árboles en cada uno de los sitios en estudio. Los pares fueron elegidos en sectores de bosque donde coexisten plantas con síntomas y sin síntomas de mal del ciprés (patrón desagregado). Los individuos que conforman cada par fueron seleccionados de acuerdo con los siguientes criterios:

- diferencia en el estado sanitario: un individuo asintomático (A) y otro sintomático (S)

- similitud en los descriptores básicos: diámetro a altura de pecho (DAP), altura total (AT), posición sociológica y nivel de competencia. Los pares fueron elegidos tratando de minimizar la diferencia de descriptores entre individuos del par. Ningún descriptor fue priorizado respecto de los otros, evaluándose el conjunto de las observaciones para la selección final.

Se estableció, una distancia máxima de 30 metros según observación a campo, entre los individuos de un par como criterio adicional a fin de asegurar mínima variabilidad en micrositio. Aplicando el software Genetic Analysis in Excell (GenAlEx) V.6 (Peakall y Smouse, 2006) se computó una matriz de distancia geográfica en base a las coordenadas de latitud y longitud registradas para cada árbol.

\subsection{1.- Estado sanitario}

El estado sanitario se asignó según los parámetros definidos en la Tabla II-2, considerando que las características arquitecturales de los árboles varían en función de las condiciones de sitio y el estado de competencia. Los árboles muertos no fueron seleccionados para formar un par.

\begin{tabular}{|c|c|c|c|c|c|}
\hline \multicolumn{2}{|c|}{ CLASIFICACION } & COPA & DEFOLIACION & COLOR FOLLAJE & VIGOR \\
\hline Asintomático & A= Asintomático & $\begin{array}{c}\text { cerrada o ligeramente abierta } \\
\text { sin ahuecamiento central }\end{array}$ & sin defoliación & verde típico de ciprés & Alto \\
\hline \multirow{3}{*}{ Sintomático } & $\mathrm{S} 1=$ inicial & con ahuecamiento central incipiente & $\begin{array}{c}\text { Inicial } \\
\text { hasta } 25 \%\end{array}$ & verde pálido o amarillamiento & Medio \\
\cline { 2 - 6 } & $\mathrm{S} 2=$ avanzado & $\begin{array}{c}\text { con ahuecamiento central avanzado } \\
\text { evidente cono central defoliado }\end{array}$ & $\begin{array}{c}\text { avanzado } \\
25 \text { a } 70 \%\end{array}$ & verde pálido o amarillamiento & $\begin{array}{c}\text { Medio } \\
\text { Bajo }\end{array}$ \\
\cline { 2 - 6 } & S3= terminal & $\begin{array}{c}\text { con ahuecamiento central terminal } \\
\text { hojas sólo en el extremo de las ramas }\end{array}$ & $\begin{array}{c}\text { terminal } \\
70 \text { a } 99 \%\end{array}$ & amarillamiento & Bajo \\
\hline
\end{tabular}

Tabla II-2: Clasificación de estado sanitario aplicado a la selección de los pares de plantas sintomáticas / asintomáticas considerando grado y patrón de defoliación, color del follaje y vigor de los árboles. 


\subsection{2.- Descriptores básicos}

\section{A-Altura total y diámetro a altura de pecho}

Para el cálculo de la altura de los árboles se midió con cinta métrica la distancia (D) desde árbol hasta el punto de observación, mientras que la pendiente $(\mathrm{P})$ y los ángulos verticales se tomaron con clinómetro Suunto. Se registraron dos datos de lectura de ángulos: lectura superior (LS) y lectura inferior (LI). El valor de altura total (AT) se calculó de acuerdo con la siguiente ecuación: $\mathrm{AT}=[[(\mathrm{LS}+\mathrm{LI}) / 100] \times \mathrm{D}] \times \mathrm{cos}(\mathrm{P})$. El diámetro del árbol a una altura de 1,30 metros (DAP) se determinó utilizando cinta diamétrica.

Un umbral de $30 \%$ se estableció para la diferencia relativa entre individuos dentro de un par como ha sido anteriormente reportado (Barichivich Henriquez, 2005); sin embargo en este caso se computó la diferencia absoluta entre el DAP del individuo asintomático y sintomático de cada par $\left(\mathrm{DAP}_{\mathrm{A}}-\mathrm{DAP}_{\mathrm{S}}\right)$ respecto del valor promedio $\left(\left(\mathrm{DAP}_{\mathrm{A}}+\mathrm{DAP}_{\mathrm{S}}\right) / 2\right)$. De la misma forma se calcularon las diferencias relativas en AT.

\section{$\underline{\text { B-Posición sociológica }}$}

De acuerdo con la ubicación relativa de la copa los individuos de un rodal pueden ser clasificados como Oprimidos (O), Intermedios (I), Codominantes (CD) o dominantes (D). Esta clasificación fue originalmente propuesta por Kraft (1884) para ser aplicada en rodales coetáneos en los cuales la ubicación de la copa se relaciona con el estado competitivo. Los bosques de A. chilensis de la zona en estudio, son en su gran mayoría bosques post-fuego y podrían ser considerados coetáneos a pesar de la existencia de estructuras diamétricas irregulares (Goya et al., 2005). Sin embargo, la asignación de la posición sociológica en algunos de estos rodales resulta compleja debido a la necesidad de evaluar la competencia en diferentes estratos dentro del bosque. Un método alternativo a la clasificación de Kraft propuesto y evaluado por Bechtold (2003) se basa en un algoritmo que permite establecer la posición sociológica de los individuos en función de dos características de la copa: posición en el dosel y exposición a la luz.

En este trabajo los individuos se clasificaron en terreno como O, I, CD, D (Kraft, 1884) o aislados (individuos con copa bien desarrollada, sin competencia aparente), determinándose además la posición de la copa y la exposición a la luz. Estos dos parámetros se utilizaron posteriormente para establecer la posición sociológica de acuerdo con el mencionado algoritmo. La posición ocupada por la copa en el dosel se determinó según los criterios establecidos por Bechtold (2003). Los individuos fueron asignados a una de las siguientes categorías: Understory (US), Overstory (OS), Superstory (SP), Open Canopy (OC) (Figura II-3). La luz que recibe cada árbol se cuantificó considerando a la copa como una pirámide de base cuadrada. Cinco partes fueron evaluadas, el vértice superior y las cuatro caras, restándose un punto al valor máximo de cinco (5) por cada parte que no recibe luz (Bechtold, 2003). 


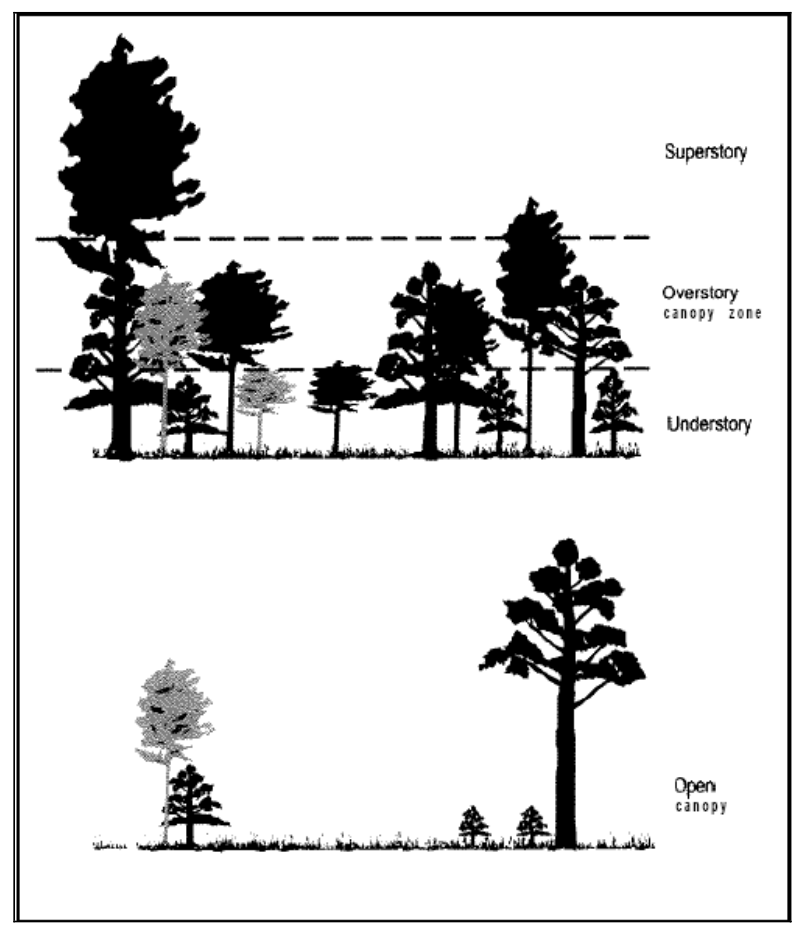

Figura II-3: Categorías de clasificación según posición de la copa del árbol en el dosel (tomado de Betchtold, 2003).

\section{C-Competencia}

Para caracterizar el nivel de competencia se realizó un relevamiento del número de tocones o árboles sobre una parcela centrada en cada individuo del par. Para la selección de competidores se empleó el concepto de zona de influencia (Staebler, 1951). La zona de influencia es un círculo con centro en el árbol de interés y radio variable. Se considera competidor aquel árbol cuya zona de influencia presenta solapamiento con la del árbol de interés. Para este trabajo, el radio de la zona de influencia se determinó observando en terreno las características de la copa del árbol central y su relación con las copas de los árboles vecinos. Éstos se incorporaron al muestreo cuando las copas contactaron o al menos se aproximaron al árbol central. Árboles con copas a más de un metro de distancia no fueron incluidos. Se consideró que en el primer caso los árboles vecinos compiten por recursos, no existiendo competencia en el segundo. Para el caso de los tocones se siguió un criterio similar, pero basado en las "marcas" o "registros" que la competencia pasada deja en la arquitectura del árbol. Es decir, árboles que crecen en contacto con sus vecinos y sufren algún nivel de competencia, desarrollan una copa de forma irregular, con alguna porción seca o faltante, o ramas más cortas. Aunque, en la actualidad, los competidores no están presentes (por corte o caída) estos registros pueden ser observados y relacionados con la presencia de tocones. Se consideró que la competencia pasada (tocones) y la 
actual (árboles) por individuos de la misma especie, es función del tamaño de los árboles y la distancia al árbol central. Cuanto más grande es el árbol vecino, puede encontrarse a mayor distancia en condiciones de competir. Los árboles y tocones se numeraron desde el Norte, avanzando en sentido horario hasta cubrir $360^{\circ}$, registrándose los valores de rumbo y distancia respecto del árbol central.

Para los tocones se midió el diámetro a altura de cuello (DAC) con forcícula, tomándose dos medidas cruzadas y registrándose el valor promedio. Cuando el estado de descomposición de los tocones fue avanzado, se realizaron estimaciones, y se ajustó el valor del DAC. En casos de deterioro muy avanzado no se hizo ninguna determinación. La medida de DAC fue utilizada para estimar el valor de DAP de los árboles aprovechados utilizando la ecuación ajustada por Loguercio et al. (1998): DAP $=0,64991255+0,80526032 *$ DAC. Para los árboles el DAP se midió con forcícula tomándose dos valores cruzados y registrándose el promedio.

El índice de competencia propuesto por Hegyi (1974) fue elegido para cuantificar el nivel de competencia, en tanto que se ajusta al concepto planteado en la selección de competidores, considerando que cuanto mayor es el diámetro del competidor y menor la distancia al árbol central mayor es el nivel de competencia.

La siguiente ecuación fue empleada en el cálculo

$$
\sum\left(\mathrm{d}_{\mathrm{j}} / \mathrm{d}_{\mathrm{i}}\right) / \text { Dist }_{\mathrm{ij}} \text { para todo } \mathrm{i} \neq \mathrm{j}
$$

con $\mathrm{d}_{\mathrm{i}}$ el diámetro del árbol en estudio, $\mathrm{d}_{\mathrm{j}}$ el diámetro del competidor y Dist $\mathrm{ij}_{\mathrm{ij}}$ la distancia entre el árbol en estudio y el competidor.

\section{3.- RESULTADOS Y DISCUSIÓN}

\section{1.- MUESTREO PAREAdo}

\subsection{1.- Estado sanitario}

Del total de árboles sintomáticos elegidos, el 50\% corresponde a la categoría S1 (inicial), el $32 \%$ a la categoría S2 (avanzado) y el 18\% a la categoría S3 (terminal). La selección no fue realizada tratando de ajustar el porcentaje de árboles en cada categoría para cada sitio, sino respetando el cumplimiento de similitud en los descriptores básicos y la diferencia en el estado sanitario (asintomático / sintomático). 


\subsection{2.- Descriptores básicos}

El diámetro a la altura de pecho (DAP), la altura total (AT) y la posición sociológica fueron los descriptores básicos empleados en terreno para seleccionar los individuos de cada par entre todas las posibles combinaciones de árboles asintomáticos y sintomáticos en un área. La distancia promedio entre individuos de un par fue de 12 metros, con un 54\% de los pares presentando distancias menores a los 10 metros y un 16\% distancias superiores a los 20 metros (Anexo 2). Los pares 11, 14 y 35 tienen distancias mayores a los 30 metros.

\section{A-Altura total y diámetro a altura de pecho}

La Tabla II-3 presenta el valor promedio de DAP y AT, según estado sanitario, para el conjunto de los sitios (EB : El Bolsón) y para cada una de los sitios en estudio (L5y6, R11, R18, R81, L9y15).

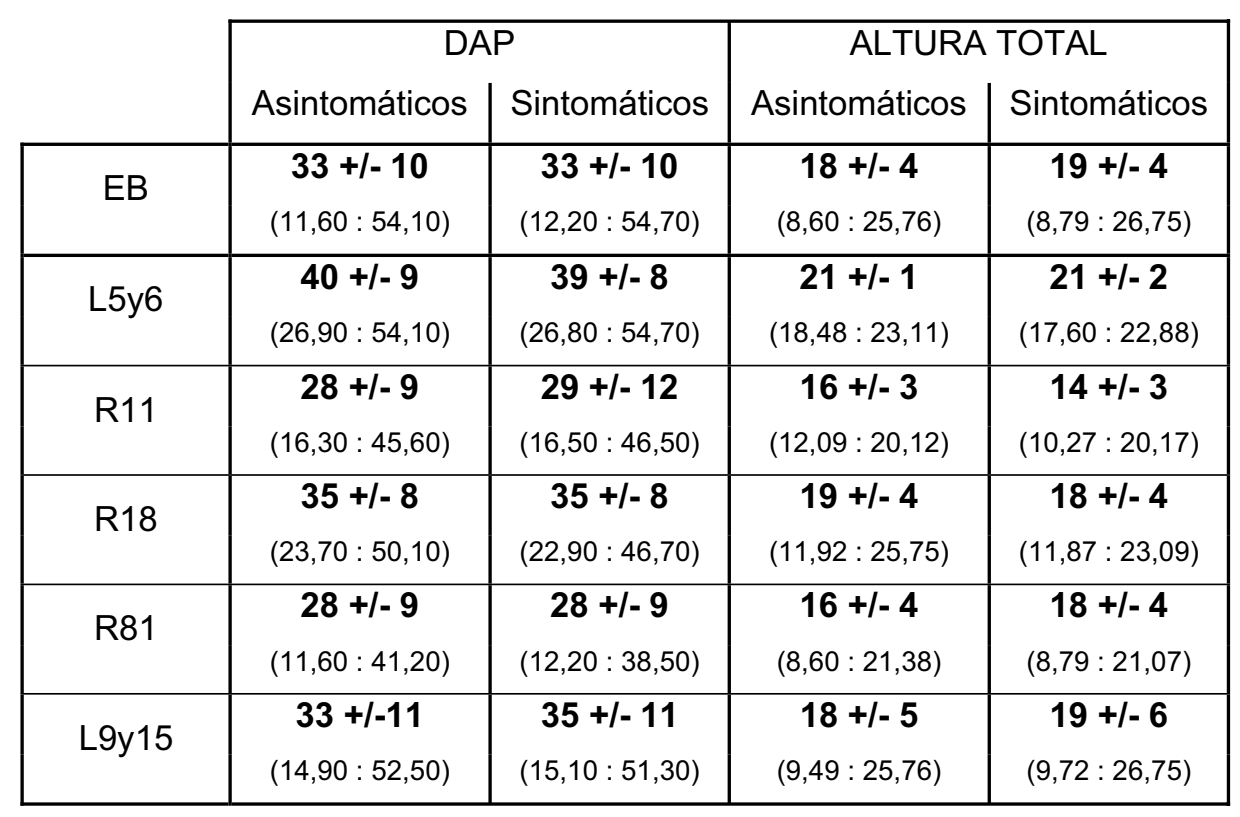

Tabla II-3: Valor promedio y desvío estándar del DAP y la altura total según estado sanitario para cada sitio de muestreo y para el área de El Bolsón (EB). Entre paréntesis se indica el valor máximo y mínimo correspondiente a cada descriptor por estado sanitario y sitio.

Los resultados muestran que la selección de individuos según estado sanitario se ajusta al criterio de similitud para estos descriptores. Si bien se muestrearon árboles de tamaños diversos, las clases diamétricas II $(20.0$ a $29.9 \mathrm{~cm})$ y III $(30.0$ a $39.9 \mathrm{~cm})$ representan más del $60 \%$ del total. La distribución completa en clases diamétricas para ambos estados sanitarios se presenta en el Gráfico II-1. 


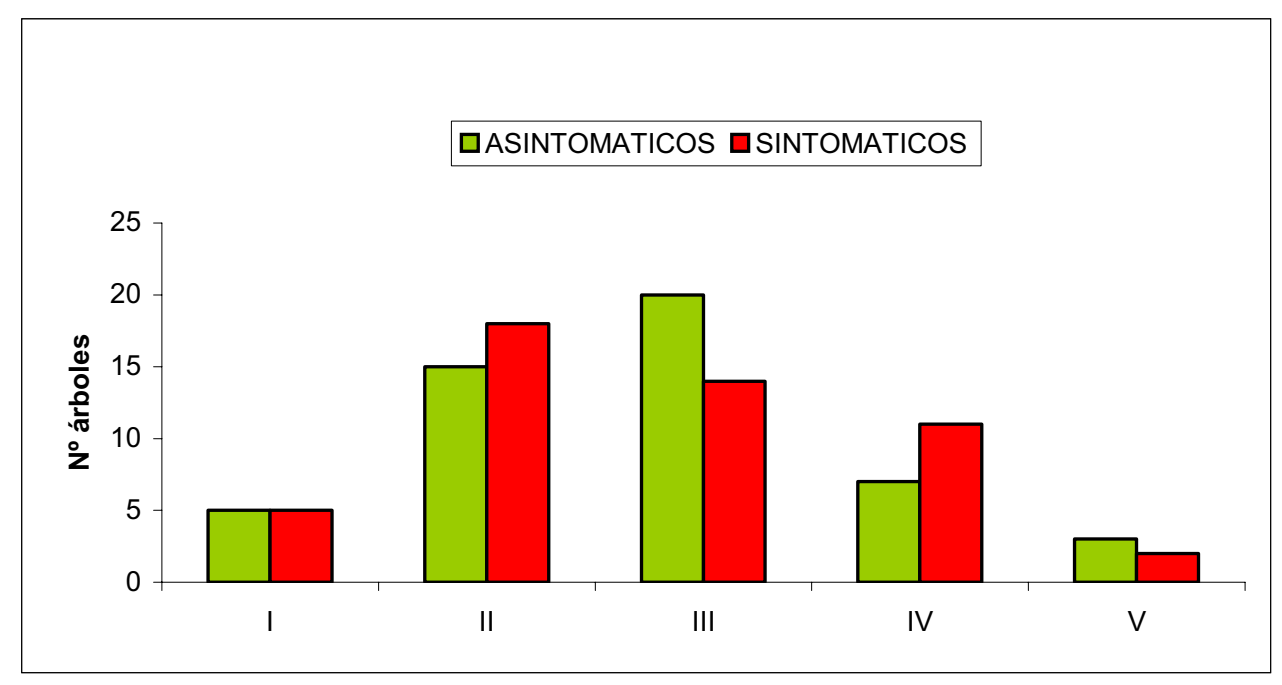

Gráfico II-1: Distribución de clases diamétricas para ambos estados sanitarios correspondiente al total de los individuos seleccionados. Clases diamétricas en números romanos, según incrementos de $10 \mathrm{~cm}$, comenzando en DAP de $10 \mathrm{~cm}$.

La correlación entre el DAP de árboles asintomáticos vs. el DAP de árboles sintomáticos, sigue una tendencia lineal con un valor de $\mathrm{r}^{2}$ de 0.779 . Sólo 1 de los 50 pares seleccionados presenta una diferencia en diámetro superior al 30\%, 15 pares presentan diferencias de entre $30 \%$ y $15 \%$, en tanto que 34 están por debajo del 15\% y 27 por debajo del 10\% (Gráfico II-2).

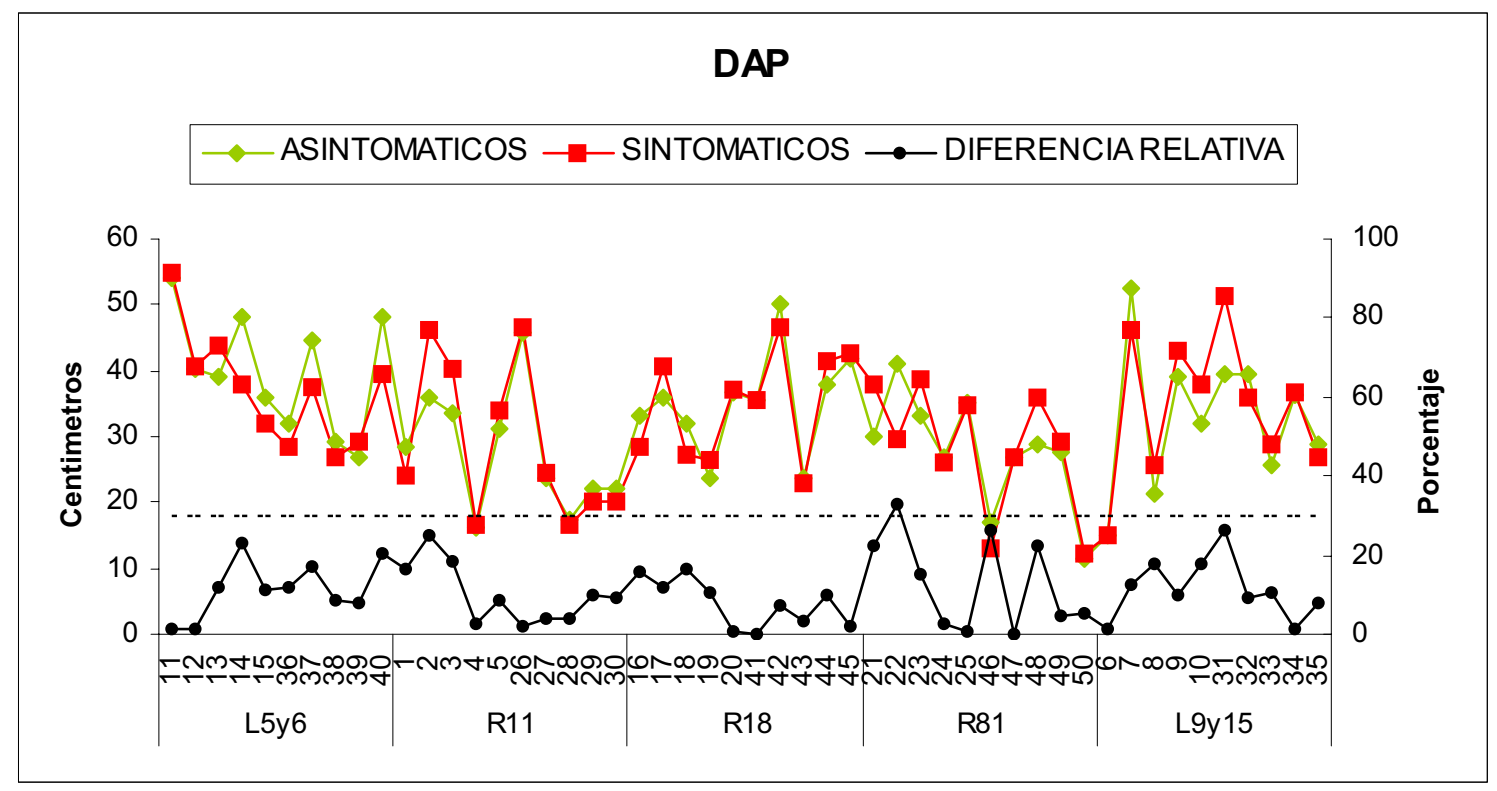

Gráfico II-2: DAP de los 100 individuos seleccionados (eje principal) y diferencia relativa entre los individuos de cada par (eje secundario). La línea negra punteada corresponde a una diferencia relativa del $30 \%$. 
Un comportamiento similar se observa para los valores de altura total con un comportamiento lineal en la relación AT de árboles asintomáticos vs. AT de árboles sintomáticos y un coeficiente de correlación de 0.771. El análisis de las diferencias relativas indica que 1 par presenta una diferencia relativa en AT superior al 30\%, 12 pares diferencias entre el $30 \%$ y el $15 \%, 37$ pares con valores por debajo del 15\% y 33 por debajo del 10\% (Gráfico II-3).

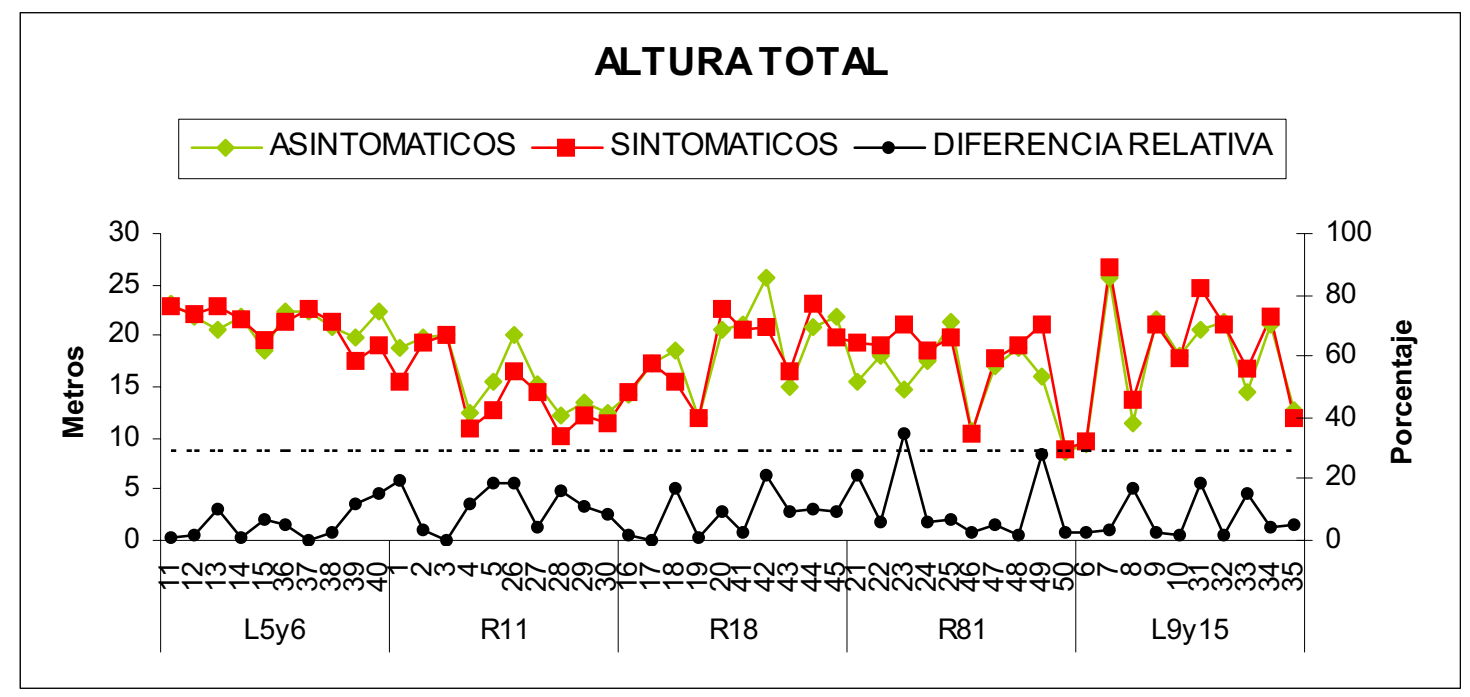

Gráfico II-3: Altura total de los 100 individuos seleccionados (eje principal) y diferencia relativa entre los individuos de cada par (eje secundario). La línea negra punteada corresponde a una diferencia relativa del 30\%.

\section{B-Posición sociológica}

El $81 \%$ de los individuos seleccionados en terreno corresponde a la categoría CD (codominante). El resto se distribuye entre las categorías I (intermedia) con un 9\%, D (dominante) con un 5\% y aislado con un 5\%. Ningún individuo oprimido fue seleccionado. Sólo en cuatro pares $(28,16,17$ y 50$)$ los individuos presentan diferencias en la posición sociológica asignada en terreno (Gráfico II-4). La aplicación del algoritmo propuesto por Bechtold (2003) ubica a los individuos de cada par en la misma clase sociológica; correspondiendo los individuos de los pares 16 y 17 a la clase CD y los individuos de los pares 28 y 50 a la clase I. Para el resto de los individuos seleccionados se confirmó la asignación de clase sociológica, utilizando el criterio de considerar a los individuos con copa en el dosel y acceso completo a la luz como codominantes. El aprovechamiento determina la mayor exposición a la luz de estos individuos y no justifica el cambio a la categoría dominante. 


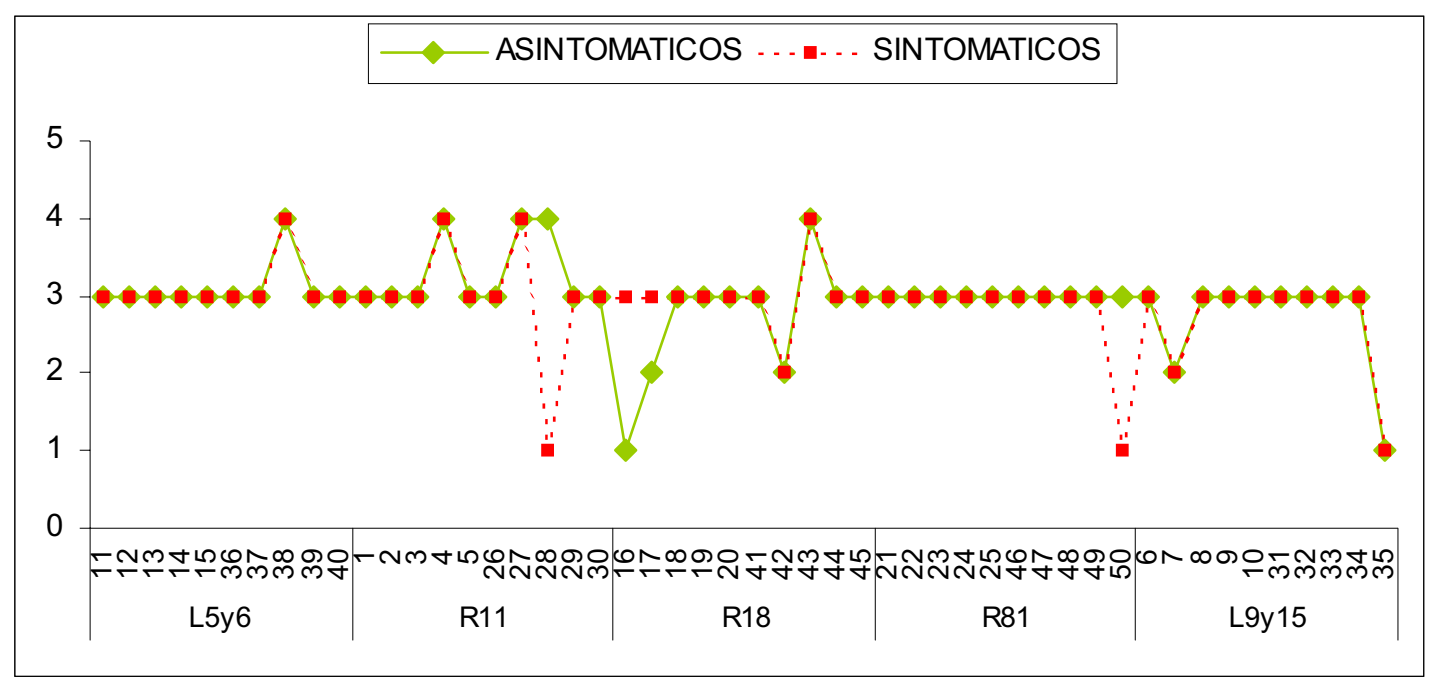

Gráfico II-4: Posición sociológica por código numérico según Bechtold (2003): Aislado (1), Dominante (2), CD (3), Intermedio (4), Oprimido (5).

\section{C-Competencia}

El cálculo del índice de competencia se efectúo en el 95\% de los árboles en estudio. Para los árboles $21 \mathrm{~S}$ y $34 \mathrm{~A}$ no fue posible determinar la zona de influencia, y en consecuencia tampoco el relevamiento de competidores, debido a que no se encontraban en pie al momento de la evaluación. Para los árboles 1S, 4S y 30A, el relevamiento fue incompleto ya que el grado de deterioro de los tocones ubicados dentro de la zona de influencia no permitió determinar el DAC. El Gráfico II-5 presenta los índices de competencia global calculados en función de la competencia actual (árboles) y pasada (tocones).

Si bien los niveles de competencia varían entre individuos y pares, en 23 (51\%) de los 45 pares que pueden ser comparados la relación entre el índice de competencia del árbol asintomático y sintomático se encuentra por debajo de 2. Para el resto existen diferencias más importantes, correspondiendo un nivel de competencia mayor al árbol asintomático en el $22 \%$ de los casos y al sintomático en el 27\%. Los árboles $13 \mathrm{~S}, 14 \mathrm{~S}, 40 \mathrm{~S}, 1 \mathrm{~A}, 16 \mathrm{~A}, 25 \mathrm{~S}, 50 \mathrm{~S}, 50 \mathrm{~A}, 6 \mathrm{~S}, 7 \mathrm{~S}$ y $33 \mathrm{~A}$ presentan una alta proporción de árboles competidores que han sido eliminados por aprovechamiento (Gráfico II-6). Por el contrario, para el resto de los árboles el aprovechamiento ha modificado la competencia en forma moderada o nula. La situación observada y evaluada en terreno puede por tanto considerarse en gran medida representativa de la historia de competencia de cada individuo. 


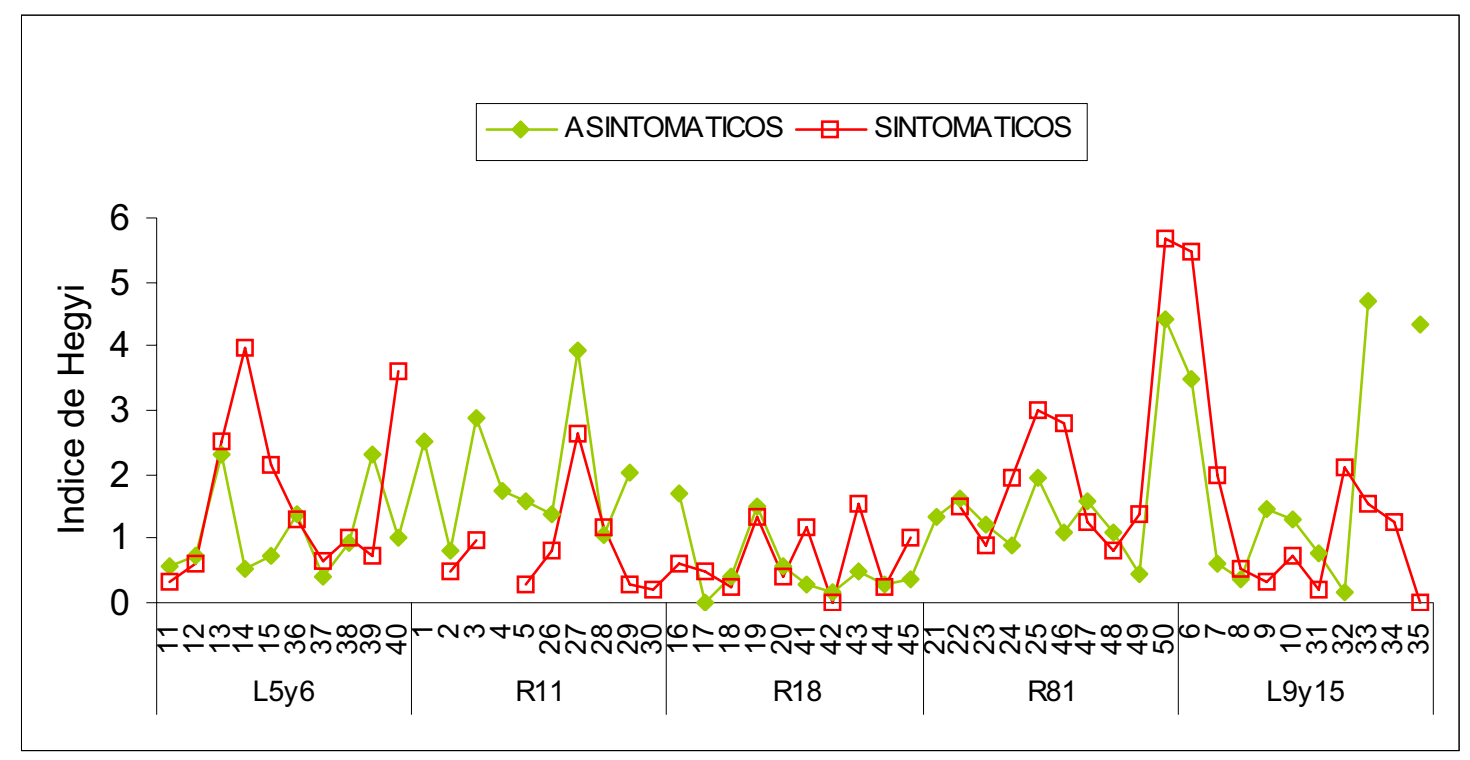

Gráfico II-5: Índice de competencia global, calculado en función de la competencia actual y pasada, para los individuos seleccionados.

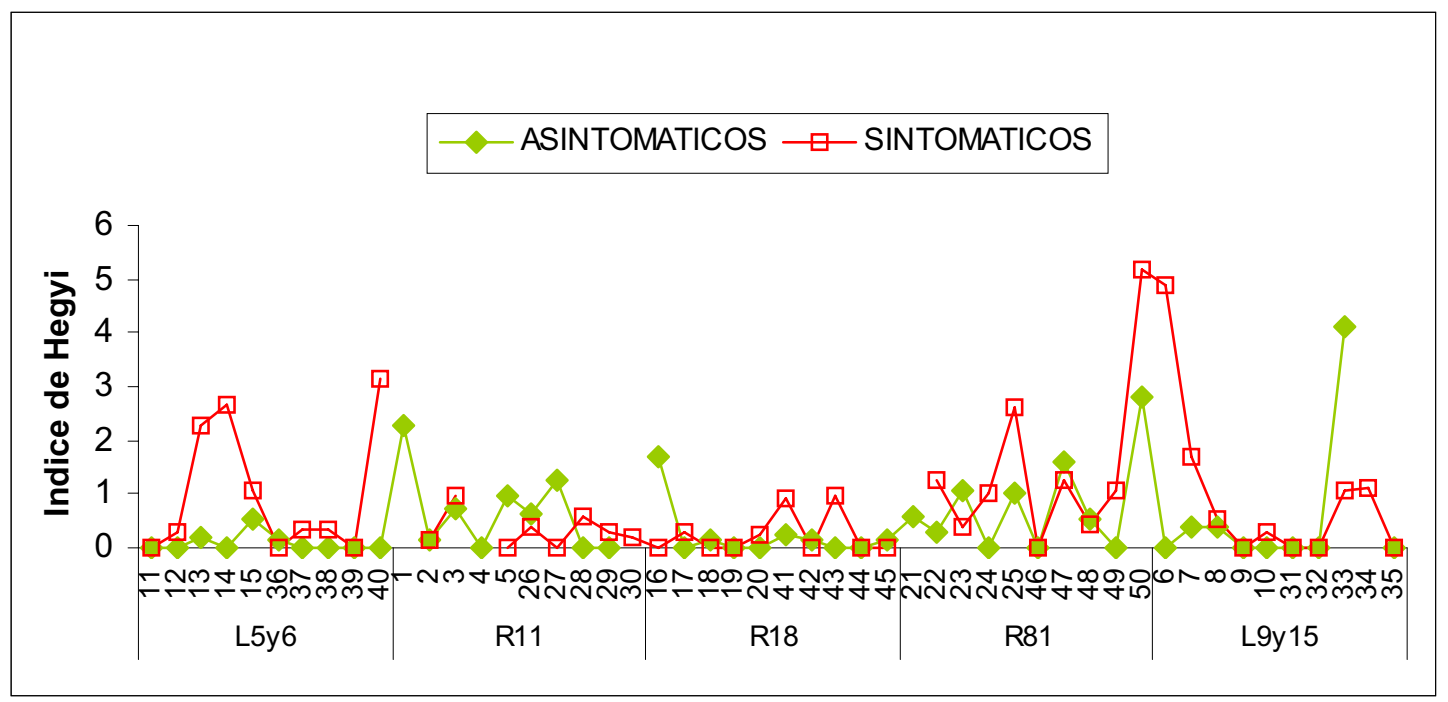

Gráfico II-6: Índice de competencia pasada para los individuos seleccionados.

En la Tabla II-4 los índices de competencia global, pasada y actual, se presentan separadamente para cada uno de los sitios de muestreo, considerando el conjunto de los árboles en cada sitio o cada una de las categorías de estado sanitario por separado. Del análisis comparativo de los índices, sobre el conjunto de los árboles muestreados en cada sitio, surge que el R18 presenta los menores índices de competencia (global, pasada o actual); en tanto que el resto de las áreas presentan niveles similares de competencia y podrían ser separadas en dos grupos R11-L5y6 y 
R81-L9y15. Por otra parte, el R81 es el único en el cual la competencia pasada es superior a la competencia actual, lo que está en relación directa con el mayor grado de aprovechamiento reportado para el sitio (Chauchard y Barnabá, 1986).

\begin{tabular}{|c|c|ccc|}
\cline { 2 - 5 } \multicolumn{1}{c|}{} & \multirow{2}{*}{ AREA } & \multicolumn{3}{c|}{ INDICE DE COMPETENCIA } \\
\hline \multirow{5}{*}{ ASINTOMATICOS } & GLOBAL & PASADA & ACTUAL \\
\hline \multirow{5}{*}{ SINTOMATICOS } & L5y6 & 1,09 & 0,09 & 1,01 \\
& R11 & 1,99 & 0,66 & 1,23 \\
& R18 & 0,58 & 0,24 & 0,33 \\
& R81 & 1,56 & 0,78 & 0,78 \\
& L9y15 & 1,91 & 0,54 & 1,37 \\
\hline & L5y6 & 1,69 & 1,01 & 0,68 \\
& R11 & 0,86 & 0,29 & 0,57 \\
& R18 & 0,70 & 0,25 & 0,46 \\
& R81 & 2,14 & 1,47 & 0,68 \\
& L9y15 & 1,42 & 0,96 & 0,46 \\
\hline \multirow{5}{*}{ CONJUNTO } & L5y6 & 1,39 & 0,55 & 0,84 \\
& R11 & 1,42 & 0,47 & 0,90 \\
& R18 & 0,64 & 0,24 & 0,40 \\
& R81 & 1,85 & 1,12 & 0,73 \\
& L9y15 & 1,66 & 0,75 & 0,91 \\
\hline
\end{tabular}

Tabla II-4: Valores promedio del índice de competencia global, pasada y actual calculado para cada sitio de muestreo sobre el conjunto de los árboles y según categorías de estado sanitario.

Cuando se comparan los valores de índices según estados sanitarios, los resultados indican tres tipos de situaciones diferentes. Para el L5y6 y el R81, el valor promedio del índice de competencia global y pasada es superior para árboles sintomáticos. El R18, sigue esta tendencia aunque las diferencias entre ambos estados sanitarios son inferiores. Para el L9y15, el valor promedio del índice de competencia global es superior para árboles asintomáticos, en tanto que la competencia pasada sigue siendo mayor para árboles sintomáticos. El R11, presenta valores promedio del índice de competencia global y pasada mayores para los árboles asintomáticos. Considerando que el aprovechamiento se realiza en base a árboles sintomáticos o muertos, estos resultados podrían reflejar la asociación de árboles sintomáticos en el espacio debida a condiciones similares de micrositio, competencia durante el establecimiento o pool génico, como ya ha sido reportado en estudios de disposición espacial para el nivel de microescala (Rosso, 1989). En el caso del R11, la diferencia en los resultados puede ser interpretada en relación con el mayor nivel de competencia reportada para el sitio (Chauchard y Barnabá, 1986), mostrando que un gran porcentaje de la mortalidad (y por tanto del aprovechamiento) en el R11 
resultaría del efecto de competencia a nivel de bosque y no estaría en relación con el mal del ciprés. Sin embargo, estos resultados deben ser interpretados con precaución en tanto que provienen de promediar el nivel de competencia sobre los individuos de los pares que no fueron seleccionados al azar dentro de las respectivas áreas, sino en relación con el muestreo pareado propuesto. Las relaciones que se derivan son por tanto sólo aproximadas y no deben considerarse como representativas del sitio en su conjunto.

\section{4.- CONCLUSIONES}

El análisis conjunto de los descriptores básicos DAP, AT y posición sociológica indica que la selección de pares se ajusta al criterio de similitud requerido para asegurar mínima o nula variabilidad en los factores no sometidos a evaluación en el presente trabajo de tesis. La determinación del nivel de competencia permitió establecer que la situación observada y evaluada en terreno puede considerarse representativa de la historia de desarrollo, e identificar árboles para los cuales la eliminación de competencia por aprovechamiento podría influir en la interpretación de resultados de las relaciones analizadas en el trabajo de tesis.

Considerando la determinación realizada por Calí (1996) que indica la existencia de caída en la tasa de crecimiento de los árboles (síntoma interno de afectación) en forma previa al desarrollo de los síntomas externos, se realizó un trabajo en colaboración para confirmar de forma adicional la selección de los individuos asintomáticos y/o sintomáticos de cada par (Mundo et al., Anexo 11). La clasificación obtenida a partir de un análisis discriminante (AD) realizado sobre las medidas de ancho de anillo de crecimiento de los árboles se contrastó contra la clasificación realizada en terreno. Sobre un total de 89 cronologías individuales que cubren el período 19402005 la clasificación del AD dio un valor del 97.7\% de identidad en la asignación. Sólo dos individuos asintomáticos, 13A y 37A (ambos pertenecientes al L5y6), fueron clasificados como sintomáticos en función de su patrón de crecimiento. Los resultados obtenidos validan, por tanto, la selección de pares realizada en terreno en función de la similitud de los descriptores básicos (DAP, AT, posición sociológica y nivel de competencia) y las diferencias en el estado sanitario.

Los datos aportados permiten concluir que la selección de pares (asintomáticos/sintomáticos) es correcta para el testeo de las hipótesis que se pondrán a prueba durante el trabajo de tesis. 



\section{CAPITULO III}

\section{CARACTERIZACIÓN GENÉTICA DE INDIVIDUOS SINTOMÁTICOS Y ASINTOMÁTICOS PARA MAL DEL CIPRÉS}

\section{INTERROGANTES}

¿Existen diferencias genéticas entre individuos sintomáticos y asintomáticos? ¿Qué mecanismo genético determina el fenotipo: resistencia o susceptibilidad? ¿El patrón ecológico del mal del ciprés está determinado por las diferencias genéticas entre bosques mésicos y xéricos de $A$. chilensis?

\section{HIPÓTESIS Y PREDICCIONES}

- Hipótesis 1: Los individuos sintomáticos y asintomáticos para mal del ciprés son genéticamente diferentes.

PREDICCIÓN 1: Existen marcadores moleculares RGA asociados de manera diferencial a grupos de individuos sintomáticos o asintomáticos.

- Hipótesis 2: Los individuos asintomáticos son genéticamente resistentes al mal del ciprés.

PREDICCIÓN 2: Los marcadores moleculares RGA que definen las diferencias entre estados sanitarios se asocian a los individuos asintomáticos.

○ Hipótesis 3: El patrón ecológico del mal del ciprés está determinado por las diferencias genéticas entre poblaciones mésicas y xéricas de $A$. chilensis.

PREDICCIÓN 3: Los marcadores moleculares RGA asociados a los individuos sintomáticos de las poblaciones mésicas están ausentes en las poblaciones xéricas. 



\section{1.- INTRODUCCIÓN}

Transcurridos más de sesenta años desde el primer reporte del mal del ciprés y, a pesar de la intensa investigación realizada, la etiología del proceso es aún desconocida. El síndrome se presenta según dos formas de distribución de las plantas afectadas, agregada y desagregada, y la mortalidad a nivel de individuo puede ocurrir en forma progresiva o rápida. Algunas características de micrositio (drenaje impedido o excesivo) se postulan como factores predisponentes; sin embargo no existe una relación unívoca entre dichas características y una determinada forma de presentación (La Manna, 2004). La existencia de susceptibilidad diferencial en los árboles fue propuesta como hipótesis en numerosas oportunidades en un intento de explicar las diversas manifestaciones del proceso. En algunos casos se señala que árboles debilitados por factores predisponentes o desencadenantes serían más susceptibles al mal del ciprés (Havrylenko et al., 1989; Rajchenberg y Cwielong, 1993; La Manna, 2004; La Manna y Rajchenber, 2004a y b; Greslebin y Hansen, 2006); en tanto que en otros se plantea la existencia de individuos genéticamente resistentes o tolerantes (Calí, 1996; Greslebin y Hansen, 2006).

La presencia del mal del ciprés, modifica fuertemente la silvicultura de los bosques de A. chilensis, limitando las intervenciones a la corta de plantas afectadas, con intensidad y frecuencia determinadas por el avance de la mortalidad. Esta medida, iniciada como forma de control, no resultó efectiva en la práctica (Loguercio y Rajchenberg, 2005). Actualmente, la silvicultura de bosques afectados se orienta a favorecer la regeneración natural, conservando una cobertura arbustiva del sotobosque a fin de mejorar las condiciones de supervivencia de los renovales (Loguercio et al., 1999a y b). Aunque la reforestación con ciprés para la recuperación de áreas afectadas es promovida, el desconocimiento de las posibilidades de supervivencia en dichas áreas condujo al reemplazo con especies de coníferas exóticas, al menos en propiedades privadas (Hennon y Rajchenberg, 2000). Considerando el rápido crecimiento y la alta capacidad de regeneración de muchas de estas especies exóticas el reemplazo de las áreas afectadas llevaría a una disminución de la superficie de bosque de A. chilensis (Loguercio et al., 1999a y b).

La necesidad de contar con estrategias efectivas de manejo o control, aún desconociendo la causa del mal del ciprés, es cada vez más evidente. En este contexto, la caracterización genética de individuos sintomáticos y asintomáticos se presenta como uno de los campos de investigación que, planteado desde los estudios iniciales, no ha sido hasta el momento desarrollado. Esta falta de investigación se asocia a la dificultad de evaluar diferencias genéticas o de respuesta en un patosistema que no se encuentra completamente definido. 
Las relaciones que se establecen entre un huésped susceptible, un agente de daño y el ambiente (Francl, 2001) son particularmente relevantes en fitopatología debido a la inmovilidad de las plantas, que imposibilita el escape frente a patógenos o condiciones ambientales adversas (Figura III-1A). Estas características enfatizan la importancia que la constitución genética del huésped tiene en la respuesta a los agentes de daño. En una distribución desagregada del mal del ciprés el agente de daño y el ambiente pueden considerarse constantes, por lo que la presencia o ausencia de síntomas en las plantas recaerá en gran medida en la capacidad de respuesta de cada individuo (Figura III-1B).

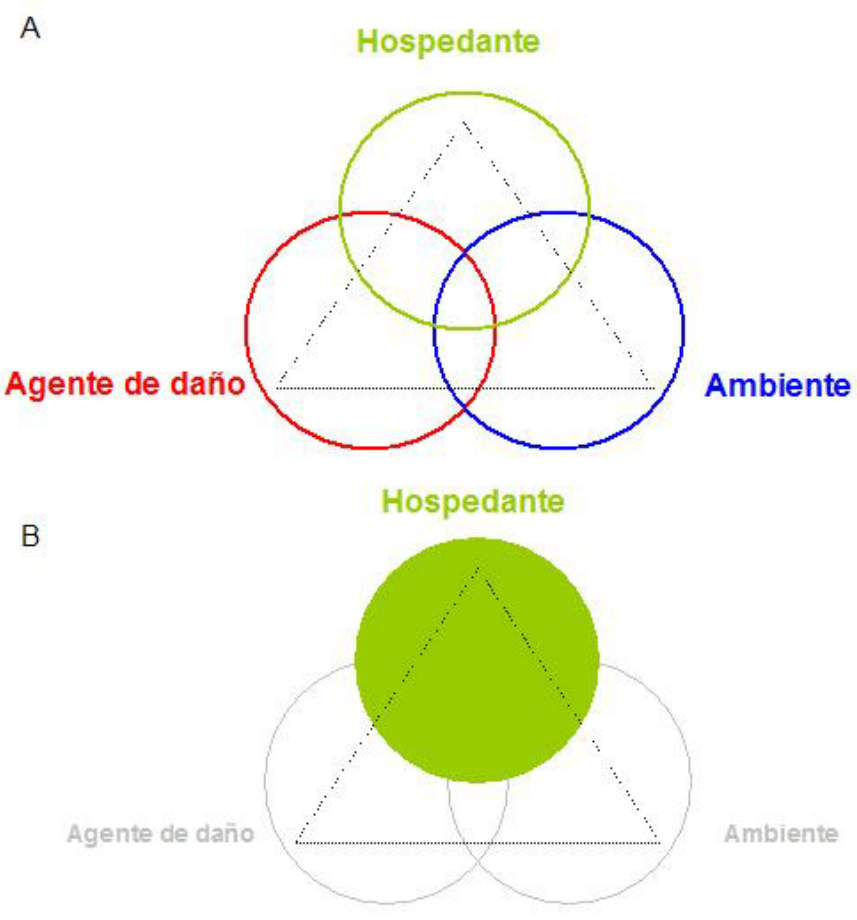

Figura III-1: Triángulo de enfermedad. A. Modelo conceptual que incorpora la interacción entre huésped, agente de daño y ambiente como factores básico para el establecimiento de una enfermedad. B. Representación del sistema de trabajo seleccionado para caracterizar la respuesta del huésped; áreas de bosque afectado por mal del ciprés con distribución desagregada en la cual la exposición al agente de daño y el condicionamiento del ambiente pueden considerarse uniformes.

Los estudios realizados por Havrylenko et al. (1989), Baccalá et al. (1998) y La Manna (2004) establecieron la existencia de un patrón ecológico en la distribución del mal del ciprés, caracterizado en términos generales por moderadas altitudes, altas precipitaciones $\mathrm{y}$ características edáficas de pobre drenaje. La Manna et al. (2008c) confirmaron a escala de paisaje las asociaciones establecidas a escala de micrositio, determinando una importante correlación entre la incidencia del mal del ciprés y variables de sitio relacionadas a pobre drenaje. Hasta el 
momento, de los cinco tipos forestales descriptos para A. chilensis, sólo los bosques compactos puros y mixtos han sido reportados con afectación por mal del ciprés. Los bosques marginales, que conforman el ecotono con la estepa, en zonas de baja precipitación media anual (600-900 $\mathrm{mm})$ se consideran libres de este disturbio. Aunque la asociación entre la mortalidad y las características de pobre drenaje está bien establecida, se desconoce si el patrón ecológico de distribución responde a factores ambientales que condicionan el desarrollo o la propagación de patógenos o a diferencias genéticas entre poblaciones xéricas y mésicas de la especie A. chilensis. El análisis de la diversidad genética mediante marcadores isoenzimáticos (Pastorino y Gallo, 2009) reveló diferencias entre poblaciones marginales xéricas y poblaciones mésicas. En este sentido, el análisis comparativo entre poblaciones mésicas afectadas por mal del ciprés y poblaciones xéricas sin afectación permitirá evaluar la influencia de la diversidad genética en el patrón ecológico de distribución del mal del ciprés.

El desconocimiento de la etiología del mal del ciprés y el carácter progresivo del marchitamiento y la defoliación complican el estudio de la respuesta diferencial, debido a que las plantas debilitadas son en muchos casos afectadas por agentes secundarios. Métodos de estudio basados en la expresión diferencial a nivel de proteínas (electroforesis bidimensional) o RNA mensajeros (diferencial display) resultarían de difícil aplicación y/o complejos en su interpretación. Por tanto, la caracterización de la constitución genética a nivel de DNA de individuos seleccionados en función de la sintomatología (asintomático/sintomático) se presenta como la estrategia más adecuada a implementar.

Las plantas son capaces de activar un conjunto de respuestas inducibles de defensa, que comprenden la muerte programada, la producción de inhibidores y la modificación de componentes tisulares en el sitio de infección, y de desencadenar mecanismos de respuesta sistémica a largas distancias. Para ello requieren un importante suministro de recursos celulares, reasignación metabólica y reprogramación genética, dado que las respuestas inducibles son mantenidas bajo estricto control genético y activadas sólo en situaciones de daño.

Debido a la ausencia de un sistema inmune circulante, las plantas desarrollaron sistemas de vigilancia celular contra los patógenos. Los genes de resistencia a enfermedades (genes R) codifican proteínas que detectan patógenos y activan mecanismos de transducción de señal que desencadenan la respuesta. Un número importante de genes de resistencia han sido clonados desde diversas especies de plantas (Hammond-Kosack y Jones, 1997; Martín et al., 2003) y, aunque codifican resistencia a diferentes patógenos (bacterias, virus, hongos), presentan importante similitud en la estructura general y conservan dominios específicos (Staskawicz et al., 1995). 
De acuerdo con Dangl y Jones (2001) estos genes pueden ser agrupados en cinco clases principales de proteínas (Figura III-2). La clase más importante corresponde a las proteínas NB-LRR, que funcionarían exclusivamente como genes de respuesta y estarían asociadas con la membrana plasmática. La principal característica de este grupo es un número variable de repeticiones ricas en leucina (LRR, leucine rich repeats) en el extremo carboxilo-terminal. Los dominios LRR se encuentran en diversas proteínas y funcionan como sitios de interacción proteína-proteína, interacción proteína-carbohidrato y unión péptido-ligando. Además, contienen un sitio de unión a nucleótidos, aunque se desconoce qué tipo de nucleótidos unen o en qué modo se produce la interacción. La clase NB-LRR se subdivide en dos grupos de acuerdo con las características estructurales del extremo amino-terminal: TIR-NB-LRR que presenta extremos con homología a dominios de señalización intracelular de Drosophila (dominio Toll) o receptores de Interleukina de mamíferos (IL-1) y CC-NB-LRR que contiene posibles dominios de $\alpha$-hélices yuxtapuestas (coiled-coil, leucine zipper) y comprendería múltiples subfamilias en función del tamaño y la localización de los dominios CC.

Las otras cuatro clases de proteínas son estructuralmente diversas y, además, para algunos de sus miembros se han demostrado funciones en procesos no relacionados con defensa (celulares o de desarrollo). eLRR, agrupa genes que codifican dominios LRR extracelulares anclados a un dominio transmembrana. Kinase, comprende genes que codifican dominios citoplasmáticos de kinasas de serina y treonina (Ser-Thr kinasas), con capacidad de autofosforilación, sin dominio LRR ni NB. La cuarta clase, denominada LRR-Kinase, agrupa proteínas que consisten de un dominio eLRR fusionado a un dominio citoplasmático de Ser-Thr kinasa. El gen RPW8, se ubica en la quinta clase y corresponde a una pequeña proteína, probablemente de membrana con un posible dominio CC. McDowell y Woffenden (2003) agregan, el gen Rpg1 que codifica dos dominios Ser-Thr kinasa fusionados que tendrían ubicación citoplasmática y los genes Ve2 y Ve1 que codifican para proteínas con posibles dominios LRR extracelulares, junto con un dominio PEST para degradación de proteínas (sólo presente en Ve2) y un dominio que podría ser marcador para endocitosis mediada por receptor (RME) (Figura III-2).

Los genes $\mathrm{R}$ fueron inicialmente aislados a través de localización cromosomal usando poblaciones segregantes e identificación de la secuencia correcta por inserción de transposones o complementación con cósmidos (Hammond-Kosack y Jones, 1997), estrategia que no es fácilmente aplicable a todos los sistemas de enfermedades de plantas. 


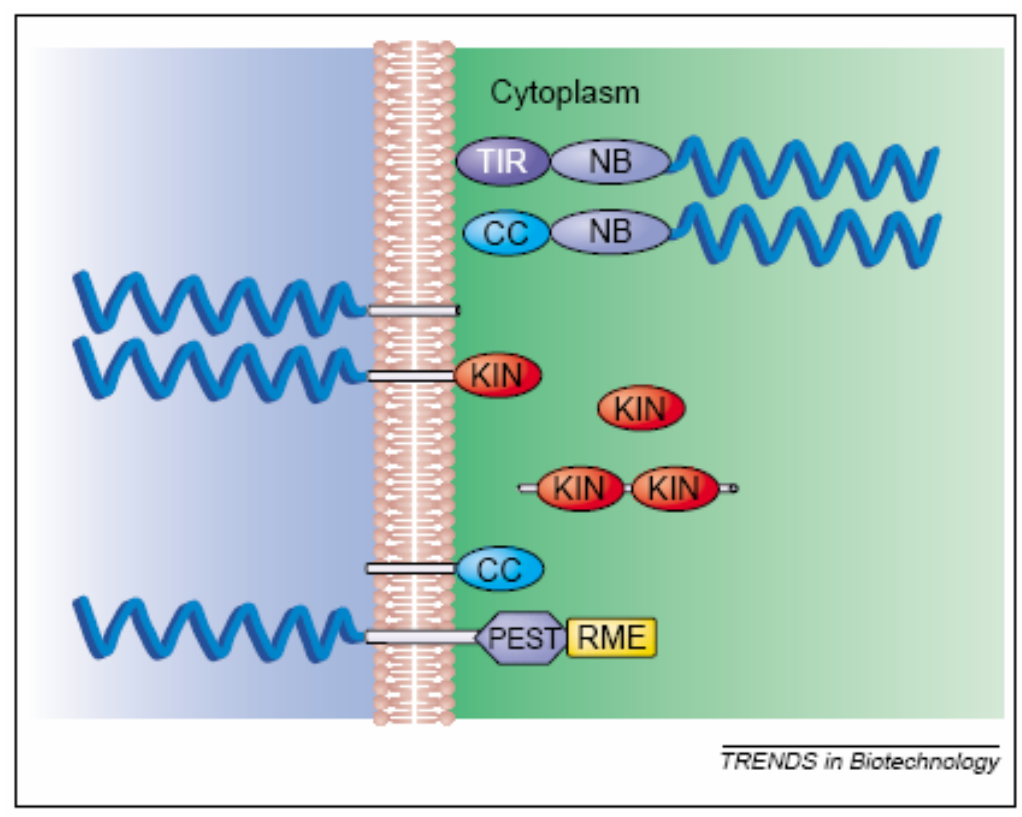

Figura III-2: Principales clases de proteínas codificadas por los genes R. LRR (zigzag azul): repeticiones ricas en leucina, función de reconocimiento específico. NB: dominio de unión a nucleótidos. TIR: dominio con homología a receptores Toll. CC: dominio coiled coil. KIN: dominios de Ser-Thr kinasa. PEST: dominios para degradación. RME: endocitosis mediada por receptor. Tomado de McDowell y Woffenden (2003).

La existencia de dominios conservados en los genes $\mathrm{R}$ posibilitó el desarrollo de una nueva metodología de caracterización genética a nivel de DNA denominada RGA (resistance gene analogs) permitiendo el aislamiento de secuencias similares en otras especies de plantas (Kanazin et al., 1996; Leister et al., 1996; Yu et al., 1996). En términos generales, la técnica se basa en la amplificación mediada por PCR de genes análogos a genes de resistencia a enfermedades, utilizando primers diseñados sobre dominios conservados de los genes R, electroforesis en gel de agarosa o poliacrilamida para separar los amplicones (fragmentos de DNA amplificados por PCR) y tinción con plata o marcado fluorescente en la detección.

Debido a la presencia de los dominios conservados cada combinación de primers empleada genera un número elevado de amplicones, que difieren en la longitud en pares de bases, para cada genotipo evaluado. Mutaciones de nucléotidos simples que modifican el sitio de unión del primer, inserciones y deleciones dan cuenta del polimorfismo observado entre genotipos o especies (Figura III-3). 


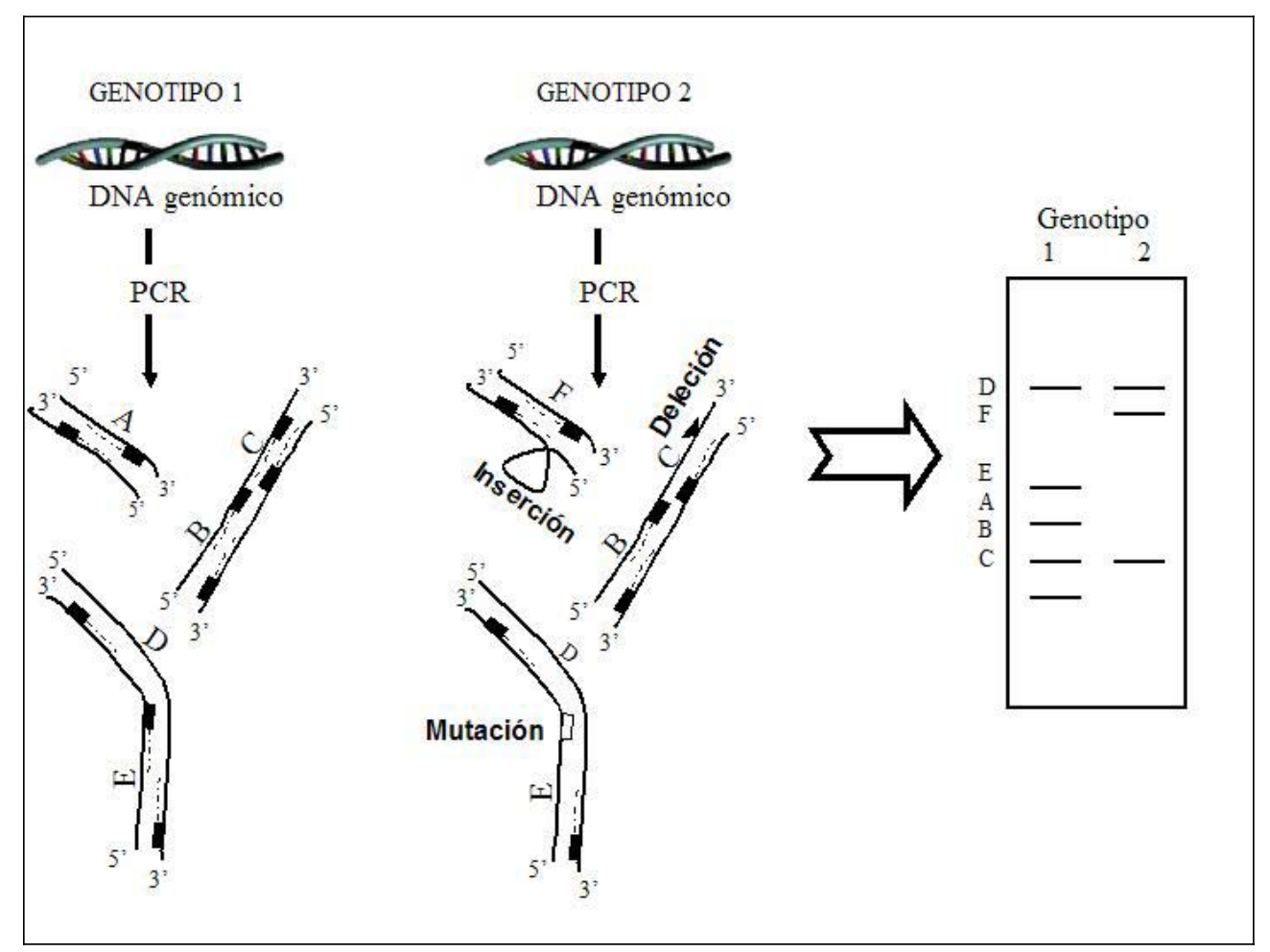

Figura III-3: Sistema de marcadores moleculares multilocus RGA (resistance gene analogs). La técnica consiste en la amplificación mediada por PCR de regiones del genoma que codifican para dominios análogos a los presentes en genes R, seguido de separación de los fragmentos amplificados mediante electroforesis. Procesos de alteración génica tales como mutaciones, inserciones, o deleciones determinan el nivel de polimorfismo detectado entre genotipos o especies.

Desde su desarrollo, la metodología RGA ha sido usada para:

- aislar genes de resistencia (Collins et al., 1998; Gentzbittel et al., 1998; Shen et al., 1998; Deng et al., 2000; Liu y Ekramoddoullah, 2003; Irigoyen et al., 2004; Martinez Zamora et al., 2004; Trognitz y Trognitz, 2005; Bozkurt et al., 2007; Glynn et al., 2008)

- desarrollar marcadores moleculares (Chen et al., 1998; Diaz y Ferrer, 2003; Xu et al., 2005; Cheng et al., 2005)

- detectar QTL (quantitative trait loci) y construir mapas de ligamiento (Chen et al., 1998; Donald et al., 2002; Peñuela et al., 2002; Rajesh et al., 2002; Madsen et al., 2003; Irigoyen et al., 2004; Tanhuanpää, 2004; Pattison et al. , 2007).

Los fundamentos básicos de la elección de este sistema para la caracterización a nivel de DNA, entre otras metodologías posibles (AFLP, RAPDs, microsatélites) fueron la similitud en la estructura general y la existencia de dominios conservados específicos en los genes de resistencia en forma independiente al patosistema en estudio, la verificación de la naturaleza codificante en la gran mayoría de los fragmentos amplificados y secuenciados, la utilización 
eficiente de la metodología en el aislamiento de genes de resistencia a enfermedades y el desarrollo de marcadores moleculares asociados a resistencia. Los marcadores RGA, sin embargo, no deben ser considerados como estrictamente selectivos ya que un gran porcentaje de los amplicones generados corresponderán a regiones del genoma que codifican para dominios análogos a los presentes en los genes R. Esta analogía de dominios no determina una misma función biológica, y por tanto, los marcadores RGA corresponden en términos generales a marcadores neutros.

El presente capítulo de la tesis comprende la caracterización genética de la especie $A$. chilensis, aplicando el sistema de marcadores moleculares multilocus RGA, a fin de evaluar las siguientes hipótesis en relación con el mal del ciprés:

- Hipótesis 1: Los individuos sintomáticos y asintomáticos para mal del ciprés son genéticamente diferentes.

PREDICCIÓN 1: Existen marcadores moleculares RGA asociados de manera diferencial a grupos de individuos sintomáticos o asintomáticos.

○ Hipótesis 2: Los individuos asintomáticos son genéticamente resistentes al mal del ciprés.

PREDICCIÓN 2: Los marcadores moleculares RGA que definen las diferencias entre estados sanitarios se asocian a los individuos asintomáticos.

○ Hipótesis 3: El patrón ecológico del mal del ciprés está determinado por las diferencias genéticas entre poblaciones mésicas y xéricas de $A$. chilensis.

PREDICCIÓN 3: Los marcadores moleculares RGA asociados a los individuos sintomáticos de las poblaciones mésicas están ausentes en las poblaciones xéricas.

\section{2.- MATERIALES Y MÉTODOS}

\section{1.- MATERial Vegetal}

La caracterización genética se realizó en los 50 pares de plantas (asintomáticas/sintomáticas) seleccionados por su fenotipo para mal del ciprés (Capitulo II) en áreas de bosque de A. chilensis afectadas por mal del ciprés en su patrón desagregado (El Bolsón: 4157’01'S $71^{\circ} 31^{\prime} 54^{\prime \prime}$ ) y en 24 individuos seleccionados al azar en un área de bosque de $A$. chilensis libre del mal del ciprés correspondiente al tipo forestal marginal (San Ramón: 4103'00' S $\left.71^{\circ} 05^{\prime} 00^{\prime}, \mathrm{O}\right)$. En total se analizaron 124 árboles. 
Cada uno de los individuos se muestreó a la altura del DAP $(1,25 \mathrm{~m})$, utilizándose un barreno de Presler para extraer muestras de aproximadamente $3 \mathrm{~cm}$ de longitud comprendiendo corteza, albura (floema) y duramen (xilema). Cada muestra se identificó con un código de número y letra; correspondiendo el primero al número de par (de 1 a 50) y la letra al estado sanitario, A (asintomático) y S (sintomático). El barreno de Presler se esterilizó por calor entre muestras y el material se conservó a $4^{\circ} \mathrm{C}$ hasta su utilización.

\section{2.- EXTRACCIÓN DE DNA Y AMPLIFICACIÓN POR PCR}

Las muestras de barreno se procesaron para separar duramen de corteza y albura. Posteriormente se utilizó una hoja de bisturí para generar discos finos de duramen, a fin de mejorar la molienda en nitrógeno liquido. El material molido se empleó en la extracción de DNA total siguiendo el método reportado por Bekesiova et al. (1999). Las extracciones de DNA se cuantificaron con Qubit Fluorometer y Quant-iT dsDNA BR Assay Kit (Molecular Probes, Invitrogen detection technologies, USA).

Cuatro combinaciones de primers se emplearon en la caracterización mediante RGA (Tabla III-1). La combinación XLRR corresponde al dominio LRR del gen RPS2 (arabidopsis) que confiere resistencia a Pseudomonas syringae p.v tomato. La combinación S1/AS1 pertenece a un grupo de primers diseñado con base en las regiones P-loop e hidrofóbica del dominio NB de los genes $\mathrm{N}$ (tabaco) que confiere resistencia al virus del mosaico del tabaco, RPS2 y L6 (lino) que confieren resistencia a Melampsora lini. Las combinaciones Ptokin1_2 y Ptokin3_4 se diseñaron a partir de la secuencia del gen Pto de tomate que confiere resistencia a Pseudomonas syringae p.v. tomato.

\begin{tabular}{|c|c|c|c|c|}
\hline Dominio & Combinación & Primer & Secuencia $\left(5 \rightarrow 3^{\prime}\right)$ & Cita \\
\hline \multirow{2}{*}{ LRR } & XLRR & $\begin{array}{c}\text { XLRR for } \\
\text { XLRR rev }\end{array}$ & $\begin{array}{c}\text { CCGTTGGACAGGAAGGAG } \\
\text { CCCATAGACCGGACTGTT }\end{array}$ & Chen et al., 1998 \\
\hline \multirow{2}{*}{ NB } & S1/AS1 & $\begin{array}{c}\text { S1 } \\
\text { AS1 }\end{array}$ & $\begin{array}{c}\text { GGTGGGGTTGGGAAGACAACG } \\
\text { CAACGCTAGTGGCAATCC }\end{array}$ & Leister et al., 1996 \\
\hline \multirow{2}{*}{ Kinase } & Ptokin1_2 & $\begin{array}{c}\text { Ptokin1 } \\
\text { Ptokin2 }\end{array}$ & $\begin{array}{c}\text { GCATTGGAACAAGGTGAA } \\
\text { AGGGGGACCACCACGTAG }\end{array}$ & Feuillet et al., 1997 \\
\cline { 2 - 6 } & Ptokin3_4 & $\begin{array}{c}\text { Ptokin3 } \\
\text { Ptokin4 }\end{array}$ & $\begin{array}{c}\text { TAGTTCGGACGTTTACAT } \\
\text { AGTGTCTTGTAGGGTATC }\end{array}$ & Zhang et al., 2002 \\
\hline
\end{tabular}

Tabla III-1: Pares de primers utilizados en la caracterización genética de A. chilensis. Se indica el dominio base para el diseño de los primers, la secuencia nucleotídica y la cita bibliográfica correspondiente. El nombre asignado a cada combinación será empleado en el desarrollo del presente capítulo. 
La reacción de PCR se realizó en un volumen final de $10 \mu$, con 9 ng de DNA total como molde, $200 \mu \mathrm{M}$ dNTPs, 1\% Tween 20, $0.04 \mathrm{U} / \mu 1$ Taq DNA polimerasa (Invitrogen, USA) y $1 \mathrm{X}$ Buffer Taq DNA polimerasa (20 mM Tris- $\mathrm{HCl}(\mathrm{pH} 8.4), 50 \mathrm{mM} \mathrm{KCl})$. Las condiciones de amplificación y la concentración final de $\mathrm{MgCl}_{2}$, se ajustaron para cada combinación de primers.

Para XLRR se utilizó una concentración final de $2.0 \mathrm{mM} \mathrm{MgCl}_{2}$ y el siguiente programa: un ciclo de desnaturalización inicial 3 min a $94^{\circ} \mathrm{C}, 45$ ciclos de desnaturalización 1 min a $94^{\circ} \mathrm{C}$, annealing del primer $1 \mathrm{~min}$ a $43.5^{\circ} \mathrm{C}$, extensión $2 \min$ a $72^{\circ} \mathrm{C}$ y un ciclo de extensión final de 7 min a $72^{\circ}$ C. Las combinaciones Ptokin1_2 y Ptokin3_4, se emplearon con una concentración final de $2.5 \mathrm{mM} \mathrm{MgCl}_{2}$ y el siguiente programa: un ciclo de desnaturalización inicial 5 min a $94^{\circ} \mathrm{C}, 45$ ciclos de desnaturalización 1 min a $94^{\circ} \mathrm{C}$, annealing de primers 1 min a $45^{\circ} \mathrm{C}$, extensión 2 min a $72^{\circ} \mathrm{C}$ y un ciclo de extensión final de 7 min a $72^{\circ} \mathrm{C}$. La combinación S1/AS1 se utilizó con una concentración final de $2,0 \mathrm{mM} \mathrm{MgCl}_{2}$ y se ajustó el siguiente programada de Touch Down PCR: un ciclo de desnaturalización inicial 3 min a $94^{\circ} \mathrm{C}, 3$ ciclos de desnaturalización 1 min a $94^{\circ} \mathrm{C}$, annealing de primers 1 min a $48^{\circ} \mathrm{C}$, extensión 2 min a $72^{\circ} \mathrm{C}$, 10 ciclos de desnaturalización $1 \mathrm{~min}$ a $94^{\circ} \mathrm{C}$, annealing de primers 1 min a $48^{\circ} \mathrm{C} \rightarrow 43.5^{\circ} \mathrm{C}$ (disminución $0.5^{\circ} \mathrm{C} /$ ciclo), extensión 2 min a $72^{\circ} \mathrm{C}, 32$ ciclos de desnaturalización 1 min a 94 ${ }^{\circ}$ $\mathrm{C}$, annealing de primers 1 min a $43.5^{\circ} \mathrm{C}$ y extensión 2 min a $72^{\circ} \mathrm{C}$; con un ciclo de extensión final de $7 \min$ a $72^{\circ} \mathrm{C}$.

En todos los casos los fragmentos amplificados se marcaron mediante la incorporación de dUTP fluorescente presente en la mezcla de reacción; se utilizó una concentración final de $0.4 \mu \mathrm{M}$ FdUTP y una relación dNTPs/FdUTP de 500. Cada PCR se combinó con el marcador de peso molecular ROX-500 (Applied Biosystems, USA) en forma previa a su separación por electroforesis. Los amplicones se separaron y detectaron en un Secuenciador Automático de DNA ABI 377 (Applied Biosystems, USA). Se utilizaron geles de acrilamida-bisacrilamida (19:1) al 4\% y urea 6M. El espesor de los geles fue de $0.2 \mathrm{~mm}$. SoftGenetics GeneMarker V1.6 (2007) fue utilizado para el análisis simultáneo de todas las muestras correspondientes a cada combinación de primers, calculando el tamaño de los amplicones a partir de la curva de calibración obtenida para ROX-500 en cada calle del gel.

\section{3.- ANÁLISIS DE LOS DATOS}

Para cada combinación de primers, se analizaron todos los amplicones detectados (marcadores) entre 40-600 pb. Debido a que niveles variables de compuestos interferentes en las muestras de 
DNA pueden determinar diferencias en el nivel de amplificación entre individuos, el scoring de los marcadores no se realizó en función de un valor fijo de señal fluorescente (umbral de detección de fluorescencia $=50$ o 100 unidades), sino aplicando un método de normalización. La misma se realizó en cada muestra, según relación porcentual, en función de la señal fluorescente del marcador más intenso. A fin de determinar la reproducibilidad de los marcadores detectados y establecer el valor de corte para el score 1 (presencia) o 0 (ausencia) se duplicó el 10\% de las muestras; realizándose nueva PCR, separación y detección en ABI 377. Únicamente los marcadores reproducibles fueron incluidos en los análisis posteriores.

RGA es un sistema de marcadores moleculares dominantes, por lo cual la presencia de un marcador en el gel puede representar tanto un homocigota (presencia / presencia) como un heterocigota (presencia / ausencia) dominante. El cálculo de parámetros genéticos para este tipo de marcadores se basa en datos de presencia o ausencia de amplicones (fenotípicos), lo que representa una desventaja respecto de los marcadores codominantes. Por tal motivo, la mayoría de los programas informáticos aplicados al análisis de marcadores dominantes calculan los parámetros genéticos, bajo un modelo de neutralidad, a partir de frecuencias alélicas estimadas y asumiendo la existencia de equilibrio de Hardy-Wienberg. Al menos cuatro métodos se han desarrollado para estimar las frecuencias alélicas en marcadores dominantes (Krauss, 2000; Vekemans et al., 2002). El método bayesiano con distribución no uniforme (Zhivotovsky, 1999) implementado en AFLP-SURV 1.0 (Vekemans et al., 2002) se aplicó en este trabajo para estimar las frecuencias alélicas. El método se seleccionó debido a que para el cálculo considera el tamaño de la población, el número de individuos en la población que carecen del marcador y la distribución estimada de las frecuencias alélicas en cada población, dando los resultados más confiables y disminuyendo los desvíos observados en casos de baja frecuencia del alelo nulo (Zhivotovsky, 1999). El programa estima las frecuencias alélicas para cada locus marcador (banda detectada o fragmento amplificado) en cada población, asumiendo un carácter dominante y bialélico; esto es, la existencia de un alelo marcador dominante que codifica para la presencia de la banda en una determinada posición del gel y un alelo recesivo nulo que codifica la ausencia de la misma. Las frecuencias alélicas se computaron a partir de una matriz binaria generada con los datos de presencia / ausencia de los marcadores para cada individuo y población y se emplearon en el cálculo de parámetros genéticos aplicando el software AFLPsurv 1.0. Para cada parámetro se obtuvo un estimador sin desvío según las ecuaciones propuestas por Lynch y Milligan (1994) para el análisis genético con marcadores dominantes bajo el siguiente modelo:

- ausencia de comigración de los alelos marcadores desde diferentes loci, es decir que se asume que cada amplicón detectado en el gel corresponde a una única porción del genoma en estudio 
- cada locus se trata como un sistema de 2 alelos, correspondiendo el alelo marcador a la porción amplificada del genoma, no siendo relevante en el desarrollo teórico el origen del alelo nulo (pérdida del sitio de annealing del primer, inserción génica, etc)

- se asume la existencia de equilibrio de Hardy-Weinberg.

Los marcadores se emplearon en el cálculo de dos parámetros de diversidad genética, el porcentaje de loci polimórficos (PLP) y la heterocigosidad esperada bajo equilibrio de HardyWeinberg $(\mathbf{H j})$. Un locus se considera polimórfico si la frecuencia de su alelo más frecuente es menor o igual a 0.95 o 0.99 . En este trabajo se determinó el porcentaje de loci polimórfico al 5\% (PLP), de acuerdo con las frecuencias alélicas estimadas para el alelo marcador y el alelo nulo. En el marco teórico del modelo de Lynch y Milligan (1994) la heterocigosidad esperada (Hj) bajo equilibrio de Hardy-Weinberg corresponde al valor de la diversidad génica en la población (Hj(i)) promediada sobre todos los loci. La diversidad génica en la población ( $\mathbf{H j ( i ) ) ~ s e ~ c a l c u l a ~}$ en base a, qj(i), la frecuencia del alelo nulo en el locus que corresponde al marcador i en la población $\mathrm{j}$; y puede entenderse como la probabilidad de que un par de alelos tomado al azar contenga un marcador y un alelo nulo. Dicho de otra forma, la probabilidad de que dos genes tomados al azar en la población j difieran en el locus i. Hj es un estimador de la diversidad genética de Nei.

Considerando que algunos de los supuestos asumidos en los métodos de estimación aplicados no necesariamente se cumplen en las poblaciones reales (ej: ausencia de comigración, sistema de 2 alelos, modelo de neutralidad), la diferenciación genética se estimó mediante un análisis molecular de la varianza (AMOVA) que se basa en los datos de presencia/ausencia del marcador. Matrices euclídeanas de distancia genética se calcularon siguiendo el método de Huff et al. (1993) y Maguire et al. (2002) implementado en el software Genetic Analysis in Excell (GenAlEx) V.6 (Peakall y Smouse, 2006), según el cual cualquier comparación con el mismo estado da un valor de $0(0 / 0$ o $1 / 1)$ en tanto que cualquier comparación con diferente estado da un valor de $1(1 / 0$ o $0 / 1)$. Cuando la comparación se realiza para todos los loci de un par dado de muestras, es equivalente al total de las diferencias entre los dos perfiles genéticos.

Las matrices de distancia obtenidas se emplearon en el análisis molecular de la varianza (AMOVA) implementado en GenAlEx, de acuerdo con el método de Excoffier et al. (1992), Huff et al. (1993), Peakall et al. (1995) y Michalakis y Excoffier (1996). Este procedimiento estadístico permite analizar el particionamiento de la variación genética y la estimación del parámetro $\Phi_{\mathrm{PT}}$. El parámetro $\Phi_{\mathrm{PT}}$ es una medida de la diferenciación genética entre poblaciones, análoga a Fst, proporcionada por GenAlEx para marcadores dominantes (datos binarios). Cuando se 
consideran dos niveles jerárquicos en el AMOVA (poblaciones y regiones) es posible calcular tres parámetros de diferenciación: $\Phi_{\mathrm{RT}}$ (diferenciación entre las regiones), $\Phi_{\mathrm{PR}}$ (diferenciación entre las poblaciones dentro de las regiones) y $\Phi_{\mathrm{PT}}$ (diferenciación entre las poblaciones).

$\Phi_{\mathrm{PT}}$ se calcula como la proporción de la varianza entre poblaciones $\left(\mathrm{V}_{\mathrm{AP}}\right)$ respecto de la varianza total $\left(\mathrm{V}_{\mathrm{AP}}+\mathrm{V}_{\mathrm{WP}}\right)$, siendo $\mathrm{V}_{\mathrm{WP}}$ la varianza dentro de las poblaciones, y representa la correlación entre individuos dentro de la población respecto del total. Cuando se trabaja con dos niveles de organización jerárquica, regiones y poblaciones, $\Phi_{\mathrm{PR}}$ corresponde a la proporción de la varianza entre las poblaciones dentro de las regiones $\left(\mathrm{V}_{\mathrm{AP}}\right)$, respecto de la varianza dentro $\left(\mathrm{V}_{\mathrm{WP}}\right)$ y entre las poblaciones $\left(\mathrm{V}_{\mathrm{AP}}\right)$, y puede interpretarse como la correlación entre individuos en una población respecto de los individuos de la misma región. $\Phi_{\mathrm{RT}}$ es la proporción de la varianza entre regiones $\left(V_{A R}\right)$ respecto de la varianza total $\left(V_{\mathrm{WP}}+\mathrm{V}_{\mathrm{AP}}+\mathrm{V}_{\mathrm{AR}}\right)$ y representa la correlación en una región respecto del total. $\Phi_{\mathrm{PT}}$, en el caso de dos niveles jerárquicos, se calcula como la proporción de la varianza entre regiones y poblaciones respecto del total.

El nivel de significación de todos los estadísticos $\Phi$ calculados se basó en 999 permutaciones. La estimación de la diferenciación genética mediante AMOVA implementada en GenAlEx V.6 permite el análisis sobre el conjunto de los marcadores o en cada marcador en forma individual. En este trabajo el análisis se realizó para el conjunto de los marcadores y para cada uno de los marcadores en forma separada.

Las frecuencias alélicas estimadas correspondientes a los marcadores obtenidos para los individuos de los pares de plantas (asintomáticas/sintomáticas) del valle de El Bolsón fueron empleadas en un análisis de agrupamiento de individuos aplicando el software Structure v.2.2 (Falush et al., 2007), que implementa un método bayesiano de agrupamiento de genotipos. Asumiendo la existencia de equilibrio de Hardy-Weinberg (H-W) y equilibrio de ligamiento dentro de cada subpoblación, busca el número de poblaciones $(\mathrm{K})$ que mejor ajusta los datos y la asignación de individuos minimizando el desequilibrio de $\mathrm{H}-\mathrm{W}$ y ligamiento en dichas subpoblaciones. El análisis se realizó bajó el modelo de pertenencia de los individuos a una población (no admixture model), con frecuencias alélicas independientes entre poblaciones, un valor de $\lambda=1$ y valores de 50.000 para ambos parámetros de la simulación (longitud del período de Burnin y número de repeticiones del método de Monte Carlo via Cadena de Markov (MCMC) posterior al período de Burnin). Se emplearon valores crecientes de $\mathrm{K}$ (1 a 6 ), realizándose 4 iteraciones para cada uno de ellos. 


\section{3.- RESULTADOS}

\section{1.- UTILIDAD DEL SISTEMA DE MARCADORES RGA EN LA CARACTERIZACIÓN DE LA} ESPECIE $A$. CHILENSIS

El material de duramen obtenido de los 50 pares de plantas seleccionados en la región de El Bolsón, se utilizó para la extracción de DNA total de acuerdo con lo indicado en Materiales y Métodos. En promedio se emplearon $212 \mathrm{mg}$ de tejido molido, con un rendimiento promedio de 2,98 $\mu \mathrm{g}$ DNA por $1 \mathrm{~g}$ tejido. Todos los individuos fueron amplificados con las cuatro combinaciones de primers. La información sobre los mg de tejido molido, la concentración del DNA extraído y el rendimiento final se presenta en el Anexo 3. Las extracciones de DNA de siete individuos no amplificaron en forma adecuada con una o varias combinaciones de primers. Estos siete individuos y sus correspondientes pares fueron eliminados, quedando un total de 43 pares (86 individuos) para los análisis posteriores. Las cuatro combinaciones de primers empleadas amplificaron marcadores en el rango de tamaño esperado (Figura III-4).

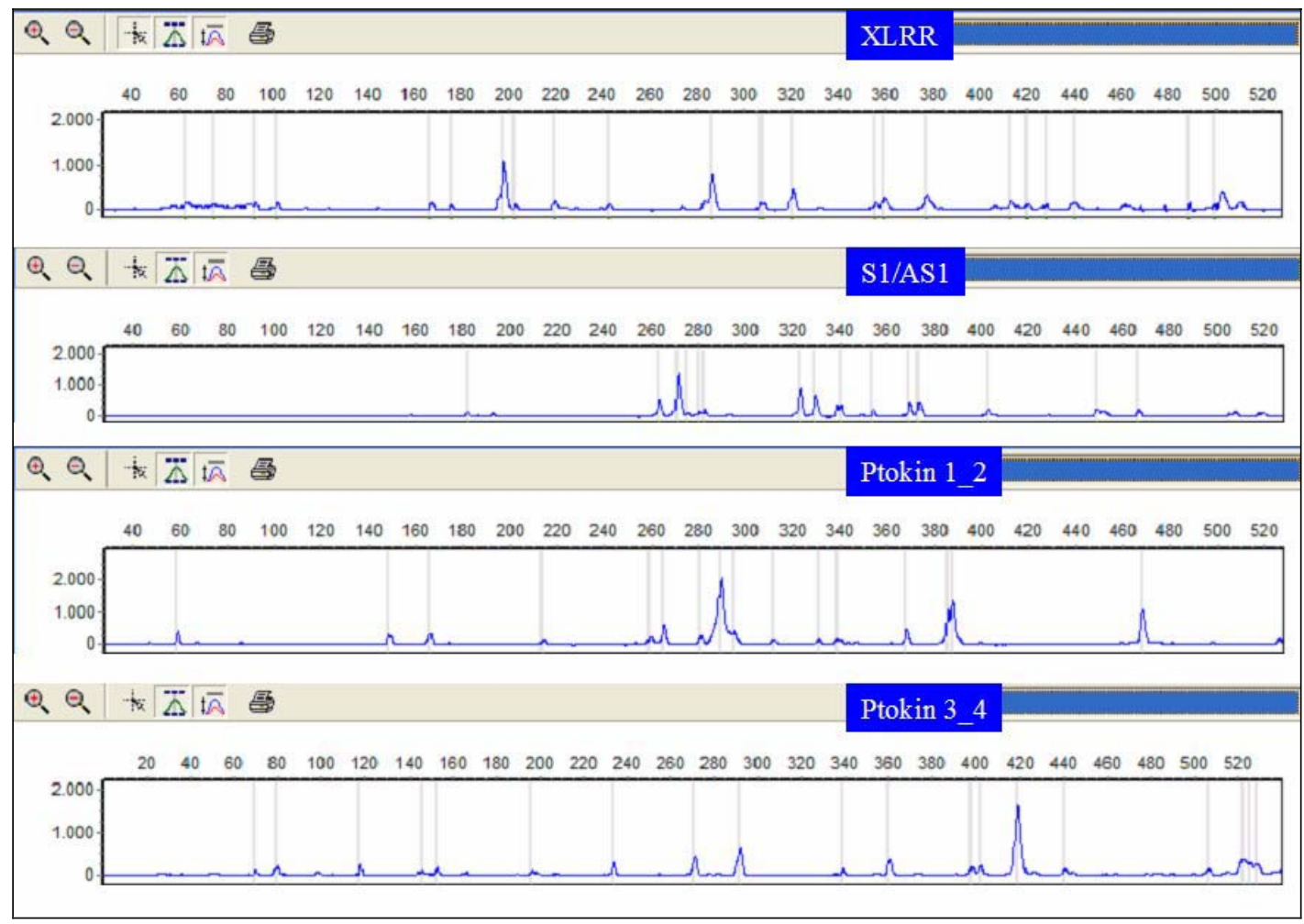

Figura III-4: Perfil de amplificación obtenido para cada combinación de primers empleada en la caracterización con RGA. En cada perfil se indica el tamaño en pares de bases (escala superior) y la intensidad de la señal fluorescente (escala margen izquierdo). Las líneas grises verticales indican la posición de los marcadores detectados (SoftGenetics, GeneMarker). 
El número de marcadores reproducibles varió entre 7 y 19, de acuerdo con la combinación de primers utilizada. En total se obtuvieron 54 marcadores que se emplearon para la construcción de una tabla binaria (1/0) en función de los valores de corte definidos para el score. De acuerdo con el análisis realizado sobre 86 individuos, 43 de los 54 marcadores tipificados fueron polimórficos (79.6\%), siendo similar el porcentaje de marcadores con polimorfismo obtenido para cada combinación de primers (Tabla III-2).

\begin{tabular}{|c|c|c|c|}
\hline \multirow{2}{*}{ Dominio } & \multirow{2}{*}{ Combinación } & \multicolumn{2}{|c|}{ Número de marcadores } \\
& & Total & Polimórficos \\
\hline LRR & XLRR & 13 & $11(84.6)$ \\
\hline NBS & S1/AS1 & 19 & $15(78.9)$ \\
\hline \multirow{2}{*}{ Kinase } & Ptokin1_2 & 15 & $11(73.3)$ \\
& Ptokin3_4 & 7 & $6(85.7)$ \\
\hline
\end{tabular}

Tabla III-2: Número de marcadores RGA, totales y polimórficos, obtenido para cada combinación de primers aplicada en la caracterización genética de A. chilensis. El porcentaje de polimorfismo detectado para cada combinación de primers se indica entre paréntesis.

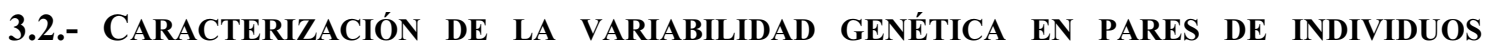
ASINTOMÁTICOS Y SINTOMÁTICOS CON DISTRIBUCIÓN DESAGREGADA

Los 43 marcadores polimórficos generados mediante el sistema RGA se emplearon en la caracterización de la variabilidad genética de dos poblaciones de A. chilensis, cada una de las cuales resultó del agrupamiento de individuos que comparten un mismo estado sanitario para mal del ciprés (sintomáticos o asintomáticos). De acuerdo con el método de muestreo pareado ambas poblaciones presentaron el mismo número de individuos $(\mathrm{n}=43)$.

Las frecuencias alélicas se computaron a partir de una matriz binaria generada con los datos de presencia / ausencia de los 43 marcadores polimórficos para cada individuo en cada población. En el Anexo 4 se presentan los resultados obtenidos para la frecuencia del marcador $\left(\mathrm{M}_{\mathrm{RGA}}\right)$, la frecuencia del alelo marcador dominante $\left(\mathrm{A}^{+}\right)$y la frecuencia del alelo recesivo nulo (A-) por locus y población. La heterocigosidad esperada bajo equilibrio de Hardy-Weinberg (Hj) es similar para ambas poblaciones, siendo 0.27494 y 0.27101 los valores obtenidos para las poblaciones asintomática y sintomática. El porcentaje de loci polimórficos (PLP), muestra diferencias entre ambas poblaciones, con valores de $67.4 \%$ para la población asintomática y $83.7 \%$ para la sintomática, sugiriendo una distribución diferencial de la diversidad entre los diferentes marcadores en cada población. 
La diferenciación entre ambas poblaciones estimada mediante un análisis molecular de la varianza $(A M O V A)$, dio un parámetro $\Phi_{\mathrm{PT}}$ de $0.025(\mathrm{p}<0.012)$ para el conjunto de los marcadores. El parámetro $\Phi_{\mathrm{PT}}$ se calculó también para cada marcador en forma individual detectándose 4 marcadores (A-403, X-198, P3-398 y P3-402) que presentan valores de $\Phi_{\mathrm{PT}}$ estadísticamente significativos (valores de $\mathrm{p}<0.05$ ), superiores al valor sobre el conjunto de los marcadores (Figura III-5). Los marcadores A-403, P3-398 y P3-402 presentan una frecuencia del $10 \%$ en el conjunto de los individuos y se asocian a la población sintomática. Si bien estos tres marcadores no son privativos, el seguimiento a nivel de individuos indica que, en su gran mayoría, la falta de exclusividad se debe a la presencia de estos marcadores en el individuo 4A. El par 4 corresponde a individuos de posición sociológica intermedia por lo que este podría ser un caso de clasificación errónea del individuo asintomático. El marcador X-198 corresponde a un fragmento de alta frecuencia $(88 \%)$ y su presencia se asocia a la población sintomática.

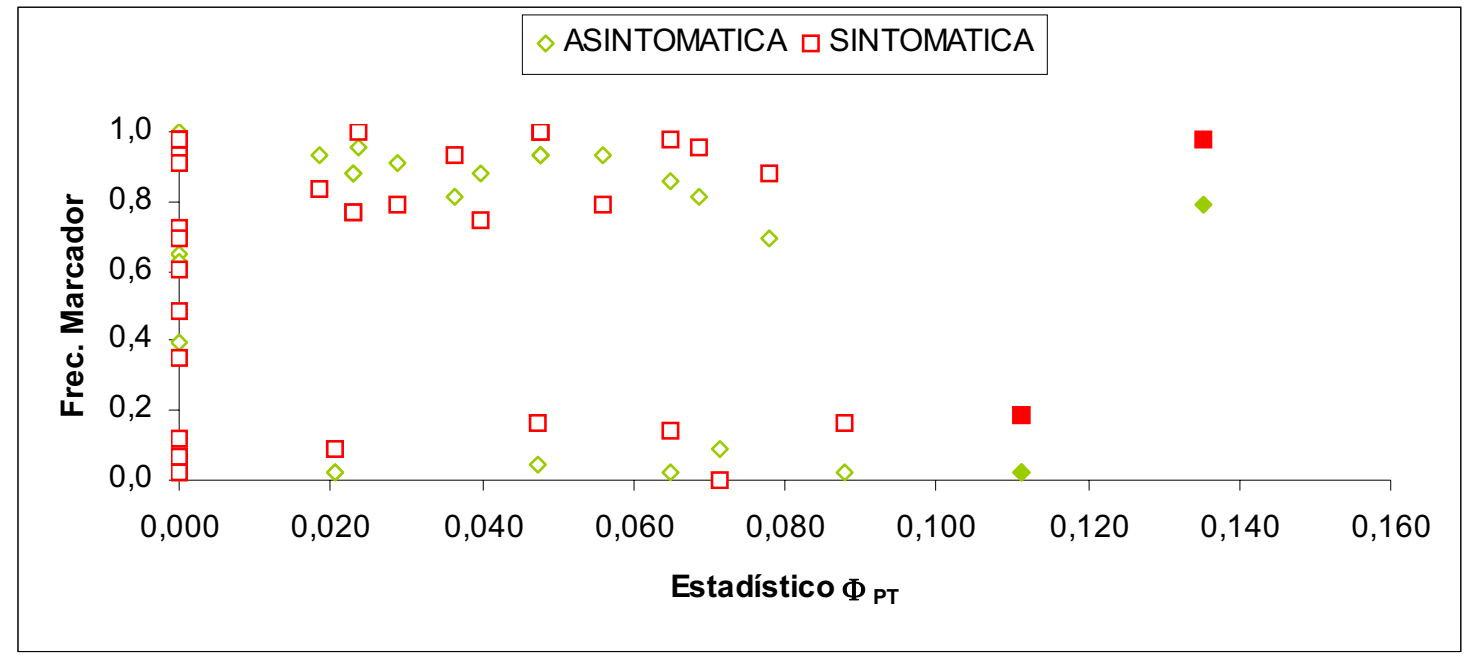

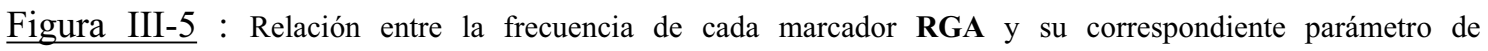
diferenciación entre las poblaciones Asintomática y Sintomática $\left(\Phi_{\mathrm{PT}}\right)$ determinado vía AMOVA. Símbolos llenos, marcadores RGA (candidatos) con $\Phi_{\mathrm{PT}}$ estadísticamente significativo.

El análisis en Structure se realizó con valores crecientes de K (1 a 6), realizándose 4 iteraciones para cada uno de ellos. En la Figura III-6 se presentan los resultados obtenidos para K igual a 2, 3, 4 y 5; en los gráficos cada individuo está representado por una línea vertical. Esta línea puede estar dividida en segmentos de diferentes colores, que indican la fracción estimada de pertenencia del individuo a cada uno de los clusters inferidos. El valor del logaritmo de la probabilidad de los datos, esto es la probabilidad de $\mathrm{K}$ cluster dados $\mathrm{X}$ genotipos $(\operatorname{Pr}(\mathrm{X} / \mathrm{K})$, en función del número de cluster fue de: $\ln \operatorname{Pr}(\mathrm{X} / \mathrm{K})=-1216.35$ para $\mathrm{K}=1, \ln \operatorname{Pr}(\mathrm{X} / \mathrm{K})=-1070.65$ para $\mathrm{K}=2, \quad \ln \operatorname{Pr}(\mathrm{X} / \mathrm{K})=-998.77$ para $\mathrm{K}=3, \quad \ln \operatorname{Pr}(\mathrm{X} / \mathrm{K})=-1051.92$ para $\mathrm{K}=4$, 
$\ln \operatorname{Pr}(\mathrm{X} / \mathrm{K})=-1102.40$ para $\mathrm{K}=5 \mathrm{y} \ln \operatorname{Pr}(\mathrm{X} / \mathrm{K})=-1011.20$ para $\mathrm{K}=6$. El valor para $\mathrm{K}=3$ corresponde al máximo y da el resultado con mejor sentido biológico. En la Figura III-6, se observa que para $\mathrm{K}=4$ el nuevo cluster generado agrupa un número bajo de individuos, en tanto que para $\mathrm{K}=5$ se observa un particionamiento adicional según $\approx 1 / \mathrm{K}$ indicativo de ausencia de estructuración. Por tanto, se asumió un valor de 3 clusters $(\mathrm{C} 1, \mathrm{C} 2$ y C3) inferido mediante simulación. El coeficiente de pertenencia de los individuos para cada uno de estos clusters se presenta en el Anexo 5.

\section{ANALISIS DE AGRUPAMIENTO DE INDIVIDUOS}

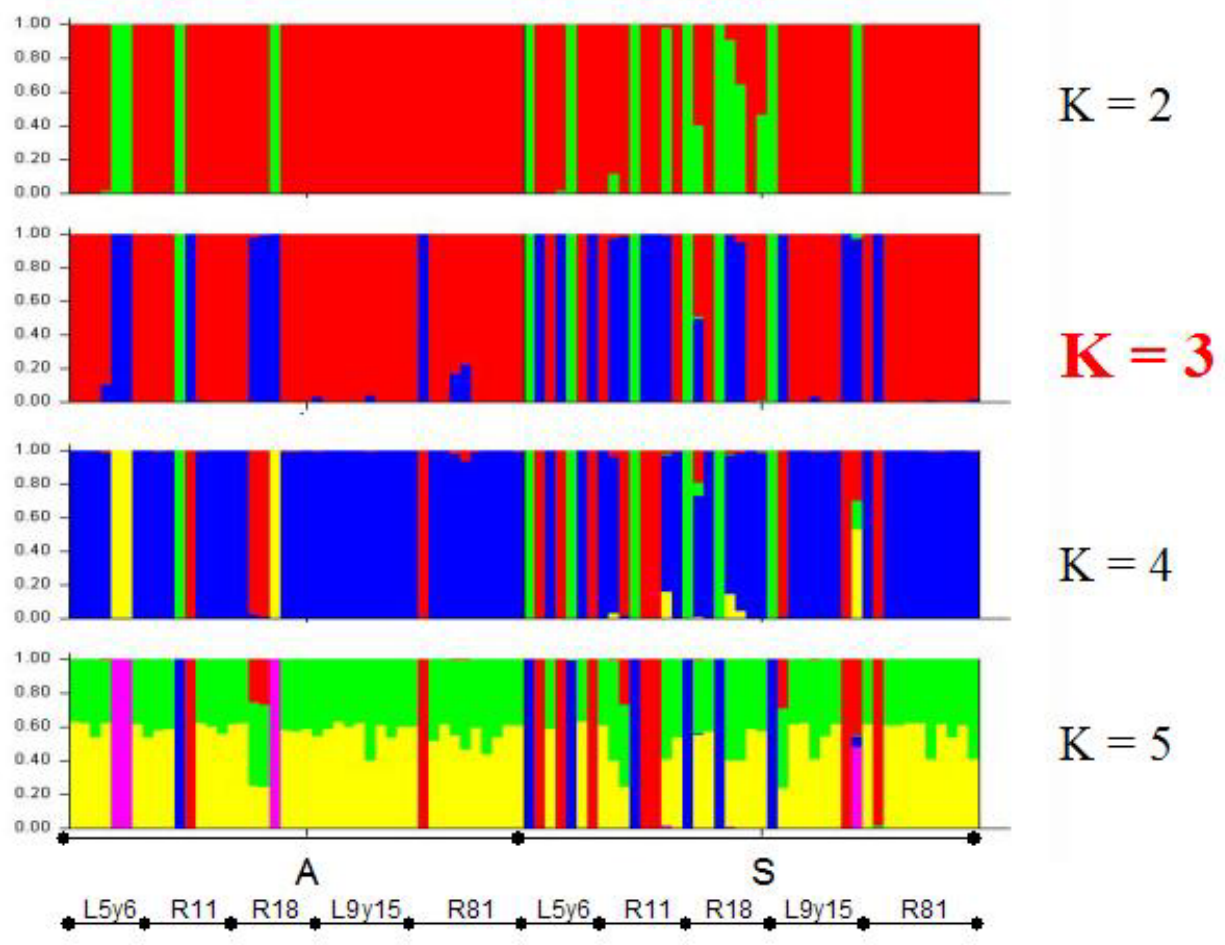

Figura III-6: Particionamiento de los 86 individuos caracterizados por RGA obtenido para K=2, 3, 4 y 5 según el método de agrupamiento implementado en Structure. Cada individuo está representado por una línea vertical dividida en $\mathrm{K}$ segmentos coloreados cuya longitud indica la fracción estimada de pertenencia del individuo a cada uno de los clusters inferidos. En el eje inferior se indican el estado sanitario y el sitio de muestreo correspondiente a cada individuo. A: asintomático. S: sintomático.

El análisis de la proporción de individuos según estado sanitario u origen geográfico en cada cluster permitió establecer que el C1 agrupa un 67\% del total de los individuos, correspondiendo un $61 \%$ a árboles asintomáticos. E1 C2 comprende un $8 \%$ del total de los individuos siendo el $86 \%$ de estos sintomáticos; y el C3 agrupa un 25\% de los individuos correspondiendo el $67 \%$ a individuos sintomáticos. Por otra parte, el $100 \%$ y el $76 \%$ de los 
individuos contenidos en los cluster $\mathrm{C} 2$ y $\mathrm{C} 3$, respectivamente, corresponden a los sitios de muestreo que se encuentran al Norte de la región en estudio (L5y6, R11, R18). Para el C1 los individuos corresponden en un 42\% a los sitios del Norte (L5y6, R11 y R18).

Estos resultados muestran que la segregación de los individuos en clusters responde a la sintomatología y sugieren la existencia de estructuración genética Norte/Sur en el área de estudio correspondiente a un bosque mésico afectado por mal del ciprés con distribución desagregada.

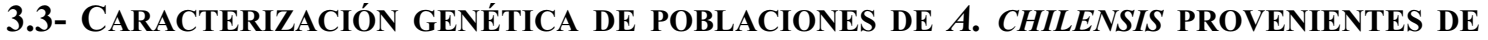
BOSQUES MÉSICOS AFECTADOS POR MAL DEL CIPRÉS (EL BOLSÓN) Y BOSQUES XÉRICOS NO AFECTADOS (SAN RAMÓN)

La población SR se comparó con las poblaciones sintomática y asintomática para mal del ciprés para evaluar si la ausencia de mal del ciprés en las zonas xéricas responde a diferencias genéticas entre poblaciones de $A$. chilensis de sitios xéricos y mésicos. Posteriormente en vista de los resultados del análisis de agrupamiento de individuos (Structure) que indican segregación según origen geográfico, la población SR se comparó con las poblaciones EB_N y EB_S. La población EB_N contiene el total de individuos provenientes de los sitios L5y6, R11 y R18 que corresponden al área Norte del valle de El Bolsón; en tanto que la población EB_S contiene el total de individuos provenientes de los sitios R81 y L9y15 que corresponden al área Sur del valle de El Bolsón.

\subsection{1.- San Ramón vs. poblaciones Asintomática y Sintomática para mal del ciprés provenientes de la región de EL Bolsón}

Los datos correspondientes a los 43 marcadores para los individuos de SR, fueron combinados con los derivados de las poblaciones A y $\mathrm{S}$, a fin de evaluar las diferencias existentes en relación con el mal del ciprés. De acuerdo con los resultados obtenidos, en términos de diversidad genética SR presenta niveles inferiores a los detectados en las poblaciones asintomática o sintomática, ya sea que se compare el PLP o la $\mathbf{H j}$ (Tabla III-3). 


\begin{tabular}{|c|c|cc|cc|}
\hline POP & $\mathrm{n}$ & $\mathrm{n}$ loci & loci $\mathrm{P}$ & $\mathrm{PLP}$ & $\mathrm{Hj}$ \\
\hline SR & 24 & 43 & 12 & 27.9 & 0.14040 \\
$\mathrm{~A}$ & 43 & 43 & 29 & 67.4 & 0.27494 \\
$\mathrm{~S}$ & 43 & 43 & 36 & 83.7 & 0.27101 \\
\hline
\end{tabular}

Tabla III-3: Parámetros genéticos calculados a partir de las frecuencias alélicas estimadas para los marcadores obtenidos por RGA. n: número de individuos caracterizados por RGA para cada población. n loci: número de loci empleados en el cálculo de estadísticos. loci P: número de loci polimórficos. PLP: porcentaje de loci polimórficos. Hj: heterocigosidad esperada. SR: San Ramón. A: Asintomática. S: Sintomática.

De acuerdo con la diferenciación previamente establecida entre las poblaciones asintomática y sintomática de El Bolsón, el AMOVA (Tabla III-4) se realizó considerando dos niveles jerárquicos: regiones (SR, EB) y poblaciones (SR, A, S). Los resultados muestran la existencia de diferenciación entre regiones y entre las poblaciones dentro de la región del EB y entre las tres poblaciones. La diferenciación entre las poblaciones A y S, es similar a la diferenciación entre las regiones SR y EB. Este resultado enfatiza la diferenciación según estado sanitario, considerando la cercanía geográfica entre los individuos de los pares.

\begin{tabular}{|c|c|c|c|c|c|}
\hline Niveles jerárquicos & Fuentes de Variación & \% de la varianza & \multicolumn{2}{|c|}{ Estadístico } & $\mathrm{p}$ value \\
\hline Regiones y Poblaciones & entre regiones & 4 & $\Phi_{\mathrm{RT}}$ & 0.038 & 0.002 \\
\cline { 1 - 1 } & entre poblaciones dentro de regiones & 3 & $\Phi_{\mathrm{PR}}$ & 0.031 & 0.004 \\
& Dentro de poblaciones & 93 & $\Phi_{\mathrm{PT}}$ & 0.068 & 0.001 \\
\hline
\end{tabular}

Tabla III-4: Análisis molecular de la varianza y parámetros $\Phi$ determinados en base a los 43 marcadores polimórficos según organización jerárquica de las poblaciones en estudio. SR: San Ramón. EB: El Bolsón. A: Asintomática. S: Sintomática.

De acuerdo con el análisis pareado de $\Phi_{\mathrm{PT}}$ (Tabla III-5) SR se diferencia más de la población $\mathrm{S}$ que de la población A, resultado que responde a lo esperado considerando la ausencia de mal del ciprés en áreas de bosque xérico.

\begin{tabular}{|c|ccc|}
\cline { 2 - 4 } \multicolumn{1}{c|}{} & SR & A & S \\
\hline SR & 0,000 & 0,001 & 0,001 \\
A & 0,063 & 0,000 & 0,008 \\
S & 0,089 & 0,025 & 0,000 \\
\hline
\end{tabular}

Tabla III-5: Matriz pareada de $\Phi_{\mathrm{PT}}$ calculada mediante análisis molecular de la varianza. Los valores de $\Phi_{\mathrm{PT}}$ se presentan por debajo de la diagonal. Los valores de significación según 999 permutaciones se presentan por encima de la diagonal. SR: San Ramón. A: Asintomática. S: Sintomática. 
La comparación entre los parámetros de diferenciación $(\Phi)$ obtenidos para cada marcador, mediante análisis molecular de la varianza, y la frecuencia del marcador para cada una de las poblaciones permitió ampliar la identificación de marcadores asociados a estado sanitario (Figura III-7). Entre los nuevos marcadores detectados A-374, X-378 y P1-249 se asocian al estado asintomático y X-199, X-265, X-273, X-540 y P3-360 al estado sintomático. El análisis permitió, por otra parte, la identificación de tres marcadores asociados a SR (X-220, X-360, X-502) y dos marcadores asociados a la región EB (A-182 y A-323). En contraposición a los marcadores asociados a estado sanitario, que en su mayoría son de baja frecuencia; los marcadores asociados a la diferenciación entre regiones presentan frecuencias intermedias. Estos resultados indican que grupos diferentes de marcadores determinan la diferenciación local, separación entre estados sanitarios (A vs. S), y la diferenciación regional.

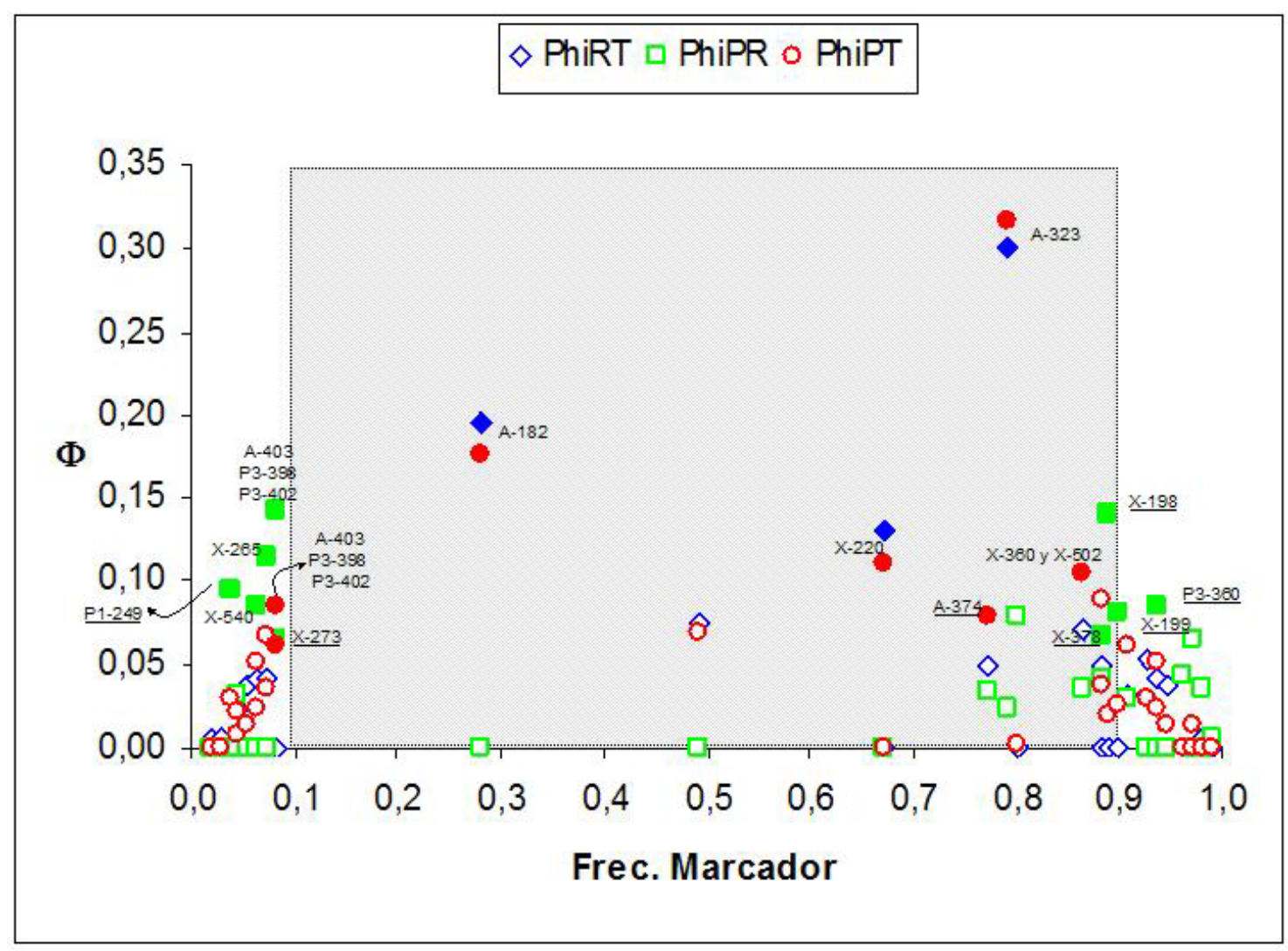

Figura III-7 : Relación entre la frecuencia de los marcadores RGA y los parámetros de diferenciación $\Phi$ determinados vía AMOVA para SR versus EB (A y S). Rectángulo gris: límites de baja, intermedia y alta frecuencia. Símbolos llenos, marcadores RGA (candidatos) detectados con parámetros $\Phi$ estadísticamente significativos. PhiPT $\left(\Phi_{\mathrm{PT}}\right)$ : diferenciación entre poblaciones. PhiRT $\left(\Phi_{\mathrm{RT}}\right)$ : diferenciación entre regiones. PhiPR $\left(\Phi_{\mathrm{PR}}\right)$ : diferenciación entre poblaciones dentro de las regiones. 


\subsection{2.- San Ramón vs. poblaciones EB_N y EB_S provenientes de la región de El Bolsón}

Considerando la estructuración genética determinada en función del origen geográfico de las áreas de muestreo dentro de la región de EB, la población SR se comparó con las poblaciones EB_N y EB_S a fin de determinar la existencia de diferencias relacionadas con la distribución geográfica de la especie. La población SR presentó menor diversidad genética que las poblaciones EB_N y EB_S (Tabla III-6). En tanto que la población EB_N presentó la mayor diversidad genética.

\begin{tabular}{|c|c|cc|cc|}
\hline POP & $\mathrm{n}$ & $\mathrm{n}$ loci & loci_P & PLP & Hj \\
\hline SR & 24 & 43 & 12 & 27.9 & 0.14040 \\
EB_N & 48 & 43 & 39 & 90.7 & 0.31187 \\
EB_S & 38 & 43 & 21 & 48.8 & 0.21991 \\
\hline
\end{tabular}

Tabla III-6: Parámetros genéticos calculados a partir de las frecuencias alélicas estimadas para los marcadores obtenidos por RGA. n: número de individuos caracterizados por RGA para cada población. EB_N: El Bolsón Norte, comprende los sitios L5y6, R11 y R18. EB_S: E1 Bolsón Sur, comprende los sitios R81 y L9y15. SR: San Ramón.

El cálculo de diferenciación a través de un AMOVA jerárquico con dos regiones (SR y EB) y dos poblaciones dentro de la región de EB (EB_N y EB_S), realizado a nivel global y para marcador, permitió avanzar en la interpretación de los datos obtenidos. Los resultados del AMOVA jerárquico mostraron la existencia de diferenciación entre regiones, entre las poblaciones dentro de la región de EB y entre las tres poblaciones (Tabla III-7).

\begin{tabular}{|c|c|c|c|c|c|}
\hline Niveles jerárquicos & Variación & \% de la varianza & \multicolumn{2}{|c|}{ Estadistico } & $p$ value \\
\hline Regiones y Poblaciones & entre regiones & 4 & $\Phi_{\mathrm{RT}}$ & 0.042 & 0.003 \\
\cline { 1 - 3 } SR (SR) y EB (EB_N, EB_S) & entre las poblaciones en las regiones & 2 & $\Phi_{\mathrm{PR}}$ & 0.025 & 0.013 \\
& en las poblaciones & 93 & $\Phi_{\mathrm{PT}}$ & 0.066 & 0.002 \\
\hline
\end{tabular}

Tabla III-7: Análisis molecular de la varianza y parámetros $\Phi$ determinados en base a los 43 marcadores polimórficos según organización jerárquica de las poblaciones en estudio. SR: San Ramón. EB: El Bolsón. EB_N: El Bolsón Norte, comprende los sitios L5y6, R11 y R18. EB_S: E1 Bolsón Sur, comprende los sitios R81 y L9y15.

El análisis pareado de $\Phi_{\mathrm{PT}}$ muestra que la población SR se diferencia en niveles similares $(0.076$ / 0.072) de las poblaciones de la región de EB_N y EB_S. Estos resultados enfatizan la diferenciación detectada entre estados sanitarios (A vs. S) y sugieren nuevamente que distintos marcadores participan de la diferenciación local y regional. 
El análisis AMOVA para cada marcador (Figura III-8) permitió identificar diez marcadores asociados a la población EB_N (A-299, A-356, A-358, A-403, A-533, X-265, X-540, P3-132, P3-398, P3-402), dos asociados a EB_S (P1-166, P1-260), dos marcadores asociados a la región EB (A-182 y A-323) y cuatro marcadores asociados a SR (A-367, X-220, X-360 y X502). En ambos casos los marcadores asociados a la diferenciación regional presentan frecuencias intermedias, en tanto que la mayoría de los marcadores relacionados a la diferenciación entre poblaciones dentro de EB presentan baja frecuencia y en su mayoría corresponden a marcadores asociados a EB_N.

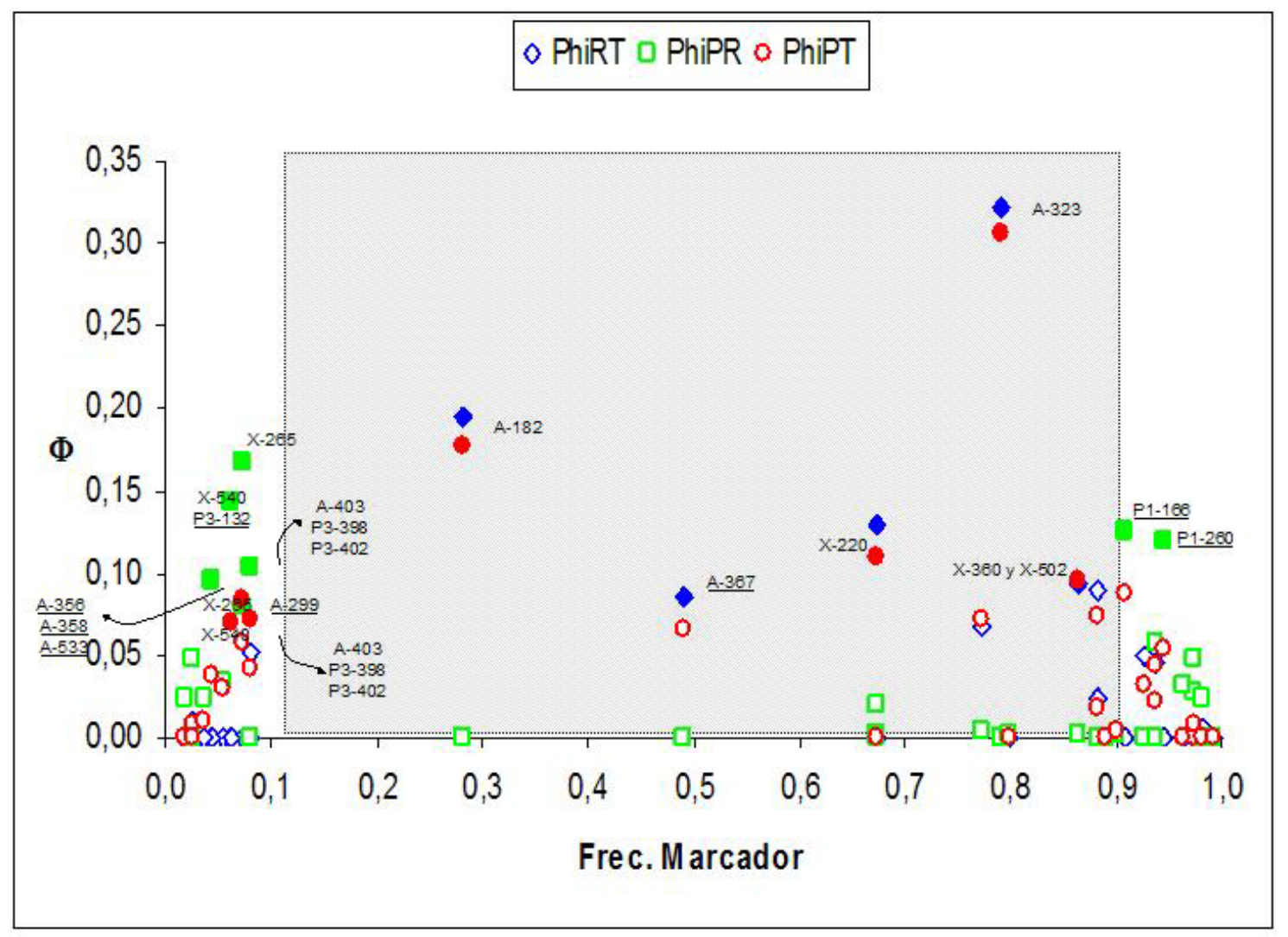

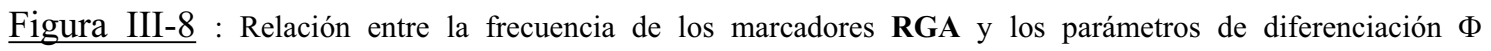
determinados vía AMOVA para SR versus EB (EB_N y EB_S). Rectángulo gris: límites de baja, intermedia y alta frecuencia. Símbolos llenos, marcadores RGA (candidatos) detectados con parámetros $\Phi$ estadísticamente significativos. PhiPT $\left(\Phi_{\mathrm{PT}}\right)$ : diferenciación entre poblaciones. PhiRT $\left(\Phi_{\mathrm{RT}}\right)$ : diferenciación entre regiones. PhiPR $\left(\Phi_{\mathrm{PR}}\right)$ : diferenciación entre poblaciones dentro de las regiones.

Los marcadores de diferenciación entre regiones (SR y EB) identificados vía AMOVA para cada marcador fueron los mismos, independientemente de que el análisis se realizará considerando SR vs. EB (EB_N y EB_S) o SR vs. EB (A y S), a excepción del marcador A-367. 
Los resultados indicarían la existencia de dos formas de diferenciación, regional y local; estando la diferenciación regional (SR vs. EB) asociada a marcadores de frecuencias intermedias, en tanto que la diferenciación local (EB_N vs. EB_S o A vs. S) se asocia mayoritariamente a marcadores de baja frecuencia.

\section{4.- DISCUSION Y CONCLUSIONES}

\section{1.- UTILIDAD DEL SISTEMA DE MARCADORES MULTILOCUS RGA EN LA} CARACTERIZACIÓN DE LA ESPECIE $\boldsymbol{A}$. CHILENSIS

El aislamiento de genes $\mathrm{R}$, el análisis de su estructura general y el hallazgo de dominios específicos conservados, sentaron las bases para avanzar en la caracterización de las funciones biológicas y de los procesos que dirigen la evolución molecular de estos genes; al tiempo que permitieron el desarrollo de la técnica RGA orientada a la caracterización de genes análogos en otras especies de las plantas. Aunque los primeros genes $\mathrm{R}$ se aislaron desde arabidopsis, tomate, tabaco y arroz, el surgimiento de la nueva metodología permitió la extensión a otras especies de plantas cultivables como por ejemplo trigo, cebada, avena, soja, garbanzo, maíz y girasol; y, particularmente, aceleró el inicio del estudio de genes análogos en especies leñosas. Entre estas últimas, la técnica RGA ha sido empleada con éxito en el aislamiento de genes candidatos en un híbrido de Poncirus trifoliata y Citrus grandis (Deng et al., 2000), en híbridos de Vitis vinifera L. y Muscadinia rotundifolia (Donald et al., 2002), en Pinus monticola Dougl. ex. D. Don. (Liu y Ekramoddoullah, 2003 y 2007), en Rosa roxburghii Tratt (Xu et al., 2005), en Carica papaya L. y Vasconcellea cauliflora Jacq. A. DC (De Paiva Rosa Amaral et al., 2006), en Pinus lambertiana (Jermstad et al., 2006) y en Prunus (Bliss et al., 2002; Gillen y Bliss, 2005; Soriano et al., 2005). Y, bajo la forma de un sistema de marcadores moleculares multilocus, en la caracterización genética de Pinus oocarpa (Diaz y Ferrer, 2003). En la gran mayoría de los casos orientados al aislamiento de genes candidatos se cuenta con patosistemas conocidos, es decir sistemas definidos de huésped y patógeno, y con información sobre la variación genética de la resistencia y sus formas de herencia en la especie en estudio.

En el caso del mal del ciprés el desconocimiento de la etiología retrasó la investigación de la variación genética de la especie en relación a la afección. En este contexto, el empleo de la técnica RGA como un sistema de marcadores multilocus se consideró una de las alternativas más apropiadas para iniciar la caracterización genética de grupos de plantas asintomáticas y sintomáticas para mal del ciprés. Todos los primers empleados, seleccionados por su frecuencia de uso, su reporte en diversas especies de plantas y un diseño basado en las secuencias 
nucleotídicas de diferentes dominios de genes R (Anexo 6), fueron efectivos en la amplificación de DNA total proveniente de $A$. chilensis.

El número de fragmentos amplificados reproducibles obtenido, para cada combinación de primers, fue similar o inferior al reportado en la bibliografía para otras especies de plantas (Tabla III-8). Sin embargo, las comparaciones deben ser analizadas considerando la distancia genética que existe entre las especies sobre las cuales han sido diseñados los primers y aquellas en las que se aplican, las condiciones en las que se realizan las amplificaciones (temperatura de annealing, concentración final de magnesio, etc), los métodos de separación (geles de agarosa o poliacrilamida), la detección de los fragmentos amplificados (bromuro de etidio, tinción con plata, fluorescencia), la metodología empleada en la normalización y reproducibilidad de los fragmentos obtenidos, y la forma en que estos fragmentos son reportados (fragmentos detectados, fragmentos reproducibles, fragmentos polimórficos). De los últimos dos aspectos, el primero no se incluye generalmente en las publicaciones científicas que emplean la técnica RGA; en tanto que para el segundo, los reportes son muchas veces ambiguos, no se indica si se informan fragmentos totales o sólo los polimórficos.

Para la combinación S1/AS1 la información disponible es escasa, con pocas referencias del número de fragmentos obtenidos o reportes de valores promediados combinando datos desde diferentes pares de primers (Tabla III-8). El valor obtenido en este trabajo para A. chilensis es superior a lo reportado en la bibliografía. Una situación similar se da para la combinación Ptokin3_4, aunque el valor para A. chilensis es del orden del reportado como promedio entre pares de primers (Tabla III-8).

Para las combinaciones XLRR y Ptokin1_2 la información es más abundante y permite una mejor comparación con los valores obtenidos en este trabajo. La gran mayoría de los datos disponibles en la bibliografía, para ambas combinaciones, corresponde a cultivos como arroz, trigo o cebada; siendo el número de fragmentos reportados mayor que el obtenido para A. chilensis (Tabla III-8). La distancia genética entre estas especies cultivadas, A. chilensis y aquellas sobre las que se diseñaron los primers podría explicar parte de las diferencias observadas. En el caso de arroz, trigo o cebada, el número de fragmentos amplificados informados varía en función del total de variedades, cultivares o líneas analizadas; señalando la influencia del mejoramiento genético en la variabilidad detectada (Tabla III-8). 


\begin{tabular}{|c|c|c|c|c|}
\hline$\frac{\pi}{0}$ & 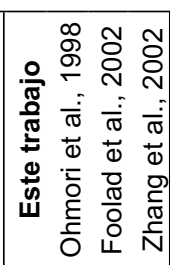 & 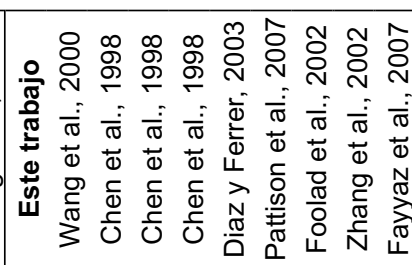 & 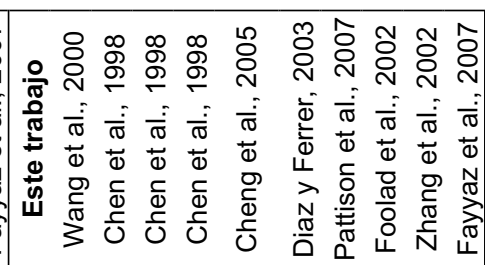 & 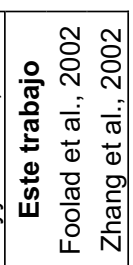 \\
\hline 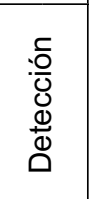 & 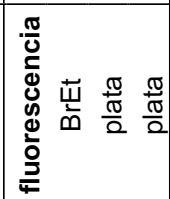 & 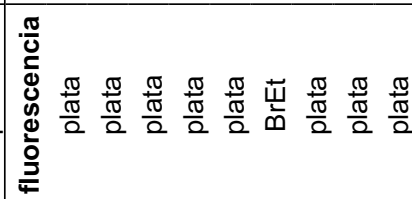 & 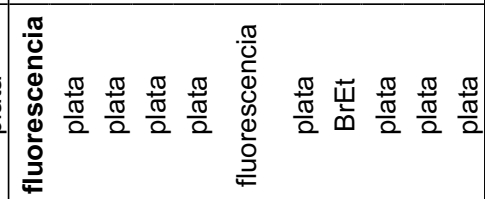 & 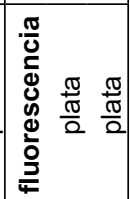 \\
\hline $\begin{array}{l}\frac{0}{0} \\
\frac{0}{0} \\
\frac{\pi}{\pi} \\
\frac{0}{0} \\
\mathscr{\infty}\end{array}$ & 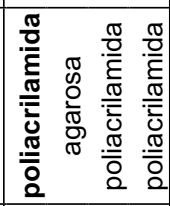 & 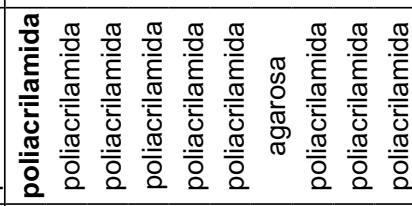 & 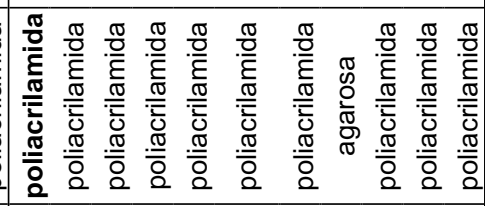 & 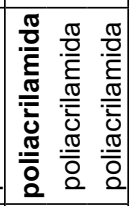 \\
\hline$\sum_{0}^{\circ} \stackrel{0}{0}$ & 年 & 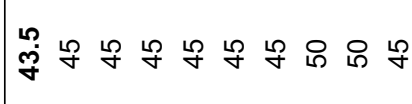 & 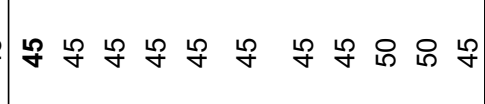 & 요요 \\
\hline$\overline{0}_{0}^{N} \sum_{\bar{\Sigma}}^{0}$ & $\sim \stackrel{\text { ?ִ }}{\longrightarrow} \leftarrow 0$ & N & 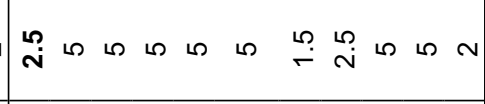 & $\stackrel{n}{\sim}$ \\
\hline $\begin{array}{l}\frac{0}{0} \\
\frac{\mathscr{0}}{0} \\
\dot{\omega}\end{array}$ & 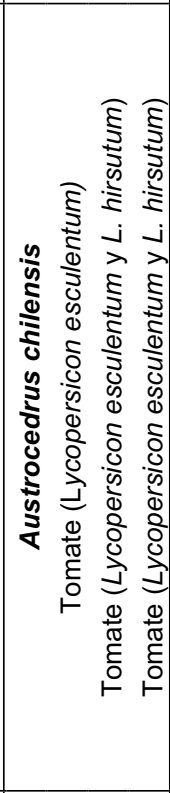 & 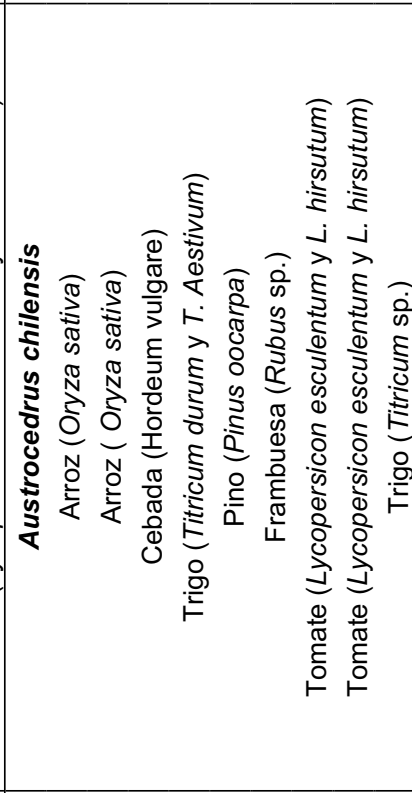 & 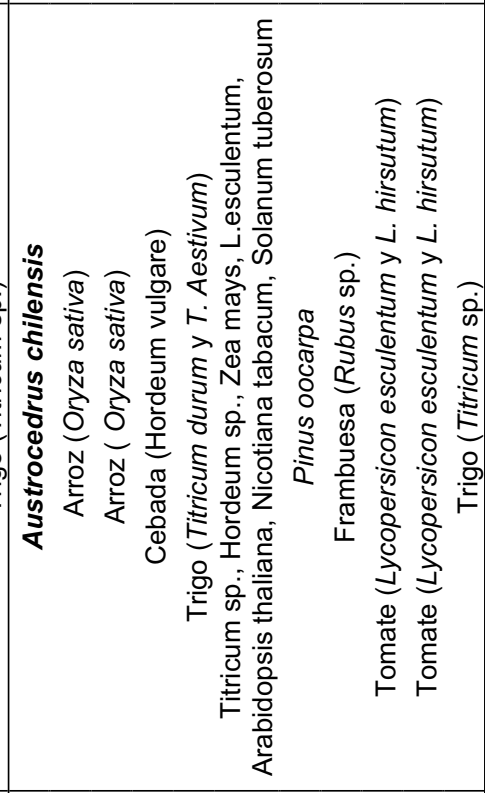 & 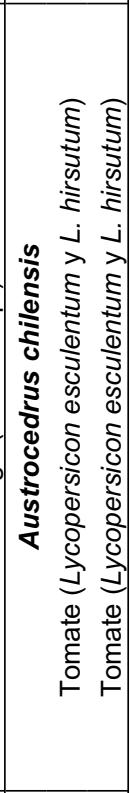 \\
\hline $\begin{array}{ll}0 & 0 \\
0 & 0 \\
0 & 0 \\
\frac{0}{\pi} & 0 \\
\frac{\pi}{0} & \frac{0}{0} \\
\frac{0}{2} & \frac{\pi}{0} \\
\frac{\pi}{0} & 0 \\
& 0 \\
\end{array}$ & $n m \sim N$ & $N \subsetneq \cong \mathscr{J} \forall \div \sim N \sim N$ & 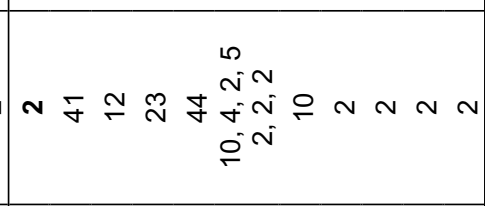 & $n \sim N$ \\
\hline 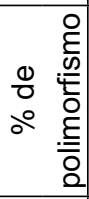 & 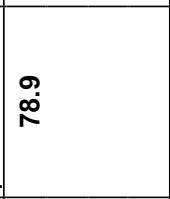 & 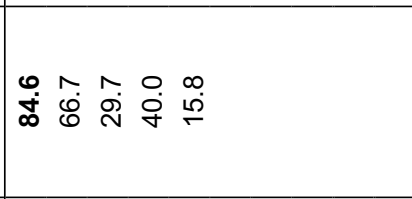 & 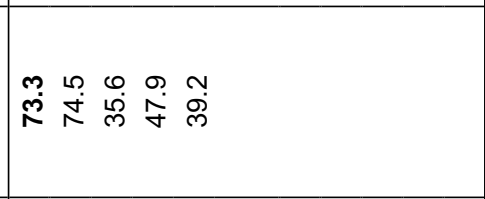 & $\hat{\mathscr{\infty}}$ \\
\hline 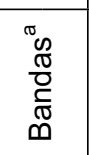 & 홓 $m$ 包의 의 & 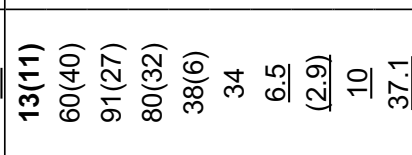 & 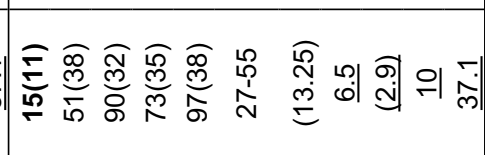 & 은 웡의 \\
\hline & $\underset{i}{\infty}$ & $\frac{\frac{r}{\underline{r}}}{\vec{x}}$ & 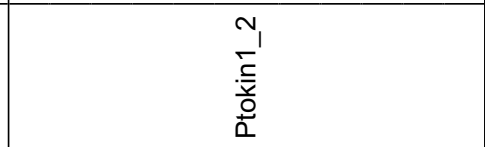 & 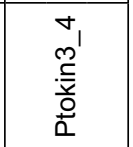 \\
\hline
\end{tabular}

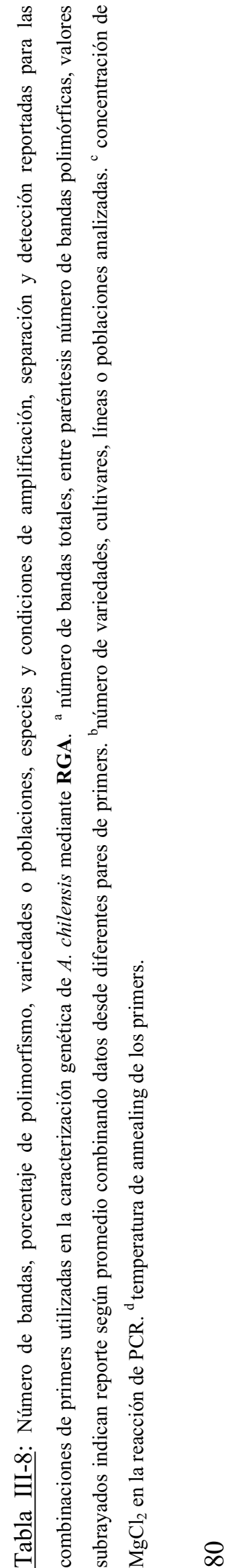


Dentro de la escasa disponibilidad de datos sobre el número de fragmentos amplificados en especies leñosas, y más específicamente en coníferas, Diaz y Ferrer (2003) reportan entre 16 y 34 fragmentos/primer en Pinus oocarpa. El número máximo (34) corresponde a la combinación XLRR, mientras que no se específica el valor exacto para Ptokin1_2. En ambos casos el número de fragmentos obtenido en $A$. chilensis es menor que para $P$. oocarpa (Tabla III-8), las diferencias podrían deberse a modificaciones en las secuencias nucleotídicas de los correspondientes dominios, a las diferencias en la metodología empleada para normalizar los datos y determinar la reproducibilidad de los fragmentos amplificados o al número de poblaciones estudiadas y la distancia geográfica entre las mismas. Las combinaciones Ptokin3_4 y S1/AS1 no fueron empleadas en $P$. oocarpa.

El porcentaje de polimorfismo en A. chilensis es, contrariamente a lo que ocurre con el número de fragmentos, mayor que en el resto de las especies reportadas. Cuando se consideran en conjunto las combinaciones XLRR y Ptokin1_2 los valores obtenidos son 79.0\%, 51.6\%, 44.0\% y $27.0 \%$ para $A$. chilensis, arroz, cebada y trigo, respectivamente (Tabla III-8). Una tendencia similar se encuentra al analizar cada combinación de primers por separado. En P. oocarpa se reporta un $47.3 \%$ de polimorfismo, sobre un total de 112 bandas generadas con cuatro combinaciones de primers (Diaz y Ferrer, 2003).

Tomados en conjunto, estos datos indicarían un mayor nivel de exigencia en la normalización o en la metodología empleada para determinar el nivel de reproducibilidad de las bandas detectadas en $A$. chilensis. Es importante mencionar que el número total de fragmentos amplificados aplicando el sistema RGA es, en general muy elevado, y que diferencias leves en la metodología de score llevan a diferencias marcadas en el número final de fragmentos. Para la construcción de un mapa de ligamiento en tomate, basado en la hibridación de Lycopersicon esculentum Mill. y L. hirsutum Humb. Bonpl., Zhang et al. (2002) emplearon 10 combinaciones de primers y amplificaron 600 fragmentos de los cuales 100 fueron reproducibles y 46 polimórficos. En este trabajo con A. chilensis para las cuatro combinaciones de primers en conjunto, se obtuvo un total de 465 fragmentos con señal fluorescente $>$ de 50 unidades. El valor se redujo a 53 fragmentos luego de la normalización de los datos y la evaluación de la reproducibilidad, siendo 43 de ellos polimórficos.

Los resultados obtenidos indican, por tanto, que la especie A. chilensis presenta regiones genómicas que pueden ser amplificadas mediante PCR empleando primers específicos diseñados sobre dominios conservados presentes en genes de resistencia a enfermedades y que 
el sistema RGA genera un número de marcadores con nivel de polimorfismo suficiente para su aplicación en la caracterización genética de la especie.

\section{2.- VARIABILIDAD GENÉTICA EN LA ESPECIE $A$. CHILENSIS}

La caracterización genética de los pares de plantas sintomáticas/asintomáticas mediante RGA permitió establecer por primera vez el papel de la constitución genética de los individuos en la expresión fenotípica del mal del ciprés, sentando las bases para avanzar en el estudio de estas diferencias. La asociación mayoritaria de los marcadores RGA con la población sintomática se contrapone con la hipótesis de resistencia genética al mal del ciprés. Por el contrario, los resultados obtenidos sustentarían la hipótesis de susceptibilidad o predisposición genética de los individuos afectados. La complementación del análisis genético poblacional con un análisis de cluster a nivel de individuos aplicando aproximaciones bayesianas (STRUCTURE), permitió establecer que la localización geográfica de los individuos contribuye, además del estado sanitario, a la separación en grupos.

La caracterización genética de la población SR ubicada en una zona libre de mal del ciprés y su comparación con las poblaciones de El Bolsón (A y S o EB_N y EB_S) según diferentes niveles jerárquicos confirmó la existencia de estructuración genética a nivel local y permitió detectar estructuración a nivel regional. Al comparar los resultados obtenidos del AMOVA con dos niveles jerárquicos (regiones y poblaciones), se detectó que los marcadores de baja frecuencia son determinantes de la diferenciación entre poblaciones dentro de la región $\mathrm{EB}$, en tanto que no contribuyen de forma importante a la diferenciación entre regiones. El cálculo de diferenciación para cada marcador vía AMOVA y el análisis de la relación entre el valor de los estadísticos $\Phi$ y la frecuencia de los marcadores, permitió identificar en conjunto 25 marcadores candidatos para estudios de genotipicación. En la Figura III-9 se presentan a modo de ejemplo algunos de los resultados obtenidos de la aplicación del sistema RGA en $A$. chilensis, señalándose la ubicación de los marcadores RGA candidatos surgidos de las cuatro combinaciones de primers.

Entre las combinaciones de primers empleadas, S1/AS1 y XLRR aportaron un 36\% de los marcadores, Ptokin1_2 un 12\% y Ptokin3_4 un 16\%. Diecinueve de los marcadores candidatos son informativos a nivel local, 12 en la diferenciación de estados sanitarios (A-374, A-403, X-198, X-199, X-265, X-273, X378, X-540, P1-249, P3-360, P3-398 y P3-402) y 12 en la diferenciación según origen geográfico (A-299, A-356, A-358, A-403, A-533, X-265, X-540, P1-166, P1-260, P3-132, P3-398 y P3-402). De estos 19 marcadores, 12 (63\%) corresponden a marcadores de baja frecuencia, $3(16 \%)$ a marcadores de frecuencia intermedia y $4(21 \%)$ a marcadores de alta frecuencia. Los restantes 6 marcadores candidatos (A-182, A-323, A-367, 
X-220, X-360 y X-502) son informativos a nivel regional en la diferenciación entre EB y SR, siendo todos marcadores de frecuencia intermedia. Estos resultados indican una diferencia importante entre los marcadores que determinan la diferenciación entre regiones y entre poblaciones dentro de la región de El Bolsón. En el primer caso se trata de marcadores de frecuencias intermedias; en tanto que para la diferenciación entre poblaciones dentro de la región de EB se trata mayoritariamente de marcadores de baja frecuencia.

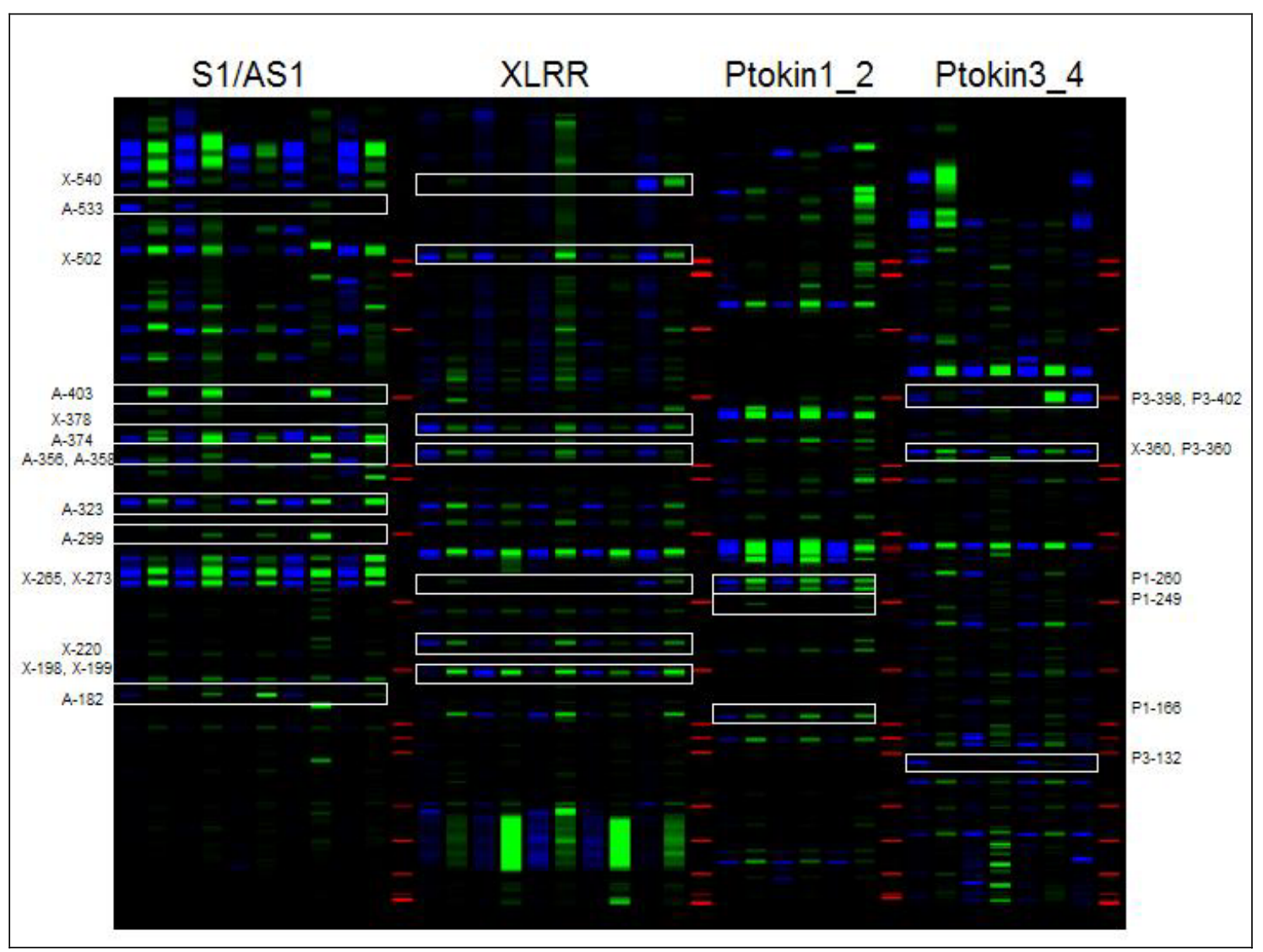

Figura III-9: Perfiles de amplificación generados mediante la aplicación del sistema RGA en A. chilensis. S1/AS1, XLRR, Ptokin1_2 y Ptokin3_4 indican las combinaciones de primers empleadas. El perfil de cada individuo corresponde al conjunto de bandas detectadas desde al parte superior hasta la parte inferior del gel (azul o verde). En rojo el perfil de bandas correspondiente al marcador de peso molecular ROX-500. Los rectángulos señalan la ubicación de los marcadores RGA candidatos, indicándose a derecha e izquierda la denominación correspondiente.

La segregación a nivel local respondió al origen geográfico (EB_N) y al estado sanitario (sintomático); sin embargo, esto no indica que EB_S no sea susceptible al mal del ciprés, sino que dada su menor diversidad genética es menos probable detectar la asociación que depende de marcadores de baja frecuencia. 
Cada uno de los fragmentos anteriormente mencionados, se presenta como candidato para estudios futuros orientados al desarrollo de marcadores asociados a estado sanitario. Estos estudios requerirán del clonado y la secuenciación de los fragmentos como paso previo al diseño de primers específicos que permitan estudios de genotipificación con un mayor tamaño poblacional en la región de El Bolsón y/o extendiendo el área de muestreo a otros bosques de A. chilensis afectados por mal del ciprés. La secuenciación de los fragmentos candidatos surgidos en este trabajo permitirá conocer con exactitud su naturaleza y avanzar en la interpretación biológica de los resultados.

\subsection{1- Comparación del sistema RGA con otros sistemas de marcadores moleculares}

Aunque el objetivo específico del trabajo fue el empleo del sistema RGA en la detección de diferencias entre grupos de individuos sintomáticos y asintomáticos para mal del ciprés; la detección de diferencias a nivel local y regional a través del análisis de las poblaciones SR, EB_N y EB_S, posibilita la comparación desde el punto de vista de la genética poblacional con otros sistemas de marcadores en $A$. chilensis y especies relacionadas.

El valor promedio del porcentaje de loci polimórficos (PLP) y la heterocigosidad esperada (Hj), dos parámetros de diversidad genética determinados para A. chilensis mediante la aplicación del sistema RGA, es superior al valor obtenido desde datos de isoenzimas (Pastorino et al. 2004; Pastorino y Gallo, 2009). Resultados similares se observan al comparar los valores promedio de PLP derivados de isoenzimas y RAPD para Pilgerodendron uviferum, de heterocigosidad esperada derivados de isoenzimas y microsatélites para Chamaecyparis nootkatensis, y de PLP y heterocigosidad esperada derivados de isoenzimas y CAPS-STS para Chamaecyparis obtusa (Tabla III-9).

RGA, RAPD, microsatélites y CAPS-STS son marcadores moleculares basados en secuencias de DNA que debido a su mayor cobertura del genoma, número de alelos por loci o número total de loci detectados son más informativos que los marcadores isoenzimáticos. Las diferencias encontradas serían, por tanto, consecuencia del tipo de marcador empleado y estarían en relación con el poder intrínseco de detección de la variabilidad correspondiente a cada uno de ellos.

Para A. chilensis, el valor promedio del PLP y la Hj determinado a través de RGA es inferior al obtenido desde microsatélites (Arana et al. enviado). Entre los parámetros de diferenciación genética el valor de $\Phi_{\mathrm{PT}}$ derivado de RGA es similar a los valores de Fst derivados de 
isoenzimas (0.066) o microsatélites (0.070) (Tabla III-9). Pastorino et al. (2004), analizaron los resultados de parámetros de diversidad dentro y entre poblaciones para A. chilensis y especies relacionadas a partir de datos de isoenzimas. La comparación es más difícil cuando se trata de parámetros derivados de marcadores basados en DNA, ya que varía el tipo de marcador empleado (RAPD, AFLP, microsatélites, ISSR, etc) y en algunos casos la forma de herencia (dominante o codominante). Es necesario considerar además la forma de cálculo de los parámetros; para marcadores dominantes la heterocigosidad esperada se reporta basada en la frecuencia de la presencia y ausencia de bandas (diversidad fenotípica) o en la frecuencias estimadas de los alelos dominante y nulo (diversidad genotípica) que, a su vez, no siempre se estiman de la misma forma o bajo los mismos supuestos. El índice de Shannon se basa en la frecuencia de bandas (presencia/ausencia) y es otro de los estimadores empleados para describir la riqueza genética con fines comparativos. Los parámetros de la diversidad entre poblaciones Fst (basado en frecuencias alélicas estimadas), Gst (calculado desde datos genotípicos o fenotípicos) y estimadores $\Phi$ (calculados via AMOVA desde matrices de distancia genética) deben también ser comparados con cuidado.

El reporte de estadísticos derivados de la aplicación del sistema RGA en coníferas es escaso, existiendo sólo una publicación para Pinus oocarpa (Díaz y Ferrer, 2003) y ningún registro entre las cupresáceas. Aunque esto limita las comparaciones entre especies, los estimadores calculados para $P$. oocarpa mediante la aplicación de RGA, RAPD y AFLP resultaron similares (Diaz y Ferrer, 2003) y se ajustaron a lo establecido por Nybon (2004) para marcadores dominantes en la comparación intraespecífica. Por tanto, en las comparaciones interespecíficas presentadas a continuación se emplean datos provenientes de distinto tipo de marcadores dominantes, considerando que los resultados serán similares para cada especie independientemente del tipo marcador dominante empleado.

A. chilensis, Fitzroya cupressoides y Pilgerodendron uviferum son especies nativas de los bosques templados de Argentina y Chile correspondientes a la familia Cupressaceae. Los valores de diferenciación entre poblaciones calculados a partir de datos de RAPD para $F$. cupressoides y P. uviferum son superiores al obtenido en este trabajo para A. chilensis (Tabla III-9), siguiendo la tendencia esperada de acuerdo con lo reportado para isoenzimas y en función del patrón geográfico de distribución de las especies según rango de extensión y continuidad (Pastorino et al. 2004). El índice de Shannon, sin embargo, presenta menor diversidad para A. chilensis que para las otras dos especies. Este comportamiento es contrario al observado para isoenzimas, donde $A$. chilensis presenta mayor variación intrapoblacional $(\mathrm{He})$ y menor diferenciación entre poblaciones (Fst) que $F$. cupressoides y P. uviferum. 
Cuando se incorporan a la comparación otras especies de la familia Cupressaceae (Tabla III-9) se observa la misma correlación entre índice de Shannon y diferenciación entre poblaciones, excepto para las especies Glyptostrobus pensilis y Cupressus chengiana. Estas discrepancias en la correlación podrían ser debidas a la diferencia entre los marcadores utilizados, los estimadores comparados o sus formas de cálculo; el índice de Shannon y los estimadores $\Phi$ se basan en datos fenotípicos y no requieren información sobre el equilibrio de Hardy-Weinberg, en tanto que la heterocigosidad esperada se basa en frecuencias alélicas estimadas asumiendo la existencia de equilibrio. El estadístico Gst calculado con POPGEN es reportado con frecuencia en la bibliografía para marcadores dominantes; sin embargo el método de estimación de frecuencias alélicas en que se basa presenta fuertes desvíos (Lynch y Milligan, 1994). En la Tabla III-9 el valor de Gst calculado para A. chilensis se presenta con fines informativos.

RAPD, AFLP, ISSR, microsatélites y RGA corresponden a marcadores derivados de amplificación mediada por PCR. RAPD, AFLP e ISSR se caracterizan por emplear primers inespecíficos, es decir que no se requiere información preliminar de secuencia en la especie de interés para la aplicación de los mismos. RGA utiliza primers específicos diseñados sobre dominios conservados presentes en genes de resistencia a enfermedades; sin embargo lejos de ser una limitación esta característica ha permitido la transferencia directa de primers entre especies de diversos géneros. Para microsatélites, se requiere el desarrollo de primers específicos o la evaluación de transferencia directa que es más compleja que para otros sistemas y puede introducir artefactos (Squirrel et al., 2003; Arnold et al., 2002).

RAPD, AFLP e ISSR, requieren la evaluación de un número importante de primers en forma previa a la selección de primers informativos. Los datos recopilados en cupresáceas (Tabla III-9), dan un valor promedio de primers evaluados respecto del promedio de primers empleados para RAPD de 56.2 / 13.2, en tanto que para ISSR y AFLP es de 79.0 / 8.2 y 38.2 / 3.0. Para RGA, Diaz y Ferrer (2003) reportan el empleo directo de 5 combinaciones de primers; y en este trabajo se emplearon 4 combinaciones desde una evaluación preliminar de 6. Considerando la rápida implementación desde el punto de vista metodológico y el direccionamiento a regiones genómicas codificantes, el sistema RGA se presenta como una herramienta molecular simple comparable al resto de las metodologías tradicionalmente aplicadas en el análisis genético poblacional, con posibilidad de brindar información sobre procesos evolutivos que se apartan de la neutralidad. 


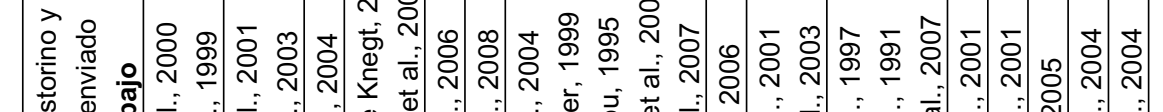

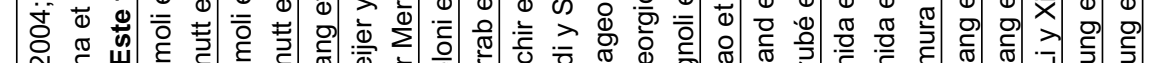

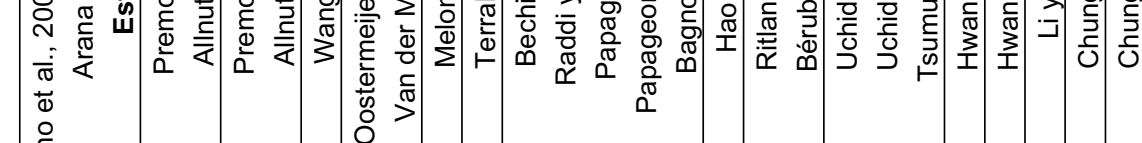

\begin{tabular}{|c|c|c|c|c|c|c|c|c|c|c|c|c|c|c|c|}
\hline 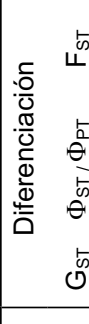 & 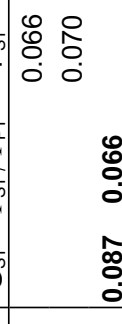 & 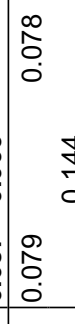 & 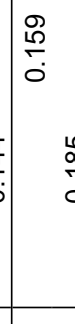 & 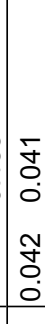 & 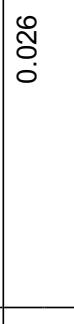 & 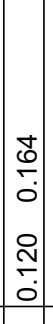 & $\begin{array}{c}\circ \\
\stackrel{0}{\circ} \\
\\
\end{array}$ & 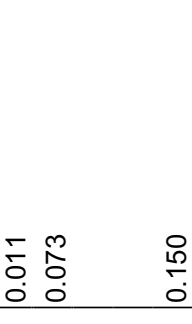 & 勇 & 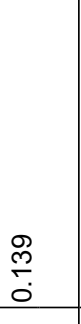 & 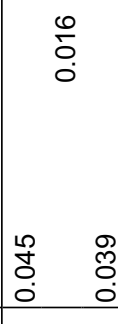 & & 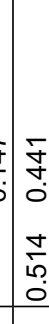 & & $\frac{7}{c}$ \\
\hline 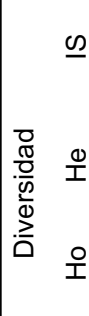 & 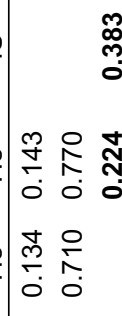 & $\begin{array}{l} \\
\hat{O} \\
0 \\
0 \\
0 \\
0 \\
0 \\
0\end{array}$ & 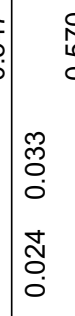 & $\underset{\square}{\check{0}}$ & 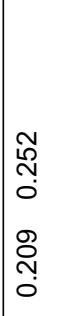 & ֻ̊. & & 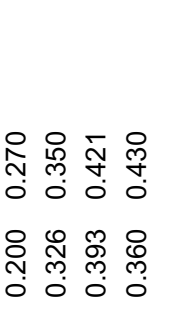 & . & 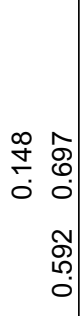 & 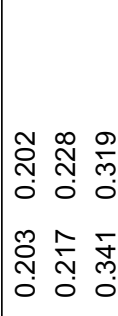 & : & b & & $\begin{array}{l}0 \\
0 \\
a \\
0\end{array}$ \\
\hline$\frac{a}{a}$ & 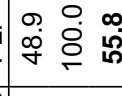 & & $\stackrel{-}{\check{r}}$ & 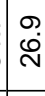 & 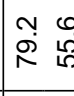 & $\mid \begin{array}{l}\mathscr{P} \\
\dot{f}\end{array}$ & $\underset{\infty}{\infty}$ & 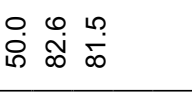 & $\begin{array}{l}\infty \\
\dot{\sim} \\
\dot{\gamma}\end{array}$ & : & $\begin{array}{lll}1 & 0 & 0 \\
\hat{L} & \dot{8} & \dot{8} \\
1 & \infty\end{array}$ & 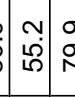 & ?ִ & & $\begin{array}{ll}3 \\
1 \\
b \\
0\end{array}$ \\
\hline 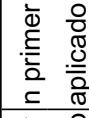 & $\infty \quad$ & $\infty$ & & 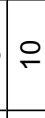 & $m$ & $m$ & m & & 응 & $\infty$ & & $\neg \subsetneq$ & 느은 & & $m$ \\
\hline 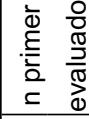 & 0 & \& & & 웅 & $\bar{n}$ & 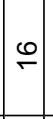 & ָั & & 음 & $\stackrel{2}{R}$ & & R & 음 & & م \\
\hline $\begin{array}{l}\frac{\sigma}{0} \\
\frac{\bar{\omega}}{\omega} \\
\frac{\omega}{I}\end{array}$ & 0 & 0 & 0 & 0 & O & 0 & $\triangle$ & 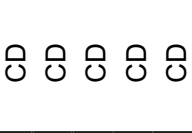 & 0 & 80 & ०० & 0 & ه| د & & 0 \\
\hline $\begin{array}{l}\grave{0} \\
\frac{0}{0} \\
\frac{0}{0} \\
\frac{\pi}{\pi} \\
\end{array}$ & 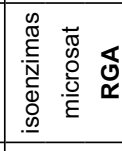 & 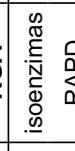 & 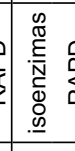 & $\begin{array}{l} \\
\underline{x} \\
\underline{d} \\
\underline{\underline{D}}\end{array}$ & 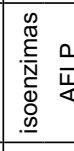 & $\begin{array}{l}0 \\
\underline{\underline{x}} \\
\underline{0} \\
\underline{0}\end{array}$ & 势 & 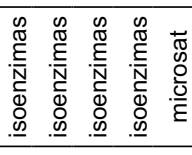 & \begin{tabular}{|l|} 
\\
0 \\
0 \\
0 \\
0 \\
\end{tabular} & 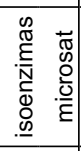 & 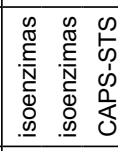 & a & 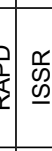 & & $\frac{9}{4}$ \\
\hline$\stackrel{\text {. }}{c}$ & 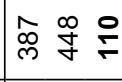 & 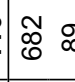 & ) & 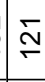 & స̃ & 훙 & & 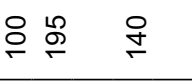 & ช & $\stackrel{\sim}{\sim}$ & 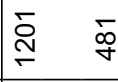 & 8 & $b ?$ & & L \\
\hline $\begin{array}{l}0 \\
\stackrel{0}{2} \\
=\end{array}$ & $\stackrel{\square}{\leftarrow} m$ & ป ? & 2 & 10 & $\cong \infty$ & is & ํ) & $m \wedge \stackrel{\infty}{\leftarrow} 0 \bar{m}$ & $\infty$ & $m$ & $=m \stackrel{\llcorner}{N}$ & $\sim \curvearrowright$ & $\mathrm{v}$ & & 운 \\
\hline $\begin{array}{l}\frac{0}{0} \\
\mathbb{0} \\
00 \\
w \\
w\end{array}$ & 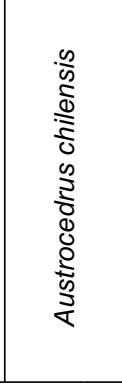 & 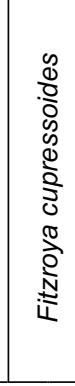 & 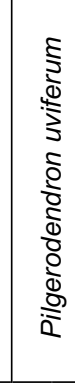 & 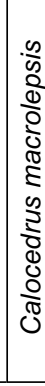 & 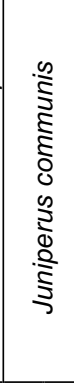 & 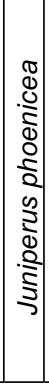 & 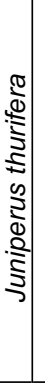 & 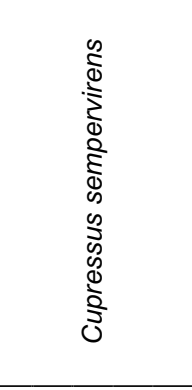 & 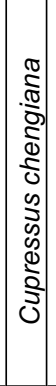 & 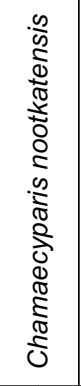 & 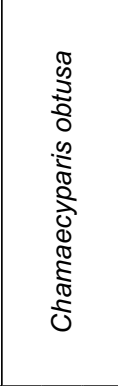 & 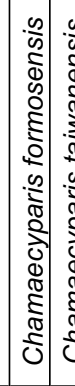 & 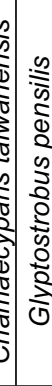 & & 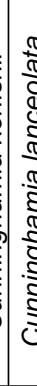 \\
\hline
\end{tabular}




\section{5.- CONCLUSIONES FINALES}

El sistema de muestreo y la metodología de análisis fueron adecuados para evaluar las hipótesis planteadas siendo posible concluir que:

○ Los individuos sintomáticos y asintomáticos para mal del ciprés difieren en el polimorfismo detectado por RGA.

- Los individuos asintomáticos no son genéticamente resistentes, en tanto que los individuos sintomáticos serian genéticamente susceptibles al mal del ciprés.

○ El patrón ecológico del mal del ciprés podría estar determinado por las diferencias genéticas entre poblaciones mésicas y xéricas de A. chilensis.

El trabajo desarrollado permitió establecer además la existencia de estructuración genética regional (SR y EB) y local (EB_N y EB_S).

Los resultados obtenidos tomados en conjunto sugieren que el proceso demográfico y/o evolutivo de estructuración genética condiciona el desarrollo del mal del ciprés. 


\section{CAPITULO IV}

\section{EL ROL DE PHYTOPHTHORA AUSTROCEDRAE EN EL MAL DEL CIPRÉS}

\section{INTERROGANTE}

¿Cuál es el rol de P. austrocedrae en el mal del ciprés?

\section{HIPÓTESIS Y PREDICCIONES}

o Hipótesis 1: La defoliación es consecuencia directa del desarrollo de lesiones necróticas debidas al ataque de $P$. austrocedrae.

PREDICCIÓN 1: Todos los árboles con defoliación presentarán lesiones necróticas producidas por $P$. austrocedrae.

o Hipótesis 2: Árboles afectados por mal del ciprés pueden a su vez ser colonizados por P. austrocedrae y presentar lesiones necróticas en cuello.

PREDICCIÓN 2: El porcentaje de árboles con síntomas de mal del ciprés afectados por $P$. austrocedrae será proporcional a la incidencia de esta última en el sitio. 


\section{1.- INTRODUCCIÓN}

El mal del ciprés se describe desde sus inicios como un proceso de defoliación lenta y gradual, acompañada de marchitamiento y amarillamiento progresivo del follaje, frecuentes pudriciones de raíz originadas por organismos saprofitos y asociación con condiciones de sitio determinantes de pobre drenaje (Varsavsky et al., 1975; Hranilovich, 1988; Havrylenko et al., 1989; Rajchenberg y Cwielong, 1993). Sin embargo, a partir de mediados de la década del noventa, otros síntomas comienzan a ser reportados con frecuencia (Capitulo I); entre ellos, lesiones necróticas en raíz y cuello, mortalidad de raíces finas, resinación, follaje rojo o amarillo intenso y mortalidad rápida (Rosso et al., 1994; Filip, 1995; Filip y Rosso, 1999; Hennon y Rajchenberg, 2000). La asociación con sitios de pobre drenaje, su forma de distribución y los nuevos síntomas reportados confluyeron para postular a un patógeno de raíz, probablemente una especie del género Phytophthora, como posible agente causal del disturbio (Rajchenberg et al., 1997; Filip y Rosso, 1999; Hansen, 2000; Hennon y Rajchenberg, 2000; La Manna y Rajchenberg 2004a). Intensos relevamientos en bosques de $A$. chilensis permitieron el aislamiento de seis especies del género Phytophthora (Greslebin et al., 2005; Greslebin et al., 2007). De entre ellas, P. austrocedrae fue la única especie aislada desde la zona de avance en lesiones necróticas de floema localizadas en cuello o raíces principales; en tanto que no pudo ser aislada desde suelo o cursos de agua en bosques de $A$. chilensis.

La denominación mal del ciprés hace referencia a un síndrome complejo que nuclea eventos de mortalidad de etiología desconocida. El Mujtar y Andenmatten (2007a, b) determinaron que los síntomas aéreos reportados, aunque característicos del mal del ciprés, son inespecíficos y podrían ser producidos por diversos agentes bióticos o abióticos. La Manna (2004) estableció que dos tipos de condiciones de sitio contrastantes, exceso o déficit de drenaje, pueden asociarse con mal del ciprés; en tanto que se han señalado dos tipos de desarrollo a nivel de individuo, progresivo y rápido (Calí, 1996; Loguercio et al., 1998 y 1999a; Filip y Rosso, 1999; Hennon y Rajchenberg, 2000), y dos formas de distribución, agregada y desagregada (Rosso et al., 1994; La Manna y Rajchenberg, 2004a; La Manna et al., 2008b).

Recientemente $P$. austrocedrae se propuso como el agente causal de la mortalidad (Greslebin y Hansen, 2007a y b). Sin embargo, su participación debe aún ser evaluada, ya que existen áreas con mal del ciprés en las cuales no se detecta la especie (Greslebin et al., 2007) e individuos con lesiones necróticas de $P$. austrocedrae que no responden a los síntomas aéreos definidos para este tipo de mortalidad. Se han reportado árboles sin defoliación con numerosas e importantes lesiones necróticas a nivel de cuello, árboles defoliados con pocas o sin lesiones necróticas y 
árboles totalmente rojos o amarillo intenso que conservan gran parte de su follaje y presentan lesiones necróticas (Greslebin y Hansen, 2007b; Greslebin y Hansen, 2006). Para estos últimos se indica mortalidad rápida (Filip, 1995; Filip y Rosso, 1999; Hennon y Rajchenberg, 2000; Greslebin y Hansen, 2006) en contraposición al desarrollo progresivo característico del mal del ciprés. Por otra parte, si bien los resultados de los ensayos de patogenicidad realizados demuestran el carácter patogénico de la especie, la relación causal requiere aún de evaluaciones detalladas, en tanto que como consecuencia de la inoculación con $P$. austrocedrae se obtiene el desarrollo de lesiones necróticas, pero no se reproducen los síntomas aéreos típicos del mal del ciprés (Greslebin y Hansen, 2007a y b).

La defoliación es el síntoma principal y más evidente detectado a nivel de bosque, se emplea desde los primeros reportes del mal del ciprés para caracterizar a los árboles afectados y en ella se basan los sistemas de clasificación (Rajchenberg y Cwielong, 1993; Havrylenko et al., 1989). Por otro lado, las lesiones necróticas presentes a nivel de raíz y cuello, comenzaron a reportarse a mediados de la década del noventa, y se ha determinado que pueden o no estar asociadas con defoliación (Floria, 2008). En este contexto es necesario establecer la relación existente entre defoliación y lesiones necróticas, a fin de determinar si corresponden a síntomas de un mismo disturbio o definen disturbios diferentes que pueden, en último término, presentarse combinados en el bosque.

El rol de P. austrocedrae en el mal del ciprés será evaluado en el presente capítulo de la tesis mediante el análisis de la relación existente entre defoliación y lesiones necróticas, bajo dos modelos alternativos:

\section{MODElo 1: P. austrocedrae es el agente causal del mal del ciprés}

El mal del ciprés es un disturbio caracterizado por la presencia de lesiones necróticas en raíces principales que se extienden al cuello del árbol, alterando tejido vitales, modificando el estado fisiológico del individuo y conduciendo a la defoliación.

o Hipótesis 1: La defoliación es consecuencia directa del desarrollo de lesiones necróticas debidas al ataque de $P$. austrocedrae.

PREDICCIÓN 1: Todos los árboles con defoliación presentarán lesiones necróticas producidas por $P$. austrocedrae. 


\section{MODELo 2: El mal del ciprés y la afección por P. austrocedrae son dos disturbios diferentes que coexisten en el bosque}

El mal del ciprés es un disturbio de origen desconocido, caracterizado por defoliación lenta, acompañada de amarillamiento y marchitamiento progresivo. $P$. austrocedrae es el agente causal de un disturbio caracterizado por lesiones necróticas en raíces principales que se extienden al cuello del árbol, alterando tejidos vitales y modificando el estado fisiológico del individuo.

o HIPóTESIs 2: Árboles afectados por mal del ciprés pueden a su vez ser colonizados por P. austrocedrae y presentar lesiones necróticas en cuello.

PREDICCIÓN 2: El porcentaje de árboles con síntomas de mal del ciprés afectados por P. austrocedrae será proporcional a la incidencia de esta última en el sitio.

\section{2.- MATERIALES Y METODOS}

\section{1.- ENSAYO PAREAdo: MODELO 1}

Para evaluar el Modelo 1 se utilizaron los 50 pares de plantas seleccionados por su fenotipo para mal del ciprés (Capitulo II ). Para cada uno de los individuos se determinó la presencia de lesiones necróticas a nivel del cuello del árbol; en cada caso se procedió en forma previa a liberar la zona del cuello eliminando la primera capa de suelo. La evaluación de la presencia de lesiones necróticas se realizó mediante descortezado, separando la corteza del árbol para exponer el floema, tejido en el cual las lesiones necróticas se desarrollan. Veinte pares de plantas (4 pares x 5 sitios de muestreo) se sometieron a un descortezado completo del cuello; en tanto que para los restantes 30 pares (6 pares x 5 áreas de muestreo) se procedió a un descortezado parcial, levantando la corteza (sin eliminarla) para exponer el floema. El descortezado parcial, se realizó sobre toda la circunferencia del cuello del árbol, y con distancias entre puntos de evaluación lo suficientemente cortas como para asegurar la detección de pequeñas lesiones. En ambos casos, el porcentaje de tejido afectado se estimó dividiendo el cuello del árbol en partes iguales y contando el número de partes con lesión.

El criterio de evaluación, se basó en las determinaciones realizadas por Floria (2008), quien estableció que la condición a nivel de cuello es un buen indicador del estado de la raíz (r: 0.892, P <0,0001). La medida de resistencia eléctrica y la extracción de tarugos, dos métodos indirectos propuestos para la evaluación de la presencia de lesiones, realizados únicamente en cuatro puntos a lo largo de la circunferencia del cuello, presentan buena correlación con el estado de raíz (r: 0.80 y 0.85, $\mathrm{P}<0,01)$ y cuello (r: 0.84 y 0.92, $\quad \mathrm{P}<0,01)$ (Floria, 2008). Sin embargo, estos métodos no permiten estimar el porcentaje de afectación, ni establecer 
completamente la naturaleza de las lesiones detectadas (activa, inactiva, antigua), por lo cual en este trabajo se decidió aplicar el método directo de evaluación (descortezado).

\section{2.- ENSAYO EN PARCELAS: MODELO 2}

Para evaluar el MODELo 2 se requieren determinaciones completas dentro de un área que no pueden ser efectuadas por medio del ensayo pareado, por tal motivo se diseñó un ensayo en parcelas. El R11 y el R18 fueron seleccionados para el ensayo en parcelas debido a que en el ensayo pareado fueron los de mayor y menor porcentaje de árboles defoliados que presentaban lesiones necróticas, respectivamente. En cada sitio se estableció una parcela de $50 \mathrm{~m}$ x $50 \mathrm{~m}$ y en cada parcela se evaluaron todos los árboles con DAP $>5 \mathrm{~cm}$. Se determinó la posición sociológica de los mismos, según los criterios definidos en el Capitulo II (Aislados, Dominantes, Codominantes, Intermedios y Oprimidos). Los árboles aislados (Ais), dominantes (D) y codominantes (CD), fueron clasificados según estado sanitario para mal del ciprés de acuerdo con los parámetros establecidos en el Capitulo II. Los árboles intermedios (I) y Oprimidos (O) no fueron clasificados para mal del ciprés, debido a que la competencia intraespecífica introduce incerteza en la clasificación. Una subparcela de 20 m x 50 m se utilizó para evaluar la presencia de lesiones necróticas, agregándose dos cuadros de 10 m x 10 m en el R11 a fin de evaluar un número de árboles similar al del R18. Para todos los árboles de estas subparcelas, se determinó el nivel de afectación en cuello mediante el método de evaluación directa por descortezado parcial.

\section{3.- RESULTADOS Y DISCUSIÓN}

\section{1.- ENSAYO PAREADO: MODELO 1}

Entre los 50 pares de plantas seleccionados en función del estado sanitario para mal del ciprés (Figura IV-1), se observó un grado variable de afectación del floema a nivel de cuello. En algunos casos los árboles presentan grandes lesiones que se extienden desde el cuello hacia el fuste, alcanzando incluso alturas cercanas al DAP (Figura IV-2). En otros las lesiones son menores y se observan como lenguas de tejido muerto separadas claramente del tejido vivo (Figura IV-3). De un total de 23 árboles con lesión a nivel de cuello, sólo 1 (4,3\%) presenta lesión activa (Figura IV-3), siendo a su vez el único caso detectado entre los 50 árboles sin defoliación (asintomáticos para mal del ciprés). El resto de los árboles con lesiones necróticas a nivel de cuello, corresponden a árboles sintomáticos para mal del ciprés con diferente grado de avance de la defoliación (S1, S2 o S3). 


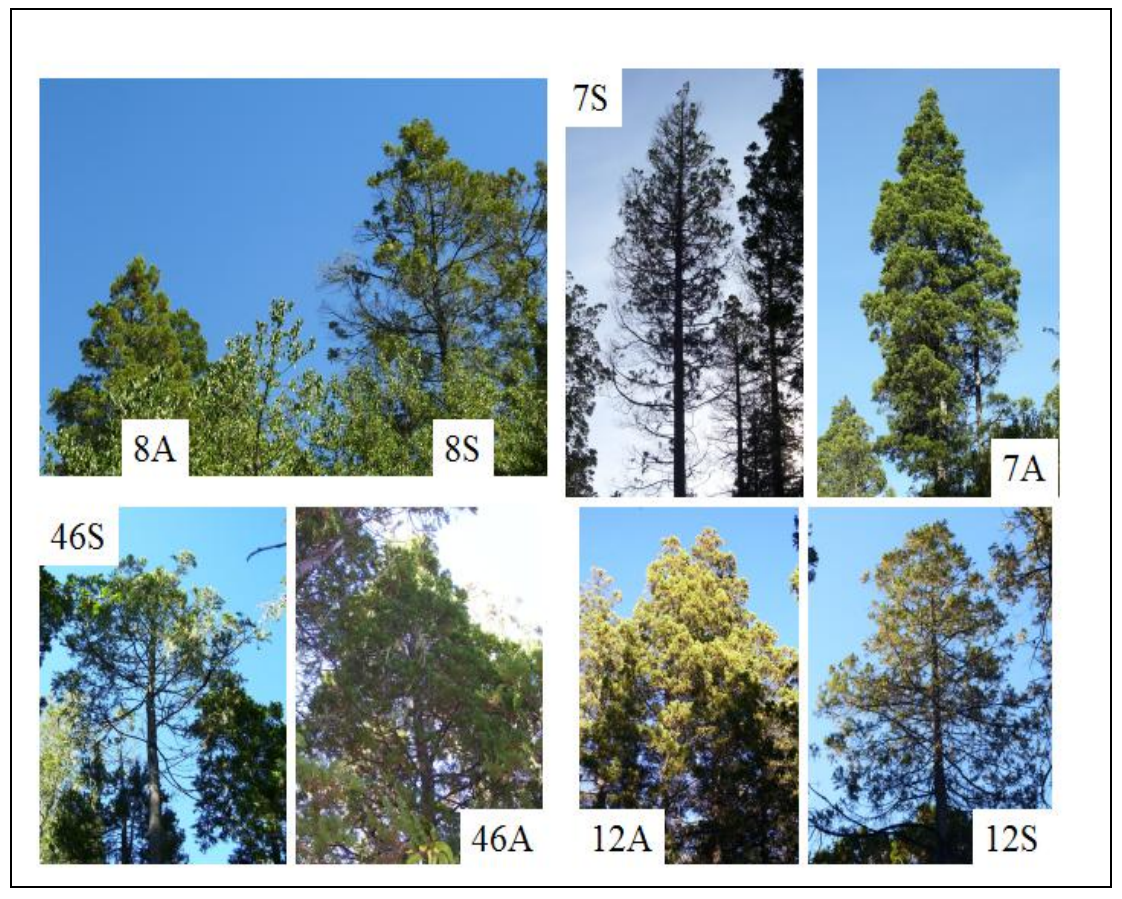

Figura IV-1: Selección de individuos en muestreo pareado según porcentaje de defoliación. Árboles asintomáticos: 8A, 7A, 46A y 12A. Árboles sintomáticos: 8S (avanzado), 7S (terminal), 46S (inicial), 12S (avanzado).

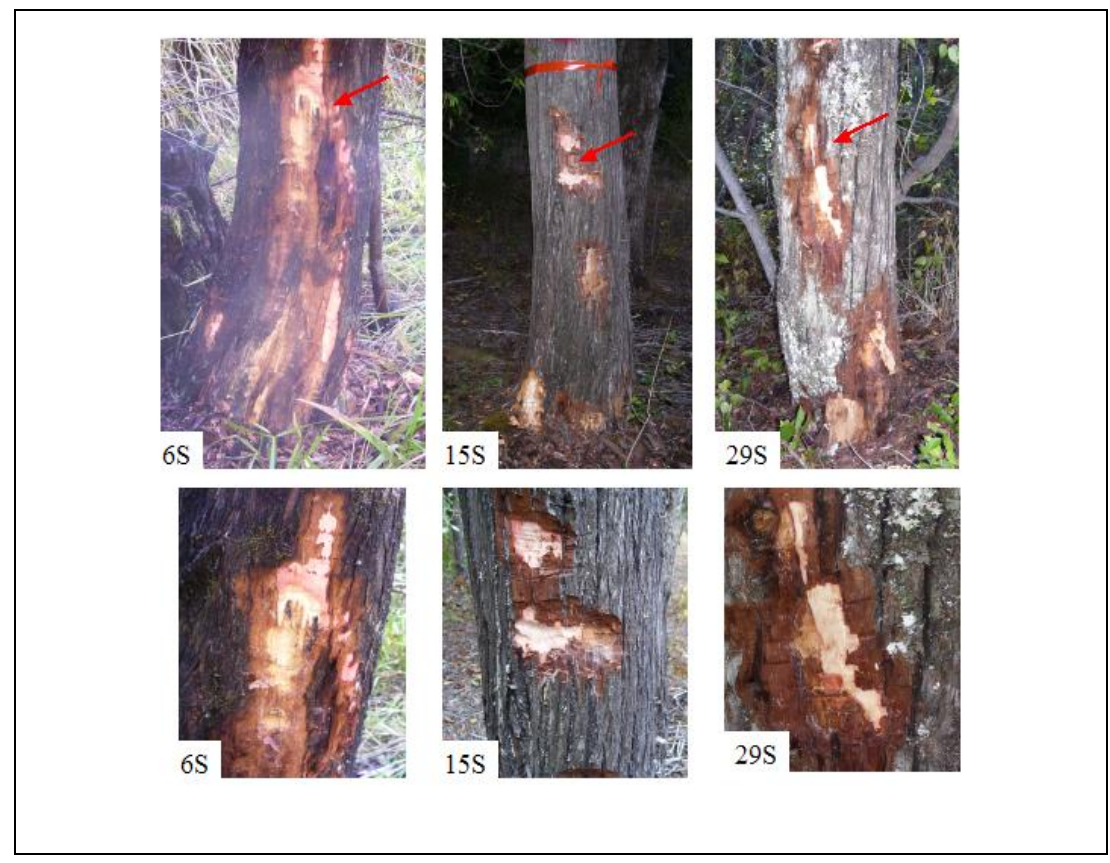

Figura IV-2: Lesiones necróticas de floema, afectando gran porcentaje del cuello del árbol, y extendiéndose hacia el fuste. La flecha roja en las imágenes del panel superior señalan la zona ampliada en el panel inferior con detalle del límite entre tejido afectado y vivo. Clasificación para mal del ciprés según porcentaje de defoliación: 6S (avanzado), 15S (terminal), 29S (inicial). 


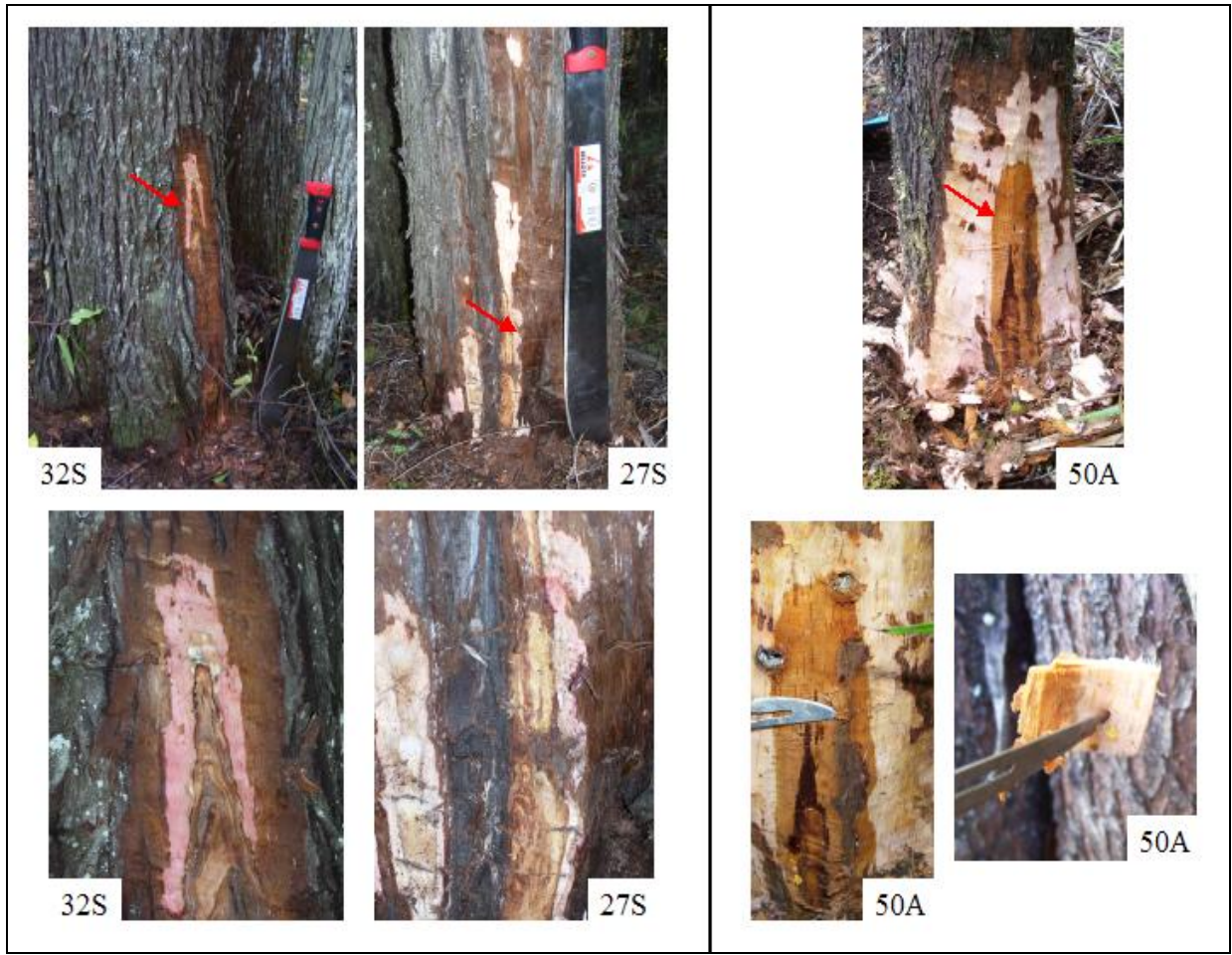

Figura IV-3: Lesiones necróticas de floema limitadas en extensión y altura. Panel izquierdo: lesiones inactivas. Panel derecho: lesión activa. La flecha roja en el panel superior señala la zona ampliada en el panel inferior, mostrando el detalle del límite entre tejido vivo y afectado. Clasificación para mal del ciprés según porcentaje de defoliación: 32S (inicial), 27S (inicial), 50A (asintomático).

Para el tamaño de muestra evaluado no existen diferencias en el número de individuos con síntomas de mal del ciprés que presentan lesiones necróticas entre los sitios de muestreo, ni entre el área Norte y Sur de El Bolsón. A nivel de cada árbol el porcentaje de tejido afectado en cuello por lesiones necróticas es variable (Gráfico IV-1). El L5y6 y el R18 presentan porcentajes de afectación del cuello superiores al 70\%. Para el R81, los porcentajes son inferiores al 25\%, y para el R11 y el L9y15 se observa una distribución más heterogénea con porcentajes que varían entre $12.5-100 \%$ y $4-65 \%$, respectivamente.

El análisis de la distribución de las lesiones necróticas, según el estado sanitario para mal del ciprés, (Gráfico IV-2), indica que entre los árboles con síntomas de mal del ciprés se observa una mayor frecuencia de lesiones necróticas entre los árboles con mayor grado de defoliación. Un 89\% de los árboles S3 presenta lesiones necróticas, en tanto que en promedio de los árboles S1 y S2 sólo un 35\% tiene lesiones en cuello. Estos resultados se correlacionaron con los reportados por Floria (2008) quien informa un 20\% de individuos sin lesión necrótica en cuello ni raíz con defoliaciones que varían entre 25\% y 85\% (S2 y S3). 

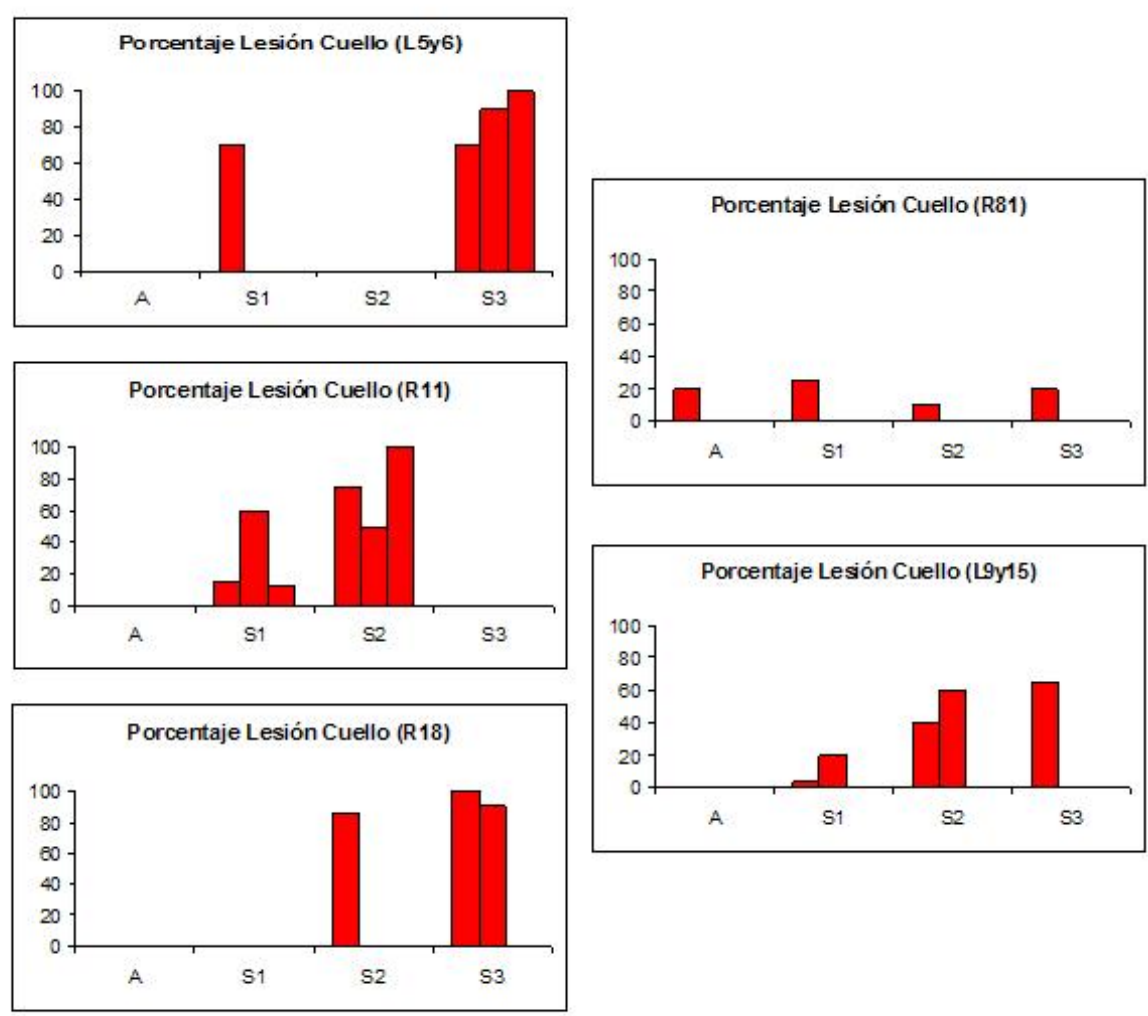

Gráfico IV-1: Distribución del porcentaje del cuello de cada individuo afectado por lesiones necróticas según estado sanitario para mal del ciprés y sitios de muestreo. Clasificación para mal del ciprés: A (asintomático), S1 (sintomático inicial), S2 (sintomático avanzado), S3 (sintomático terminal).

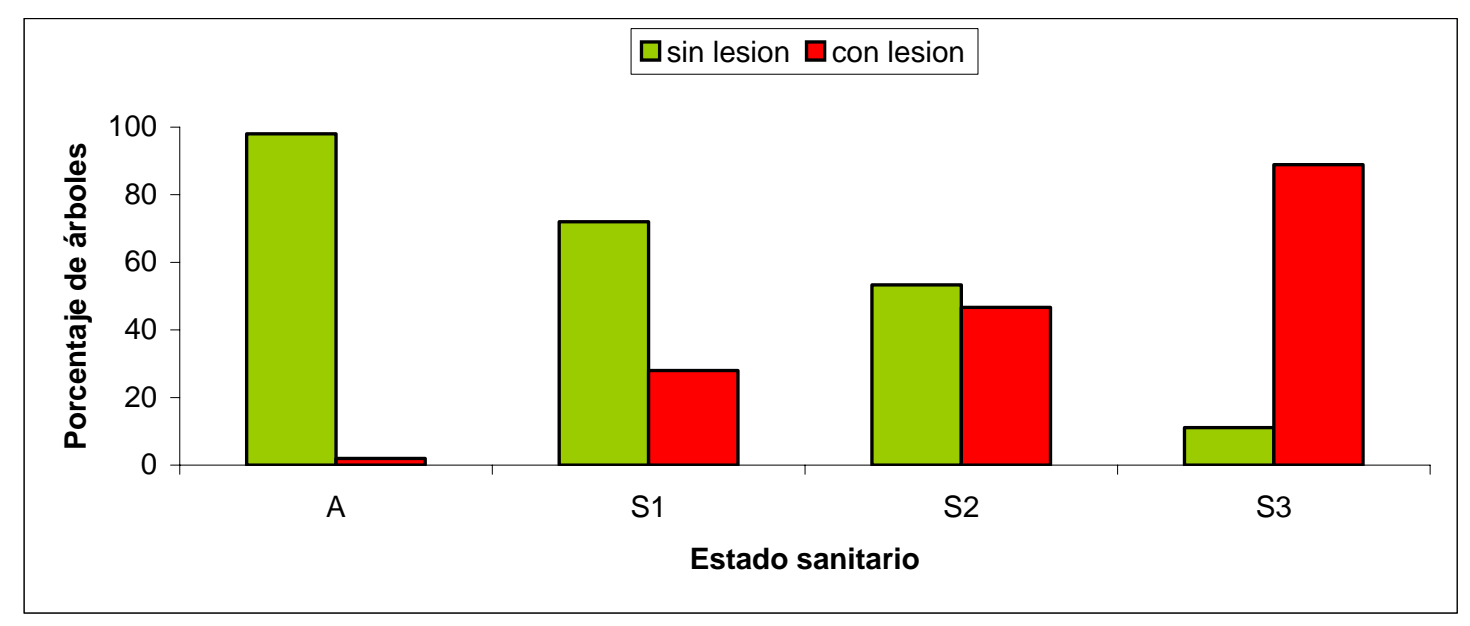

Gráfico IV-2: Porcentaje de individuos con lesiones necróticas según estado sanitario para mal del ciprés. Clasificación para mal del ciprés: A (asintomático), S1 (sintomático inicial), S2 (sintomático avanzado), S3 (sintomático terminal). 
Cuando se considera la zona de El Bolsón en conjunto el porcentaje de árboles con defoliación que presenta lesiones necróticas es del 44\%, no existiendo diferencias entre EB_N (43\%) y EB_S (45\%). Estos valores son inferiores al 80\% reportado por Floria (2008) para una zona del Valle del Río Grande (Chubut).

La baja frecuencia de detección de lesiones necróticas activas (1 entre 23 lesiones detectadas) y el menor porcentaje de árboles con síntomas de mal del ciprés que presentan lesiones necróticas a nivel de cuello (44\%) sugieren menor incidencia de $P$. austrocedrae en el área de El Bolsón (Río Negro) respecto de la reportada por Floria (2008) para la región del valle del Río Grande (Chubut). Del mismo modo contrastan los datos registrados en relación a la presencia de hojas amarillas o rojas. En la zona de El Bolsón, de acuerdo con los criterios definidos para el muestreo pareado (Capitulo II) se seleccionaron árboles sin hojas amarillas o rojas. En más de tres años de observaciones sucesivas, sólo dos árboles mostraron cambios de color en el follaje (Figura IV-4). Por el contrario, Floria (2008) reporta gran frecuencia de hojas amarilllas y rojas, e individuos que muestran cambios importantes en la coloración del follaje entre observaciones sucesivas.

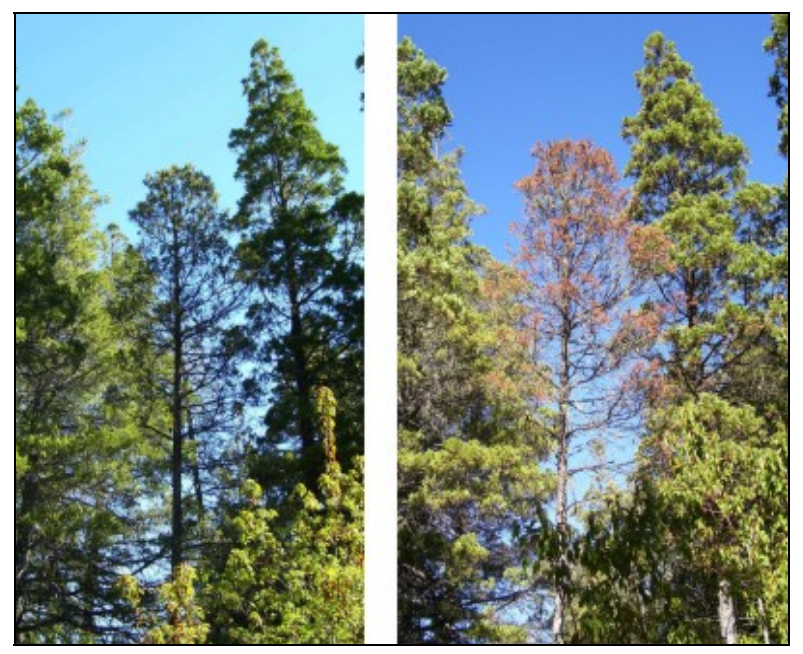

Figura IV-4: Cambio de color de follaje y mortalidad súbita del árbol 28S. Panel izquierdo registrada al momento de la selección, Noviembre 2006, clasificación para mal del ciprés S2 (avanzado). Panel derecho registrada en Abril 2007.

La diferencia entre las áreas mencionadas es también evidente en observaciones generales a nivel de bosque; en el área de El Bolsón aunque es posible observar algunos árboles con follaje rojo no se detectan manchones o grupos de árboles afectados tan importantes como los reportados para la zona del Valle del Río Grande (Figura IV-5). 


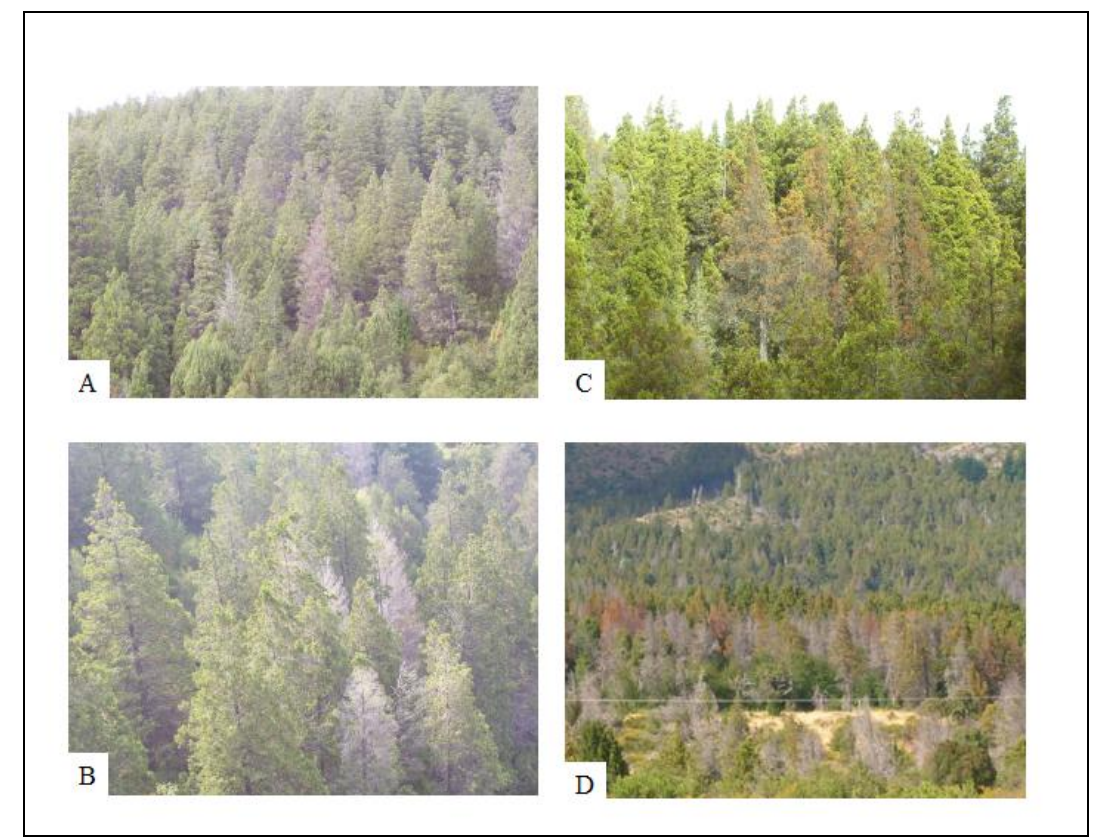

Figura IV-5: Manifestaciones del cambio de color del follaje a nivel de bosque. Panel izquierdo (A-B): El Bolsón. A- bajo número de árboles con follaje rojo, sin agregación. B-árboles con distinto grado de defoliación. Panel derecho (C-D): Valle del Río Grande. C: grupo de árboles con follaje rojo. D- alto número de árboles con follaje rojo, acompañados de árboles completamente defoliados, agregación de individuos afectados, imagen tomada de Floria (2008).

Los resultados obtenidos rechazan, por tanto, la hipótesis planteada en relación al modelo de un disturbio único, ya que un importante porcentaje de la defoliación no es consecuencia directa de la presencia de lesiones necróticas, en vista de lo cual, defoliación y lesiones necróticas no deberían ser consideradas como síntomas exclusivos de un mismo disturbio.

El modelo planteado y el ensayo de pares no permiten, sin embargo, determinar:

o si la incidencia de $P$. austrocedrae influye en el porcentaje de árboles defoliados que presentan lesión a nivel de cuello

o si la asociación entre la defoliación y las lesiones necróticas se debe a la acción de $P$. austrocedrae sobre árboles afectados por el mal del ciprés,

o si la defoliación es síntoma de dos disturbios diferentes que afectan en forma simultánea a los bosques de A. chilensis, siendo P. austrocedrae responsable de parte de la defoliación observada.

Para avanzar sobre estos interrogantes se diseñó el ensayo en parcelas. 


\section{2.- ENSAYO EN PARCELAS: MODELO 2}

El número total de árboles con diámetro $>5 \mathrm{~cm}$ en las parcelas fue de 169 para el R11 y 140 para el R18, correspondiendo en ambos casos un 5\% a árboles muertos (Gráfico IV-3). El porcentaje de árboles que por su posición sociológica no pueden ser clasificados para mal del ciprés (NC), es mayor en el R11 que en el R18 (Gráfico IV-3), lo que se corresponde con las diferencias de densidad y nivel de competencia informadas para los sitios (Capitulo II, Anexo 1).

La incidencia del mal del ciprés debe ser reportada en función del porcentaje de árboles con síntomas, sin considerar en el total a los árboles muertos o en fuerte situación de competencia (intermedios y oprimidos), ya que de esta forma se elimina la mayor parte de las incertezas en la clasificación de árboles sintomáticos debidas a competencia. De acuerdo con este cálculo, ambas parcelas presentan incidencias similares de mal del ciprés, con valores de 32\% para la parcela del R11 y 35\% para la parcela del R18.

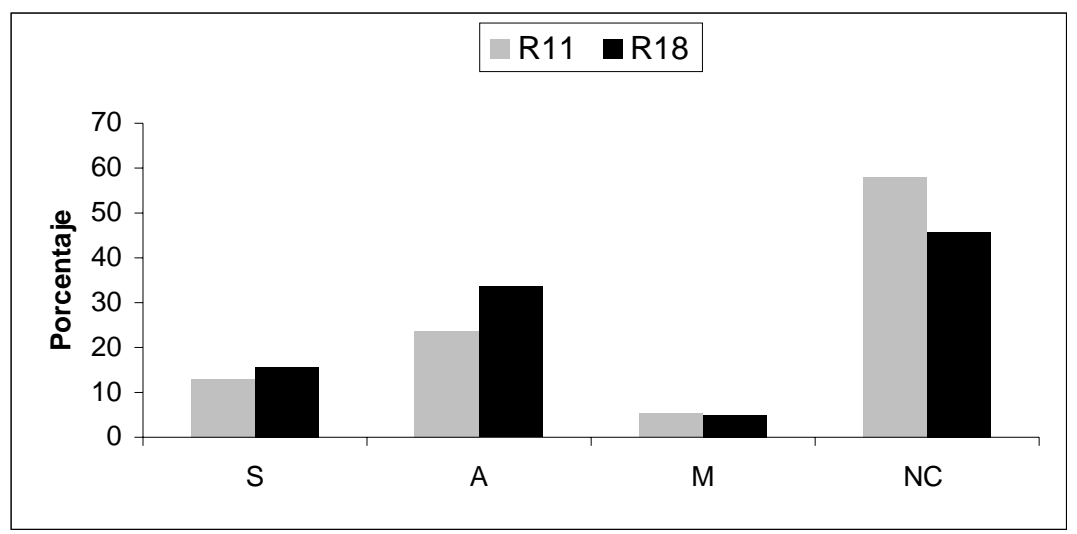

Gráfico IV-3: Distribución de árboles según síntomas aéreos para las parcelas del R11 y R18. Código de clasificación de individuos: S (sintomático para mal del ciprés), A (asintomático para mal del ciprés), M (muerto), NC (no clasificables para mal del ciprés, individuos en situación de competencia).

Los únicos aislamientos exitosos de $P$. austrocedrae provienen de lesiones necróticas y hasta el momento la especie no ha sido aislada, ni detectada mediante métodos moleculares, desde muestras de suelo o agua. Por tal motivo, la única forma de determinar la incidencia de P. austrocedrae en un área consiste en evaluar, mediante un método destructivo y laborioso, el estado de los tejidos a nivel de cuello o raíz en la totalidad de los árboles a fin de establecer el porcentaje que presenta lesiones necróticas. La determinación se realizó en una subparcela de 20 m x 50 m en cada sitio. Dado que el total de árboles en la subparcela del R11 era inferior al del R18, se sumaron dos cuadros de $10 \mathrm{~m}$ x $10 \mathrm{~m}$ a fin de evaluar un número similar de árboles en cada sitio. De un total de 71 árboles analizados en el R11, 4 correspondieron a árboles muertos 
que no fueron considerados en las evaluaciones posteriores debido a que se desconoce la causa de muerte. En el R18, de entre 70 árboles evaluados sólo 1 estaba muerto y no fue considerado. Entre los 67 árboles vivos en el R11, 12 (18\%) presentan lesiones necróticas a nivel de cuello y 6 (9\%) tienen lesiones necróticas y síntomas aéreos de mal del ciprés (Gráfico IV-4). Entre los 69 árboles vivos del R18, 5 (7\%) presentan lesiones necróticas a nivel de cuello y 2 (3\%) tienen lesiones necróticas y síntomas aéreos de mal del ciprés (Gráfico IV-4). Estos resultados tomados en conjunto muestran que el porcentaje de árboles con defoliación que presentan lesiones necróticas a nivel de cuello tiene relación directa con la incidencia de $P$. austrocedrae en el sitio; 9\% vs. 18\% para el R11 y 3\% vs. 7\% para el R18.

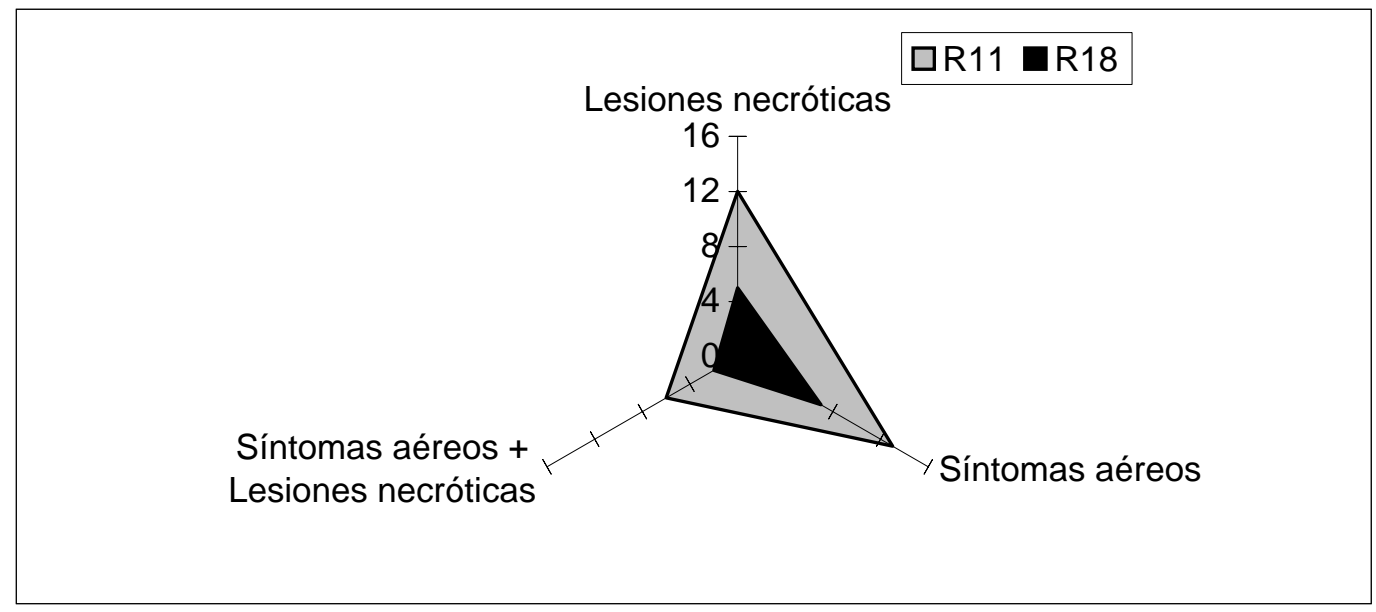

Gráfico IV-4: Correlación entre la incidencia de P. austrocedrae en un sitio (número de árboles con lesiones necróticas) y el número de individuos con síntomas aéreos de mal del ciprés (defoliación y amarillamiento) que presentan simultáneamente lesiones necróticas a nivel de cuello.

De los 12 árboles que presentaron lesiones a nivel de cuello en el R11, 5 (42\%) corresponden a árboles en situación de competencia (intermedios u oprimidos) y 7 (58\%) a árboles codominantes (Gráfico IV-5). Para el R18, de los 5 árboles que presentaron lesiones en cuello, 3 (60\%) corresponden a árboles en competencia y 2 (40\%) a árboles codominantes clasificados como sintomáticos para mal del ciprés, es decir árboles con defoliación (Gráfico IV-5). Los individuos codominantes afectados por $P$. austrocedrae presentan síntomas aéreos de mal del ciprés. En ninguno de los rodales se observaron árboles dominantes o aislados con lesiones necróticas. 


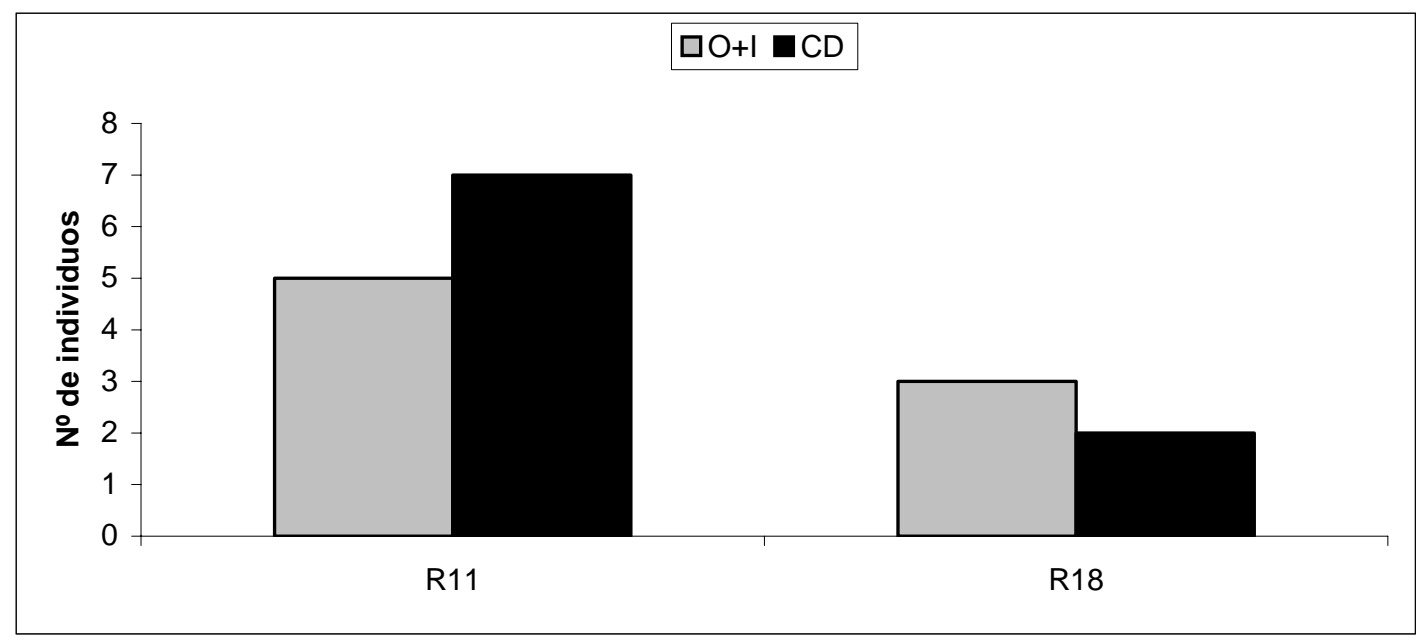

Gráfico IV-5: Distribución de los individuos afectados por $P$. austrocedrae entre clases sociológicas. O+I: oprimidos e intermedios. CD: codominantes.

Los resultados muestran que en promedio un $50 \%$ de los árboles afectados por $P$. austrocedrae corresponden a árboles en situación de competencia y, por tanto, en desventaja para responder a la acción de un patógeno. El resto de los árboles afectados por $P$. austrocedrae corresponden a árboles codominantes que presentan defoliación o cambio en el color del follaje. Aunque la afectación por $P$. austrocedrae podría conducir a defoliación, la agresividad determinada para la especie en los ensayos de patogenicidad (Greslebin y Hansen, 2007a y b) no se condice con la descripción tradicional del mal del ciprés como un proceso lento de defoliación y marchitamiento progresivo y gradual. Una interpretación alternativa es que los árboles afectados y debilitados por el mal del ciprés serían más susceptibles al ataque por $P$. austrocedrae; en cuyo caso la cantidad de árboles afectados por mal del ciprés que presentan lesiones necróticas debería estar en relación con la incidencia de $P$. austrocedrae en el sitio. Esta correlación se demostró en el ensayo en parcelas de acuerdo con la predicción del MODELO 2.

Tomados en conjunto los resultados obtenidos en el ensayo de parcelas sugieren que $P$. austrocedrae actuaría como agente secundario sobre individuos que están debilitados, ya sea por desarrollo en condiciones de alta competencia o porque han sido previamente afectados por el mal del ciprés.

\section{4.- DISCUSION}

Desde sus inicios el mal del ciprés se definió como un proceso lento de defoliación progresiva y gradual, acompañada de marchitamiento general (Capitulo I). La defoliación se asoció con 
frecuencia al deterioro de raíces (Varsavsky, 1975; Havrylenko et al., 1989; Rajchenberg y Cwielong 1993; Hennon y Rajchenberg, 2000) y se considera un síntoma inespecífico que podría derivar de la acción de diferentes agentes bióticos o abióticos (El Mujtar y Andenmatten, 2007b). Es importante señalar que la falta de especificidad del síntoma, aunque dificulta la clarificación del origen etiológico del proceso, no modifica su papel como síntoma evidente y característico en el cual se basan incluso los sistemas de clasificación de los árboles afectados. La falta de correlación entre el grado de defoliación y la afectación de raíces o cuello por lesiones necróticas (Floria, 2008), no debe ser interpretado como una falta de representatividad de la defoliación sino consecuencia de su inespecificidad y del rol que $P$. austrocedrae tiene en el sistema.

Por tal motivo, a fin de establecer la relación que existe entre la defoliación, síntoma característico del mal del ciprés, y la presencia de lesiones necróticas producidas por $P$. austrocedrae, dos modelos alternativos que definen la presencia de uno o dos disturbios fueron evaluados mediante un ensayo pareado y un ensayo en parcelas.

A través del ensayo pareado se pudo establecer que la defoliación no es consecuencia directa de las lesiones necróticas producidas por $P$. austrocedrae, ya que el 56\% de los árboles con defoliación no presentan lesiones necróticas. En vista de los resultados obtenidos, el modelo de disturbio único no puede ser aceptado y, por tanto, la defoliación y las lesiones necróticas no deberían ser consideradas como síntomas exclusivos de un mismo disturbio. El grado de defoliación no es el mejor indicador del estado sanitario en raíz o cuello (Floria, 2008); sin embargo, esta falta de correlación lejos de invalidar el uso de la defoliación como síntoma característico del mal del ciprés, señala que $P$. austrocedrae no debería considerarse como el agente etiológico del proceso.

De acuerdo con el ensayo en parcelas, el mal de ciprés y la afectación por $P$. austrocedrae tienen distinta incidencia en los sitios analizados. El R11 presenta incidencias del 32\% para el mal del ciprés y 18\% para la afección por $P$. austrocedrae; en tanto que para el R18 los valores son del 35\% y el 7\%, respectivamente. Se determinó que el porcentaje de árboles con defoliación que presentan lesiones necróticas a nivel de cuello, 9\% para el R11 y 3\% para el R18, tiene relación directa con la incidencia de $P$. austrocedrae en el sitio. Y se estableció que el 50\% de los árboles afectados por $P$. austrocedrae corresponden a árboles en situación de competencia, en tanto que del 50\% restante la mayoría corresponde a árboles con mal del ciprés. Siendo válido, por tanto, considerar que la especie actúa en gran medida sobre individuos debilitados (competencia o mal del ciprés), al menos en la zona de El Bolsón. 
El desconocimiento de la dinámica de $P$. austrocedrae a nivel de bosque y a nivel de individuo y de los síntomas aéreos derivados de su acción, hace difícil establecer si la especie es responsable de parte de la defoliación; sin embargo algunas características ya determinadas permiten avanzar en el análisis de esta hipótesis. Un gran porcentaje de las lesiones necróticas detectadas son inactivas, y no todos los árboles presentan lesiones de gran magnitud. Por el momento, no se conoce si la inactivación de las lesiones es consecuencia de mecanismos de defensa de las plantas o si responde a cambios en las condiciones ambientales que afectan negativamente el desarrollo de la especie (Greslebin y Hansen, 2007b).

La agresividad demostrada por $P$. austrocedrae en los ensayos de patogenicidad (Greslebin y Hansen, 2007a y b) contrasta con la definición del mal del ciprés como un proceso de mortalidad lenta (Varsavsky et al., 1975; Havrylenko et al., 1989; Rajchenberg y Cwielong, 1993). La mortalidad rápida de árboles asociada a cambio de coloración en el follaje, comenzó a ser reportada a mediados de la década del noventa coincidiendo con los informes de lesiones necróticas y decaimiento de raíz (Capitulo I). Su frecuencia de aparición parece ser mayor en los últimos años y estar asociada a sitios donde la incidencia de P. austrocedrae es más alta (Greslebin y Hansen, 2006; Floria, 2008; El Mujtar obs. pers.).

La cantidad de hojas amarillas o rojas (evaluadas durante el mes de Enero) no presenta asociación significativa con el porcentaje de tejido afectado por lesiones necróticas en raíz o cuello (Floria, 2008). Estos resultados coinciden con lo observado en los ensayos de patogenicidad realizados en plantas de $A$. chilensis de cinco años, donde la presencia de hojas rojas fue el único síntoma externo detectado, observándose en el 20\% de las plantas inoculadas, aunque las lesiones necróticas no diferían en tamaño entre plantas con y sin síntomas aéreos (Greslebin y Hansen, 2007a y b). Hasta el momento, únicamente se demostró que $P$. austrocedrae es el agente causal de las lesiones necróticas presentes en cuello o raíz; sin embargo se desconoce cuáles son los síntomas aéreos derivados de la afectación de tejidos vitales por $P$. austrocedrae, si estos síntomas son específicos o inespecíficos y cuál es su velocidad de desarrollo (lenta o rápida).

Actualmente en los bosques de A. chilensis los síntomas aéreos pueden ser observados en diversas combinaciones, siendo las principales: defoliación sin hojas amarillas o rojas, defoliación con hojas amarillas o rojas, hojas amarillas o rojas en la totalidad de la copa sin defoliación, hojas amarillas o rojas en patrón de distribución central que pueden o no asociarse a defoliación (Figura IV-6). 


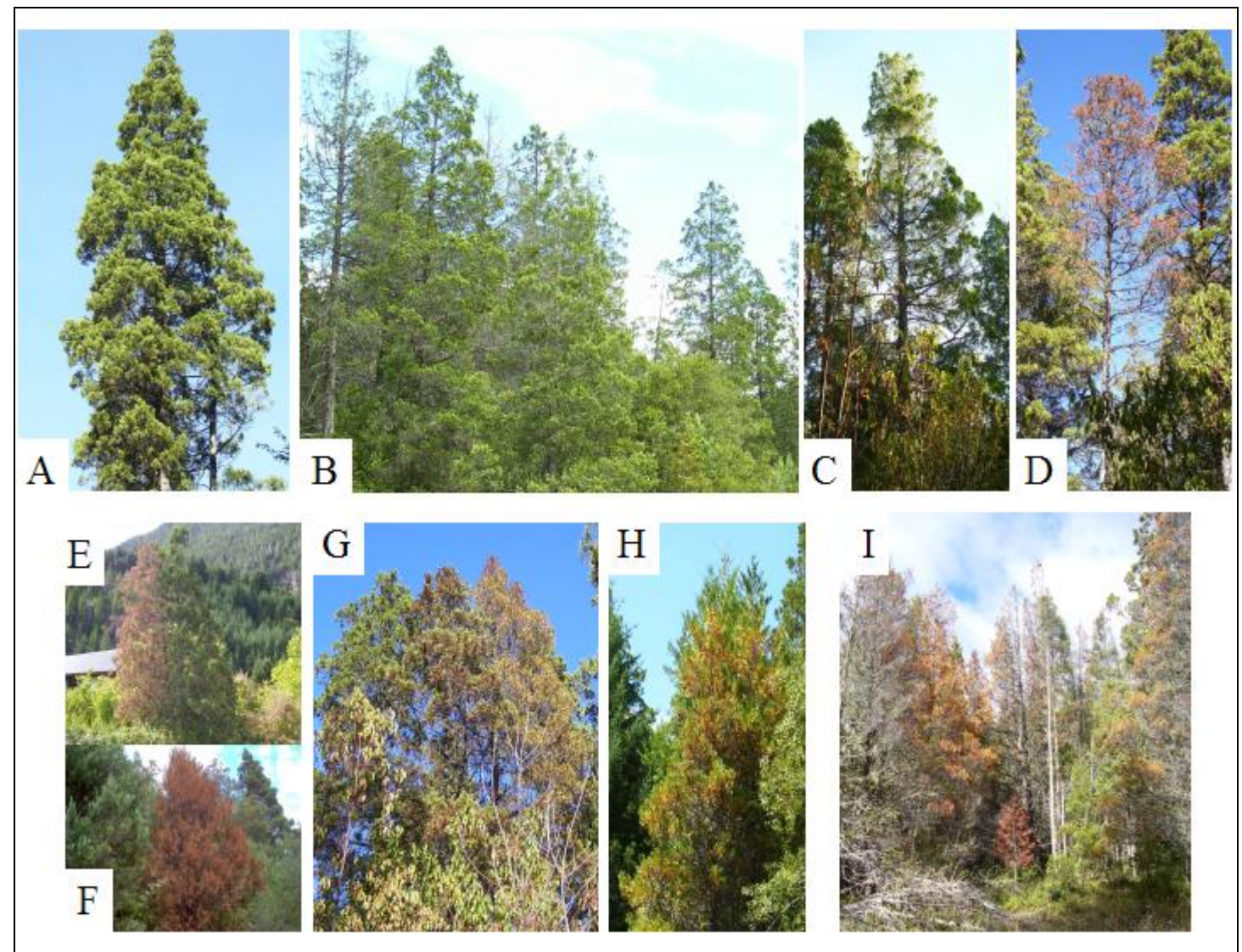

Figura IV-6: Presentación de síntomas aéreos a nivel de bosque. A: copa sin síntomas aéreos. B-C: defoliación en grado variable sin hoja amarillas o rojas. D: defoliación con follaje rojo. E-G: follaje rojo sin defoliación. H: hojas amarillas y rojas en patrón de distribución central. I: follaje rojo, defoliación total y agregación. Imágenes A-H: El Bolsón. Imagen I: Valle del Río Grande.

El seguimiento de los 50 pares de árboles empleados en el presente trabajo y las observaciones realizadas en visitas periódicas al bosque durante más de tres años, sugiere que la mortalidad rápida, caracterizada por la presencia de hojas rojas retenidas en la planta, podría estar asociada a $P$. austrocedrae y que la distribución de hojas amarillas o rojas en un patrón central sería la etapa previa a la afectación completa de la copa que conduce a la presencia de hojas rojas en la totalidad del follaje. Una evaluación preliminar de estas hipótesis se realizó en 5 árboles seleccionados por presentar un patrón de afectación central. Los resultados muestran que todos ellos tienen lesiones necróticas a nivel de cuello, independientemente del DAP, la posición sociológica y la presencia o ausencia de defoliación; y que en un período inferior a un año (Abril 2007-Enero 2008) el patrón central deriva en un patrón completo con la totalidad del follaje afectado (Figuras IV-7 y IV-8). 
Esta correlación se confirmó durante el año 2008 mediante la evaluación de 15 nuevas plantas con patrón de afectación central, en las cuales se verificó la presencia de lesiones necróticas en cuello. En la mayoría de los casos analizados en el período 2007-2008 (20 plantas en total) las lesiones necróticas detectadas en cuello son de gran magnitud pero inactivas; considerando que las evaluaciones se realizaron a fines o principios del verano, los resultados sugieren que el estrés hídrico podría ser un factor importante para el desarrollo del patrón central en plantas con extensa afectación previa de tejidos a nivel de raíz y cuello. El estudio de la tasa de crecimiento en plantas afectadas por $P$. austrocedrae, con o sin cambio de color del follaje, mediante técnicas dendrocronológicas permitirá clarificar la dinámica de acción de la especie y establecer que porcentaje de la mortalidad (lenta o rápida) se asocia con las lesiones necróticas.
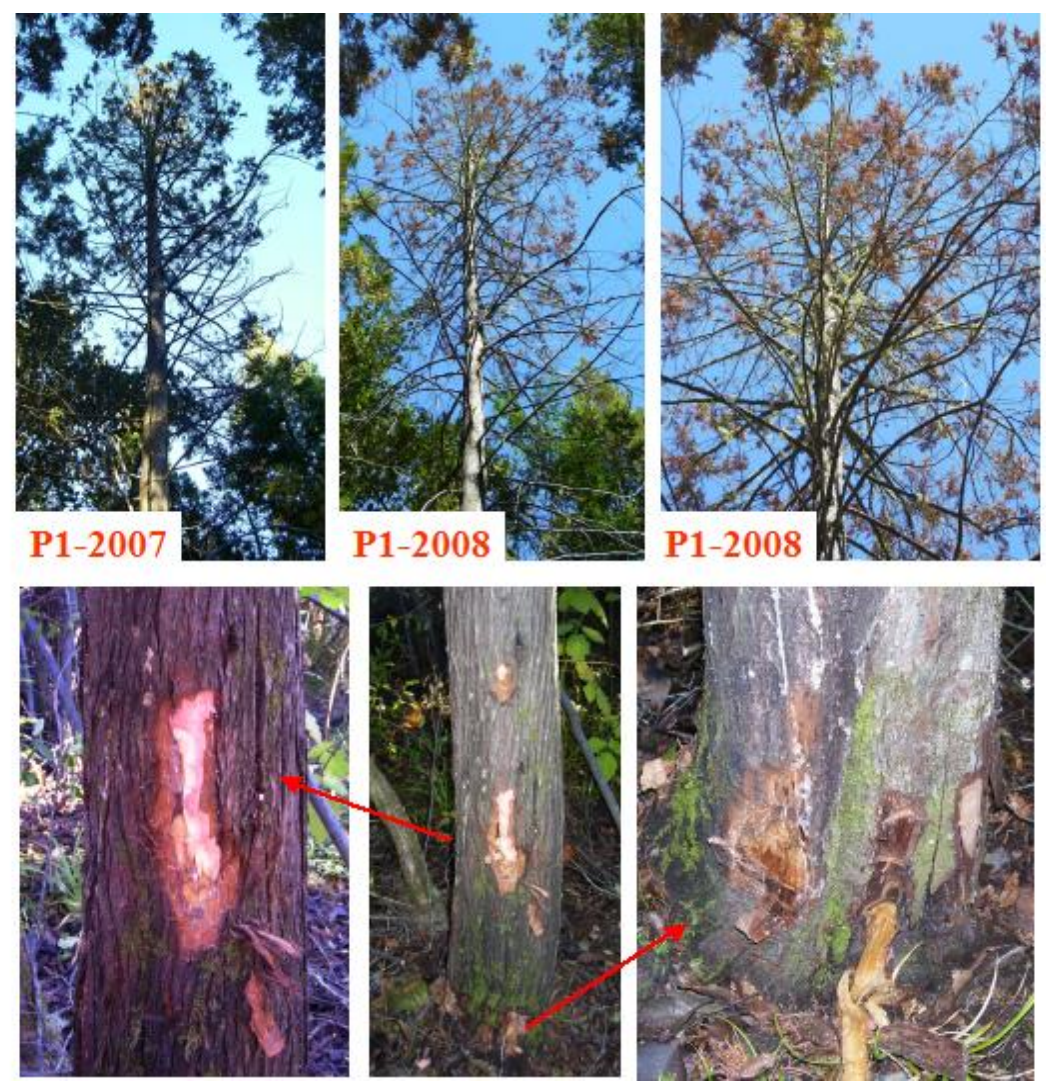

Figura IV-7: Presencia de lesiones necróticas en el individuo P1 seleccionado por cambio de color en follaje con distribución central. Las flechas rojas en imagen central panel inferior señalan las regiones ampliadas en las imágenes a izquierda (transición tejido vivo-muerto) y derecha (cuello con lesiones secas y mortalidad completa). Panel superior, cambio de patrón de distribución central a completo. 


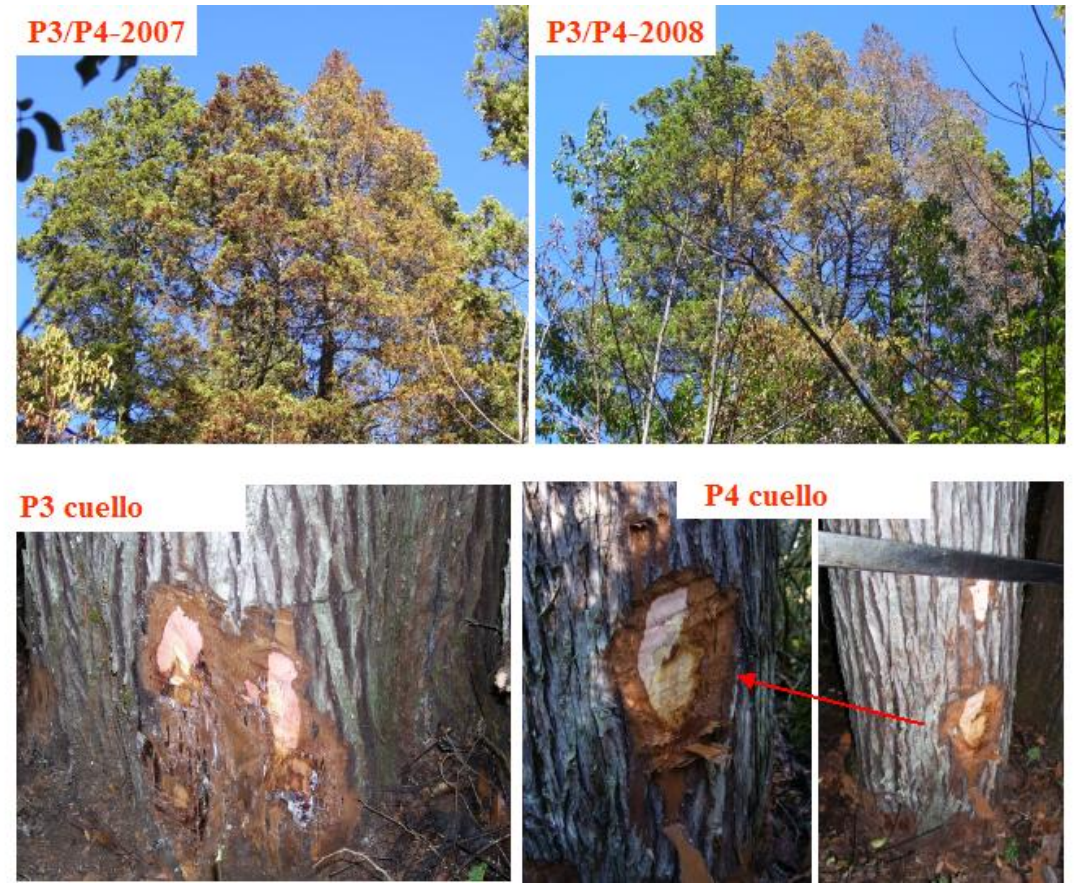

Figura IV-8: Presencia de lesiones necróticas en los individuos P3 y P4 seleccionados por cambio de color en follaje con distribución central. La flechas roja en imagen derecha (panel inferior) señala la zona ampliada en la imagen a su izquierda (transición tejido vivo-muerto). Panel superior, cambio de patrón de distribución central a completo.

La agregación parece ser otra característica de la mortalidad rápida asociada a cambio de color del follaje, en tanto que nuevos árboles aparecen en relación a individuos anteriormente afectados. Las Figuras IV-9 y IV-10 muestran algunas de las observaciones preliminares de esta agregación, realizadas en bosques de A. chilensis de la zona de El Bolsón, en donde se observa más frecuentemente en grupos de renovales o árboles de pequeño porte.

El Valle del Río Grande se reporta como una zona con intensa afectación de los bosques de A. chilensis, que presenta un aumento notorio en extensión e importancia durante los últimos años (La Manna y Rajchenberg, 2004b; Greslebin et al., 2005; Floria, 2008). La agregación es evidente en esta región aún para árboles adultos y ciertas áreas manifiestan un proceso rápido de mortalidad claramente asociado con cambio de color de follaje y lesiones necróticas. Una de estas áreas ubicada dentro del predio propiedad de la familia Berwin, que fue sometida a tala rasa hace aproximadamente seis años (Sr. Berwin com. pers.), muestra un claro borde de avance de mortalidad en el cual pueden observarse árboles de distinto porte, con diverso grado de afectación y cambio marcado en la coloración del follaje (Figura IV-11). Observaciones personales en el sitio indican una elevada incidencia de $P$. austrocedrae, siendo incluso posible detectar lesiones necróticas en individuos que no presentan síntomas a nivel de copa. 


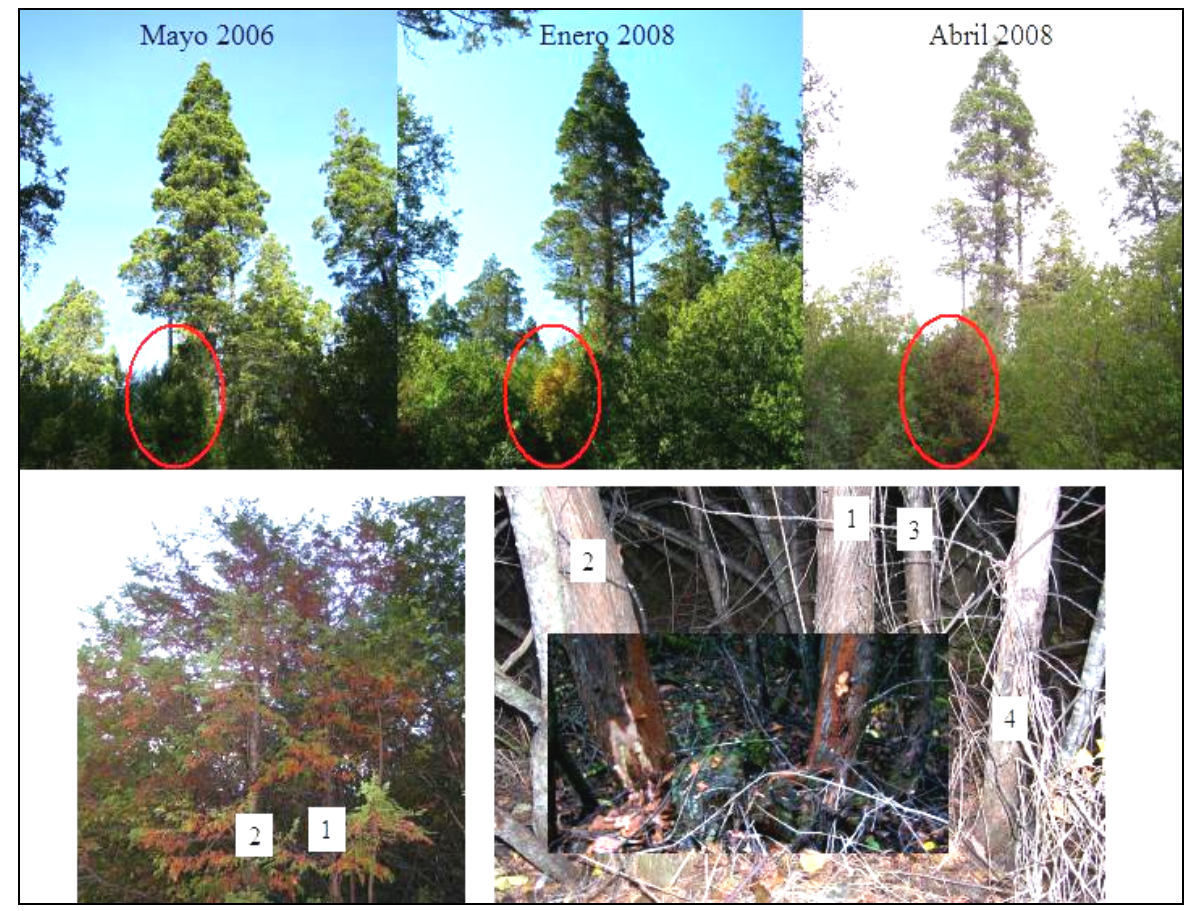

$\underline{\text { Figura IV-9: }}$ Avance temporal del cambio de color de follaje. El óvalo rojo señala un grupo de árboles de pequeño porte que presenta cambio de color con el tiempo: verde, amarillo, rojo. Panel inferior izquierdo, muestra el patrón de distribución central en los árboles 1 y 2, pertenecientes al grupo señalado con ovalo rojo en el panel superior. Panel inferior derecho: grupo de árboles afectados y estados de cuello de los árboles 1 y 2. (El Bolsón).

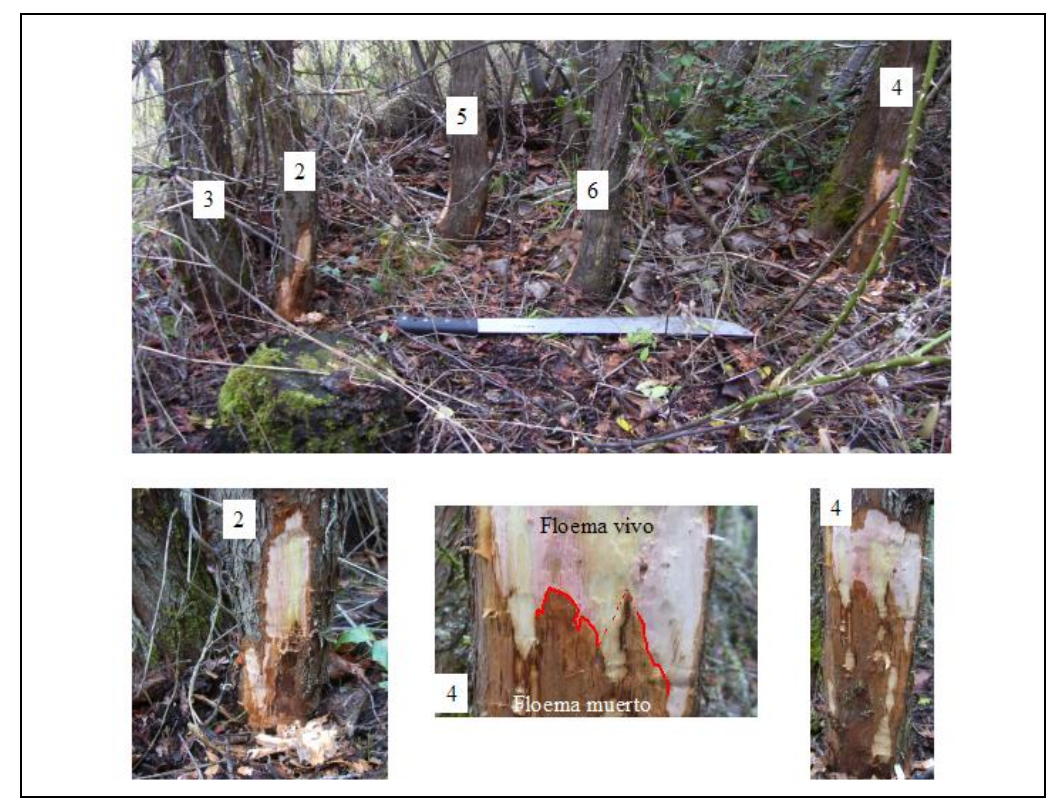

Figura IV-10: Agregación de individuos con cambio de color de follaje (Panel superior) y detalle de las lesiones necróticas presentes en los individuos 2 y 4 (Panel inferior). Imagen central: limite entre tejido vivo y muerto. (El Bolsón). 


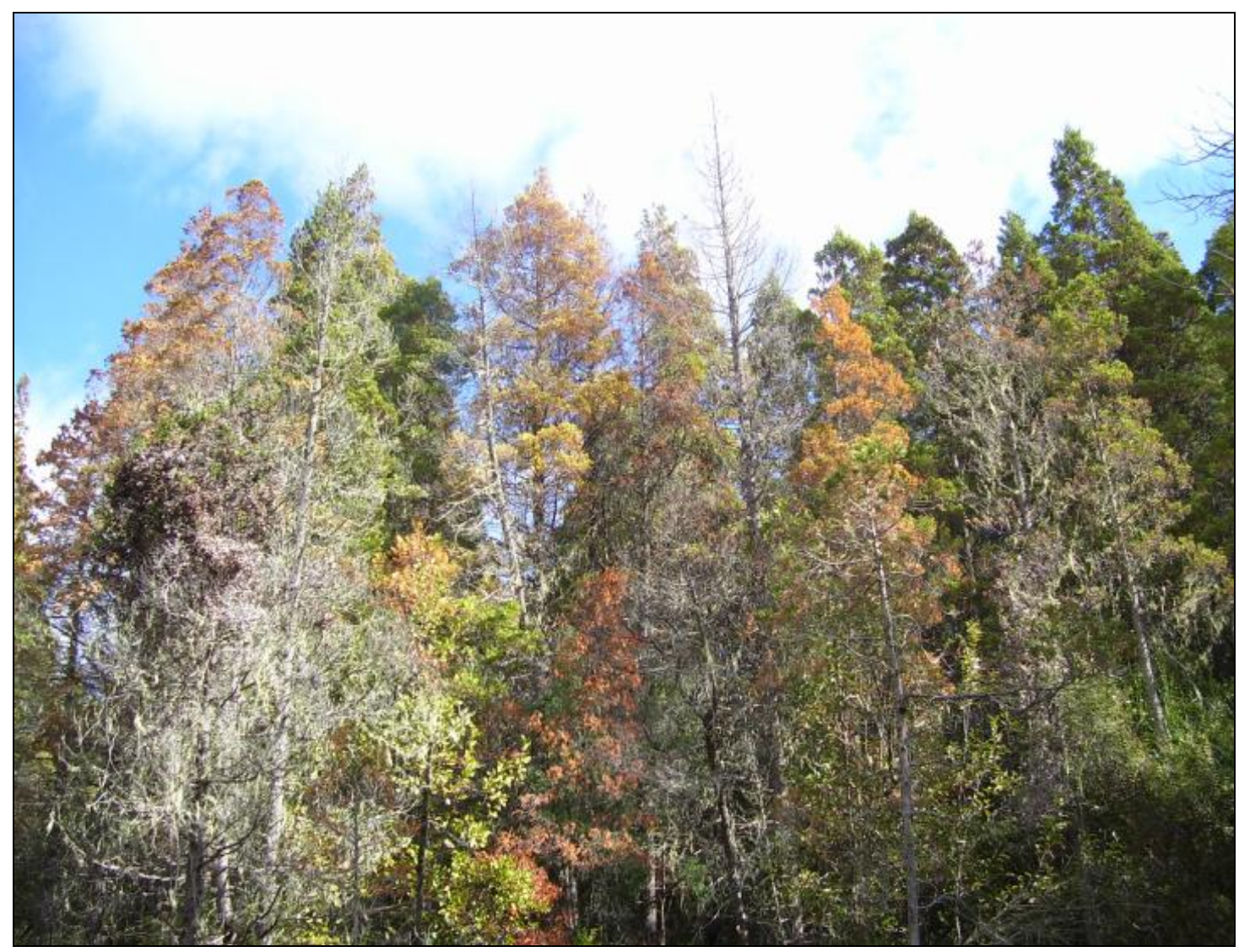

Figura IV-11: Agregación de individuos de distinto porte con cambio de coloración de follaje. Primer plano límite de la zona sometida a tala rasa; segundo plano, borde de avance de la mortalidad en el cual pueden observarse árboles de distinto porte, con cambio marcado en la coloración del follaje y árboles con follaje verde completo. (Valle del Río Grande).

Hasta el momento, se desconoce el origen geográfico de $P$. austrocedrae, por lo que la detección de la especie a través del rango de distribución de A. chilensis y en la gran mayoría de las áreas afectadas por mal del ciprés (Greslebin y Hansen 2006, Greslebin y Hansen 2007b), no debería ser considerada como evidencia para validar su rol de agente causal en dicho proceso, hasta tanto no se establezca si corresponde a una especie nativa o introducida. Los síntomas aéreos, el patrón de afectación, la agregación y la velocidad de muerte surgen como aspectos a considerar en relación al papel de $P$. austrocedrae en la sanidad de los bosques de A. chilensis. Los individuos empleados en estas evaluaciones no deberían ser seleccionados en base a la defoliación sino a la presencia de lesiones necróticas, síntoma exclusivo de P. austrocedrae. 


\section{5.- CONCLUSIONES}

El trabajo desarrollado en el presente capítulo fue adecuado para evaluar las hipótesis planteadas en relación a dos modelos alternativos propuestos. Los resultados obtenidos permiten concluir que $P$. austrocedrae no es el agente causal del mal del ciprés y que actuaría como agente secundario sobre individuos previamente debilitados (mal del ciprés o desarrollo en alta competencia).

El análisis comparativo de los datos aportados en este trabajo, con los reportados en otros bosques mésicos de $A$. chilensis confirma la necesidad de establecer los síntomas específicos derivados de la acción de $P$. austrocedrae a fin de poder estudiar cada disturbio en forma independiente.

El aislamiento y la identificación de especies de Phytophthora en bosques de A. chilensis (Greslebin et al., 2005; Greslebin et al., 2007) constituyó un avance importante en términos de la detección del primer agente patogénico asociado con el mal del ciprés. Sin embargo, las complicaciones inherentes a dichos aislamientos dificultan relevamientos extensivos tendientes a determinar la dinámica de especies en diferentes áreas y retardan la clarificación de los síntomas específicos de P. austrocedrae. En el Anexo 7 se presentan los resultados preliminares obtenidos en el desarrollo de métodos moleculares de detección e identificación de especies del género Phytophthora que permitirán avanzar más rápidamente en estos aspectos. 


\section{5.- CONCLUSIONES}

El trabajo desarrollado en el presente capítulo fue adecuado para evaluar las hipótesis planteadas en relación a dos modelos alternativos propuestos. Los resultados obtenidos permiten concluir que $P$. austrocedrae no es el agente causal del mal del ciprés y que actuaría como agente secundario sobre individuos previamente debilitados (mal del ciprés o desarrollo en alta competencia).

El análisis comparativo de los datos aportados en este trabajo, con los reportados en otros bosques mésicos de $A$. chilensis confirma la necesidad de establecer los síntomas específicos derivados de la acción de $P$. austrocedrae a fin de poder estudiar cada disturbio en forma independiente.

El aislamiento y la identificación de especies de Phytophthora en bosques de A. chilensis (Greslebin et al., 2005; Greslebin et al., 2007) constituyó un avance importante en términos de la detección del primer agente patogénico asociado con el mal del ciprés. Sin embargo, las complicaciones inherentes a dichos aislamientos dificultan relevamientos extensivos tendientes a determinar la dinámica de especies en diferentes áreas y retardan la clarificación de los síntomas específicos de $P$. austrocedrae. En el Anexo 7 se presentan los resultados preliminares obtenidos en el desarrollo de métodos moleculares de detección e identificación de especies del género Phytophthora que permitirán avanzar más rápidamente en estos aspectos. 


\section{CAPITULO V}

\section{RELACIÓN ENTRE EL MAL DEL CIPRÉS Y ÁFIDOS DEL GÉNERO CINARA}

\section{INTERROGANTES}

¿Están los áfidos del género Cinara asociados al mal del ciprés?

¿Existe un impacto diferencial de Cinara cupressi entre individuos sintomáticos y asintomáticos?

\section{HIPÓTESIS Y PREDICCIONES}

- Hipótesis 1: La colonización por áfidos del género Cinara (C. cupressi o C. tujafilina) debilita a los individuos de A. chilensis determinando una mayor susceptibilidad al mal del ciprés.

PREDICCIÓN 1: Los árboles sintomáticos para mal del ciprés presentan mayor incidencia de áfidos del género Cinara.

○ Hipótesis 2: El ingreso de la especie agresiva C. cupressi a la región de estudio determina un desplazamiento de la especie $C$. tujafilina desde uno de sus huéspedes naturales.

PREDICCIÓN 2: C. cupressi es la especie detectada con mayor frecuencia en A. chilensis y coloniza con mayor frecuencia los individuos debilitados para mal del ciprés. 



\section{1.- INTRODUCCIÓN}

Austrocedrus chilensis es una cupresácea nativa de los bosques Andino Patagónicos de Argentina y Chile. Desde hace más de sesenta años, los bosques de A. chilensis en Argentina son afectados por mal del ciprés; sin embargo para los bosques chilenos sólo se conocen algunos reportes dispersos de su presencia, sin un análisis detallado, ni registros históricos (La Manna, 2004; Stange Hofmman, 2004). Observaciones personales efectuadas durante el año 2005 en bosques de $A$. chilensis ubicados entre la VI y VIII Región de Chile, indicaron ausencia del mal del ciprés en la zona. Por el contrario, se observaron árboles de diverso porte afectados por áfidos del género Cinara (Figura V-1). En Chile se considera a Cinara (Cupressobium) cupressi (Buckton) como el agente responsable del enrojecimiento del follaje de A. chilensis (Silva et al., 2005), implementándose medidas de control biológico y químico sobre el áfido y manejo silvicultural de los bosques afectados.
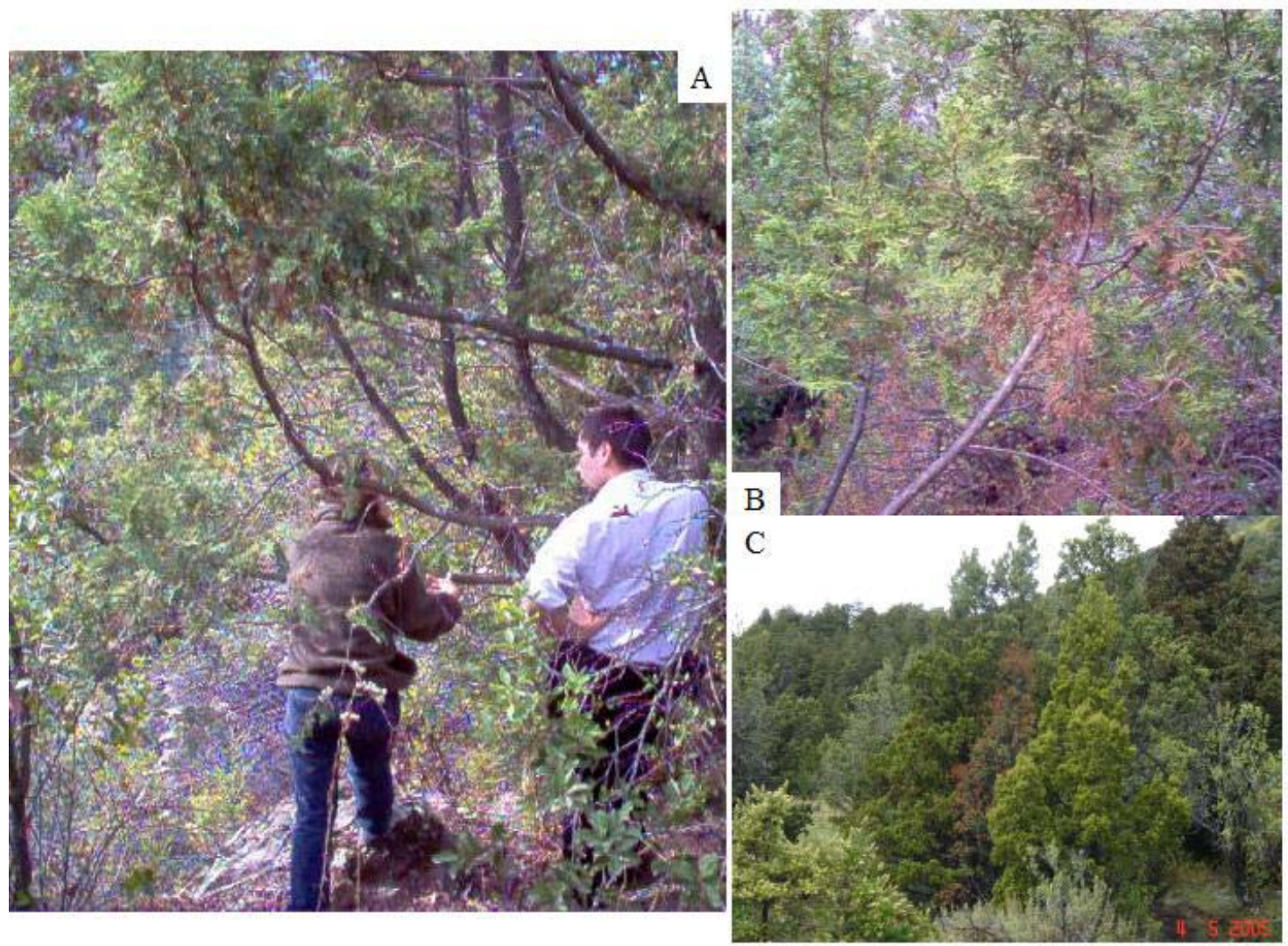

Figura V-1: Síntomas en follaje producidos por áfidos del género Cinara observados en bosques de $A$. chilensis en Chile. A-B: Ramillas secas, color marrón rojizo, retenidas en la planta (Sierras de Bella Vista - VI Región, Fotos: M. Perdomo). C: ciprés con follaje rojo y completamente seco, rodeado de individuos en buen estado sanitario. (Parque Nacional Laguna del Laja - VIII Región, Foto: A. Sartori). 
Los áfidos son vectores de numerosas enfermedades de plantas; pueden dañar al huésped en forma directa, por remoción de savia y el desarrollo de heridas, o indirectamente transmitiendo otros patógenos. Unas 200 especies de áfidos del género Cinara Curtis (Lachninae) colonizan coníferas, principalmente en las familias Pinaceae y Cupressaceae. Delfino y Binazzi (2002) resumen las asociaciones entre áfidos y coníferas (nativas o exóticas) en Argentina, indicando a Cinara Curtis y Eulachnus del Guercio (Lachninae) como los géneros de mayor importancia.

Cinara (Cupressobium) tujafilina (del Guercio) es una especie cosmopolita, frecuente en zonas áridas y cálidas, reportada en Thuja, Callitris, Chamaecyparis, Libocedrus y Widdringtonia. Se considera estrictamente anholocíclica, aunque existe un reporte de hembra ovípara (Remaudière y Binazzi, 2003). C. tujafilina coloniza rametos lignificados en las plantas huéspedes, produce abundante melaza y establece asociaciones con hormigas. El desarrollo de fumagina sobre la melaza, conduce a marchitamiento y alteración del crecimiento del follaje. En Argentina, la especie fue reportada por primera vez en 1926 como Dilachnus juniperi (de Geer) sobre Thuja occidentalis (Blanchard, 1926) y en 1990 se registró colonizando Thuja orientalis y A. chilensis en el Bolsón (Delfino y Binazzi, 2002). Sin embargo, debido a la falta de estudios temporales, se desconoce la fecha de ingreso de $C$. tujafilina en bosques de $A$. chilensis; y la relación entre la presencia del áfido y el mal del ciprés no ha sido previamente evaluada.

Cinara cupressi, nativa del oeste Paleártico, se encuentra en Europa, América del Norte y África, viviendo sobre Juniperus, Cupressus, Thuja, Chamaecyparis, Widdringtonia y otras coníferas. Su ciclo de vida es holocíclico, pero en áreas secas y cálidas se comporta como anholocíclica (Delfino y Binazzi, 2005). Produce abundante cantidad de melaza, siendo la asociación con hormigas menos frecuente que para C. tujafilina. De acuerdo con Watson et al. (1999) los áfidos comúnmente identificados como C. cupressi constituirían un complejo de especies, con C. cupressi sensu lato y una nueva especie denominada Cinara (Cupressobium) cupressivora Watson y Voetglin sp. n.. Sin embargo, Remaudière y Binazzi (2003) rechazan la creación de esta nueva especie debido a que los criterios aplicados no serían satisfactorios. Un $25 \%$ de los especimenes no puede ser identificado aplicando la función de discriminación propuesta por Watson et al. (1999). Hasta la fecha, la existencia de la especie C. cupressivora es controvertida. La afectación de importantes aéreas de cipreses y juniperus se asocia a estallidos (outbreaks) de C. cupressi en varios países (Ciesla, 1991; Watson et al., 1999). En África, la especie produce secado del follaje que progresa de abajo hacia arriba y de dentro hacia fuera en la copa. En Chile, C. cupressi se reportó por primera vez en 2003 (Silva et al., 2005) en cipreses exóticos, pero un año después afectaba diversas especies de árboles (Cupressus, Chamaecyparis, Juniperus, Thuja y el híbrido Cupressocyparis), incluyendo la conífera nativa A. chilensis. La 
especie muestra importante capacidad de dispersión, adaptabilidad a climas y huéspedes diversos. En A. chilensis produce enrojecimiento del follaje y mortalidad de rametos y ramas, las cuales pueden ennegrecerse a consecuencia del desarrollo de fumagina.

El primer reporte de C. cupressi en Argentina, corresponde a la detección de la especie en cipreses exóticos de uso ornamental en la provincia de Córdoba (2001), siendo posteriormente detectada en la provincia de Santa Cruz (2003) (Delfino y Binazzi, 2005). Para la región de los bosques argentinos de $A$. chilensis, no existían reportes previos de la presencia de C. cupressi. Sin embargo, en el marco de la presente tesis, la especie fue detectada colonizando Cupressus sp., y A. chilensis en un relevamiento realizado en la ciudad de El Bolsón y bosques aledaños durante el período primavera-verano 2006-2007 (Figura V-2).

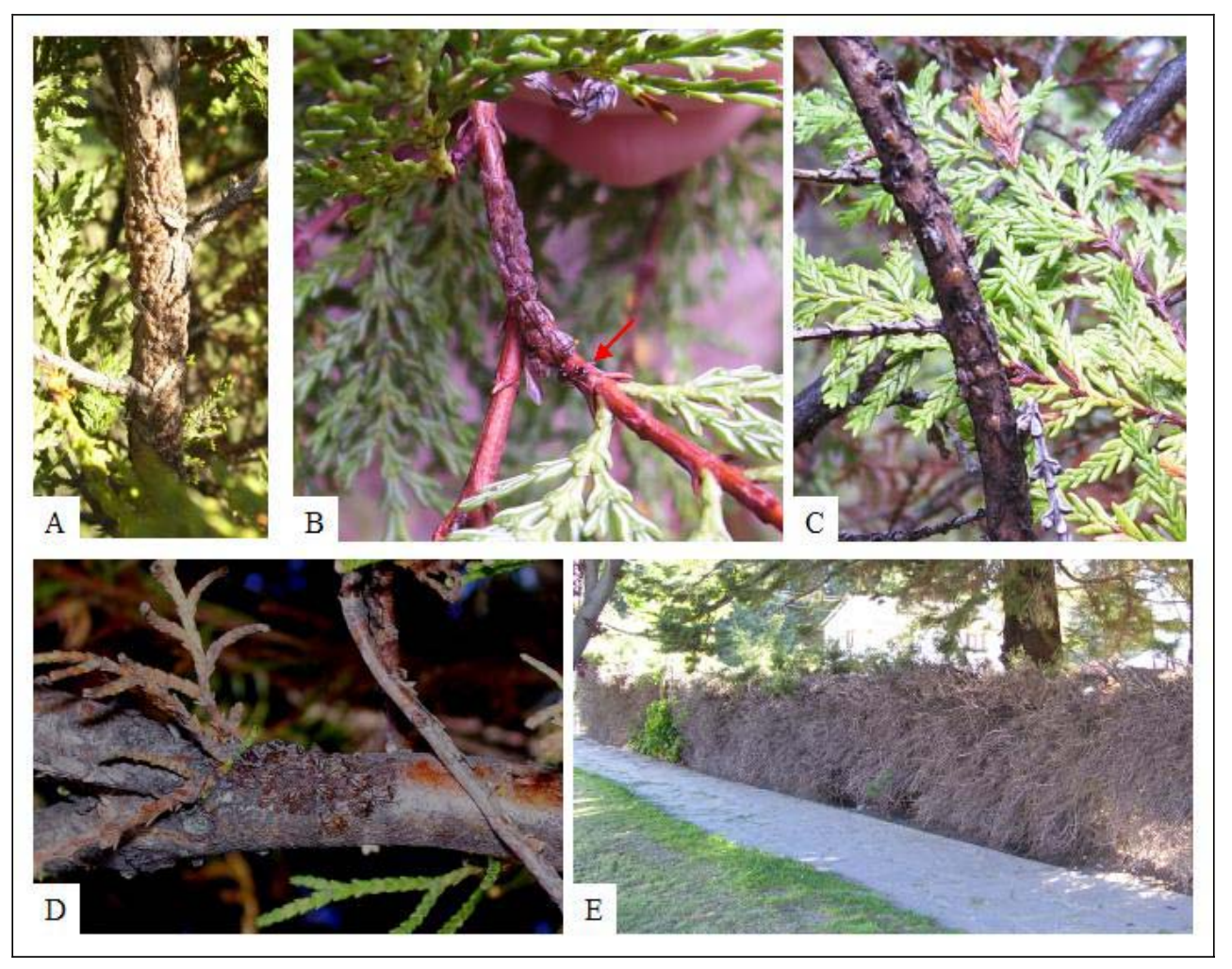

Figura V-2: Colonias de C. cupressi detectadas en El Bolsón (Argentina). A-C: colonias en ramas, y ramillas sobre A. chilensis, la flecha en $\mathrm{B}$ señala una hormiga asociada a la colonia, en $\mathrm{C}$ se observa fumagina sobre la rama (coloración negra). D: colonia de C. cupressi en Cupressus sp. E: cerco completamente seco afectado por C. cupressi.

En la actualidad es frecuente observar árboles que mueren rápidamente, presentan intenso cambio de coloración del follaje, fumagina en fuste o ramas y presencia de áfidos (Figura V-3). El follaje de los árboles afectados presenta coloración roja o amarronada que puede distribuirse en forma homogénea en toda la copa (Figura V-3 C) o de manera heterogénea (Figura V-3 A,B,G). La fumagina es abundante y puede ser fácilmente detectada en fuste y ramas (Figura V-3 D,E,F). 

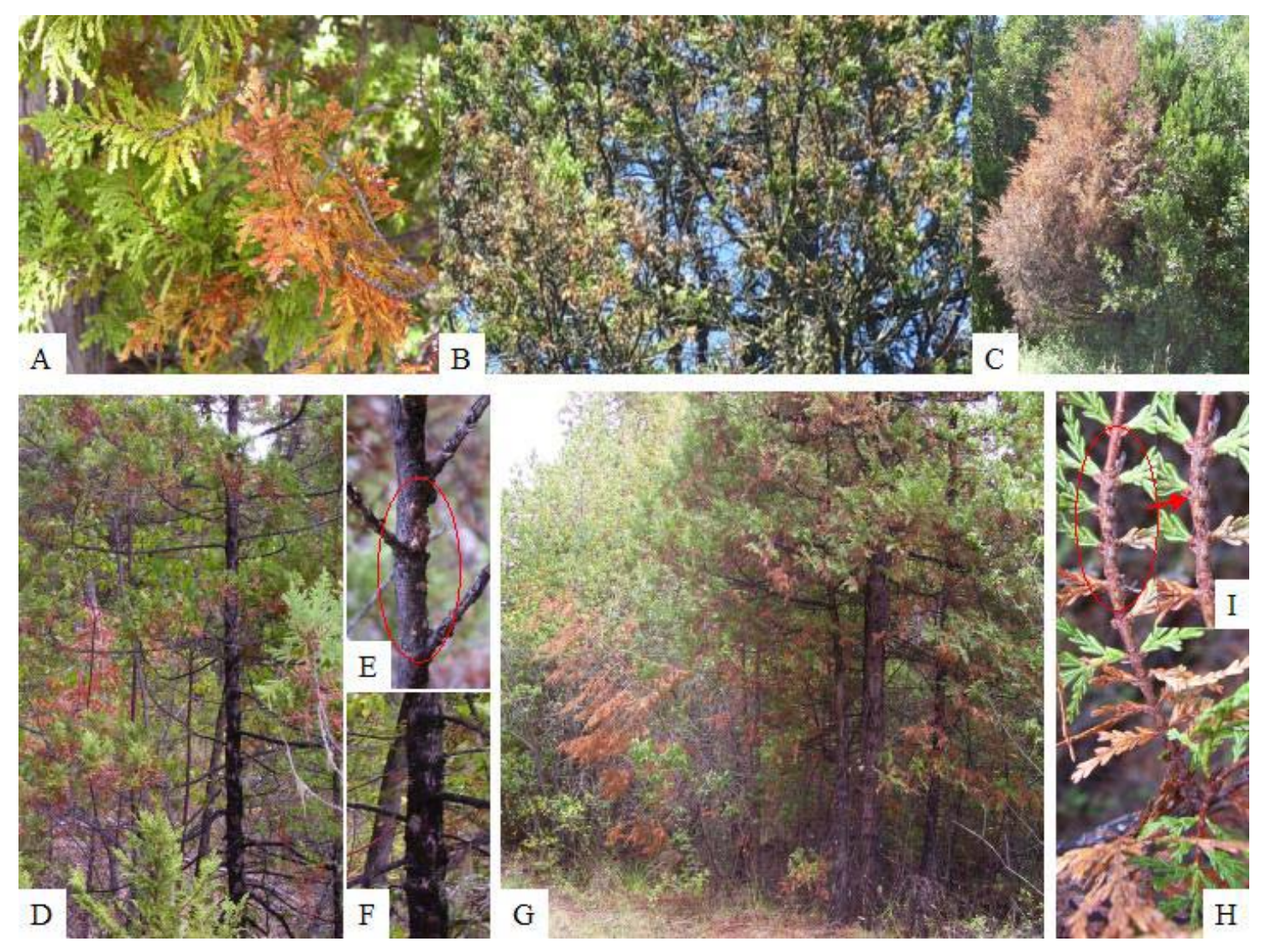

Figura V-3: Síntomas en follaje producidos por áfidos del género Cinara observados en bosques de $A$. chilensis en región de El Bolsón (Argentina). A-C: afectación parcial o completa de la copa, en árboles de diverso porte. D: individuo con afectación parcial de copa, mostrando importante presencia de fumagina en fuste y ramas (coloración negra). E: parte de una rama del árbol de la imagen $\mathrm{D}$, con fumagina y presencia de áfidos (óvalo rojo). F: parte de fuste en árbol de la imagen D con abundante presencia de fumagina. G: grupo de individuos con afectación de copa y fumagina en fuste y ramas; renoval a la izquierda de la imagen presenta la totalidad de la copa roja. H: rama mostrando cambio de coloración de hojas y presencia de pulgones (óvalo rojo), la flecha roja señala la ampliación de la colonia de pulgones en la imagen I.

Como se mencionó anteriormente, el último relevamiento en la región se realizó en el año 1990. La fecha precisa de ingreso de C. cupressi, aunque no precisamente definida, sería posterior a los reportes iniciales del mal del ciprés no teniendo por tanto relación directa con dicha mortalidad.

Entre las especies del género Cinara Curtis, sólo C. cupressi y C. tujafilina, colonizan A. chilensis. Las demás especies del género reportadas en la región del Suroeste de Argentina, corresponden a especies introducidas y colonizan especies exóticas de árboles que se emplean como ornamentales o en plantaciones: Cinara (Cupressobium) juniperi (de Geer) coloniza 
Juniperus communis L.; Cinara maritimae (Dufour) coloniza Pinus contorta, Cinara piceae (Panzer) coloniza Picea sp. y Cinara pilicornis (Hartig) y Cinara costata (Zetterstedt) colonizan Picea abies (L.) Karst. (Delfino y Binazzi, 2002).

C. tujafilina no es considerada como peste en nuestro país ni en Chile; sin embargo, su relación con el mal del ciprés no ha sido establecida y podría debilitar a los individuos de $A$. chilensis al afectar la tasa de fotosíntesis como efecto secundario de la acumulación de fumagina. Por otra parte, se desconoce el impacto que una especie agresiva como C. cupressi puede tener en bosques de $A$. chilensis afectados por mal del ciprés y cuál es el rol de esta especie en relación a los nuevos síntomas descriptos para A. chilensis en Argentina.

Por tal motivo, el presente capítulo de la tesis se orienta a establecer la asociación entre el mal del ciprés y las especies del género Cinara que colonizan A. chilensis, considerando las siguientes hipótesis:

- Hipótesis 1: La colonización por áfidos del género Cinara (C. cupressi o C. tujafilina) debilita a los individuos de A. chilensis determinando una mayor susceptibilidad al mal del ciprés.

PREDICCIÓN 1: Los árboles sintomáticos para mal del ciprés presentan mayor incidencia de áfidos del género Cinara.

○ Hipótesis 2: El ingreso de la especie agresiva C. cupressi a la región de estudio determina un desplazamiento de la especie C. tujafilina desde uno de sus huéspedes naturales.

PREDICCIÓN 2: C. cupressi es la especie detectada con mayor frecuencia en $A$. chilensis y coloniza con mayor frecuencia los individuos debilitados para mal del ciprés.

La identificación tradicional de especies en el género Cinara requiere observaciones microscópicas y análisis morfométricos de los especimenes en estudio. La separación entre C. cupressi y C. tujafilina es compleja debido a que comparten muchos caracteres morfológicos y microscópicos. Ambas especies presentan esclerificaciones espinopleurales en el tórax y en el primer y segundo tergites abdominal; presentan tibias pálidas excepto en el extremo distal que es oscuro, siendo para C. cupressi también oscuro el extremo basal. La pigmentación del fémur es útil en la identificación de los individuos ápteros, ya que C. tujafilina presenta siempre fémur pálido mientras que en $C$. cupressi la mitad distal es más oscura. Sin embargo, este caracter es altamente variable en $C$. cupressi, siendo necesaria la evaluación de caracteres suplementarios 
tales como la presencia de pelos en el segmento III del rostro y en el segmento VIb de la antena, para diferenciar C. tujafilina de C. cupressi con fémur pálido.

Estudios filogenéticos y taxonómicos en insectos aplican diversos marcadores moleculares para el diagnóstico de grupos entomológicos de interés. El DNA mitocrondrial (mtDNA) es útil como marcador molecular debido a la organización simple y uniforme del genoma, la ausencia de recombinación, mayor tasa de mutación que el DNA nuclear y una relación elevada mitocondria / núcleo por célula (Loxdale y Lushai, 1998). Primers universales para mtDNA diseñados sobre secuencias conservadas que rodean regiones informativas para estudios filogenéticos y poblacionales, pueden ser aplicados en el desarrollo de métodos de diferenciación (Simon et al., 1994; Folmer et al., 1994; Lunt et al., 1996). En estudios taxonómicos y filogenéticos se emplean genes nucleares o mitocondriales como citocromo oxidasa I y II (CO-I y CO-II), factor de elongación nuclear $1 \alpha$ y tRNA de leucina (Loxdale y Lushai, 1998; Normark, 2000).

Métodos moleculares basados en el gen mitocondrial que codifica para CO-I se aplican en identificación de insectos de diversos órdenes (Otranto et al., 2003; Asokan et al., 2007; Lozier et al., 2008) y en estadios inmaduros (Harvey et al., 2003; Chen et al., 2004; Thyssen et al., 2005). Uno de los métodos empleados es el polimorfismo de longitud de los fragmentos de restricción (RFLP) desde amplificaciones sobre mtDNA para distinguir, por ejemplo, linajes de subespecies de abejas (Hall y Smith, 1991), especies de noctuidos (Lepidoptera) morfológicamente indistinguibles en estadio larval (Roehrdanz, 1997), taxones y biotipos de áfidos (Valenzuela et al., 2007; Sunnucks et al., 1997; Sufran, 2003) y especies en el género Phortica (Cantacessi et al., 2008; Otranto et al., 2008).

Normak (2000) estudió el género Cinara (Curtis) aplicando sistemática molecular para reconstruir la evolución de la familia de áfidos Lachnidae, con base en secuencias del factor de elongación nuclear $1 \alpha$ y CO-II. Favret y Voetglin (2004) realizaron un análisis filogenético molecular de especies del género Cinara que colonizan diversas especies de pino en el Suroeste de Estados Unidos, empleando secuencias de DNA del gen CO-I y factor de elongación nuclear $1 \alpha$. Sin embargo, hasta el momento no se cuenta con una herramienta de diagnóstico rápida que permita la identificación de $C$. cupressi y $C$. tujafilina. Por tal motivo, y para poder abordar la evaluación de la segunda hipótesis planteada se propone en el presente trabajo el desarrollo de un método molecular de PCR-RFLP, basado en el gen CO-I, para identificar C. cupressi y C. tujafilina en colonias de áfidos presentes en A. chilensis. 


\section{2.- MATERIALES Y MÉTODOS}

2.1.- ASOCIACIÓN ENTRE EL MAL DEL CIPRÉS Y LA PRESENCIA DE ÁFIDOS DEL GÉNERo CINARA

\subsection{1- Recolección de muestras e identificación morfológica}

Para evaluar la asociación existente entre la presencia de áfidos y el mal del ciprés, se emplearon 20 de los 50 pares de plantas seleccionados por su fenotipo para mal del ciprés (Capitulo II). El muestreo se realizó en abril de 2007, según una metodología al azar eligiéndose cuatro pares en cada una de los sitios de estudio (L5y6, R11, R18, R81, L9y15); y colectando de cada árbol dos fragmentos de ramas de aproximadamente $30 \mathrm{~cm}$. En caso de no encontrarse áfidos se colectó una rama adicional. Las colonias de áfidos detectadas se recolectaron en bolsas individuales.

En laboratorio se procedió, bajo lupa, a la separación de adultos y ninfas presentes en cada colonia, conservándose en etanol $96 \%$ en recipientes separados. El número total de adultos ápteros para cada árbol se determinó sumando los correspondientes a cada una de las colonias detectadas en el mismo. Debido a que los adultos alados se encontraron en numerosas oportunidades alejados de las colonias, y considerando que pueden migrar entre árboles, no se los utilizó en el conteo total. Adultos (ápteros y alados) tomados al azar del total de colonias detectadas se conservaron en etanol $65 \%$ para la identificación microscópica de las especies. Los preparados se realizaron siguiendo los métodos de montaje para insectos pequeños en bálsamo de Canadá propuesto por Remaudière (1992). Los criterios establecidos por Watson et al. (1999), Remaudière y Binazzi (2003), Delfino y Binazzi (2005) se aplicaron en la identificación morfológica de las especies. La separación de individuos bajo lupa y la identificación morfológica fue realizada por el Dr. Miguel Ángel Delfino (Cátedra de Entomología. Facultad de Ciencias Exactas, Físicas y Naturales. Universidad Nacional de Córdoba).

\section{2.- DESARROLlO DE UN MÉTODO MOLECULAR DE IDENTIFICACIÓN DE LAS ESPECIES C. CUPRESSI Y C. TUJAFILINA}

\subsection{1- Recolección de muestras e identificación morfológica}

Colonias aisladas de áfidos fueron recolectadas desde plantas ornamentales (Cupressus sp., Thuja sp.) en la ciudad de El Bolsón y desde bosques de A. chilensis (Figura V-4). Los áfidos para determinaciones microscópicas se conservaron en etanol $65 \%$ y fueron identificados por el Dr. Miguel Angel Delfino de acuerdo con lo anteriormente indicado. 

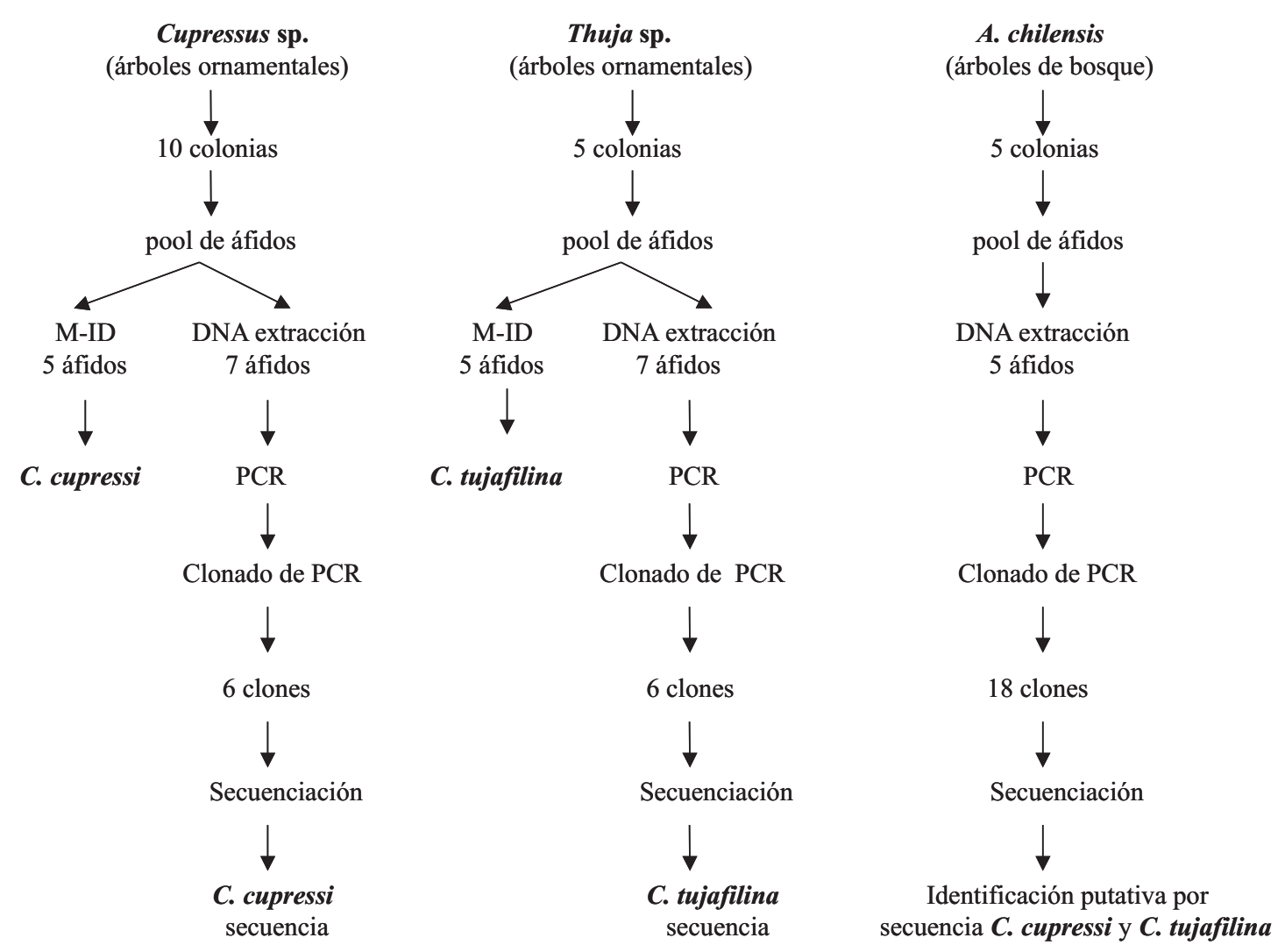

Figura V-4: Esquema de muestreo y procesamiento de las especies del género Cinara en estudio, según huésped, incluyendo identificación morfológica (M-ID), identificación molecular, extracción de DNA, PCR y secuenciación.

\subsection{2- Amplificación por PCR y secuenciación}

El desarrollo de un método molecular de identificación requiere de especímenes de cada una de las especies en estudio. La preparación de adultos para la identificación morfológica en microscopio no permite su uso posterior en métodos moleculares. El método alternativo propuesto por Favret y Voetglin (2004), que involucra la extracción de embriones desde individuos adultos en forma previa a la identificación morfológica y el empleo de los embriones en los procedimientos moleculares, no pudo ser aplicado en vista de las grandes distancias entre el área de muestreo (El Bolsón), y los laboratorios entomológico (Córdoba) y molecular (La Plata).

Observaciones previas realizadas en el área de estudio, mostraron que árboles ornamentales de Cupressus sp. eran colonizados por C. cupressi, en tanto que los de Thuja sp. eran colonizados por C. tujafilina. En contraste, los relevamientos realizados en bosques de A. chilensis mostraron que ambas especies de áfidos, C. cupressi y C. tujafilina, colonizan ciprés de la cordillera y que la pigmentación de las patas de los pulgones es altamente variable, no siendo útil como criterio de separación a campo. Por esta razón colonias representativas de cada 
especie de áfido fueron colectadas desde Cupressus sp. y Thuja sp. para determinar la secuencia nucleotídica de $C$. cupressi y $C$. tujafilina, respectivamente. Como los áfidos se reproducen partenogenéticamente y forman con frecuencia colonias de individuos genéticamente iguales (Loxdale y Lushai, 2003), varias colonias (al menos 5) de cada especie fueron colectadas desde diferentes ramillas o ramas a fin de detectar variaciones genéticas intraespecíficas. Los áfidos empleados para la extracción de DNA fueron conservados en etanol 96\%. El DNA se extrajo a partir de 7 individuos de C. cupressi o C. tujafilina provenientes de colonias previamente identificadas mediante criterios morfológicos, y a partir de 5 áfidos no identificados colectados desde A. chilensis (Figura V-4). Para la extracción de DNA se siguió el método reportado por Hammond et al. (1996).

Un fragmento del gen CO-I (aproximadamente $690 \mathrm{pb}$, excluyendo la secuencia de los primers) se amplificó con los primers universales COIS, 5'-GGAGGATTTGGAAATTGATTAGTTCC-3' (C1-J-1718, Simon et al., 1994); COIA, 5'-GCTAATCATCTAAAAATTTTAATTCCTGTTGG-3' (C1-J-2441, modificado desde Simon et al., 1994). Las reacciones de PCR se realizaron en $25 \mu 1$ en buffer 1X, conteniendo concentraciones finales de $200 \mu \mathrm{M}$ dNTPs, $0.5 \mu \mathrm{M}$ primers directo $\mathrm{y}$ reverso, $2 \mathrm{mM} \mathrm{MgCl}_{2}$ y $0.02 \mathrm{U} / \mu \mathrm{l}$ de Taq DNA polimerasa (Invitrogen Life Technologies, USA). Todas las amplificaciones se realizaron en el termociclador GeneAmp PCR System 9700 (Applied Biosystems, USA).

El ciclado aplicado consistió de, un ciclo de desnaturalización inicial de $94^{\circ} \mathrm{C}$ por $6 \mathrm{~min}$, seguido de 35 ciclos de desnaturalización inicial a $94^{\circ} \mathrm{C}$ por $1 \mathrm{~min}$, annealing de primers a $50^{\circ}$ $\mathrm{C}$ por $90 \mathrm{~s}$ y extensión a $72^{\circ} \mathrm{C}$ por $90 \mathrm{~s}$, y un ciclo de extensión final a $72^{\circ} \mathrm{C}$ durante $5 \mathrm{~min}$ Todas las amplificaciones se separaron por electroforesis en gel de agarosa 2\% (TAE 1X). Los amplicones del tamaño esperado fueron liberados del gel, purificados con GENECLEAN Kit (QbioGene, MP Biomedicals, USA) y clonados en el vector pCR 2.1-TOPO (Invitrogen Life Technologies, USA).

DNA plasmídico, de al menos 6 clones positivos, preparado de acuerdo con el protocolo de lisis alcalina / PEG (Applied Biosystems, USA, P/N 4305080) se secuenció en ambos sentidos (MACROGEN, USA). Las secuencias de haplotipos únicos se depositaron en GenBank (Tabla V1) y fueron comparadas con las disponibles en la base de datos aplicando la herramienta de búsqueda BLASTN (Altschul et al., 1997). DnaSP (Rozas et al., 2003) se empleó en el análisis de sitios polimórficos y monomórficos.

Huésped Identificación No. de Haplotipo Número acceso Identificación Molecular 
Morfológica clones

A. Árboles Ornamentales

$\begin{array}{ccc}\text { Thuja sp. } & \text { C. tujafilina } & 5 \\ \text { Thuja sp. } & \text { C. tujafilina } & 1 \\ \text { Cupressus sp. } & \text { C. cupressi } & 6\end{array}$

B. Árboles de Bosque

$\begin{array}{ccccc}\text { A. chilensis } & \text { No identificado } & 2 & 1 & \text { EU881685 } \\ \text { " " } & " & 1 & 3 & \text { EU881686 } \\ " \text { " } & " & 10 & 4 & \text { EU881688 } \\ " \text { " } & " & 1 & 5 & \text { EU881689 } \\ " \text { " } & " & 1 & 6 & \text { EU881690 } \\ " \text { " } & " ~ & 1 & 7 & \text { EU881692 } \\ " \text { " } & " & 2 & 8 & \text { EU881691 }\end{array}$

(Genbank)

$\begin{array}{cc}{\text { EU } 881684^{a}}^{a} & \text { C. tujafilina } \\ \text { EU881683 } & \text { C. tujafilina } \\ {\text { EU } 881687^{b}}^{\text {C. cupressi }}\end{array}$

Tabla V-1: Huésped, identificación morfológica y molecular de las especies de Cinara, haplotipos y números de acceso en Genbank de las secuencias clonadas. ${ }^{a} \mathrm{o}^{b}$ indican secuencias idénticas (mismo haplotipo) reportadas bajo diferente número de acceso por provenir de áfidos con y sin identificación morfológica.

\subsection{3- Método de identificación molecular (PCR-RFLP)}

Las secuencias de C. cupressi y C. tujafilina se alinearon usando ClustalX (Thompson et al., 1997), se editaron con Bioedit (Hall, 1999) y se analizaron con Clone manager (Scientific \& Educational Software, 1995) a fin de detectar y seleccionar enzimas de restricción útiles en la diferenciación de ambas especies.

Para evaluar el funcionamiento del método molecular PCR-RFLP, preparaciones de DNA plasmídico provenientes de clones positivos, cuantificadas con Qubit Fluorometer y Quant-iT dsDNA BR Assay Kit (Molecular Probes, Invitrogen Detection Technologies, USA) y diluidas a $100 \mathrm{ng} / \mu \mathrm{l}$ se amplificaron con los primers COIS y COIA usando las mismas condiciones de ciclado que en la PCR original. Siete microlitros de cada producto de PCR se digirieron con $1.0 \mathrm{U}$ de la endonucleasa de restricción Hae III (New England Biolabs, USA), en un volumen total de $10 \mu \mathrm{l}$ del buffer apropiado, a $37^{\circ} \mathrm{C}$ durante 1 hora. Las digestiones se separaron por electroforesis en gel de agarosa $2 \%$ (TAE $1 \mathrm{X}$ ) y los productos de digestión se visualizaron por tinción con bromuro de etidio.

El funcionamiento del método PCR-RFLP para la diferenciación de material proveniente de campo se evaluó amplificando DNA extraído a partir de 7 individuos de C. cupressi o C. tujafilina (provenientes de colonias morfológicamente identificadas) con los primers COIS y 
COIA, y realizando la digestión de los amplicones obtenidos con Hae III, usando las mismas condiciones señaladas anteriormente. Las digestiones fueron separadas por electroforesis en gel de agarosa $2 \%$ (TAE $1 \mathrm{X})$ y visualizadas con bromuro de etidio.

\section{3.- Distribución de LAS ESPECIES C. CUPRESSI Y C. TUJAFILINA SEgúN ESTAdo SANITARIO DEL HUÉSPED}

Del total de pares muestreados se seleccionaron aquellos pares con al menos una colonia con 3 adultos ápteros (o 6 ninfas) a fin de determinar, mediante aplicación del método de identificación molecular desarrollado, la distribución de las especies detectadas en relación al estado sanitario del huésped. En todos los casos, para cada árbol, los adultos ápteros fueron seleccionados al azar desde la colonia con mayor número de adultos. La extracción de DNA, la amplificación del fragmento CO-I y la digestión con Hae III se realizaron de acuerdo a lo anteriormente indicado.

\section{3.- RESULTADOS}

\section{1.- ASOCIACIÓN ENTRe El MAL DEL CIPRÉS Y LA PRESENCIA DE ÁFIDOS DEL GÉNERo CINARA}

La identificación morfológica de las especies confirmó los resultados de observaciones preliminares realizadas en la zona de El Bolsón (Noviembre 2006). Tanto C. cupressi como C. tujafilina colonizan A. chilensis, determinándose una relación de 80/20 para esa época del año y la metodología de muestreo aplicada. Para El Bolsón en conjunto, el número total de pulgones asociado a árboles asintomáticos y sintomáticos fue de 140 y 171, con un valor promedio de 28 y 34, y un desvío estándar de 21 y 20, respectivamente. Un resultado similar se obtuvo para cada uno de los sitios de estudio (Gráfico V-1), presentando el R11 y el R18 ligeros desvíos hacia los árboles sintomáticos.

A nivel de sitio, los L5y6 y L9y 15 presentan los mayores números de pulgones, siendo seguidos por R18 y R11. En el R81 el registro de pulgones fue prácticamente nulo para ambos estados sanitarios, sin embargo las plantas mostraron en todos los casos, signos de la presencia de áfidos (fumagina, restos de adultos parasitados). El número total de pulgones por árbol fue variable, existiendo además variación en el número de adultos en cada colonia detectada. 


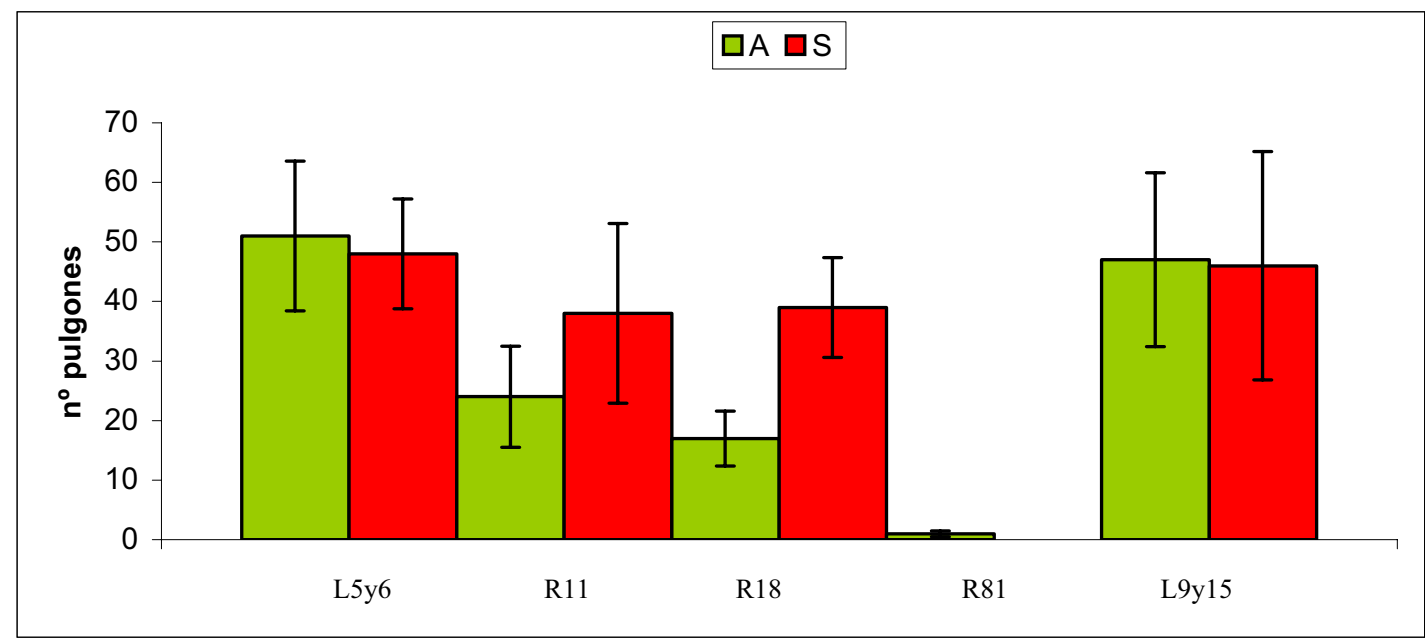

Gráfico V-1: Relación entre áfidos y estado sanitario según número total de pulgones adultos detectados. Las barras verticales indican el valor del desvío estándar. Los resultados se presentan para cada uno de los sitios de muestreo (L5y6, R11, R18, R81 y L9y15).

\section{2.- DESARRollo DE UN MÉTOdO MOLECULAR (PCR-RFLP) DE IDENTIFICACIÓN DE LAS ESPECIES C. CUPRESSI Y C. TUJAFILINA}

La identificación de las especies confirmó los resultados de observaciones preliminares efectuadas en el sitio (Noviembre 2006). De acuerdo con el análisis en microscopio los áfidos colectados desde Cupressus sp. correspondieron a C. cupressi, en tanto que los de Thuja sp. correspondieron a C. tujafilina.

DNA extraído de individuos provenientes de colonias previamente identificadas (C. cupressi desde Cupressus sp. o C. tujafilina desde Thuja sp.) fue amplificado, clonado y secuenciado. Las secuencias de 6 clones de C. cupressi y C. tujafilina se emplearon para búsqueda en Genbank vía BLASTN. Las secuencias provenientes de C. tujafilina presentaron un 99\% de identidad nucleotídica con secuencias del gen CO-I correspondientes a C. tujafilina colectada en Europa (Durak et al., 2008). Las secuencias de C. cupressi mostraron entre $91-92 \%$ de identidad nucleotídica con C. tujafilina. Las secuencias de C. cupressi generadas en el presente trabajo, son las únicas secuencias disponibles en bases de datos, y la comparación entre ambas especies muestra que las diferencias existentes permiten el desarrollo de un método molecular de identificación. Cada haplotipo único detectado se presenta en la Figura V-5; el marco de lectura se indica con tripletes alternados de letras minúsculas y mayúsculas en la primera secuencia del alineamiento. 

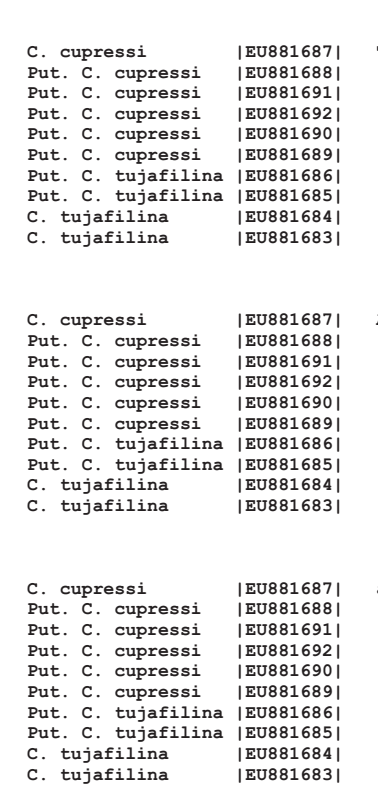
$\begin{array}{ll}\text { C. cupressi } & \mid \text { EU881687| } \\ \text { Put. C. cupressi } & |\mathrm{E} 0881688|\end{array}$ Put. c. cupressi Eves81681 Put. c. cupressi |EU881692| $\begin{array}{ll}\text { Put. C. cupressi } & \text { |EU881690| } \\ \text { Put. c. cupressi } & |\mathrm{EU} 881689|\end{array}$ \begin{tabular}{l|l|} 
Put. C. Cupressi & $\mid$ EU881689| \\
Put. c. tujafilina & $|\mathrm{EU} 881686|$
\end{tabular} Put. C. tujafilina $\mid$ EU881686|
Put. c. tujafilina $\mid$ EU881685 \begin{tabular}{l|l|l|l} 
Put. C. tujafilina & EU8886885 \\
c. tujafilina & |EU81684| \\
\hline
\end{tabular} c. tujafilina |EU881683|

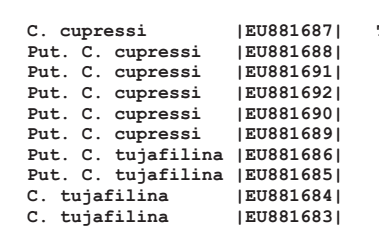

$\begin{array}{llllllllll}10 & 20 & 30 & 40 & 50 & 60 & 70 & 80 & 90 & 100\end{array}$

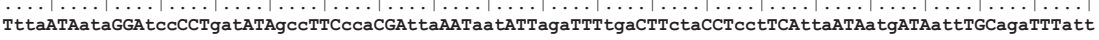

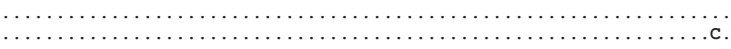

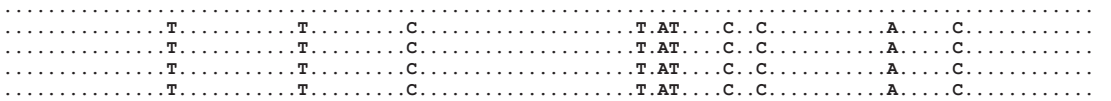

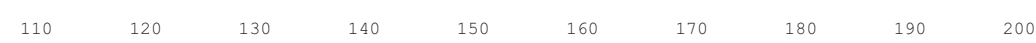

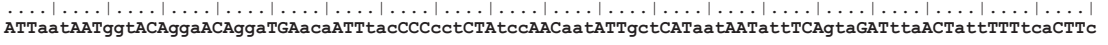

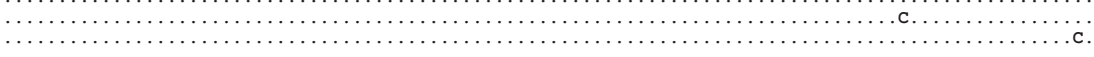

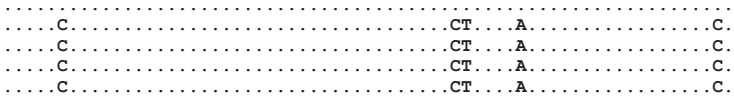

$\begin{array}{lllllllll}210 & 220 & 230 & 240 & 250 & 260 & 270 & 280 & 290\end{array}$

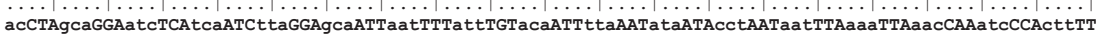

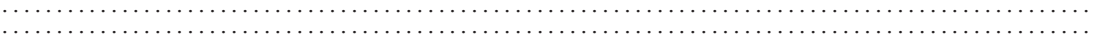
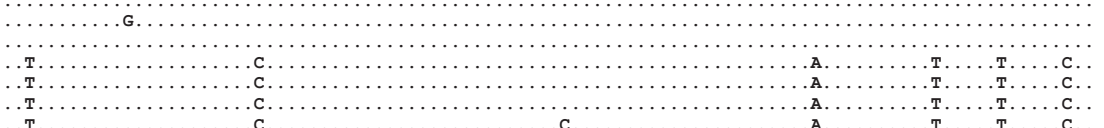

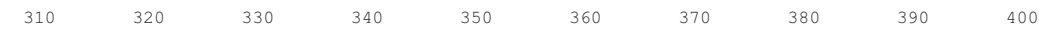

CccaTGAtcaATTattATTacaGCTacaCrTttaATTCttTCACttCCAgtaTTAgccGGAgctATTacaATAttaTTAacaGATcgaAATt taAATace
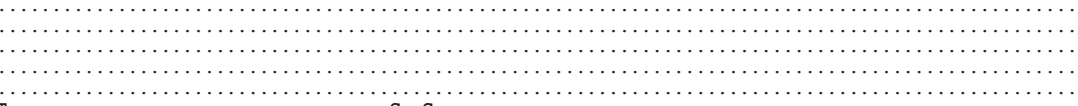

$\begin{array}{llllllllll}410 & 420 & 430 & 440 & 450 & 460 & 470 & 480 & 490 & 500\end{array}$

TCAtttTTTgacCCAtCaGGAggaGGAgatCCAattTTAtatCAAcatTTAtttTGAtttTTTggtCACCCEGAggtgTATattTTAattCTAccaGGA

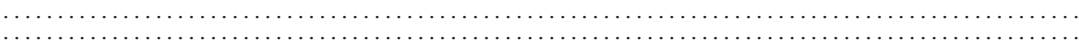

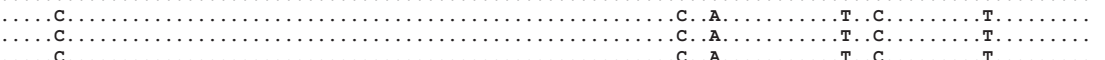

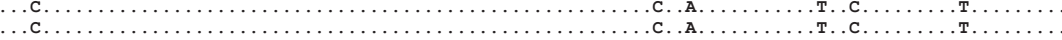

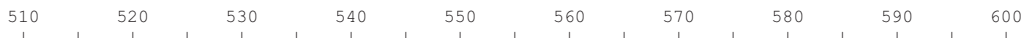

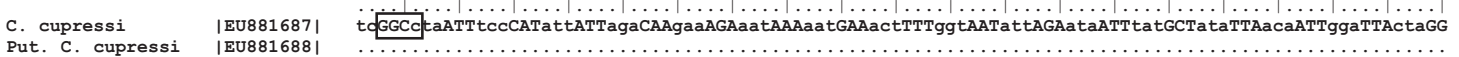
Put. c. cupressi put. c. cupressi Put. c. cupressi |EU881692|
Put. C. cupressi |EU881690| Put. C. cupressi |EU81698 Put. c. tujafilina |EU881686| Put. C. tujafilina |EU881685| $\begin{array}{ll}\text { c. tujafilina } & \mid \text { EU881684| } \\ \text { c. tujafilina } & \mid \text { EU881683| }\end{array}$

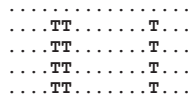

c...c.c.

$\begin{array}{lllllllll}610 & 620 & 630 & 640 & 650 & 660 & 670 & 680 & 690\end{array}$

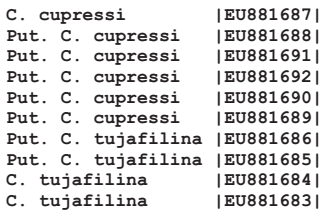

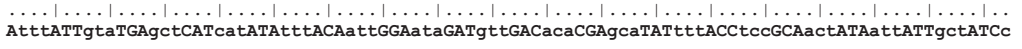

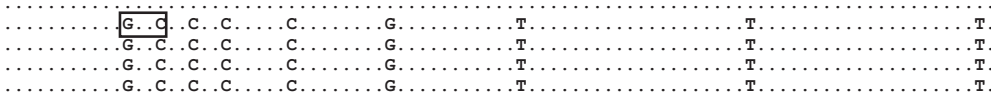

Figura V-5: Alineamiento de haplotipos de secuencia única de CO-I para especies de Cinara depositadas en GenBank. Recuadros negros señalan los sitios de restricción para Hae III (GGCC). Tripletes alternados de letras mayúsculas y minúsculas en la secuencia superior indican el marco de lectura. Los puntos en el alineamiento corresponden a nucleótidos idénticos a la secuencia superior. 
DNA extraído desde áfidos no identificados morfológicamente, provenientes de $A$. chilensis, fueron también amplificados, clonados y secuenciados. Las secuencias de 18 clones se separaron en dos grupos de 99\% (3 clones) y 91\% (15 clones) de identidad nucleotídica respecto de las secuencias de C. tujafilina reportada por Durak et al., (2008). El grupo de menor identidad presenta la misma secuencia nucleotídica que la obtenida para los áfidos colectados desde Cupressus sp. La secuencia de cada haplotipo único detectado pudo ser alineada y fácilmente clasificada como putativa C. tujafilina o C. cupressi. Cuarenta y cuatro sitios polimórficos fueron detectados entre ambas especies, encontrándose mínima diversidad nucleotídica intraespecífica para C. tujafilina, en tanto que todas las secuencias de C. cupressi fueron idénticas (Figura V-5 y Tabla V-1).

El haplotipo más frecuente de C. cupressi y C. tujafilina se encuentra presente también en las secuencias derivadas de los áfidos colectados desde A. chilensis (putativa C. cupressi y putativa C. tujafilina); sin embargo, entre estos clones se detecta mayor diversidad nucleotídica (Figura V-5 y Tabla V-1). La secuenciación de clones adicionales es necesaria para definir con precisión la frecuencia y distribución de los sitios polimórficos en cada especie y de acuerdo con los huéspedes, ya que los diferencias obtenidas podrían resultar del mayor número de clones secuenciados en A. chilensis.

El alineamiento de las secuencias de C. cupressi y C. tujafilina permitió determinar la existencia de diferencias en relación al sitio para la enzima de restricción Hae III. Se seleccionó la enzima Hae III, entre otras posibilidades, porque produce patrones de bandas para cada especie de áfido que pueden ser fácilmente diferenciados en gel de agarosa $2 \%$. La ubicación del sitio de restricción en cada especie se indica en el Figura V-5. Perfiles de dos bandas se esperan para ambas especies, $530 \mathrm{pb}$ y $220 \mathrm{pb}$ para C. cupressi y $640 \mathrm{pb}$ y $110 \mathrm{pb}$ para C. tujafilina.

Preparaciones plasmídicas de clones provenientes de ambas especies, se cuantificaron, amplificaron y digirieron con Hae III, presentándose en la Figura V-6 los perfiles de bandas de 2 clones por especie, C. tujafilina (Líneas 1 y 2) y C. cupressi (Líneas 3 y 4). Los fragmentos en cada perfil tienen el tamaño esperado y ambas especies pueden ser fácilmente discriminadas de acuerdo con lo predicho. DNA extraído desde áfidos no identificados, colectados desde A. chilensis, fue también cuantificado, amplificado y clonado. Se digirieron 5 clones para evaluar la performance del método PCR-RFLP en desarrollo. Los perfiles resultantes se presentan en la Figura V-6 (Líneas 5, 6, 7, 8 y 9), 3 de ellos muestran el patrón de C. tujafilina (Líneas 5,6 y 9), y 2 el patrón de C. cupressi (Líneas 7 y 8). 


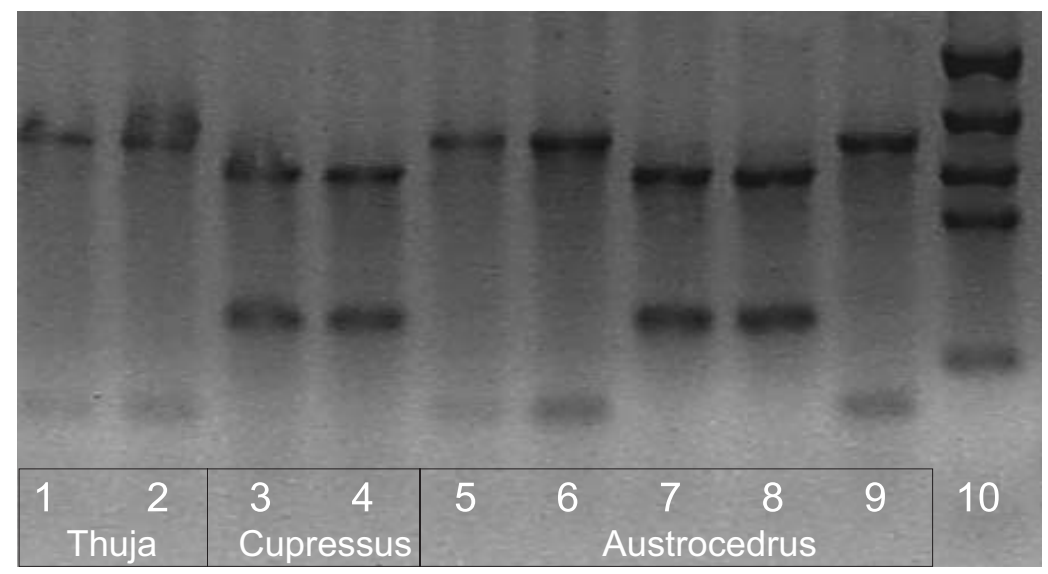

Figura V-6: Perfiles de restricción de clones amplificados con primers COIS y COIA, digeridos con Hae III y separados por electroforesis en gel de agarosa $2 \%$ (TAE 1X). Clones de C. tujafilina recolectados desde Thuja sp. (Líneas 1 y 2); clones de C. cupressi recolectados desde Cupressus sp. (Líneas 3 y 4) y clones desde áfidos provenientes de A. chilensis (Líneas 5, 6, 7, 8 y 9). Marcador de peso molecular (Línea 10): pcDNAII digerido con DdeI/XhoI (1140, 758, 540, 409 y $166 \mathrm{pb})$.

Extracciones de DNA provenientes de áfidos colectados de Thuja sp. y Cupressus sp. se amplificaron por PCR, siendo los fragmentos resultantes digeridos y separados por electroforesis sin previo clonado. Los perfiles obtenidos se corresponden con los esperados para C. tujafilina y C. cupressi (Figura V-7) indicando que el método de PCR-RFLP desarrollado puede ser empleado en forma directa sobre el material recolectado, sin requerir una etapa previa de clonado y selección de clones.

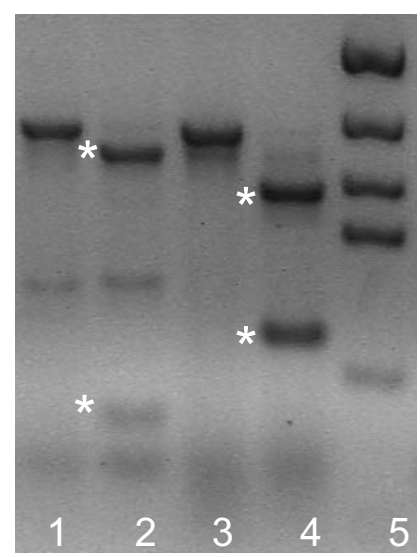

Figura V-7: Amplicones obtenidos por PCR (Líneas 1 y 3) y perfiles de PCR-RFLP (Líneas 2 y 4) separados por electroforesis en gel de agarosa 2\% (TAE 1X). Líneas 1 y 2, C. tujafilina recolectada desde Thuja sp.; Líneas 3 y 4 , C. cupressi recolectada desde Cupressus sp. Marcador de peso molecular (Línea 5): pcDNAII digerido con DdeI/Xhol (1140, 758, 540, 409 y $166 \mathrm{pb})$. Las bandas esperadas para C. cupressi y C. tujafilina se indican con *. 


\section{3.- DisTRIBUCIÓN DE LAS ESPECIES $C$. CUPRESSI Y C. TUJAFILINA SEgÚN ESTADo SANITARIO DEL HUÉSPED}

El método de identificación molecular desarrollado se aplicó en áfidos aislados desde 8 pares de plantas (asintomáticas / sintomáticas); correspondiendo 2 pares a cada uno de los sitios de muestreo que presentaron colonias de áfidos (L5y6, R11, R18 y L9y15). Los perfiles de digestión obtenidos indican que C. cupressi es la especie detectada con mayor frecuencia, independientemente del estado sanitario del huésped (Figura V-8). Para 14 de los 16 casos analizados, el patrón de digestión obtenido corresponde a C. cupressi, en tanto que para 1 caso (6S) se observa el patrón de C. tujafilina. La identificación realizada sobre los áfidos provenientes del individuo $16 \mathrm{~S}$ se correspondería con la presencia de ambas especies en una misma colonia; la banda adicional ubicada por encima de la banda inferior del perfil de C. cupressi, es frecuentemente observada en amplificaciones sobre C. tujafilina (Figura V-7).

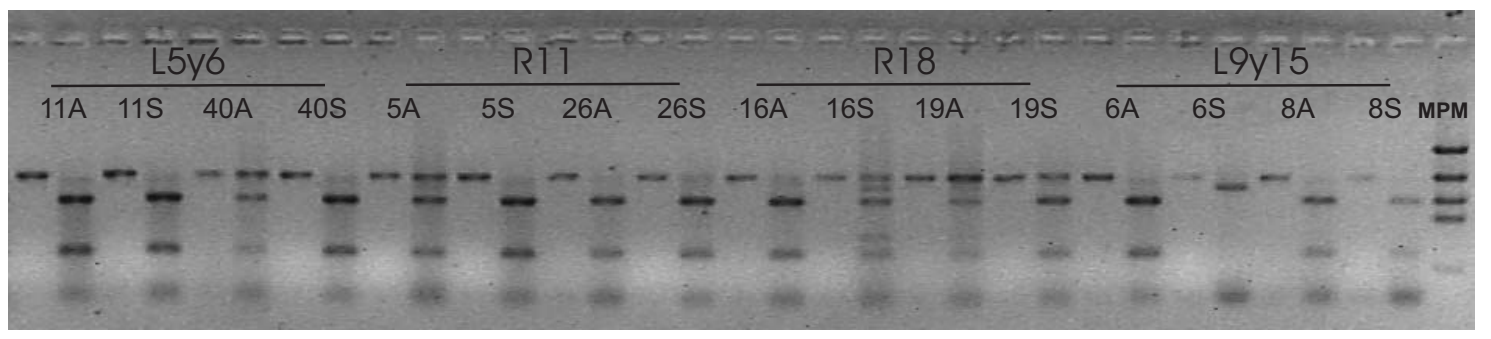

Figura V-8: Aplicación del método de PCR-RFLP con base en el gen CO-I a pulgones obtenidos desde colonias aisladas en pares de plantas con y sin síntomas del mal del ciprés. MPM: marcador de peso molecular, pcDNAII digerido con $\mathrm{DdeI} / \mathrm{XhoI}(1140,758,540,409$ y $166 \mathrm{pb})$.

Es llamativa la importante cantidad del fragmento CO-I no digerido presente para los áfidos aislados de los individuos 40A, 5A, 16S, 19A y 19S; no siendo el resultado de digestión incompleta como puede verse al comparar dichas muestras con las correspondientes a las muestras $11 \mathrm{~A}, 11 \mathrm{~S}, 40 \mathrm{~S}, 5 \mathrm{~S}$ y $6 \mathrm{~A}$, que presentan mayor intensidad en el perfil de bandas y ausencia del fragmento no digerido (Figura V-8). La falta de digestión podría ser debida a la modificación del sitio de restricción correspondiente, sin embargo esto no se corresponde con el bajo nivel de variabilidad intraespecífica detectada por secuenciación. Por tal motivo, y considerando la controversia actual en relación a la existencia de la especie C. cupressivora, los fragmentos no digeridos fueron recuperados del gel, reamplificados y conservados para su secuenciación a fin de determinar la razón de esta ausencia de digestión. Por otra parte, debido a que en el método se emplean primers universales para insectos, la amplificación simultánea del parasitoide que desarrolla en especies de Cinara podría también dar cuenta del fragmento no digerido. 


\section{4.- DISCUSIÓN}

A través de un ensayo de pares se estableció que la sintomatología del mal del ciprés no está determinada por la presencia de áfidos del género Cinara Curtis, y que no existe mayor susceptibilidad de los individuos sintomáticos a ser afectados por pulgones. La metodología aplicada fue útil para determinar la existencia de variación en el nivel de colonización entre áreas y entre individuos dentro de cada área. Su implementación en otras estaciones del año permitirá caracterizar la dinámica de los áfidos del género Cinara Curtis en los bosques de A. chilensis.

El análisis de la distribución diferencial de especies en función del estado sanitario del huésped y el estudio de la dinámica de las especies C. cupressi y C. tujafilina, requiere un método de diagnóstico que permita la rápida identificación de cada una de ellas. La diferenciación morfológica entre ambas especies aunque posible, es compleja y requiere mucho tiempo, por lo que se desarrolló un método molecular para resolver este problema.

En el presente trabajo se determinó que el grado de variación de secuencia nucleotídica en una región del gen mitocondrial CO-I, entre ambas especies, es adecuado para un método diagnóstico de diferenciación. Considerando los resultados obtenidos se desarrolló un método molecular basado en el polimorfismo de longitud de los fragmentos de restricción (RFLP) para discriminar entre $C$. cupressi y C. tujafilina. El método molecular emplea un único sitio de restricción (Hae III), sin embargo otras endonucleasas, como Apo I o Pst I, podrían también ser utilizadas. Aunque la variación intraespecífica puede afectar la identificación de especies, el nivel detectado en el material de estudio fue muy bajo y no afectó los sitios diagnósticos (Hae III) o los sitios alternativos propuestos (Apo I o Pst I).

Aplicando el método de PCR-RFLP, clones provenientes de muestras de áfidos colectadas desde A. chilensis se clasificaron fácilmente como putativa C. tujafilina y putativa C. cupressi, verificando la presencia de ambas especies de áfidos en ciprés de la cordillera y confirmando la primer detección de $C$. cupressi en la especie nativa A. chilensis en Argentina. Un mayor número de muestras y clones debería ser evaluado a fin de determinar la frecuencia relativa de especies. Sin embargo, la relación $83 \%$ vs. $17 \%$ (putativa C. cupressi / putativa C. tujafilina) determinada en función del número de clones secuenciado, se aproxima a la relación $80 \%$ vs. 20\% (C. cupressi / C. tujafilina) obtenida del análisis morfológico de adultos ápteros y alados tomados al azar del total de colonias provenientes del muestreo de pares. Por tanto, aunque el ingreso de C. cupressi sería posterior al de C. tujafilina, los datos recabados indican que actualmente es la especie más abundante en bosques de A. chilensis en la zona de El Bolsón. 
El análisis de áfidos provenientes de colonias aisladas obtenidas desde árboles con y sin síntomas de mal del ciprés mediante el método de PCR-RFLP, confirma la predominancia de C. cupressi en A. chilensis e indica que no existe segregación diferencial de C. cupressi o C. tujafilina en relación al estado sanitario de los individuos.

Aunque muestras provenientes de otras áreas de bosque deberán ser evaluadas para validar la aplicación del método en diferentes regiones geográficas, se espera que el mismo funcione adecuadamente en la discriminación dado el bajo nivel de polimorfismo detectado dentro de cada especie y la información disponible para otras especies del mismo y otros géneros. Foottit et al. (2008), usando una región del gen CO-I correspondiente a 300 especies desde más de 130 géneros de áfidos, detectó bajo nivel de variación intraespecífica y demostró que los métodos moleculares son útiles para la identificación de especies de áfidos.

El método desarrollado podría ser extendido a otras especies de Cinara que colonizan coníferas nativas y exóticas en Argentina, empleando la misma región de CO-I en combinación con diversas enzimas de restricción. Valenzuela et al. (2007) emplearon un método similar para identificar 25 especies de áfidos comúnmente detectados en el Sur de Australia. El análisis in silico de las secuencias disponibles en bases de datos indica que C. cupressi y C. tujafilina podrían ser separadas de todas las especies del género Cinara reportadas por Favret y Voegtlin (2004) usando el método diagnóstico de PCR-RFLP basado en Hae III.

\section{5.- CONCLUSIONES}

Los resultados obtenidos permiten concluir que:

- Las especies C. cupressi y C. tujafilina no determinan un debilitamiento de los individuos de $A$. chilensis que los predisponga al mal del ciprés, y no presentan asociación directa con el disturbio.

- C. cupressi es la especie más abundante en bosques de A. chilensis en El Bolsón, presentando idéntica distribución entre plantas con y sin síntomas del mal del ciprés.

El método desarrollado para la diferenciación molecular de las especies C. cupressi y C. tujafilina, se presenta como una herramienta útil para analizar la variación estacional de las especies en relación con áreas geográficas o huéspedes, y la distribución de cada especie en árboles individuales. Su aplicación ayudará a esclarecer la relación entre los nuevos síntomas aéreos reportados en $A$. chilensis (hojas rojas y mortalidad súbita del follaje) y dos grupos de 
agentes bióticos, C. cupressi y Phytophthora austrocedrae (Capitulo IV); en tanto que si bien en Chile se considera a $C$. cupressi como el único agente responsable del enrojecimiento de A. chilensis hasta el momento no se ha investigado la presencia de $P$. austrocedrae. 



\section{CAPITULO VI}

\section{RELACIÓN ENTRE EL MAL DEL CIPRÉS Y BACTERIAS ENDÓGENAS PRESENTES EN XILEMA DE $\boldsymbol{A}$. CHILENSIS}

\section{INTERROGANTES}

¿Existen bacterias en xilema de A. chilensis?

¿Están las bacterias de xilema asociadas al mal del ciprés?

\section{HIPÓTESIS Y PREDICCIONES}

- Hipótesis 1: Existen bacterias patógenas específicamente asociadas a xilema de las plantas afectadas por mal del ciprés.

PREDICCIÓN 1: Todos los árboles con síntomas de mal del ciprés presentan bacterias patogénicas en xilema que no se detectan en los árboles asintomáticos.

- Hipótesis 2: La alteración fisiológica de tejidos en las plantas con el mal del ciprés afecta las bacterias endofíticas presentes en xilema.

PREDICCIÓN 2: Existen diferencias entre las bacterias endofíticas de xilema de plantas con y sin síntomas del mal del ciprés. 



\section{1.- INTRODUCCIÓN}

Fitoplasmas, espiroplasmas, proteobacterias y Xylella fastidiosa forman un grupo de procariotes endógenos fitopatogénicos conocidos bajo el nombre de bacterias fastidiosas. A diferencia de los organismos patogénicos exógenos como algunas especies de Erwinia, Pseudomonas o Xanthomonas que colonizan el espacio intercelular de los tejidos de plantas (apoplasto), las bacterias patogénicas endógenas están restringidas a los sistemas de conducción floema y xilema. Aunque varios de estos agentes pueden ser obtenidos actualmente en cultivo, los complejos requerimientos nutricionales que presentan limitaron durante mucho tiempo su aislamiento llevando a confundir la etiología de las enfermedades que producen. Algunas de estas enfermedades fueron consideradas durante mucho tiempo como derivadas de agentes abióticos, sequía para la necrosis marginal en árboles forestales, o bien de origen viral debido a la distribución sistémica del agente y la transmisión por injerto o insectos vectores.

Entre las bacterias fastidiosas de floema se encuentran los fitoplasmas, microorganismos sin pared celular, con ultraestructura y morfología similar a los micoplasmas humanos y de animales; los espiroplasmas, sin pared celular, con morfología helicoidal y móviles; y las proteobacterias (Liberobacter y Phlomobacter) con pared celular gram negativa. Xylella fastidiosa, Pseudomonas syzygii y Clavibacter xyli, conforman el grupo de bacterias fastidiosas de xilema. (Bové y Garnier, 2003).

Sin embargo, no todas las interacciones entre plantas y microorganismos conducen al desarrollo de enfermedades. Por el contrario, diversos estudios muestran que los tejidos de plantas sanas puede ser colonizados internamente por microorganismos fúngicos o bacterianos que establecen interacciones beneficiosas con las plantas huéspedes (Tervet y Hollis, 1948; Hollis, 1951; Clay, 1988; Schardl et al., 2004; Zinniel et al., 2002). Estos microorganismos se conocen con el nombre de endofitos (Wilson, 1995). Entre las bacterias, la mayor parte de la información disponible proviene de estudios en especies cultivadas como arroz (Reinhold-Hurek y Hurek, 1998; Sun et al., 2008; Koomnok et al., 2007; Mano y Morisaki, 2008), maíz (Triplett, 1996), caña de azúcar (Döbereiner et al., 1995; Mendes et al., 2007), algodón (Misaghi y Donndelinger, 1990; Hallmann et al., 1998), soja (Hung y Annapurna, 2004; Kuklinsky-Sobral et al., 2005; Hung et al., 2007) y papa (Sturz, 1995; Sturz et al., 1999; Reiter et al., 2002; Sessitsch et al., 2004). El conocimiento de las bacterias endofíticas de árboles es más limitado, existiendo reportes para cítricos (Gardner et al., 1982; Araújo et al., 2002; Rivera Rodríguez, 2006), pera (Whitesides y Spotts, 1991), roble (Brooks et al., 1994), olmo (Mocali et al., 2003), picea (Cankar et al., 2005) y álamo (Ulrich et al., 2008). 
El mal del ciprés se postula como una enfermedad de declinamiento (Calí, 1996; Filip y Rosso, 1999; La Manna y Rajchenberg, 2004a y b) aunque entre los agentes bióticos únicamente los hongos se han evaluado como posibles patógenos. La participación de virus y bacterias como factores contribuyentes o causales no ha sido estudiada. Los datos de sintomatología, patrón de agregación y condiciones de sitio para el mal del ciprés podrían orientar a dichos agentes (Agrios, 1991; Davis, 2001; Hopkins, 2001). Todos los modelos planteados hasta el momento para la mortalidad del ciprés se basan en el supuesto de un origen radical del proceso y consideran que sea cual fuere el agente causal genera un desequilibrio entre los compartimentos aéreo y subterráneo de la planta, lo que conduce a estrés hídrico que sería en último término el responsable de la aparición de los síntomas a nivel de copa (Capitulo I). Sin embargo, síntomas aéreos similares a los reportados para el mal del ciprés se describieron para otras especies forestales, en cuyo caso el origen del proceso no es radical.

El amarillamiento del olmo (Ulmus sp.) se caracteriza por pérdida de color y caída de hojas y, al momento de la aparición de los síntomas aéreos, las raíces finas presentan importantes niveles de afectación (Sherald, 1999). En el caso del amarillamiento del fresno (Fraxinus sp.) los síntomas son inespecíficos y difíciles de diferenciar de los presentes en declinamientos causados por factores ambientales adversos (Roberts, 2004). Si bien la falta de relación entre el inicio de la afectación y la detección de los organismos asociados (Sinclair et al., 1993) retardó la determinación de la etiología de estos procesos, actualmente se conoce que ambas enfermedades de amarillamiento son producidas por fitoplasmas. La falta de sincronización sería debida al bajo título del agente biótico, su distribución errática en los tejidos y la ausencia de síntomas locales que limiten la búsqueda a tejidos o sitios específicos. Este tipo de organismos similares a micoplasmas se reportaron también en Fagus sp. y Larix sp. (Nienhaus, 1985).

Los marchitamientos vasculares, por otra parte, son producidos por bacterias que se multiplican dentro de los vasos del xilema, causando muerte a distancia en las partes aéreas de la planta al interferir en el movimiento del agua (Worral, 2005). Bacterial Scorch es una enfermedad producida por bacterias limitadas a xilema, cuyo representante más conocido es Xylella fastidiosa. El agente produce decoloración, marchitamiento, quemado y curvado de las hojas y defoliación. La enfermedad se observa con frecuencia luego de un fuerte estrés, por ejemplo sequía. Entre los géneros afectados por X. fastidiosa se encuentran Ulmus, Quercus, Acer y Morus. En los amarillamientos producidos por fitoplasmas y los marchitamientos vasculares generados por bacterias, la afección del compartimento de conducción lleva a un estado de estrés que determina la aparición de síntomas en la parte aérea y subterránea de la planta. 
La presencia de virus o fitoplasmas en plantas afectadas por mal del ciprés se evaluó, en forma preliminar, por microscopía electrónica obteniéndose resultados negativos (Dr. Eliot Kitajima com. pers.); en tanto que se detectaron corpúsculos semejantes a bacterias en material proveniente de plantas afectadas (Dra. Claudia Nome com. pers.). La falta de información previa sobre la existencia de bacterias endógenas, patogénicas o no patogénicas, para $A$. chilensis planteó la necesidad de avanzar en la caracterización de las bacterias endógenas presentes en la especie a fin de poder evaluar el rol de estos agentes bióticos en el desarrollo de la mortalidad.

Considerando los resultados negativos obtenidos para la detección de signos causados por virus o fitoplasmas mediante microscopía electrónica, el trabajo propuesto para el presente capítulo de tesis se orienta a evaluar dos modelos alternativos en relación al mal del ciprés (Capitulo I) y las bacterias de xilema.

\section{Modelo Medio o DE DOBLE víA (Figura VI-1): Bacterias patogénicas de xilema son la causa del mal del ciprés}

El mal del ciprés es una enfermedad producida por bacterias de xilema que alteran el estado fisiológico del árbol, conduciendo a defoliación y amarillamiento gradual y predisponiendo al ataque por agentes secundarios.

- Hipótesis 1: Existen bacterias patógenas específicamente asociadas a xilema de las plantas afectadas por mal del ciprés.

PREDICCIÓN 1: Todos los árboles con síntomas de mal del ciprés presentan bacterias patogénicas en xilema que no se detectan en los árboles asintomáticos.

\section{MODELO ASCENDENTE (Figura VI-1): El mal del ciprés comienza a nivel de la raíz}

El mal del ciprés es un disturbio de origen radical, debido a la acción de agentes bióticos o abióticos (hongos o condiciones de sitio), caracterizado por un debilitamiento lento del árbol, asociado a un desbalance hídrico que modifica el estado fisiológico de tejidos vitales y conduce a defoliación y amarillamiento gradual.

- Hipótesis 2: La alteración fisiológica de tejidos en las plantas con el mal del ciprés afecta las bacterias endofíticas presentes en xilema.

PREDICCIÓN 2: Existen diferencias entre las bacterias endofíticas de xilema de plantas con y sin síntomas del mal del ciprés. 


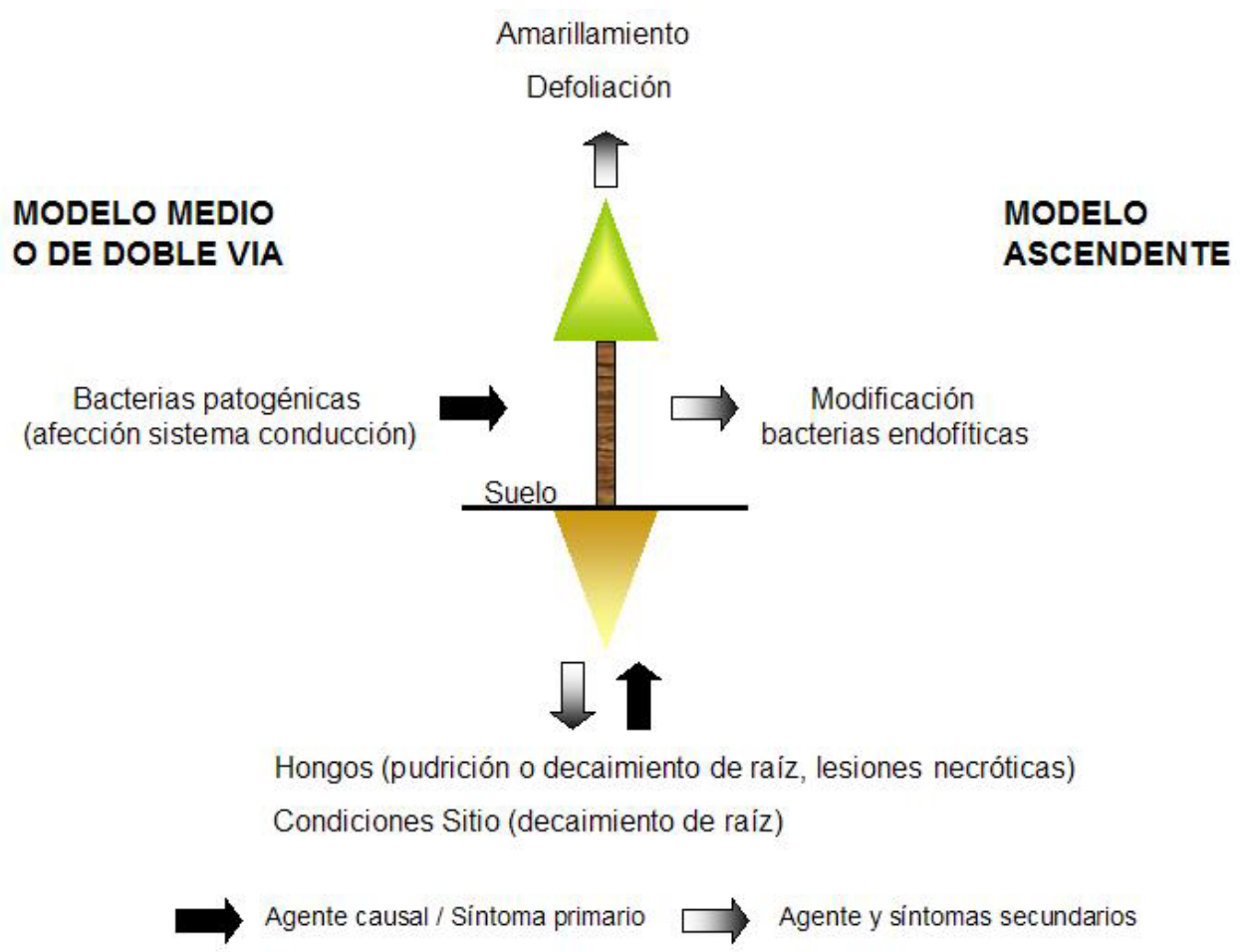

Figura VI-1: Representación esquemática de los dos modelos etiológicos evaluados. A la izquierda ModELO MEDIO o DE DOBLE VÍA, que considera a las bacterias patogénicas endógenas que afectan el sistema de conducción como agente causal del mal del ciprés; siendo el amarillamiento, la defoliación y la afección de raíz síntomas secundarios. A la derecha Modelo AsCEndente, que considera al mal del ciprés como un proceso de origen radical producido por agentes bióticos o abióticos, que lleva a estrés hídrico y conduce al amarillamiento y la defoliación; siendo la modificación de las bacterias endofíticas un síntoma secundario del proceso.

La evaluación de ambos modelos requiere detectar diferencias entre bacterias en xilema de árboles sintomáticos y asintomáticos para mal del ciprés. El aislamiento directo de bacterias endógenas desde material vegetal y su posterior caracterización e identificación precisa de la puesta a punto de los medios adecuados de cultivo excediendo el tiempo disponible en el marco del presente trabajo de tesis. Sin embargo, la detección de bacterias endofíticas o patogénicas puede ser rápidamente abordada mediante un ensayo de PCR para el gen 16S rRNA. Esta técnica es ampliamente utilizada (Harmsen y Karch, 2004) debido a la presencia de dichos genes en todas las bacterias y al alto grado de conservación de su secuencia nucleotídica. Ambas características convierten al gen en un target útil para la rápida detección e identificación de especies (Weisburg et al., 1991), existiendo numerosos pares de primers universales disponibles para su amplificación y diversas metodologías moleculares como DGGE (Denaturing Gradient Gel Electrophoresis), TGGE (Temperature Gradiente Gel Electrophoresis), SSCP (Single Strand Conformation Polymorphism) o secuenciación aplicables al análisis de la diversidad presente en 
los fragmentos amplificados. Para muchas enfermedades de plantas producidas por bacterias no cultivables, la identificación del agente causal fue posible a través de un ensayo de PCR para el gen 16S rRNA (Garnier y Bové, 1993; Jagoueix et al., 1994; Zreik et al., 1998; Avila et al., 1998; Bové y Garnier, 2003).

DGGE y TGGE (Figura VI-2) son técnicas de separación electroforética de ácidos nucleicos que se basan en el cambio de la velocidad de migración de las moléculas en respuesta a la modificación de su estructura bajo la acción de agentes desnaturalizantes (Fisher y Lerman, 1983).

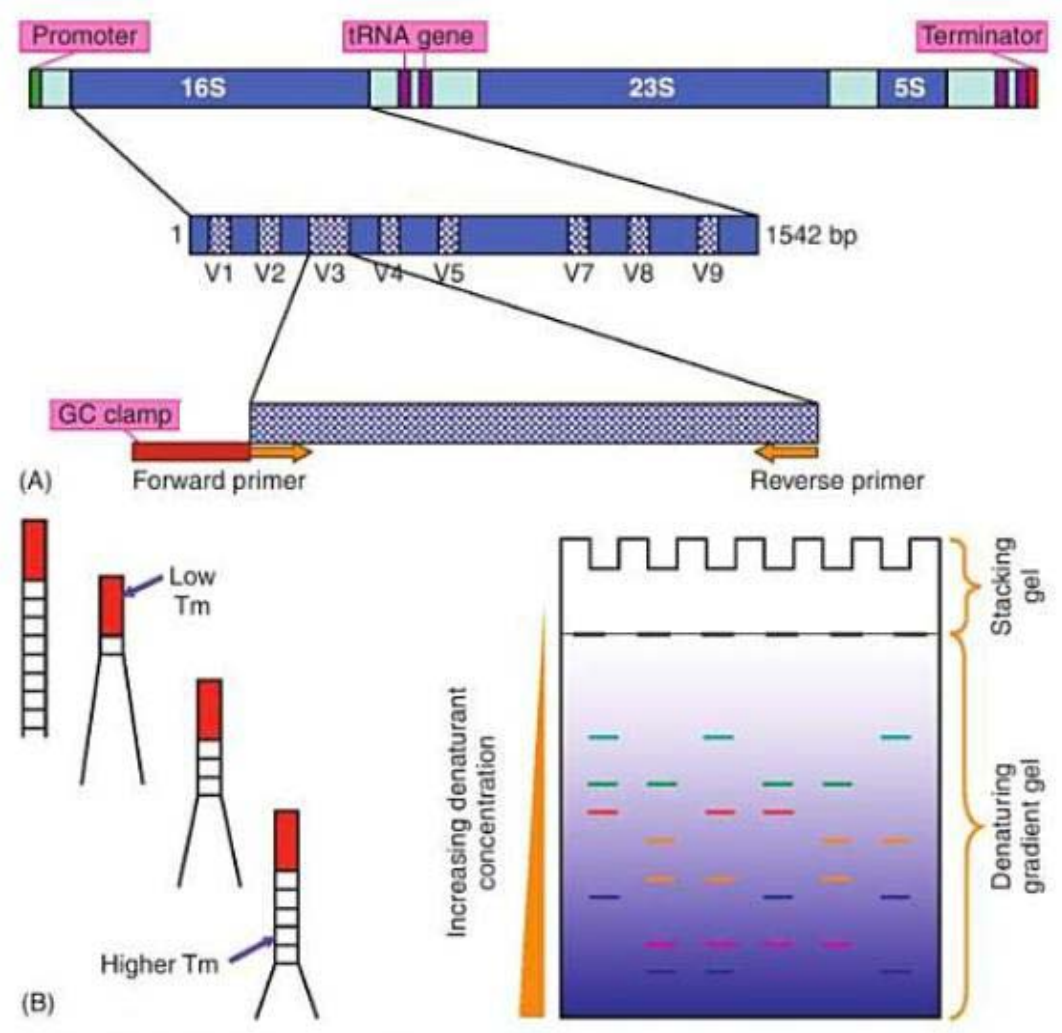

Figura VI-2: A. Ubicación de la región variable V3 del gen 16S rRNA y estrategia de amplificación. B. Representación esquemática de la técnica de DGGE (similar para TGGE). Tomado de Eldor (2007).

La concentración de estos agentes desnaturalizantes, urea y formamida para DGGE y temperatura para TGGE, aumenta en la dirección de migración de las moléculas durante la electroforesis. Los amplicones de DNA (fragmentos de DNA amplificados por PCR) tienen estructura compacta de doble cadena y migran a mayor velocidad que las moléculas de DNA desnaturalizadas. Las condiciones de desnaturalización de una molécula aumentan con el contenido de guanina (G) y citosina (C) y dependen de la secuencia en que estos nucleótidos se organizan, debido a las interacciones entre nucleótidos vecinos. Amplicones con diferente 
secuencia y contenido de $\mathrm{G}+\mathrm{C}$ se desnaturalizan y detienen su movimiento en regiones diferentes del gel, permitiendo un rápido análisis de la diversidad presente en el material de partida. Ambas técnicas se limitan a fragmentos de no más de 500 pb por lo que no es posible emplear la secuencia completa del gen. La aplicación de DGGE a la región variable (V3) del gen 16S rRNA fue descripta originalmente por Muyzer et al. (1993) y actualmente es una de las técnicas más ampliamente usadas en ecología microbiana (Eldor, 2007).

Si bien la presencia de bacterias endógenas ha sido reportada para otras especies de plantas, hasta el momento no ha sido evaluada en $A$. chilensis. La detección de bacterias en xilema de A. chilensis será evaluada por tanto, inicialmente mediante la amplificación por PCR del gen 16S rRNA y en segundo término mediante la técnica de DGGE que determina la diversidad de la región V3 del gen 16S rRNA. La combinación de ambos métodos permitirá evaluar los dos modelos planteados y sus correspondientes hipótesis.

\section{2.- MATERIALES Y MÉTODOS}

\section{1.- DETECCIÓN DE BACTERIAS EN XILEMA DE $A$. CHILENSIS MEDIANTE LA AMPLIFICACIÓN POR PCR DEL GEN 16S RRNA}

La detección se realizó sobre los 50 pares de plantas (asintomática / sintomática) seleccionados mediante el muestreo pareado (Capitulo II). Para cada individuo la extracción de DNA total obtenidas desde xilema (Capítulo III) se empleó en la amplificación del gen 16S rRNA mediada por los primers fD1 (5'-AGAGTTTGATCCTGGCTCAG-3') y rD1 (5'-AAGGAGGTGATCCAGCC-3') (Weisburg et al., 1991). Las reacciones de PCR se realizaron en $10 \mu \mathrm{L}$ en buffer $1 \mathrm{X}$, conteniendo una concentración final de $0.5 \mu \mathrm{M}$ de los primers fD1 y rD1, $200 \mu \mathrm{M}$ dNTPs, $2 \mathrm{mM} \mathrm{MgCl}_{2}$ y $0.02 \mathrm{U} / \mu \mathrm{L}$ de Taq DNA polimerasa (Invitrogen Life Technologies, USA). El ciclador térmico GeneAmp PCR System 9700 (Applied Biosystems) se empleó en las amplificaciones por PCR. La combinación $\mathrm{fD} 1 / \mathrm{rD} 1$ amplifica un fragmento de aproximadamente $1.5 \mathrm{~kb}$ y ha sido reportada con distintas condiciones de ciclado (Weisburg et al., 1991; Jagoueix et al., 1994). Luego de algunos ensayos preliminares se estableció el siguiente programa de PCR: un ciclo de desnaturalización inicial a $94^{\circ} \mathrm{C}$ por 3 min, seguido por 35 ciclos de desnaturalización a $94^{\circ} \mathrm{C}$ por $30 \mathrm{~s}$, annealing de primers a $54^{\circ} \mathrm{C}$ por $30 \mathrm{~s}$ y extensión a $72^{\circ} \mathrm{C}$ por $1 \mathrm{~min}$, con un ciclo de extensión final a $72^{\circ} \mathrm{C}$ durante $7 \mathrm{~min}$. Debido a que la relación DNA ciprés / DNA bacterias es desconocida, para la reacción de PCR se empleó $1 \mu \mathrm{L}$ de la extracción de DNA total. En los casos de amplificación negativa se repitió la PCR empleando $1 \mu \mathrm{L}$ de diluciones seriadas $1 / 10$ y 
1/100 del DNA total. Las amplificaciones se separaron por electroforesis en gel de agarosa $0.80 \%$ (TAE $1 \mathrm{X}$ ) y se visualizaron por tinción con bromuro de etidio.

\section{2.- CARACTERIZACIÓN MEDIANTE DGGE DE LA DIVERSIDAD DE LA REGIÓN V3 DEL GEN 16S rRNA AMPLIFICADA DESDE XILEMA DE $A$. CHILENSIS}

Para el análisis mediante DGGE los productos de amplificación generados con el par de primers fD1/rD1 se utilizaron como molde en una nested PCR con los primers F341GC (5'-CGCCCGCCGCGCGCGGCGGGCGGGGCGGGGGCACGGGGGGCCTACGGGAGGCAGCAG-3') y R518 (5'-ATtACCGCGGCTGCTGG-3') (Muyzer et al., 1993). Diferentes diluciones de la PCR fD1/rD1 se emplearon en la nested PCR a fin de obtener similares niveles de amplificación para todas las muestras evaluadas. Las reacciones de PCR se realizaron en $25 \mu \mathrm{L}$ en buffer $1 \mathrm{X}$, conteniendo una concentración final de $0.5 \mu \mathrm{M}$ de los primers F341GC y R518, $200 \mu \mathrm{M}$ dNTPs, $1.5 \mathrm{mM}$ $\mathrm{MgCl}_{2}$ y $0.02 \mathrm{U} / \mu \mathrm{L}$ de Taq DNA polimerasa (Invitrogen Life Technologies, USA). El ciclador térmico GeneAmp PCR System 9700 (Applied Biosystems, USA) se empleó en las amplificaciones por PCR, utilizándose un programa de Touch Down PCR de: un ciclo de desnaturalización inicial a $94^{\circ} \mathrm{C}$ por 4 min; 20 ciclos de desnaturalización a $94^{\circ} \mathrm{C}$ por $45 \mathrm{~s}$, annealing de primers a $65^{\circ} \mathrm{C} \rightarrow 55^{\circ} \mathrm{C}$ (disminución $0.5^{\circ} \mathrm{C} /$ ciclo) por 1 min y extensión a $72^{\circ} \mathrm{C}$ por $30 \mathrm{~s} ; 20$ ciclos de desnaturalización a $94^{\circ} \mathrm{C}$ por $45 \mathrm{~s}$, annealing de primers a $55^{\circ} \mathrm{C}$ por $1 \mathrm{~min}$ y extensión a $72^{\circ} \mathrm{C}$ por $30 \mathrm{~s}$; y un ciclo de extensión final a $72^{\circ} \mathrm{C}$ por 5 min. El ciclado se ajustó tomando como base los parámetros proporcionados por la Dra. María Eugenia Farias (PROIMI, Tucumán). Los productos de amplificación se evaluaron en gel de agarosa $2.0 \%$ en forma previa a su aplicación en el gel de DGGE.

La electroforesis en gradiente de agente desnaturalizante se realizó en el equipo DCode ${ }^{\mathrm{TM}}$ Universal Mutation Detection System (BIORAD) empleando un gel de poliacrilamida 8\% (TAE $1 \mathrm{X}$ ) con un gradiente de $30 \%$ a $60 \%$ en urea y formamida. La separación se realizó a $120 \mathrm{~V}$ y $60^{\circ} \mathrm{C}$ durante $4 \mathrm{~h}$. Luego de la electroforesis los fragmentos se visualizaron por tinción con SYBR Green (Invitrogen Life Technologies, USA) en relación 1:10000 en TAE 1X, durante 20 min. Los geles se fotografiaron y las imágenes registradas se analizaron con GelCompar II v.4.602 (Applied Maths, 1998-2005).

Debido a la imposibilidad de realizar el análisis por DGGE de la región V3 del gen 16S rRNA para los 50 pares de individuos, la evaluación se realizó empleando únicamente 15 pares de plantas (asintomática / sintomática). Esto es, 3 pares de plantas por cada sitio de muestreo (análisis a nivel de individuo) seleccionadas al azar. Los amplicones derivados de la 
combinación fD1/rD1 correspondiente a cada uno de estos individuos se emplearon como moldes en la nested PCR con los primers F341GC y R518. Para el estudio a nivel de individuos se generó una tabla binaria $(1 / 0)$ en base a la presencia o ausencia de bandas que posteriormente se empleó en el estudio de correlación entre bandas y estado sanitario o áreas de muestreo mediante un test de Chi cuadrado basado en tablas de contingencia y en un análisis de componentes principales (PCA). Ambos análisis se realizaron de acuerdo con la metodología implementada en el software GelCompar II v.4.602 (Applied Maths, 1998-2005).

El análisis se realizó además para cada sitio de muestreo, empleando un pool de los amplicones derivados de la combinación fD1/rD1 como molde para la nested PCR con los primers F341GC y R518. Los amplicones correspondiente a cada uno de los individuos asintomáticos de un sitio (10 individuos) se combinaron generándose un pool asintomático para cada sitio de muestreo. El mismo procedimiento se llevó a cabo con los productos de amplificación de los individuos sintomáticos.

Para cada uno de los análisis (individuos o sitios) se computaron matrices de similitud empleando coeficientes basados en las bandas de cada perfil (coeficiente de Dice) o en las curvas densitométricas (correlación de Pearson). Las matrices se emplearon en el análisis de agrupamiento mediante el método de ligamiento promedio (UPGMA). La significación de los dendrogramas obtenidos se evaluó a través del valor de similitud promedio en cada rama, el cálculo del correspondiente desvío estándar (obtenido de la reconstrucción de los valores de similitud a partir de las ramas del dendrograma y su comparación con los valores de la matriz original) y los coeficientes de correlación cofenética (correlación entre los coeficientes de similitud derivados del dendrograma y los correspondientes a la matriz original). Por otra parte, se empleó un método de reemplazo o bootstrap $(\mathrm{n}=1000)$ para el análisis de significación. En este caso en lugar de comparar el dendrograma y la matriz de similitud, se determina la influencia de cada caracter en el agrupamiento obtenido. Para cada caracter reemplazado se recalcula el agrupamiento, siendo el número relativo de dendrogramas que presentan un determinado grupo una medida de significación de dicho grupo.

Por otra parte, se evalúo la distribución de las muestras en relación a grupos predefinidos según sintomatología (asintomáticos y sintomáticos) y áreas de muestreo (El Bolsón Norte y El Bolsón Sur) considerando el reporte previo de mayor incidencia del mal del ciprés en el Sur de la región de El Bolsón (Chauchard y Barnabá, 1986). Este análisis se efectúo bajo el método Jackknife según criterios de máxima similitud con cada grupo y distribución equitativa en casos donde una muestra puede ser asignada a más de un grupo. El método consiste en tomar una muestra y 
chequear su identidad respecto de los grupos definidos. El porcentaje de los casos en que las muestras son identificadas en el grupo al que fueron asignadas es una medida de la estabilidad del grupo.

\section{3.- RESULTADOS Y DISCUSIÓN}

\section{1.- DETECCIÓN DE BACTERIAS EN XILEMA DE $A$. CHILENSIS MEDIANTE LA AMPLIFICACIÓN POR PCR DEL GEN 16S rRNA}

Las extracciones de DNA total obtenidas desde xilema para los 50 pares de plantas seleccionados en la región de El Bolsón (Capítulo III), se amplificaron con la combinación de primers fD1/rD1. La Figura VI-3 presenta un esquema general del ensayo aplicado y algunos de los resultados obtenidos. Para 87 de las 100 muestras evaluadas se obtuvo amplificación positiva utilizando $1 \mu \mathrm{L}$ de DNA total como molde en la reacción de PCR. Las muestras $1 \mathrm{~A}, 2 \mathrm{~S}$, 7S, 11S, 12S, 17S, 19S, 21A, 27S, 28S, 41A, 48A, 48S, 50A y 50S, dieron amplificación muy tenue o negativa. Diluciones seriadas $(1 / 10$ y $1 / 100)$ del DNA total se evaluaron para cada una ellas (Figura VI-4). Las muestras 2S, 11S, 17S, 28S, 41 A, 48S, dieron resultado positivo en una o ambas diluciones. Para las muestras 7S, 12S, 21A, 27S, 48A, 50A y 50S los resultados fueron positivos pero muy tenues, en tanto que las muestras 1A y 19S, no dieron amplificación con ninguna de las diluciones ensayadas. La relación entre amplificación y dilución, no fue siempre la misma, por ejemplo la muestra $11 \mathrm{~S}$ amplificó con la dilución $1 / 100$ y no lo hizo con la 1/10, mientras que la muestra $2 \mathrm{~S}$ dio una relación inversa (Figura VI-4).

En el Anexo 8 se presenta el resultado obtenido para la amplificación del gen 16S rRNA en cada una de las muestras evaluadas. El análisis sobre los 50 pares de plantas muestra la presencia de bacterias en xilema de $A$. chilensis, tanto en individuos sintomáticos como asintomáticos para mal del ciprés, no existiendo por tanto diferencias entre estados sanitarios.

La amplificación por PCR del gen 16S rRNA a partir de extracciones de DNA total obtenido de xilema de $A$. chilensis, permitió detectar la presencia de bacterias en este tejido. Sin embargo, la metodología no fue útil para establecer diferencias entre plantas con y sin síntomas de mal del ciprés. Los resultados indican que la amplificación en muestras de DNA total depende de la relación DNA ciprés / DNA bacterias y de la calidad de la extracción de DNA total (presencia de compuestos interferentes) y sugiere que la relación DNA ciprés / DNA bacterias varía entre plantas y probablemente entre puntos de muestreo en un mismo individuo. 
A

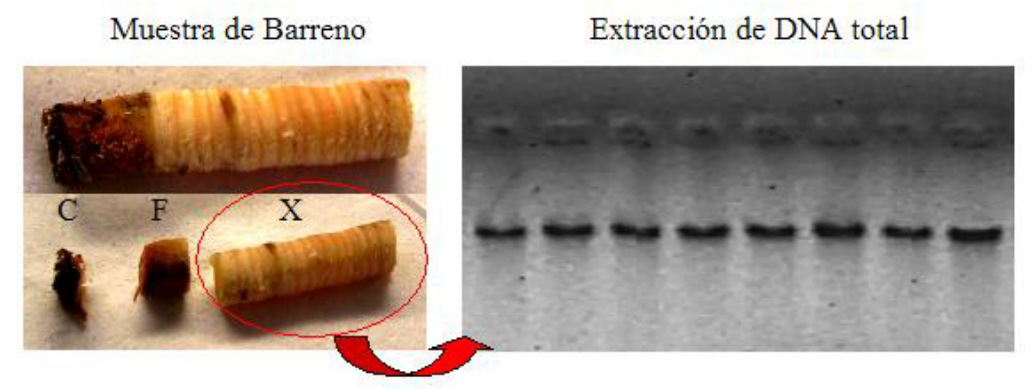

$\mathrm{B}$ Amplificación del gen $16 \mathrm{~S}$ rRNA
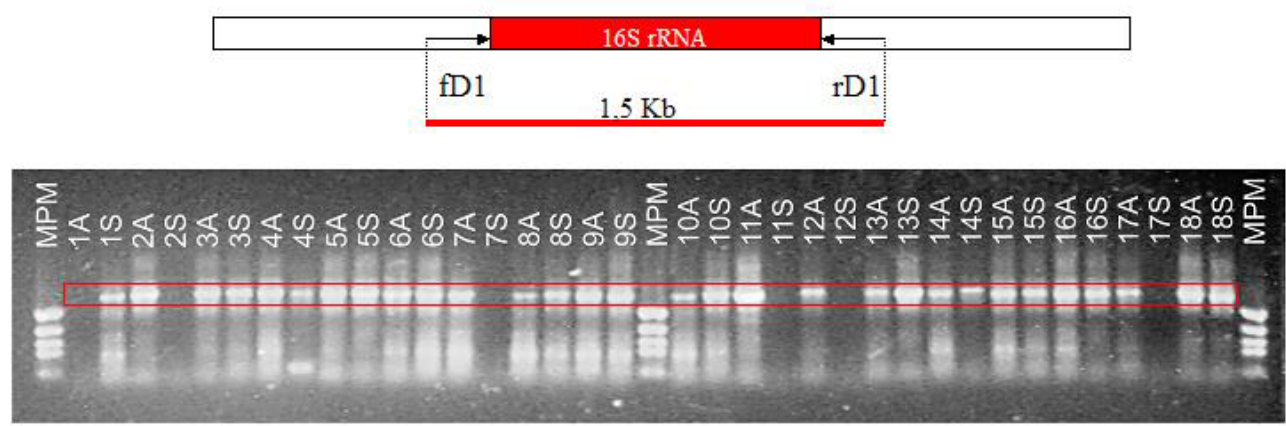

Figura VI-3: Ensayo de PCR para el gen 16S rRNA. A- En la imagen izquierda la organización de los tejidos que fueron separados en forma previa a la extracción de DNA total. C: corteza. F: albura (floema). X: duramen (xilema). La imagen derecha muestra extracciones de DNA total obtenidas desde xilema de A. chilensis. B- En la parte superior se esquematiza la amplificación del gen 16S rRNA mediante la aplicación de la combinación de primers fD1/rD1. Las flechas negras indican el sitio de annealing de los primers; el rectángulo rojo, la ubicación del gen en el genoma bacteriano y la línea roja el fragmento amplificado. En la parte inferior PCR sobre el gen 16S rRNA sobre muestras de DNA total extraído de xilema de A. chilensis. MPM: marcador de peso molecular, pcDNA II digerido con las enzimas de restricción DdeI y XhoI (1140, 758, 540, 409 y 166 pb). El recuadro rojo señala los fragmentos correspondientes al tamaño esperado. Identificación de las muestras según materiales y métodos.

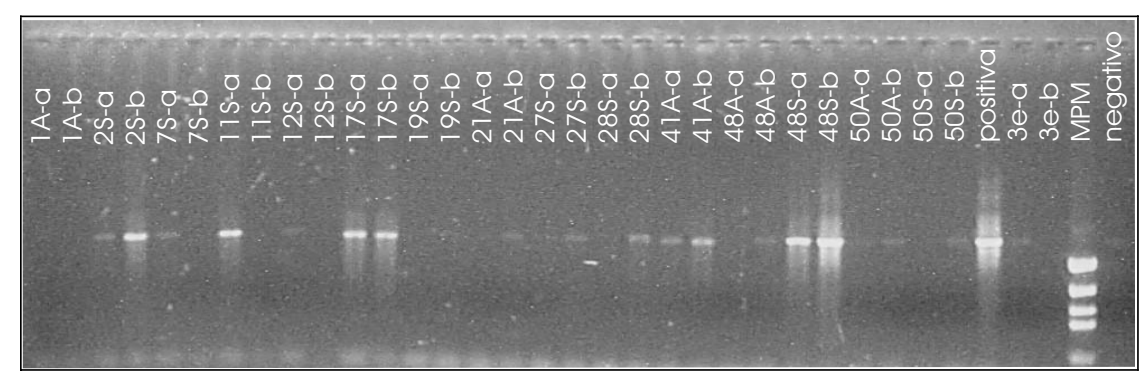

Figura VI-4: Amplificación por PCR con la combinación de primers fD1/rD1 sobre diluciones seriadas de DNA total extraído de xilema de A. chilensis. a: dilución 1/100. b: dilución 1/10. MPM: marcador de peso molecular, pcDNA II digerido con las enzimas de restricción DdeI y XhoI (1140, 758, 540, 409 y 166 pb). 3e: corresponde a una muestra de $A$. chilensis proveniente de una zona de estepa. Identificación del resto de las muestras según materiales y métodos. 


\section{2.- CARACTERIZACIÓN MEDIANTE DGGE DE LA DIVERSIDAD DE LA REGIÓN V3 DEL GEN}

\section{S rRNA AMPLIFICADA DESDE XILEMA DE $A$. CHILENSIS}

La técnica DGGE, se aplicó a fin de caracterizar la diversidad presente en la región variable V3 del gen 16S rRNA amplificada desde xilema de A. chilensis vía nested PCR sobre amplicones fD1/rD1. En la Figura VI-5 se presenta la estrategia de amplificación de la región V3 y se ejemplifica la diferencia de resolución de ambas técnicas.

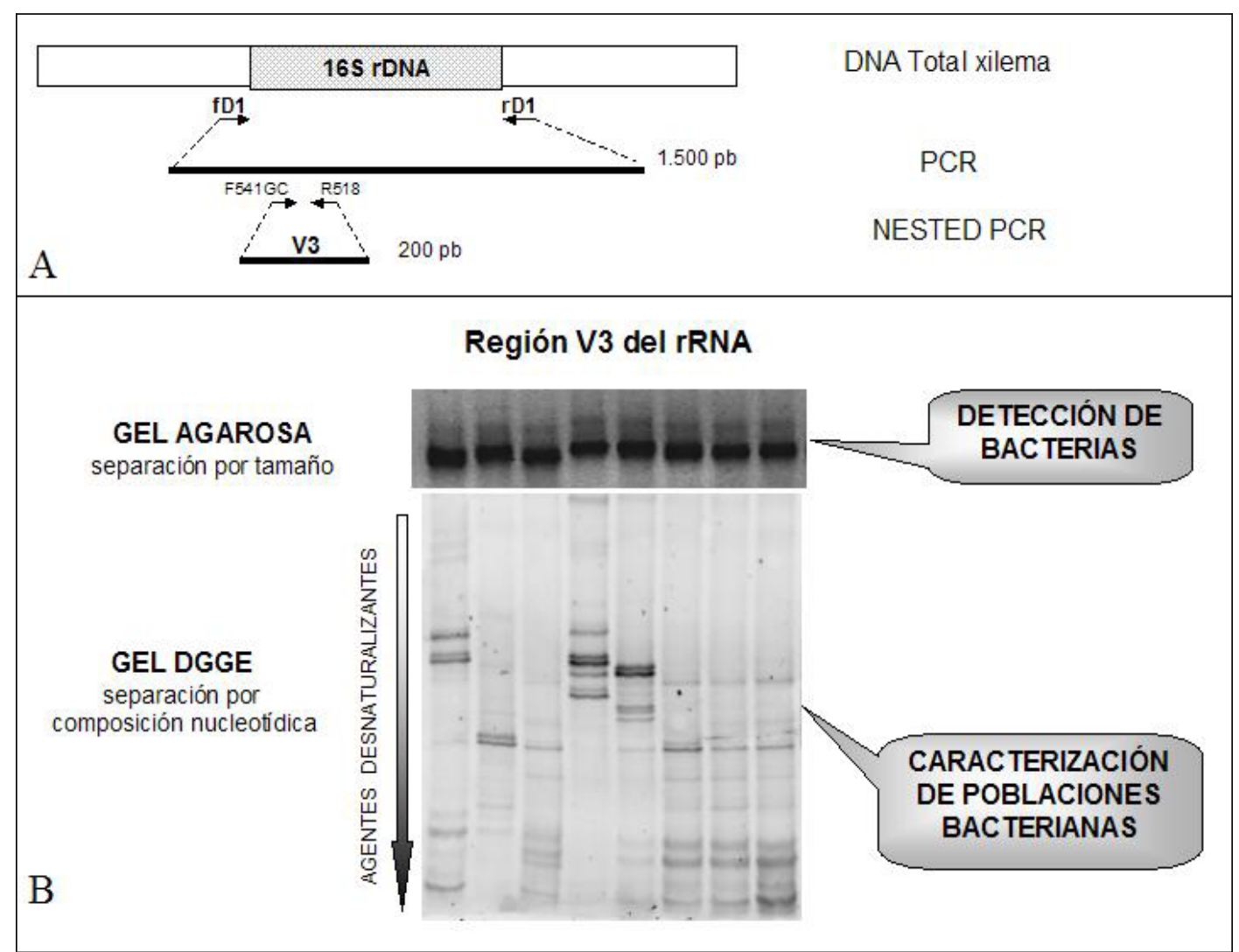

Figura VI-5: Caracterización de la región V3 del gen 16S rRNA. A- La amplificación comprenden una nested PCR con los primers F341GC y R518 sobre amplicones fD1/rD1. B- Diferencias entre la separación en geles de agarosa o geles de DGGE.

\subsection{1-Caracterización de las poblaciones bacterianas de xilema en individuos de la especie}

\section{A. chilensis}

El análisis a nivel de individuos permitió detectar un gran nivel de variabilidad en los perfiles de bandas (amplicones) generados por DGGE. La Figura VI-6 presenta la matriz de similitud determinada para el coeficiente Dice y el agrupamiento UPGMA correspondientes al análisis de las 30 muestras evaluadas ( 3 pares de plantas por cada sitio de muestreo). La significación del dendrograma obtenido es relativamente baja (Anexo 9), con bajos valores de desvío estándar y 
altos coeficientes cofenéticos en algunos grupos, pero baja significación general por análisis de bootstrap.

La correlación entre grupos predefinidos en función del estado sanitario (Asintomático, Sintomático) muestra que no existe segregación diferencial en relación al mal del ciprés, aunque el grupo sintomático muestra mayor consistencia. El 66.7\% de las muestras sintomáticas agrupan con las sintomáticas, en tanto que el $60 \%$ de las muestras asintomáticas agrupan con las sintomáticas. La correlación en función del origen geográfico de las áreas de muestreo (EB_N y EB_S) muestra un mayor agrupamiento en la región Norte. El $77.8 \%$ de las muestras provenientes de EB_N segregan con muestras del Norte, y sólo un 50.0\% de las muestras provenientes de EB_S segregan con las muestras del Sur.

Tanto la matriz como el agrupamiento indican la presencia de un grupo de alta similitud constituido por 4 de los 6 individuos del R18 y 3 de los 6 individuos del R11 (Figura VI-6). Estos resultados sugieren que, aunque existe gran diversidad dentro y entre sitios de muestreo, algunos sitios presentan menores niveles de variabilidad con un perfil de bandas de DGGE mayoritario, es decir compartido por un alto porcentaje de individuos. Esto puede verificarse al comparar el perfil de bandas de DGGE obtenido para el pool asintomático y sintomático de cada sitio con el obtenido para los individuos. En el caso del R18, la correspondencia entre perfiles es muy elevada (altos valores de similitud), indicando que el perfil observado para el pool (asintomático o sintomático) corresponde en gran medida al perfil mayoritario (Figura VI-7A).

El mismo tipo de comparación muestra que este perfil mayoritario se encuentra también en el R11 y el L5y6, aunque existe un mayor número de individuos con perfiles modificados (Figura VI-7 B y C en Anexo 10). El R81, presenta mayor variabilidad interna, diferencias entre los perfiles detectados para los 6 individuos analizados y menor similitud entre el perfil mayoritario del R18 y el obtenido para el pool asintomático o sintomático (Figura VI-7 D, Anexo 10). Un resultado similar se observa en el L9y15 (Figura VI-7 E, Anexo 10), con perfiles para el pool sintomático y asintomático que difieren del perfil mayoritario del R18. Sin embargo, la variabilidad interna es algo menor a la observada en el R81 como revela la matriz de similitud. 


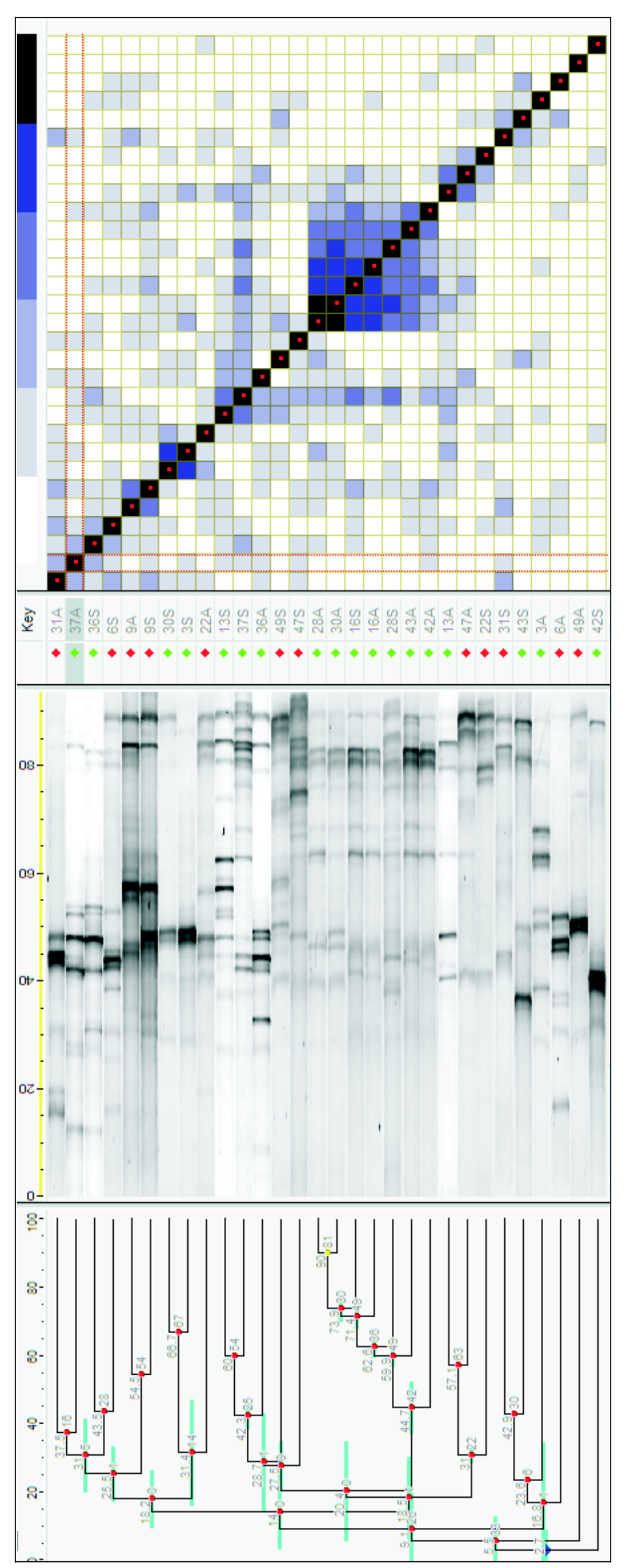

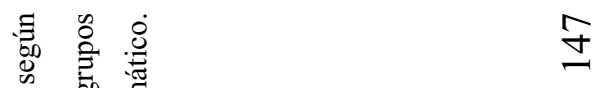

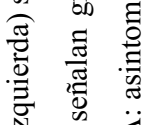

त)

苛 है

竞

๑ิ

胥 :

ठ

尊

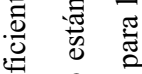

造

尊

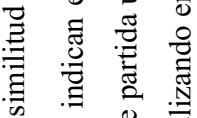

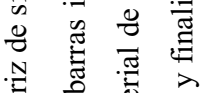

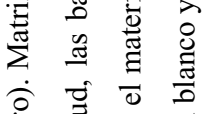

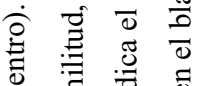

运泉

떵 क क

웜 댕

疍

:

व

尝产

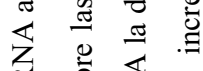

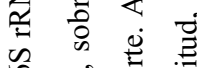

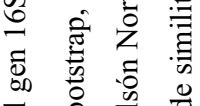

要

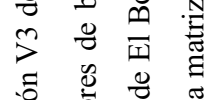

:

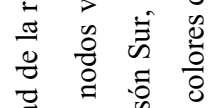

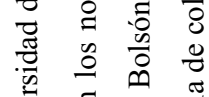

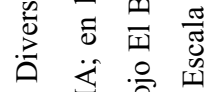

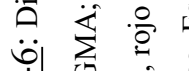

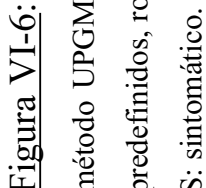




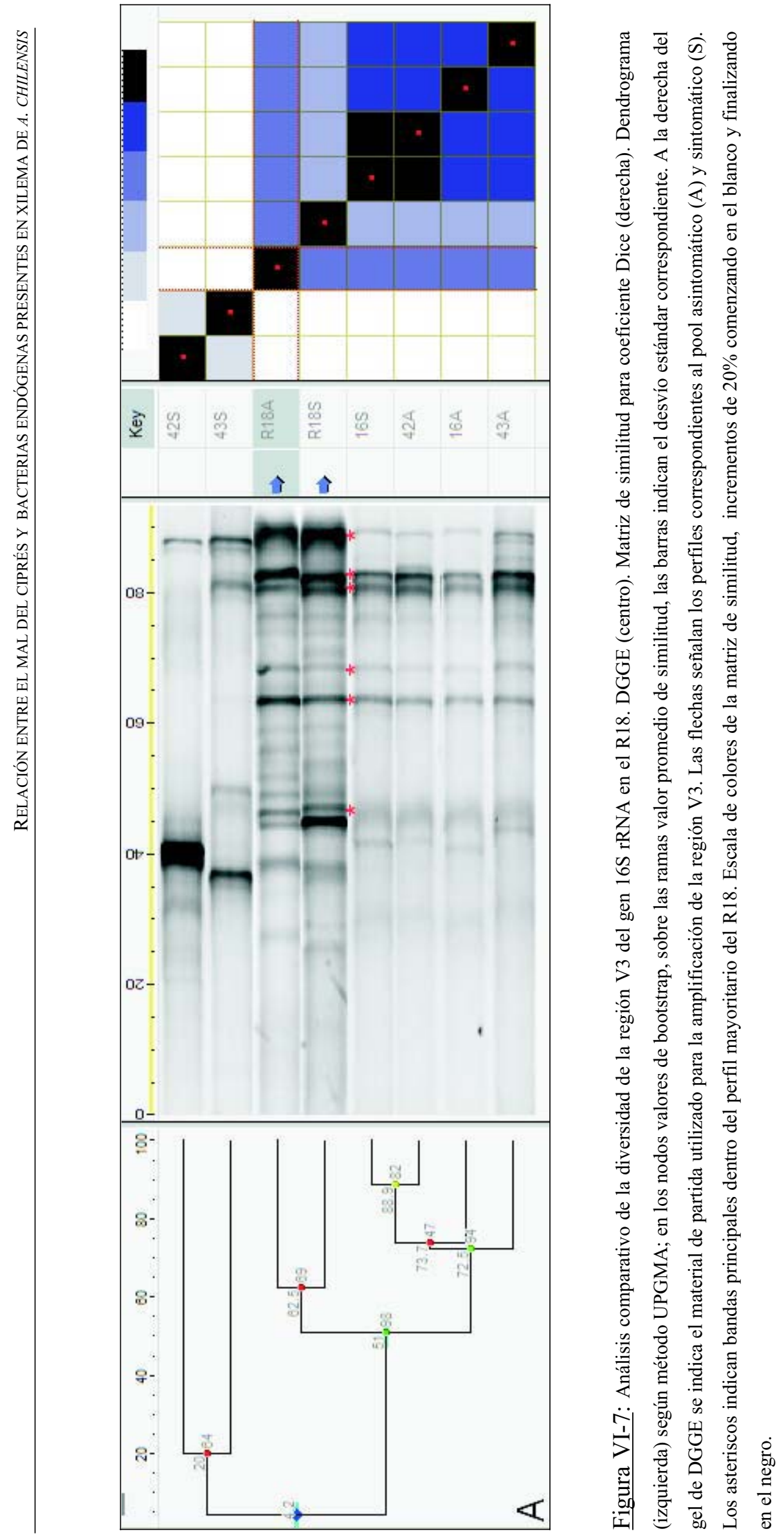


El análisis de la frecuencia de distribución de bandas entre estados sanitarios mediante test de Chi cuadrado identificó una única banda con diferencia significativa entre los grupos sintomático y asintomático (Tabla VI-1). Sin embargo, esta banda es de baja frecuencia (13.3\%) detectándose en 1 individuo sintomático del L5y6, 1 individuo sintomático del R11 y en 2 individuos sintomáticos del R81.

El análisis entre los grupos EB_N y EB_S permitió detectar 5 bandas con frecuencias de entre el $10 \mathrm{y}$ el $33.3 \%$, que presentan distribución diferencial entre grupos (Tabla VI-1). Tres de las bandas se asocian a EB_N y 2 a EB_S. En tanto que en el análisis con las 5 áreas de muestreo se detectaron 13 bandas con frecuencias de entre 13.3 y $43 \%$, que se distribuyen en forma diferencial entre sitios (Tabla VI-1).

\begin{tabular}{|c|c|c|c|c|}
\hline & ID banda & $p$ value & Frec. Banda & Distribución \\
\hline A vs $S$ & 91.2 & 0.031686 & 13.3 & $\mathrm{~S}(4)$ \\
\hline \multirow{5}{*}{ EB_N vs. EB_S } & 68.4 & 0.007001 & 26.7 & EB_N(8) \\
\hline & $\overline{76.0}$ & 0.007001 & 26.7 & $\mathrm{~EB} \_\mathrm{N}(8)$ \\
\hline & $\overline{82.6}$ & 0.017706 & 33.3 & EB_N(9) EB $S(1)$ \\
\hline & $\overline{45.1}$ & 0.002700 & 16.7 & EB $S(5)$ \\
\hline & 55.2 & 0.025347 & 10.0 & $E B^{-} S(3)$ \\
\hline \multirow{13}{*}{$\begin{array}{l}\text { L5y6, R11, R18, } \\
\text { R81 y L9y15 }\end{array}$} & 27.3 & 0.001002 & 13.3 & L5y6(4) \\
\hline & 38.0 & 0.043795 & 13.3 & L5y6(3) R11(1) \\
\hline & 44.5 & 0.043795 & 13.3 & L5y6(3) R11(1) \\
\hline & 41.9 & 0.033707 & 23.3 & L5y6(4) R18(2) R81(1) \\
\hline & 84.4 & 0.023893 & 20.0 & L5y6(3) R81(3) \\
\hline & 48.0 & 0.011122 & 43.3 & L5y6(6) R11(2) R81(2) L9y15(3) \\
\hline & 49.0 & 0.002986 & 23.3 & R11(5) R81(1) L5y6(1) \\
\hline & 40.4 & 0.023893 & 20.0 & R11(4) R81(1) L5y6(1) \\
\hline & $\underline{68.4}$ & 0.023893 & 26.7 & R18(4) R11(3) L5y6(1) \\
\hline & 76.0 & 0.023893 & 26.7 & R18(4) R11(3) L5y6(1) \\
\hline & $\overline{57.3}$ & 0.043795 & 13.3 & L9y15(3) L5y6(1) \\
\hline & 45.1 & 0.006122 & 16.7 & L9y15(4) R81(1) \\
\hline & 30.7 & 0.002986 & 23.3 & L9y15(5) R81(1) L5y6(1) \\
\hline
\end{tabular}

Tabla VI-1: Valores de probabilidad del análisis de Chi cuadrado de la distribución de bandas de DGGE según grupos predefinidos: A vs. S, EB_N vs. EB_S y L5y6, R11, R18, R81 y L9y15. ID: identificación de la banda. Únicamente se muestran los resultados de las bandas con distribución diferencial. En negrita se indica el grupo con mayor presencia de banda. En itálica y subrayado bandas pertenecientes al patrón mayoritario del R18.

La baja frecuencia de las bandas es esperable de acuerdo con la alta variabilidad encontrada en los perfiles de DGGE; en tanto que la distribución diferencial por áreas confirma los resultados anteriores marcando que la mayor similitud entre los sitios de muestreo del Norte se asocia a bandas del patrón mayoritario del R18 (Tabla VI-1). La distribución diferencial de bandas entre sitios señala, además, cierta estructuración geográfica de la diversidad. La falta de bandas asociadas mayoritariamente al R81, confirma su alto nivel de variabilidad. 
Las 74 bandas detectadas se emplearon en un análisis de componentes principales (PCA), determinándose que los dos primeros componentes (sobre un total de 20) dan cuenta del 16.9\% y $10.7 \%$ de la varianza, con un total acumulado de $27.6 \%$. El ordenamiento obtenido en la representación gráfica de los individuos y las bandas, permite establecer algunas correlaciones (Figura VI-8). Si bien la gran mayoría de las bandas presenta una distribución alrededor del centro algunas se separan y muestran mayor correlación con grupos particulares. Las bandas 68.4, 76.0, 82.6, 63.4 y 46.4 que corresponden al patrón mayoritario del R18 correlacionan en gran medida con individuos de EB_N (celeste R11 y amarillo R18, en la Figura VI-8), en tanto que las bandas $45.1,30.7,88.9,80.2,81.8,83.6,55.2$ y 57.3 se asocian a individuos del L9y15 (rojo, en la Figura VI-8) y a algunos individuos del R81 (lila, en Figura VI-8) o del R18. Las bandas 38.0, $44.5,41.9,27.3,48.0,73.7$ y 62.7 y 84.4 correlacionan en gran medida con los individuos del L5y6 (verde en Figura VI-8) y algunas de ellas, además, con individuos del R11 y R81. Las bandas 49.0 y 40.4 se asocian mayoritariamente a individuos del R11.

Estos resultados se corresponden con los derivados del análisis de Chi cuadrado y permiten observar la distribución de bandas adicionales (que aún con bajo nivel de significación, $p>0.5$ ) muestran una tendencia a la asociación con sitios o grupos de individuos particulares. La falta de segregación en función del estado sanitario es evidente, en tanto que se manifiesta la segregación por sitios, a un lado R18 y R11, por otro L9y15, y posiciones intermedias, L5y6 y R81. Tomados en conjunto, muestran un importante nivel de variabilidad en las poblaciones bacterianas detectadas entre individuos dentro y entre sitios de muestreo, con estructuración asociada a la procedencia de las muestras empleadas, mayor agrupación al Norte del área de El Bolsón (R18, R11 y L5y6), menor nivel de variabilidad para el R18 y ausencia de estructuración en función del estado sanitario.

La información aportada permite rechazar la hipótesis de la existencia de bacterias específicamente asociadas a xilema de las plantas afectadas por mal del ciprés y, por tanto, descartar el Modelo Medio o DE DOBle vía al menos en lo que respecta a xilema. El alto grado de variabilidad de las poblaciones bacterianas detectado entre individuos y áreas, limita el análisis del Modelo AsCENDENTE. Sin embargo considerando el mínimo nivel de variación detectado en el R18, uno de los sitios con alta incidencia de mal del ciprés en la actualidad, los resultados indicarían que aunque el estado fisiológico del árbol puede modificar las especies endofiticas presentes en xilema, otras condiciones asociadas a la distribución geográfica serían más determinantes según lo demuestra la segregación preponderante en relación al sitio. 

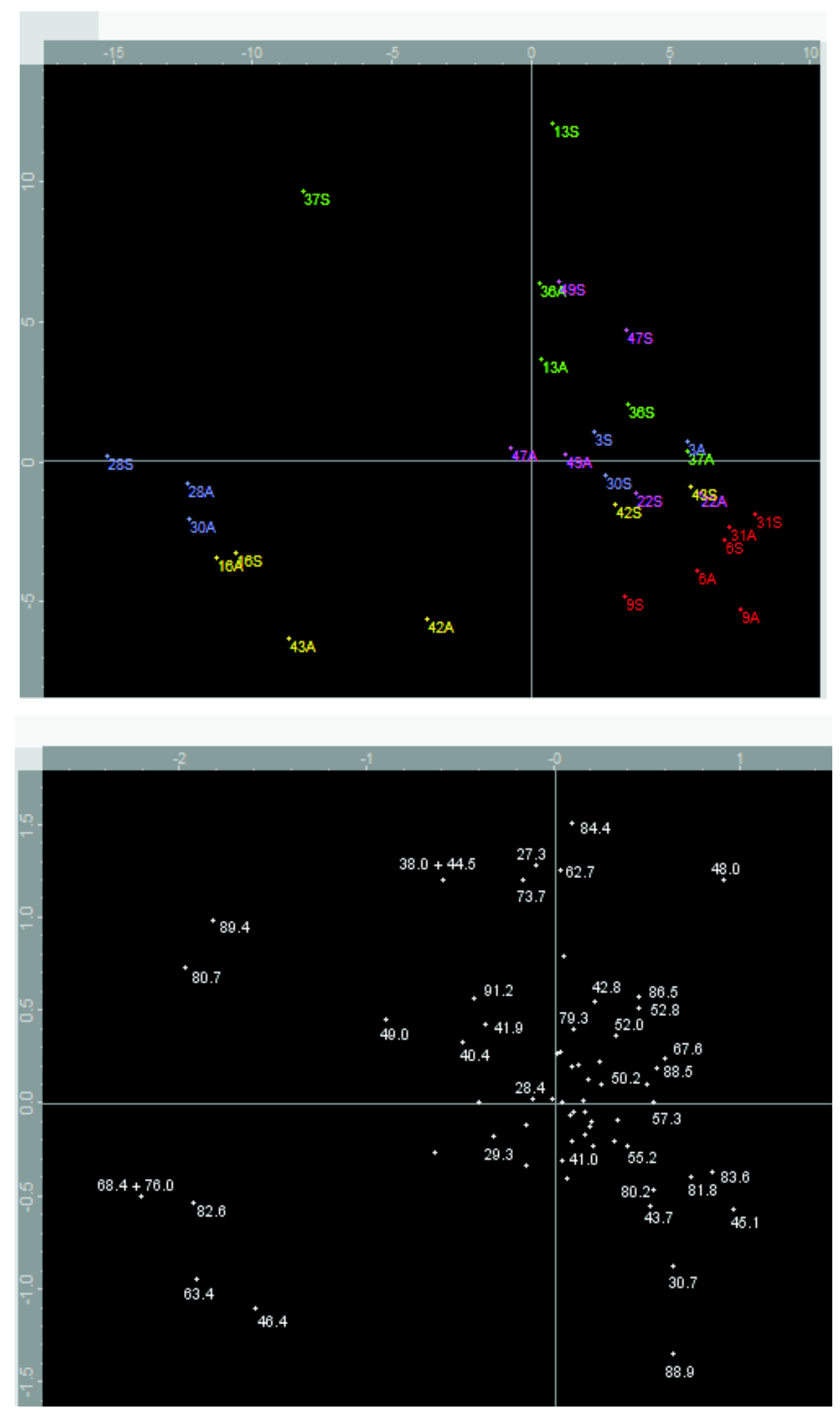

Figura VI-8: Ordenamiento espacial de individuos (arriba) y bandas (abajo) según los dos primeros componentes del PCA. Color de individuos según sitio de muestreo: celeste R11, amarillo R18, lila R81, verde L5y6 y rojo L9y15. Identificación de bandas, se indica únicamente para bandas con frecuencia mayor al 10\%. 
Es importante recordar que, en ausencia de secuenciación, las bandas dan información relativa en tanto que no es posible descartar la presencia de más de una variante de secuencia con idéntica composición de nucleótidos en una posición del gel. El aumento del número total de individuos analizados permitirá definir con mayor precisión la segregación de grupos y la detección de bandas marcadoras.

\subsection{2- Caracterización de las poblaciones bacterianas de xilema en pooles de individuos de}

\section{la especie $A$. chilensis}

Los resultados obtenidos sobre pooles de DNA de individuos sintomáticos y asintomáticos en cada sitio muestran gran variación en las poblaciones bacterianas detectadas, ya sea que se analice la curva densitométrica o los patrones de bandas. Sobre un total de 74 bandas analizadas, $21(28,4 \%)$ presentan frecuencias $>$ al 15\% y $38(51.4 \%)$ frecuencias $>$ al $10 \%$. La Figura VI-9 presenta la matriz de similitud determinada para el coeficiente Dice y el agrupamiento UPGMA correspondientes al análisis de las 10 muestras evaluadas (1 pool asintomático y 1 pool sintomático para cada sitio).

El dendrograma muestra dos grupos principales, uno formado por las muestras L9y15S, R81S, R11S y L9y15A y el otro por las muestras L5y6S, R18S, R18A, R81A, L5y6A y R11A; que a su vez se dividen en subgrupos. Sin embargo, la significación del dendrograma es relativamente baja (Tabla VI-2), correspondiendo los mayores valores de significación al agrupamiento de las muestras (L9y15S y R81S), (L5y6S, R18S y R18A) y (L5y6A y R11A). A diferencia de lo que ocurre con el resto de las muestras, las provenientes del R18S (A y S), presentan buenos niveles de similitud y segregan en los mismos grupos ya sea que el análisis se realice en función del coeficiente de Dice o la correlación de Pearson.

\begin{tabular}{|c|c|c|c|c|}
\hline Nodo & Similitud Promedio & Desvío Estándar & Coeficiente Cofenético & Valor de Bootstrap \\
\hline 1 & 83,9 & 0,00 & 100 & 99 \\
2 & 47,7 & 3,93 & 98 & 28 \\
3 & 40,1 & 7,42 & 94 & 27 \\
4 & 68,8 & 0,00 & 100 & 34 \\
5 & 65,6 & 3,12 & 50 & 46 \\
6 & 48,3 & 5,63 & 90 & 20 \\
7 & 42,1 & 10,45 & 76 & 23 \\
8 & 56,3 & 0,00 & 100 & 44 \\
\hline
\end{tabular}

Tabla VI-2: Valores de significación del dendrograma obtenido para el análisis de la diversidad de la región V3 del gen 16S rRNA en y entre áreas de muestreo (Figura VI-9). Nodos según orden derecha izquierda y arriba abajo. 


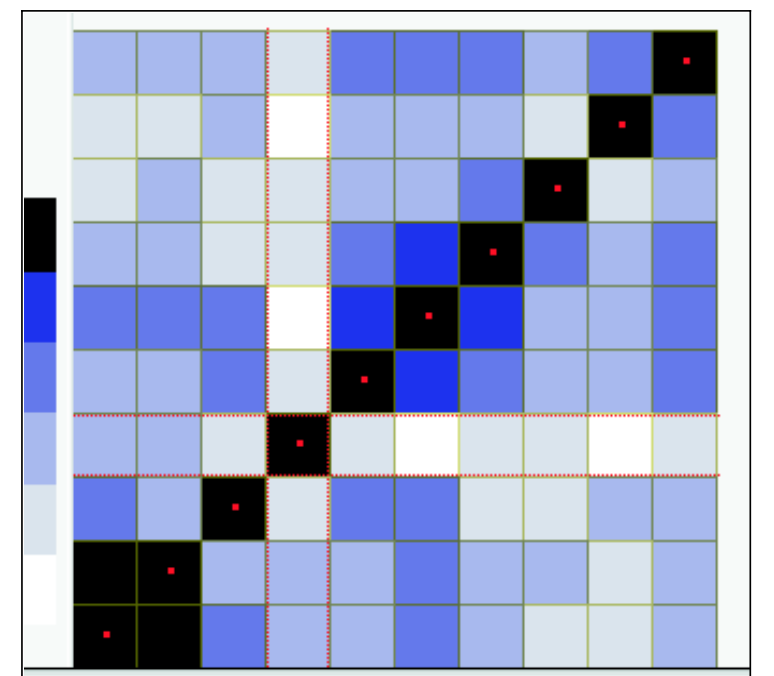

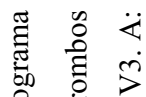

กิ
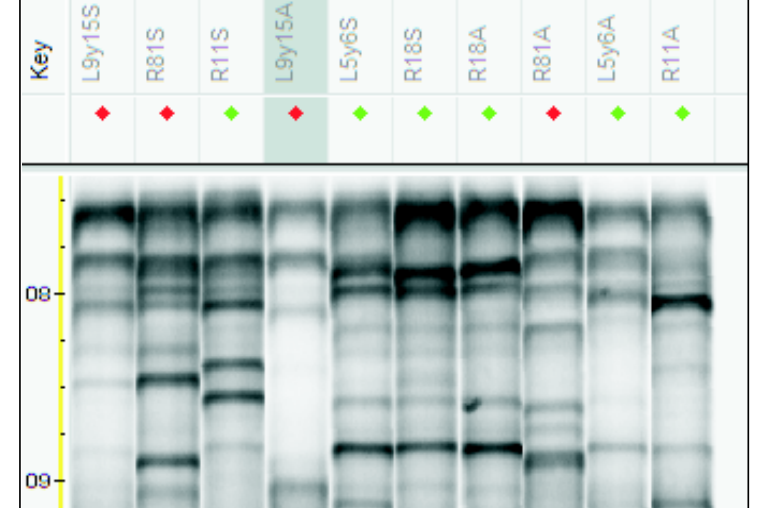

矛

宁 苛

造 :

范

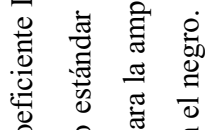

¿

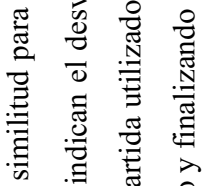

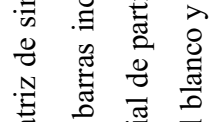

离

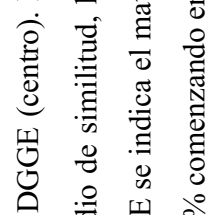

웜

突

寻

䜦

空

总

苛 एँ

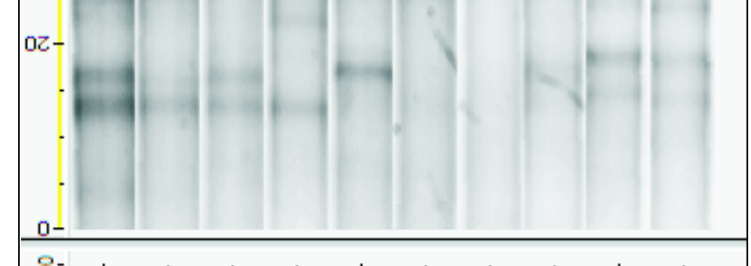

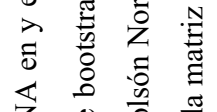

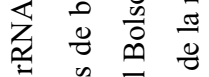

苟

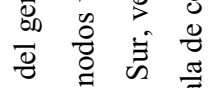

$>$ s

: $\overline{0}$ क

总

च

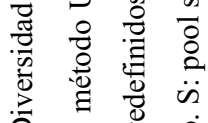

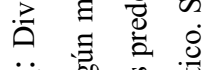

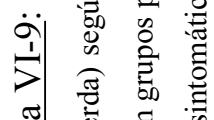

矛苟 
La correlación entre grupos predefinidos en función del estado sanitario (Asintomático, Sintomático) o el origen geográfico de las áreas de muestreo, considerando El Bolsón Norte (L5y6, R11, R18) y El Bolsón Sur (L9y15 y R81), indica que el 90\% de las muestras sintomáticas agrupan de acuerdo a lo esperado, en tanto que el $40 \%$ de las muestras asintomáticas se agrupan. Por otra parte, el $83.3 \%$ de las muestras provenientes de El Bolsón Norte (EB_N) segregan con muestras del Norte y el 75\% de las muestras provenientes de El Bolsón Sur (EB_S) segregan con las muestras del Sur. Estos resultados indican mayor estabilidad en los grupos predefinidos según origen geográfico respecto de los correspondientes al estado sanitario, siendo para estos últimos más estable el grupo sintomático.

\section{4.- CONCLUSIONES}

El trabajo desarrollado en el presente capítulo de tesis permitió establecer la existencia de poblaciones bacterias endógenas en xilema de $A$. chilensis que varían entre individuos dentro y entre sitios de muestreo y concluir que no existen bacterias endógenas de xilema asociadas al mal del ciprés, descartándose el rol de las mismas como agentes causales de la mortalidad.

La variabilidad de las poblaciones bacterianas detectada se estructuró en relación a la procedencia de las muestras empleadas sugiriendo la posible influencia de factores asociados al sitio de muestreo. 


\section{CAPITULO VII}

\section{PATRONES DE CRECIMIENTO Y FACTORES ABIÓTICOS ASOCIADOS AL MAL DEL CIPRÉS}

\section{INTERROGANTES}

¿Existen patrones de crecimiento diferenciales entre individuos sintomáticos $\mathrm{y}$ asintomáticos?

¿Estos patrones diferenciales tienen asociación con alguna variable climática?

\section{HIPÓTESIS Y PREDICCIONES}

- Hipótesis 1: Las condiciones de sitio de pobre drenaje actúan como factores predisponentes para el mal del ciprés mediante un efecto directo de anoxia en el suelo que determina un estrés recurrente y la mortalidad de las raíces, modificando el estado fisiológico del individuo y conduciendo a la defoliación.

1. PREDICCIÓN 1: La acción predisponente del sitio se evidencia en los individuos afectados por mal del ciprés como una caída en el crecimiento radial que es consecuencia del estrés recurrente y la mortalidad de las raíces.

2 .

- Hipótesis 2: Las condiciones de sitio de pobre drenaje actúan como factores predisponentes para el mal del ciprés mediante un efecto indirecto generando las condiciones adecuadas para el desarrollo y la vehiculización de agentes secundarios o un patógeno de suelo que produce la mortalidad de las raíces, modificando el estado fisiológico del individuo y conduciendo a la defoliación.

3. PREDICCIÓN 2: La acción predisponente del sitio se evidencia en los individuos afectados por mal del ciprés como una caída en el crecimiento radial que es consecuencia de la mortalidad de las raíces producida por agentes secundarios o un patógeno de suelo.

- Hipótesis 3: Diferencias en las condiciones de sitio determinan diferencias en la dinámica de crecimiento.

PREDICCIÓN 3: Existen patrones de crecimiento diferenciales entre las áreas Norte y Sur de El Bolsón que determinan la distribución diferencial del mal del ciprés. 



\section{1.- INTRODUCCIÓN}

Las enfermedades de decaimiento de bosques naturales son procesos lentos y progresivos, para los cuales se observa un desfasaje temporal entre el momento del daño y el desarrollo de los síntomas aéreos o la muerte de los individuos. La acción de agentes abióticos, en particular los factores climáticos, ha sido considerada en diferentes procesos de mortalidad actuando como agente primario o afectando la interacción entre el huésped y los agentes bióticos (Pedersen, 1998; Suarez et al., 2004; Dobbertin, 2005; Bigler et al. 2006; Desprez-Loustau et al., 2006; Bigler et al., 2007).

Para el mal del ciprés, existen pocos trabajos que evalúen el desarrollo temporal a nivel de individuo o de bosque (Havrylenko et al., 1989) y gran parte de esta caracterización proviene de observaciones del grado de afectación sobre el conjunto de ejemplares en un sitio (Varsavsky et al. 1975). Loguercio et al. (1998 y 1999a) mediante un estudio comparativo de crecimiento de pares de árboles dominantes con y sin síntomas de mal del ciprés establecieron que existen diferencias en el crecimiento en función del estado sanitario de los individuos.

La formación de anillos anuales en plantas leñosas resulta de la periodicidad estacional de los procesos de crecimiento. Estos anillos presentan algunas características como por ejemplo, la sensibilidad al clima, el rango de cobertura temporal, la alta resolución y la posibilidad de establecer un fechado preciso del año de formación del anillo, que los hacen útiles para estudios temporales retrospectivos. La dendrocronología, que comprende el estudio de la secuencia cronológica de los anillos de crecimiento, ha sido extensamente aplicada para detectar cambios en la tasa de crecimiento en individuos afectados respecto de los no afectados y para establecer la asociación entre dichos cambios y agentes bióticos o abióticos (Veblen et al., 1991; Swetnam y Lynch, 1993; Cherubini et al., 2002; Bergeron et al., 2002; Krause et al., 2003; Marçais y Bréda, 2006; Bréda y Badeau, 2008).

En el caso del mal del ciprés la dendrocronología se empleó para analizar la influencia del clima en el desarrollo temporal (Calí, 1996) y el impacto del mal del ciprés en la dinámica de los bosques de A. chilensis (Amoroso, 2009). Estos estudios permitieron establecer:

- la existencia de diferencias en el patrón de ancho de anillos de crecimiento entre árboles asintomáticos y sintomáticos

- la caída en el crecimiento radial (síntoma interno) que comienza varios años antes que la sintomatología de la copa (amarillamiento y defoliación)

- la distribución de los individuos afectados en relación a cursos de agua. 
La correlación entre el inicio de la caída en el crecimiento radial y las variables climáticas presenta resultados ambiguos. En un estudio la correlación se comprobó sólo en una de las dos parcelas evaluadas proponiéndose un posible efecto disparador de la mortalidad para eventos climáticos cálidos-secos (Calí, 1996), en tanto que en el otro la caída en el crecimiento radial sería impredecible en el tiempo (Amoroso, 2009). Sin embargo, en este último caso, el análisis se efectuó entre árboles clasificados por estado sanitario o posición sociológica (Amoroso, 2009). La combinación de ambos factores no fue considerada por lo cual es difícil determinar qué porcentaje de la mortalidad es debida al mal del ciprés y cuánto a la competencia intraespecífica. La falta de discriminación en el origen de la mortalidad (mal del ciprés o competencia) podría condicionar la detección de la fecha exacta del inicio del mal del ciprés en un sitio y/o dificultar el análisis de correlación entre la caída en la tasa de crecimiento y diversos eventos climáticos.

La existencia de un patrón ecológico asociado con el mal del ciprés (Baccalá et al., 1998), la acción disparadora propuesta para los eventos climáticos cálidos-secos en relación con el inicio de la caída en la tasa de crecimiento radial (Calí, 1996) y el aislamiento desde suelos y cursos de agua en bosques de $A$. chilensis de diferentes especies fúngicas que podrían actuar como agentes secundarios (Rajchenberg y Cwielong, 1993; Rajchenberg et al., 1997; Greslebin et al., 2005) sentaron las bases para considerar al mal del ciprés dentro del grupo de las enfermedades de declinamiento. Por otra parte, el aislamiento de la especie patogénica Phytophthora austrocedrae, un hongo acuático que requiere condiciones de sitio similares a las determinadas para el desarrollo de la mortalidad, llevó a proponer a esta especie como el agente causal del mal del ciprés. En este modelo la asociación entre la mortalidad y las condiciones de sitio se interpreta en términos de un efecto predisponente indirecto. Sin embargo, hasta el momento ninguno de los modelos ha sido probado en forma completa para el mal del ciprés, y por tanto, es necesario establecer el rol de los factores abióticos ya sea que determinen una afectación directa de las plantas o condiciones ideales para el establecimiento de un agente secundario o un patógeno.

Este tipo de estudio se dificulta en sistemas biológicos complejos como los bosques naturales que están sometidos a diversas condiciones de estrés. Para ello es imprescindible contar con métodos de muestreo robustos que provean mínima variabilidad de los factores no analizados. En este sentido, el muestreo pareado aplicado en el presente trabajo de tesis constituye un sistema de estudio clave no sólo para determinar el rol de los factores abióticos en el mal del ciprés sino para confrontar estos resultados con los obtenidos en relación a los agentes bióticos y a la variabilidad genética. 
Por tal motivo, y considerando la utilidad de la dendrocronología en este tipo de estudios, se estableció un trabajo en colaboración (Mundo et al., Anexo 11) para analizar cada uno de los individuos de los 50 pares de plantas seleccionados por su fenotipo para mal del ciprés (Capitulo II ). Los objetivos principales de este trabajo fueron:

○ analizar el patrón de crecimiento radial de árboles sintomáticos y asintomáticos a fin de validar el muestreo pareado

- determinar la fecha en que los patrones de crecimiento de árboles con y sin síntomas se diferencian

○ y evaluar la relación entre la fecha de separación y registros climáticos históricos.

Los datos generados en este trabajo en colaboración fueron posteriormente empleados para analizar el efecto predisponente del sitio tanto en su acción directa como indirecta. Las siguientes hipótesis fueron evaluadas:

- HiPótesis 1: Las condiciones de sitio de pobre drenaje actúan como factores predisponentes para el mal del ciprés mediante un efecto directo de anoxia en el suelo que determina un estrés recurrente y la mortalidad de las raíces, modificando el estado fisiológico del individuo y conduciendo a la defoliación.

PREDICCIÓN 1: La acción predisponente del sitio se evidencia en los individuos afectados por mal del ciprés como una caída en el crecimiento radial que es consecuencia del estrés recurrente y la mortalidad de las raíces.

- Hipótesis 2: Las condiciones de sitio de pobre drenaje actúan como factores predisponentes para el mal del ciprés mediante un efecto indirecto generando las condiciones adecuadas para el desarrollo y la vehiculización de agentes secundarios o un patógeno de suelo que produce la mortalidad de las raíces, modificando el estado fisiológico del individuo y conduciendo a la defoliación.

PREDICCIÓN 2: La acción predisponente del sitio se evidencia en los individuos afectados por mal del ciprés como una caída en el crecimiento radial que es consecuencia de la mortalidad de las raíces producida por agentes secundarios o un patógeno de suelo. 
Los bosques de $A$. chilensis del área de estudio corresponden a bosques mésicos fuertemente afectados por los incendios de principio de siglo pasado generados para habilitar tierras para pastoreo y agricultura (Willis, 1914). Sin embargo, esta condición de origen postfuego no implica necesariamente que los bosques tengan estructuras y dinámicas similares. Después de un disturbio por fuego, el establecimiento de $A$. chilensis se inicia en la proximidad de individuos femeninos remanentes en las áreas donde la intensidad del incendio fue menor (Gobbi y Sancholuz, 1992), pero depende de las condiciones del sitio siendo rápida en los sitios húmedos y mésicos, y más lenta en los xéricos (Veblen et al., 1995). La probabilidad de establecimiento se ve disminuida debido a que el fuego elimina la hojarasca y el banco de semillas. La cobertura del sotobosque luego de un incendio, se recupera lentamente, siendo mayor en los sitios más intensamente afectados (Urretavizcaya y Defossé, 2004). Esta recuperación, y su efecto nodriza, permite la recolonización de las áreas incendiadas. La alta temperatura del suelo que se observa en sitios parcial o completamente quemados tendría un efecto negativo sobre el establecimiento de las plántulas, especialmente en los sitios xéricos. Por el contrario el contenido de humedad del suelo es mayor en los sitios con grado medio de afectación, probablemente gracias al efecto protector de la cobertura de plantas, y no parece afectar el establecimiento (Urretavizcaya y Defossé, 2004).

Los patrones de regeneración de $A$. chilensis varían en función de las características del sitio y de las especies asociadas (Urretavizcacha y Defossé, 2004; Rovere et al., 2005; Veblen et al., 2005, Urretavizcacha et al., 2006). La dinámica de crecimiento difiere en relación a las características edáficas y estructurales entre sitios, las primeras condicionan los procesos de colonización y desarrollo estructural y éstos influyen en los patrones de crecimiento ligados a la competencia (Goya et al., 1998). En este sentido, Goya et al., (2005) reportan 3 sitios pertenecientes a un área de la Reserva Forestal LMRA quemada y desmotada a fines del siglo pasado con distribución de clases diamétricas marcadamente diferentes, valores similares de área basal, volumen total y biomasa, y diferencias en abundancia, altura dominante y volumen comercial. Debido a que los sitios presentan similares condiciones topográficas y edáficas, indican que las diferencias se originarían en los procesos de colonización, tasas de crecimiento individual y competencia en el rodal (Ferrando, 1997). El análisis de series de ancho de anillos de crecimiento en rodales de similar estructura muestra patrones bien diferenciados que reflejan el crecimiento de los individuos en condiciones diferentes de competencia y el impacto de la variación en las características del sitio en el establecimiento y el desarrollo posterior (Goya et al., 1998). 
Considerando las diferencias reportadas en las características de sitio (profundidad del suelo y pendiente) entre el área Norte y Sur de la región de El Bolsón y el impacto de las mismas en el establecimiento y el crecimiento de los individuos en bosques afectados masivamente por incendios, es posible plantear la existencia de una dinámica diferencial entre las áreas Norte y Sur que determine la mayor incidencia del mal del ciprés en el Sur.

Por tanto, los datos de crecimiento radial establecidos en el trabajo en colaboración, para cada uno de los individuos muestreados, se emplearon para evaluar la siguiente hipótesis:

- Hipótesis 3: Diferencias en las condiciones de sitio determinan diferencias en la dinámica de crecimiento.

PREDICCIÓN 3: Existen patrones de crecimiento diferenciales entre las áreas Norte y Sur de El Bolsón que determinan la distribución diferencial del mal del ciprés.

\section{2.- MATERIALES Y MÉTODOS}

\section{1.- CRECIMIENTO RADIAL DE INDIVIDUOS SINTOMÁTICOS Y ASINTOMÁTICOS PARA MAL DEL CIPRÉS Y ASOCIACIÓN CON CLIMA}

Los individuos de los 50 pares de plantas seleccionados por su fenotipo para mal del ciprés (Capitulo II ) se caracterizaron mediante técnicas dendrocronológicas. La metodología aplicada se presenta en Mundo et al. (Anexo 11).

\section{2.- ANÁLISIS DEL EFECTO PREDISPONENTE DEL SITIO}

El efecto predisponente del sitio, en su acción directa o indirecta, se analizó contrastando los patrones de crecimiento radial obtenidos para los individuos sintomáticos y asintomáticos respecto de los patrones de crecimiento esperados en función de las hipótesis planteadas.

\section{3.- CARACTERIZACIÓN DE PATRONES DE CRECIMIENTO DE ÁREAS CON MAYOR Y MENOR INCIDENCIA DEL MAL DEL CIPRÉS}

Los datos de ancho de anillos de crecimiento y sus respectivos índices, para cada uno de los individuos muestreados, se promediaron en función del origen geográfico de los individuos y se emplearon en el análisis de los patrones de crecimiento entre el área Norte (EB_N) y Sur (EB_S) de El Bolsón. El impacto diferencial de la sequía entre áreas se evalúo comparando los valores promedio de crecimiento antes y luego del evento de sequía. 


\section{3.- RESULTADOS Y DISCUSIÓN}

\section{1.- CRECIMIENTO RADIAL DE INDIVIDUOS SINTOMÁTICOS Y ASINTOMÁTICOS PARA MAL DEL CIPRÉS Y ASOCIACIÓN CON CLIMA}

Los resultados principales del trabajo en colaboración se presentan a continuación, el trabajo completo puede consultarse en el Anexo 11.

El análisis comparativo de las cronologías de crecimiento promedio y la correlación con los registros climáticos permitió establecer la existencia de diferencias significativas en los patrones de crecimiento entre árboles con y sin síntomas y una fuerte asociación con eventos climáticos extremos (sequías). En la Figura VII-1 A se presentan los resultados obtenidos para la región de El Bolsón, observándose la separación de las cronologías promedio luego del año 1944. Esta separación de las cronologías entre árboles sintomáticos y asintomáticos se corresponde con lo reportado previamente por Calí (1996), Loguercio et al. (1998, 1999a) y Amoroso (2009). Sin embargo, más que la separación de las cronologías promedio lo que se observa es una inversión de los patrones de crecimiento, como puede verse claramente en la Figura VII-1 B en función de la diferencia del índice de crecimiento promedio entre árboles sintomáticos y asintomáticos. La diferencia es positiva antes del período de cruce (en este caso 1944) y negativa luego del mismo. Esta inversión, a pesar no de ser analizada o considerada, está presente en los trabajos de Calí (1996) y Loguercio et al. (1998, 1999a), indicando por tanto un registro común en los patrones de crecimiento de plantas con y sin síntomas de mal del ciprés. La falta de discriminación en el origen de la mortalidad (mal del ciprés o competencia) podría explicar la ausencia de inversión en el trabajo de Amoroso (2009), donde únicamente se reporta una separación de los patrones de crecimiento debido a una caída en el crecimiento de los individuos sintomáticos.

En el análisis para cada uno de los sitios de muestreo se detectó la inversión de las curvas estando las fechas de cruce asociadas a eventos de sequía (Mundo et al., Anexo 11). La inversión de las curvas se detectó en las siguientes fechas : 1932 (L5y6), 1943 (R18), 1944 (R11) y 1963 (R81 y L9y15). En el caso del L5y6 si bien el cruce de las cronologías se produce en el año 1932, las diferencias son claramente negativas y continuas a partir del año 1943. A diferencia de lo reportado en trabajos anteriores, la asociación de los eventos de sequía con el inicio de la caída en la tasa de crecimiento de los individuos sintomáticos fue clara y significativa (Mundo et al., Anexo 11), sugiriendo que la selección de individuos según un muestreo pareado representa la mejor condición para evaluar el impacto del clima y los patrones de crecimiento en relación con el mal del ciprés, limitando la influencia de la competencia en el desarrollo de los individuos. 


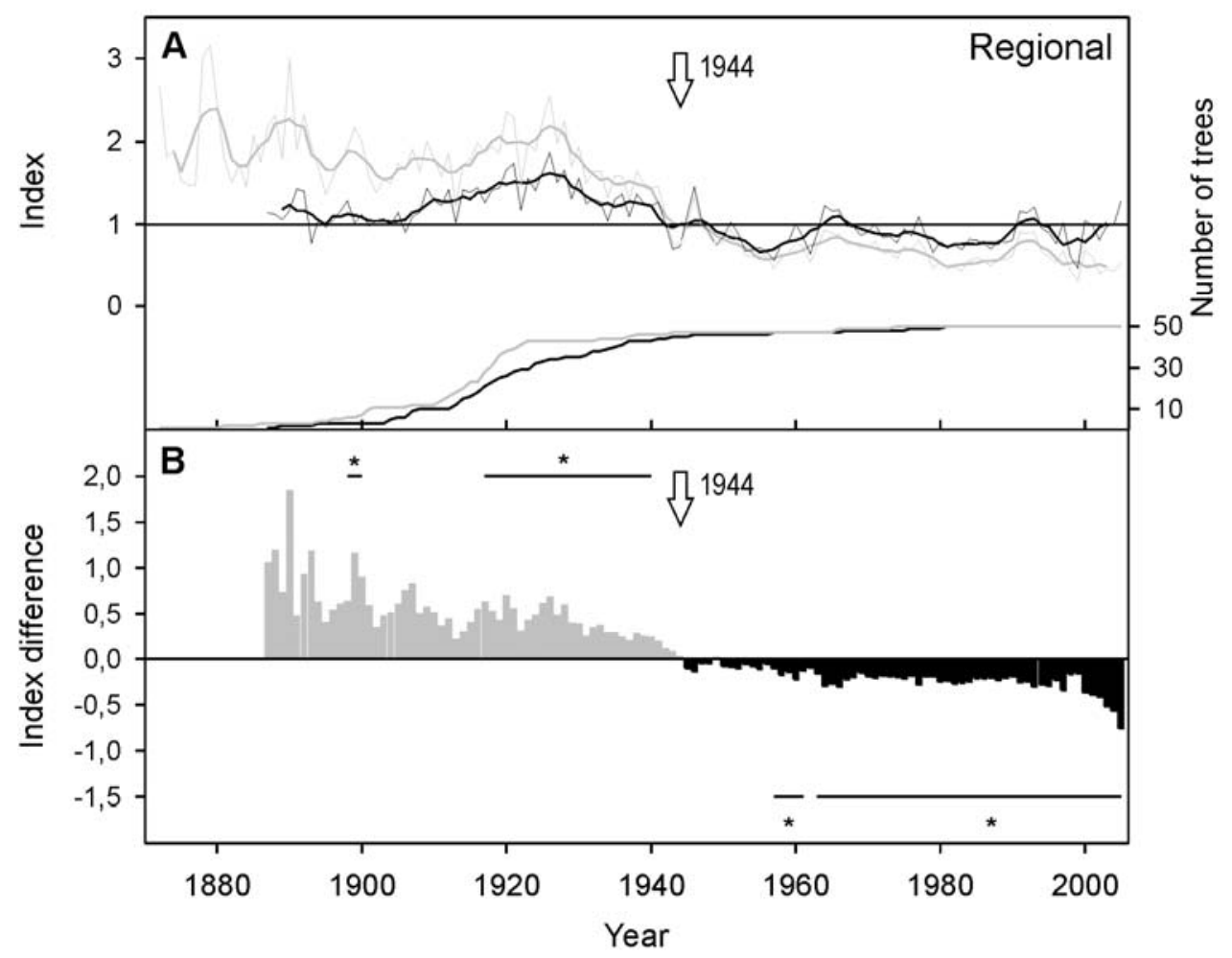

Figura VII-1: Cronologías promedio de árboles sintomáticos y asintomáticos para la región de El Bolsón. A) Cronologías promedio de índice de anillos de crecimiento de árboles sintomáticos (gris) y asintomáticos (negro) y tamaño de muestra para cada año. Se presentan además las curvas medias móviles de a 5 años a fin de determinar en forma más clara la fecha de separación de las cronologías, las flechas indican la intersección. B) Diferencias entre los índices de anillo de crecimiento entre cronologías para cada año. Las líneas horizontales con asteriscos indican períodos en que las diferencias son estadísticamente significativas $(\mathrm{p}<0.05)$ según análisis t-pareado. (Tomado de Mundo et al., Anexo 11).

En resumen, los resultados muestran un patrón común de mayor susceptibilidad a la sequía de los árboles con mayor ancho de anillo de crecimiento y una separación de los sitios de muestreo, en función del evento de sequía que determina la inversión de las cronologías, que coincide con las anteriormente establecidas en el presente trabajo de tesis.

La separación Norte-Sur de los sitios de muestreo en El Bolsón está, por tanto, definida en base a tres análisis diferentes:

- análisis genético vía RGA

- caracterización de las poblaciones bacterianas de xilema por DGGE

- análisis de los patrones de crecimiento radial mediante dendrocronología.

Los datos aportados refuerzan la necesidad de evaluar las diferencias en los patrones de crecimientos entre el área Norte y Sur de El Bolsón. 


\section{2.- ANÁLISIS DEL EFECTO PREDISPONENTE DEL SITIO}

Los resultados obtenidos en el análisis de pares permiten analizar la asociación entre el déficit de drenaje y el mal del ciprés. Bajo las hipótesis planteadas el efecto predisponente del sitio, ya sea a través de la anoxia del suelo (efecto directo) o por la acción de agentes secundarios o patógenos (efecto indirecto), afectaría el sistema de raíces debilitando al árbol y conduciendo al desarrollo de los síntomas aéreos. La destrucción de raíces, determina un menor aporte de agua a las hojas, lo que conduce a defoliación y a una menor producción de fotosintetatos. En estas condiciones las plantas derivan recursos a la reposición de raíces, limitando el crecimiento secundario. Por tanto, en ambos casos, debería observarse una caída en la tasa de crecimiento en los árboles afectados por mal del ciprés.

El efecto predisponente del déficit de drenaje debido al debilitamiento del estado fisiológico del árbol por estrés recurrente (La Manna, 2004) propuesto para explicar la asociación entre características de micrositio y mal del ciprés, se contradice con los resultados del análisis de las cronologías de crecimiento promedio de árboles sintomáticos y asintomáticos reportado en el presente trabajo. Siendo la condición de micrositio una característica que no depende del evento de sequía, su efecto debería evidenciarse tanto antes como después de un proceso climático extremo. Sin embargo, los individuos afectados por la sequía son los de mejor estado fisiológico, es decir no evidencian ningún efecto negativo de las condiciones de sitio y presentan mayor ancho de anillo de crecimiento.

Una explicación alternativa propuesta para el efecto predisponente del déficit de drenaje es su acción indirecta, según la cual el mayor contenido de agua propicia el desarrollo de microorganismos patógenos u oportunistas (La Manna, 2004). La idea de una acción indirecta de las condiciones de micrositio, se consolidó con el aislamiento de $P$. austrocedrae, que requiere agua para su dispersión. Asumiendo que $P$. austrocedrae fuera el agente causal del mal del ciprés (Greslebin y Hansen, 2007a y b), la afectación de las raíces debería conducir a una caída en el ancho del anillo de crecimiento. Esta disminución debería detectarse en los individuos sintomáticos independientemente de la acción de eventos climáticos extremos. Esto se contradice también con los resultados del análisis de cronologías de crecimiento promedio de árboles sintomáticos y asintomáticos reportado en el presente trabajo. Si bien la acción de una sequía extrema podría potenciar la caída de crecimiento en árboles previamente afectados por P. austrocedrae, estos individuos deberían tener una caída previa de su tasa de crecimiento. Sin embargo, los resultados obtenidos muestran que los árboles con síntomas sólo presentan caída en la tasa de crecimiento luego de la sequía, descartando la acción de P. austrocedrae como 
agente causal del mal del ciprés. Este análisis verifica de forma independiente los resultados presentados en relación al rol de $P$. austrocedrae en el mal del ciprés (Capitulo IV).

La acción contribuyente de microorganismos oportunistas y de la propia $P$. austrocedrae en el debilitamiento de individuos previamente afectados por la sequía es esperable debido a que en condiciones de menor asimilación de carbono, se produce una distribución preferencial al crecimiento primario y se limita la síntesis de compuestos secundarios basados en carbono entre los cuales se encuentran algunos de los metabolitos de defensa (Jönsson, 2006). Sin embargo, nuevas investigaciones serán necesarias a fin de poder establecer el impacto de las variaciones climáticas de alta y baja frecuencia en el desarrollo de los propios microorganismos. Tres tipos de interacción sequía-patógenos pueden ser planteadas: un efecto directo de la sequía en el patógeno, un efecto indirecto mediado por cambios en las interacciones dentro de la comunidad de microorganismos y un efecto en la interacción mediado por cambios fisiológicos en el huésped (Desprez-Lousteau et al., 2006). El balance entre estos diferentes mecanismos determinará el impacto final de los microorganismos en un individuo debilitado.

Es importante resaltar, sin embargo, que la mortalidad de $A$. chilensis por efecto de la sequía se produce independientemente de la acción de microorganismos secundarios, como se evidencia en la ausencia de lesiones necróticas o pudriciones en árboles con síntomas de mal del ciprés (Capitulo IV) y en la detección de mortalidad episódica asociada a sequías extremas en sitios xéricos (Villalba y Veblen, 1998).

En resumen, los datos aportados indican que la asociación entre el déficit de drenaje y el mal del ciprés no está determinada por ninguno de los mecanismos propuestos para el efecto predisponente del sitio, sugiriendo que otra causa aún no establecida es la responsable de dicha asociación. Esto descarta al modelo de declinamiento propuesto para el mal del ciprés en el cual se contempla a los eventos cálidos-secos como factores disparadores, la condición de sitio como factor predisponente y los agentes secundarios como factores contribuyentes.

\section{3.- CARACTERIZACIÓN DE PATRONES DE CRECIMIENTO DE ÁREAS CON MAYOR Y MENOR INCIDENCIA DEL MAL DEL CIPRÉS}

El análisis de las cronologías del área Norte y Sur de El Bolsón, es útil para evaluar diferencias en los patrones de crecimiento que pudieran asociarse a las condiciones de sitio y/o a los procesos de establecimiento posteriores a los incendios masivos de principios de siglo pasado. En ambas áreas el reclutamiento de individuos comienza aproximadamente en la misma época y 
sigue una tendencia similar (Figura VII-2 A, B), por lo que las diferencias en las condiciones de sitio entre el Norte y el Sur de El Bolsón no determinan una diferencia en el patrón de establecimiento. La mayor incidencia del mal del ciprés en el área Sur no puede por tanto ser explicada en función de diferencias en el patrón de establecimiento que determinen una mayor susceptibilidad.
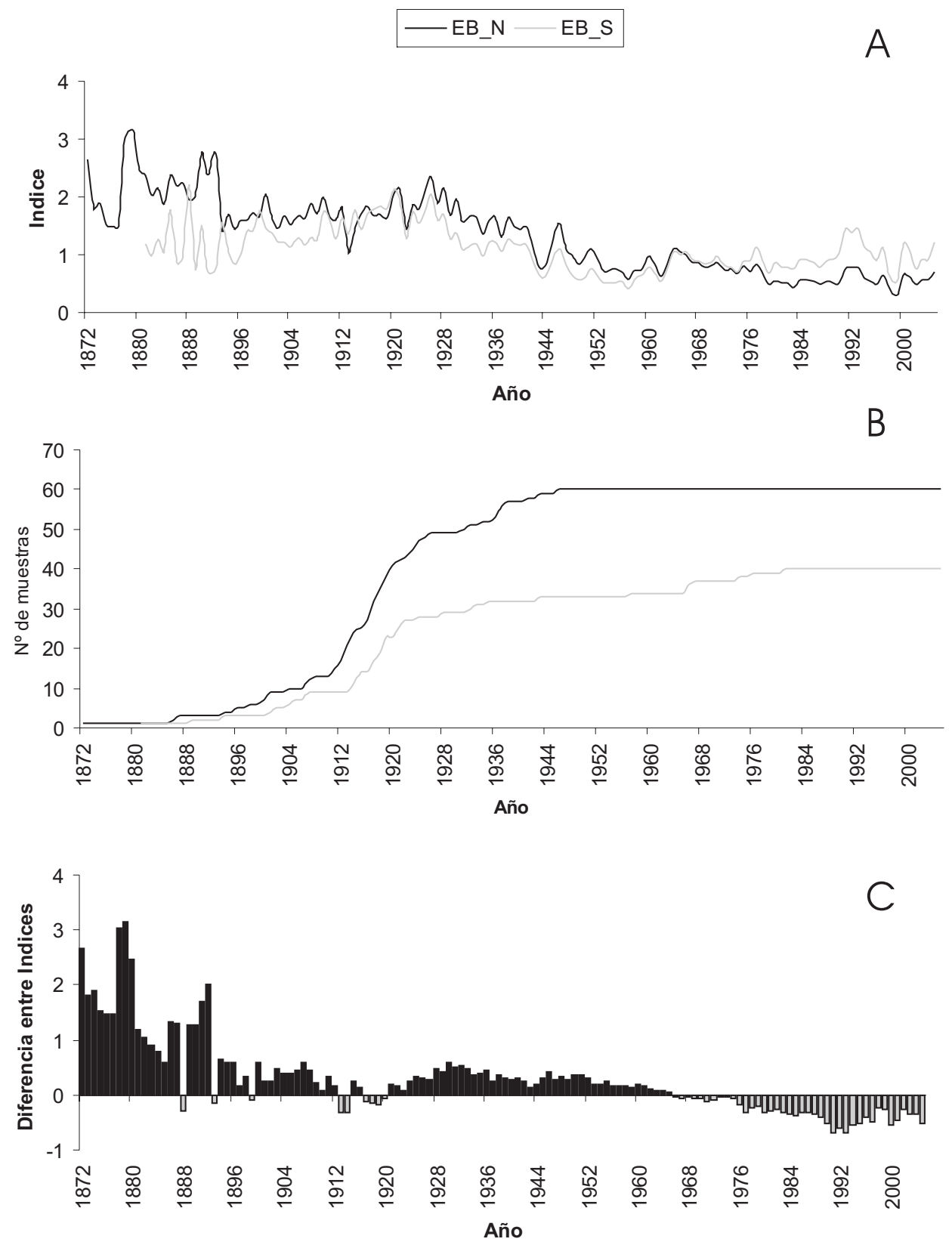

Figura VII-2: Cronologías de crecimiento promedio para el área Norte y Sur de El Bolsón. A: Cronologías promedio del índice de anillos de crecimiento para el área EB_N (negro) y EB_S (gris). B: Tamaño de muestra para cada año. C: Diferencia entre la cronología promedio del índice de anillo de crecimiento de EB_N y EB_S. 
Los resultados obtenidos muestran además que, si bien se observa una tendencia de crecimiento homogéneo en la región, existen algunas diferencias puntuales. El crecimiento promedio para EB_N es superior al de EB_S hasta el año 1963 en que se aproximan. Posteriormente las curvas de crecimiento se invierten siendo mayor el crecimiento para EB_S que para EB_N (Figura VII-2 A, C). EB_N evidencia un patrón caracterizado por buen crecimiento inicial que cae con el tiempo (Figura VII-2) y manifiesta una falta de respuesta a la mejora de las condiciones climáticas que comienza alrededor de 1963 y prevalece al menos por 10 años (Villalba y Veblen, 1997; Villalba y Veblen, 1998). EB_S presenta un crecimiento inicial algo más limitado, pero evidencia un incremento del crecimiento desde mediados de la década de 1960. Este aumento podría indicar una respuesta al período más húmedo y frío anteriormente señalado; sin embargo, la tendencia continúa durante la década de 1980 correspondiente a un período regional cálido y seco (Villalba y Veblen, 1997; Villalba y Veblen, 1998).

El análisis de los crecimientos promedio antes y después de dos sequías importantes en el área de estudio: 1942-1943, 1962 es útil para detectar respuestas diferenciales ante un mismo evento de sequía entre las áreas Norte y Sur. Aunque otros eventos de sequía se detectaron para la región (Mundo et al., Anexo 11) la elección de estos eventos en particular se basa en que la mayor frecuencia de sequías en las últimas décadas hace difícil comparar valores promedio entre períodos cortos de tiempo. En general después de un evento de sequía se observa un pulso positivo de crecimiento que luego se estabiliza alrededor de un valor medio (Figuras VII-1 y VII-2). Cuando los eventos extremos se producen en alta frecuencia no se alcanza el período necesario de estabilización. Por otra parte, el bajo número de muestras antes del año 1920 hace difícil el análisis para las sequías detectadas a principio del siglo pasado. El impacto de un evento de sequía puede evaluarse a través de la diferencia relativa en el crecimiento promedio antes y después del evento climático. La sequía de 1942-1943 tuvo en términos generales similar impacto en ambas regiones (Gráfico VII-1) con caídas del índice de crecimiento cercanas al 50\%. La respuesta a la sequía de 1962, tuvo efectos diferentes (Gráfico VII-1), para EB_N la caída en el índice de crecimiento fue del orden del $8 \%$, en tanto que para EB_S no se observó una caída en el índice del crecimiento sino un aumento del orden del 38\%. Estos resultados muestran variaciones en la respuesta a las condiciones climáticas extremas entre áreas. La diferencia Norte-Sur detectada en la manifestación y la intensidad de los eventos de mortalidad a lo largo del ecotono se asoció a variaciones en la intensidad de las condiciones climáticas cálidas y secas (Villalba y Veblen, 1998), si bien no es posible descartar variaciones de microclima dentro del área de El Bolsón que determinen un mayor o menor impacto de la sequía entre sitios, es poco probable que estas diferencias sean las únicas responsables del patrón establecido. 


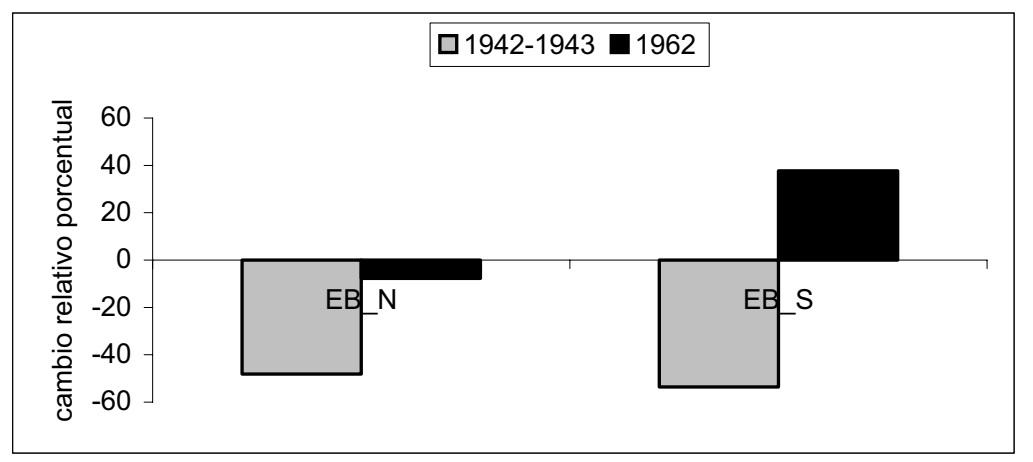

Gráfico VII-1: Cambio relativo en el crecimiento promedio correspondiente a los períodos entre los eventos de sequía extremos de 1942-1943, 1962.

El análisis de los patrones de crecimiento permitió verificar diferencias en la dinámica de crecimiento entre áreas, sin embargo estas diferencias no responden a lo esperado en función de las condiciones de sitio. Esto es, el área Sur con suelos más profundos y menores pendientes presenta crecimientos iniciales ligeramente menores que el área Norte con suelos menos profundos, afloramientos rocosos y mayores pendientes. Considerando que el aumento del crecimiento en EB_S, se da a continuación del momento de inversión de curvas (1963) detectado en el análisis diferencial entre individuos sintomáticos y asintomáticos para mal del ciprés, la liberación posterior del crecimiento podría ser consecuencia de la mortalidad de un gran número de individuos. Esta idea se corresponde con el mayor reporte de mal del ciprés en el Sur de El Bolsón y permite explicar el patrón de crecimiento observado para EB_S. La discrepancia entre las condiciones de sitio y el patrón de crecimiento podría ser explicada considerando que los individuos muestreados en el área Sur corresponden a individuos inicialmente oprimidos en su crecimiento. Los árboles que durante los primeros períodos de desarrollo del bosque dominaron el lugar no estarían actualmente presentes porque murieron a causa del mal del ciprés, liberando recursos y permitiendo el desarrollo de los individuos oprimidos. Esta interpretación es coherente con los resultados obtenidos del análisis de los patrones de crecimiento de árboles sintomáticos y asintomáticos para mal del ciprés que indica que los individuos de mayor crecimiento presentan mayor susceptibilidad a la sequía, la cual se asocia al inicio de la caída en la tasa de crecimiento y posterior mortalidad.

Tomados en conjunto los resultados muestran que las condiciones de sitio no determinaron un establecimiento diferencial entre las áreas, y que los patrones de crecimiento detectados responden a la mayor presencia de mal del ciprés en el área Sur de El Bolsón. Sin embargo, no es posible aún explicar cuál es la razón que determina la mayor presencia de mal del ciprés en sitios con suelos profundos y pendientes limitadas. 


\section{4.- CONCLUSIONES}

Los datos aportados en el presente capitulo de la tesis indican que el muestreo pareado resultó adecuado, y superior a otras metodologías aplicadas, para analizar los patrones de crecimiento de individuos sintomáticos, determinar la relación entre el clima y el mal del ciprés, y evaluar el efecto predisponente del sitio. Los resultados permiten concluir que:

- Existen patrones de crecimiento diferenciales entre individuos asintomáticos y sintomáticos para mal del ciprés.

- Los individuos sintomáticos presentan crecimientos radiales superiores a los de los individuos asintomáticos antes del evento de sequía que determina el inicio de la afectación por mal del ciprés.

○ Los individuos sintomáticos muestra mayor susceptibilidad a eventos extremos de sequía que los individuos asintomáticos.

- La asociación entre el déficit de drenaje y el mal del ciprés no puede ser explicada por ninguno de los mecanismos propuesto, hasta el momento, para el efecto predisponente del sitio.

Es importante destacar que la susceptibilidad diferencial de los individuos sintomáticos se corresponde con la determinada previamente, y de manera independiente, mediante la caracterización genética vía RGA (Capitulo III). Esta confirmación de resultados sugiere que en la mayor susceptibilidad de los individuos sintomáticos a la sequía se debe buscar la explicación al origen del mal del ciprés, y que los marcadores RGA candidatos podrían estar funcionalmente ligados a la respuesta al estrés hídrico. 



\section{CAPITULO VIII}

\section{SUSCEPTIBILIDAD DIFERENCIAL AL MAL DEL CIPRÉS ENTRE INDIVIDUOS FEMENINOS Y MASCULINOS DE $A$. CHILENSIS}

\section{INTERROGANTES}

¿Son los individuos femeninos de A. chilensis más afectados que los individuos masculinos por el mal del ciprés?

¿Existen patrones de crecimiento diferenciales entre individuos femeninos y masculinos?

\section{HIPÓTESIS Y PREDICCIONES}

○ Hipótesis 1: Los individuos femeninos de A. chilensis son más sensibles al estrés hídrico.

PREDICCIÓN 1: Los individuos femeninos de A. chilensis son afectados con mayor frecuencia por el mal del ciprés.

○ HiPótesis 2: El mal del ciprés afecta mayoritariamente a individuos femeninos de la especie A. chilensis.

PREDICCIÓN 2: Los individuos femeninos y masculinos de A. chilensis se diferencian en sus patrones de ancho de anillos de crecimiento. 



\section{1.- INTRODUCCIÓN}

Austrocedrus chilensis es una especie dioica, esto es con sexos separados (Figura VIII-1). Los conos masculinos son amentiformes, cilíndricos y formados generalmente por 5 pares de brácteas; en tanto, que los femeninos son leñosos, ovoides, de color castaño, de 8-15 x 5-8 mm, compuestos por 4 escamas coriáceas (brácteas) opuestas (Grosfeld, 2002). Las semillas son ovoides, con un ala membranácea unilateral, obtusa, de 6-8 $\mathrm{mm}$ y se ubican dentro de las brácteas superiores fértiles (Grosfeld, 2002). Existen reportes contradictorios en relación a la edad reproductiva mínima. Rovere (2000) señala que no existen diferencias entre sexos y que la madurez sexual se daría entre los 15-20 años. En tanto que Grosfeld (2002) indica que la edad reproductiva mínima varía entre 20 y 35 años para los individuos femeninos; y que los individuos masculinos comienzan a producir estructuras reproductivas a una edad mínima de 45 años.

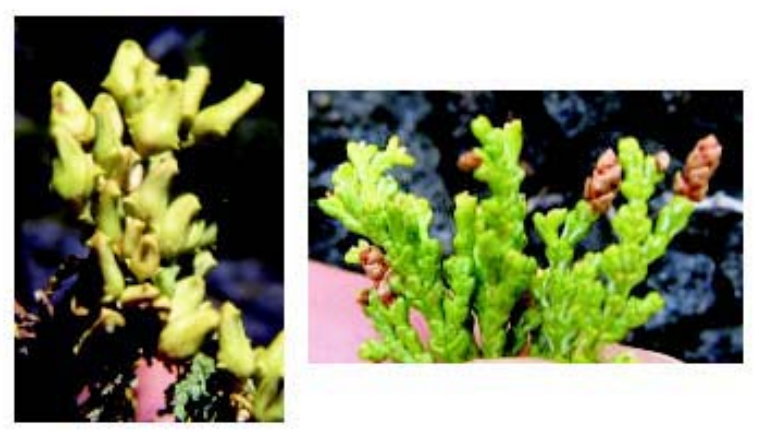

Figura VIII-1: Conos masculinos (izquierda) y femeninos (derecha) de Austrocedrus chilensis. Fotos: Darian Stark y Carlos Le Quesne.

El ciclo completo para la producción de semillas se produce en el curso de un año, con la diferenciación de estróbilos femeninos y masculinos en otoño, la floración, polinización y fecundación en primavera, la formación y maduración del fruto entre primavera y verano, y la diseminación de las semillas en verano (Donoso et al., 2006). La producción de semillas es variable con años de alta producción seguidos por años de generación casi nula, y variación de la producción entre sitios durante el mismo año (Donoso et al., 2006). La producción de semillas totales (viables y no viables) es variable entre tipos forestales, disminuye desde los bosques puros densos hacia los bosques puros ralos, y es menor en los bosques mixtos (Rovere et al., 2005). Entre sexos la frecuencia de eventos reproductivos es similar, en tanto que la magnitud de cada evento podría variar con el sexo y las condiciones de sitio (Rovere y Le Quesne, 2005). 
El costo reproductivo varía entre sexos, siendo mayor el número de estructuras reproductivas para los individuos masculinos pero con una inversión en biomasa y nitrógeno menor que la de los femeninos (Rovere, 2000). En promedio, los árboles femeninos presentan un alto costo reproductivo, asignando entre 4-25 veces más biomasa que los árboles masculinos (Rovere, 2000). Se han reportado dos formas de compensación del costo reproductivo, la fotosíntesis de las estructuras reproductivas femeninas y la distribución espacial diferencial de sexos (Rovere y Le Quesne, 2005). Estudios de ecofisiología diferencial entre sexos muestran que los conos femeninos son fotosintéticos, aunque presentan menor tasa de fotosíntesis neta que las hojas, valores más altos de conductancia estomática y disposición más superficial de los estomas. Estas características sugieren que los individuos femeninos mitigan parcialmente el mayor costo reproductivo mediante fotosíntesis en los conos, pero a expensas de un aumento en el costo hídrico (Nuñez y Rovere, 2003; Rovere y Le Quesne, 2005; Nuñez y Rovere, 2005). La segregación espacial entre sexos indica que los individuos femeninos ocupan preferentemente las laderas S-SE (más húmedas, frescas y con menor irradiación) y los masculinos las laderas N-NO (más cálidas, secas y con mayor irradiación) (Nuñez et al., 2008).

La fructificación en relación al mal del ciprés está escasamente estudiada reportándose en algunos casos intensa fructificación o producción de semillas antes de la muerte del individuo (Hranilovich, 1988; Rajchenberg et al., 1997). A pesar de que no existe un acuerdo general sobre su inclusión en el conjunto de síntomas del mal del ciprés (Havrylenko et al., 1989, Rosso, 1989) es una manifestación externa frecuentemente empleada por Guardaparques o habitantes de zonas cercanas a bosques de $A$. chilensis para identificar individuos afectados por mal del ciprés. Este reporte de fructificación sugiere, indirectamente, una mayor incidencia del mal del ciprés sobre individuos femeninos no habiéndose determinado hasta el momento si existe una susceptibilidad diferencial entre sexos.

Considerando que todos los modelos etiológicos para el mal del ciprés refieren a la existencia de estrés hídrico en las plantas (Capitulo II), es posible considerar que los individuos femeninos expuestos naturalmente a un mayor costo hídrico (estructuras reproductivas) evidencien en forma más intensa los procesos de desequilibrio de agua asociados al mal del ciprés. Bajo el supuesto de mayor frecuencia de individuos femeninos entre los sintomáticos es esperable, por otra parte, que los patrones de crecimiento de ambos sexos reproduzcan en gran medida el patrón diferencial establecido para estados sanitarios (Capitulo VII). Esto es, que existan diferencias en el patrón de crecimiento entre sexos y que los individuos femeninos reflejen las tendencias de crecimiento de los individuos sintomáticos. 
En este capítulo de la tesis, por tanto, se evaluarán las siguientes hipótesis:

○ Hipótesis 1: Los individuos femeninos de A. chilensis son más sensibles al estrés hídrico.

PREDICCIÓN 1: Los individuos femeninos de A. chilensis son afectados con mayor frecuencia por el mal del ciprés.

- HiPótesis 2: El mal del ciprés afecta mayoritariamente a individuos femeninos de la especie A. chilensis.

PREDICCIÓN 2: Los individuos femeninos y masculinos de A. chilensis se diferencian en sus patrones de ancho de anillos de crecimiento.

\section{2.- MATERIALES Y MÉTODOS}

\section{1.- DIFERENCIAS EN LA RELACIÓN DE SEXOS EN GRUPOS DE INDIVIDUOS SINTOMÁTICOS Y} ASINTOMÁTICOS PARA MAL DEL CIPRÉS

La frecuencia de individuos femeninos entre los árboles afectados por mal del ciprés se evaluó determinando el sexo de los individuos sintomáticos y asintomáticos entre los 50 pares de plantas muestreados (Capitulo II). Se aplicó un test exacto de Fisher y un análisis de Chi cuadrado para determinar la significación estadística de las diferencias. Para el análisis de las relaciones en el área Norte y Sur de El Bolsón se realizó una nueva determinación basada en el recuento del número total de individuos en una parcela de $10 \mathrm{~m}$ de radio centrada en cada uno de los individuos seleccionados en el muestreo pareado (100 parcelas establecidas). Todos los árboles dentro de cada parcela se clasificaron según sexo y estado sanitario, construyéndose tablas de contingencia para el área Norte (EB_N) y Sur (EB_S) del valle de El Bolsón que se evaluaron mediante test exacto de Fisher y análisis de Chi cuadrado.

\section{2.- DIFERENCIAS EN LOS PATRONES DE CRECIMIENTO ENTRE INDIVIDUOS FEMENINOS Y MASCULINOS DE LA ESPECIE $A$. CHILENSIS}

Los datos de ancho de anillo de crecimiento determinados para cada uno de los individuos de los 50 pares (Capitulo VII) se emplearon en el análisis comparativo del crecimiento en función del sexo de los individuos. Considerando las diferencias reportadas en la incidencia del mal del ciprés y las características de suelo entre el Sur y el Norte del valle de El Bolsón (Chauchard y Barnabá, 1986) el análisis se realizó para el conjunto de los individuos y para cada área en forma independiente (EB_N y EB_S). 


\section{3.- RESULTADOS Y DISCUSIÓN}

\section{1.- DIFERENCIAS EN LA RELACIÓN DE SEXOS EN GRUPOS DE INDIVIDUOS SINTOMÁTICOS Y ASINTOMÁTICOS PARA MAL DEL CIPRÉS}

\subsection{1.- Ensayo sobre pares}

Se obtuvo una relación de sexos $(\mathrm{r}=\mathbf{M} / \mathbf{F})$ igual a 1 para la región de El Bolsón, señalando un equilibrio entre sexos en el área estudiada. Sin embargo, el análisis de la distribución de individuos femeninos y masculinos entre los sintomáticos reveló una relación de sexos menor a 1 en este grupo. Esto es, una mayor proporción de individuos femeninos (Tabla VIII-1) en el grupo de los sintomáticos. Las diferencias son estadísticamente significativas $(p<0.05)$ según test exacto de Fisher y análisis de Chi cuadrado.

\begin{tabular}{|c|c|ccc|}
\cline { 3 - 5 } \multicolumn{2}{c}{} & Masculino & Femenino & $r$ \\
\hline \multirow{3}{*}{ EB } & Total & 45 & 45 & 1,000 \\
& Sintomático & 16 & 28 & 0,571 \\
& Asintomático & 29 & 17 & 1,706 \\
\hline
\end{tabular}

Tabla VIII-1: Relación de sexos entre los grupos de individuos sintomáticos y asintomáticos para mal del ciprés en la región de El Bolsón.

\subsection{2.- Ensayo en parcelas}

El análisis para las áreas Norte y Sur de El Bolsón realizado sobre el total de individuos caracterizados en cada una de las parcelas establecidas, muestra una mayor presencia de individuos femeninos entre los sintomáticos en el área Norte (EB_N), en tanto que no se observan diferencias significativas en la distribución de los individuos femeninos entre estados sanitarios para el área Sur (EB_S) (Tabla VIII-2).

\begin{tabular}{|c|c|cc|c|}
\cline { 3 - 5 } \multicolumn{2}{c|}{} & Masculino & Femenino & $\mathrm{r}=\mathbf{M} / \mathbf{F}$ \\
\hline \multirow{2}{*}{ EB_N * } & Sintomático & 32 & 74 & 0,43 \\
& Asintomático & 84 & 81 & 1,04 \\
\hline \multirow{2}{*}{ EB_S } & Sintomático & 43 & 26 & 1,65 \\
& Asintomático & 75 & 49 & 1,53 \\
\hline
\end{tabular}

Tabla VIII-2: Relación de sexos entre los grupos de individuos sintomáticos y asintomáticos correspondientes al área Norte y Sur de El Bolsón. EB_N: El Bolsón Norte. EB_S: El Bolsón Sur. * indica diferencias significativas $\mathrm{p}<0.05$. 
Los resultados muestran además que existen diferencias en la relación de sexos entre las áreas cuando se considera el conjunto de los individuos independientemente del estado sanitario. Siendo el valor de r inferior a 1 para EB_N y superior a 1 para EB_S (Gráfico VIII-1).

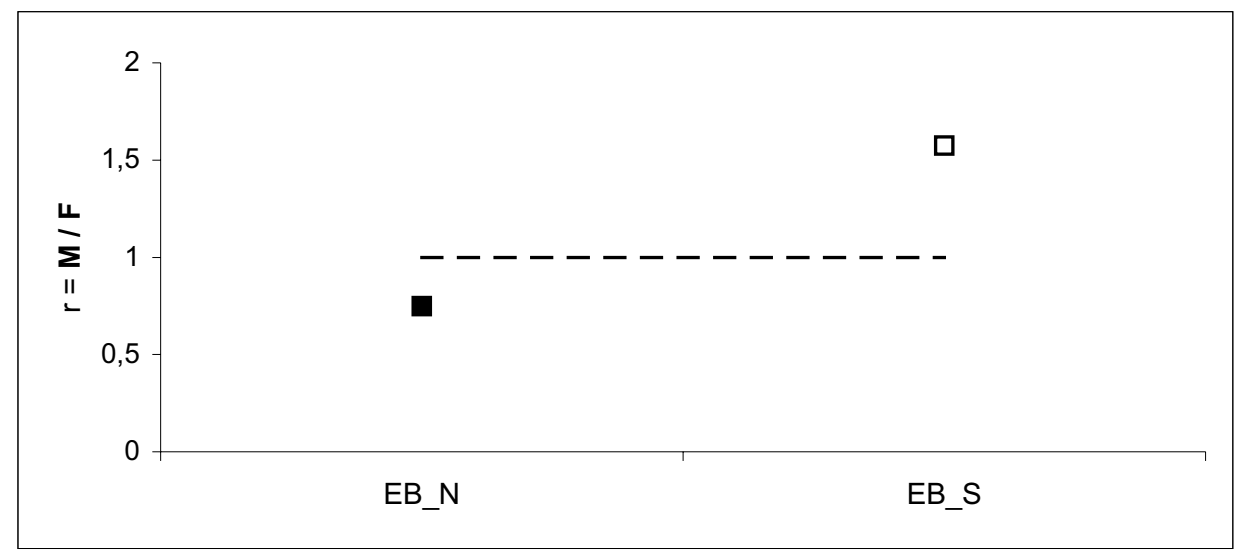

Gráfico VIII-1: Valores de la relación de sexo para las áreas Norte (EB_N) y Sur (EB_S) de la región de El Bolsón. La línea de puntos indica el valor esperado en ausencia de segregación diferencial de sexos. Diferencias estadísticamente significativas $(\mathrm{p}<0.01)$.

Tanto el ensayo en pares como el ensayo en parcelas, confirman la mayor frecuencia de individuos femeninos entre los árboles afectados por mal del ciprés; aunque se observan diferencias entre el Norte y el Sur del área de estudio.

Desvíos de la razón de sexos fueron reportados en un $22 \%$ de los bosques de A. chilensis en Argentina, no estando las tendencias hacia uno u otro sexo determinadas por las condiciones de sitio ni la edad de los árboles (Rovere y Le Quesne, 2005). En Chile poblaciones marginales y longevas de la especie $A$. chilensis presentaron un marcado desbalance de la relación de sexos (Le Quesne et al., 1999 y 2000). Por otra parte, estudios de la segregación espacial según exposiciones contrastantes (Nuñez et al., 2008) indican una menor proporción de individuos femeninos en exposiciones N-NO respecto de las exposiciones S-SE. Este patrón diferencial de distribución es constante a lo largo de un importante gradiente de precipitación, sugiriendo que la humedad no sería el único factor determinante de la segregación. Diferencias en la radiación solar, temperatura y condiciones de suelo jugarían también un papel importante (Nuñez et al., 2008).

Si bien la exposición de algunos de los sitios de muestreo correspondientes al área Norte de El Bolsón (L5y6 y R11) podría dar cuenta de la segregación diferencial observada, para el otro sitio (R18) no es posible establecer una correlación adecuada. Lo mismo ocurre con los sitios 
correspondientes al área Sur de El Bolsón (R81 y L9y15) que no se ajustan al patrón establecido por Nuñez et al. (2008). Esta falta de correlación no se contrapone necesariamente con los patrones reportados, por el contrario señala que el desvío de la relación de sexos depende de factores adicionales aún no identificados.

Uno de estos factores podría ser la presencia de mal del ciprés. La predisposición diferencial para los individuos femeninos al mal del ciprés podría conducir a cambios en la relación de sexos y a su vez este cambio debería influir en la manifestación del patrón de segregación esperado en función a la exposición. Por ejemplo, para un sitio en exposiciones S-SE (según definición de Nuñez et al., 2008) se espera un valor de $\mathrm{r}$ menor a 1, pero si el sitio presenta mal del ciprés la mortalidad tenderá a llevar el valor de $\mathrm{r}$ nuevamente hacia 1. La relación de sexos final estará determinada, por tanto, por el sentido y la intensidad de cambio de ambos procesos que pueden actuar en el mismo sentido o en sentido contrario. Relaciones de sexo mayores a 1 podrían derivar no sólo de la segregación espacial de individuos masculinos a zonas más cálidas, secas e irradiada. Los individuos femeninos ubicados en estas zonas sufrirán más intensamente el impacto del estrés hídrico y por tanto su mortalidad será mayor y se generará un desvío de la razón de sexos.

\section{2.- DIFERENCIAS EN LOS PATRONES DE CRECIMIENTO ENTRE INDIVIDUOS FEMENINOS Y} MASCULINOS DE LA ESPECIE $A$. CHILENSIS

El análisis comparativo de las series de crecimiento de individuos femeninos y masculinos, se realizó en una primera etapa a nivel del valle de El Bolsón. Los resultados obtenidos muestran diferencias entre los patrones de crecimiento en función del sexo de los individuos (Figura VIII-2), para el período que comienza alrededor de 1910 donde el número de individuos es adecuado para la comparación.

Se observa una alta correspondencia con lo reportado para el análisis entre estados sanitarios (Capitulo VII) con un patrón similar de inversión de cronologías (Figura VIII-2). Esta inversión se produce en el mismo momento que para el análisis por estado sanitario (1944) y muestra un mayor crecimiento de los individuos femeninos antes de esa fecha y una posterior disminución gradual. Considerando la correlación establecida entre el punto de inversión y las sequías de 1942-1943 (Mundo et al., Anexo 11), los resultados indicarían un mayor impacto de la sequía en los individuos femeninos, lo que se corresponde con la hipótesis de una mayor sensibilidad de estos individuos al estrés hídrico. 

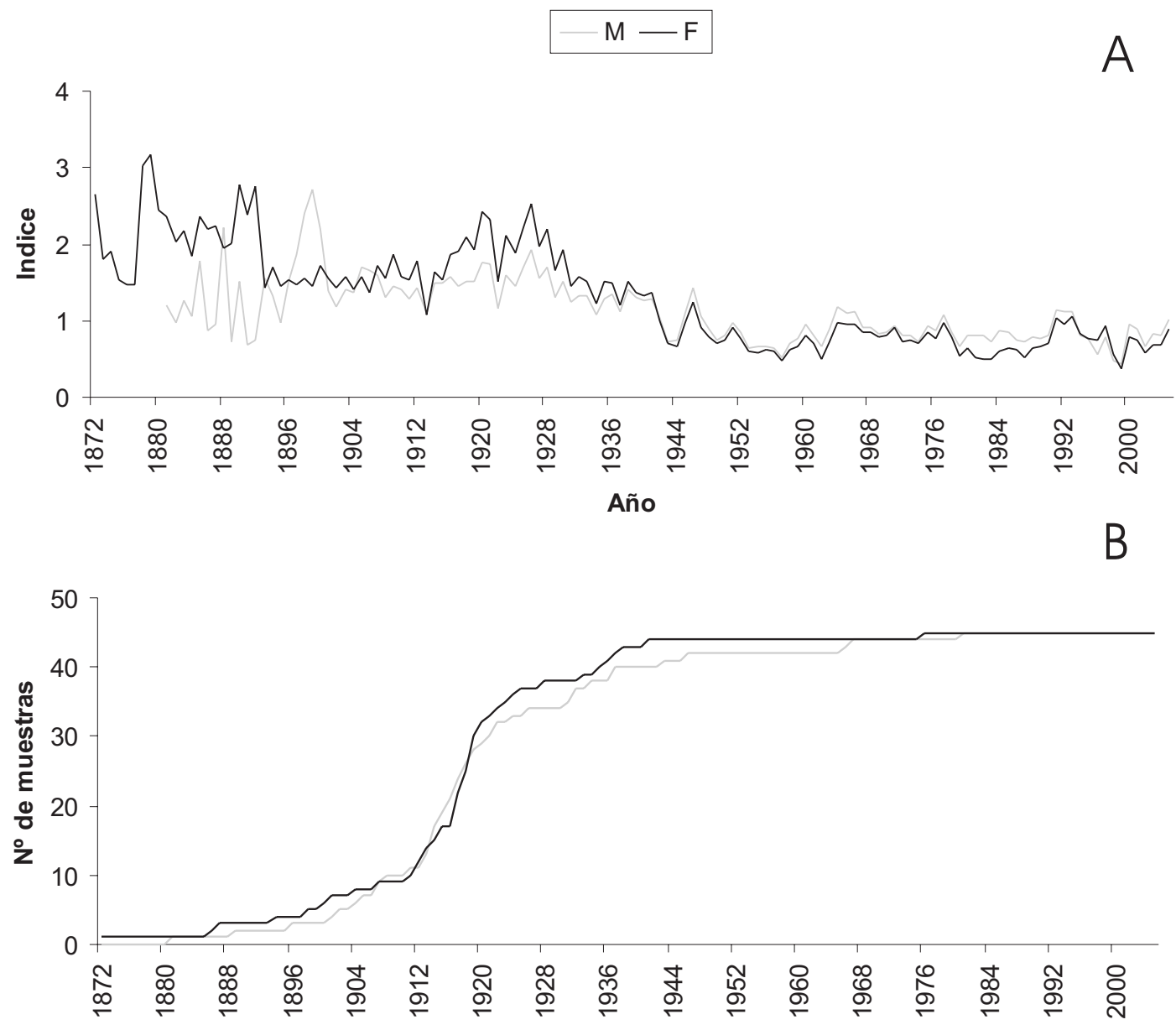

Año

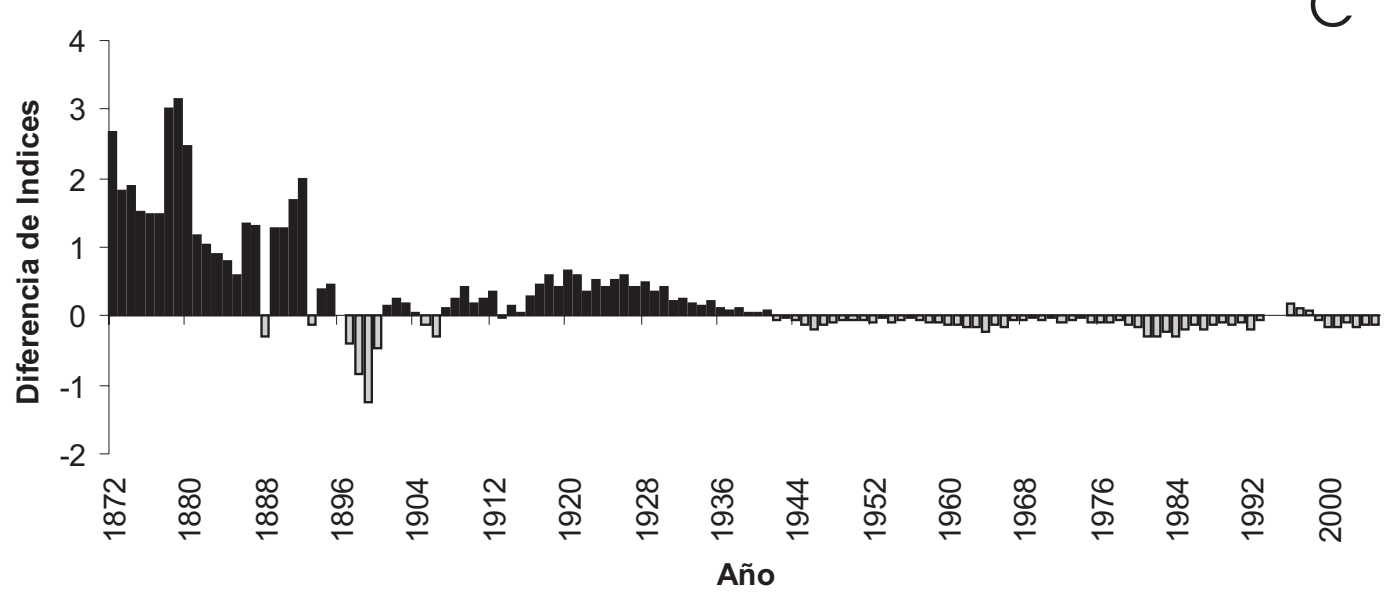

Figura VIII-2: Cronologías promedio de árboles femeninos y masculinos para la región de El Bolsón. A: Cronologías promedio de índice de anillos de crecimiento de árboles femeninos (negro) y masculinos (gris). B: Tamaño de muestra para cada año. C: Diferencia entre la cronología promedio del índice de anillo de crecimiento de individuos femeninos y masculinos. 
El análisis se realizó además para las áreas Norte y Sur de El Bolsón en forma independiente. Para el área Norte (Figura VIII-3) se observa un comportamiento similar al regional; es decir, diferencias de los patrones de crecimiento entre sexos que reflejan las diferencias observadas entre individuos sintomáticos y asintomáticos. Los individuos femeninos presentan crecimientos superiores a los masculinos antes de la sequía de 1942-1943 y una disminución de la tasa de crecimiento luego del año 1944. La comparación para los años anteriores a 1910 es difícil de realizar debido al bajo número de muestras.

Para el área Sur de El Bolsón, se observa un comportamiento diferente (Figura VIII-4). Si bien los individuos femeninos muestran crecimientos superiores a los masculinos antes de la sequía de los años 1942-1943, posteriormente el crecimiento de ambos sexos no presenta grandes diferencias observándose alternancia en la diferencia de índices desde 1944 hasta el 2005. Si bien el bajo número de árboles y la diferencia de individuos entre clases (femenino vs. masculino) podría determinar este comportamiento, los resultados concuerdan con la ausencia de predisposición diferencial determinada para este área mediante el análisis de los valores de $r$ sobre las parcelas de $10 \mathrm{~m}$ de radio.

Diversas especies dioicas manifiestan una respuesta diferencial entre sexos al estrés hídrico o al clima, al menos durante algún período del desarrollo de los árboles. Los individuos femeninos de Populus cathayana son más sensibles y evidencian en mayor grado los efectos negativos del crecimiento en ambientes con incremento de temperatura y estrés hídrico (Xu et al., 2008). En Taxus baccata el porcentaje de individuos femeninos correlaciona positivamente con la precipitación, señalándose que el esfuerzo reproductivo conduciría a diferencias competitivas que serían potenciadas por la menor tolerancia del sexo femenino a la sequía (Iszkulo et al., 2009). Al alcanzar la madurez sexual se produce una disminución del crecimiento radial en Juniperus thurifera que es más intensa en los individuos femeninos, los cuales correlacionan además de manera diferencial con el clima (Montesinos et al., 2006). El crecimiento de los individuos masculinos correlaciona con la precipitación de invierno y primavera de la estación de crecimiento, en tanto que los femeninos lo hacen sólo con la precipitación de primavera. Analizando la sensibilidad del crecimiento radial al clima en relación al sexo y la edad, Rozas et al. (2009) establecieron una interacción significativa en individuos jóvenes femeninos de Juniperus thurifera. La mayor sensibilidad de este grupo al estrés hídrico del verano se atribuye a un uso menos eficiente del agua en el sexo femenino y a diferencias de ajuste fisiológico durante la ontogenia. 


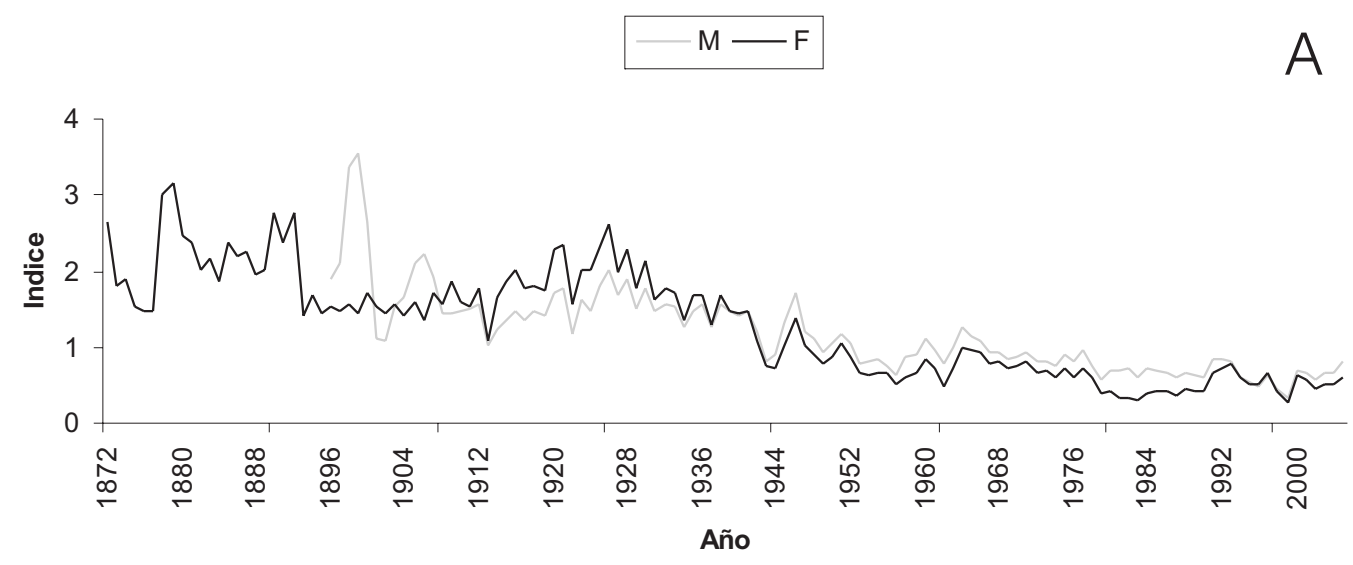

B
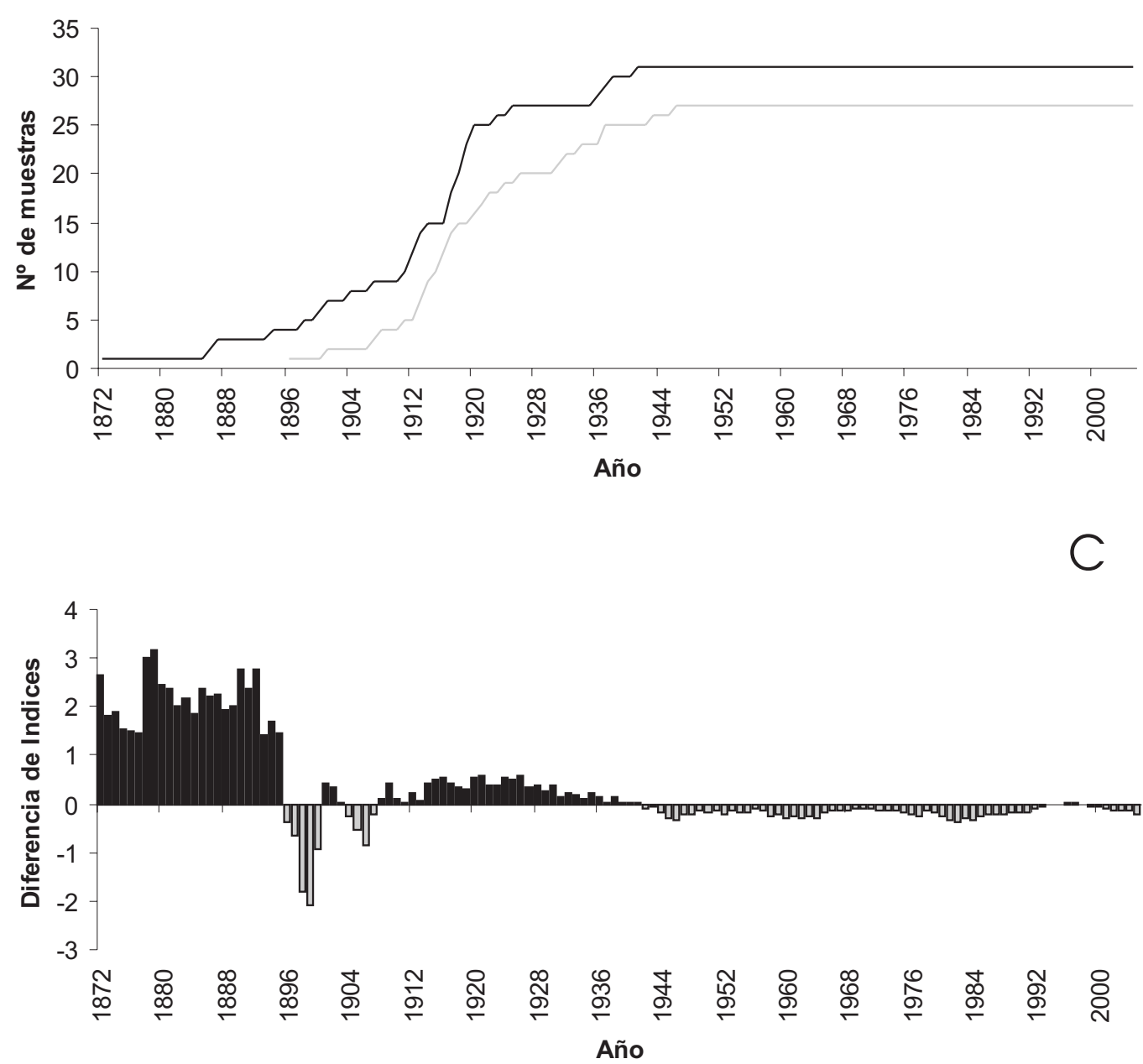

Figura VIII-3: Cronologías promedio de árboles femeninos y masculinos para el área Norte de El Bolsón (EB_N). A: Cronologías promedio de índice de anillos de crecimiento de árboles femeninos (negro) y masculinos (gris). B: Tamaño de muestra para cada año. C: Diferencia entre la cronología promedio del índice de anillo de crecimiento de individuos femeninos y masculinos. 


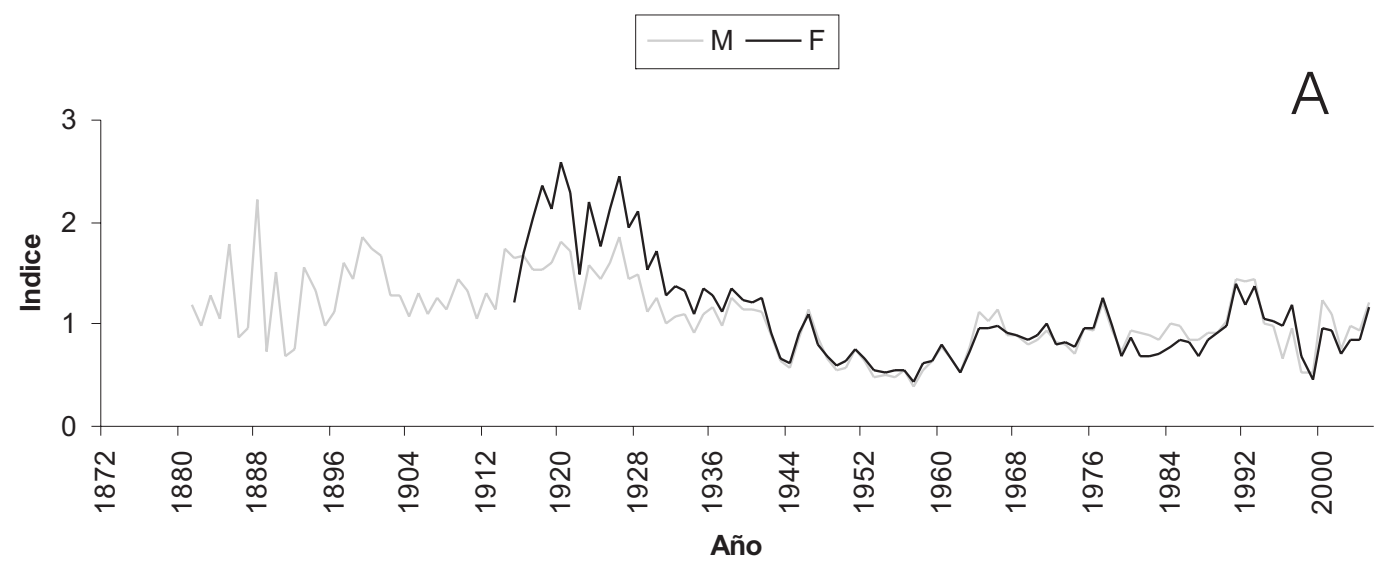

B
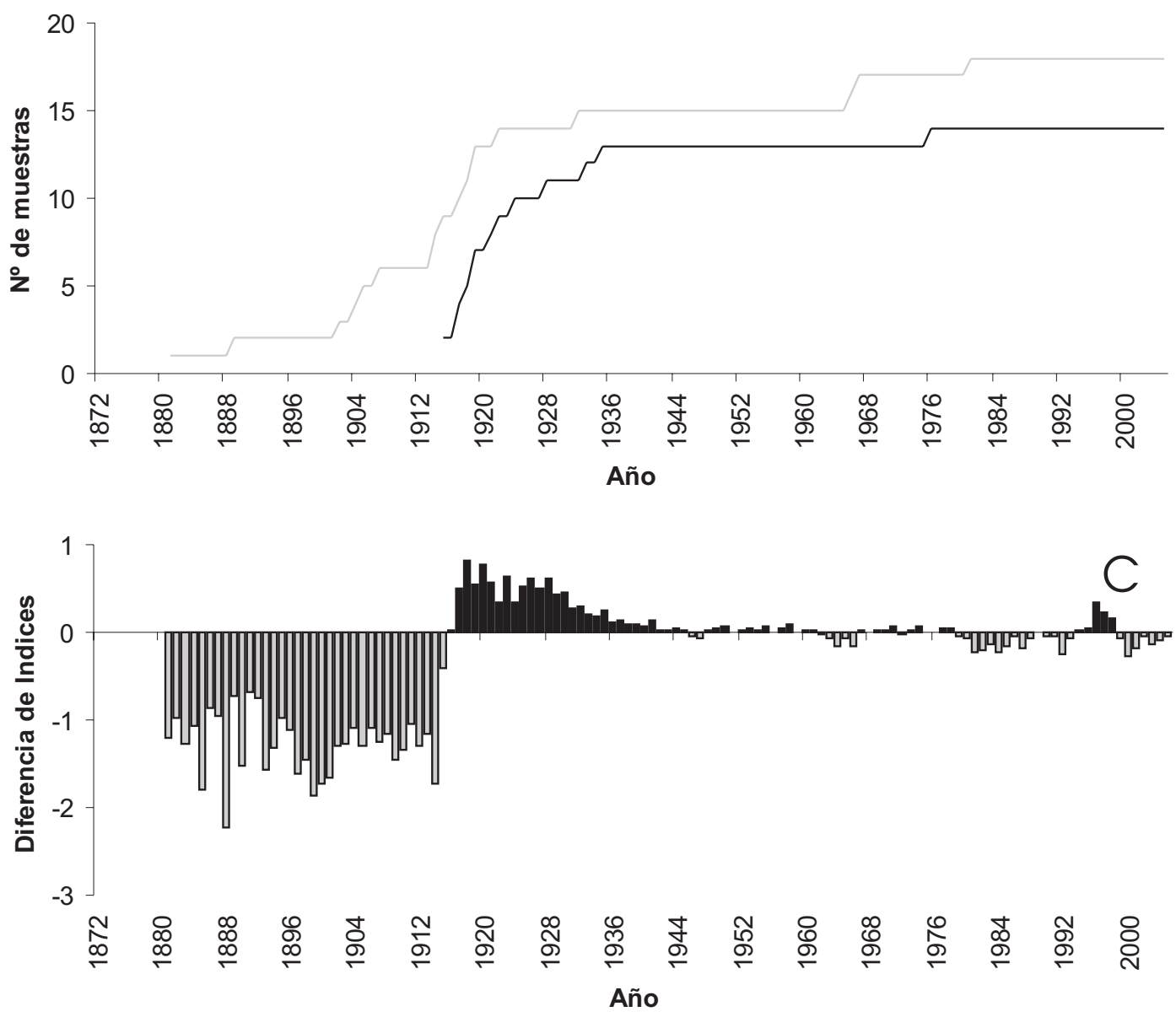

Figura VIII-4: Cronologías promedio de árboles femeninos y masculinos para el área Sur de El Bolsón (EB_S). A: Cronologías promedio de índice de anillos de crecimiento de árboles femeninos (negro) y masculinos (gris). B: Tamaño de muestra para cada año. C: Diferencia entre la cronología promedio del índice de anillo de crecimiento de individuos femeninos y masculinos. 
Existen pocos estudios en la bibliografía que evalúen los factores que determinan el crecimiento diferencial entre sexos en $A$. chilensis. Nuñez et al. (2008) reportan, para un sitio, que los individuos masculinos crecen en área basal un 92.1\% más que los individuos femeninos en la exposición N-NO y sólo un 13.5\% más en la exposición S-SE. El crecimiento de los individuos femeninos fue similar en ambas exposiciones lo que sugiere que la disponibilidad de agua y luz influirían de manera diferente o que el costo reproductivo o los mecanismos de compensación variarían en distintos ambientes (Nuñez et al., 2008). El análisis de las funciones de correlación muestra que el incremento de área basal responde positivamente a la precipitación de la estación de crecimiento en ambas exposiciones; en tanto, que lo hace negativamente con la temperatura de la estación de crecimiento sólo en la exposición SE. Estos resultados indicarían un impacto diferencial del estrés hídrico entre los sitios, sugiriendo que en los sitios más húmedos, frescos y menos irradiados los individuos son más sensibles al efecto negativo de las altas temperaturas durante el período de crecimiento. Estos resultados se basan únicamente en evaluaciones del crecimiento para ambos sexos en dos exposiciones contrastantes de un único sitio; repeticiones del estudio en más sitios permitirán establecer con mayor exactitud la validez de este patrón de respuesta diferencial.

Patrones de crecimiento variable entre individuos femeninos y masculinos, y similar variación interanual y correlación del crecimiento con el clima durante la estación de crecimiento entre individuos femeninos y masculinos resultan del análisis del promedio del crecimiento radial anual (Rovere et al., 2003). Sin embargo, es importante señalar que estos resultados promedio deben ser considerados teniendo en cuenta que el comportamiento del promedio del crecimiento radial anual no siempre se corresponde con el comportamiento de la cronología del crecimiento radial debido a que los sexos pueden manifestar diferencias en sentidos opuestos a lo largo del tiempo para un determinado sitio. Las diferencias entre sexos deben ser analizadas sobre cronologías, ya que éstas permiten detectar cambios en los patrones de crecimientos para un mismo sexo con el tiempo o patrones diferenciales entre sexos. Los patrones identificados deberían, por otra parte, ser analizados no sólo en función de factores climáticos, sino incorporando características asociadas al sitio (tipo de suelo o exposición).

Es importante mencionar que aunque varios de los sitios de muestreo de los trabajos mencionados (Rovere et al., 2003; Núñez et al., 2008) se encuentran en áreas donde se ha reportado mal del ciprés (Havrylenko, 1989; Rosso, 1989; Rosso et al., 1994; Rajchenberg et al., 1997; Baccalá et al., 1998; La Manna, 2004), no se indica la sintomatología de los individuos ni la forma de discriminar su influencia en el análisis del crecimiento anual de los árboles afectados. 


\section{4.- CONCLUSIONES}

Los resultados obtenidos en el presente capítulo permiten concluir que el mal del ciprés afecta con mayor frecuencia a los individuos femeninos y que esta diferencia estaría determinada por una susceptibilidad diferencial de los individuos femeninos a la sequía.

Los datos aportados señalan diferencias entre el área Norte y Sur de El Bolsón, que se corresponden con las derivadas anteriormente desde:

○ el análisis genético mediante RGA

- la caracterización de las poblaciones bacterianas de xilema por DGGE

- el análisis del índice de anillo de crecimiento radial por dendrocronología.

Tomados en conjuntos, los resultados sugieren que la susceptibilidad diferencial entre sexos no está definida exclusivamente por el mayor costo hídrico de los individuos femeninos, sino que las características del sitio $\mathrm{u}$ otros factores aún no determinados podrían determinar conjuntamente el balance global en cada sitio. 


\section{CAPITULO IX}

AVANCES EN EL CONOCIMIENTO SOBRE EL MAL DEL CIPRÉS

Y NUEVA HIPÓTESIS SOBRE SU ETIOLOGÍA 



\section{1.- INTRODUCCIÓN}

Los bosques constituyen sistemas biológicos complejos, que dependen de la interacción entre las condiciones de sitio, la potencialidad de las especies presentes, el impacto de los disturbios que los afectan y la naturaleza de los procesos de establecimiento. El ambiente tiene también un papel preponderante ya que influye en las relaciones entre los diferentes componentes del sistema. Diversos tipos de disturbio entre los que se encuentran, el cambio climático global, la explotación de recursos maderables y no maderables, la presión social, la incorporación de especies exóticas y el uso turístico, afectan el ambiente y por tanto el equilibrio en que dichos sistemas se desarrollan y evolucionan.

Desde un punto de vista general la mortalidad como consecuencia de una enfermedad, puede entenderse como el resultado final de un proceso que resulta de la interacción entre el huésped, un agente de daño y el ambiente. Comprender los procesos de mortalidad que ocurren en los bosques requiere contemplar, al menos desde el punto de vista conceptual, cada uno de estos aspectos. La longevidad de los árboles hace difícil dilucidar la etiología, en tanto que el agente de daño puede actuar durante mucho tiempo o incluso determinar cambios en los individuos que no se evidencian de manera inmediata. Si un agente de daño es determinante de la mortalidad o si la misma se produce como consecuencia de la acción sucesiva o conjunta de diversos agentes de daño, es también un aspecto que debe ser evaluado al momento de definir la etiología de un proceso.

La mortalidad de $A$. chilensis, conocida como mal del ciprés, se reportó por primera vez a mediados de la década del cuarenta (Varsavsky et al., 1975) y desde entonces diversos modelos etiológicos se aplicaron como marco conceptual en las investigaciones realizadas (Capitulo I). Las publicaciones reportadas sobre el tema, entre 1975 y 2009, dan cuenta de los diversos aspectos analizados en relación al mal del ciprés. Entre los más relevantes se encuentran, la caracterización de la sintomatología (Rosso, 1989; Havrylenko et al., 1989), la asociación con agentes fúngicos (Varsavsky et al., 1975; Rajchenberg y Cwielong, 1993; Merlo, 1994; Barroetaveña y Rajchenberg, 1996; Rajchenberg et al., 1997; Greslebin et al., 2005; Greslebin y Hansen, 2006; Greslebin et al., 2007; Greslebin y Hansen, 2007 a, b; Floria y Greslebin, 2007; Floria, 2008), el efecto de los factores climáticos en la mortalidad (Calí, 1996), los estudios de la distribución espacial (Rosso et al., 1989; Rosso et al., 1994; La Manna et al., 2008b), la asociación entre el mal del ciprés y las condiciones de sitio (La Manna et al., 2001; La Manna y Rajchenberg, 2004 a, b), la caracterización del patrón ecológico de la mortalidad (Havrylenko et al., 1989; Rosso, 1989; Baccalá et al., 1998; La Manna et al., 2008c), la relación entre el mal del ciprés, la estructura y la silvicultura de bosques de A. chilensis (Loguercio et al., 1998; 
La Manna et al., 2006) y la relación entre el mal del ciprés y la regeneración de los bosques (La Manna et al., 2008a; Amoroso, 2009).

A pesar de la extensa investigación realizada, con más de 25 publicaciones, la etiología del mal del ciprés es aún desconocida. Si bien gran cantidad de información está disponible, una de las mayores limitaciones al momento de analizar el impacto de diferentes factores en el desarrollo de la mortalidad deriva de la imposibilidad de contrastar información relacionada a diversos aspectos sobre los mismos individuos.

Mediante análisis dendrocronológicos se establecieron diferencias en el patrón de ancho de anillos de crecimiento entre árboles con y sin síntomas de la mortalidad (Calí, 1996). En ellos se estudió la correlación entre la caída en la tasa de crecimiento de árboles sintomáticos con eventos climáticos cálidos y secos y la distribución de los individuos afectados en relación a cursos de agua. Sin embargo, la interpretación posterior de estos resultados se basó en hipótesis sobre la presencia de patógenos de suelo y el consecuente ataque sobre árboles debilitados, asumiendo que la asociación a cursos de agua responde a las condiciones de sitio necesarias para el mantenimiento y la dispersión del supuesto agente. Ninguna determinación se realizó a posteriori sobre estos individuos a fin de evaluar las hipótesis planteadas. Del mismo modo, hasta el momento, los estudios relacionados con la acción de agentes fúngicos se realizaron en ausencia de determinaciones dendrocronológicas. Por tanto, no es posible contrastar el impacto de los factores climáticos con la presencia de pudriciones o lesiones necróticas en los individuos.

La Manna (2004) analizó la relación entre el mal del ciprés y las condiciones de sitio, determinando que la mortalidad se asocia mayoritariamente a suelos mal drenados, aunque puede también estar presente en sitios con exceso de drenaje. Estos estudios se realizaron mediante una metodología de parcelas pareadas y, debido a la falta de una relación directa causa efecto, los resultados obtenidos se interpretaron en el marco de diversas teorías: declinamiento de bosques (Houston, 1981; Manion, 1991), senescencia de cohorte (Mueller-Dombois, 1992) y efecto del cambio climático (Hepting, 1963; Leaphart y Stage, 1971, Auclair et al., 1992). La interpretación de la acción del sitio como factor predisponente (declinamiento de bosques), en la que se postula que las condiciones de mal drenaje propiciarían el desarrollo de microorganismos y que el debilitamiento fisiológico del árbol por estrés recurrente favorecería la acción de los mismos, es la más ampliamente adoptada. Sin embargo, aunque la asociación entre la mortalidad y las características de pobre drenaje está bien establecida, hasta el momento no se efectuaron estudios a nivel de individuo que permitan verificar las hipótesis planteadas en relación al efecto 
directo del sitio, ni se ha determinado la abundancia relativa de microorganismos en sitios con y sin déficit de drenaje.

La respuesta diferencial en los árboles se propuso en numerosas oportunidades para explicar diversas manifestaciones del proceso, como por ejemplo, mortalidad progresiva o rápida. Las diferencias encontradas se asociaron a susceptibilidad al mal del ciprés de los árboles debilitados por factores predisponentes o desencadenantes (Havrylenko et al., 1989; Rajchenberg y Cwielong, 1993; La Manna, 2004; La Manna y Rajchenber, 2004a y b; Greslebin y Hansen, 2006) o a la existencia de individuos genéticamente resistentes o tolerantes (Calí, 1996; Greslebin y Hansen, 2006). Sin embargo, hasta el momento del inicio de la presente tesis, no se había realizado ninguna evaluación sobre estas hipótesis.

Por otra parte, el marchitamiento y la defoliación progresiva aunque características del mal del ciprés son inespecíficas y podrían ser consecuencias de causas diversas; siendo necesario evaluar el patrón de apertura de la copa en referencia a las características del sitio y el proceso de competencia dentro del bosque, lo que imposibilita comparaciones directas entre diferentes estudios en ausencia de información precisa sobre la forma de muestreo de los árboles.

Filip y Rosso (1999) puntualizaron la necesidad de combinar análisis, proponiendo estudios dendrocronológicos y de excavación de raíces en árboles con diferente grado de síntomas en la copa y evaluaciones del papel que el agua tiene en el proceso en relación a las hipótesis de su acción como posible factor predisponente (pobre drenaje) o desencandente (sequía). El Mujtar y Andenmatten (2007a) aplicaron una guía básica de diagnóstico de enfermedades de plantas al mal del ciprés y lo compararon con otras enfermedades forestales, estableciendo que la información disponible era insuficiente para discriminar entre diferentes grupos de agentes de daño (bióticos, abióticos o combinaciones de ambos) y señalando la necesidad de contar con un modelo de análisis que considere la complejidad del proceso. Al mismo tiempo, analizando el mal del ciprés bajo el modelo de triángulo de enfermedad plantearon la necesidad de caracterizar la relación entre agentes bióticos no fúngicos y el mal del ciprés, evaluar las diferencias genéticas existentes entre plantas con y sin síntomas, determinar y cuantificar el estrés hídrico en plantas afectadas y evaluar el impacto que el cambio climático (entre otros factores ambientales) tiene en el proceso (El Mujtar y Andenmatten, 2007b). 


\section{2.- APORTES DE LA INVESTIGACIÓN DESARROLLADA EN LA TESIS AL CONOCIMIENTO DEL MAL DEL CIPRÉS}

La presente tesis tuvo como objetivo general el estudio simultáneo del mismo grupo de individuos desde diversos aspectos a fin de avanzar en la identificación de la etiología del o los procesos actualmente englobados bajo la denominación mal del ciprés. Se seleccionaron 100 individuos según un muestreo pareado (asintomático / sintomático), procurando la similitud en descriptores básicos (altura total, diámetro a altura de pecho, posición sociológica y nivel de competencia) a fin de limitar factores no considerados que pudieran dar cuenta de las diferencias observadas en los síntomas aéreos (Capitulo II). La selección de los pares se verificó, en forma adicional, mediante la correlación de la separación obtenida por análisis discriminante de cronologías individuales basadas en la medida de ancho de anillos de crecimiento y la clasificación por estado sanitario efectuada en el bosque (Mundo et al., Anexo 11). Se seleccionaron 5 sitios de muestreo, abarcando la distribución Norte Sur de los bosques de A. chilensis en el valle de El Bolsón (Capítulo II), con una distancia máxima entre áreas de 11,8 km. En el desarrollo de la tesis los 50 pares de plantas se emplearon en el análisis de la diversidad genética entre individuos sintomáticos y asintomáticos para mal del ciprés (Capitulo III), en la caracterización de la relación entre el mal del ciprés y los agentes bióticos P. austrocedrae (Capitulo IV), áfidos del género Cinara (Capitulo V) y bacterias endógenas de xilema (Capitulo VI), en la detección de patrones de crecimiento diferenciales y factores abióticos asociados al mal del ciprés (Capitulo VII) y en el análisis de la susceptibilidad diferencial al mal del ciprés entre individuos femeninos y masculinos de A. chilensis (Capitulo VIII).

La aplicación del sistema molecular multilocus RGA al análisis de la diversidad genética permitió detectar una diferenciación cercana al 3\% entre las poblaciones asintomática y sintomática para el mal del ciprés e identificar marcadores moleculares asociados a la diferenciación entre estados sanitarios (Capitulo III). Estos marcadores se ubican en los extremos de frecuencia, mayores al $90 \%$ o inferiores al 10\% y se asocian mayoritariamente a los individuos sintomáticos indicando un mecanismo de susceptibilidad genética diferencial y descartando la existencia de resistencia genética en los individuos asintomáticos. Una gran parte de los marcadores de baja frecuencia se asocia a individuos sintomáticos, por lo que podría esperarse una mayor frecuencia de estos marcadores en sitios con mayor incidencia de mal del ciprés. Sin embargo, los clusters determinados no responden a esta condición, agrupando individuos que provienen del área Norte para la cual se reporta menor incidencia del mal del ciprés. La aplicación del sistema RGA a las áreas de muestreo, en forma independiente del estado sanitario, confirmó la existencia de un patrón de estructuración genética local entre las 
regiones Norte y Sur de El Bolsón que está determinada por marcadores de baja frecuencia o privativos (diferenciación local) asociados al área Norte. Por el contrario, la diferenciación genética regional, entre San Ramón y El Bolsón, estuvo determinada por el cambio en la frecuencia de marcadores comunes entre poblaciones.

Estos resultados sugieren que la constitución genética de las poblaciones condiciona el desarrollo de la mortalidad y que los individuos sintomáticos son más susceptibles al mal del ciprés.

La secuenciación de los marcadores RGA asociados a la diferenciación permitirá identificar sus posibles funciones biológicas y avanzar en el análisis de su implicancia en la mortalidad de ciprés de la cordillera. Por otra parte, la secuencia nucleotídica de cada marcador podrá emplearse en el diseño de primers específicos permitiendo la evaluación de un mayor número de individuos y sitios de muestreo en la región a fin de avanzar en la interpretación de la estructuración genética detectada.

Greslebin y Hansen (2007 a, b) propusieron recientemente a $P$. austrocedrae como el agente causal del mal del ciprés. Sin embargo, los resultados obtenidos en esta tesis muestran que la relación entre la defoliación y la presencia de lesiones necróticas producidas por $P$. austrocedrae (Capitulo IV) se contrapone con esta hipótesis. Se determinó que un 56\% de los árboles con defoliación no presentan lesiones necróticas, que la incidencia del mal del ciprés y la afectación por $P$. austrocedrae difieren en un mismo sitio, que el porcentaje de árboles con defoliación y lesiones necróticas tiene relación directa con la incidencia de $P$. austrocedrae en el lugar y que el 50\% de los árboles con lesiones corresponde a individuos en situación de competencia.

Los resultados obtenidos señalan que $P$. austrocedrae no debería considerarse como el agente etiológico del mal del ciprés.

La presencia de lesiones necróticas se asocia a mortalidad del cambium o cambial dieback (Greslebin y Hansen, 2007b). Recientemente, Amoroso et al. (2008) determinaron un 38\% de mortalidad de cambium sobre un total de 811 muestras de barreno provenientes de 12 parcelas de muestreo, estableciendo un valor máximo de 39 años para el cambial dieback. La mortalidad de cambium reportada presenta el mismo patrón en plantas con y sin síntomas de mal del ciprés y se observa mayoritariamente en árboles oprimidos e intermedios. Estos resultados se corresponden con los obtenidos en la presente tesis, indicando que las lesiones necróticas se observan con mayor frecuencia en árboles debilitados y, por tanto, que $\boldsymbol{P}$. austrocedrae estaría actuando en gran 
medida como un agente secundario. El comportamiento de $P$. austrocedrae deberá ser evaluado a futuro en relación con los nuevos síntomas aéreos registrados en A. chilensis, condiciones de sitio y grado de incidencia. Los métodos moleculares de diagnóstico reportados en el Anexo 7 contribuirán al desarrollo de estos estudios.

Entre las especies de áfidos del género Cinara, C. cupressi y C. tujafilina se detectaron en A. chilensis (Capitulo V), siendo $C$. cupressi la especie de mayor frecuencia en los bosques de ciprés de la cordillera del área de El Bolsón. La especie presenta igual distribución entre plantas con y sin síntomas de mal del ciprés, confirmando que $C$. cupressi no actúa como agente causal ni determina una mayor predisposición a la afección. En Chile se considera al complejo C. cupressi como el agente responsable del enrojecimiento del follaje de $A$. chilensis (Silva et al., 2005) que conduce al deterioro de los bosques naturales. En tal sentido, la aplicación del método molecular de identificación desarrollado en la presente tesis (Capitulo V) permitirá avanzar en la caracterización y el monitoreo de la dinámica poblacional de C. cupressi y C. tujafilina en Argentina.

El estudio de las poblaciones bacterianas presentes en xilema de A. chilensis (Capitulo VI) permitió establecer que no existe segregación en función del estado sanitario, descartando a las bacterias de xilema como posibles agentes causales del mal del ciprés. La variabilidad de dichas poblaciones se estructura en relación a la procedencia de las muestras empleadas, observándose un agrupamiento mayoritario de las muestras correspondientes al área Norte. La identificación, mediante secuenciación, de las bacterias detectadas en xilema de A. chilensis deberá ser realizada a futuro a fin de avanzar en el conocimiento de las asociaciones obtenidas y el patrón de segregación establecido. El estudio indirecto de bacterias endógenas de floema y virus realizado mediante la observación microscópica de tejidos en el marco del proyecto PICT 25518 arrojó resultados negativos (Dr. Elliot Kitajima com. pers.), indicando que al menos su presencia es lo suficientemente baja como para no ser detectada mediante la aplicación de estas metodologías.

En resumen, la caracterización de agentes bióticos en relación al mal del ciprés responde a los interrogantes planteados en el trabajo de tesis descartando la acción de $\boldsymbol{P}$. austrocedrae, áfidos del género Cinara y bacterias endógenas de xilema como agentes responsables de esta mortalidad y aportando un conjunto de ensayos moleculares de detección e identificación de dichos agentes que permitirán un rápido avance en las investigaciones futuras en relación a la sanidad de los bosques de $A$. chilensis. 
De acuerdo con el conjunto de los datos recabados, el mal del ciprés no sería producido por agentes bióticos, respondiendo la asociación determinada para hongos saprofitos $\mathrm{y}$ $P$. austrocedrae a la acción de dichos agentes sobre individuos debilitados. Si P. austrocedrae puede actuar como agente primario conduciendo a la mortalidad de las plantas es aún tema de estudio, para lo cual será imprescindible definir el origen de $P$. austrocedrae (nativa o introducida), la sintomatología producida por la especie, el patrón de distribución y las condiciones que favorecen su desarrollo y/o la respuesta de defensa de las plantas.

El análisis comparativo de las cronologías de crecimiento promedio y la correlación con los registros climáticos (Capitulo VII) permitió establecer la existencia de diferencias significativas en los patrones de crecimiento entre árboles con y sin síntomas de mal del ciprés y una fuerte asociación con eventos climáticos extremos (sequías). Los resultados muestran mayor susceptibilidad a la sequía de los árboles con mayor ancho de anillo de crecimiento independientemente del área de estudio.

Los patrones de crecimiento diferencial determinados para árboles sintomáticos y asintomáticos para mal del ciprés se utilizaron para evaluar la acción predisponente del sitio, en su efecto directo e indirecto, estableciéndose que ninguno de los mecanismos propuesto hasta el momento es capaz de explicar la asociación entre el déficit de drenaje y el mal del ciprés (Capitulo VII).

El análisis del impacto de la mortalidad en relación al sexo de los individuos muestreados (Capitulo VIII) permitió establecer que el mal del ciprés afecta con mayor frecuencia a los individuos femeninos y que esta diferencia estaría determinada por una susceptibilidad diferencial de los individuos femeninos a la sequía.

La susceptibilidad diferencial de los individuos afectados por el mal del ciprés se estableció a partir de tres análisis independientes:

○ caracterización genética vía RGA

- análisis de los patrones de crecimiento radial mediante dendrocronología entre individuos sintomáticos y asintomáticos

○ análisis de la susceptiblidad diferencial entre individuos femeninos y masculinos. 


\section{La separación entre el área Norte (EB_N) y Sur (EB_S) de El Bolsón se estableció en base a cuatro análisis diferentes independientes:}

○ caracterización genética vía RGA

- caracterización de las poblaciones bacterianas de xilema por DGGE

- análisis de los patrones de crecimiento radial entre individuos sintomáticos y asintomáticos

○ análisis de la susceptiblidad diferencial entre individuos femeninos y masculinos.

Dos interrogantes principales surgen al considerar el conjunto de los estudios realizados y los resultados obtenidos:

1. ¿cuál o cuáles son los procesos que conducen a la separación entre las áreas Norte y Sur de El Bolsón?

2. ¿qué nos dice la inversión de las cronologías promedio en relación a eventos de sequía sobre la etiología del mal del ciprés?

\section{1.- ESTRUCTURACIÓN NORTE-SUR}

La interpretación de patrones de distribución requiere conocer las causas, procesos y factores que modifican la dinámica de la vegetación. Desde el punto de vista de la dinámica de parches, la discontinuidad espacial de la distribución de especies refleja la heterogeneidad del ambiente abiótico, las diferencias de oportunidad para el establecimiento y crecimiento, y la influencia de diversos disturbios sobre la disponibilidad de recursos y la intensidad de las interacciones biológicas (Veblen et al., 2005). Si bien no es posible abordar la discusión formal de todos estos aspectos, una revisión breve de los principales disturbios y factores que afectan el crecimiento y la distribución de $A$. chilensis ayudará a comprender el patrón establecido.

La separación entre el área Norte y Sur de El Bolsón, responde a diferencias en la diversidad genética detectada, el evento de sequía que determina la inversión de las cronologías de crecimiento entre individuos sintomáticos y asintomáticos, la relación de sexos establecida y el porcentaje de individuos femeninos y masculinos afectados por mal del ciprés, y la diversidad de poblaciones bacterianas detectadas por DGGE (Figura IX-1). Entre los principales factores que podrían explicar algunas de las características de la separación Norte-Sur, se encuentran el proceso de recolonización luego del período de las glaciaciones cuaternarias, diferencias en la intensidad o frecuencia de fuego, variaciones en las características de suelo y condiciones de sitio e impacto diferencial del clima (Figura IX-1). 


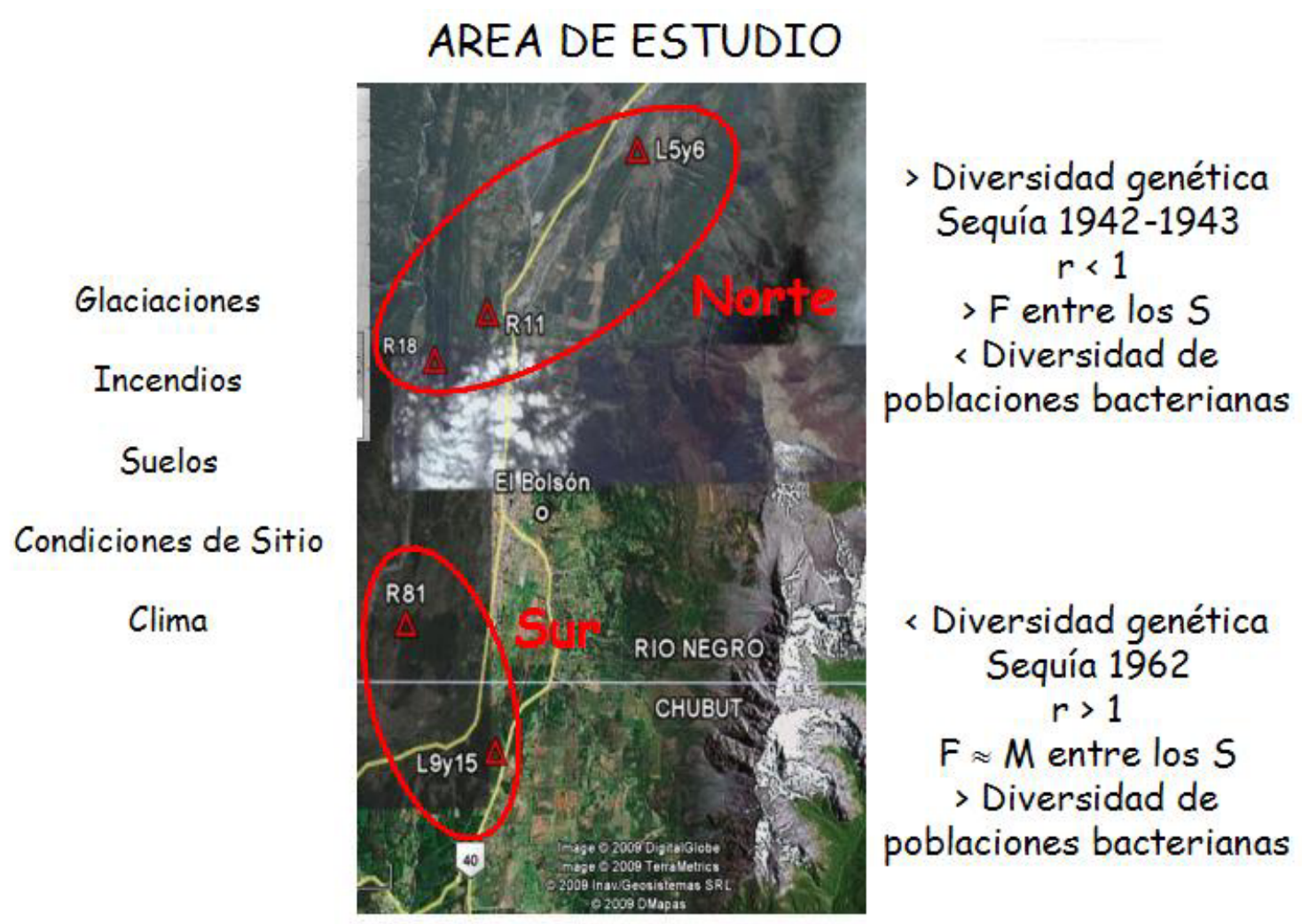

Figura IX-1: Características que definen la estructuración Norte-Sur en la región de El Bolsón y principales factores que podrían determinar su origen.

\subsection{1- Glaciaciones Cuaternarias}

Pastorino y Gallo (2002) en su estudio de la historia evolutiva de $A$. chilensis establecieron que el patrón de variación geográfica y genética de la especie responde en gran medida a la influencia del fenómeno de las glaciaciones cuaternarias. Diversos refugios de pequeño tamaño, ubicados al Este de la cordillera de los Andes en el límite con la estepa y en la misma cordillera, habrían permitido la supervivencia de ciprés a la glaciación y la recolonización de las áreas cubiertas de hielo una vez retirado el glaciar. Para la región del paralelo $42^{\circ}$ se propuso un patrón que respondería a la existencia de un refugio interglacial entre los $41^{\circ} 20^{\prime}-41^{\circ} 50^{\prime} \mathrm{S}$ y los $71^{\circ} 30^{\prime}-$ $71^{\circ} 50^{\prime} \mathrm{O}$, con recolonización Norte-Sur y Oeste-Este (Pastorino y Gallo, 2002).

La Reserva Forestal LMRA corre en dirección Norte-Sur, entre los $41^{\circ} 40^{\prime}-42^{\circ} 12^{\prime}$ S y los $71^{\circ} 42^{\prime}-71^{\circ} 20^{\prime} \mathrm{O}$, disminuyendo gradualmente su altitud. Si bien no existen grandes diferencias entre los valores de altitud en los sitios de muestreo propiamente dichos, los rodales R11 y R18 se ubican en una zona general de mayor altitud, en tanto que el R81 se encuentra en la parte más 
baja (Figura IX-2). Los lotes L5y6 y L9y15 se ubican por fuera de la reserva forestal, en áreas que descienden de altura en dirección al valle central. En términos generales, el área Norte de El Bolsón presenta mayor altitud y menores pendientes que el área Sur.

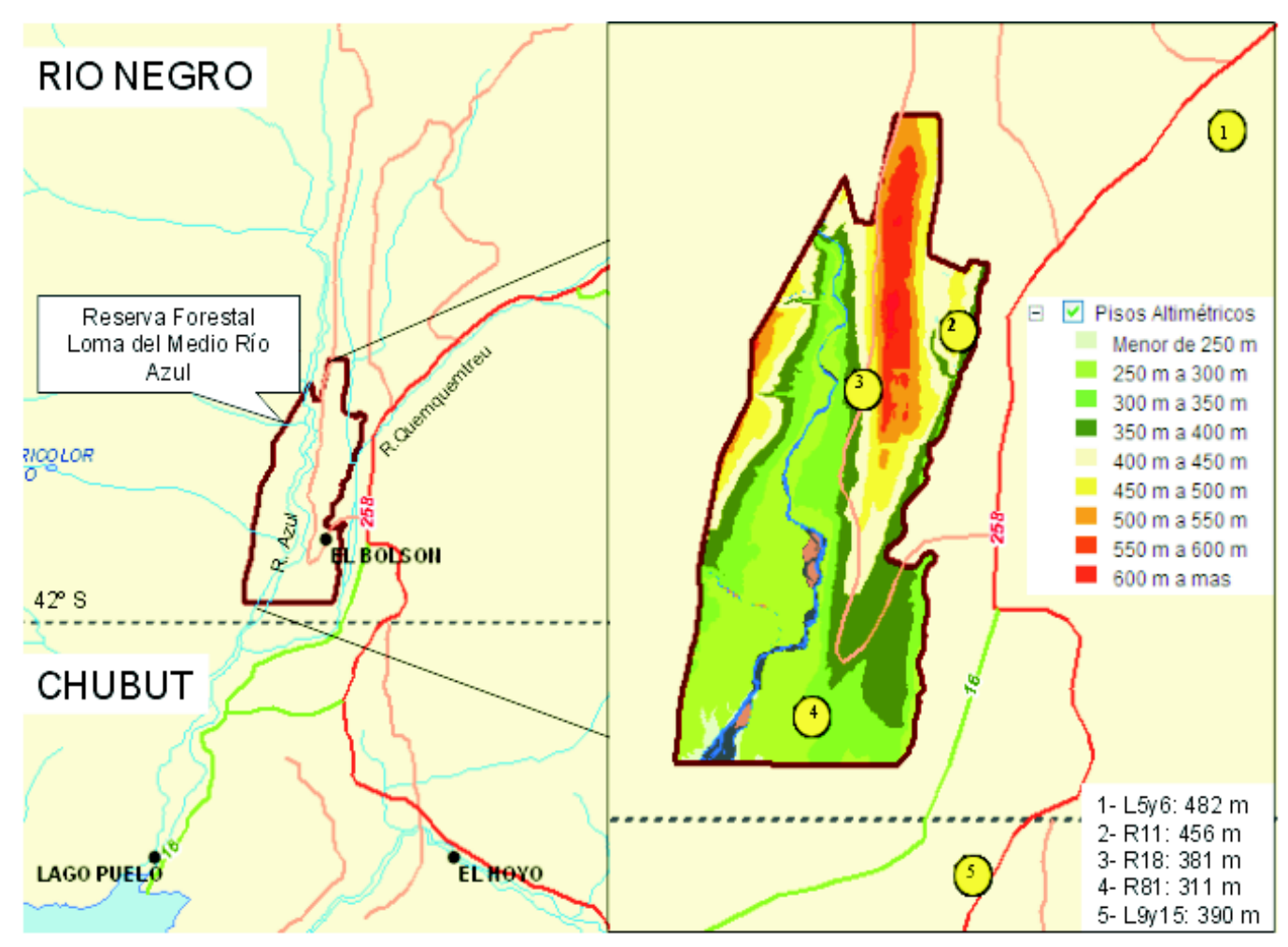

Figura IX-2: Pisos altimétricos del área de estudio. Izquierda: Ubicación y límites de la Reserva Forestal Loma del Medio Río Azul. Derecha: Pisos altimétricos correspondientes a la reserva y ubicación de los sitios de muestreo. Referencias en las imágenes. Fuente de información: SIG de la Reserva Forestal LMRA. GEOINTA. http://geointa.inta.gov.ar/SIGRESFORLM.

La estructuración genética detectada podría, por tanto, asociarse a la presencia del mencionado refugio interglaciario. La distancia entre el área Norte (R11, R18 y L5y6) y Sur (R81 y L9y15), respecto del posible refugio podría explicar los patrones de diversidad y diferenciación genética. La hipótesis es consistente con la diferenciación local detectada, presentando el área Norte mayor proporción de los marcadores de baja frecuencia asociados a la diferenciación. Sin embargo, para distancias tan cortas como las estudiadas $(<12 \mathrm{~km})$ la diferenciación producida como consecuencia de la migración Norte-Sur debería haber sido eliminada por efecto del flujo génico ya que no se observa aislamiento entre las áreas. Por otra parte, este proceso de recolonización desde un posible refugio glaciario no explica el resto de las diferencias detectadas (por ejemplo diferencia en la razón de sexos o en la susceptibilidad diferencial de los individuos femeninos). 


\subsection{2- Incendios}

Si bien los bosques de $A$. chilensis del área de estudio corresponden a bosques mésicos fuertemente afectados por los incendios de principio de siglo pasado (Willis, 1914), el establecimiento posterior en las áreas estudiadas no muestra diferencias importantes (Capitulo VII). Hasta donde fue posible consultar, la búsqueda bibliográfica no reveló diferencias en la frecuencia o intensidad de incendios entre las áreas, por lo que no podría ser esta la causa principal de la estructuración Norte-Sur.

\subsection{3- Clima}

Los patrones de cambio de las condiciones climáticas afectan directa e indirectamente la dinámica de los bosques. El efecto indirecto se refiere al impacto sobre el régimen de disturbios, en tanto que el directo comprende cambios en el establecimiento o la mortalidad de los individuos. En el Norte de la Patagonia las variaciones climáticas están regidas por la celda subtropical de alta presión sobre el sudeste del Océano Pacífico y los eventos El NiñoOscilación del Sur, que en su modo negativo se asocia a veranos cálidos y secos (Veblen et al., 2005). Entre el bosque y la estepa, en el ecotono, los períodos de alta mortalidad en la especie responden a primaveras y veranos muy secos, en un patrón episódico de alta frecuencia (uno o dos años) en la variación climática (Villalba y Veblen, 1998; Villalba et al., 2005). La mortalidad masiva en estos sitios correlaciona con crecimientos por debajo del promedio en cronologías de referencia cercanas (Villalba y Veblen, 1998), evidenciando un impacto diferencial entre individuos de la misma especie. La diferencia Norte-Sur (entre los $39^{\circ}-42^{\circ}$ de latitud Sur) detectada en la manifestación y la intensidad de los eventos de mortalidad a lo largo del ecotono se asoció a variaciones en la intensidad de las condiciones climáticas cálidas y secas (Villalba y Veblen, 1998). Considerando la cercanía entre el Norte y Sur de la región de El Bolsón es difícil pensar que variaciones de microclima determinen exclusivamente la separación entre las áreas.

\subsection{4- Condiciones de sitio}

Las diferencias detectadas en la diversidad de poblaciones bacterianas, podrían estar asociadas a diferencias en las condiciones de sitio entre el área Norte y Sur. Sin embargo, en lo que respecta al establecimiento y crecimiento de individuos las áreas estudiadas no muestra diferencias importantes (Capitulo VII).

Las características del área Sur se asemejan a las reportadas en relación al patrón ecológico del mal del ciprés, esto es altitudes moderadas, poca pendiente y características de pobre drenaje. 
Considerando, además, que el mal del ciprés fue reportado con mayor incidencia en el área Sur y que el aprovechamiento forestal se implementó tempranamente a consecuencia de la alta mortalidad (Chauchard y Barnabá 1986), es posible pensar en la acción directa del mal del ciprés como determinante de la estructuración Norte-Sur.

\subsection{5- Mal del ciprés}

El análisis genético vía RGA reveló que los marcadores que contribuyen a la diferenciación son mayoritariamente marcadores de baja frecuencia asociados a los individuos sintomáticos. De acuerdo con esta asociación, la mayor incidencia del mal del ciprés y el aprovechamiento selectivo de los individuos afectados explicaría la menor diversidad genética del área Sur.

Del mismo modo, la mayor susceptibilidad de los individuos femeninos al mal del ciprés, explicaría por qué el área con mayor incidencia de mortalidad y consecuente aprovechamiento selectivo presenta una relación de sexos superior a 1.

Las diferencias respecto de la sequía que determina la inversión de las cronologías, puede también explicarse considerando el mayor impacto del mal del ciprés en el área Sur. El análisis de las cronologías de crecimiento reveló que los individuos sintomáticos corresponden a los de mayor crecimiento antes del evento de sequía (Capitulo VII), lo que sugiere que son árboles dominantes con buen acceso a los recursos del bosque. El análisis comparativo de las cronologías de crecimiento entre el Norte y el Sur reveló que la sequía de 1942-1943 tuvo un impacto similar en ambas áreas (Capítulo VII). Este resultado sugiere que tanto en el Norte como en el Sur esta sequía produjo importante mortalidad. Si consideramos el aprovechamiento selectivo realizado en el Sur, es posible explicar las diferencias respecto de la sequía que determina la inversión de curvas. La secuencia temporal del proceso puede resumirse de la siguiente manera:

○ la sequía del año 1942-1943 produjo importante mortalidad de individuos dominantes en el área Norte y Sur

- en el área Sur estos individuos fueron selectivamente aprovechados lo que determinó una liberación importante de recursos que fueron utilizados por los individuos remanentes en el sitio, estableciéndose nuevos procesos de competencia intraespecífca y la liberación del crecimiento de algunos individuos oprimidos que lograron una posición de dominancia. Durante la sequía de 1962 estos nuevos individuos dominantes fueron afectados. 
○ en el área Norte, parte de los individuos afectados por la sequía de 1942-1943 (que no fueron aprovechados) continúan vivos con bajos niveles de crecimiento, pero limitando el acceso a los recursos de los individuos oprimidos. El impacto de la sequía de 1962 fue, por tanto, menos intenso en el área Norte ya que ni los individuos afectados ni los oprimidos presentaban altas tasas de crecimientos en el momento de la sequía.

La diferencia detectada entre el Norte y el Sur en la susceptibilidad diferencial de los individuos femeninos al mal del ciprés es difícil de explicar bajo cualquiera de los factores considerados. La mayor susceptibilidad de los individuos femeninos al mal del ciprés, la mayor incidencia del mal del ciprés en el Sur y el aprovechamiento selectivo, explican la mayoría de individuos masculinos en el lugar; sin embargo esto no explica porqué los individuos femeninos remanentes no evidencian mayor susceptibilidad a la sequía de 1962. Tomados en conjunto, los datos sugieren que la susceptibilidad diferencial entre sexos no está definida exclusivamente por el mayor costo hídrico de los individuos femeninos, sino que depende de mecanismos o factores adicionales que actúan conjuntamente para determinar el balance global en cada sitio.

Por el momento, la mayor incidencia del mal del ciprés en el área Sur sumada al aprovechamiento selectivo, es la hipótesis que mejor explica la estructuración Norte-Sur observada en la región de El Bolsón.

\section{2.- Patrones de CREcimiento y MORTAlidad en $A$. Chilensis interpretación FISIOLÓGICA DE LAS DIFERENCIAS DETECTADAS}

El crecimiento radial de $A$. chilensis está asociado positivamente a la precipitación durante la primavera tardía y el inicio del verano, y negativamente a la temperatura durante el mismo período (Villalba y Veblen, 1997; Mundo et al., Anexo 11). Como se indicó anteriormente, el análisis de las cronologías promedio muestra un comportamiento diferencial entre las plantas con y sin síntomas, antes y luego de la fecha de inversión (Capitulo VII). El impacto del evento de sequía fue mayor en las plantas sintomáticas que, a partir de ese momento, iniciaron una caída sostenida en el crecimiento radial (Capitulo VII). Estas diferencias no pueden ser explicadas teniendo en cuenta únicamente la correlación entre el crecimiento radial y el aporte de agua. El patrón diferencial detectado en las cronologías promedio sugiere que los árboles con mayor crecimiento radial (mayor ancho de anillo de crecimiento) serían más susceptibles al impacto de un evento de sequía extremo, y que la alteración se mantendría, e incluso potenciaría, con el tiempo. En otras palabras, los resultados indican una respuesta diferencial a la sequía entre los árboles sintomáticos y asintomáticos. 
El principal mecanismo fisiológico de $A$. chilensis para evitar el daño por sequía es un fuerte control de estomas; la especie no presenta mecanismos adicionales como ajuste osmótico o elástico y a pesar de sus altos valores de resistencia hidráulica tiene mayor vulnerabilidad a la cavitación que otras especies que evaden la sequía (Gyenge et al., 2005). El comportamiento de la conductancia estomática en relación al potencial agua y al déficit de presión de vapor (Gyenge et al., 2007) y las características de la curva de vulnerabilidad o pérdida de conductividad debida a embolismo (Gyenge et al., 2005) ubican a ciprés de la cordillera entre las especies isohídricas; esto es, especies que reducen la conductancia estomática y mantienen valores constantes del potencial agua en la hoja a medida que disminuye el potencial agua del suelo y aumenta la demanda evaporativa (Mc Dowell et al., 2008).

La mortalidad diferencial entre especies de plantas en relación a la sequía, puede analizarse mediante un modelo general que contempla tres hipotéticos mecanismos de mortalidad: falla hidráulica, privación de carbono y cambios demográficos en agentes bióticos (Mc Dowell et al., 2008). La hipótesis de falla hidráulica predice que un reducido aporte de agua del suelo acoplado con altas demandas evaporativas conduce a cavitación de los conductos de xilema y de la rizosfera, deteniendo el flujo de agua. La falla hidráulica sería particularmente probable si la sequía es lo suficientemente intensa como para que la planta entre en déficit de agua antes de llegar a un déficit de carbono (Figura IX-3).

La hipótesis de privación de carbono predice que el cierre de los estomas, para prevenir la falla hidráulica, disminuye la captura fotosintética de carbono y conduce a una privación de nutrientes como resultado de la demanda metabólica continua de carbohidratos. El proceso podría ser exacerbado por fotoinhibición o un incremento de la respiración asociada al aumento de la temperatura durante la sequía. La privación de carbono sería particularmente probable si la sequía es lo suficientemente moderada como para no conducir a falla hidráulica y lo suficientemente extensa como para agotar las reservas de carbono (Figura IX-3).

El tercer mecanismo sugiere que la sequía lleva a cambios demográficos en agentes bióticos que posteriormente conducen a la mortalidad de las plantas (Figura IX-3). Los agentes bióticos podrían amplificar o ser amplificados por el estrés fisiológico, pudiendo los tres mecanismos propuestos operar en forma inclusiva o exclusiva. Como queda indicado, la relevancia de cada mecanismo se relaciona a la intensidad y duración de la sequía. 


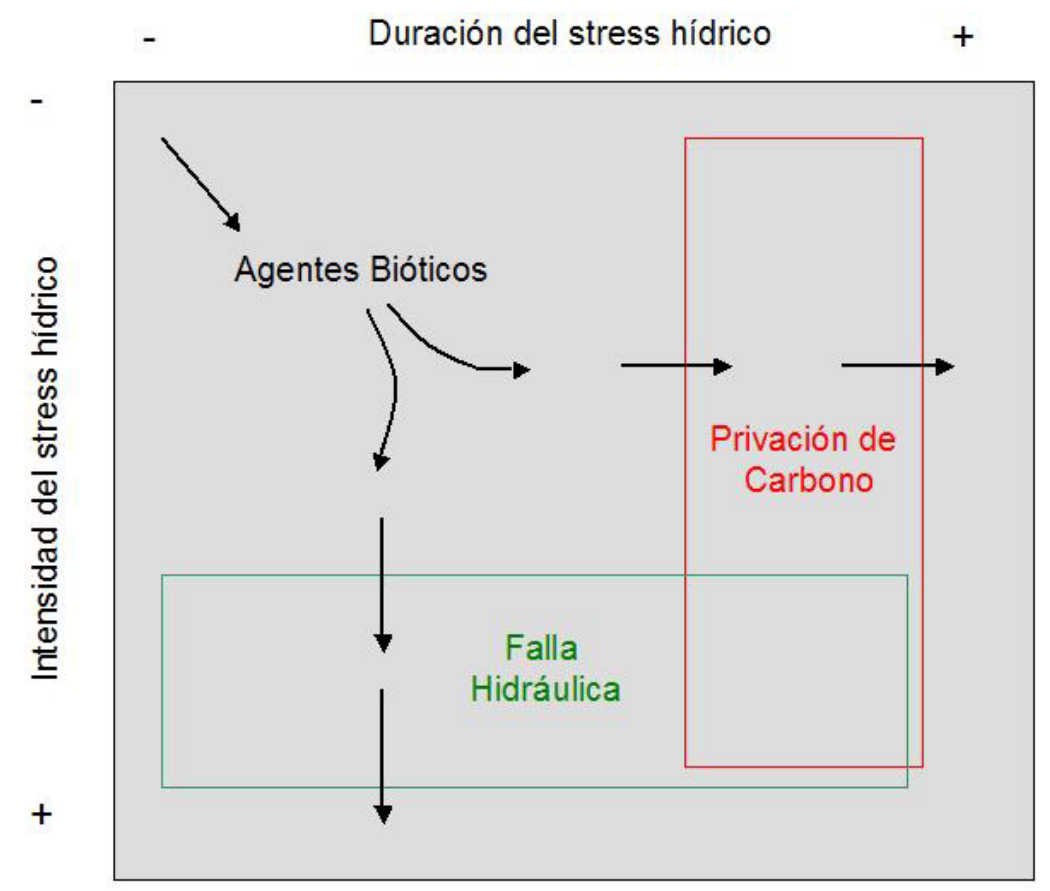

Figura IX-3: Relaciones teóricas, basadas en el marco hidráulico, entre la duración y la intensidad de la sequía, y los tres mecanismos hipotéticos de mortalidad. La privación de carbono ocurría cuando la duración de la sequía es lo suficientemente extensa que la disminución de la fotosíntesis supera las reservas de carbono. La falla hidráulica ocurriría con sequías intensas que llevan a las plantas a sobrepasar el umbral de desecación irreversible antes de caer en privación de carbono. La acción de agentes bióticos como insectos o patógenos, pueden amplificar o ser amplificados por la falla hidráulica o la privación de carbono. Modificado de Mc Dowell et al. (2008).

Si bien este modelo es válido para entender las diferencias de mortalidad entre especies frente a la sequía, podría ser utilizado para explicar el comportamiento frente al mal del ciprés que remite a un análisis entre individuos dentro de la misma especie (diferencias intraespecíficas). En este sentido, es importante considerar que aunque la variación genética no representa un mecanismo de mortalidad o supervivencia per se, las diferencias en características asociadas a la resistencia a la sequía, como vulnerabilidad del xilema a la cavitación, conductancia hidráulica, eficiencia del uso de agua, tamaño y densidad de estomas, podrían tener un rol importante en los mecanismos de mortalidad (Mc Dowell et al., 2008). Las relaciones de agua en las hojas, la resistencia hidráulica y la vulnerabilidad a la sequía no muestran diferencias entre procedencias de $A$. chilensis (Gyenge et al., 2005), en tanto que un ensayo de estrés hídrico sobre plantines de 8 procedencias, que incluyen poblaciones de estepa y de zona húmeda, indica que las diferencias se observarían entre familias y entre genotipos, pero no entre procedencias (Pastorino, com. pers.). 
El ancho de un anillo de crecimiento $\left(\mathrm{L}_{\mathrm{T}}\right)$ puede expresarse como $\Sigma \mathrm{D}_{\mathrm{R}}^{i}$, con $i$ variando entre 1 y N (Vaganov et al., 2006). El parámetro $i$ es el número serial de la traqueida en una fila, $\mathrm{N}$ el número total de traqueidas en la correspondiente fila de un anillo y $\mathrm{D}_{\mathrm{R}}^{i}$ el diámetro radial de la traqueida $i$. Diferencias en el número o el diámetro de las células conducen, por tanto, a diferencias en el ancho entre anillos de crecimiento.

La formación de anillos anuales en plantas leñosas es el resultado de la periodicidad estacional de los procesos de crecimiento, la cual está a su vez determinada por fluctuaciones ambientales asociadas con el ciclo anual y depende de la especie y de las condiciones locales en que la planta se desarrolla. Diversos factores externos e internos influyen sobre esta periodicidad estacional determinando el número y tamaño de las células. Entre los primeros, destacan los factores físicos y geográficos (climatología y topografía) que determinan modificaciones en tres variables principales: luz, temperatura y agua (Vaganov et al., 2006). El background genético es uno de los principales factores internos que influyen la dinámica del crecimiento estacional, entre los cuales se encuentran además la edad (del individuo o tejido analizado) y la longevidad de la especie (Vaganov et al., 2006). Dado el muestreo pareado realizado en el presente trabajo, la influencia de los factores externos en el ancho del anillo de crecimiento entre individuos sintomáticos y asintomáticos puede considerarse despreciable. La observación de un patrón diferencial característico entre plantas con y sin síntomas del mal del ciprés en los 5 sitios evaluados (Mundo et al., Anexo 11) y en los sitios estudiados en trabajos anteriores (Calí, 1996; Loguercio et al., 1998 y 1999a), sugieren que la edad no sería un factor determinante en los patrones observados en individuos de esta especie. El background genético de las plantas con y sin síntomas surge, por tanto, como uno de los factores a considerar en el análisis de las diferencias establecidas.

La existencia de relaciones especie específicas entre la formación de traqueidas y el crecimiento de otras partes de la planta indican un fuerte control genético de la formación de traqueidas (Mitchell, 1961; Smirnov, 1964; Kennedy, 1969; Vaganov y Tersok, 1977). El valor de heredabilidad (h ${ }^{2}$ ) es usado como un indicador cuantitativo de la influencia de los factores genéticos en la estructura del anillo de crecimiento. La densidad de madera y el porcentaje de madera tardía correlacionan en la mayoría de las coníferas (Pereligin, 1969; Poluboyarinov, 1976; Zobel y Jett, 1995), con valores de $\mathrm{h}^{2}$ en el rango de 0.15 a 0.92 (Goggans, 1962; Nicholls et al., 1980; Kennedy, 1966). El control genético del tamaño de las traqueidas y del espesor de la pared celular fue establecido para varias especies de coníferas en América del Norte (Van Buijtenen, 1965; Boyle et al., 1987). En un nivel intraespecífico, se determinó la influencia genética sobre las características de los vasos para clones de Eucalytus globulus (Leal et al., 2003), genotipos de Metrosideros polymorpha (Fisher et 
al., 2007) y morfotipos de hojas en Ilex paraguariensis (Dünisch et al., 2004). El control genético se estableció también a través del estudio de las relaciones entre la anatomía y fisiología de los vasos y las características morfológicas de las hojas para diferentes procedencias de Fagus crenata (Bayramzadeh et al,. 2008), y en evaluaciones densitométricas aplicadas a ensayos de procedencia sobre 16 orígenes de Pinus sylvestris (Savva et al., 2002).

De acuerdo con la bibliografía consultada, no existen estudios para $A$. chilensis que establezcan la influencia del control genético sobre características de la estructura del anillo de crecimiento. Sin embargo, Roig (1992) reportó que la longitud de las traqueidas determinada en estudios de maceración varía considerablemente entre individuos que crecen en el mismo sitio y bajo las mismas condiciones ecológicas; en tanto que no se observa correlación entre esta característica celular y la latitud o la altitud. Considerando que el diámetro y la longitud de las traqueidas en coníferas presentan importante correlación (Sperry et al., 2006; Hacke y Jansen, 2009), es esperable una variación en el diámetro de la traqueida entre individuos de $A$. chilensis que desarrollan en el mismo sitio.

Las funciones de transporte de agua y soporte mecánico residen en el xilema secundario de angiospermas y gimnospermas. A diferencia de las angiospermas, que presentan un sistema multicelular de vasos para el transporte y fibras para el soporte mecánico, en las gimnospermas ambas funciones asientan en el sistema de traqueidas. La longitud, el diámetro y el espesor de la pared de los conductos influyen en la resistencia al flujo, la protección contra la cavitación o la implosión; existiendo complejas relaciones entre estas tres funciones que determinan la dimensión final de los conductos (Sperry et al., 2006).

En los árboles el agua se transporta en el xilema bajo tensión (presión negativa) y en condiciones de sequía la tensión aumenta haciendo más probable la vaporización del agua (cavitación). La cavitación conduce a embolismo, interrupción del flujo en los conductos del xilema, limitando el aporte de agua a los tejidos. En el marco hidráulico del modelo de Mc Dowell et al. (2008), cuando la intensidad y la extensión de la sequía aumentan se produce falla hidráulica. De acuerdo con la Ley de Hagen-Poiseuille, la conductividad del lumen es proporcional a la cuarta potencia de su diámetro; sin embargo, la necesidad de resistir la cavitación puede limitar el tamaño del conducto. Esta limitación se demostró para el caso de la cavitación inducida por ciclos de congelamiento/descongelamiento, siendo mayor la resistencia para menores diámetros (Davis et al., 1999; Hacke y Sperry, 2001; Feild y Brodribb, 2001; Pittermann y Sperry, 2003; Cavender-Bares, 2005; Cochard, 2006; Pittermann y Sperry, 2006; Fisher et al., 2007). Los conductos de menores dimensiones son también, en general, más resistentes a la cavitación inducida por 
sequía (Hacke y Sperry, 2001; Domec y Gartner, 2002; Willson y Jackson, 2006; Fisher et al., 2007), aunque las relaciones son más complejas que las observadas para la cavitación por ciclos de congelamiento/descongelamiento (Sperry et al., 2006). Esta mayor complejidad es consistente con el mecanismo propuesto para la cavitación por sequía, que depende en gran medida de las características de las conexiones entre conductos o pits (Hacke y Sperry, 2001; Cochard, 2006; Sperry et al., 2006; Hacke y Jansen, 2009).

El transporte bajo presiones negativas derivó evolutivamente en el desarrollo de paredes más densas, con agregado de ligninas, estableciéndose la existencia de un factor de reforzamiento $(\mathrm{t} / \mathrm{b})^{2}(\mathrm{t}=$ espesor y $\mathrm{b}=$ extensión de la pared) que es proporcional a la resistencia a la cavitación y la implosión de los conductos (Hacke et al., 2001; Sperry et al., 2006; Pittermann et al., 2006). La limitación mecánica en el diámetro de las traqueidas explicaría la relación entre menores diámetros y resistencia a la cavitación; una mayor presión negativa requiere traqueidas más fuertes con mayores relaciones $(\mathrm{t} / \mathrm{b})^{2}$ para resistir la implosión (Sperry et al., 2006). Este comportamiento es consistente con la tendencia a un incremento en la densidad de la madera, a la relación entre $(\mathrm{t} / \mathrm{b})^{2}$ y la densidad frente a la vulnerabilidad a la cavitación y la resistencia a la sequía (Hacke et al., 2001; Hacke y Sperry, 2001; Sperry et al. 2006; Martinez-Meier et al., 2008; Dalla-Salda et al., 2009).

La información presentada sugiere que la respuesta diferencial a la sequía entre los árboles sintomáticos $\mathrm{y}$ asintomáticos, se asocia a diferencias en el diámetro de las traqueidas entre individuos dentro de un mismo sitio; que estas diferencias estarían determinadas en gran medida por el background genético de los individuos y que conducirían a estados fisiológicos diferentes frente a cambios en las condiciones climáticas.

\section{3.- NUEVA HIPÓTESIS SOBRE EL ORIGEN DEL MAL DEL CIPRÉS}

Considerando la relación entre el ancho del anillo de crecimiento y la vulnerabilidad a la cavitación con respecto al diámetro de la traqueida, la inversión de las cronologías promedio entre árboles con y sin síntomas de mal del ciprés, su asociación a eventos de sequía extremos y la mayor susceptibilidad a la sequía de los árboles con mayor ancho de anillo de crecimiento, es posible plantear una nueva hipótesis para el mal del ciprés según la cual la mortalidad diferencial de árboles sería consecuencia de una susceptibilidad diferencial a la cavitación. Si fuese así, el diseño de muestreo pareado empleado sugiere un importante control genético en la resistencia a la cavitación, ya que prácticamente no existen diferencias ambientales entre los individuos de un par. La falla hidráulica podría asociarse también a diferencias en la respuesta 
de la conductancia estomática al potencial agua del suelo y la demanda evaporativa; sin embargo de acuerdo con los resultados del análisis dendrocronológico aún en ese caso debería establecerse una correlación entre esta característica y el diámetro de las traqueidas. Aunque la hipótesis de privación de carbono asociada al cierre de los estomas es el mecanismo diferencial de respuesta esperado para $A$. chilensis en una comparación entre especies; en el caso del mal del ciprés no explica las diferencias intraespecíficas. De acuerdo con Mc Dowell et al. (2008) el mecanismo de privación de carbono predice que los individuos con menores reservas serán más afectados debido a la caída en la tasa fotosintética y a la demanda continua de carbohidratos. Sin embargo, en el mal del ciprés los árboles afectados por la sequía corresponden a los de mayor ancho de anillos de crecimiento y es de esperar que sean éstos los de mayores reservas.

La vulnerabilidad del xilema a la cavitación se relaciona con la respuesta diferencial a la sequía en un importante rango de especies, que desarrollan en condiciones ecológicas diversas, sugiriendo que es necesario mantener conductos funcionales para sobrevivir a sequías extremas (Hacke y Sperry, 2001; Hacke et al., 2001). Aunque los estudios de diferencias en la vulnerabilidad del xilema a la cavitación entre genotipos son más escasos, la misma ha sido establecida entre clones de Sacharum (caña de azúcar) (Neufeld et al., 1992), Eucalyptus (Willigen y Panmenter, 1998; Pita et al., 2003), Hevea Brasiliensis (árbol del caucho) (Sangsing et al., 2004), Populus (álamo) y Salix (sauce) (Cochard et al., 2007); entre variedades de Olea (olivo) (Ennajeh et al., 2008) y entre poblaciones de Ambrosia dumosa (Mencuccini y Comstock, 1997) y Pseudotsuga menziessi (Kavanagh et al., 1999). Para A. chilensis un ensayo de estrés hídrico sugiere vulnerabilidad diferencial entre familias y genotipos (Pastorino, com. pers.). La verificación de la hipótesis planteada requiere del estudio de las características estructurales de la madera y de la evaluación de la susceptibilidad a la cavitación en plantas con y sin síntomas del mal del ciprés. Posteriormente será necesario el estudio de estas variables entre progenies de los genotipos susceptibles y resistentes que pudieran ser detectados a fin de establecer la influencia del control genético en la respuesta diferencial (heredabilidad).

El planteo de una nueva hipótesis requiere, necesariamente, que la misma se ajuste a las descripciones previas de la problemática que intenta explicar. En este sentido, una forma de avanzar en el análisis de la hipótesis planteada consiste en contrastar el conocimiento previo sobre el mal del ciprés con las predicciones derivadas del modelo. A continuación se analiza la información disponible sobre el mal del ciprés en relación a los resultados obtenidos en el presente trabajo de tesis y la hipótesis propuesta. 


\section{4.- EL MAL DEL CIPRÉS BAJO LA HIPÓTESIS DE CAVITACIÓN}

Todos los modelos etiológicos planteados en relación al mal del ciprés se basan en el supuesto de un origen radical y consideran que sea cual fuere el agente causal genera un desequilibrio entre los compartimentos aéreo y subterráneo de la planta, lo que conduce a estrés hídrico que sería en último término el responsable de la aparición de los síntomas aéreos (Capitulo I).

La hipótesis de cavitación se ajusta a esta descripción, ya que las traqueidas de las raíces son más susceptibles a la cavitación que las traqueidas en la madera del fuste (Hacke et al., 2000; Hacke y Sperry, 2001; Matzner et al, 2001; Sperry et al., 2006; Hacke y Jansen, 2009). Esta diferencia en la susceptiblidad a la cavitación entre el fuste y la raíz, depende de las funciones que asientan en cada tejido. El fuste cumple con las funciones de sostén y conducción, y del compromiso entre ambas resulta el tamaño de la traqueida. El soporte mecánico, conduce al espesamiento de paredes y limita en forma consecuente el diámetro de la traqueida debido a la necesidad de mantener el factor de reforzamiento. La raíz por el contrario, tiene como función principal el aporte de agua, por lo que desarrolla traqueidas de mayor diámetro. Este tejido estará, por tanto, más expuesto a sufrir cavitación durante la sequía explicando por qué el inicio de la afectación se da a nivel de raíz (Figura IX-4).

La cavitación de las raíces determina un menor aporte de agua a las hojas, lo que conduce al desarrollo de los síntomas aéreos de amarillamiento y defoliación (Rosso, 1989; Havrylenko et al., 1989) y a una menor producción de fotosintetatos. En estas condiciones las plantas derivan recursos al crecimiento primario, limitando el crecimiento secundario lo que explica la caída en la tasa de crecimiento (Calí, 1996; Loguercio et al., 1998 y 1999a; Amoroso, 2009). La limitación en carbono podría conducir a una disminución del metabolismo secundario y, consecuentemente a la menor síntesis de compuestos de defensa. La mortalidad de raíces por cavitación y la falta de compuestos de defensa, facilitarían la colonización por organismos secundarios explicando la aparición de pudriciones, lesiones necróticas y mortalidad de raíces finas (Varsavsky et al., 1975; Rajchenberg y Cwielong, 1993; Merlo, 1994; Barroetaveña y Rajchenberg, 1996; Rajchenberg et al., 1997; Greslebin y Hansen, 2006; Greslebin et al., 2007; Greslebin y Hansen 2007a y b; Floria y Greslebin, 2007; Floria, 2008).

El patrón de desarrollo de la mortalidad puede ser explicado en función de un análisis de la variabilidad del diámetro de traqueidas dentro de los diferentes tejidos de un mismo individuo. La cavitación de las raíces explica a su vez la aparición de los síntomas aéreos, subterráneos e internos (Figura IX-4). 


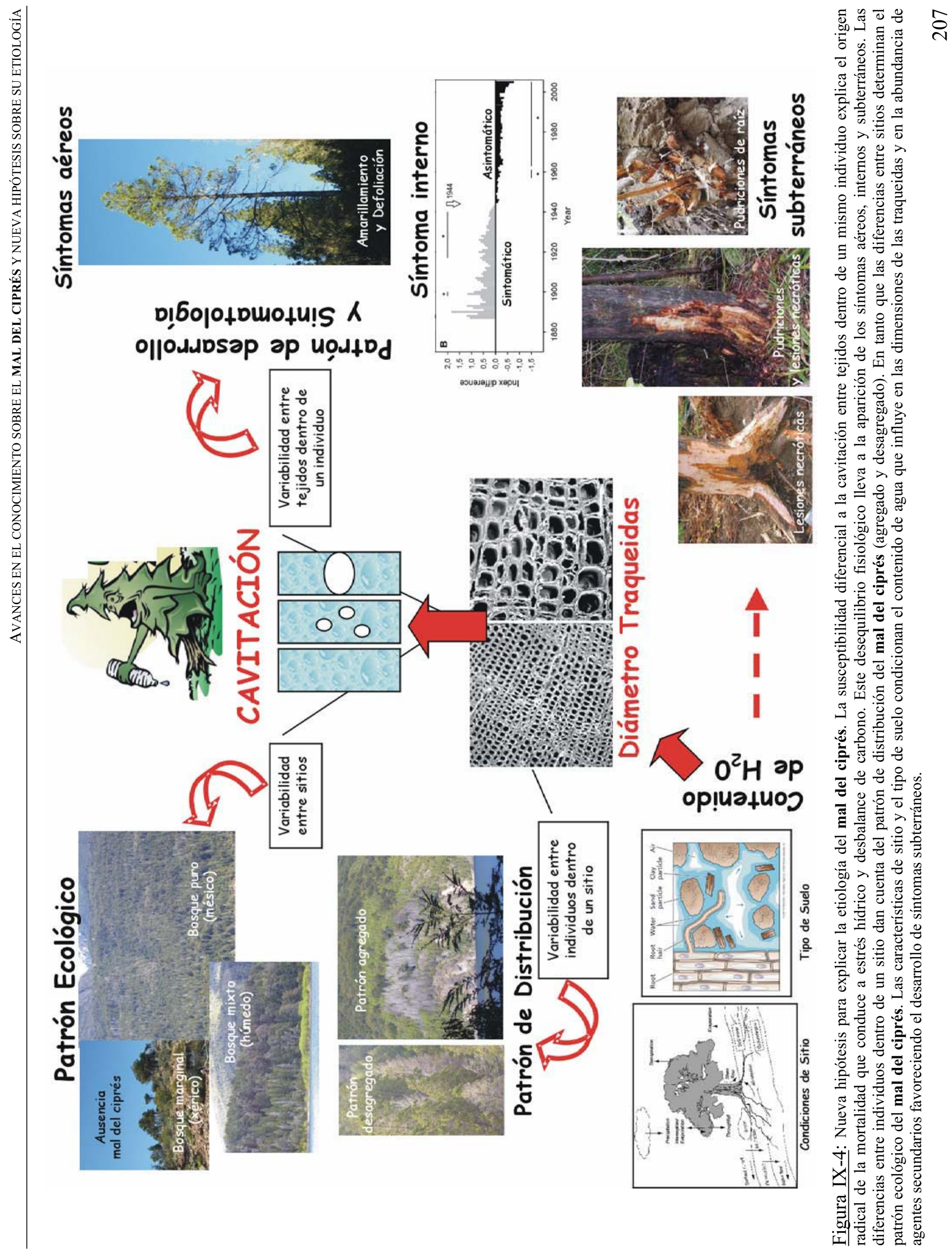


El patrón desagregado del mal del ciprés, remite a diferencias entre individuos de la misma especie dentro de un mismo sitio. Dentro de los sitios mésicos o húmedos, los individuos desarrollan con buen aporte de agua, condición que permite que se manifiesten las diferencias competitivas entre individuos. Los individuos dominantes en estos sitios, requieren mayor aporte de agua, lo que conduce al desarrollo de traqueidas de mayor diámetro, que serán más sensibles a la cavitación. En el momento de una sequía extrema, estos individuos dominantes serán más intensamente afectados. Es decir, que el patrón desagregado del mal del ciprés puede ser explicado en función del análisis de la variabilidad del diámetro de las traqueidas dentro de un sitio (Figura IX-4).

El patrón agregado del mal del ciprés, hace referencia a un grupo de individuos afectados (manchón) que se diferencian claramente de los individuos no afectados del sitio. Este patrón de distribución ha sido explicado en base a diferencias marcadas entre las condiciones de sitio en el lugar del manchón (La Manna, 2004). Algunos de los casos de patrón agregado del mal del ciprés, corresponden a sitios con buen aporte de agua pero con características de exceso de drenaje (La Manna, 2004). En este sentido, la hipótesis de cavitación puede explicar el patrón agregado del mal del ciprés (Figura IX-4). En el caso de pobre drenaje los individuos desarrollan en suelos con alto contenido de agua lo que sugiere un mayor diámetro de traqueidas y por tanto mayor susceptibilidad a la sequía; y en el caso de sitios con exceso de drenaje los individuos que en condiciones normales tienen un aporte suficiente de agua para crecer, ante un evento de sequía estarían sometidos a un estrés hídrico muy intenso derivado no sólo del bajo aporte de agua sino del exceso de drenaje del sitio, lo cual explicaría la mayor susceptibilidad a la cavitación.

Es importante considerar que, de acuerdo con los resultados de la caracterización genética vía RGA, la agregación de los individuos en un sitio afectado (Rosso, 1989) podría también ser consecuencia de un background genético compartido. En este sentido el patrón de recolonización en un sitio, el número de plantas madres iniciales y diferencias en el grado de flujo génico entre poblaciones podrían condicionar el desarrollo agregado o desagregado del mal del ciprés. Este aspecto debería ser considerado a futuro en el análisis del patrón de distribución del mal del ciprés y la agregación de individuos afectados.

El patrón ecológico descripto para el mal del ciprés, sitios con alta precipitación anual, pendiente poco pronunciada y bajas a moderadas altitudes (Havrylenko et al., 1989; Baccalá et al., 1998), puede ser explicado bajo la hipótesis de cavitación. Los individuos de sitios xéricos desarrollan en condiciones de intenso estrés hídrico, están más expuestos a la cavitación y por tanto se espera que presenten traqueidas de menor diámetro. Por el contrario, los individuos de 
sitios mésicos o húmedos desarrollan con buen aporte de agua, están menos expuestos a la cavitación y por tanto se espera que presenten traqueidas de mayor diámetro. Ante un evento extremo de sequía regional, los árboles de las zonas xéricas serán menos apartados de su condición normal de desarrollo y evidenciarán menor impacto de la sequía; en tanto que los individuos en zonas mésicas o húmedas serán fuertemente afectados por la sequía. Estas diferencias permiten explicar por qué el mal del ciprés no ha sido reportado en la estepa; es decir que el patrón ecológico del mal del ciprés puede ser explicado en función de un análisis de la variabilidad del diámetro de las traqueidas entre sitios (Figura IX-4).

Los resultados del análisis genético vía RGA, sumados a la hipótesis de cavitación, permiten entender también el patrón ecológico del mal del ciprés desde el punto de vista genético. El análisis RGA reveló que la diferenciación entre individuos sintomáticos y asintomáticos está determinada por marcadores de baja frecuencia asociados a los individuos afectados. Los resultados del análisis de cronologías de crecimiento muestran que estos individuos son susceptibles a la sequía. Por tanto es posible considerar que en las áreas xéricas, sometidas a constante estrés hídrico, estas variantes genéticas hayan ido desapareciendo con el tiempo explicando la menor diversidad genética detectada entre los individuos de la región xérica.

La falla hidráulica ocurre también en los suelos y presenta una funcionalidad similar a la cavitación de xilema. En los suelos la cavitación varía en función de la textura, el contenido de agua, la conductividad hidráulica y la profundidad de la napa de agua (Mc Dowell et al., 2008). Se requiere mayor tensión para extraer agua desde suelos de textura fina debido al menor tamaño de poro, por lo cual estos suelos en condiciones de abundancia de agua tendrán menor conductancia que los suelos más arenosos. Sin embargo, se espera que los suelos de textura fina mantengan una conductancia hidráulica durante más tiempo y a potenciales de agua más negativos que los suelos más porosos, debido a la menor pérdida de agua por drenaje o transpiración. La profundidad de la napa de agua impacta en las propiedades hidráulicas limitando o permitiendo el acceso al agua en períodos secos. Debido a que las plantas pueden responder a estas limitaciones ajustando la densidad y/o conductancia hidráulica de raíces finas, la profundidad de enraizamiento y otras características de la raíz (Mc Dowell et al, 2008) es difícil predecir en que sitios el balance será negativo. La Manna y Rajchenberg (2004a y b) establecieron que el agua retenida a la presión de 1 bar en el horizonte $C$ es significativamente superior en sitios con mal del ciprés y que depende de la textura del suelo; texturas más finas se asocian a valores mayores de agua retenida. Bajo $\mathrm{pH}$ en $\mathrm{NaF}$, abundancia de propiedades redoximórficas, texturas finas y alto contenido de humedad al final de la estación seca son las principales propiedades de micrositio asociadas a la presencia de mal del ciprés (La Manna y Rajchenberg 2004a). En términos 
generales, estas propiedades de micrositio refieren a un mayor contenido de agua y a deficiencias en el drenaje. Evaluaciones ecofisiológicas serán necesarias a fin de determinar el balance global entre la cavitación del suelo y los tejidos en el momento de una sequía.

El mayor contenido de agua al final de la estación seca de los suelos de textura fina, la asociación a cursos de agua o planicies de inundación de los ríos y el patrón ecológico descripto para sitios con mayor incidencia de mal del ciprés (Havrylenko et al., 1989; Rosso, 1989; Calí, 1996; Baccalá et al., 1998; La Manna, 2004; La Manna y Rajchenberg 2004a y b), sugieren una interpretación alternativa de la relación entre el contenido de agua del suelo y el mal del ciprés. Sitios con mayor disponibilidad de agua requerirán menor protección contra la cavitación pudiendo las plantas beneficiarse de la mayor eficiencia hidráulica de conductos mayores, condición que los expondrá a la cavitación en el momento de un evento de sequía extremo que se aparte de las condiciones normales en que las plantas desarrollan. Esta interpretación basada en la hipótesis de susceptibilidad diferencial a la cavitación explica la asociación entre las condiciones de sitio y la presencia del mal del ciprés que hasta el momento no había podido ser explicada por ninguna de las hipótesis de efecto predisponente del sitio, directo o indirecto, anteriormente propuestas (Figura IX-4).

Por último, la hipótesis de cavitación no contradice la asociación entre las condiciones de sitio y la presencia de organismos saprófitos o patógenos. El contenido de agua, además de condicionar el mayor o menor diámetro de las traqueidas, influye en el desarrollo de estos organismos bióticos. Los sitios donde es más probable que los individuos de ciprés sean afectados por cavitación coinciden con los sitios donde es más probable el desarrollo de los organismos secundarios. Esto explica no solo la asociación entre el mal del ciprés y los síntomas subterráneos derivados de la acción de organismos secundarios (mortalidad de raíces, pudriciones, lesiones necróticas), sino las diferencias en la proporción de individuos con mal del ciprés que son afectados por organismos secundarios (Figura IX-4). 


\section{CONCLUSIÓN DEL TRABAJO DE TESIS}

El trabajo desarrollado en la tesis constituye el primer abordaje interdisciplinario sobre el mal del ciprés en el cual se analizaron aspectos relacionados con el huésped, factores bióticos y abióticos sobre un mismo grupo de individuos seleccionados mediante un sistema de muestreo pareado caso-control (sintomático-asintomático).

Este análisis integrado permitió formular una nueva hipótesis etiológica para el mal del ciprés según la cual la mortalidad diferencial de árboles sería consecuencia de una susceptibilidad diferencial a la cavitación.

La hipótesis de cavitación explica el conocimiento sobre el mal del ciprés generado en más de sesenta años de investigación y aporta un marco referencial a través del cual es posible comenzar a bosquejar las complejas relaciones que conducen a la muerte de individuos de A. chilensis.

El estudio de las características estructurales de la madera y la evaluación de la susceptibilidad a la cavitación en plantas con y sin síntomas del mal del ciprés serán necesarios para verificar la hipótesis planteada. El análisis de estas variables entre progenies de los genotipos susceptibles y resistentes que pudieran ser detectados permitirá establecer la influencia del control genético en la respuesta diferencial (heredabilidad). La secuenciación de los marcadores RGA que contribuyen a la diferenciación entre individuos sintomáticos y asintomáticos contribuirán a la identificación de los factores que determinan la susceptibilidad diferencial a la sequía. 



\section{BIBLIOGRAFÍA}

Adams JC, Morehart AL, 1982. Decline and Death of Pinus spp. In Delaware Caused by Bursaphelenchus xylophilus. Journal of Nematology 14: 382-385.

Agrios GN, 1991. Fitopatología. Editorial Limusa.

Alexander SA, Palmer CJ, 1999. Forest health monitoring in the United States: First four years. Environmental Monitoring and Assessment 55: 267-277.

Allnutt TR, Newton AC, Lara A, Premoli A, Armesto JJ, Vergara R and Gardner M, 1999. Genetic variation in Fitzroya cupressoides (alerce) a threatened South American conifer. Molecular Ecology 8: 975-987.

Allnutt TR, Newton AC, Premoli A, Lara A, 2003. Genetic variation in the threatened South American conifer Pilgerodendron uviferum (Cupressaceae), detected using RAPD markers. Biological Conservation 114: 245-253.

Altschul SF, Madden TL, Schäffer AA, Zhang J, Miller W, Lipman DJ, 1997. Gapped-BLAST and PSI-BLAST: a new generation of protein database search programs. Nucleic Acids Research 25: 3389-3402.

Alvarez Taboada MF, Barrio Anta M, Gorgoso Varela J, Alvarez González JG, 2003. Influencia de la competencia en el crecimiento en sección en Pinus radiata D. Don. Investigación Agraria. Sistemas y Recursos Forestales 12(2): 25-35.

Amoroso MM, 2009. Stand development patterns as a consequence of the decline in Austrocedrus chilensis forests. Tesis para optar al título de Doctor en Filosofía. The University of British Columbia (Vancouver, Canada). 140 pp.

Amoroso MM, Daniels LD, 2008. Cambial dieback in declining Austrocedrus chilensis forests in northern Patagonia. Proceedings of the First American Dendrochronology Conference "AmeriDendro 2008" (Vancouver, Canada).

Anand R, Paul L, Chanway Ch, 2006. Research on Endophytic Bacteria: Recent Advances with Forest Trees. 89-106. En: Schulz B, Boyle C, Sieber TN. Soil Biology. Volumen 9. Microbial Root Endophytes.

Araújo WL, Marcon J, Maccheroni W, JD van Elsas, van Vuurde JWL, Azevedo JL, 2002. Diversity of Endophytic Bacterial Populations and Their Interaction with Xylella fastidiosa in Citrus Plants. Applied and Environmental Microbiology 68: 4906-4914.

Arnold C, Rossetto M, McNally J, Henry RJ, 2002. The application of SSRs characterized for grape (Vitis vinifera) to conservation studies in Vitaceae. American Journal of Botany 89: $22-28$. 
Asokan R, Kumar K, Verghese A, 2007. Molecular identification of fruit flies, Bactrocera spp. (Diptera: Tephtitidae) using mitochondrial cytochrome oxidase I. Current Science. 93 (12): 1668-1669.

Auclair AN, Worrest RC, Lachance D, Martin HC, 1992 citado por La Manna, 2004 . Climatic perturbation as a general mechanism of forest dieback. 38-58 pp. En: Manion PD, Lachance D. Forest Decline Concepts. The American Phytopathological Society Press, St. Paul, USA.

Avila F, Madden T, Schaffer A, Zhang H, Zhang Z, Miller W, Lipman D, 1998. Polymerase chain reaction detection and phylogenetic characterization of an agent associated with yellow vine disease of cucurbits. Phytopathology 88:428-436.

Ayres MP, Lombardero MJ, 2000. Assessing the consequences of global change for forest disturbance from herbivores and pathogens. The Science of the Total Environment 262: 263-286.

Baccalá NB, Rosso PH, Havrylenko M, 1998. Austrocedrus chilensis mortality in the Nahuel Haupi National Park (Argentina). Forest Ecology and Management 109, 261-269.

Bagnoli F, Fineschi S, Sebastián F, Buonamici A, Cossu C, Vendramin GG, 2007. Genetic structure of Cupressus sempervirens L. (Cupressaceae) in its primary and secondary distribution area analysed through nuclear microsatellites. Proceedings of the 51st Italian Society of Agricultural Genetics Annual Congress (Riva del Garda, Italy).

Barichivich Henríquez JE, 2005. Muerte apical episódica en bosques de alerce (Fitzroya cupressoides [Mol.] Johnston) de la Cordillera de la Costa de Valdivia. Proyecto para optar al Título de Ingeniero Forestal. Universidad Austral de Chile. Chile. 79 pp.

Barroetaveña C, Rajchenberg, 1996. Hongos Aphyllophorales (Basidiomycetes) que causan pudriciones en Austrocedrus chilensis en pie. Boletín de la Sociedad Argentina de Botánica 31(3-4), 201-216.

Bayramzadeh V, Funada R, Kubo T, 2008. Relationships between vessel element anatomy and physiological as well as morphological traits of leaves in Fagus crenata seedlings originating from different provenances. Trees 22: 217-224.

Bechir A, El Mousadik A, Pichot Ch, 2004. Diversité allozymique de peuplements de cyprès naturels et introduits au Maroc: conséquences pour la gestion des ressources. Annals of Forest Science 61: 669-676.

Bechtold W, 2003. Crown Position and Light Exposure Classification-An Alternative to FieldAssignde Crown Class. Northern Journal of Applied Forestry 20(4):154-160.

Beever RE, Forster RLS, Rees-George J, Robertson GI, Wood GA, Winks CJ, 1996. Sudden Decline of Cabbage tree (Cordyline Australis): Search for the cause. New Zealand Journal of Ecology 20: 53-68. 
Bekesiova I, Jan-Peter N, Amlynarova L. 1999. Isolation of High Quality DNA and RNA from Leaves of the Carnivorous Plant Drosera rotundifolia. Plant Molecular Biology Reporter 17: 269-277.

Bergeron Y, Denneler B, Charron D, Girardin M-P, 2002. Using dendrochronology to reconstruct disturbance and forest dynamics around Lake Duparquet, northwestern Québec. Dendrochronologia 20:175-189.

Bérubé Y, Ritland C, Ritland K, 2003. Isolation, characterization, and cross-species utility of microsatellites in yellow cedar (Chamaecyparis nootkatensis). Genome 46: 353-361.

Bigler Ch, Bräker OU, Bugmann H, Dobbertin M, Rigling A, 2006. Drought as an Inciting Mortaliy Factor in Scots Pine Stands of the Valais, Switzerland. Ecosystems 9: 330-343.

Bigler Ch, Gavin DG, Gunning Ch, Veblen T, 2007. Drought induces lagged tree mortality in a subalpine forest in the Rocky Mountains. Oikos 116: 1983-1994.

Blanchard EE, 1926 citado por Delfino y Binazzi, 2002. Aphid notes. Part VI: Argentine species of the subtribes Callipterina, Pterochlorina, Lachnina and of the tribes Eriosamtini and Phemphigini. Physis 8: 324-327.

Bliss FA, Arulsekar S, Foolad MR, Becerra V, Gillen AM, Warburton ML, Dandekar AM, Kocsisne GM, Mydin KK, 2002. An expanded genetic linkage map of Prunus based on an interspecific cross between almond and peach. Genome 45: 520-529.

Bové JM, Garnier M, 2003. Pholem and xylem restricted plant pathogenic bacteria. Plant Science 164: 423-438.

Boyle TJ, Balatinecz JJ, McCawPM, 1987 citado por Vaganov et al., 2006. Genetic control of some wood properties of black spruce. Can Tree Improv Assoc Meet 21. 198 pp.

Bozkurt O, Hakki EE, Akkaya M S, 2007. Isolation and sequence analysis of wheat NBS-LRR type disease resistance gene analogs using degenerate PCR primers. Biochemical Genetics 45: 469-486.

Brand D, Perez A, Barrios D, Pastorino M, Gallo L, Ayesa J, 2004. Natural range of the "Patagonian cypress" in Argentina - scale 1:250.000. IV Southern connections conference. January. P.126.

Bréda N, Badeau V, 2008. Forest tree responses to extreme drought and some biotic events: Towards a selection according to hazard tolerance? Comptes Rendus Geosciences 340: 651-662.

Brooks DS, Gonzalez CF, Appel DN, Filer TH, 1994. Evaluation of endophytic bacteria as potential biological control agents for oak wilt. Biological Control 4:373-381.

Buamscha G, Gobbi M, Mazzarino MJ, Laos F, 1998. Indicators of nitrogen conservation in Austrocedrus chilensis forests along a moisture gradient in Argentina. Forest Ecology and Management 112: 253-261. 
Calí S, 1996. Austrocedrus chilensis: Estudio de los anillos de crecimiento y su relación con la dinámica del "mal del ciprés" en el Parque Nacional Nahuel Huapi, Argentina. Tesis de Licenciatura en Ciencias Biológicas. Universidad Nacional del Comahue. Argentina. 143 pp.

Cankar K, Kraigher H, Ravnikar M, Rupnik M, 2005. Bacterial endophytes from seeds of Norway spruce (Picea abies L. Karst). FEMS Microbiology Letters 244: 341-345.

Cantacessi C, Traversa D, Testini G, Lia RP, Carfachia C, Máca J, Otranto D, 2008. Molecular identification of Phortica variegata and Phortica semivirgo (Drosophilidae, Steganinae) by PCR-RFLP of the mitochondrial cytochrome oxidase c subunit I gene. Parasitology Research 103: 727-730.

Cavender-Bares J, 2005. Impacts of freezing on long distance transport in woody plants. 401424 pp. En: Holbrook NM, Zwieniecki MA. Vascular transport in plants. Elsevier Academic Press, Amsterdam, Netherlands.

Chauchard L, 1987. Inventario Forestal Lotes 5y6-Sección "Los Repollos" y Lotes 9y15Sección "El Puelo". Instituto Forestal Nacional-Dirección Forestal Andina. Informe interno inédito. $32 \mathrm{pp}$.

Chauchard L, Barnabá L, 1986. Plan de Ordenación Forestal Cuartel Loma del Medio-Río Azul. Provincia de Río Negro. Instituto Forestal Nacional-Dirección General de Bosques Río Negro. Informe interno inédito. $62 \mathrm{pp}$.

Chen XM, Line RF, Leung H, 1998. Genome scanning for resistance-gene analogs in rice, barley, and wheat by high-resolution electrophoresis. Theoretical and Applied Genetics 97: 345-355.

Chen WY, Hung TH, Shiao SF, 2004. Molecular Identification of Forensically Important Blow Fly Species (Diptera: Calliphoridae) in Taiwan. Journal of Medical Entomology 41(1): 4757.

Cheng J, Yan J, Krugman T, Fahima T, 2005. Application of fluorescence-based resistance gene analog analysis for genotyping plant genetic resources. Biotechnology Letters 27: 83-89.

Cherubini P, Fontana G, Rigling D, Dobbertin M, Brang P, Innes JL, 2002. Tree-Life History Prior to Death: Two Fungal Root Pathogens Affect Tree-Ring Growth Diffferently. The Journal of Ecology 90: 839-850.

Chung JD, Lin TP, Tan YC, Lin MY, Hwang SY, 2004. Genetic diversity and biogeography of Cunninghamia konishii (Cupressaceae), an island species in Taiwan: a comparison with Cuninghamia lanceolata, a mainland species in China. Molecular Phylogenetics and Evolution 33: 791-801.

Ciesla W, 1991. Cypress aphid, Cinara cupressi, a new pest of conifers in eastern and southern Africa. FAO Plant Protection Bulletin 39: 82-93. 
Clay K, 1988 citado por Anand et al. 2006: Fungal endophytes of grasses: a defensive mutualism between plants and fungi. Ecology 69: 10-16.

Cochard H, 2006. Cavitation in trees. Physique 7: 1018-1026.

Cochard H, Casella E, Mencuccini M, 2007. Xylem vulnerability to cavitation varies among poplar and willow clones and correlates with yield. Tree Physiology 27: 1761-1767.

Collins NC, Webb CA, Seah S, Ellis JG, Hulbert SH, Pryor A, 1998. The Isolation and Mapping of Disease Resistance Gene Analogs in Maize. Molecular Plant Microbe Interactions 11: 968-978.

Dale HV, Joyce LA, McNulty S, Neilson RP, 2000. The interplay between climate change, forests, and disturbances. The Science of the Total Environment 262: 201-204.

Dalla-Salda G, Martinez-Meier A, Cochard H, Rozenber P, 2009. Variation of wood density and hydraulic properties of Douglas-fir (Pseudotsuga mensiezzii (Mirb.) Franco) clones related to a heat and drought wave in France. Forest Ecology and Management 257: 182-189.

Dangl JL, Jones JDG, 2001. Plant pathogens and integrated defence responses to infection. Nature 411:826-833.

Davis M, 2001. Fastidious Phloem-Limited Bacteria. 275-282 pp. En «Laboratory Guide for Identification of Plant Pathogenic Bacteria». Schaad N, Jones J, Chun W. APS Press. The American Phytopathological Society. St. Paul, Minnesota.

Davis SD, Sperry JS, Hacke UG, 1999. The relationship between xylem conduit diameter and cavitation caused by freezing. American Journal of Botany 86: 1367-1372.

Delfino M., Binazzi A, 2005. Further data on conifer aphids from Argentina (Aphididae Lachninae Eulachinini). REDIA. 88: 3-7.

Delfino M, Binazzi A, 2002. Áfidos en Coníferas en la Argentina (Hemiptera: Aphididae). Revista de la Sociedad Entomológica Argentina 61(3-4): 27-36.

Deng Z, Huang S, Ling P, Chen C, Yu C, Weber CA, Moore GA, Gmitter Jr FG, 2000. Cloning and characterization of NBS-LRR class resistance-gene candidate sequences in citrus. Theoretical and Applied Genetics 101: 814-822.

De Paiva Amaral P, Martins Alves PC, Florencio Martins N, Rodríguez Da Silva F, De Capdeville G, Texeira Júnior M, 2006. Identification and characterization of a resistance gene analog (RGA) from the Caricaceae Dumort family. Revista Brasileira de Fruticultura 28: $458-462$.

de Vries W, Vel E, Reinds GJ, Deelstra H, Klap JM, Leeters EEJM, Hendriks CMA, Kerkvoorden M, Landmann G, Herkendell J, Haussmann T, Erisman JW, 2003. Intensive monitoring of forest ecosystems in Europe. 1. Objectives, set-up and evaluation strategy. Forest Ecology and Management 174: 77-95. 
Deschamps JR, Vizcarra Sanchez J, 1988. Decaimiento y muerte del ciprés de la cordillera (Austrocedrus chilensis): estado actual de su conocimiento. Actas III Congreso Forestal Argentino (Santiago del Estero), 689-690.

Desprez-Loustau ML, Marçais B, Nageleisen LM, Piou D, Vannini A, 2006. Interactive effects of drought and pathogens in forest trees. Annals of Forest Science. 63: 597-612.

Dezzoti A, Sancholuz L, 1991. Los bosques de Austrocedrus chilensis en Argentina: ubicación, estructura y crecimiento. Bosque 12(2): 43-52.

Díaz V, Ferrer E, 2003. Genetic variation of populations of Pinus oocarpa revealed by resistance gene analog polymorphism (RGAP). Genome 46: 404-410.

Diaz-Vaz JE, 1985. Austrocedrus chilensis. Descripción anatómica. Bosque 6(1): 49-50.

Dimitri, M. 1989. Iconografía dendrológica: Árboles exóticos e indígenas de la Argentina. Consejo profesional de Ingeniería Agronómica. Orientación Gráfica Editora. Buenos Aires. 188 pp.

Dobbertin M, 2005. Tree growth as indicator of tree vitality and of tree reaction to environmental stress: a review. European Journal of Forest Research 124: 319-333.

Döbereiner J, Urquiaga S, Boddey RM, 1995. Alternatives for nitrogen nutrition of crops in tropical agriculture. Fertilizer Research 42:339-346.

Domec JCh, Gartner BL, 2002. How do water transport and water storage differ in coniferous earlywood and latewood? Journal of Expermental Botany 53: 2369-2379.

Donald TM, Pellerone F, Adam-Blondon AF, Bouquet A, Thomas MR, Dry IB, 2002. Identification of resistance gene analogs linked to a powdery mildew resistance locus in grapevine. Theoretical and Applied Genetics 104: 610-618.

Donoso C, 1982. Reseña ecológica de los bosques mediterráneos de Chile. Bosque 4(2): 117146.

Donoso C, 1993. Bosques Templados de Chile y Argentina: variación, estructura y dinámica. Editorial Universitaria, Santiago. 484 pp.

Donoso C, Escobar B, Pastorino M, Gallo L, Aguayo J, 2006. Austrocedrus chilensis (D. Don) Pic. Ser. Et Bizzarri. 54-67 pp. En: Donoso C. Las especies arbóreas de los bosques templados de Chile y Argentina. Autoecología. Marisa Cúneo Ediciones, Valdivia, Chile.

Drohan PJ, Stout SL, Petersen GW, 2002. Sugar mapple (Acer saccharum Marsh.) decline during 1979-1989 in northern Pennsylvania. Forest Ecology and Management 170: 1-17.

Dünisch O, Reissmann CB, Oliszeski A, 2004. Variability of vessel characteristics in the xylem of Ilex paraguariensis (mate-tree) from south Brazil. IAWA Journal 25: 449-458.

Durak R, Sadowska-Woda I, Machordom A, Borowiak-Sobkowiak B, 2008. Biological and genetic studies of Polish populations of Cinara tujafilina. Bulletin of Insectology. 61(1): 159-160. 
Eldor AP, 2007. Soil microbiology, ecology, and biochemistry. Academic Press 532 pp.

El Mujtar V, Andenmatten E, 2007a. "Mal del ciprés": búsqueda de la causa más probable de daño mediante un análisis deductivo y comparativo. Bosque 28(1): 3-9.

El Mujtar V, Andenmatten E, 2007b. Análisis del "Mal del ciprés" mediante un "Modelo de Enfermedad": Vacíos de información y perspectivas. Revista de la Facultad de Agronomía de La Plata. 106(2): 119-133.

Ennajeh M, Tounekti T, Vadel AM, Khemira H, Cochard H, 2008. Water relations and drought induced embolism in olive (Olea europaea) varieties "Meski" and "Chemlali" during sever drought. Tree Physiology 28: 971-976.

Excoffier L, Smouse PE, Quattro JM, 1992 citado en GenAlEx. Analysis of molecular variance inferred from metric distances among DNA haplotypes: Application to human mitocondrial DNA restriction sites. Genetics 131: 479-491.

Falush D, Stephens M, Pritchard JK, 2007. Inference of population structure using multilocus genotype data: dominant markers and null alleles. Molecular Ecology Notes 7: 574-578.

Favret C, Voegtlin J, 2004. Speciation by host-switching in pinyon Cinara (Insecta: Hemiptera: Aphididae). Molecular Phylogenetics and Evolution 32: 139-151.

Fayyaz E, AA Shahnejat-Bushehri, Tabatabaei BES, Adel J, 2007. Constructing a Preliminary Wheat Genetic Map Using RGA and AFLP Markers. International Journal of Agriculture and Biology 9: 863-867.

Feild TS, Brodribb T, 2001. Stem water transport and freeze-thaw xylem embolism in conifers and angiosperms in a Tasmanian treeline heath. Oecologia 127: 314-320.

Ferrando JJ, 1997 citado por Goya et al., 2005. Biomasa, productividad y descomposición de rodales de ciprés de la cordillera (Austrocedrus chilensis). Informe Final de Beca de Perfeccionamiento. UNLP. Inédito.

Feuillet C, Schachermayr G, Séller B,1997. Molecular cloning of a new receptor-like kinase gene encoded at the Lr10 disease resistance locus of wheat. The Plant Journal 11: 45-52.

Filip G, 1995: Comparison of forest diseases in Andean Patagonian and Oregon Cascade forest ecosystems. A report to the OSU Research Council. 19 pp.

Filip GM, Rosso PH, 1999. Cypress mortality (mal del ciprés) in the Patagonian Andes: comparisons with similar forest diseases and declines in North America. European Journal of Forest Pathology. 29: 89-96.

Fisher JB, Goldstein G, Jones TJ, Cordell S, 2007. Wood vessel diameter is related to elevation and genotype in the Hawaiian tree Metrosideros polymorpha (Myrtaceae). American Journal of Botany 94: 709-715. 
Fischer SG, Lerman LS, 1983. Biochemistry DNA fragments differing by single base-pair substitutions are separated in denaturing gradient gels: Correspondence with melting theory. Proceedings of the National Academy of Sciences 80: 1579-1583.

Floria MP, 2008. Caracterización y evaluación de la sintomatología del Mal del Ciprés. Seminario de Licenciatura. Universidad Nacional de la Patagonia San Juan Bosco. Argentina.

Floria MP, Greslebin AG, 2007. "Mal del Ciprés" Disease: Analysis of the Association Between Aerial Symptoms and Vitality of Trees. Proceedings of the 4th IUFRO meeting on Phytophthora in forests and natural ecosystems (Monterey, CA, USA).

Folmer O, Black M, Hoeh W, Lutz R, Vrijenhoek R, 1994. DNA primers for amplification of mitochondrial cytochrome $\mathrm{c}$ oxidase subunit I from diverse metazoan invertebrates. Molecular Marine Biology and Biotechnology 3: 294-299.

Foolad MR, Zhang LP, Khan AA, Niño-Liu D, Lin GY, 2002. Identification of QTLs for early blight (Alternaria solani) resistance in tomato using backcross populations of a Lycopersicon esculentum $\times$ L. hirsutum cross. Theoretical and Applied Genetics 104:945958.

Foottit RG, Maw HEL, Von Dohlen CD, Hebert PDN, 2008. Species identification of aphids (Insecta: Hemiptera: Aphididae) through DNA barcodes. Molecular Ecology Resources 8(6): 1189-1201.

Francl LJ, 2001. The Disease Triangle: A plant pathological paradigm revisited. The Plant Health Instructor.

http://www.apsnet.org/education/InstructorCommunication/TeachingArticles/Francl/Top.html.

Gallo L, Pastorino M, Donoso C, 2004. Variación en Austrocedrus chilensis (D. Don) Pic. Ser et Bizzarri (Ciprés de la Cordillera). 233-252 pp. En: Donoso C, Ipinza R, Premoli A, Gallo L. Variación intraespecífica en las especies arbóreas de los bosques templados de Chile y Argentina. Chile. Editorial Universitaria.

Gardner JM, Feldman AW, Zablotowicz M, 1982. Identity and behavior of xylem-residing bacteria in rough lemon roots of Florida citrus trees. Applied and Environmental Microbiology 43: 1335-1342.

Garnier M, J Bove, 1993. Citrus Greening Disease and the greening bacterium. 212-219 pp. En: Moreno P, da Graça J, Timmer L. Proceedings 12eme Conf. Intern. Organization Citrus Virologists. Departament of Plant Pathology, Riverside, California.

Gentzbittel L, Mouzeyar S, Badaoui S, Mestries E, Vear F, Tourvieille De Labrouhe D, Nicolas P, 1998. Cloning of molecular markers for disease resistance in sunflower, Helianthus annuus L. Theoretical and Applied Genetics 96: 519-525. 
Gillen AM, Bliss FA, 2005. Identification and Mapping of Markers Linked to the Mi Gene for Root-knot Nematode Resistance in Peach. Journal of the American Society for Horticultural Science 130: 24-33.

Glynn NC, Comstock JC, Sood SG, Dang PM, Chaparro JX, 2008. Isolation of nucleotide binding site-leucine rich repeat and kinase resistance gene analogues from sugarcane (Saccharum spp.) Pest Management Science 64: 48-56.

Gobbi M, Sancholuz L, 1992: Regeneración post-incendio del ciprés de la cordillera (Austrocedrus chilensis) en los primeros años. Bosque 13: 25-32.

Goggans JF, 1962 citado por Vaganov et al., 2006. The correlation, variation and inheritance of wood properties in loblolly pine. (School of Forestry Research Technical Report 14) North Carolina State University, Raleigh. 155 pp.

Goya JF, Ferrando J, Bocos D, Yapura P, 1995. Estructura y desarrollo de un rodal coetáneo de Austrocedrus chilensis en El Bolsón, Río Negro, Argentina. Revista de la Facultad de Agronomía de La Plata 71: 165-171.

Goya JF, Yapura PF, Ferrando JJ, Barrera MD, Arturi MA, 1998. Crecimiento individual y de rodales de Austrocedrus chilensis en El Bolsón, Río Negro, Argentina. Revista de la Facultad de Agronomía de La Plata 103: 149-155.

Goya JF, Ferrando JJ, Yapura PF, 2005. Aspectos silviculturales de los bosques de Austrocedrus chilensis de El Bolsón, Río Negro. 18 pp. En: Arturi M, Frangi J, Goya J. Ecología y Manejo de los Bosques de Argentina. Editorial de la Universidad Nacional de La Plata, Argentina.(CD).

Greslebin AG, Hansen EM, Winton LM, Rajchenberg M, 2005. Phytophthora species from declining Austrocedrus chilensis forests in Patagonia, Argentina. Mycologia 97(1): 218228.

Greslebin AG, Hansen EM, Sutton W, 2007. Phytophthora austrocedrae sp. nov., a new species associated with Austrocedrus chilensis mortality in Patagonia (Argentina). Mycological Research III: 308-316.

Greslebin AG, Hansen EM, 2006. Novedades sobre el mal del ciprés. CIEFAP Patagonia Forestal XII(1): 11-14.

Greslebin AG, Hansen EM, 2007a. La causa del "mal del ciprés". CIEFAP Patagonia Forestal XIII(1): 5-8.

Greslebin, AG, Hansen EM, 2007b. The Decline of Austrocedrus Forests in Patagonia (Mal del Ciprés): Another Phytophthora-Caused Forest Disease. Proceedings of the 4th IUFRO meeting on Phytophthora in forests and natural ecosystems (Monterey, CA, USA). 
Grodzki W, 2007. Spatio-temporal patterns of the Norway spruce decline in the Beskid Slaski and Zywiecki (Western Carpathians) in southern Poland. Journal of Forest Science 53: 3844.

Grosfeld J, 2002. Análisis de la variabilidad morfológica y arquitectural de Austrocedrus chilensis (D. Don) Pic. Serm. et Bizzarri, Fitzroya cupressoides (Molina) I. M. Johnst., Pilgerodendron uviferum (D. Don) Florin y Cupressus sempervirens L. (Cupressaceae). Tesis para obtener el grado de Doctor en Ciencias Biológicas. Universidad Nacional del Comahue. Argentina. 300 pp.

Gyenge JE, Fernández ME, Dalla Salda G, Schlichter T, 2005. Leaf and whole-plant water relations of the Patagonian conifer Austrocedrus chilensis (D. Don) Pic. Ser. et Bizzarri: implications on its drought resistance capacity. Annals of Forest Science. 62: 297-302.

Gyenge JE, Fernández ME, Schlichter T, 2007. Influence of radiation and drought on gas exchange of Austrocedrus chilensis seedlings. Bosque 28: 220-225.

Hacke UG, Sperry JS, Ewers BE, Ellsworth DS, Schäefer KVR, Oren R, 2000. Influence of soil porosity on water use in Pinus taeda. Oecologia 124: 495-505.

Hacke UG, Sperry JS, Pockman WT, Davis SD, McCulloh KA, 2001. Trends in wood density and structure are linked to prevention of xylem implosion by negative pressure. Oecologia 126: 457-461.

Hacke UG, Jansen S, 2009. Embolism resistance of three boreal conifer species varies with pit structure. New Phytologist 182: 675-686.

Hacke UG, Sperry JS, 2001. Functional and ecological xylem anatomy. Perspectives in Plant Ecology, Evolution and Systematics. 4: 97-115.

Hall TA, 1999. BioEdit: a user-friendly biological sequence alignment editor and analysis program for Windows 95/98/NT. Nucleic Acids Symposium Series 41: 95-98.

Hall HG, Smith DR, 1991. Distinguishing African and European honeybee matrilines using amplified mitochondrial DNA. Proceedings of the National Academy of Sciences USA 88: $4548-4552$.

Hallmann J, Quadt-Hallmann A, Rodríguez-Kábana R, Kloepper JW, 1998. Interactions between Meloidogyne incognita and endophytic bacteria in cotton and cucumber. Soil Biology and Biochemistry 30: 925-937.

Hammond JBW, Spanswick G, Mawn JA, 1996. Extraction of DNA from preserved animal specimens for use in ramdomly amplified polymorphic DNA analysis. Analitical Biochemistry. 240: 298-300.

Hammond-Kosack KE, Jones JDG, 1997. Plant disease resistance genes. Annual Review of Plant Physiology and Plant Molecular Biology 48:575-607. 
Hansen EM, 2000. Phytophthora in the Americas. 23-27 pp. En: Hansen EM, Sutton W. First International Meeting on Phytophthoras in Forest and Wildland Ecosystems, Phytophthora Disease of Forest tree (Grant Pass, Oregon, USA).

Hao B, Li W, Linchum M, Li Y, Rui Z, Mingxia T, Weikai B, 2006. A Study of Conservation Genetics in Cupressus chengiana, an Endangered Endemic of China, Using ISSR Markers. Biochemical Genetics 44: 31-45.

Harmsen D, Karch H, 2004. 16S rDNA for Diagnosing Pathogens: a Living Tree. Analyzing rRNA genes through the use of high-quality reference databanks provides a powerful method for identifying microorganisms. ASM News 70: 19-24.

Harvey ML, Dadour IR, Gaudieri S, 2003. Mitochondrial DNA cytochrome oxidase I gene: potential for distinction between immature stages of some forensically important fly species (Diptera) in western Australia. Forensic Science International 131: 134-139.

Havrylenko M, Rosso PHA, Fontenla SB, 1989. Austrocedrus chilensis: contribución al estudio de su mortalidad en Argentina. Bosque 10(1): 29-36.

Hegyi F, 1974 citado por Alvarez Taboada et al., 2003. A simulation model for managing jackpine stands. Growth Models for Tree and Stand Simulation. Proceedings IUFRO Meeting. S4.01.04, Royal College of Forestry, Stockolm. 74-90.

Hennon PE, Rajchenberg M, 2000. El "mal del ciprés". Algunas observaciones, comparaciones e ideas. CIEFAP Patagonia Forestal VI(2): 4-6.

Hennon PE, Shaw CG, 1997. The Enigma of Yellow-Cedar Decline. What is killing these long lived, defensive trees? Journal of Forestry 95: 4-10.

Hepting GH, 1963 citado por La Manna, 2004. Climate and forest disease. Annual Review of Phytopatology 1: 31-50.

Holgmren AS, 2006. Evaluación del efecto de Cinara cupressi (Buckton) (Hemiptera, Aphididae) post control químico, sobre Austrocedrus chilensis (D. Don). Proyecto para optar al Título de Ingeniero Forestal. Pontificia Universidad Católica de Chile. 65 pp.

Hollis JP, 1951 citado por Anand et al. 2006. Bacteria in healthy potato tissue. Phytopathology 41: 320-366.

Hopkins D, 2001. Xylella fastidiosa. 201-213 pp. En «Laboratory Guide for Identification of Plant Pathogenic Bacteria». Schaad N, Jones J., Chun W. APS Press. The American Phytopathological Society. St. Paul, Minnesota.

Horsley S, Long R, Bailey S, Hallett R, Hall T, 2000. Factors associated with the decline disease of sugar maple on the Allegheny Plateau. Canadian Journal of Forest Research 30: $1365-1378$.

Houston DR, 1981 citado por La Manna, 2004. Stress trigered tree diseases - the diebacks and declines. USDA Forest Service. NE-INF 41-81. 36 pp. 
Hranilovich S, 1964. Estudios relacionados con cipresal zona Lago Puelo y Golondrinas. Expediente 675/64. Dirección General de Bosques y Parques. Ministerio de Economía. Chubut. Argentina. (Comunicación Oficial: Archivos del Campo Forestal General San Martín INTA). $12 \mathrm{pp}$.

Hranilovich S, 1988. Informe Histórico sobre el "mal del ciprés" de la cordillera (Austrocedrus chilensis). Revista de la Asociación Forestal Argentina 3: 58-62.

Hueck, K. 1978. Los bosques de Sudamérica. Ecología, composición e importancia económica. Sociedad Alemana de cooperación técnica (GTZ). Alemania. 476 pp.

Huff DR, Peakall R, Smouse PE, 1993 citado en GenAlEx. RAPD variation within and among natural populations of outcrossing buffalograss Buchloe dactyloides (Nutt) Engelm. Theoretical and Applied Genetics 86: 927-934.

Hung PQ, Kumar SM, Govindsamy V, Annapurna K, 2007. Isolation and characterization of endophytic bacteria from wild and cultivated soybean varieties. Biology and Fertility of Soils 44:155-162.

Hung PQ, Annapurna K, 2004. Isolation and characterization of endophytic bacteria in soybean (Glycine sp.). Omonrice 12: 92-101.

Hwang SY, Lin HW, Kuo YS, Lin TP, 2001. RAPD variation in relation to population differentiation of Chamaecyparis formosensis and Chamaecyparis taiwanensis. Botanical Bulletin Academia Cínica 42: 173-179.

Instituto Forestal Nacional (IFONA), 1986 citado por La Manna, 2004. Pre-carta Forestal Nacional, Provincia de Río Negro. IFONA, Dpto. Administración de Bosques Naturales, Buenos Aires.

Irigoyen ML, Loarce Y, Fominaya A, Ferrer E, 2004. Isolation and mapping of resistance gene analogs from the Avena strigosa genome. Theoretical and Applied Genetics 109: 713-724.

Iszkulo G, Jasinska AK, Giertych MJ, Boratynski A, 2009. Do secondary sexual dimorphism and female intolerance to drought influence the sex ratio and extinction risk of Taxus baccata? Plant Ecology 200: 229-240.

Jagoueix S, Bove J, Garnier M, 1994. The phloem-limited bacterium of greening disease of citrus is a member of the alpha subdivision of the Proteobacteria. International Journal of Systematic Bacteriology 44: 379-386.

Jermstad KD, Sheppard LA, Kinloch BB, Delfino-Mix A, Ersoz ES, Krutovsky KV, Neale DB, 2006. Isolation of a full-length CC-NBS-LRR resistance gene analog candidate from sugar pine showing low nucleotide diversity. Tree Genetics \& Genomes 2: 76-85.

Jönsson U, 2006. A conceptual model for the development of Phytophthora disease in Quercus robur. New Phytologist 171: 55-68. 
Kanazin V, Fredrick Marek L, Shoemaker RC, 1996. Resistance gene analogs are conserved and clustered in soybean. Proceedings of the National Academy of Sciences 93:1174611750.

Kandler O, Innes JL, 1995. Air pollution and forest decline in Central Europe. Environmental Pollution 90: 171-180.

Kavanagh KL, Bond BJ, Aitken SN, Gartner BL, Knowe S, 1999. Shoot and root vulnerability to xylem cavitation in four populations of Douglas-fir seedlings. Tree Physiology 19: 3137.

Kennedy RW, 1966 citado por Vaganov et al., 2006. Intra-increment variation and heritability of specific gravity, parallel to grain tensile strength, stiffness and tracheid lendth in clonal Norway spruce. TAPPI 49:292-295.

Kennedy RW, 1969 citado por Vagano et al., 2006. Wood formation in jack pine seedlings of various provenances. (11th Commission for Tree Breeding, Canada, part 2) Commission for Tree Breeding, Ottawa. 101-109 pp.

Koomnok Ch, Teaumroong N, Rerkasem B, Lumyong S, 2007. Diazotroph Endophytic Bacteria in Cultivated and Wild Rice in Thailand. ScienceAsia 33: 429-435.

Kraft G, 1884 citado por Bechtold, 2003. Zur Lehre von den Durch Forstungen. Schlagstellungen und Lichtungshieben, Hanover, Germany.

Krause C, Gionest F, Morin H, MacLean DA, 2003. Temporal relations between defoliation caused by spruce budworm (Choristoneura fumiferana Clem.) and growth of balsam fir (Abies balsamea (L.) Mill.). Dendrochronologia 21: 23-31.

Krauss SL, 2000. Accurate gene diversity estimates from amplified fragment length polymorphism (AFLP) markers. Molecular Ecology 9: 1241-1245.

Krugliak PE, 1998. Recuperación y sistematización de información meteorológica del período 1953-1997. Campo Forestal General San Martín-INTA. Informe Práctica Profesional Técnico Universitario en Información y Gestión Ambiental. Universidad Nacional de la Patagonia San Juan Bosco. Argentina. 20 pp.

Kuklinsky-Sobral J, Araújo WL, Mendes R, Pizzirani-Kleiner AA, Azevedo JL, 2005. Isolation and characterization of endophytic bacteria from soybean (Glycine max) grown in soil treated with glyphosate herbicide. Plant and Soil 273: 91-99.

La Manna L, 2004. La declinación de los bosques de Austrocedrus chilensis: relación entre el "Mal del ciprés" y el sitio. Tesis para optar al título de Doctora en Ciencias Biológicas. Universidad de Buenos Aires. Argentina. 291 pp.

La Manna L, Rajchenberg M, Taladriz L, 2001. El "mal del ciprés" en el Valle 16 de Octubre:¿los suelos pueden decirnos algo? CIEFAP Patagonia Forestal VII(4):11-12. 
La Manna L, Bava J, Collantes M, Rajchenberg M, 2006. Características estructurales de los bosques de Austrocedrus chilensis afectados por "mal del ciprés" en Patagonia, Argentina. Bosque 27(2): 135-145.

La Manna L, Collantes M, Bava J, Rajchenberg M. 2008a. Seedling recruitment of Austrocedrus chilensis in relation to cattle use, microsite environmental and forest disease. Ecología Austral 18: 27-41.

La Manna L, Carabelli F, Gómez M, Matteucci S. 2008b. Disposición espacial de parches de Austrocedrus chilensis con síntomas de defoliación y mortalidad en el Valle 16 de Octubre (Chubut, Argentina). Bosque 29(1): 23-32.

La Manna L, Matteucci SD, Kitzberger T, 2008c. Abiotic factors related to the incidence of the Austrocedrus chilensis disease syndrome at a landscape scale. Forest Ecology and Management 256: 1087-1095.

La Manna L, Rajchenberg M, 2004a. The decline of Austrocedrus chilensis forests in Patagonia, Argentina: soil features as predisponsing factors. Forest Ecology and Management 190, 345-357.

La Manna L, Rajchenberg M, 2004b. Soil propierties and Austrocedrus chilensis forest decline in Central Patagonia, Argentina. Plant and Soil 263, 29-41.

Lanciotti ML, Cremona MV, 1999. Los suelos del área de influencia de la Agencia de Extensión Rural de El Bolsón. Instituto Nacional de Tecnología Agropecuaria. 27 pp.

Leal S, Pereira H, Grabner M, Wimmer R, 2003. Clonal and site variation of vessels in 7-yearold Eucalyptus globulus. IAWA Journal 24: 185-195.

Leapthart CD, Stage AR, 1971 citado por La Manna, 2004. Climate: a factor in the origin of the pole blight disease of Pinus monticola Dougl. Ecology 52: 229-239.

Leister D, Ballvora A, Salamini F, Gebhardt C, 1996. A PCR based approach for isolating pathogen resistance genes from potato with potential for wide applications in plant. Nature Genetics 14: 421-429.

Le Quesne C, Aravena JC, Jiménez H, Villa R, Vergara JC, 1999 citado por Rovere y Le Quesne, 2005. Caracterización de un rodal de Austrocedrus chilensis (D. Don) Pic. Ser et Biz. en la Reserva Nacional Río de los Cipreses, VI Región, Chile. Serie Técnica CONAF Año 2, 3.18 pp.

Le Quesne C, Aravena JC, Alvaraez García MA, Fernández Prieto JA, 2000 citado por Rovere y Le Quesne, 2005. Dendrocronología de Austrocedrus chilensis (Cupressaceae) en Chile Central. En: Roig F. Dendrocronología en América Latina. Editorial de la Universidad Nacional de Cuyo. Mendoza. Argentina.

Letourneau F, 2006. Estudio de las interacciones positivas y negativas sobre el crecimiento de Austrocedrus chilensis durante una etapa inicial del desarrollo, en un matorral sucesional 
mésico. Tesis para optar al título de Doctor en Ciencias Biológicas. Universidad Nacional del Comahue. Argentina. 182 pp.

Li F, Xia N, 2005. Population structure and genetic diversity of an endangered species, Glyptostrobus pensilis (Cupressaceae). Botanical Bulletin of Academia Sinica 46: 155162.

Liu JJ, Ekramoddoullah AKM, 2003. Isolation, genetic variation and expression of TIR NBSLRR resistance gene analogs from western white pine (Pinus monticola Dougl. ex. D. Don.). Molecular Genetics and Genomics 270: 432-441.

Liu JJ, Ekramoddoullah AKM, 2007. The CC-NBS-LRR Subfamily in Pinus monticola: Targeted Identification, Gene Expression, and Genetic Linkage with Resistance to Cronartium ribicola. Phytopathology 97: 728-736.

Loguercio GA, Urretavizcaya F, Rey M, Andenmatten E, 1998. El "mal del cipres" como condicionante de la silvicultura del ciprés de la cordillera Austrocedrus chilensis (D. Don) Florin et Boutelje en el norte de la Patagonia Argentina. I Congreso Latinoamericano IUFRO (Valdivia, Chile). 22 pp.

Loguercio GA, Rajchenberg M, Rodriguez N, Pantaenius P, 1999a. Curso-Taller de actualización en silvicultura de los bosques de ciprés de la cordillera (El Bolsón). 60 pp.

Loguercio GA, Burschel P, Rey M, 1999b. El Bosque de Ciprés de la cordillera su conservación y uso. CIEFAP Folleto de Divulgación 14, 1-22.

Loguercio GA, Rajchenberg M, 2005. El "mal del ciprés" y la silvicultura del ciprés de la cordillera. 18 pp. En: Arturi M, Frangi J, Goya J. Ecología y Manejo de los Bosques de Argentina. Editorial de la Universidad Nacional de La Plata, Argentina.(CD).

Loxdale H, Lushai G, 1998. Molecular markers in entomology. Bulletin of Entomological Research 88: 577-600.

Loxdale HD, Lushai G, 2003. Rapid changes in clonal lines: the death of a "sacred cow". Biological Journal of the Linnean Society 79: 3-16.

Lozier JD, Foottit RG, Miller GL, Mills NJ, Roderick GK, 2008. Molecular and morphological evaluation of the aphid genus Hyalopterus Koch (Insecta: Hemiptera: Aphididae), with a description of a new species. Zootaxa 1688: 1-19.

Lunt DH, Zhang DX, Szymura JM, Hewitt GM, 1996. The insect cytochrome oxidase I gene: evolutionary patterns and conserved primers for phylogenetics studies. Insect Molecular Biology 5: 153-165.

Lynch M, Milligan BG, 1994. Analysis of population genetic structure with RAPD markers. Molecular Ecology 3: 91-99.

Madsen LH, Collins NC, Rakwalska M, Backes G, Sandal N, Krusell L, Jensen J, Waterman EH, Jahoor A, Ayliffe M, Pryor AJ, Langridge P, Schulze-Lefert P, Stougaard J, 2003. 
Barley disease resistance gene analogs of the NBS-LRR class: identification and mapping. Molecular Genetics and Genomics 269: 150-161.

Maguire TL, Peakall R, Saenger P, 2002 citado en GenAlEx. Comparative anaylsis of genetic diversity in the mangrove species Avicennia marina (Forsk.) Vierh. (Avicenniaceae) detected by AFLPs and SSRs. Theoretical and Applied Genetics 104: 388-398.

Manion PD, 1981. Tree disease concepts. Prentice Hall. Englewood Cliffs, NJ, 339 pp.

Manion PD, 1991 citado por La Manna, 2004 . Tree disease concepts. $2^{\circ}$ ed. Prentice Hall, Englewood Cliffs, New York, USA. 402 pp.

Mano H, Morisaki H, 2008: Endophytic Bacteria in the Rice Plant. Microbes and Environments 23: $109-117$.

Marçais B, Bréda N, 2006. Role of an opportunistic pathogen in the decline of stressed oak tres. Journal of Ecology 94: 1214-1223.

Martín GB, Bogdanove AJ, Sessa G, 2003. Understanding the functions of plant disease resistance proteins. Annual Reviews of Plant Biology. 54: 23-61.

Martínez Zamora MG, Castagnaro AP, Díaz Ricci JC, 2004. Isolation and diversity analysis of resistance gene analogues (RGAs) from cultivated and wild strawberries. Molecular Genetics and Genomics 272: 480-487.

Martinez-Meier A, Sánchez Leopoldo, Pastorino M, Gallo L, Rozenberg P, 2008. GAT is hot in tree rings? The wood density of surviving Douglas-firs to the 2003 drought and heat wave. Forest Ecology and Management 256: 837-843.

Matzner SL, Rice KJ, Richards JH, 2001. Intra-specific variation in xylem cavitation in interior live oak (Quercus wislizenii A. DC.). Journal of Experimental Botany 52: 783-789.

McDowell N, Pockman wt, Allen CD, Breshears DD, Cobb N, Kolb T, Plaut J, Sperry J, West A, Williams DG, Yepez EA, 2008. Mechanisms of plant survival and mortality during drought: why do some plants survive while others succumb to drought? New Phytologist 178: 719-739.

McDowell JM, Woffenden BJ, 2003. Plant disease resistance genes: recent insights and potential applications. Trends in Biotechnology 21: 178-183.

McLaughlin D. 1998. A decade of forest tree monitoring in Canada: evidence of air pollution effects. Environmental Reviews 6: 151-171.

Meloni M, Perini D, Filigheddu R, Binelli G, 2006. Genetic Variation in Five Mediterranean Populations of Juniperus phoenica as Revealed by Inter-Simple Sequence Repeat (ISSR) Markers. Annals of Botany 97: 299-304.

Mencuccini M, Comstock J, 1997. Vulnerability to cavitation in populations of two desert species, Hymenoclea salsola and Ambrosia dumosa, from different climatic regions. Journal of Experimental Botany 48: 1323-1334. 
Mendes R, Pizzirani-Kleiner AA, Araujo WL, Raaijmakers JM, 2007. Diversity of Cultivated Endophytic Bacteria from Sugarcane: Genetic and Biochemical Characterization of Burkholderia cepacia Complex Isolates. Applied and Environmental Microbiology 73:7259-7267.

Mendez JL, La Rocca SM, 2007. Primer Inventario Nacional de Bosques Nativos. Proyecto Bosques Nativos y Áreas Protegidas BIRF 4085-AR 1998-2005. Informe Regional Bosque Andino Patagónico. Secretaria de Ambiente y Desarrollo Sustentable de la Nación (Argentina). Producciones Gráficas S.A. 61 pp.

Merlo P, 1985. Informe sobre el mal que afecta al ciprés de la cordillera. Decaimiento y muerte de Austrocedrus chilensis. (Comunicación Oficial: Archivos del Campo Forestal General San Martín INTA). 3 pp.

Merlo P, 1994. Avances en el estudio del "Mal del ciprés de la cordillera" (Austrocedrus chilensis (Don) Florin et Boutleje). III Congreso Latinoamericano de Fitopatologia (Santiago de Chile). 9 pp.

Michalakis Y, Excoffier L, 1996 citado por GenAlEx. A generic estimation of population subdivision using distances between alleles with special reference for microsatellite loci. Genetics 142: 1061-1064.

Misaghi IJ, Donndelinger, CR, 1990. Endophytic Bacteria in Symptom-Free Cotton Plants. Phytopathology 80: 808-811.

Mitchell KJ, 1961 citado por Vagano et al., 2006. Apical growth in relation to the transition from springwood to summerwood in conifers.(Univ B C For Club 19) University of British Columbia,Vancouver. 71 pp.

Mocali S, Bertelli E, Di Cello F, Mengoni A, Sfalanga A, Viliani F, Caciotti A, Tegli S, Surico $\mathrm{G}$, Fani R, 2003. Fluctuation of bacteria isolated from elm tissues during different seasons and from different plant organs. Research in Microbiology 154: 105-114.

Montesinos D, De Lui M, Verdu M, Ravento J, García-Fayos P, 2006. When, How and How Much: Gender-specific Resource-use Strategies in the Dioecious Tree Juniperus thurifera. Annals of Botany 98: 885-889.

Mueller-Dombois D, 1992 citado por La Manna, 2004. A natural dieback theory, cohort senescence as an alternative to the decline disease theory. 26-37 pp. En: Manion PD, Lachance D. Forest Decline Concepts. The American Phytopathological Society Press, St. Paul, USA.

Muyzer G, De Waal EC, Uitierlinden AG, 1993. Gradient Gel Electrophoresis Analysis of Polymerase Chain Reaction-Amplified Genes Coding for 16S rRNA. Applied and Environmental Microbiology 59: 695-700. 
Neufeld HS, Grantz DA, Meinzer FC, Goldstein G, Crisosto G,Crisosto C, 1992. Genotypic Variability in Vulnerability of Leaf Xylem to Cavitation in Water-Stressed and WellIrrigated Sugarcane. Plant Physiology 100: 1020-1028.

Nicholls JW, Morris JD, Pederick LA, 1980 citado por Vaganov et al., 2006. Heritability estimates of density characteristics in juvenile radiata wood. Silvae Genetica 29:54-61.

Nienhaus F, 1985. Infectious diseases in forest trees caused by viruses, mycoplasma-like organisms and primitive bacteria. Experiencia 41, Birkhäuser Verlag. CH-4010 Basel Switzerland.

Niklasson M, Lindbladh M, Björkman L, 2002. A long-term record of Quercus decline, logging and fires in a southern Swedish Fagus-Picea forest. Journal of Vegetation Science 13: 765-774.

Normark B, 2000. Molecular Systematics and Evolution of the Aphid Family Lachnidae. Molecular Phylogenetics and Evolution 14(1): 131-140.

Nuñez CI, Nuñez MA, Kitzberger T, 2008. Sex-related spatial segregation and growth in a dioecious conifer along environmental gradients in northwestern Patagonia. Ecoscience 15: $73-80$.

Nuñez C, Rovere A, 2003. ¿Fotosintetizan los conos de árboles femeninos de Austrocedrus chilensis? XXIX Jornadas Argentinas de Botánica y XV Reunión Anual de la Sociedad de Botánica de Chile.

Nuñez CI, Rovere AE, 2005. Dimorfismo sexual en el Ciprés de la Cordillera. Patagonia Forestal XI(3): 5-6pp.

Nybon H, 2004. Comparison of different nuclear DNA markers for estimating intraspecific genetic diversity in plants. Molecular Ecology 13: 1143-1155.

Ohmori T, Murata M, Motoyoshi F, 1998. Characterization of disease resistance gene-like sequences in near-isogenic lines of tomato. Theoretical and Applied Genetics $96: 331$ 338.

Oostermeijer JGB, De Knegt B, 2004. Genetic population structure of the wind pollinated, dioecious shrub Juniperus communis in fragmented Dutch heathlands. Plant Species Biology 19: 175-184.

Otranto D, Traversa D, Guida B, Tarsitano E, Fiorente P, Stevens JR, 2003. Molecular characterization of the mitochondrial cytochrome oxidase I gene of Oestridae species causing obligate myiasis. Medical and Veterinary Entomology 17: 307-315.

Otranto D, Stevens JR, Testini G, Cantacessi C, Máca J, 2008. Molecular characterization and phylogenesis of Steganinae (Diptera, Drosophilidae) inferred by the mitochondrial cytochrome c oxidase subunit I. Medical and Veterinary Entomology 22: 37-47. 
Papageorgiou AC, 1995 citado por Pastorino et al., 2004. Genetische Untersuchungen zur Züchtung und Generhaltung bei der Mittelmeerzypresse (Cupressus sempervirens L.) in Griecheland. Ph. D. Thesis. University of Göttingen.

Papageorgiou AC, Finkeldey R, Hattemer HH, Xenopoulos S, 2005. Genetic differences between autochthonous and breeding populations of common cypress (Cupressus sempervirens L.) in Greece. European Journal of Forest Research 124: 119-124.

Pastorino M, Gallo L, Hattemer HH, 2004. Genetic variation in natural populations of Austrocedrus chilensis, cypress of the Andean-Patagonian Forest. Biochemical Systematics and Ecology 32: 993-1008.

Pastorino M, Fariña M, Bran D, Gallo L. 2006. Extremos geográficos de la distribución natural de Austrocedrus chilensis (Cupressaceae). Boletín de la Sociedad Argentina de Botánica. 41(3-4): 307-311.

Pastorino M, Gallo L, 2002. Quaternary evolutionary history of Austrocedrus chilensis, a cypress native to the Andean-Patagonian forest. Journal of Biogeography 29: 1167-1178.

Pastorino MJ, Gallo LA, 2009. Preliminary operational management units of a highly fragmented forest tree species of southern South America. Forest Ecology and Management 257: 2350-2358.

Pattison JA, Samuelian SK, Weber CA, 2007. Inheritance of Phytophthora root rot resistance in red raspberry determined by generation means and molecular linkage analysis. Theoretical and Applied Genetics 115: 225-236.

Peakall R, Smouse PE, Huff DR, 1995 citado en GenAlEx. Evolutionary implications of allozyme and RAPD Variation in diploid populations of dioecious buffalograss Buchloe dactyloides. Molecular Ecology 4: 135-147.

Peakall R, Smouse PE, 2006. GENALEX 6: Genetic analysis in Excel. Populatin genetic software for teaching and research. Molecular Ecology Notes 6: 288-295.

Pedersen BS, 1998. The role of Stress in the Mortality of Midwestern Oaks as Indicated by Growth prior to Death. Ecology 79:79-93.

Peñuela S, Danesh D, Young ND, 2002. Targeted isolation, sequence analysis, and physical mapping of nonTIR NBS-LRR genes in soybean. Theoretical and Applied Genetics 104: 261-272.

Pereligin LM, 1969 citado por Vagano et al., 2006. Wood science (in Russian). Lesnaya Promishlennost, Moscow. 316 pp.

Petriccione B, Pompei E, 2002. The CONECOFOR Programme: general presentation, aims and co-ordnation. Journal of Limnology 61: 3-11. 
Pita P, Gasco A, Pardos JA, 2003. Xylem cavitation, leaf growth and leaf water potential in Eucalyptus globulus clones under well-watered and drought conditions. Functional Plant Biology 30: 891-899.

Pittermann J, Sperry JS, Hacke UG, Wheeler JK, Sikkema EH, 2006. Inter-tracheid pitting and the hydraulic efficiency of conifer wood: the role of tracheid allometry and cavitation protection. American Journal of Botany 93: 1265-1273.

Pittermann J, Sperry J, 2003. Tracheid diameter is the key trait determining the extent of freezing induced embolism in conifers. Tree Physiology 23: 907-914.

Pittermann J, Sperry JS, 2006. Analysis of Freeze-Thaw Embolism in Conifers. The Interaction between Cavitation Pressure and Tracheid Size. Plant Physiology 140: 374-382.

Poluboyarinov OI, 1976 citado por Vagano et al., 2006. The density of wood (in Russian). Lesnaya Promishlennost, Moscow. 160 pp.

Premoli AC, Kitzberger T, Veblen TT, 2000. Conservation genetics of the endangered conifer Fitzroya cupressoides in Chile and Argentina. Conservation Genetics 1: 57-66.

Premoli AC, Souto CP, Allnutt TR, Nexton AC, 2001. Effects of population disjunction on isozyme variation in the widespread Pilgerodendron uviferum. Heredity 87: 337-343.

Raddi S, Sümer S, 1999. Genetic diversity in natural Cupressus sempervirens L. populations in Turkey. Biochemical Systematics and Ecology 27: 799-814.

Rajchenberg M, Barroetaveña C, Cwielong PP, Rossini M, Cabral D, Sivori A, 1997. Fungal species associated with the decline of Austrocedrus chilensis in Patagonia, Argentina: preliminary results. Root and Butt Rots of Forest Trees (Carcans-Maubuisson, France). Les Colloques 89: 235-244.

Rajchenberg M, Cwielong PP, 1993. El mal del ciprés (Austrocedrus chilensis): su relación con las pudriciones radiculares $\mathrm{y}$ el sitio. Actas Congreso Forestal Argentino y Latinoamericano (Paraná, Entre Ríos, Argentina). 14 pp.

Rajchenberg M, Gomez C, 2005. Enfermedades y plagas en Austrocedrus chilensis. Libro de Actas de la I Reunión sobre ecología, conservación y uso de los bosques de ciprés de la cordillera (Esquel. Argentina). 5 pp.

Rajesh PN, Tekeoglu M, Gupta VS, Ranjekar PK, Muehlbauer FJ, 2002. Molecular mapping and characterization of an RGA locus RGAPtokin1-2 $2_{171}$ in chickpea. Euphytica 128: 427433.

Reinhold-Hurek B, Hurek T, 1998. Interactions of Gramineous plants with Azoarcus spp. and other diazotrophs: identification, localization, and perspectives to study their function. Critical Reviews in Plant Sciences 17:29-54. 
Reiter B, Pfeifer U, Schwab H, Sessitsch A, 2002. Response of Endophytic Bacterial Communities in Potato Plants to Infection with Erwinia carotovora subsp. atroseptica. Applied and Environmental Microbiology 68: 2261-2268.

Remaudière G, 1992. A simplified method for mounting aphids and other small insects in Canada balsam. Revue Française d'Entomologie 14(4): 185-186.

Remaudière G, Binazzi A, 2003. Les Cinara du Pakistan. II. Le sous-genre Cupressobium (Hemiptera, Aphididae, Lachninae). Revue Française d'Entomologie 25(2): 85-96.

Ritland C, Pape T, Ritland K, 2001. Genetic structure of yellow cedar (Chamaecyparis nootkatensis). Canadian Journal of Botany 79: 822-828.

Rivera Rodríguez G, 2006. Bacterias presentes en el sistema vascular de algunos cítricos en Puerto Rico. Tesis para optar al grado de Maestro en Ciencias en Biología. Universidad de Puerto Rico. 85 pp.

Roberts D, 2004. Ash tree decline. Michigan State University Extension. http//:web1.msue.msu.edu/reg_se/Roberts/ash/decline.html\#what

Rodríguez R, 2004. Monografía. Ciprés de la cordillera (Austrocedrus chilensis). Especie con problemas de conservación en Chile. Endesa. Grupo Enersis. 71 pp.

Roehrdanz RL, 1997. Identification of tobacco budworm and corn earworm (Lepidoptera: Noctuidae) during early developmental stages by polymerase chain reaction and restriction fragment length polymorphism. Annals of Entomological Society of America 9: 329-332.

Roig FA, 1992. Comparative wood anatomy of Southern South American Cupressaceae. IAWA Bulletin 13: 151-162.

Rosso PHA, 1989. Caracterización sintomatológica y espacial del mal que afecta a las poblaciones de ciprés de la cordillera (Austrocedrus chilensis) del Parque Nacional Nahuel Huapi. Tesis de Licenciatura en Ciencias Biológicas. Universidad Nacional del Comahue. Argentina. 58 pp.

Rosso PHA, Havrylenko M, Fontenla SB, 1989. Austrocedrus chilensis: asociación espacial entre individuos sanos y afectados por la mortalidad. Bosque 10(2): 85-88.

Rosso PH, Baccalá N, Havrylenko M, Fontenla S, 1994. Spatial pattern of Austrocedrus chilensis wilting and the scope of autocorrelation analysis in natural forests. Forest Ecology and Management 67: 273-279.

Rovere A, 2000 citado por Rovere y Le Quesne, 2005. Razón de sexos y crecimiento diferencial del ciprés de la cordillera A. chilensis (Cupressaceae), a lo largo de un gradiente de precipitación. Tesis doctoral. Universidad Nacional del Comahue. Argentina.

Rovere AE, Aizen MA, Kitzberger T, 2003. Growth and climatic response of male and female trees of Austrocedrus chilensis, a dioecious conifer from the temperate forests of southern South Amererica. Ecoscience 10: 195-203. 
Rovere AE, Gobbi ME, Relva MA, 2005. Regeneración de Austrocedrus chilensis. 16 pp. En: Arturi M, Frangi J, Goya J. Ecología y Manejo de los Bosques de Argentina. Editorial de la Universidad Nacional de La Plata, Argentina.(CD).

Rovere AE, Le Quesne C, 2005. Austrocedrus chilensis: ¿Existen diferencias somáticas y demográficas a consecuencia de la dioicidad en ésta confiera? Libro de Actas de la I Reunión sobre ecología, conservación y uso de los bosques de ciprés de la cordillera (Esquel, Chubut). 135-140.

Rozas, J., J. C. Sánchez-del Barrio, X. Messeguer, and R. Rozas. 2003. DnaSP, DNA polymorphism analyses by coalescent and other methods. Bioinformatics 19: 2496-2497.

Rozas V, DeSoto L, Olano JM, 2009. Sex-specific, age-dependent sensitivity of tree-ring growth to climate in the dioecious tree Juniperus thurifera. New Phytologist 182: 687-697.

Sangsing K, Kasemsap P, Thanisawanyangkura S, Sangkhasila K, Gohet E, Thaler P, Cochard $\mathrm{H}, 2004$. Xylem embolism and stomatal regulation in two rubber clones (Hevea brasiliensis Muell. Arg.). Trees 18: 109-114.

Savva Y, Schweingruber F, Milyutin L, Vaganov E, 2002. Genetic and environmental signals in tree rings from different provenances of Pinus sylvestris L. planted in the southern, central Siberia. Trees 16: 313-324.

Schardl CL, Leuchtmann A, Spiering MJ, 2004 citado por Anand et al. 2006. Symbioses of grasses with seedborne fungal endophytes. Annual Review of Plant Biology 55: 315-340.

Schlegel FM, 1962 citado por Pastorino et al., 2006. Hallazgo de un bosque de cipreses cordilleranos en la provincia de Aconcagua. Boletín Universidad de Chile 32: 43-46.

Schmithüsen J, 1960 citado por Pastorino et al., 2006. Die Nadelhölzer in den Waldgesellschaften der südlichen Anden. Vegetatio 9: 313-327.

Schulze ED, 1989. Air Pollution and Forest Decline in a Spruce (Picea abies) Forest. Science 244: 776-783.

Seibert P, 1982 citado por La Manna, 2004: Carta de vegetación de la región de El Bolsón y su aplicación a la planificación del uso de la tierra. Fundación para la Educación, la Ciencia y la Cultura, Buenos Aires. 120 pp.

Sessitsch A, Reiter B, Berg G, 2004. Endophytic bacterial communities of field-grown potato plants and their plant-growth-promoting and antagonistic abilities. Canadian Journal of Microbiology 50: 239-249.

Shen KA, Meyers BC, Islam-Faridi MN, Chin DB, Stelly DM, Michelmore RW, 1998. Resistance Gene Candidates Identified by PCR with Degenerate Oligonucleotide Primers Map to Clusters of Resistance Genes in Lettuce. Molecular Plant Microbe Interactions 11: 815-823. 
Sherald J, 1999. Elm yellows. Park Science 19(2). http//:www2.nature.nps.gov/parksci/vol19/vol19(2)/10sherald.htm

Shurtleff MC, Averre III CW, 1997 citado por La Manna y Rajchenberg, 2004a. The Plant Disease Clinic and Field Diagnosis of Abiotic Diseases. APS Press, St. Paul, USA. 245 pp.

Silva J, Ruilova A, Urrutia A, 2005. El Complejo Cinara cupressi (Hemiptera: Aphididae): una amenaza para las cupresáceas nativas de Chile. CONAF 23(46): 1-7.

Simon C, Frati R, Beckenbach A, Crespi B, Liu H, 1994. Evolution, weighting, and phylogenetic utility of mitochondrial gene sequences and a compilation of conserved poymerase chain reaction primers. Annals of Entomological Society of America. 87: 651701.

Sinclair W, Griffths H, Treshow M, 1993. Impact of ash yellows mycoplasmalike organisms on radial growth of naturally infect white, green, and velvet ash. Canadian Journal of Forest Research. 23: 2467-2472.

Smirnov VV, 1964 citado por Vagano et al., 2006. Seasonal growth of the main species of trees (in Russian). Nauka, Moscow. 167 pp.

Soriano JM, Vilanova S, Romero C, Llácer G, M L Badenes, 2005. Characterization and mapping of NBS-LRR resistance gene analogs in apricot (Prunus armeniaca L.). Theoretical and Applied Genetics 110: 980-989.

Sperry JS, Hacke UG, Pittermann J, 2006. Size and function in conifer tracheids and angiosperm vessels. American Journal of Botany 93: 1490-1500.

Squirrell J, Hollingsworth PM, Woodhead M, Russell J, Lowe AJ, Gibby M, Powell W. 2003. How much effort is required to isolate nuclear microsatellites from plants? Molecular Ecology 12: 1339-1348.

Staebler GR, 1951 citado por Alvarez Taboada et al., 2003. Growth an spacing in an eveng-aged stand of Douglas-fir. Master's thesis, University of Michigan.

Stange Hofmann RD, 2004. Análisis de la distribución espacial de la mortalidad en una plantación de Austrocedrus chilensis, Valdivia, Chile. Proyecto para optar al Título de Ingeniero Forestal Universidad Austral de Chile. Chile. 43 pp.

Staskawicz BJ, Ausubel FM, Baker BJ, Ellis JG, Jones JD, 1995. Molecular genetics of plant disease resistance. Science 268: 661-667.

Sturz AV, 1995. The role of endophytic bacteria during seed piece decay and potato tuberization. Plant and Soil 175: 257-263.

Sturz AV, Christie BR, Matheson BG, Arsenault WJ , Buchanan NA, 1999. Endophytic bacterial communities in the periderm of potato tubers and their potential to improve resistance to soil-borne plant pathogens. Plant Pathology 48: 360-369. 
Suarez ML, Ghermandi L, Kitzberger T, 2004. Factors predisposing episodic drought-induce tree mortality in Nothofagus - site, climatic sensitivity and growth trends. Journal of Ecology. 92:954-966.

Sufran KA, 2003. Polymerase chain reaction-restriction fragment length polymorphisms identity mtDNA haplotypes of greenbug (Hemiptera: Aphididae). Journal of the Kansas Entomological Society 76: 551-556.

Sun L, Qiu F, Zhang X, Dai X, Dong X, Song W, 2008. Endophytic bacterial diversity in rice (Oryza sativa L.) roots estimated by $16 \mathrm{~S}$ rDNA sequence analysis. Microbial Ecology 55: 415-424.

Sunnucks P, Driver F, Brown WV, Carver M, Hales DF, Milne WM, 1997. Biological and genetic characterization of morphologically similar Therioaphis trifolii (Hemiptera: Aphididae) with different host utilization. Bulletin of Entomological Research 87: 425436.

Swetnam TW, Lynch AM, 1993. Multicentury, regional-scale patterns of western spruce budworm outbreaks. Ecological Monographs 63: 399-424.

Tanhuanpää P, 2004. Identification and mapping of resistance gene analogs and a white rust resistance locus in Brassica rapa ssp. oleifera. Theoretical and Applied Genetics 108: 1039-1046.

Terrab A, Schönswetter P, Talavera S, Vela E, Stuessy TF, 2008. Range-wide phylogeography of Juniperus thurifera L, a presumptive keystone species of western Mediterranean vegetation during cold stages of the Pleistocene. Molecular Phylogenetics and Evolution 48: 94-102.

Tervet IW, Hollis JP, 1948 citado por Anand et al. 2006. Bacteria in the storage organs of healthy plants. Phytopathology 38: 960-967.

Thompson JD, Gibson TJ, Plewniak F, Jeanmougin F, Higgins DG, 1997. The ClustalX windows interface: flexible strategies for multiple sequence alignment aided by quality analysis tools. Nucleic Acids Research 24: 4876-4882.

Thyssen PJ, Lessinger AC, Azeredo-Espin AML, Linhares AX, 2005. The value of PCR-RFLP Molecular Markers for the Differentiation of Immature Stages of Two Necrophagous Flies (Diptera: Calliphoridae) of Potential Forensic Importance. Neotropical Entomology 34(5): 777-783.

Tortorelli LA, 1956. Maderas y bosques argentinos. Editorial ACME, S.A.C.I. Buenos Aires. $910 \mathrm{pp}$.

Triplett EW, 1996: Diazotrophic endophytes: progress and prospects for nitrogen fixation in monocots. Plant Soil 186:29-38. 
Trognitz FCh, Trognitz BR, 2005. Survey of resistance gene analogs in Solanum caripense, a relative of potato and tomato, and update on R gene genealogy. Molecular Genetics and Genomics 274: 595-605.

Tsumura Y, Matsumoto A, Tani N, Ujino-Ihara T, Kado T, Iwata H, Uchida K, 2007. Genetic diversity and the genetic structure of natural populations of Chamaecyparis obtusa: implications for management and conservation. Heredity 99: 161-172.

Uchida K, Tsumura Y, Ohba K, 1991 citado por Pastorino et al., 2004. Inheritance of isozyme variation in leaf tissues of Hinoki, Chamaecyparis obtusa, and allozyme diversity of two natural forests. Japanese Journal of Breeding 41: 11-24.

Uchida K, Tomaru Nobuhiro, Tomaru Ch, Yamamoto Ch, Ohba K, 1997. Allozyme Variation in Natural Populations of Hinoki, Chamaecyparis obtusa (Sieb. Et Zucc.) Endl. and Its Comparison with the Plus-trees Selected from Artificial Stands. Breeding Science 47: 714.

Ulrich K, Ulrich A, Ewald D, 2008. Diversity of endophytic bacterial communities in poplar grown under field conditions. FEMS Microbiology Ecology 63: 169-180.

Urretavizcaya MF, Defossé GE, Gonda HE, 2006. Short-term effects of fire on plant cover and soil conditions in two Austrocedrus chilensis (cypress) forests in Patagonia, Argentina. Annals of Forest Science 63: 63-71.

Urretavizcaya MF, Defossé GE, 2004. Soil seed bank of Austrocedrus chilensis (D. Don) Pic. Serm. et Bizzarri related to different degrees of fire disturbance in two sites of southern Patagonia, Argentina. Forest Ecology and Management 187: 361-372.

Vaganov EA,.Hughes MK, Shashkin AV, 2006. Growth Dynamics of Conifer Tree Rings Images of Past and Future Environments. Ecological Studies 183. Springer Berlin Heidelberg NewYork. 351 pp.

Vaganov EA, Terskov IA, 1977 citado por Vagano et al., 2006. Analysis of tree growth by tree ring structure (in Russian). Nauka,Novosibirsk. 98 pp.

Valenzuela I, Hoffman AA, Malipatil MB, Ridland PM, Weeks AR, 2007. Identification of aphid species (Hemiptera: Aphididae: Aphidinae) using a rapid polymerase chain reaction restriction fragment length polymorphism method based on the cytochrome oxidase subunit I gen. Australian Journal of Entomology 46: 305-312.

Van Buijtenen JP, 1965 citado por Vaganov et al., 2006. Inheritance of fiber properties in North American conifers. (IUFRO section 41, vol 2) IUFRO,Melbourne. 12 pp.

Van der Merwe, Winfield MO, Arnold GM, Parker JS, 2000. Spatial and temporal aspects of the genetic structure of Juniperus communis populations. Molecular Ecology 9:379-386. 
Varsavsky E, Bettuci L, García Rodriguez D, Gomez C, 1975. Observaciones preliminares sobre la mortalidad del ciprés (Austrocedrus chilensis) en los bosques patagónicos. Fundación Bariloche 19: 1-11.

Veblen TT, Hadley KS, Reid MS, Rebertus A, 1991. Methods of detecting past spruce beetle outbreaks in Rocky Mountain subalpine forests. Canadian Forest Research 21: 242-254.

Veblen TT, Burns B, Kitzberger T, Lara A, Villalba R. 1995. The ecology of the conifers of southern south America. 120-142 pp. En: Enright N, Hill R. Ecology of the Sourthern Conifers. Melbourne University Press.

Veblen T, Kitzberger T, Villalba R, 2005. Nuevos paradigmas en ecología y su influencia sobre el conocimiento de la dinámica de los bosques del sur de Argentina y Chile. 48 pp. En: Arturi M, Frangi J, Goya J. Ecología y Manejo de los Bosques de Argentina. Editorial de la Universidad Nacional de La Plata, Argentina.(CD).

Veblen TT, Schlegel FM, 1982. Reseña ecológica de los bosques del sur de Chile. Bosque 4(2):73-115.

Vekemans X, Beauwens T, Lemaire M, Roldan-Ruiz I, 2002. Data from amplified fragment length polymorphism (AFLP) markers show indication of size homoplasy and of a relationship between degree of homoplasy and fragment size. Molecular Ecology 11: 139151.

Villalba R, Masiokas MH, Kitzberger T, Boninsegna JA, 2005. Biogegraphical Consequences of Recent Climate Changes in the Southern Andes of Argentina. 157-166. En: Huber UM. Global Change and Mountain Regions. Springer.

Villalba R, Veblen TT, 1997. Regional Patterns of Tree Populations Age Structures in Northern Patagonia: Climatic and Disturbance Influences. The Jounal of Ecology 85: 113-124.

Villalba R, Veblen TT, 1998. Influences of Large-Scale Climatic Variability on Episodic Tree Mortality in Northern Patagonia. Ecology 79: 2624-2640.

Wang ZH, Borromeo ES, Teng P, Leung H, Zhu YY, 2000. Differentiation of rice varieties cultivated in Yunnan, China, using PCR markers corresponding to conserved motifs of disease resistance genes. International Rice Research Newsletter 25: 11-12.

Wang DL, Li ZC, Hao G, Chiang TY, Ge XJ, 2004. Genetic diversity of Calocedrus macrolepsis (Cupressaceae) in southwestern China. Biochemical Systematics and Ecology 32: 797-807.

Watson G, Voegtlin D, Murphy S, Foottit R, 1999. Biogeography of the Cinara cupresssi complex (Hemiptera: Aphididae) on Cupressaceae, with description of a pest species introduced into Africa. Bulletin of Entomological Research 89: 271-283.

Weisburg W, Barns S, Pelletier D, Lane D, 1991. 16S ribosomal DNA amplification for phylogenetic study. Journal of Bacteriology 173: 697-703. 
Whitesides SK, Spotts RA, 1991. Frequency, distribution, and characteristics of endophytic Pseudomonas syringae in pear trees. Phytopathology 81: 453-457.

Willigen CV, Pammenter NW, 1998. Relationship between growth and xylem hydraulic characteristics of clones of Eucalyptus spp. at contrasting sites. Tree Physiology 18: 595600 .

Willis B, 1914. El Norte de la Patagonia. Tomo I. EUDEBA, Buenos Aires. 500 pp.

Wilson CJ, Jackson RB, 2006. Xylem cavitation caused by drought and freezing stress in four co-ocurring Juniperus species. Physiologia Plantarium 127: 374-382.

Wilson D, 1995. Endophyte - The evolution of a term, and clarification of its use and definition. Oikos 73: 274-276.

Worral J, 2005. Forest \& Shade Tree Pathology. http//: www.forestpathology.org

Xu Q, Wen X, Deng X, 2005. Isolation of TIR and nonTIR NBS-LRR resistance gene analogues and identification of molecular markers linked to a powdery mildew resistance locus in chestnut rose (Rosa roxburghii Tratt). Theoretical and Applied Genetics 111: 819-830.

Xu X, Yang F, Xiao X, Zhang S, Korpelainen H, Li Ch, 2008. Sex-specific responses of Populus cathayana to drought and elevated temperatures. Plant Cell and Environment 31: 850-860.

Yu YG, Buss GR, Saghai Maroof MA, 1996. Isolation of a superfamily of candidate diseaseresistance genes in soybean based on a conserved nucleotide-binding site. Proceedings of the National Academy of Sciences 93: 11751-11756.

Zhang LP, Khan A, Niño-Liu D, Foolad MR, 2002. A molecular linkage map of tomato displaying chromosomal locations of resistance gene analogs based on a Lycopersicon esculentum $\times$ Lycopersicon hirsutum cross. Genome 45: 133-146.

Zhivotovsky LA, 1999 citado en Vekemnas et al., 2002. Estimating population structure in diploids with multilocus dominant DNA markers. Molecular Ecology 8: 907-913.

Zinniel DK, Lambrecht P, Harris NB, Feng Z, Kuczmarski D, Higley P, Ishimaru CA, A Arunakumari, Barletta RG, Vidaver AK, 2002. Isolation and Characterization of Endophytic Colonizing Bacteria from Agronomic Crops and Prairie Plants. Applied and Environmental Microbiology 68: 2198-2208.

Zobell BJ, Jett JB, 1995 citado por Vagano et al., 2006. Genetics of wood production. Springer, Berlin Heidelberg NewYork. 337 pp.

Zreik L, Bove J, Garnier M, 1998. Phylogenetic characterization of the bacterium-like organism associated with marginal chlorosis of strawberry and proposition of a Candidatus taxon for the organism, "Candidatus Phlomobacter fragariae". International Journal of Systematic Bacteriology 48: 257-261. 

ANEXOS 



\section{ANEXO 1 \\ INCIDENCIA Y DESARROLLO TEMPORAL DEL MAL DEL CIPRÉS}

\section{1.- INTRODUCCIÓN}

Para el desarrollo del presente trabajo de tesis, se seleccionaron cinco sectores de muestreo ubicados de Norte a Sur en los siguientes sitios: Lotes 5 y6 (Reserva Forestal, Sección Los Repollos, Río Negro), Rodales 11 (R11), 18 (R18) y 81 (R81) (Reserva Forestal Loma del Medio-Río Azul, Río Negro) y Lotes 9y15 (Reserva Forestal, Sección El Puelo, Chubut) (Figura A1-1). Aunque los Rodales 11 y 18 se ubican al Norte de la Reserva Forestal Loma del Medio-Río Azul (LMRA) en áreas cercanas; fueron elegidos debido a que presentan diferencias en exposición e impacto turístico.

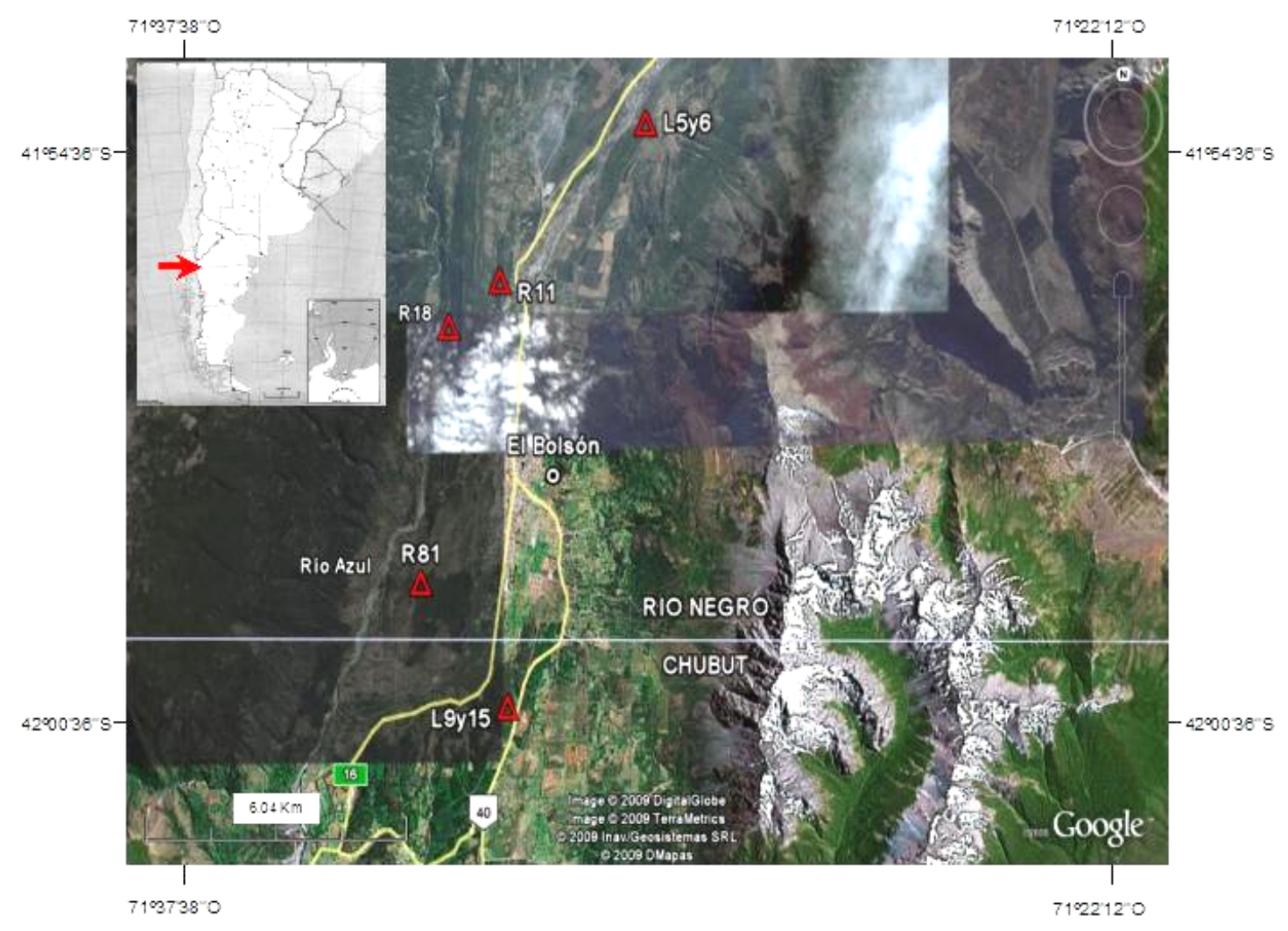

Figura A1-1: Mapa de la zona de estudio mostrando la ubicación de los sitios de muestreo (L5y6, R11, R18, R81 y L9y15) y la localidad de El Bolsón. La línea gris indica el límite entre las provincias de Río Negro y Chubut. En el vértice superior izquierdo se ubica la zona de estudio en el mapa de Argentina (flecha roja). 
En la zona el aprovechamiento forestal se realiza exclusivamente en base a la extracción de árboles con síntomas o muertos. Dada la falta de estudios epidemiológicos para el mal del ciprés en la región y considerando que la extracción de individuos en forma diferencial en los distintos sitios puede llevar a una evaluación incorrecta de la sanidad actual y/o a una interpretación errónea del avance de la mortalidad en cada sitio, información adicional fue solicitada y analizada.

\section{2.- MATERIALES Y MÉTODOS}

La caracterización de los sitios de muestreo se realizó en tres escalas espaciales diferentes (Figura A1-2), rodal, parcela permanente e individuo a fin de identificar diferencias o similitudes en la incidencia del mal del ciprés y su dinámica de avance en cada sitio (escala temporal).

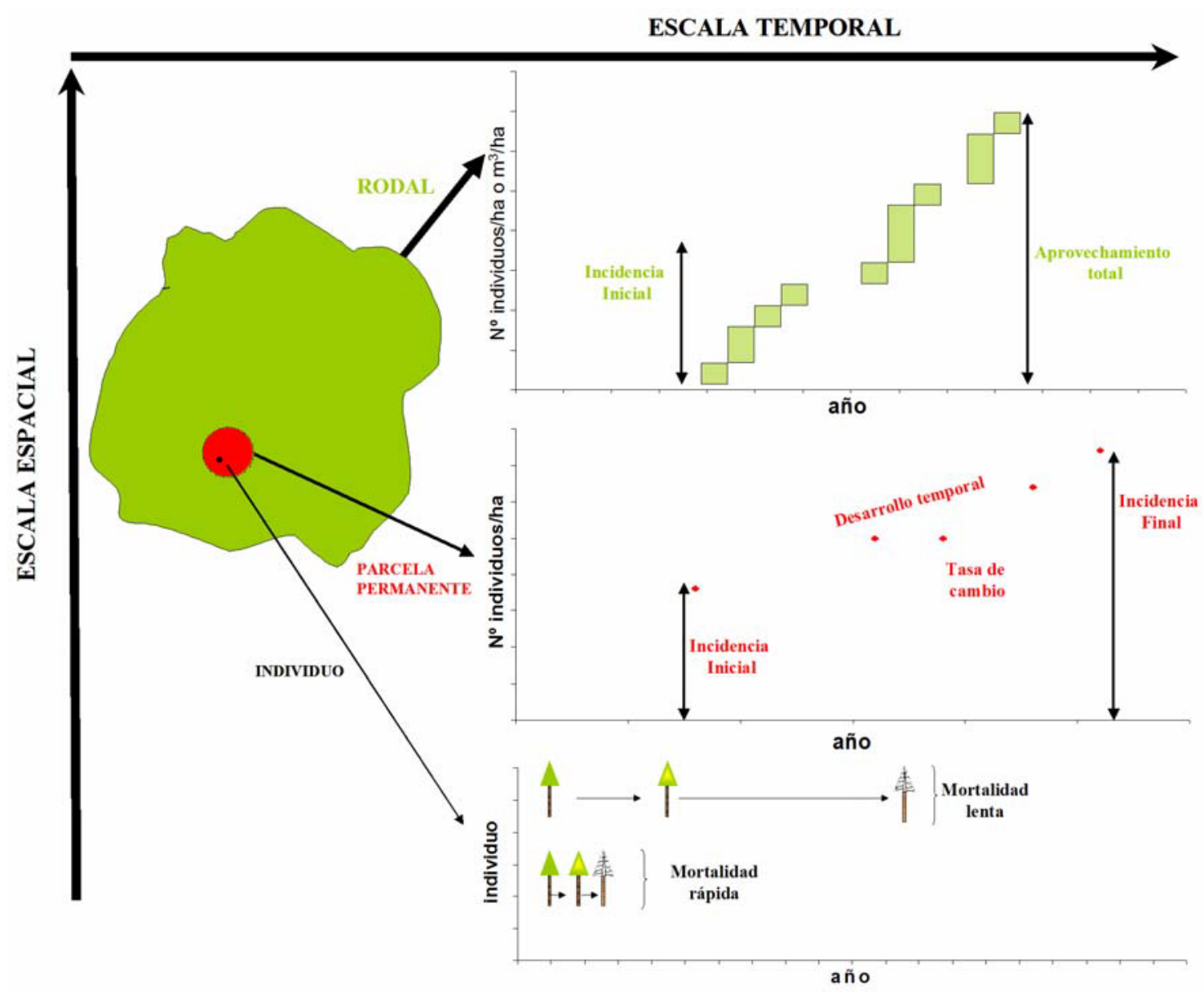

Figura A1-2: Representación esquemática de la caracterización de los sitios mediante el análisis en escala espacial (rodal, parcela permanente e individuo) y temporal. 
En todas las bases de datos consultadas los árboles enfermos fueron clasificados en función del grado de defoliación y el amarillamiento de la copa. Debido a que la caída en la tasa de crecimiento de los árboles (síntoma interno de afección) precede el desarrollo de los síntomas externos (Calí, 1996) es, en rigor, incorrecto considerar como sanos a los árboles que no muestran síntomas externos. Por tal motivo, la información recabada fue recodificada según se detalla a continuación. Los árboles caracterizados como "sanos" se reclasificaron como "asintomáticos" (A). Los árboles caracterizados como "enfermos" se reclasificaron como "sintomáticos"(S), en tanto que para los árboles "muertos" (M) se mantuvo la codificación.

\section{1-CARACTERIZACIÓN A NIVEL DE RODAL}

\subsection{1- Incidencia del mal del ciprés}

Los datos de frecuencia ( $\mathrm{n}^{\mathrm{o}}$ de árboles/ha) y el volumen $\left(\mathrm{m}^{3} / \mathrm{ha}\right)$ de árboles asintomáticos, sintomáticos y muertos, provenientes del Plan de Ordenación del Cuartel Loma del Medio-Río Azul (Chauchard y Barnabá, 1986) y del Inventario Forestal de los L5y6 y L9y15 (Chauchard, 1987) se emplearon para el cálculo de la incidencia del mal del ciprés en los distintos sitios. Los cálculos de incidencia se realizaron para individuos sintomáticos (ISINT) o muertos (IMOR) y en función del número (frec) o volumen (vol) de los individuos, de acuerdo con las siguientes ecuaciones:

$$
\begin{aligned}
& \operatorname{ISINT}(\text { frec })=\left[\mathrm{n}^{\mathrm{o}} \text { sintomáticos } /\left(\mathrm{n}^{\mathrm{o}} \text { asintomáticos }+\mathrm{n}^{\mathrm{o}} \text { sintomáticos }+\mathrm{n}^{\mathrm{o}} \text { muertos }\right)\right] \text { x } 100 \\
& \operatorname{ISINT}(\mathrm{vol})=\left[\mathrm{m}^{3} \text { sintomáticos } /\left(\mathrm{m}^{3} \text { asintomáticos }+\mathrm{m}^{3} \text { sintomáticos }+\mathrm{m}^{3} \text { muertos }\right)\right] \text { x } 100 \\
& \operatorname{IMOR}(\text { frec })=\left[\mathrm{n}^{\mathrm{o}} \text { muertos } /\left(\mathrm{n}^{\mathrm{o}} \text { asintomáticos }+\mathrm{n}^{\mathrm{o}} \text { sintomáticos }+\mathrm{n}^{\mathrm{o}} \text { muertos }\right)\right] \text { x } 100 \\
& \operatorname{IMOR}(\mathrm{vol})=\left[\mathrm{m}^{3} \text { muertos } /\left(\mathrm{m}^{3} \text { asintomáticos }+\mathrm{m}^{3} \text { sintomáticos }+\mathrm{m}^{3} \text { muertos }\right)\right] \text { x } 100
\end{aligned}
$$

La distribución según clases diamétricas de los árboles sintomáticos o muertos, en función del número o el volumen de los individuos, se empleó para analizar la contribución de la competencia a la mortalidad en cada sitio. La información de la distribución en clases diamétricas, según incrementos de a $10 \mathrm{~cm}$, se obtuvo del Plan de Ordenación del Cuartel Loma del Medio-Río Azul (Chauchard y Barnabá, 1986) y del Inventario Forestal de los L5y6 (Chauchard, 1987), no existiendo registros para los L9y15.

\subsection{2- Historia de aprovechamiento}

Los registros de aprovechamiento (volumen de madera extraída por año) para el período 19872007 se solicitaron al Servicio Forestal Andino y al Campo Forestal Gral. San Martín y se emplearon para caracterizar la historia de aprovechamiento en cada sitio. 


\section{2- CARACTERIZACIÓN A NIVEL DE PARCELA PERMANENTE}

\subsection{1- Análisis del desarrollo temporal del mal del ciprés}

A finales de la década del ochenta, se inició la instalación de una red de parcelas permanentes en la Reserva Loma del Medio-Río Azul propiedad de INTA, administradas bajo el Convenio INTA-Servicio Forestal Andino de Río Negro. Su objetivo inicial fue la generación de una base de datos que permitiera el desarrollo de estudios silviculturales, de crecimiento y rendimiento, ecológicos y sanitarios en los bosques de $A$. chilensis del valle de El Bolsón.

Tres de estas Parcelas Permanentes (PP), las establecidas en los Rodales 11, 18 y 81 de la Reserva Forestal LMRA, se emplearon para el análisis del desarrollo temporal del mal del ciprés. Este tipo de caracterización no pudo ser efectuada para los L5y6 y L9y15 debido a la falta de PP en dichas áreas. La Tabla A1-1 resume la información general de las parcelas permanentes empleadas y los años en que se efectuaron los correspondientes inventarios. Se contó al menos con tres inventarios para cada parcela. La PP16-R11 registra cinco inventarios con un período de evaluación total de 18 años, la PP12-R18 cuatro con un período total de 15 años y la PP26-R81 tres con un período total de 7 años.

\begin{tabular}{|c|c|c|c|c|}
\hline & & PP16-R11 & PP12-R18 & PP26-R81 \\
\hline $\begin{array}{c}\text { Información } \\
\text { general }\end{array}$ & $\begin{array}{c}\text { Superficie }\left(\mathrm{m}^{2}\right) \\
\text { Pendiente }\left({ }^{\circ}\right) \\
\text { Exposición } \\
\text { Densidad (individuos/ha) }\end{array}$ & $\begin{array}{c}1000 \\
10 \\
\text { E-SE } \\
960\end{array}$ & $\begin{array}{c}1000 \\
25 \\
\text { O-SO } \\
1130\end{array}$ & $\begin{array}{c}1000 \\
14 \\
\text { O-SO } \\
580\end{array}$ \\
\hline Inventarios & $\begin{array}{l}1988 \\
1996 \\
1999 \\
2003 \\
2006\end{array}$ & $\begin{array}{l}\sqrt{ } \\
\sqrt{ } \\
\sqrt{ } \\
\sqrt{ } \\
\sqrt{ }\end{array}$ & $\begin{array}{l}\sqrt{ } \\
\sqrt{ } \\
\sqrt{ } \\
\sqrt{ } \\
x\end{array}$ & $\begin{array}{l}x \\
x \\
V \\
V \\
\sqrt{ }\end{array}$ \\
\hline
\end{tabular}

Tabla A1-1: Superficie, pendiente, exposición y densidad de las parcelas permanentes analizadas y años en los que se efectuaron los correspondientes inventarios. Fuente de información: Campo Forestal Gral. San Martín

La información disponible fue recodificada a los fines de estandarizar la nomenclatura y ajustar las categorías de estado sanitario de acuerdo con los criterios básicos anteriormente mencionados. Los árboles clasificados como "sanos" independientemente de la forma del fuste, fueron codificados como "asintomáticos" (A). Los árboles clasificados como "enfermos" independientemente de la forma del fuste o de la cuantificación de la sintomatología, fueron codificados como "sintomáticos" (S). Los árboles clasificados como "muertos", mantuvieron su 
codificación (M). Los árboles para los cuales no existe información en un año de inventario fueron codificados como "no determinados" (ND). Por último, los árboles clasificados como "aprovechados", "caídos" o "descalzados" fueron codificados como un único grupo con denominación $(\mathrm{X})$.

Luego de la codificación por inventario, especie, individuo y estado sanitario se analizó el desarrollo temporal a nivel de individuo. Se establecieron tres clases de tendencia para analizar el comportamiento de las diferentes categorías de estado sanitario en función de los años de inventario en las PP. Cada clase responde a una desarrollo temporal definido según se detalla a continuación:

- CLASE DIRECTA: comportamiento esperado para el proceso en estudio, árboles que siguen la tendencia $\mathrm{A} \rightarrow \mathrm{S}, \mathrm{M}, \mathrm{X}$

- ClASE INVERSA: comportamiento en sentido inverso al esperado para el proceso, árboles que siguen una tendencia del tipo $\mathrm{S} \rightarrow \mathrm{A}$

- ClASE ALTERNADA: comportamiento que alterna estados sanitarios sin una tendencia precisa, árboles que presentan un desarrollo temporal del tipo $\mathrm{S} \rightarrow \mathrm{A} \rightarrow \mathrm{S}$, o $\mathrm{A} \rightarrow \mathrm{S} \rightarrow \mathrm{A}$.

Árboles con un solo dato de inventario (incorporaciones recientes) no fueron incluidos en el análisis, por lo cual el número de individuos se mantuvo constante en cada PP en el período total del análisis. Sólo los árboles correspondientes a la clase DIRECTA fueron posteriormente empleados para el análisis del desarrollo temporal del mal del ciprés en cada parcela.

\subsection{2- Distribución espacial de la mortalidad}

Los datos de ubicación de cada árbol respecto del centro de parcela (rumbo y distancia) fueron transformados a coordenadas x e y. Empleando dichas coordenadas se generaron mapas de distribución de los diferentes estados sanitarios, para cada parcela permanente e inventario.

\section{3.-CARACTERIZACIÓN A NIVEL DE INDIVIDUO}

\subsection{1- Desarrollo temporal del mal del ciprés}

La información disponible en los registros de las parcelas permanentes, permite un seguimiento de árboles individuales y fue empleada para determinar el tiempo de desarrollo del mal del ciprés a nivel de individuo dentro de la clase DIRECTA anteriormente definida con base en los síntomas aéreos. 


\section{3.- RESULTADOS Y DISCUSIÓN}

\section{1-CARACTERIZACIÓN A NIVEL DE RODAL}

\subsection{1- Incidencia del mal del ciprés}

En la Tabla A1-2 se presentan los datos de frecuencia ( $n^{\circ}$ de árboles $/ \mathrm{ha}$ ) y volumen $\left(\mathrm{m}^{3} / \mathrm{ha}\right)$ junto con los valores de incidencia calculados, en base a árboles con síntomas o árboles muertos, para cada uno de los sitios de muestreo. Las incidencias se corresponden con los valores porcentuales de cada categoría (sintomáticos o muertos) y se indican entre paréntesis junto a los valores absolutos.

La ISINT(frec) calculada fue inferior al 10\% para los cinco sitios analizadas, presentando el R11 y los L5y6 los valores más bajos, el R18 el valor más alto, y el R81 y los L9y15 valores intermedios. Las IMOR(frec) fueron mayores que las ISINT(frec), existiendo diferencias marcadas en las variaciones observadas para cada uno de los sitios (Gráfico A1-1). Para el R11 el valor de ISINT(frec) correspondió al 7\% del valor de IMOR(frec), en tanto que para el R81 el porcentaje fue del 21\%, para los L5y6 del 36\% y se aproximó al 50\% para el R18 y los L9y15 (44 y 49\%, respectivamente). Las ISINT(vol) se encuentran por debajo del 15\%, presentando los Lotes 5 y6 el menor valor, el R11 y el R81 los valores mayores, y el R18 y los Lotes 9y15 valores intermedios.

Las IMOR(vol) resultaron también mayores que las IsINT(vol) (Gráfico A1-1), aunque la diferencia entre ambas fue menor que para las incidencias calculadas en base a la frecuencia. Dada la relación entre volumen y DAP, considerada para los cálculos volumétricos (Chauchard y Barnabá, 1986), esta menor diferencia indicaría una mayor contribución de los árboles muertos en número que en volumen, de lo que se deriva una distribución diferencial de tamaños en los estados sanitarios sintomático y muerto. Si existiera una única causa de mortalidad, se esperaría una distribución de tamaños similar entre ambas categorías. La falta de discriminación de los factores que producen la mortalidad es una de las posibles explicaciones de esta distribución diferencial, pudiendo los árboles muertos representar la suma de la acción simple o combinada de diferentes procesos. Para el R11, la contribución diferencial de los árboles muertos en número y en volumen es lo suficientemente alta como para producir una inversión de la tendencia general. En este caso, la ISINT(vol) mostró un valor superior a la IMOR(vol). Considerando que este rodal se caracterizó como "denso" y que se menciona la baja probabilidad de supervivencia de la regeneración debido a la densidad (Chauchard y Barnabá, 1986), la inversión en la tendencia no resulta sorprendente. Por el contrario, puede ser explicada por la contribución a la mortalidad total de un gran número de árboles de pequeño porte eliminados por competencia. 


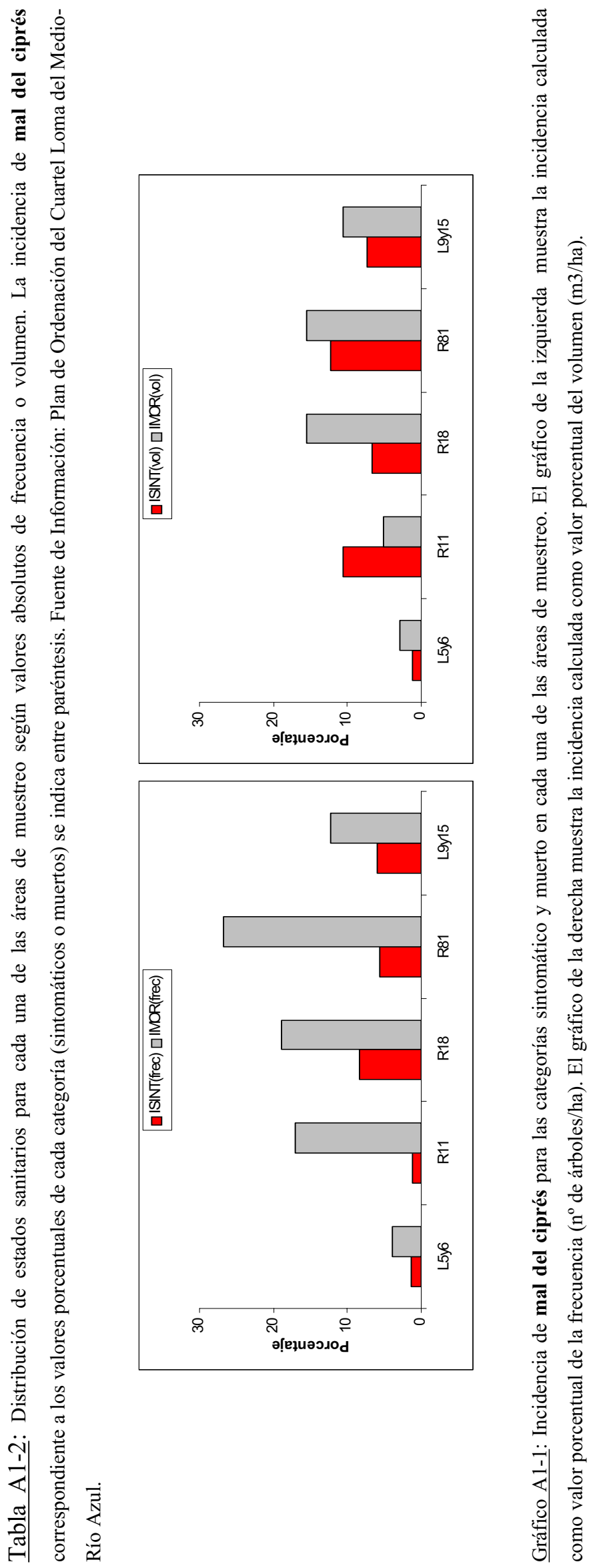

$\stackrel{\text { d }}{ }$

\begin{tabular}{|c|c|c|c|c|c|}
\hline \multirow{4}{*}{ 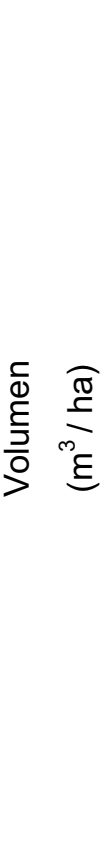 } & 㔄 & 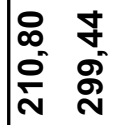 & $\begin{array}{c}\hat{m} \\
\stackrel{N}{N}\end{array}$ & \begin{tabular}{l}
\multirow{2}{*}{} \\
$\stackrel{\infty}{\infty}$ \\
$\infty$
\end{tabular} & \\
\hline & $\begin{array}{l}0 \\
\frac{0}{2} \\
\frac{1}{0} \\
\stackrel{2}{2}\end{array}$ & 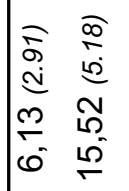 & 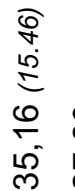 & 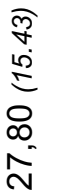 & 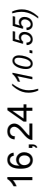 \\
\hline & 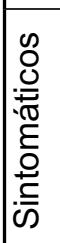 & 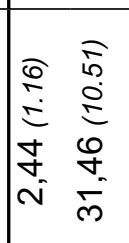 & 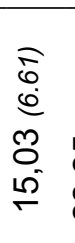 & 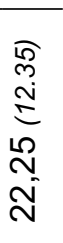 & 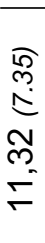 \\
\hline & 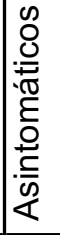 & 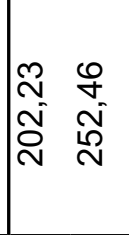 & 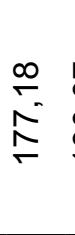 & $\begin{array}{l}\hat{0} \\
0 \\
0 \\
0\end{array}$ & $\frac{1}{\sim}$ \\
\hline \multirow{4}{*}{ 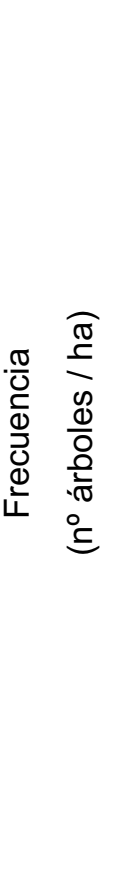 } & 㔄 & 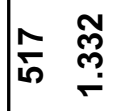 & 웅 & $\check{\aleph}_{\infty}$ & 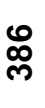 \\
\hline & 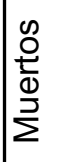 & 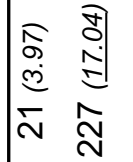 & 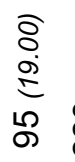 & 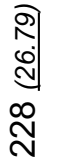 & 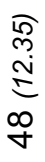 \\
\hline & 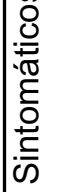 & 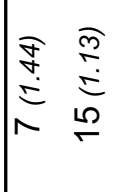 & 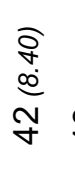 & $\begin{array}{l}\vec{F} \\
\dot{b} \\
\stackrel{\infty}{0} \\
\infty \\
\dot{+}\end{array}$ & $\begin{array}{l}\mathbb{f} \\
\mathbb{0} \\
\text { N }\end{array}$ \\
\hline & 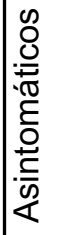 & $\stackrel{\circ}{\circ} \stackrel{\circ}{\circ}$ & ల్లి & $\frac{L_{0}}{5}$ & $\frac{n}{m}$ \\
\hline $\begin{array}{l}\stackrel{2}{3} \\
\text { क }\end{array}$ & & 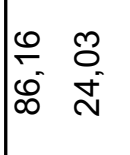 & & & $\begin{array}{l}\infty \\
\infty \\
6 \\
6\end{array}$ \\
\hline 离 & & \begin{tabular}{ll}
0 & \multicolumn{2}{c}{} \\
10 & $\frac{1}{10}$ \\
0 & $\frac{\pi}{0}$ \\
0 & 0 \\
0 & $\mathbb{1}$
\end{tabular} & $\frac{\infty}{\frac{\infty}{\pi}}$ & $\begin{array}{l}\frac{5}{0} \\
\frac{\pi}{0} \\
\frac{1}{x}\end{array}$ & 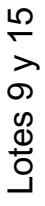 \\
\hline
\end{tabular}


El Gráfico A1-2 presenta la distribución de individuos sintomáticos y muertos según clases diamétricas para frecuencia o volumen. En los gráficos que corresponden al R11 se observa claramente la contribución diferencial a frecuencia o volumen de las distintas clases diámetricas y ambos estados sanitarios. Existe un importante número de árboles muertos en las clases diamétricas inferiores que contribuyen mucho a la IMOR(frec) y poco a la IMOR(vol), en tanto que se da una tendencia inversa para los árboles sintomáticos. Una situación similar puede observarse para el R81; en este caso aunque la contribución diferencial no es tan marcada es importante recordar que el Plan de Ordenación señala el alto nivel de explotación del rodal (Chauchard y Barnabá, 1986). En el R18 y los L5y6, por el contrario, hay una distribución más homogénea de árboles muertos y sintomáticos entre las distintas clases diamétricas lo que resulta en menor diferencia entre los tipos de incidencia calculados. Para los L9y15 no se cuenta con datos de clases diamétricas, razón por la cual no se presentan los gráficos correspondientes.

La comparación entre los diferentes valores de incidencia calculados y el análisis de la distribución diferencial de individuos sintomáticos y muertos entre clases diamétricas, sumados a la ausencia de explotación previa (Chauchard y Barnabá, 1986) permite concluir que un gran porcentaje de la mortalidad en el R11 sería resultado del efecto de competencia a nivel de bosque. Para el R81, la mortalidad sería probablemente el resultado combinado de competencia y mal del ciprés, aunque debería analizarse el efecto del aprovechamiento en la estructura diamétrica. En el R18 y los L5y6 la mortalidad parece debida en su gran mayoría al mal del ciprés. Para los L9y15, con un comportamiento similar al R18 y considerando su baja densidad, es esperable una mortalidad relacionada al mal del ciprés.

Los valores de ISINT(frec) pueden ser comparados con los reportados por Havrylenko et al. (1989) para las parcelas Gutierrez (5.5\%) y Llao-Llao (32.0\%). Esta última parcela presenta un valor superior de incidencia, en tanto que la parcela Gutierrez y las áreas en estudio tienen valores similares. Una situación diferente se presenta al compara los valores de IMOR(frec). En este caso, los valores reportados son del 14\% para la parcela Gutierrez y del $9.7 \%$ para la parcela LlaoLlao. Con excepción de los L5y6 (3.97\%) el resto de las áreas en estudio presentan valores superiores de incidencia en mortalidad. La bibliografía disponible reporta gran variación en la incidencia del mal del ciprés (5\% a 70\%). Sin embargo, el cálculo se realiza generalmente sin discriminar entre individuos sintomáticos y muertos, siendo difícil establecer que porcentaje de la mortalidad reportada es debida al proceso de competencia dentro del sitio. La combinación de los valores obtenidos, ISINT(frec) + IMOR(frec), ubica a las áreas en estudio dentro del grupo de incidencia baja o media (L5y6=5.41\%, R11=18.17\%, R18=27.40\%, R81=32.43\% y L9y15=18.39\%) de acuerdo con el rango reportado por Rosso (1989), Rosso et al. (1994) y Calí (1996). 

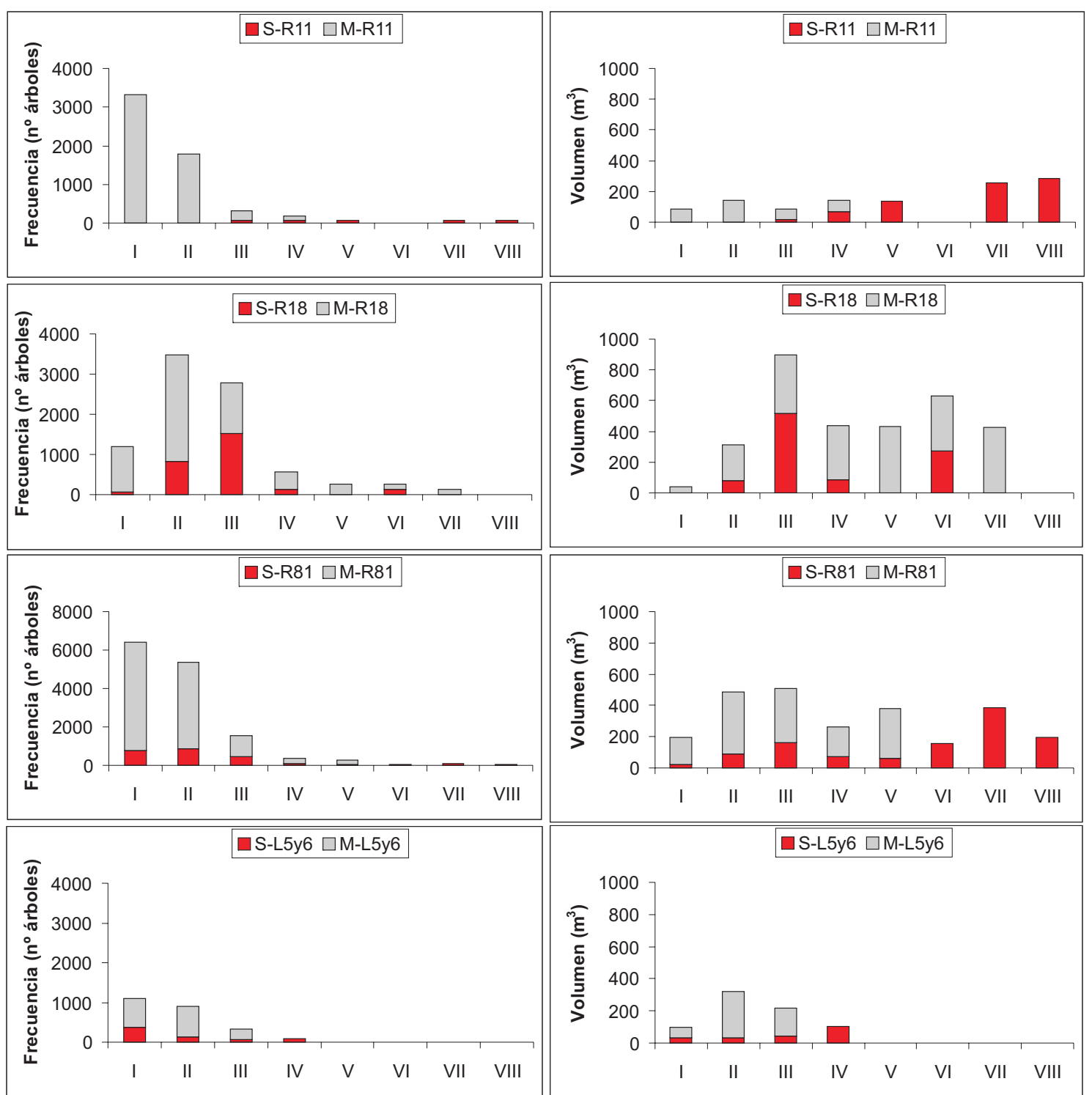

Gráfico A1-2: Distribución de individuos sintomáticos y muertos según clases diamétricas para cada una de las áreas de muestreo. A la izquierda se presentan la distribución en frecuencia y a la derecha en volumen. Clases diamétricas en números romanos, según incrementos de $10 \mathrm{~cm}$, comenzando en DAP de $10 \mathrm{~cm}$. Fuente de Información: Plan de Ordenación del Cuartel Loma del Medio-Río Azul.

\subsection{2- Historia de aprovechamiento}

De acuerdo con el análisis de los registros en el período 1987-2007 se aprovecharon $84 \mathrm{~m}^{3} / \mathrm{ha}$ para el R81, $48 \mathrm{~m}^{3} /$ ha para el R18, $43 \mathrm{~m}^{3} /$ ha para el R11 y $4 \mathrm{~m}^{3} /$ ha para los L5y6 (Gráfico A1-3). 


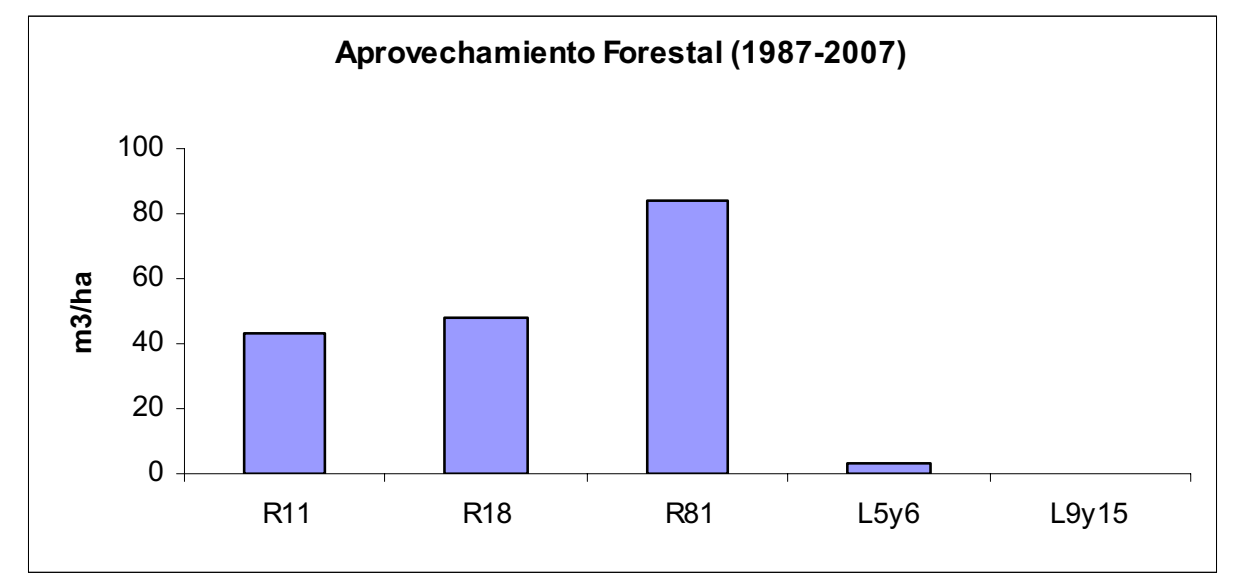

Gráfico A1-3: Volumen de madera extraído para cada una de las áreas de muestreo en el período 1987-2007 (sin considerar registros del año 2002 que no pudieron ser recuperados). Fuente de registros: Servicio Forestal Andino y Campo Forestal Gral. San Martín.

Sin embargo, la distribución temporal de las cortas no fue homogénea (Gráfico A1-4) existiendo años de aprovechamiento más intenso. El volumen extraído en el R11 durante el año 1991, representa el 37\% del total del período. En el caso del R18, la extracción para el mismo año corresponde a un $21 \%$ del total. Para el R81, la distribución es más homogénea y los picos más importantes representan el 18\% (2003) y 14\% (2000) del total del período. Los L9y15 no registraron aprovechamiento en el período analizado.

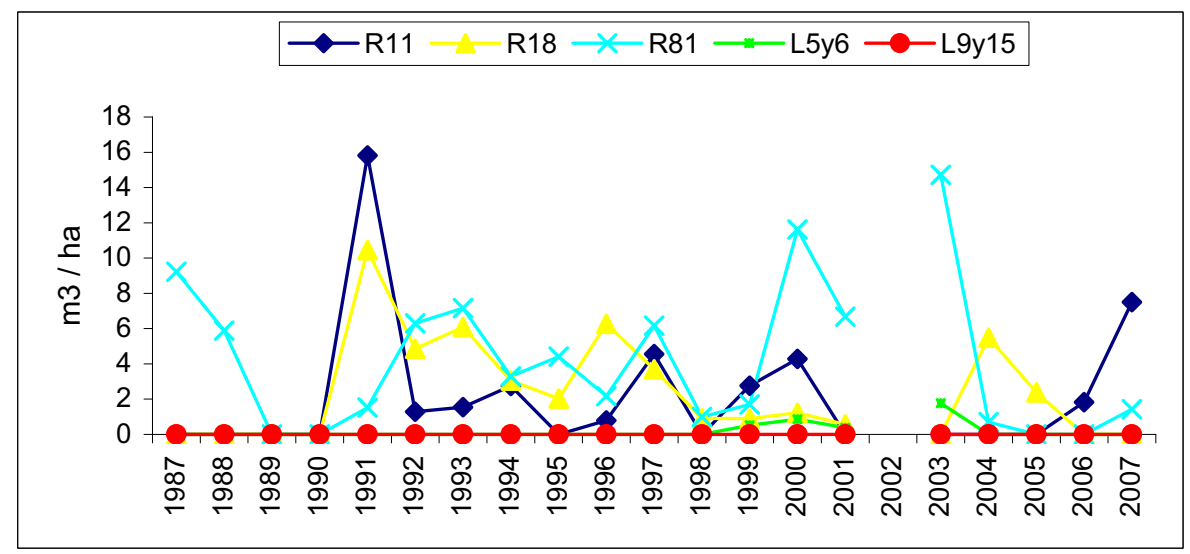

Gráfico A1-4: Distribución temporal del aprovechamiento forestal, en el período 1987-2007, para cada una de las áreas de muestreo (sin considerar registros del año 2002 que no pudieron ser recuperados). Fuente de registros: Servicio Forestal Andino y Campo Forestal Gral. San Martín. 


\section{2- CARACTERIZACIÓN A NIVEL DE PARCELA PERMANENTE}

\subsection{1- Análisis del desarrollo temporal del mal del ciprés}

Los inventarios de tres parcelas permanentes (PP) se utilizaron en el análisis del desarrollo temporal del mal del ciprés: parcela permanente 16 del Rodal 11 (PP16-R11), parcela permanente 12 del Rodal 18 (PP12-R18) y parcela permanente 26 del Rodal 81 (PP26-R81).

Para las tres parcelas en estudio, la clase de tendencia DIRECTA representó más del $65 \%$ de los datos analizados (Tabla A1-3). La clase ALTERNADA varío entre el 11 y 31\%, mientras que la clase INVERSA no superó el $8 \%$. Por tanto, la contribución de la clase DIRECTA al total se consideró como un buen parámetro de la tendencia general de la parcela y fue empleada en el análisis del desarrollo temporal del mal del ciprés en cada sitio.

\begin{tabular}{|c|c|c|c|}
\cline { 2 - 4 } \multicolumn{1}{c|}{} & \multicolumn{3}{c|}{ TENDENCIA } \\
\hline PARCELA & ALTERNADA & INVERSA & DIRECTA \\
\hline PP16-R11 & 25 & 8 & 67 \\
PP12-R18 & 11 & 3 & 86 \\
PP26-R81 & 31 & 3 & 66 \\
\hline
\end{tabular}

Tabla A1-3: Distribución porcentual de clases de tendencia para cada parcela permanente analizada.

El análisis de la tendencia temporal en la clase DIRECTA para cada una de las PP evidenció una disminución del número de individuos asintomáticos (Tabla A1-4). Debido a que los individuos $\mathrm{S}$ pueden mantenerse en ese estado o evolucionar a $\mathrm{M}$ o X, es posible observar disminuciones entre inventarios para esta categoría. Una situación similar puede darse para individuos $\mathrm{M}$, que pasan a X. Sin embargo, estas disminuciones deben interpretarse como avance de la afectación y no deben confundirse con una caída en el número de individuos afectados.

El Gráfico A1-5 presenta la variación del número de individuos afectados para cada PP e inventario. Como el estado real para los individuos ND se desconoce, se adoptó la posición más conservadora agrupándolos con los individuos A. Dicha agrupación se realizó asumiendo el riesgo de una subestimación de la afectación. Las agrupaciones se realizaron, únicamente, con el fin de simplificar la representación gráfica de los resultados. Los datos completos para la tendencia DIRECTA figuran en la Tabla A1-4. 


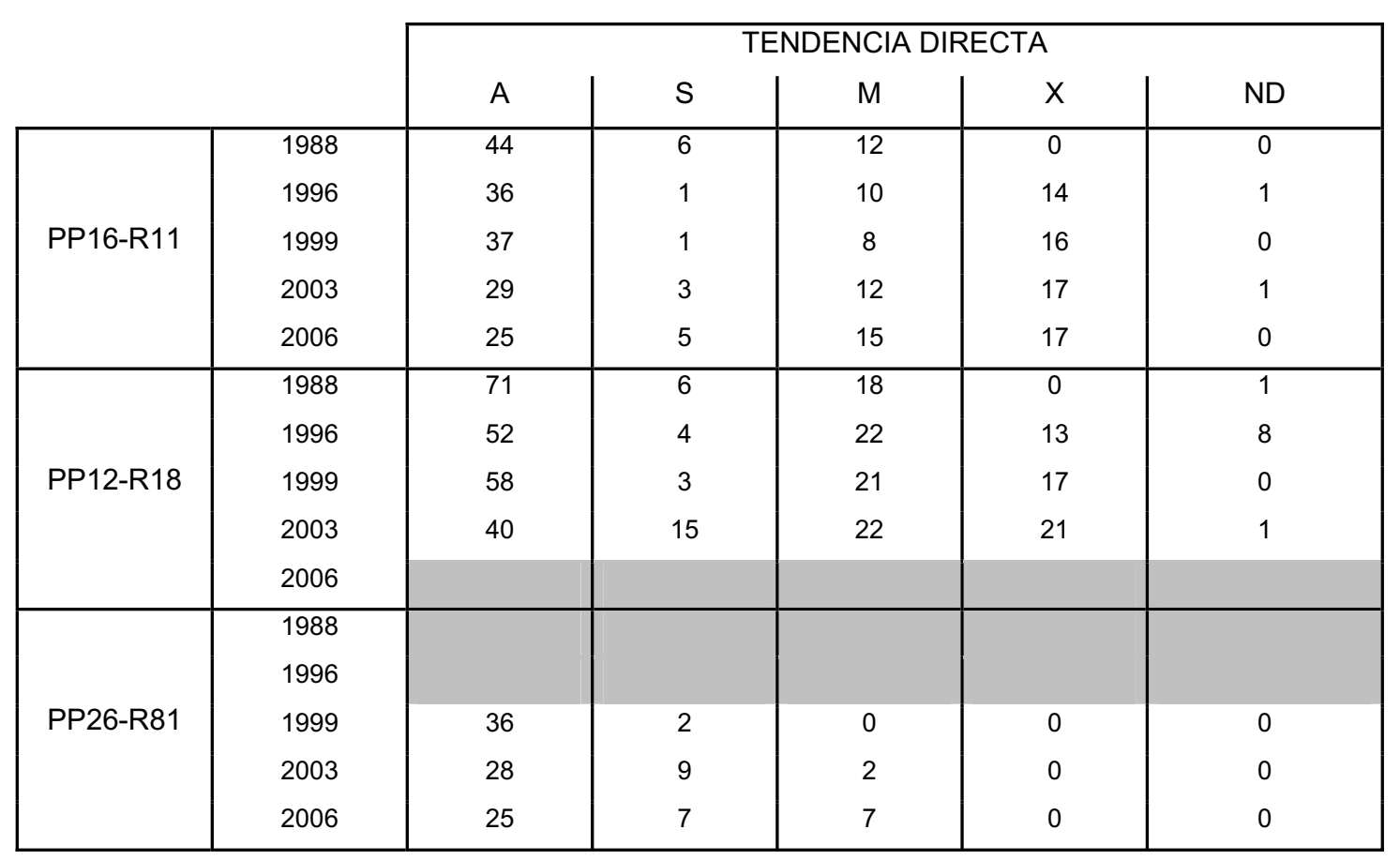

Tabla A1-4: Número de árboles, por categoría e inventario, para la tendencia directa de desarrollo temporal en cada una de las parcelas permanentes. Categorías: asintomático (A), sintomático (S), muerto (M), X (aprovechado), ND (no determinado).

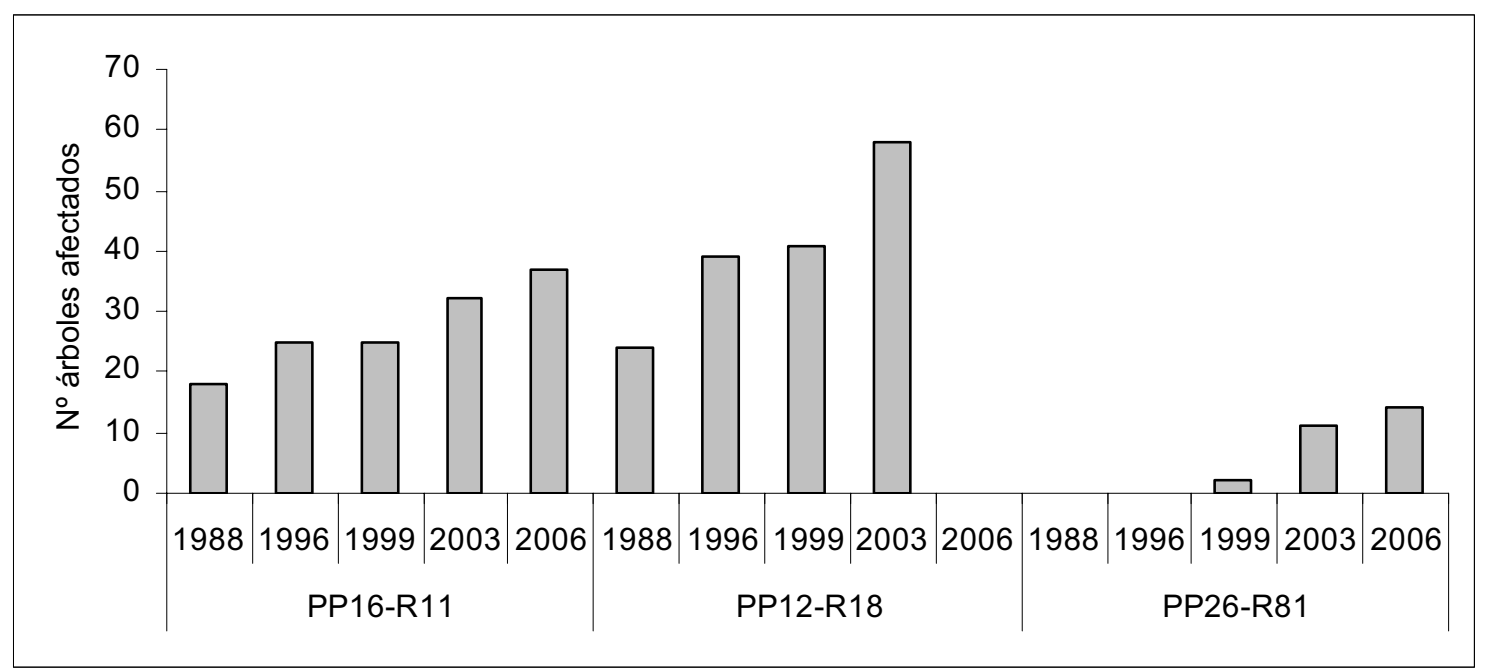

Gráfico A1-5: Número de árboles afectados $(\mathrm{S}+\mathrm{M}+\mathrm{X})$, para la CLASE DIRECTA de desarrollo temporal en cada una de las parcelas permanentes. S: sintomático. M: muerto. X: aprovechado, caído o descalzado. 
En la PP16-R11 el porcentaje de árboles afectados $(\mathrm{S}+\mathrm{M}+\mathrm{X})$ aumentó del 29 al 60\%, en un período de 18 años. Una tendencia similar se observó para la PP12-R18 con un aumento de los árboles afectados del 25 al 59\% en un lapso de 15 años. Mientras que para la PP26-R81, en un período de 7 años, los valores variaron del 5 al 36\%. Havrylenko et al. (1989) reportan un aumento en el porcentaje de árboles afectados $(\mathrm{S}+\mathrm{M})$ del 24 al $61 \%$ en el período primavera 1988invierno 1989; en tanto que Rosso et al. (1994) informan un aumento del 52.3 al $72.3 \%$ en el período Diciembre 1990-Septiembre 1991 (ambos sobre parcelas en Llao-Llao). De la comparación resulta evidente que el desarrollo temporal del mal del ciprés difiere ampliamente entre áreas observándose un incremento mucho mayor para los lugares estudiados por Havrylenko et al. (1989) y Rosso et al. (1994).

Los resultados presentados en el Gráfico A1-5, muestran que el número de árboles afectados aumenta con el tiempo; sin embargo, ese análisis no permite evaluar como se distribuye la aparición de árboles afectados a lo largo del período analizado. Mediante el análisis de la evolución temporal del cambio de estado sanitario, $\mathrm{A} \rightarrow \mathrm{S}+\mathrm{M}+\mathrm{X}$, para cada una de las PP se determinó que la aparición de árboles afectados se daría en pulsos de mayor frecuencia como los que se evidencian en los años 1996 y 2003 (Gráfico A1-6). Por otra parte, es esperable que dichos pulsos sean determinados por factores de impacto a gran escala, ya que los años de mayor frecuencia son los mismos para las distintas PP. Como los inventarios no se realizan todos los años, los factores que determinan los pulsos de aparición de árboles afectados pueden presentarse en cualquier momento dentro del período entre inventarios.

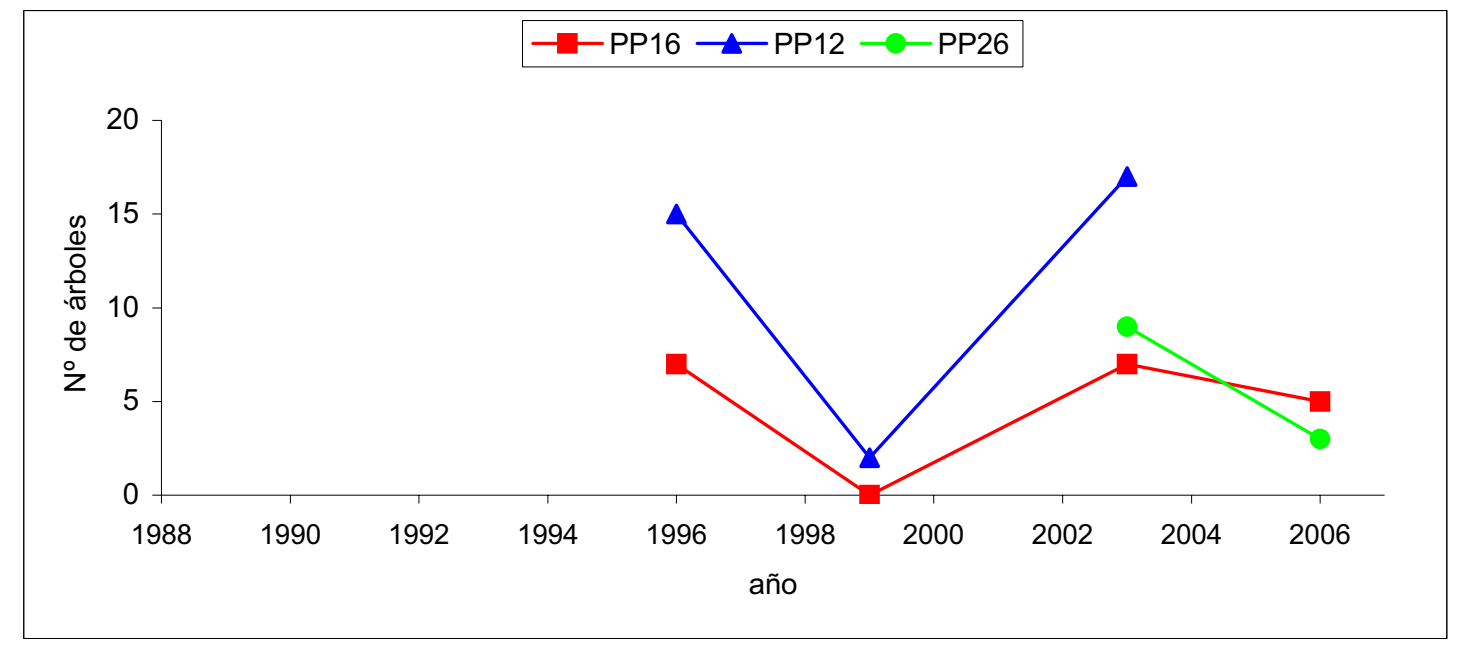

Gráfico A1-6: Evolución del cambio de estado sanitario para cada parcela permanente. En el eje de ordenadas se gráfica el número de árboles que en el período entre inventarios pasaron de asintomáticos a afectados $(\mathrm{A} \rightarrow \mathrm{S}+\mathrm{M}+\mathrm{X})$. 
El análisis retrospectivo de estallidos o brotes de agentes bióticos (primarios o secundarios) que pudieran explicar estos pulsos, aunque complejo, debería ser considerado a futuro. En cuanto a los agentes abióticos, el impacto del clima puede ser evaluado en relación a registros históricos. La década del ochenta en conjunto es considerada un período cálido y seco (Villalba y Veblen, 1997) al igual que los años finales de la década del noventa (Suarez et al. 2004; Le Quesne et al., 2006). El pulso detectado en 1996, responde a los cambios producidos en el período 1988-1996, los bajos niveles de precipitación registrados deberían ser considerados al menos como un factor contribuyente en el desarrollo de síntomas. Los años 1998-1999 corresponden a un período de sequía regional que condujo a importante mortalidad en Nothofagus (Suarez y Kitzberger, 2008); sin embargo el inventario correspondiente no evidenció un pulso de frecuencia lo que podría explicarse en función de la diferencia temporal entre el evento de sequía y la manifestación de síntomas externos en los árboles; pudiendo el pulso detectado en el inventario de 2003 dar cuenta de este retardo.

\subsection{2- Distribución espacial de la mortalidad}

Las coordenadas $(\mathrm{x}, \mathrm{y})$ de cada árbol para cada inventario y PP, se utilizaron para analizar el avance temporal del mal del ciprés. El Gráfico A1-7 muestra la aparición de árboles afectados $(\mathrm{S}+\mathrm{M}+\mathrm{X})$ en función del tiempo para las tres parcelas en estudio. Los árboles afectados del primer año de inventario corresponden al valor de incidencia inicial, y representan el punto de partida para el análisis temporal.

Los mapas obtenidos para las tres parcelas muestran que existe una distribución relativamente homogénea y que los árboles afectados no avanzan con un patrón de expansión desde un foco central. Si bien existe cercanía entre árboles afectados, también se observa la aparición aislada de individuos con síntomas. Estos resultados son sólo cualitativos y no deben interpretarse como determinantes de un patrón de agregación espacial definido; sin embargo, permiten una visualización simple de la relación entre individuos afectados y los pulsos de mayor (1996, 2003) o menor (1999) frecuencia antes mencionados. 

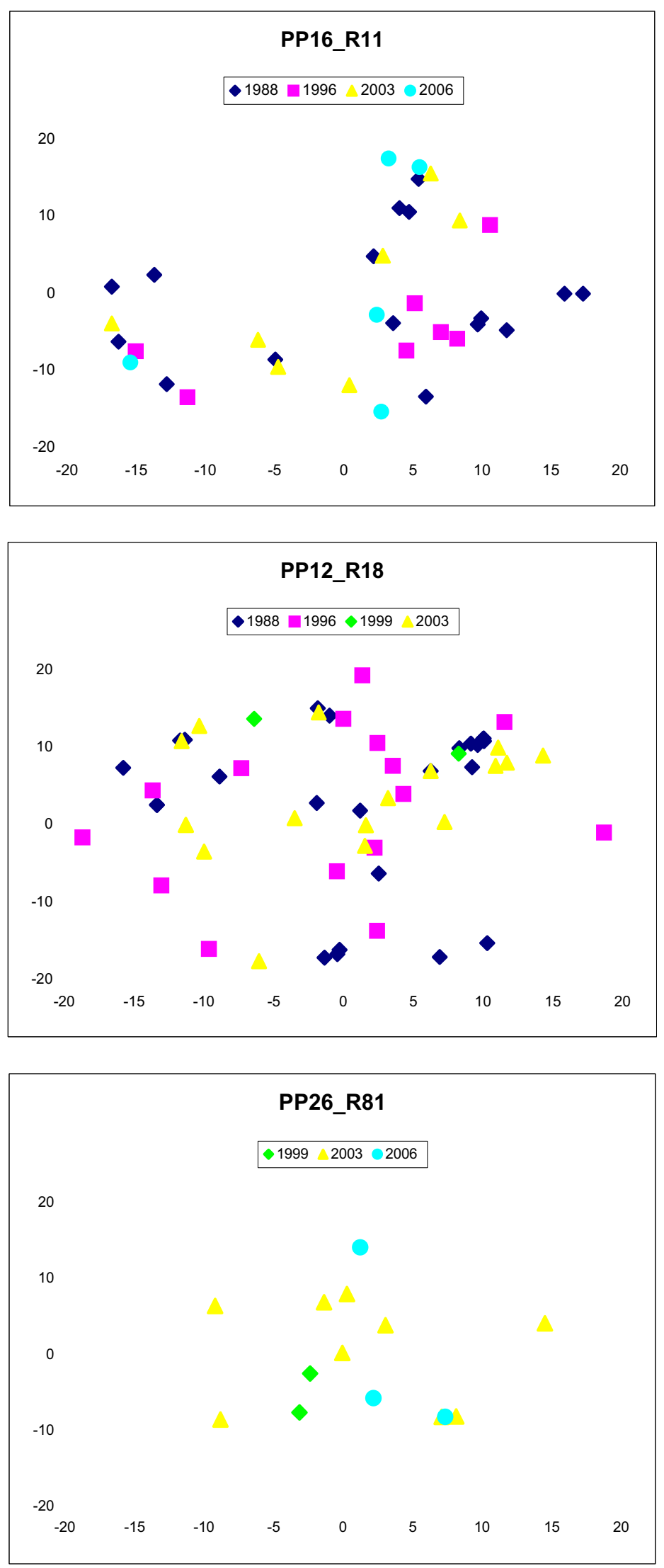

Gráfico A1-7: Distribución espacial de la mortalidad en función del tiempo para las tres parcelas en estudio. En los ejes $\mathrm{x}$ e $\mathrm{y}$, se indica la distancia en metros desde el centro de parcela. 


\section{3.-CARACTERIZACIÓN A NIVEL DE INDIVIDUO}

\subsection{1- Desarrollo temporal del mal del ciprés}

El análisis de la evolución temporal del cambio de estado sanitario para cada una de las parcelas permanentes muestra que la mortalidad no evoluciona de la misma forma en todos los individuos. Para el mismo lapso de tiempo (años entre inventarios) algunos árboles pasan de $\mathrm{A} \rightarrow \mathrm{S}$ en tanto que otros pasan de $\mathrm{A} \rightarrow \mathrm{M}$. El seguimiento de árboles individuales en el tiempo indica que el lapso mínimo de transición $\mathrm{A} \rightarrow \mathrm{S}$ determinado fue de 3 años, en tanto que para el cambio $\mathrm{A} \rightarrow \mathrm{M}$ el valor varió entre 3 y 4 años. Por otra parte, el tiempo mínimo de transición $S \rightarrow M$ fue de 3 años, aunque algunos individuos $S$ permanecieron en el mismo estado $(S \rightarrow S)$ durante un tiempo de 3 a 11 años. Es decir, que algunos individuos pasarían del estado $\mathrm{A} \rightarrow \mathrm{M}$ en un tiempo de 3 años (el tiempo real podría ser menor ya que el valor obtenido se corresponde con el tiempo mínimo entre inventarios), en tanto que otros individuos lo harían en un período mayor o igual a 15 años. Estos resultados indican que existen dos tendencias generales de mortalidad lenta y rápida, como ya ha sido reportado anteriormente (Havrylenko et al., 1989; Calí, 1996; Loguercio et al., 1998, 1999a; Filip y Rosso, 1999; Hennon y Rajchenberg, 2000). Las tres parcelas permanentes analizadas muestran similares tiempos de transición entre estados sanitarios sugiriendo que las diferencias de comportamiento dependen de variaciones a nivel de individuo.

\section{4.- CONCLUSIONES}

Los resultados obtenidos en el presente trabajo permiten concluir que:

- La incidencia del mal del ciprés en los sitios de muestreo es moderada en relación a lo reportado para otros bosques de $A$. chilensis afectados por la mortalidad.

- La competencia, intra o interspecífica, afecta las estimaciones de la incidencia del mal del ciprés en un sitio y por tanto su influencia debe ser evaluada al momento de realizar dichas estimaciones.

- El aprovechamiento forestal limita la comparación de la incidencia entre sitios si se desconoce el número exacto de individuos extraídos en cada lugar.

- La menor incidencia detectada en el Sur de El Bolsón respecto del Norte, sería consecuencia su mayor grado de aprovechamiento.

- El mayor aprovechamiento del área Sur podría conducir a una liberación del crecimiento de los individuos remanentes.

- El incremento del número de individuos afectados con el tiempo, responde a pulsos que podrían ser consecuencia del impacto de períodos climáticos desfavorables (cálidos y secos). 
- La aparición de individuos afectados a lo largo del tiempo presenta una distribución espacial homogénea que se corresponde con el patrón desagregado del mal del ciprés en estos sitios.

- La mortalidad a nivel de individuo responde a dos tendencias generales, mortalidad rápida o lenta.

\section{5.- BIBLIOGRAFÍA}

Calí S, 1996. Austrocedrus chilensis: Estudio de los anillos de crecimiento y su relación con la dinámica del "mal del ciprés" en el Parque Nacional Nahuel Huapi, Argentina. Tesis de Licenciatura en Ciencias Biológicas. Universidad Nacional del Comahue. Argentina. 143 pp.

Chauchard L, 1987. Inventario Forestal Lotes 5y6-Sección "Los Repollos" y Lotes 9y15Sección "El Puelo". Instituto Forestal Nacional-Dirección Forestal Andina. Informe interno inédito. $32 \mathrm{pp}$.

Chauchard L, Barnabá L, 1986. Plan de Ordenación Forestal Cuartel Loma del Medio-Río Azul. Provincia de Río Negro. Instituto Forestal Nacional-Dirección General de Bosques Río Negro. Informe interno inédito. 62 pp.

Filip GM, Rosso PH, 1999. Cypress mortality (mal del ciprés) in the Patagonian Andes: comparisons with similar forest diseases and declines in North America. European Journal of Forest Pathology. 29: 89-96.

Havrylenko M, Rosso PHA, Fontenla SB, 1989. Austrocedrus chilensis: contribución al estudio de su mortalidad en Argentina. Bosque 10(1): 29-36.

Hennon PE, Rajchenberg M, 2000. El "mal del ciprés". Algunas observaciones, comparaciones e ideas. CIEFAP Patagonia Forestal VI(2): 4-6.

Le Quesne C, Stahle DW, Cleaveland MK, Therrell MD, Aravena JC, Barichivich J, 2006. Ancient Austrocedrus Tree-Ring Chronologies Used to Reconstruc Central Chile Precipitation Variability from A.D. 1200 to 2000. Journal of Climate 19: 5731-5744.

Loguercio GA, Urretavizcaya F, Rey M, Andenmatten E, 1998. El "mal del cipres" como condicionante de la silvicultura del ciprés de la cordillera Austrocedrus chilensis (D. Don) Florin et Boutelje en el Norte de la Patagonia Argentina. I Congreso Latinoamericano IUFRO (Valdivia, Chile). 22 pp.

Loguercio GA, Rajchenberg M, Rodriguez N, Pantaenius P, 1999a. Curso-Taller de actualización en silvicultura de los bosques de ciprés de la cordillera (El Bolsón). 60 pp.

Rosso PHA, 1989. Caracterización sintomatológica y espacial del mal que afecta a las poblaciones de ciprés de la cordillera (Austrocedrus chilensis) del Parque Nacional Nahuel 
Huapi. Tesis de Licenciatura en Ciencias Biológicas. Universidad Nacional del Comahue. Argentina. 58 pp.

Rosso PH, Baccalá N, Havrylenko M, Fontenla S, 1994. Spatial pattern of Austrocedrus chilensis wilting and the scope of autocorrelation analysis in natural forests. Forest Ecology and Management 67: 273-279.

Suarez ML, Ghermandi L, Kitzberger T, 2004. Factors predisposing episodic drought-induce tree mortality in Nothofagus - site, climatic sensitivity and growth trends. Journal of Ecology. 92:954-966.

Suarez ML, Kitzberger T, 2008. Recruitment patterns following a severe drought: long-term compositional shifts in Patagonian forests. Canadian Journal of Forest Research 38: 30023010 .

Villalba R, Veblen TT, 1997. Regional Patterns of Tree Populations Age Structures in Northern Patagonia: Climatic and Disturbance Influences. The Jounal of Ecology 85: 113-124. 


\section{ANEXO 2}

DISTANCIA GEOGRÁFICA ENTRE INDIVIDUOS DE UN PAR

\begin{tabular}{c|cccccccccc} 
& \multicolumn{11}{|c}{ L5y6 } \\
\hline Par & 11 & 12 & 13 & 14 & 15 & 36 & 37 & 38 & 39 & 40 \\
Distancia $(\mathrm{m})$ & 33,8 & 22,9 & 11,8 & 48,0 & 3,4 & 17,9 & 5,4 & 1,6 & 17,5 & 3,3
\end{tabular}

\begin{tabular}{c|cccccccccc} 
& \multicolumn{11}{|c}{$\mathrm{R} 11$} \\
\hline Par & 1 & 2 & 3 & 4 & 5 & 26 & 27 & 28 & 29 & 30 \\
Distancia $(\mathrm{m})$ & 25,1 & 6,4 & 13,3 & 7,2 & 15,0 & 13,9 & 5,2 & 5,7 & 3,2 & 2,9
\end{tabular}

\begin{tabular}{c|cccccccccc} 
& \multicolumn{11}{|c}{$\mathrm{R} 18$} \\
\hline Par & 16 & 17 & 18 & 19 & 20 & 41 & 42 & 43 & 44 & 45 \\
Distancia $(\mathrm{m})$ & 10,2 & 25,8 & 13,1 & 6,8 & 9,1 & 17,9 & 6,8 & 9,3 & 8,4 & 12,0
\end{tabular}

\begin{tabular}{c|cccccccccc} 
& \multicolumn{10}{|c}{$\mathrm{R} 81$} \\
\hline Par & 21 & 22 & 23 & 24 & 25 & 46 & 47 & 48 & 49 & 50 \\
Distancia $(\mathrm{m})$ & 11,7 & 1,6 & 5,6 & 29,6 & 17,3 & 5,1 & 3,3 & 4,5 & 6,3 & 3,6
\end{tabular}

\begin{tabular}{c|cccccccccc} 
& \multicolumn{11}{|c}{ L9y15 } \\
\hline Par & 6 & 7 & 8 & 9 & 10 & 31 & 32 & 33 & 34 & 35 \\
Distancia $(\mathrm{m})$ & 6,2 & 20,4 & 15,7 & 27,4 & 12,7 & 5,7 & 6,1 & 4,8 & 17,3 & 36,2
\end{tabular}

Tabla A2-1: Distancia geográfica entre los individuos de cada uno de los pares asintomático / sintomático seleccionados para el desarrollo del trabajo de tesis. 



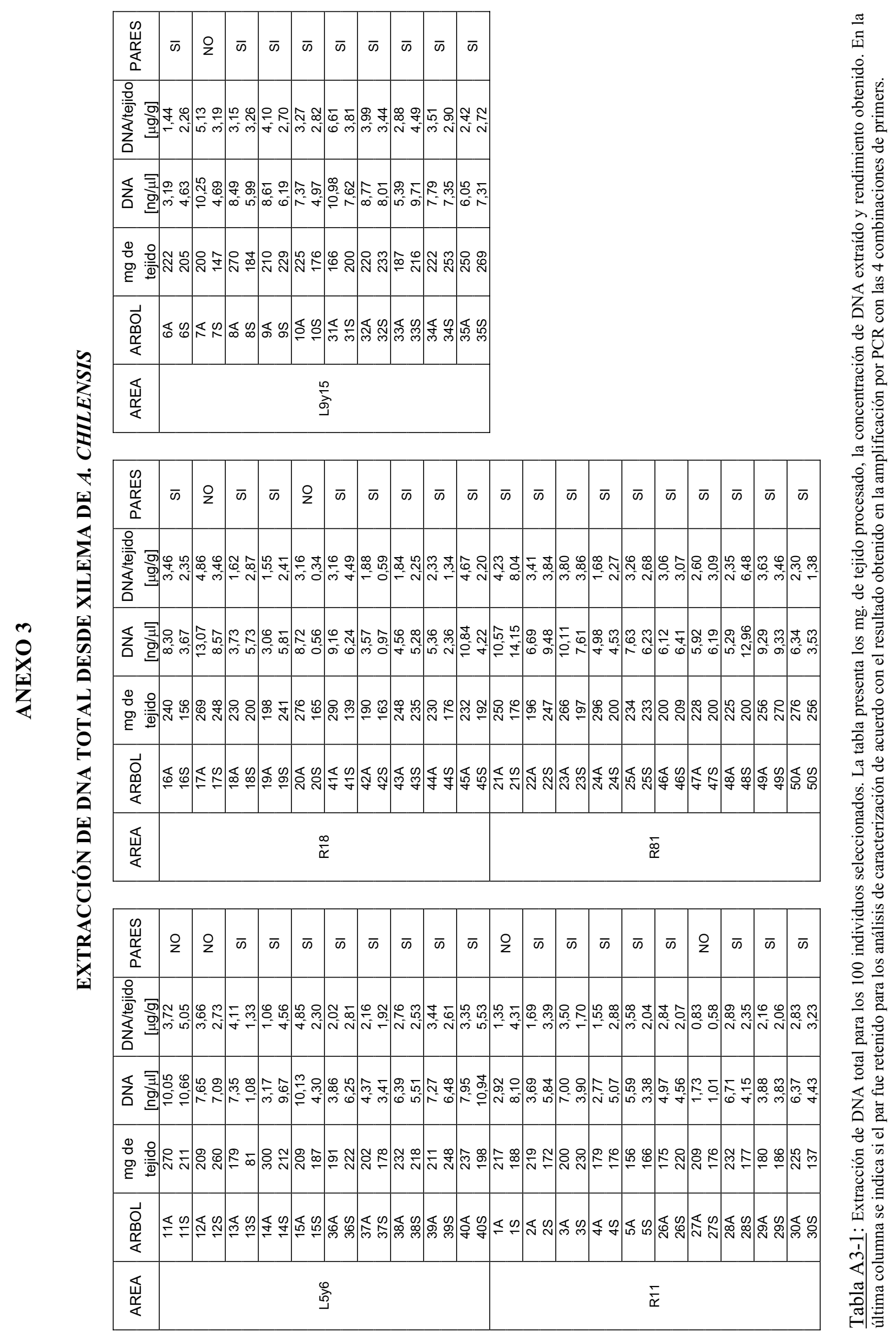





\section{ANEXO 4 \\ FRECUENCIAS ALÉLICAS ESTIMADAS PARA MARCADORES RGA}

\begin{tabular}{|c|c|c|c|c|c|c|c|}
\hline \multirow{3}{*}{ Combinación } & \multirow{3}{*}{ Locus } & \multicolumn{6}{|c|}{ POBLACION } \\
\hline & & \multicolumn{3}{|c|}{ ASINTOMATICA $(n=43)$} & \multicolumn{3}{|c|}{ SINTOMATICA $(n=43)$} \\
\hline & & $M_{\text {RGA }}$ & $A+$ & A- & $M_{\text {RGA }}$ & $A+$ & A- \\
\hline \multirow{15}{*}{ S1/AS1 } & A-182 & 0,34884 & 0,19574 & 0,80426 & 0,34884 & 0,19635 & 0,80365 \\
\hline & A-193 & 0,97674 & 0,84620 & 0,15380 & 0,97674 & 0,84378 & 0,15622 \\
\hline & A-296 & 0,02326 & 0,01496 & 0,98504 & 0,04651 & 0,02771 & 0,97229 \\
\hline & A-299 & 0,06977 & 0,03871 & 0,96129 & 0,11628 & 0,06392 & 0,93608 \\
\hline & A-323 & 0,81395 & 0,57009 & 0,42991 & 0,93023 & 0,73527 & 0,26473 \\
\hline & A-352 & 0,02326 & 0,01496 & 0,98504 & 0,02326 & 0,01594 & 0,98406 \\
\hline & A-354 & 0,65116 & 0,41135 & 0,58865 & 0,72093 & 0,47344 & 0,52656 \\
\hline & A-356 & 0,02326 & 0,01496 & 0,98504 & 0,09302 & 0,05170 & 0,94830 \\
\hline & A-358 & 0,02326 & 0,01496 & 0,98504 & 0,09302 & 0,05170 & 0,94830 \\
\hline & A-367 & 0,39535 & 0,22499 & 0,77501 & 0,48837 & 0,28752 & 0,71248 \\
\hline & A-374 & 0,88372 & 0,66006 & 0,33994 & 0,74419 & 0,49579 & 0,50421 \\
\hline & A-379 & 0,06977 & 0,03871 & 0,96129 & 0,06977 & 0,03963 & 0,96037 \\
\hline & A-403 & 0,02326 & 0,01496 & 0,98504 & 0,18605 & 0,10160 & 0,89840 \\
\hline & A-467 & 0,60465 & 0,37333 & 0,62667 & 0,69767 & 0,45201 & 0,54799 \\
\hline & A-533 & 0,06977 & 0,03871 & 0,96129 & 0,04651 & 0,02771 & 0,97229 \\
\hline \multirow{11}{*}{ XLRR } & $X-198$ & 0,79070 & 0,54402 & 0,45598 & 0,97674 & 0,84378 & 0,15622 \\
\hline & $X-199$ & 0,81395 & 0,57009 & 0,42991 & 0,95349 & 0,78285 & 0,21715 \\
\hline & $X-220$ & 0,62791 & 0,39204 & 0,60796 & 0,60465 & 0,37355 & 0,62645 \\
\hline & $X-243$ & 0,97674 & 0,84620 & 0,15380 & 0,97674 & 0,84378 & 0,15622 \\
\hline & $X-265$ & 0,02326 & 0,01496 & 0,98504 & 0,16279 & 0,08887 & 0,91113 \\
\hline & $X-273$ & 0,04651 & 0,02676 & 0,97324 & 0,16279 & 0,08887 & 0,91113 \\
\hline & $X-360$ & 0,88372 & 0,66006 & 0,33994 & 0,76744 & 0,51917 & 0,48083 \\
\hline & $X-378$ & 0,93023 & 0,73647 & 0,26353 & 0,79070 & 0,54375 & 0,45625 \\
\hline & $x-413$ & 0,90698 & 0,69587 & 0,30413 & 0,79070 & 0,54375 & 0,45625 \\
\hline & $X-502$ & 0,88372 & 0,66006 & 0,33994 & 0,76744 & 0,51917 & 0,48083 \\
\hline & $X-540$ & 0,02326 & 0,01496 & 0,98504 & 0,13953 & 0,07631 & 0,92369 \\
\hline \multirow{11}{*}{ Ptokin1_2 } & P1-148 & 0,93023 & 0,73647 & 0,26353 & 0,90698 & 0,69493 & 0,30507 \\
\hline & P1-150 & 0,93023 & 0,73647 & 0,26353 & 0,90698 & 0,69493 & 0,30507 \\
\hline & P1-166 & 0,93023 & 0,73647 & 0,26353 & 0,83721 & 0,59737 & 0,40263 \\
\hline & P1-249 & 0,09302 & 0,05079 & 0,94921 & 0,00000 & 0,00429 & 0,99571 \\
\hline & P1-260 & 0,93023 & 0,73647 & 0,26353 & 0,93023 & 0,73527 & 0,26473 \\
\hline & P1-281 & 0,90698 & 0,69587 & 0,30413 & 0,90698 & 0,69493 & 0,30507 \\
\hline & P1-331 & 0,69767 & 0,45199 & 0,54801 & 0,88372 & 0,65931 & 0,34069 \\
\hline & P1-368 & 0,93023 & 0,73647 & 0,26353 & 1,00000 & 0,94369 & 0,05631 \\
\hline & P1-386 & 0,93023 & 0,73647 & 0,26353 & 1,00000 & 0,94369 & 0,05631 \\
\hline & P1-388 & 0,95349 & 0,78446 & 0,21554 & 1,00000 & 0,94369 & 0,05631 \\
\hline & P1-468 & 0,93023 & 0,73647 & 0,26353 & 1,00000 & 0,94369 & 0,05631 \\
\hline \multirow{6}{*}{ Ptokin3_4 } & P3-63 & 0,04651 & 0,02676 & 0,97324 & 0,02326 & 0,01594 & 0,98406 \\
\hline & P3-132 & 0,09302 & 0,05079 & 0,94921 & 0,06977 & 0,03963 & 0,96037 \\
\hline & P3-292 & 1,00000 & 0,94934 & 0,05066 & 0,97674 & 0,84378 & 0,15622 \\
\hline & P3-360 & 0,86047 & 0,62765 & 0,37235 & 0,97674 & 0,84378 & 0,15622 \\
\hline & P3-398 & 0,02326 & 0,01496 & 0,98504 & 0,18605 & 0,10160 & 0,89840 \\
\hline & P3-402 & 0,02326 & 0,01496 & 0,98504 & 0,18605 & 0,10160 & 0,89840 \\
\hline
\end{tabular}

Tabla A4-1: Frecuencia del marcador RGA y frecuencias alélicas estimadas para los 43 marcadores polimórficos. $\mathrm{M}_{\mathrm{RGA}}$ : frecuencia del fragmento marcador. $\mathrm{A}+$ : frecuencia estimada del alelo marcador dominante. A-: frecuencia estimada del alelo recesivo nulo. n: número de individuos caracterizados mediante RGA. 



\section{ANÁLISIS DE AGRUPAMIENTO DE INDIVIDUOS (STRUCTURE)}

\begin{tabular}{|c|c|c|c|c|c|c|c|c|c|c|c|}
\hline & \multirow{2}{*}{ SITIO } & \multirow{2}{*}{ INDIVIDUO } & \multicolumn{3}{|c|}{ CLUSTER } & & \multirow{2}{*}{ SITIO } & \multirow{2}{*}{ INDIVIDUO } & \multicolumn{3}{|c|}{ CLUSTER } \\
\hline & & & 1 & 2 & 3 & & & & 1 & 2 & 3 \\
\hline \multirow{43}{*}{ 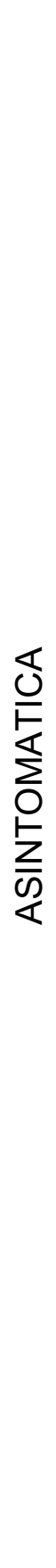 } & \multirow{8}{*}{ L5y6 } & $13 \mathrm{~A}$ & 1,000 & 0,000 & 0,000 & \multirow{34}{*}{\multicolumn{2}{|c|}{ 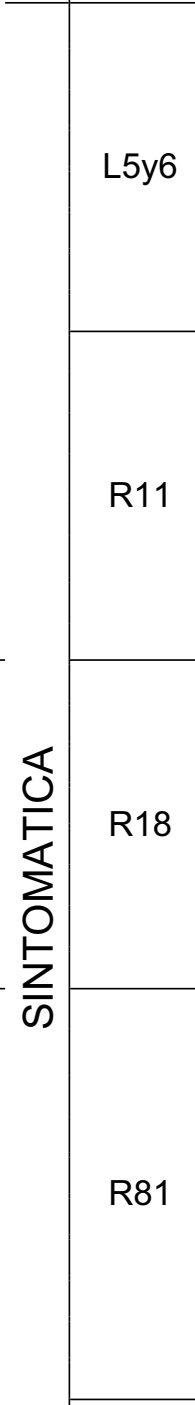 }} & $13 \mathrm{~S}$ & 0,000 & 1,000 & 0,000 \\
\hline & & $14 \mathrm{~A}$ & 0,997 & 0,000 & 0,003 & & & $14 S$ & 0,000 & 0,000 & 1,000 \\
\hline & & $15 \mathrm{~A}$ & 0,999 & 0,000 & 0,001 & & & $15 \mathrm{~S}$ & 0,999 & 0,000 & 0,001 \\
\hline & & $36 \mathrm{~A}$ & 0,895 & 0,000 & 0,105 & & & $36 \mathrm{~S}$ & 0,000 & 0,000 & 1,000 \\
\hline & & $37 \mathrm{~A}$ & 0,000 & 0,000 & 1,000 & & & $37 S$ & 0,000 & 1,000 & 0,000 \\
\hline & & $38 \mathrm{~A}$ & 0,000 & 0,000 & 1,000 & & & $38 \mathrm{~S}$ & 1,000 & 0,000 & 0,000 \\
\hline & & $39 A$ & 0,999 & 0,000 & 0,001 & & & $39 S$ & 0,000 & 0,000 & 1,000 \\
\hline & & $40 \mathrm{~A}$ & 0,999 & 0,000 & 0,001 & & & $40 \mathrm{~S}$ & 0,997 & 0,000 & 0,003 \\
\hline & \multirow{8}{*}{ R11 } & $2 A$ & 0,998 & 0,000 & 0,002 & & & $2 S$ & 0,022 & 0,000 & 0,978 \\
\hline & & $3 A$ & 1,000 & 0,000 & 0,000 & & & $3 S$ & 0,008 & 0,000 & 0,992 \\
\hline & & $4 \mathrm{~A}$ & 0,000 & 1,000 & 0,000 & & & $4 S$ & 0,000 & 1,000 & 0,000 \\
\hline & & $5 A$ & 0,000 & 0,000 & 1,000 & & & $5 S$ & 0,000 & 0,000 & 1,000 \\
\hline & & $26 \mathrm{~A}$ & 0,990 & 0,000 & 0,010 & & & $26 S$ & 0,000 & 0,000 & 1,000 \\
\hline & & $28 \mathrm{~A}$ & 0,999 & 0,000 & 0,001 & & & $28 S$ & 0,001 & 0,000 & 0,999 \\
\hline & & $29 \mathrm{~A}$ & 0,999 & 0,000 & 0,001 & & & $29 \mathrm{~S}$ & 0,997 & 0,000 & 0,003 \\
\hline & & $30 \mathrm{~A}$ & 1,000 & 0,000 & 0,000 & & & $30 \mathrm{~S}$ & 0,000 & 1,000 & 0,000 \\
\hline & \multirow{8}{*}{ R18 } & $16 \mathrm{~A}$ & 1,000 & 0,000 & 0,000 & & & $16 S$ & 0,486 & 0,020 & 0,493 \\
\hline & & $18 \mathrm{~A}$ & 0,015 & 0,000 & 0,985 & & & $18 \mathrm{~S}$ & 0,999 & 0,000 & 0,001 \\
\hline & & $19 A$ & 0,004 & 0,000 & 0,996 & & & $19 \mathrm{~S}$ & 0,000 & 1,000 & 0,000 \\
\hline & & $41 \mathrm{~A}$ & 0,000 & 0,000 & 1,000 & & & $41 \mathrm{~S}$ & 0,003 & 0,000 & 0,997 \\
\hline & & $42 A$ & 0,998 & 0,000 & 0,002 & & & $42 S$ & 0,044 & 0,000 & 0,956 \\
\hline & & $43 \mathrm{~A}$ & 0,999 & 0,000 & 0,001 & & & $43 \mathrm{~S}$ & 0,998 & 0,000 & 0,002 \\
\hline & & $44 A$ & 1,000 & 0,000 & 0,000 & & & $44 \mathrm{~S}$ & 0,987 & 0,006 & 0,006 \\
\hline & & $45 \mathrm{~A}$ & 0,969 & 0,000 & 0,031 & & & $45 \mathrm{~S}$ & 0,000 & 1,000 & 0,000 \\
\hline & \multirow{10}{*}{ R81 } & $21 \mathrm{~A}$ & 0,000 & 0,000 & 1,000 & & & $21 S$ & 0,000 & 0,000 & 1,000 \\
\hline & & $22 \mathrm{~A}$ & 0,999 & 0,000 & 0,001 & & & $22 S$ & 1,000 & 0,000 & 0,000 \\
\hline & & $23 \mathrm{~A}$ & 0,999 & 0,000 & 0,001 & & & $23 \mathrm{~S}$ & 0,999 & 0,000 & 0,001 \\
\hline & & $24 \mathrm{~A}$ & 0,831 & 0,000 & 0,169 & & & $24 \mathrm{~S}$ & 0,999 & 0,000 & 0,001 \\
\hline & & $25 \mathrm{~A}$ & 0,777 & 0,000 & 0,223 & & & $25 S$ & 1,000 & 0,000 & 0,000 \\
\hline & & $46 \mathrm{~A}$ & 0,996 & 0,000 & 0,004 & & & $46 S$ & 0,991 & 0,000 & 0,009 \\
\hline & & 47A & 0,995 & 0,000 & 0,005 & & & $47 \mathrm{~S}$ & 0,994 & 0,000 & 0,006 \\
\hline & & $48 \mathrm{~A}$ & 0,998 & 0,000 & 0,002 & & & $48 S$ & 0,998 & 0,000 & 0,002 \\
\hline & & $49 \mathrm{~A}$ & 1,000 & 0,000 & 0,000 & & & $49 S$ & 1,000 & 0,000 & 0,000 \\
\hline & & $50 \mathrm{~A}$ & 0,997 & 0,000 & 0,003 & & & $50 \mathrm{~S}$ & 0,981 & 0,000 & 0,019 \\
\hline & \multirow{9}{*}{ L9y15 } & $6 \mathrm{~A}$ & 1,000 & 0,000 & 0,000 & & \multirow{9}{*}{ L9y15 } & $6 S$ & 0,003 & 0,000 & 0,997 \\
\hline & & $8 \mathrm{~A}$ & 0,997 & 0,000 & 0,003 & & & $8 S$ & 0,999 & 0,000 & 0,001 \\
\hline & & $9 \mathrm{~A}$ & 0,999 & 0,000 & 0,001 & & & 9S & 0,999 & 0,000 & 0,001 \\
\hline & & $10 \mathrm{~A}$ & 1,000 & 0,000 & 0,000 & & & $10 \mathrm{~S}$ & 0,968 & 0,000 & 0,032 \\
\hline & & $31 \mathrm{~A}$ & 0,961 & 0,000 & 0,039 & & & $31 \mathrm{~S}$ & 0,997 & 0,000 & 0,003 \\
\hline & & $32 \mathrm{~A}$ & 0,999 & 0,000 & 0,001 & & & $32 \mathrm{~S}$ & 1,000 & 0,000 & 0,000 \\
\hline & & $33 A$ & 0,999 & 0,000 & 0,001 & & & 335 & 0,000 & 0,000 & 1,000 \\
\hline & & $34 \mathrm{~A}$ & 0,997 & 0,000 & 0,003 & & & $34 \mathrm{~S}$ & 0,000 & 0,024 & 0,976 \\
\hline & & $35 \mathrm{~A}$ & 0,999 & 0,000 & 0,001 & & & $35 \mathrm{~S}$ & 1,000 & 0,000 & 0,000 \\
\hline
\end{tabular}

Tabla A5-1: Coeficientes de pertenencia a cada uno de los clusters inferidos en Structure de los 86 individuos caracterizados por RGA, clasificados según área de muestreo y estado sanitario. 



\section{ANEXO 6 \\ REFERENCIAS DE LOS PRIMERS EMPLEADOS EN EL SISTEMA RGA}

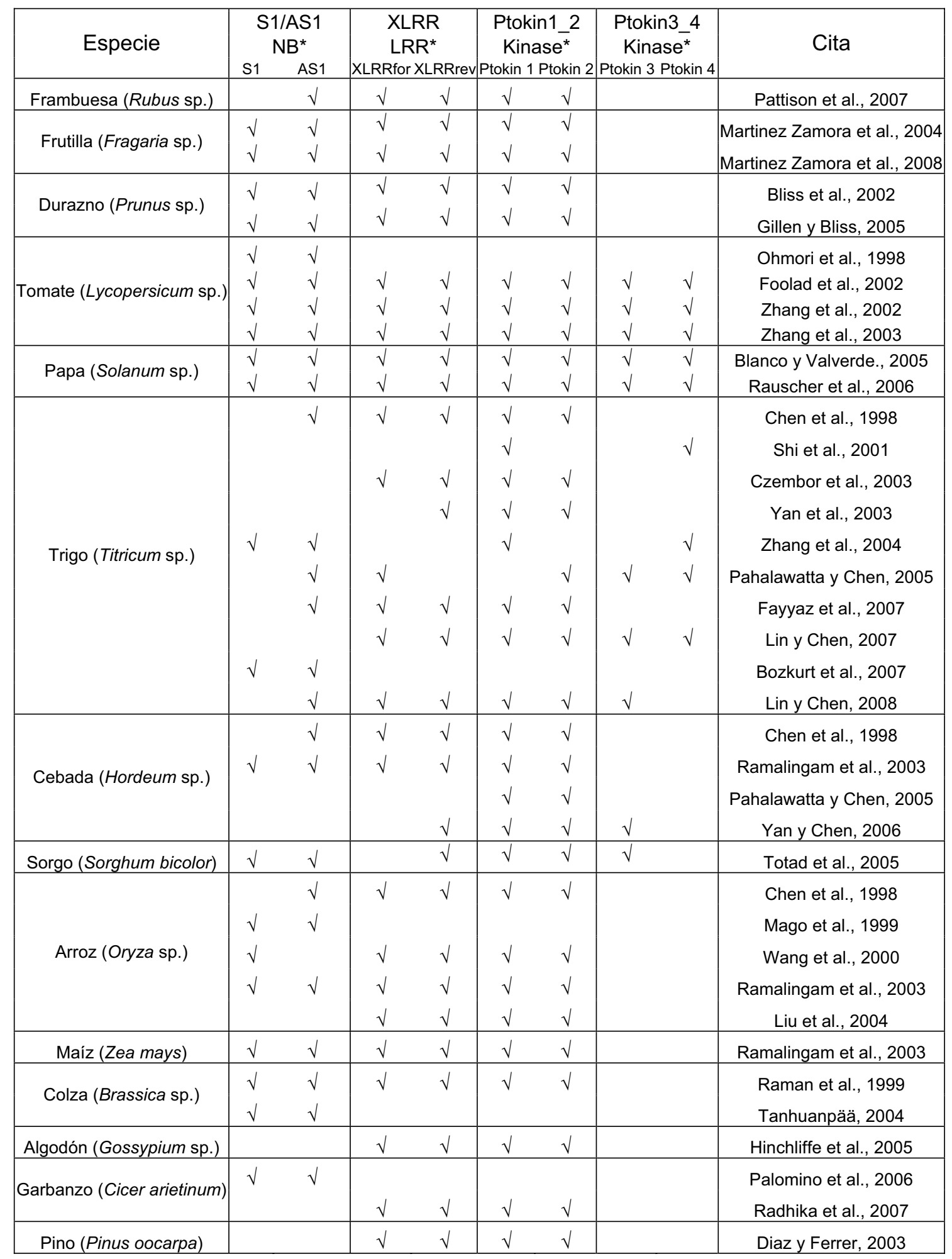

Tabla A6-1: Reporte de la aplicación en otras especies de los primers utilizados en la caracterización genética de A. chilensis mediante RGA. *indica el dominio conservado sobre el cual se realizó el diseño de los primers. 


\section{BIBLIOGRAFÍA}

Blanco M, Valverde R, 2005. Identificación y mapeo de AFLPs ligados al gen de resistencia al PVX en Solanum commersonii. Agronomía Costarricense 29: 57-71.

Bliss FA, Arulsekar S, Foolad MR, Becerra V, Gillen AM, Warburton ML, Dandekar AM, Kocsisne GM, Mydin KK, 2002. An expanded genetic linkage map of Prunus based on an interspecific cross between almond and peach. Genome 45: 520-529.

Bozkurt O, Hakki EE, Akkaya M S, 2007. Isolation and sequence analysis of wheat NBS-LRR type disease resistance gene analogs using degenerate PCR primers. Biochemical Genetics 45: 469-486.

Chen XM, Line RF, Leung H, 1998. Genome scanning for resistance-gene analogs in rice, barley, and wheat by high-resolution electrophoresis. Theoretical and Applied Genetics 97: 345-355.

Czembor PC, Arseniuk E, Czaplicki A, Song Q, Cregan PB, Ueng PP, 2003. QTL mapping of partial resistance in winter wheat to Stagonospora nodorum blotch. Genome 46: 546-554.

Díaz V, Ferrer E, 2003. Genetic variation of populations of Pinus oocarpa revealed by resistance gene analog polymorphism (RGAP). Genome 46: 404-410.

Fayyaz E, AA Shahnejat-Bushehri, Tabatabaei BES, Adel J, 2007. Constructing a Preliminary Wheat Genetic Map Using RGA and AFLP Markers. International Journal of Agriculture \& Biology 9: 863-867.

Foolad MR, Zhang LP, Khan AA, Niño-Liu D, Lin GY, 2002. Identification of QTLs for early blight (Alternaria solani) resistance in tomato using backcross populations of a Lycopersicon esculentum $\times$ L. hirsutum cross. Theoretical and Applied Genetics 104:945958.

Gillen AM, Bliss FA, 2005. Identification and Mapping of Markers Linked to the Mi Gene for Root-knot Nematode Resistance in Peach. Journal of the American Society for Horticultural Science 130: 24-33.

Hinchliffe DJ, Lu Y, Potenza C, Segupta-Gopalan Ch, Cantrell RG, Zhang J, 2005. Resistance gene analogue markers are mapped to homeologous chromosomes in cultivated tetraploid cotton. Theoretical and Applied Genetics 110: 1074-1085.

Lin F, Chen XM, 2007. Genetics and molecular mapping of genes for race-specific all-stage resistance and non-race-specific high-temperature adult-plant resistance to stripe rust in spring wheat cultivar Alpowa. Theoretical and Applied Genetics 114:1277-1287.

Lin F, Chen XM, 2008. Molecular mapping of genes for race-specific overall resistance to stripe rust in wheat cultivar Express. Theoretical and Applied Genetics 116:797-806. 
Liu B, Zhang S, Zhu X, Yang Q, Wu S, Mei M, Mauleon R, Leach J, Mew T, Leung H. Candidate Defense Genes as Predictors of Quantitative Blast Resistance in Rice. Molecular Plant Microbe Interactions 17: 1146-1152.

Mago R, Nair S, Mohan M, 1999. Resistance gene analogues from rice: cloning, sequencing and mapping. Theoretical and Applied Genetics 99: 50-57.

Martínez Zamora MG, Castagnaro AP, Díaz Ricci JC, 2004. Isolation and diversity analysis of resistance gene analogues (RGAs) from cultivated and wild strawberries. Molecular Genetics and Genomics 272: 480-487.

Martínez Zamora MG, AP Castagnaro, Díaz Ricci JC, 2008. Genetic Diversity of Pto-Like Serine/Threonine Kinase Disease Resistance Genes in Cultivated and Wild Strawberries. Journal of Molecular Evolution 67: 211-221.

Ohmori T, Murata M, Motoyoshi F, 1998. Characterization of disease resistance gene-like sequences in near-isogenic lines of tomato. Theoretical and Applied Genetics $96: 331$ 338.

Pahalawatta V, Chen X, 2005. Genetic Analysis and Molecular Mapping of Wheat Genes Conferring Resistance to the Wheat Stripe Rust and Barley Stripe Rust Pathogens. Phytophology 95: 427-432.

Palomino C, Satovic Z, Cubero JI, Torres AM, 2006. Identification and characterization of NBS-LRR class resistance gene analogs in faba bean (Vicia faba L.) and chickpea (Cicer arietinum L.). Genome 49: 1227-1237.

Pattison JA, Samuelian SK, Weber CA, 2007. Inheritance of Phytophthora root rot resistance in red raspberry determined by generation means and molecular linkage analysis. Theoretical and Applied Genetics 115: 225-236.

Radhika P, Gowda SJM, Kadoo NY, Mhase LB, Jamadagni BM, Sainani MN, Chandra S, Gupta VS, 2007. Development of an integrated intraspecific map of chickpea (Cicer arietinum L.) using two recombinant inbred linepopulations. Theoretical and Applied Genetics 115: 209-216.

Ramalingam J, Vera Cruz CM, Kukreja K, Chittoor JM, Wu JL, Lee SW, Baraoidan M, George ML, Cohen MB, Hulbert SH, Leach JE, Leung H, 2003. Candidate Defense Genes from Rice, Barley and Maize and Their Association with Qualitative and Quantitative Resistance in Rice. Molecular Plant-Microbe Interactions 16: 14-24.

Raman R, Ash G, Wratten N, Raman H, 1999. Comparative Analysis of Resistance Gene Analogs in Brassica napus L.10th International Rapeseed Congress (Canberra, Australia).

Rauscher GM, Smart CD, Simko I, Bonierbale M, Mayton H, Greenland A, Fry WE, 2006. Characterization and mapping of $\mathrm{R}_{\mathrm{Pi} \text {-ber }}$, a novel potato late blight resistance gene from Solanum berthaultii. Theoretical and Applied Genetics 112: 674-687. 
Shi ZX, Chen XM, Line RF, Leung H, Wellings CR. Development of resistance gene analog polymorphism markers for the $\operatorname{Yr} 9$ gene resistance to wheat stripe rust. Genome 44: 509516.

Tanhuanpää P, 2004. Identification and mapping of resistance gene analogs and a white rust resistance locus in Brassica rapa ssp. oleifera. Theoretical and Applied Genetics 108: 1039-1046.

Totad AS, Fakrudin B, Kuruvinashetti MS, 2005. Isolation and characterization of resistance gene analogs (RGAs) from sorghum (Sorghum bicolor L. Moench). Euphytica 143: 179188.

Wang ZH, Borromeo ES, Teng P, Leung H, Zhu YY, 2000. Differentiation of rice varieties cultivated in Yunnan, China, using PCR markers corresponding to conserved motifs of disease resistance genes. International Rice Research Newsletter 25: 11-12.

Yan GP, Chen XM, Line RF, Wellings CR, 2003. Resistance gene-analog polymorphism markers co-segregating with the YR5 gene for resistance to wheat stripe rust. Theoretical and Applied Genetics 106: 636-643.

Yan GP, Chen XM, 2006. Molecular mapping of a recessive gene for resistance to stripe rust in barley. Theoretical and Applied Genetics 113: 529-537.

Zhang LP, Khan A, Niño-Liu D, Foolad MR, 2002. A molecular linkage map of tomato displaying chromosomal locations of resistance gene analogs based on a Lycopersicon esculentum $\times$ Lycopersicon hirsutum cross. Genome 45: 133-146.

Zhang LP, Lin GY, Niño-Liu D, Foolad MR, 2003. Mapping QTLs conferring early blight (Alternaria solani) resistance in a Lycopersicon esculentum $\times$ L. hirsutum cross by selective genotyping. Molecular Breeding 12: 3-19.

Zhang Z, Xu J, Xu Q, Larkin P, Xin Z, 2004. Development of novel PCR markers linked to the BYDV resistance gene $B d v 2$ useful in wheat for marker-assisted selection. Theoretical and Applied Genetics 109: 433-439. 


\section{ANEXO 7 \\ DESARROLLO DE MÉTODOS MOLECULARES BASADOS EN PCR PARA LA DETECCIÓN E IDENTIFICACIÓN DE ESPECIES DEL GÉNERO PHYTOPHTHORA}

\section{1.- INTRODUCCIÓN}

La denominación mal del ciprés hace referencia a un síndrome complejo que nuclea eventos de mortalidad de etiología desconocida. Los síntomas aéreos descriptos, aunque característicos del mal del ciprés, son inespecíficos y podrían ser producidos por diversos agentes bióticos o abióticos (El Mujtar y Andenmatten, 2007a y b). Y se han reportado manifestaciones contrastantes del proceso como por ejemplo; la asociación con condiciones de sitio de pobre drenaje, pero la presencia en sitios con exceso de drenaje (La Manna, 2004); dos tipos de desarrollo a nivel de individuo, progresivo y rápido (Calí, 1996; Loguercio et al., 1998 y 1999a; Filip y Rosso, 1999; Hennon y Rajchenberg, 2000); y dos formas de distribución, agregada y desagregada (Rosso et al., 1994; La Manna y Rajchenberg, 2004a; La Manna et al., 2008b).

La asociación con sitios de pobre drenaje, el patrón ecológico de distribución, la presencia de decaimiento de raíz, mortalidad de raíces finas y lesiones necróticas fueron las características principales que llevaron a postular que el mal del ciprés era producido por un patógeno de raíz, probablemente una especie del género Phytophthora (Rajchenberg et al., 1997; Filip y Rosso, 1999; Hansen, 2000; Hennon y Rajchenberg, 2000; La Manna y Rajchenberg 2004a). Intensos relevamientos en bosques de $A$. chilensis permitieron el aislamiento de seis especies del género Phytophthora (Greslebin et al., 2005; Greslebin et al., 2007). P. syringae (aislada desde suelo y cursos de agua) y $P$. gonapodyides (aislada desde suelo) fueron las especies detectadas con mayor frecuencia en los bosques de A. chilensis. P. cambivora (aislada desde suelo) y los taxones no descriptos P. taxon Pgchlamydo y P. taxon Raspberry (aislados desde cursos de agua), se detectaron con menor frecuencia. P. austrocedrae fue la única especie aislada desde la zona de avance en lesiones necróticas de floema localizadas en cuello o raíces principales; en tanto que no pudo ser aislada desde suelo o cursos de agua en bosques de $A$. chilensis.

Recientemente $P$. austrocedrae se propuso como el agente causal de la mortalidad (Greslebin y Hansen, 2007a y b). Sin embargo, su participación debe aún ser evaluada, ya que existen áreas con mal del ciprés en las cuales no se detecta la especie (Greslebin et al., 2007) e individuos con lesiones necróticas de $P$. austrocedrae que no responden a los síntomas aéreos definidos para este tipo de mortalidad. Se han reportado árboles sin defoliación con numerosas e importantes lesiones necróticas a nivel de cuello, árboles defoliados con pocas o sin lesiones necróticas y 
árboles totalmente rojos o amarillo intenso que conservan gran parte de su follaje y presentan lesiones necróticas (Greslebin y Hansen, 2007b; Greslebin y Hansen, 2006). Para estos últimos se indica mortalidad rápida (Filip, 1995; Filip y Rosso, 1999; Hennon y Rajchenberg, 2000; Greslebin y Hansen, 2006) en contraposición al desarrollo progresivo característico del mal del ciprés. Por otra parte, si bien los resultados de los ensayos de patogenicidad realizados demuestran el carácter patogénico de la especie, la relación causal requiere aún de evaluaciones detalladas, en tanto que como consecuencia de la inoculación con $P$. austrocedrae se obtiene el desarrollo de lesiones necróticas, pero no se reproducen los síntomas aéreos típicos del mal del ciprés (Greslebin y Hansen, 2007a y b).

Phytophthora austrocedrae es una especie de crecimiento muy lento, sensible a Hymexazol, características que dificultan su aislamiento debido al sobrecrecimiento de hongos de rápido desarrollo. Se pueden detectar tres grupos de lesiones necróticas que afectan floema, activas, inactivas y antiguas (Capitulo I). Hasta el momento, los aislamientos de P. austrocedrae únicamente son exitosos a partir de lesiones frescas y activas; requiriéndose al menos 20 días para obtener crecimiento suficiente para la identificación morfológica, que debe ser realizada por un experto en el género Phytophthora. El empleo de métodos tradicionales no permitió la detección de $P$. austrocedrae en suelo o cursos de agua. En tanto que el aislamiento de las cinco especies restantes del género requirió el empleo de sistemas de captura (cebos frutales) para aumentar la concentración de inóculo de partida, retardando el procesamiento de las muestras y limitando el número de sitios que pueden ser caracterizados.

Los métodos de identificación basados en DNA constituyen una alternativa ventajosa respecto de los métodos tradicionales, ya que la amplificación por PCR puede ser realizada directamente desde DNA extraído de tejidos infectados, sin necesidad de aislamiento previo. Los métodos moleculares simplifican el diagnóstico en casos donde es difícil, o incluso imposible, aislar el patógeno y permiten un análisis rápido y simultáneo de numerosas muestras. Regiones del DNA ribosomal conocidas como ITS (internal transcribed spacer), presentan tasas de evolución neutra que se aproximan a la tasa de especiación (White et al., 1990; Lee y Taylor, 1992), característica que las hace especialmente útiles para la discriminación de especies fúngicas. Los genes del rRNA son de copia múltiple, lo que a su vez incrementa la sensibilidad de detección respecto de genes de copia única. Los métodos moleculares para la identificación de especies diseñados en los últimos años, están basados en la amplificación con primers específicos (Winton y Hansen, 2001; Grote et al., 2002; Hayden et al., 2004; Nechwatal y Mendgen 2006) o en la digestión con enzimas de restricción de regiones ITS amplificadas desde genes de rRNA (Cooke et al., 2000a y b). Sin embargo, aunque el análisis de patrones de digestión derivados de ITS constituyen una 
herramienta útil para la identificación de muchas especies en el género Phytophthora, los métodos actualmente disponibles fallan para resolver en forma adecuada las especies que corresponden al Clado 6 (Brasier et al., 2003), dentro del cual se ubican tres de las especies aisladas desde bosques de A. chilensis (Greslebin et al., 2005). Regiones informativas para la separación de especies estrechamente relacionadas, no resueltas por ITS, se detectaron mediante el análisis de la secuencia del DNA mitocondrial (Martin y Tooley, 2003); desarrollándose ensayos de análisis del polimorfismo de longitud de los fragmentos de restricción (RFLP) basados en los genes citocromo oxidasa I y II (Martin y Tooley, 2004). Sin embargo la existencia de polimorfismos intraespecíficos limitan su aplicación en $P$. syringae, la especie más estrechamente relacionada a P. austrocedrae.

El aislamiento y la identificación de especies de Phytophthora en bosques de A. chilensis (Greslebin et al., 2005; Greslebin et al., 2007) constituyó un avance importante en términos de la detección del primer agente patogénico asociado con el mal del ciprés. Sin embargo, las complicaciones inherentes a dichos aislamientos dificultan relevamientos extensivos tendientes a determinar la dinámica de especies en diferentes áreas y retardan la clarificación de la relación existente entre la especie $P$. austrocedrae y los síntomas descriptos para el mal del ciprés.

El desarrollo de métodos moleculares de identificación, que permitirá avanzar en cada uno de estos aspectos, será abordado en el presente trabajo de acuerdo con los siguientes objetivos específicos:

- OBjetivo 1: Desarrollar un método molecular de detección de P. austrocedrae aplicado a lesiones necróticas de floema presentes en cuello y raíz en individuos de la especie A. chilensis.

- OBjetivo 1: Desarrollar un método molecular de identificación de especies de Phytophthora presentes en bosques de A. chilensis basado en el polimorfismo de longitud de los fragmentos de restricción (RFLP).

\section{2.- MATERIALES Y MÉTODOS}

\section{1.- RECOLECCIÓN DE MUESTRAS Y EXTRACCIÓN DE DNA DESDE LESIONES NECRÓTICAS}

La corteza externa de los árboles seleccionados se eliminó a fin de exponer las lesiones necróticas presentes en floema y detectar el margen entre tejido vivo y afectado. Muestras de 
tejido correspondientes a la zona de avance de la lesión se recolectaron y mantuvieron a $4^{\circ} \mathrm{C}$ hasta su utilización. La recolección se realizó en las áreas de muestreo en El Bolsón a partir de los tres tipos de lesión y en la provincia de Chubut (material cedido por la Dra. Greslebin). Para la extracción del DNA se empleó el método reportado por Bekesiova et al. (1999). Las muestras se molieron en nitrógeno líquido y se incubaron a $65^{\circ} \mathrm{C}$ en buffer de extracción. Luego de un paso de limpieza con cloroformo, el DNA fue precipitado con etanol y acetato de sodio y resuspendido en TE (Tris 10mM pH 8.0, EDTA $1 \mathrm{mM}$ ). El RNA se removió por digestión con RNasa. Para evaluar el impacto de la oxidación del floema y la generación de inhibidores en la amplificación por PCR, muestras recolectadas desde un árbol se conservaron según tres métodos diferentes: (i) mantenidas a $4^{\circ} \mathrm{C}$, (ii) recolectadas en recipientes cerrados conteniendo silicagel, (iii) recolectadas en buffer de conservación (BC: Tris-HCl $100 \mathrm{Mm} \mathrm{pH} \mathrm{8.0,} \mathrm{Na}_{2}$ EDTA $5 \mathrm{Mm}, \mathrm{NaCl} 1.4 \mathrm{M}, \mathrm{CTAB} 2 \%(\mathrm{p} / \mathrm{v})$ PVP-40 2\% (p/v) y $\beta$-mercaptoetanol $0.2 \%(\mathrm{v} / \mathrm{v}))$ y mantenidas a $4^{\circ} \mathrm{C}$.

\section{2.- EXTRACCIÓN DE DNA DESDE CULTIVOS DE PHYTOPHTHORA SP}

El micelio se separó de la superficie del agar y el DNA se extrajo de acuerdo con el método reportado por Winton y Hansen (2001). Las muestras se molieron en nitrógeno líquido y se incubaron a $65^{\circ} \mathrm{C}$ en buffer de extracción conteniendo CTAB. Luego de un paso previo de limpieza con cloroformo, el DNA se precipitó con isopropanol, se resuspendió en TE y se cuantificó con Qubit Fluorometer y Quant-iT dsDNA BR Assay Kit (Molecular Probes, Invitrogen detection technologies, USA). Los aislamientos de Phytophothora empleados en el presente trabajo, fueron gentilmente cedidos por la Dra. Greslebin (condiciones de cultivo, Greslebin et al. 2005 y 2007) y se encuentran depositados en la colección de Cultivos del Centro de Investigación y Extensión Forestal Andino Patagónico Forestal (CIEFAP) en la ciudad de Esquel: P. austrocedrae (AG243, AG203, AG209, AG210, AG225, AG235, AG240, AG245), P. gonapodyides (AG8, AG15, AG28, AG33, AG35, AG42, AG56, AG58, AG160), P. syringae (AG6, AG5, AG41, AG60, AG66, AG67, AG100, AG186, AG187), P. taxon Pgchlamydo (AG29, AG27, AG30, AG32, AG34, AG46, AG47, AG48, AG49, AG52), P. taxon Raspberry (AG43), P. cambivora (AG44), aislamiento incógnita (AG50, AG51, AG163, AG170) y aislamiento no identificado (AG246).

\section{3.- DISEÑO DE PRIMERS}

Las secuencias completas de las regiones ITS1, 5.8S e ITS2 del rDNA para cepas representativas de cada una de las morfoespecies reportadas por Greslebin et al. (2005) se alinearon 
con las cepas representativas de P. austrocedrae (DQ995184, DQ995185) empleando ClustalX (Thompson et al., 1997). Bioedit (Hall, 1999), se aplicó para la detección de regiones específicas de P. austrocedrae.

\section{4.- AMPLIFICACIÓN DEL DNA EXTRAído DESDE LESIONES NECRÓTICAS DE FLOEMA Y SECUENCIACIÓN DE LOS FRAGMENTOS AMPLIFICADOS}

El DNA extraído desde lesiones necróticas de floema se utilizó como molde para la amplificación mediada por PCR empleando dos combinaciones de primers diferentes. Las reacciones de PCR se realizaron en $25 \mu \mathrm{L}$ o $10 \mu \mathrm{L}$ en buffer $1 \mathrm{X}$, conteniendo una concentración final de $0.5 \mu \mathrm{M}$ de los primers directo y reverso, $200 \mu \mathrm{M}$ dNTPs, $0.05 \%$ (p/v) de hidrolizado ácido de caseína y $0.02 \mathrm{U} / \mu \mathrm{L}$ de Taq DNA polimerasa (Invitrogen Life Technologies, USA). El ciclador térmico GeneAmp PCR System 9700 (Applied Biosystems) se utilizó en las amplificaciones por PCR. Los parámetros de ciclado y la concentración final de $\mathrm{MgCl}_{2}$, se ajustaron de acuerdo con la correspondiente combinación de primers. DC6 (Cooke et al., 2000a) e ITS4 (White et al., 1990) se usaron con $1.5 \mathrm{mM} \mathrm{MgCl}_{2}$ y un ciclado de, un ciclo de desnaturalización inicial a $96^{\circ} \mathrm{C}$ por 3 min., seguido por 35 ciclos de desnaturalización a $94^{\circ} \mathrm{C}$ por 1 min, annealing de primers a $55^{\circ} \mathrm{C}$ por 1 min y extensión a $72^{\circ} \mathrm{C}$ por $1 \mathrm{~min}$, con un ciclo de extensión final a $72^{\circ} \mathrm{C}$ durante 7 min. La combinación For1-aust y Rev1-aust se usó con $1.4 \mathrm{mM} \mathrm{MgCl}_{2}$ y un ciclado de, un ciclo de desnaturalización inicial a $96^{\circ} \mathrm{C}$ por 2 min, seguido por 35 ciclos de desnaturalización a $94^{\circ} \mathrm{C}$ por $30 \mathrm{~s}$, annealing de primers a $60^{\circ} \mathrm{C}$ por $20 \mathrm{~s}$ y extensión a $72^{\circ} \mathrm{C}$ por $30 \mathrm{~s}$, con un ciclo de extensión final a $72^{\circ} \mathrm{C}$ durante $7 \mathrm{~min}$. Todas las amplificaciones se separaron por electroforesis en geles de agarosa 2.0\% (TAE 1X). Los amplicones generados con el par de primers For1-aust y Rev1-aust se purificaron con GENECLEAN Kit (QbioGene, MP Biomedicals, USA) y se clonaron en el vector pCR 2.1-TOPO (Invitrogen Life Technologies, USA). Los clones positivos fueron secuenciados con el primer universal T7-promotor en MACROGEN (USA). Las secuencias obtenidas se compararon con las disponibles en GenBank aplicando la herramienta de búsqueda BLASTN (Altschul et al., 1997).

\section{5.- ANÁLISIS IN SILICO}

Las secuencias de las regiones ITS1, 5.8S e ITS2 del rDNA, disponibles en bases de datos públicas, para cada una de las morfoespecies en estudio fueron alineadas usando ClustalX (Thompson et al., 1997), editadas con Bioedit (Hall, 1999) y analizadas en Clone Manager (Version 4.01) a fin de detectar y confirmar la presencia de los sitios de restricción específicos en las diferentes cepas de cada morfoespecie. 


\section{6.- ENSAYOS RFLP}

Los amplicones obtenidos con la combinación de primers DC6/ITS4 se usaron como molde en una PCR anidada con la combinación de primers ITS5 (White et al., 1990) e ITS4. Las reacciones de PCR se realizaron en $25 \mu \mathrm{L}$ en buffer $1 \mathrm{X}$, conteniendo una concentración final de $0.5 \mu \mathrm{M}$ de los primers directo y reverso, $200 \mu \mathrm{M}$ dNTPs, $1.5 \mathrm{mM} \mathrm{MgCl}_{2}$ y $0.02 \mathrm{U} / \mu \mathrm{L}$ de Taq DNA polimerasa (Invitrogen Life Technologies); empleando el termociclador GeneAmp PCR System 9700 (Applied Biosystems). Los parámetros de ciclado usados comprendieron, un ciclo de desnaturalización inicial de $96^{\circ} \mathrm{C}$ por $2 \mathrm{~min}$, seguido de 35 ciclos de desnaturalización a $96^{\circ} \mathrm{C}$ por $20 \mathrm{~s}$, annealing de primers a $55^{\circ} \mathrm{C}$ por $20 \mathrm{~s}$, y extensión a $72^{\circ} \mathrm{C}$ por $1 \mathrm{~min}$, con un ciclo de extensión final a $72^{\circ} \mathrm{C}$ por $7 \mathrm{~min}$. Todas las amplificaciones se separaron por electroforesis, en geles de agarosa $2.0 \%$, para evaluar rendimiento y calidad. Los fragmentos amplificados se digirieron con tres combinaciones de enzimas de restricción: A) BsiEI, PpuMI, SpeI; B) PpuMI, SpeI, FspI; C) BsiEI, PpuMI. Las digestiones se realizaron en $15 \mu \mathrm{L}$ a $37^{\circ} \mathrm{C}$ y se separaron por electroforesis en gel de agarosa 2\%. El tamaño de los fragmentos de restricción de todas las especies se estimó directamente desde el gel empleando LabWorks V.4.6 (UVP BioImaging Systems, UK).

\section{3.- RESULTADOS}

\section{1.- DesarRollo de UN MÉTOdo MOlecular de Detección de P. AUSTRocedRaE A PARTIR DE LESIONES NECRÓTICAS DE FLOEMA PRESENTES EN CUELLO Y RAÍZ EN INDIVIDUOS DE $\boldsymbol{A}$. CHILENSIS}

Las secuencias completas de las regiones ITS1, 5.8S e ITS2 del rDNA de cepas representativas de cada una de las morfoespecies reportadas por Greslebin et al. (2005) se alinearon con las cepas representativas de P. austrocedrae (DQ995184, DQ995185) a fin de detectar regiones específicas que permitan el desarrollo de primers específicos. El alto nivel de identidad nucleotídica entre $P$. austrocedrae y $P$. syringae restringió las posibilidades de diseño. Los primers directo For1-aust (5'-TGGAGGCGTGCTTGTACTG-3') y reverso Rev1-aust (5'-ACTTCGCACCACATCGTCG-3') generados amplifican un fragmento de 197 pb de la región ITS2 específico de $P$. austrocedrae.

Extracciones de DNA provenientes de lesiones necróticas de floema fueron amplificadas con éxito empleando la combinación de primers For1-aust/Rev1-aust, tanto para lesiones activas (Líneas 7-8 en Figura A7-1) como inactivas (Líneas 9-13 en Figura A7-1). Los fragmentos amplificados 
tienen el tamaño esperado (197 pb) y se corresponden con el obtenido para la especie P. austrocedrae (Líneas 2-6 en Figura A7-1).

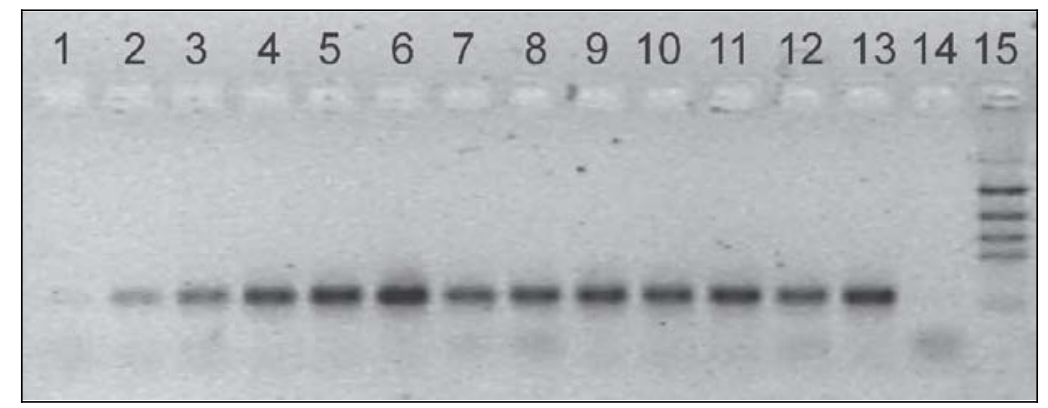

Figura A7-1: Detección de P. austrocedrae mediante amplificación por PCR con primers específicos. Electroforesis en gel de agarosa 2\% (TAE 1X) de la amplificación con los primers For1-aust/Rev1-aust de DNA extraído de: Línea 1: lesiones provenientes del árbol 32S; Líneas 2-6: lesiones provenientes del árbol 32S + micelio del aislamiento AG243 de P. austrocedrae, 0.06, 0.6, 6, 60 y 600 pg, respectivamente; Líneas 7-8: lesiones activas provenientes de los árboles 50A y Las Rocas; Línea 9-13: lesiones inactivas provenientes de los árboles, Ap5L1, Ap7L1, Ap9, R6(1)L1 and R6(4)L1, respectivamente; Línea 14: control negativo (H20); Línea 15: marcador de peso molecular: pcDNA II digerido con las enzimas de restricción DdeI y XhoI (1140, 758, 540, 409 y 166 pb).

Diluciones seriadas $(1 / 10)$ de DNA cuantificado extraído de micelio de P. austrocedrae (aislamiento AG243) fueron suplementadas con DNA extraído a partir de lesiones necróticas y empleadas para determinar la sensibilidad de la combinación de primers For1-aust/Rev1-aust (Líneas 2-6 en Figura A7-1). La suplementación de DNA proveniente de micelio, con DNA extraído desde material vegetal, se realizó a fin de evaluar la sensibilidad del ensayo de PCR en la misma matriz en la que va a ser aplicada a futuro (muestras provenientes de lesiones necróticas). La extracción de DNA obtenida a partir de lesiones necróticas del árbol 32S se eligió para la suplementación porque la amplificación de $P$. austrocedrae en esa muestra fue prácticamente indetectable (Línea 1 en Figura A7-1). Por tanto, en esas condiciones, la suplementación aporta la matriz de planta sin modificar de manera importante la concentración de DNA blanco. La amplificación fue positiva aún en muestras conteniendo 0.06 pg de DNA proveniente de micelio (Línea 2 en Figura A7-1). Esta cantidad de DNA corresponde, aproximadamente, a una copia genómica si el promedio entre el genoma de $P$. infestans $(250 \mathrm{Mb})$ y $P$. sojae $(62 \mathrm{Mb})$ se utiliza en el cálculo. Las mismas diluciones seriadas (1/10), en idénticas condiciones de suplementación, se amplificaron con la combinación de primers genéricos DC6/ITS4 (Líneas 2-6 en Figura A7-2). Una débil banda puede ser observada con 0.6 pg de DNA (Línea 3 en Figura A7-2), de manera tal que la combinación de los primers diseñados en este trabajo (For1-aust/Rev1aust) resultó ser al menos un orden de magnitud más sensible que la combinación genérica DC6/ITS4. 


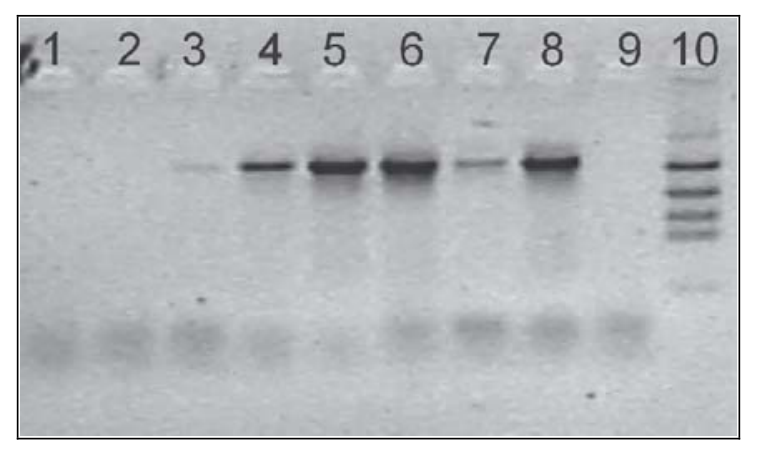

Figura A7-2: Detección de P. austrocedrae mediante amplificación por PCR con primers genéricos. Electroforesis en agarosa 2\% (TAE 1X) de las amplificaciones con los primers DC6/ITS4 de DNA extraído desde: Línea 1: lesiones provenientes del árbol 32S; Líneas 2-6: lesiones provenientes del árbol 32S + micelio del aislamiento AG243 de P. austrocedrae, 0.06, 0.6, 6, 60 y 600 pg, respectivamente; Líneas 7-8: lesiones provenientes del árbol 50A y Las Rocas; Línea 9: control negativo $\left(\mathrm{H}_{2} 0\right)$; Línea 10: marcador de peso molecular: pcDNA II digerido con las enzimas de restricción DdeI y XhoI (1140, 758, 540, 409 y 166 pb).

Amplificaciones de DNA obtenidas desde lesiones provenientes del árbol 50A conservadas según tres métodos diferentes se compararon para determinar el impacto de la oxidación de tejidos y la generación de compuestos interferentes en la detección por PCR: muestras mantenidas a $4^{\circ} \mathrm{C}$ hasta extracción de DNA (Líneas 3-5, Figura A7-3A), muestras recolectadas en un recipiente cerrado conteniendo silicagel (Líneas 6-8, Figura A7-3A) y muestras recolectadas en BC y mantenidas a $4^{\circ} \mathrm{C}$ hasta extracción del DNA (Líneas 9-11, Figura A7-3A). Tres diluciones seriadas se emplearon para evaluar la influencia de inhibidores de PCR (Figura A7-3A). Comparativamente la recolección de muestras en $\mathrm{BC}$ dio los mejores resultados, ya que se obtienen extracciones de DNA con menor contenido de inhibidores (amplificaciones positivas a menores diluciones) y mayor rendimiento (Figura A7-3B). Las muestras mantenidas a $4^{\circ} \mathrm{C}$, presentan menores rendimientos en la extracción de DNA o bien las extracciones obtenidas presentan coloración marrón que indica oxidación de componentes provenientes de la planta y presencia de inhibidores de PCR.

Los amplicones generados con los primers For1-aust/Rev1-aust para DNA obtenido desde lesiones de dos árboles (50A y Las Rocas) se purificaron, clonaron y secuenciaron a fin de determinar la identidad de los clones positivos y confirmar la especificidad del ensayo. Las secuencias obtenidas se compararon con las disponibles en GenBank aplicando BLASTN. Todos los clones fueron idénticos a las secuencias reportadas para $P$. austrocedrae, detectándose únicamente un cambio nucleotídico (T/C) en uno de los clones provenientes de la 
muestra Las Rocas. Las secuencias se depositaron en GenBank bajo los siguientes números de acceso: EU582022, EU582023, EU582024, EU582025, EU582026, EU582027.

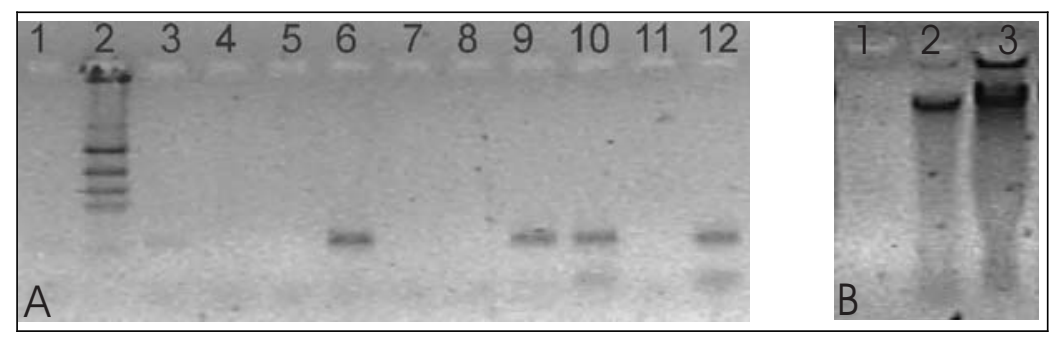

Figura A7-3: Impacto de la conservación de muestras en la detección de $P$. austrocedrae por PCR. A- Electroforesis en gel de agarosa 2\% (TAE 1X) de amplificaciones con los primers For1-aust/Rev1-aust de DNA extraído desde lesiones del árbol 50A conservadas según tres métodos diferentes y en tres diluciones seriadas 1/1000, 1/100 y 1/10, respectivamente. Líneas 3-5: conservación a $4^{\circ}$ C. Líneas 6-8: conservación in silicagel. Líneas 9-11: conservación en BC. Línea 12: control positivo micelio P. austrocedrae. Línea 1: control negativo (H20). Línea 2: marcador de peso molecular: pcDNA II digerido con las enzimas de restricción DdeI y XhoI (1140, 758, 540, 409 y $166 \mathrm{pb})$. B- DNA extraído desde lesiones del árbol 50A conservadas según tres métodos diferentes. Línea 1: conservación a $4^{\circ}$ C. Línea 2: conservación en silicagel. Línea 3: conservación en BC.

\section{2.- DesarRollo de UN MÉTOdo MOLECULAR DE IDENTIFICACión DE ESPECIES DE PHYTOPHTHORA PRESENTES EN BOSQUES DE A. CHILENSIS BASADO EN EL POLIMORFISMO DE LONGITUD DE LOS FRAGMENTOS DE RESTRICCIÓN (RFLP)}

\subsection{1-Análisis in silico}

Cuatro enzimas de restricción se seleccionaron para el desarrollo de ensayos de RFLP, a partir del análisis in silico realizado sobre el alineamiento de todas las secuencias disponibles de las regiones ITS1, 5.8S e ITS2 del rDNA para cada morfoespecie en estudio ( $P$. austrocedrae, P. syringae, $P$. gonapodyides, P. taxon Pgchlamydo y P. cambivora). El tamaño esperado de los fragmentos de restricción, generados con tres combinaciones de enzimas se estimaron incluyendo los primers en el cálculo de la extensión total.

De acuerdo con las predicciones in silico, los perfiles generados con la combinación A (BsiEI, PpuMI y SpeI) serían adecuados para la identificación de las cinco especies. Sólo $P$. austrocedrae y $P$. gonapodyides tendrían perfiles con dos bandas y por tanto serían fácilmente diferenciadas de las restantes especies. El tamaño de los fragmentos generados para $P$. austrocedrae y $P$. gonapodyides y la distancia relativa entre fragmentos dentro de cada perfil sería suficiente para diferenciar ambas especies. El fragmento más grande y el más pequeño para $P$. gonapodyides deberían ser más grande y más pequeño, respectivamente, que los 
correspondientes a $P$. austrocedrae; siendo por tanto diferentes los perfiles esperados para ambas especies. Perfiles de tres bandas se esperan para P. syringae, P. cambivora y P. taxon Pgchlamydo. Una diferencia de $42 \mathrm{pb}$ entre los fragmentos de menor tamaño en los perfiles y la distancia relativa entre fragmentos dentro de cada perfil sería suficiente para separar $P$. syringae y P. taxon Pgchlamydo. Una diferenciación similar se espera para $P$. syringae y $P$. cambivora, con una separación de $25 \mathrm{pb}$ entre las bandas más pequeñas de cada perfil. El tamaño de los fragmentos generados para P. taxon Pgchlamydo y P. cambivora y la distancia relativa entre fragmentos dentro de cada perfil serían suficientes para diferenciar ambas especies. Los fragmentos más grande y más pequeño esperados para $P$. cambivora deberían ser más grande y más pequeño, respectivamente, que los correspondientes a P. taxon Pgchlamydo; siendo por tanto posible su separación.

Los perfiles esperados para la combinación B (FspI, PpuMI y SpeI) serían adecuados para identificar tres de las cinco especies bajo estudio P. austrocedrae, P. taxon Pgchlamydo and $P$. cambivora; y se espera que esta combinación sea la más adecuada para la separación de $P$. austrocedrae de las restantes especies. El análisis predice un perfil de banda única para $P$. austrocedrae, debido a que la digestión produciría dos fragmentos de tamaños similares (alrededor de $460 \mathrm{pb}$ ) que no serían resueltos mediante electroforesis en gel de agarosa $2 \%$. Las secuencias disponibles para $P$. syringae y $P$. gonapodyides no muestran sitios de restricción para las enzimas de esta combinación, por lo que se espera un perfil de banda única para ambas especies, de un tamaño de aproximadamente el doble que el predicho para $P$. austrocedrae. Perfiles de dos bandas se esperan para P. cambivora y P. taxon Pgchlamydo, diferenciándose entre ellas por la distancia relativa de las bandas dentro de cada perfil.

Los perfiles esperados para la combinación C (BsiEI y PpuMI) serían útiles para identificar tres de las cinco especies en estudio P. syringae, P. cambivora y P. austrocedrae. Los perfiles predichos para $P$. syringae y $P$. cambivora tendrían tres bandas y deberían ser fácilmente diferenciadas de las restantes especies. P. syringae y P. cambivora podrían separarse por la distancia relativa de las bandas esperadas en los correspondientes perfiles de digestión. $P$. austrocedrae se separaría adecuadamente del resto de las especies con perfiles de dos bandas por la distancia relativa entre bandas dentro de cada perfil.

Por tanto, el análisis in silico predice un robusta identificación de las especies de Phtytophthora en estudio mediante la aplicación de los ensayos RFLP propuestos, en base a la selección de cuatro enzimas de restricción y según tres combinaciones diferentes. La combinación A debería dar una identificación completa de las cinco especies en estudio. La combinación B sería óptima para la identificación de $P$. austrocedrae y útil para validar la separación entre $P$. taxon Pgchlamydo y $P$. cambivora. La combinación C daría la mejor separación entre P. taxon Pgchlamydo y $P$. cambivora. 


\subsection{2- Ensayos RFLP}

Extracciones de DNA provenientes de micelio para un aislamiento de $P$. austrocedrae, P. syringae, P. gonapodyides P. cambivora y P. taxon Pgchlamydo, se emplearon como molde en amplificaciones por PCR. Los amplicones obtenidos, únicos y del tamaño esperado, fueron digeridos con las tres combinaciones de enzimas seleccionadas. El tamaño de los amplicones generados es mayor que el esperado en función de las secuencias disponibles en las bases de datos. Estas diferencias corresponden a la falta de secuencia entre el sitio de pegado de primers y los extremos 5' (34 pb) y 3' (41 pb) en las secuencias reportadas en GenBank. En la Tabla A7-1, se presentan los resultados obtenidos para la combinación A.

\begin{tabular}{|c|c|c|c|}
\hline Aislamiento $^{\mathrm{a}}$ & $\begin{array}{c}\mathrm{TE}^{\mathrm{b}} \\
\text { (tamaño esperado en } \mathrm{pb})\end{array}$ & $\begin{array}{c}\mathrm{TO}^{\mathrm{c}} \\
\text { (tamaño obtenido en pb) }\end{array}$ & $\begin{array}{c}(\mathrm{TO}-\mathrm{TE})^{\mathrm{d}} \\
(\text { en pb) }\end{array}$ \\
\hline \multirow{3}{*}{$\begin{array}{l}\text { P. syringae } \\
\text { (AG6) }\end{array}$} & $443^{\mathrm{f}}$ & $447^{\mathrm{f}}$ & --- \\
\hline & 284 & 327 & 43 \\
\hline & 128 & 159 & 31 \\
\hline \multirow{2}{*}{$\begin{array}{c}\text { P. gonapodyides } \\
\text { (AG8) }\end{array}$} & 593 & 628 & 35 \\
\hline & 268 & 309 & 41 \\
\hline \multirow{4}{*}{$\begin{array}{c}\text { P. taxon Pgchlamydo } \\
\text { (AG29) }\end{array}$} & --- & $628^{\mathrm{e}}$ & --- \\
\hline & $424^{\mathrm{f}}$ & $426^{\mathrm{f}}$ & --- \\
\hline & 267 & 309 & 42 \\
\hline & 170 & 204 & 34 \\
\hline \multirow{2}{*}{$\begin{array}{l}\text { P. taxon Raspberry } \\
\text { (AG43) }\end{array}$} & 592 & 628 & 36 \\
\hline & 269 & 309 & 40 \\
\hline \multirow{2}{*}{$\begin{array}{l}\text { P. cambivora } \\
\text { (AG44) }\end{array}$} & $443^{f}$ & $447^{f}$ & --- \\
\hline & 277 & 318 & 41 \\
\hline \multirow{2}{*}{$\begin{array}{l}\text { P. austrocedrae } \\
\text { (AG243) }\end{array}$} & $\frac{153}{150}$ & 188 & 35 \\
\hline & $601^{1}$ & $609^{1}$ & -- \\
\hline \multirow{3}{*}{ AG246 } & & $426^{f}$ & \\
\hline & & 313 & \\
\hline & & 207 & \\
\hline
\end{tabular}

Tabla A7-1: Tamaños estimados y obtenidos para los fragmentos derivados del ensayo PCR-RFLP. ${ }^{\mathrm{a}}$ Todas las secuencias empleadas en las estimaciones han sido reportadas en Greslebin et al. (2005); ${ }^{\mathrm{b}}$ Tamaño de fragmento esperado según análisis in silico; ${ }^{\mathrm{c}}$ Tamaño de fragmento obtenido según estimación con LabWorks V.4.6 (UVP BioImaging Systems, UK); ${ }^{\mathrm{d}}$ Diferencia entre el tamaño esperado y el obtenido; ${ }^{\mathrm{e}}$ Banda no esperada para P. taxon Pgchlamydo; ${ }^{\mathrm{f}}$ Fragmentos internos generados por digestión, la estimación de tamaño no presenta ambigüedades.

Los perfiles obtenidos para $P$. austrocedrae, $P$. syringae, $P$. gonapodyides y $P$. cambivora coinciden, para las tres combinaciones de enzimas de restricción, con lo predicho en el análisis in silico y proporcionan una buena identificación de las especies (Figuras A7-4, 5 y 6). En el caso de P. taxon Pgchlamydo, los perfiles obtenidos presentan una banda no esperada con las combinaciones A y B (banda de mayor tamaño en la Línea 3 de la Figura A7-4 y Línea 5 de la 
Figura A7-5) y el perfil esperado para la combinación C. Los genes del RNA ribosomal (rDNA) comprenden una familia multigénica en la cual las copias se organizan en repeticiones en tandem. Polimorfismos presentes en copias génicas diferentes podría explicar la banda adicional en P. taxon Pgchlamydo, que resulta de la pérdida de un sitio de restricción SpeI. Esta banda suplementaria refuerza, sin embargo, la separación de P. taxon Pgchlamydo de las restantes especies. Los resultados obtenidos mediante RFLP con las tres combinaciones de enzimas, confirman las predicciones del análisis in silico, mostrando que los ensayos RFLP desarrollados son útiles para separar exitosamente a $P$. austrocedrae del resto de las especies más comúnmente aisladas en bosques de A. chilensis. P. syringae, la especie detectada con mayor frecuencia en bosques de A. chilensis y la más directamente relacionada a $P$. austrocedrae, puede ser fácilmente separada de esta última. Los ensayos RFLP proporcionan, además, buena diferenciación para P. syringae, P. gonapodyides, P. cambivora y P. taxon Pgchlamydo.

Los taxones AG246 (una especie caracterizada pero aún no identificada) y P. taxon Raspberry corresponden a especies raramente aisladas desde bosques de $A$. chilensis. Un aislamiento de cada una de ellas fue incluido en los ensayos RFLP a fin de evaluar si podrían ser separados de las restantes especies en estudio. Los tamaños de los fragmentos de restricción para estos aislamientos se presentan en la Tabla A7-1.

Los perfiles obtenidos para P. taxon Raspberrry fueron, en todas las combinaciones evaluadas, similares a los de $P$. gonapodyides (Lineas 2 y 4 en Figura A7-4, Líneas 4 y 6 en Figura A7-5 y Líneas 2 y 4 en Figura A7-6). Sin embargo, aunque P. taxon Raspberry no puede ser separada de $P$. gonapodyides, es fácilmente diferenciada del resto de las especies aisladas en bosques de A. chilensis de acuerdo con lo predicho y confirmado para $P$. gonapodyides.

Para AG246 los perfiles obtenidos, con todas las combinaciones de enzimas, fueron similares a los correspondientes perfiles de P. taxon Pgchlamydo; pero se diferenciaron por la banda adicional (no predicha por análisis in silico) detectada en P. taxon Pgchlamydo con las combinaciones A y B (Líneas 3 y 7 en la Figura A7-4, Líneas 5 y 9 en la Figura A7-5, y Líneas 3 y 7 en la Figura A7-6). 

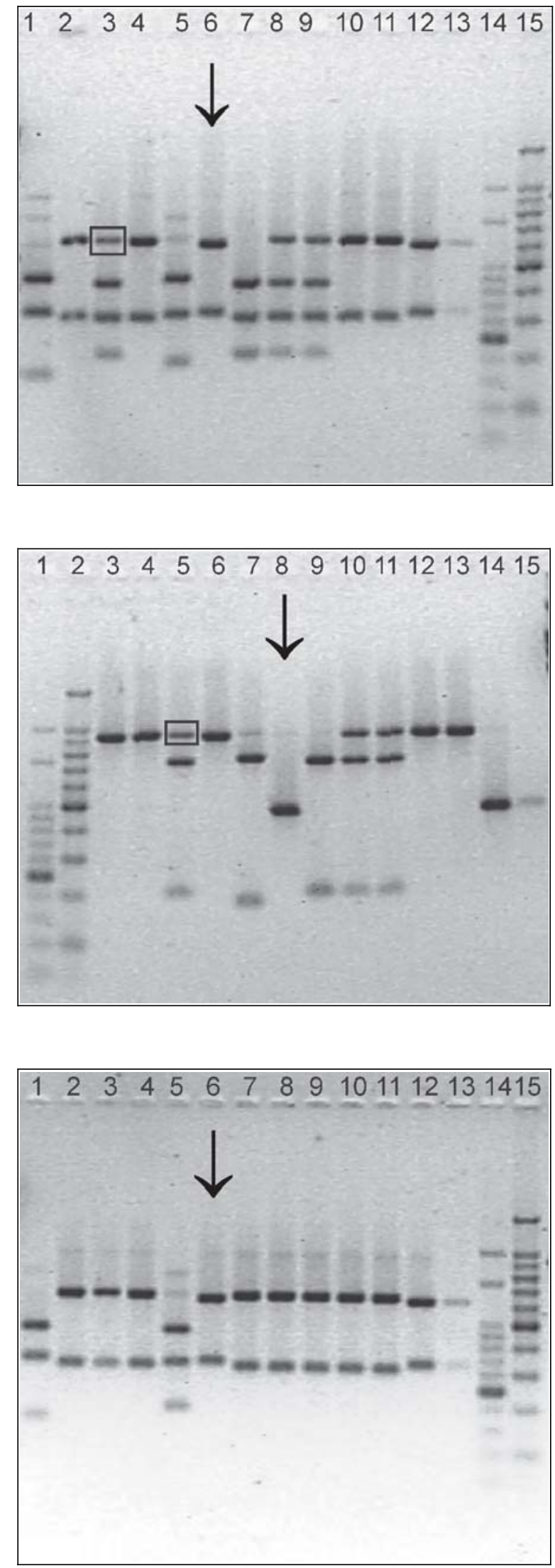

Figura A7-4: PCR-RFLP Combinación A. Electroforesis en gel de agarosa 2\% (TAE 1X) de amplicones generados por heminested-PCR con los primers ITS5/ITS4 y digeridos con BsiEI, PpuMI y SpeI. Líneas 1-13: P. syringae (AG6), P. gonapodyides (AG8), P. taxon Pgchlamydo (AG29), P. taxon Raspberry (AG43), P. cambivora (AG44), P. austrocedrae (AG243), aislamiento no identificado (AG246), aislamientos incógnita (AG50), (AG51), (AG163) y (AG170), lesiones de los árboles 50A y Las Rocas. El rectángulo pequeño muestra la banda no esperada para P. taxon Pgchlamydo. La flecha negra indica la calle correspondiente a $P$. austrocedrae. Línea 14: ladder de $50 \mathrm{pb}$, la banda más intensa corresponde a $250 \mathrm{pb}$. Línea 15: ladder de 100 $\mathrm{pb}$, la banda más intensa corresponde a $500 \mathrm{pb}$. (PB-L, Productos Bio-Lógicos).

Figura A7-5: PCR-RFLP Combinación B. Electroforesis en gel de agarosa $2 \%$ (TAE $1 \mathrm{X}$ ) de amplicones generados por heminested-PCR con los primers ITS5/ITS4 y digeridos con PpuMI SpeI y FspI. Líneas 3-15: P. syringae (AG6), P. gonapodyides (AG8), P. taxon Pgchlamydo (AG29), P. taxon Raspberry (AG43), P. cambivora (AG44), P. austrocedrae (AG243), aislamiento no identificado (AG246), aislamientos incógnita (AG50), (AG51), (AG163) y (AG170), lesiones de los árboles 50A y Las Rocas. El rectángulo pequeño muestra la banda no esperada para P. taxon Pgchlamydo. La flecha negra indica la calle correspondiente a $P$. austrocedrae. Línea 1: ladder de $50 \mathrm{pb}$, la banda más intensa corresponde a $250 \mathrm{pb}$. Línea 2: ladder de $100 \mathrm{pb}$, la banda más intensa corresponde a $500 \mathrm{pb}$. (PB-L, Productos Bio-Lógicos).

Figura A7-6: PCR-RFLP Combinación C. Electroforesis en gel de agarosa 2\% (TAE 1X) de amplicones generados por heminested-PCR con los primers ITS5/ITS4 y digeridos con BsiEI y PpuMI. Líneas 1-13: P. syringae (AG6), P. gonapodyides (AG8), P. taxon Pgchlamydo (AG29), P. taxon Raspberry (AG43), P. cambivora (AG44), P. austrocedrae (AG243), aislamiento no identificado (AG246), aislamientos incógnita (AG50), (AG51), (AG163) y (AG170), lesiones de los árboles 50A y Las Rocas. La flecha negra indica la calle correspondiente a $P$. austrocedrae. Línea 14: ladder de $50 \mathrm{pb}$, la banda más intensa corresponde a $250 \mathrm{pb}$. Línea 15: ladder de $100 \mathrm{pb}$, la banda más intensa corresponde a $500 \mathrm{pb}$. (PB-L, Productos BioLógicos). 
El taxon AG246 pudo ser además separado del resto de las especies. Con la combinación A, un perfil de tres bandas para AG246 proporciona una buena separación de P. austrocedrae, P. gonapodyides y P. taxon Raspberry que presentan perfiles de dos bandas; y de P. taxon Pgchlamydo que presenta un perfil de cuatro bandas. Entre las especies con perfiles de tres bandas, AG246 pudo ser diferenciada de $P$. syringae y $P$. cambivora por la distancia relativa de las bandas en cada perfil. Con la combinación B, un perfil de dos bandas para AG246 da buena separación de $P$. austrocedrae, P. syringae, P. gonapodyides y P. taxon Raspberry que presentan perfiles de banda única y de P. taxon Pgchlamydo que tiene un perfil de tres bandas. La distancia relativa entre bandas dentro de cada perfil, permite la separación entre AG246 y P. cambivora. Con la combinación C, un perfil de dos bandas para AG246 permite una buena separación de $P$. syringae y $P$. cambivora que presentan perfiles de tres bandas; y de P. austrocedrae en base a la distancia relativa de fragmentos dentro de cada perfil. Por tanto, AG246 puede ser exitosamente identificada mediante los ensayos RFLP diseñados.

Los aislamientos AG50, AG51, AG163 y AG170, proporcionados por la Dra. Alina Greslebin como muestras incógnitas, fueron empleados en la validación de los métodos desarrollados. Los aislamientos AG50 y AG51 se clasificaron como P. taxon Pgchlamydo, de acuerdo con sus perfiles de restricción (Líneas 3, 8 y 9 en la Figura A7-4, Líneas 5, 10 y 11 en la Figura A7-5 y Líneas 3, 8 y 9 en la Figura A7-6); en tanto que los aislamientos AG163 y AG170 podrían corresponder a $P$. gonapodyides o P. taxon Raspberry (Líneas 2, 10 y 11 en la Figura A7-4, Líneas 4, 12 y 13 en la Figura A7-5 y Líneas 2, 10 y 11 en la Figura A7-6). Las clasificaciones establecidas en base a los perfiles RFLP fueron confirmadas por la Dra. Greslebin de acuerdo con la identificación morfológica de los aislamientos.

Extracciones de DNA provenientes de lesiones obtenidas de los árboles 50A y Las Rocas, fueron amplificadas y digeridas en las mismas condiciones que las aplicadas para DNA extraído de micelio. Ambas muestras producen perfiles de bandas idénticos a los de P. austrocedrae con las tres combinaciones de enzimas evaluadas (Líneas 12 y 13 en la Figura A7-4, Líneas 14 y 15 en la Figura A7-5 y Líneas 12 y 13 en la Figura A7-6). Estos resultados coinciden con los derivados de la amplificación y secuenciación de clones anteriormente mencionados para el método de identificación de $P$. austrocedrae. confirmando la especificidad de los métodos.

Con el objeto de evaluar la variabilidad intraespecífica del ensayo RFLP, varios aislamientos de P. taxon Pgchlamydo, P. austrocedrae, P. syringae y P. gonapodyides se analizaron con la combinación A. La banda adicional en P. taxon Pgchlamydo se detectó en el perfil de otros nueve aislamientos de la especie (Líneas 25-33 en la Figura A7-7), indicando que la variante 
detectada sería la más frecuente entre los aislamientos de la especie correspondientes a la zona de los bosques de $A$. chilensis. Todos los aislamientos evaluados para $P$. austrocedrae y P. gonapodyides mostraron los perfiles de banda esperados sin que ninguna banda adicional fuera detectada (Líneas 9-15 y 1-8 en la Figura A7-7, respectivamente). Sólo algunos de los aislamientos de $P$. syringae mostraron bandas adicionales cuyos tamaños se corresponden con el esperado para amplicones que han perdido sitios de restricción (Líneas 17-24 en la Figura A7-7). La diferenciación entre P. syringae y las otras especies de Phytophthora estudiadas no es afectada por esta variabilidad intraespecífica.

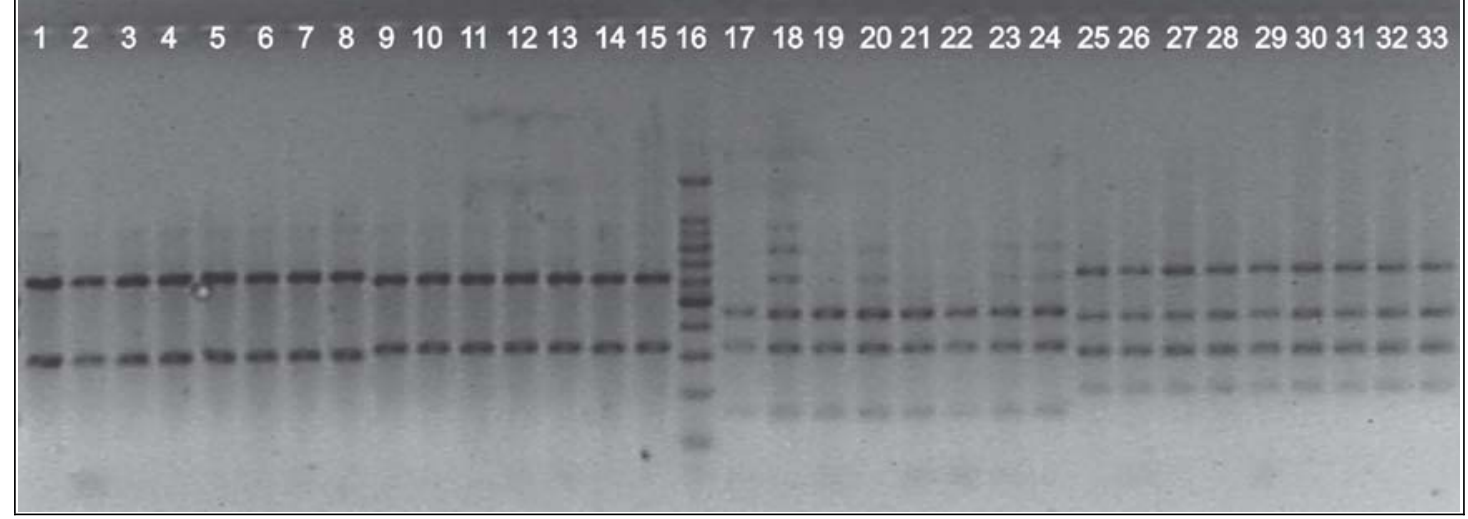

Figura A7-7: PCR-RFLP Combinación A, análisis de la variabilidad intraespecífica. Electroforesis en gel de agarosa 2\% (TAE 1X) de amplicones generados por heminested-PCR con los primers ITS5/ITS4 y digeridos con BsiEI, PpuMI y SpeI (Combinación A). Líneas 1-18: P. gonapodyides (aislamientos AG: 15, 28, 33, 35, 42, 56, 58, 160). Líneas 9-15: P. austrocedrae (aislamientos AG: 203, 209, 210, 225, 235, 240, 245). Líneas 17-24: P. syringae (aislamientos 5, 41, 60, 66, 97, 100, 186, 187). Líneas 25-33: P. taxon Pgchlamydo (aislamientos AG: 27, 30, 32, 34, 46, 47, 48, 49, 52). Línea 16: ladder de 100 pb, la banda más intensa corresponde a 500 pb. (PB-L, Productos BioLógicos).

\section{4.- DISCUSION Y CONCLUSIONES}

La identificación tradicional de especies de Phytophthora se basa en características morfológicas y patrones de crecimiento en medios específicos. Esta metodología requiere el aislamiento y el crecimiento del organismo en cultivo puro, la inducción de esporangios y formación de oogonias, y el examen morfológico de éstas y otras estructuras características; siendo además necesario tener importante entrenamiento y experiencia suficiente para lograr diferenciar con claridad especies estrechamente relacionadas. Por otra parte, el aislamiento de especies de Phytophthora puede ser muy difícil cuando los tejidos afectados se acompañan de pudriciones o en casos de lesiones inactivas o antiguas en las cuales ya no es posible encontrar al patógeno vivo. 
P. austrocedrae es la única especie de Phytophthora aislada desde lesiones necróticas activas y su rol como agente causal de las mismas ha sido claramente establecido mediante ensayos de patogenicidad (Greslebin y Hansen, 2007a y b). Sin embargo, aunque posible desde lesiones activas, el aislamiento de $P$. austrocedrae desde lesiones inactivas o antiguas no ha sido exitoso. A diferencia de las lesiones activas, de fácil diferenciación, las lesiones inactivas o antiguas pueden en algunos casos confundirse con heridas o cicatrices de origen no patogénico. Por otro lado, la falta de detección de $P$. austrocedrae en muestras de suelo o agua dificulta el seguimiento de la dinámica en el bosque y la determinación precisa de la incidencia de la especie.

En este trabajo se desarrollaron dos métodos moleculares, basados en PCR, para detectar e identificar especies de Phytophthora presentes en bosques de A. chilensis. La combinación de primers diseñada (For1-aust/Rev1-aust) resultó adecuada para detectar $P$. austrocedrae en material proveniente de lesiones necróticas, activas e inactivas, presentando mayor sensibilidad que la combinación de primers genérica DC6/ITS4. El análisis realizado in silico predijo una buena identificación de las especies de Phytophthora en estudio usando cuatro enzimas de restricción que fueron evaluadas en tres combinaciones diferentes. El ensayo RFLP resultó robusto en la identificación de $P$. austrocedrae, $P$. syringae, $P$. gonapodyides, P. taxon Pgchlamydo, P. cambivora. La combinación A permitió una completa identificación de todas las especies en estudio que presentaron perfiles de RFLP únicos y diferentes del perfil de $P$. austrocedrae. La combinación B fue óptima para la identificación de $P$. austrocedrae y útil para validar la diferenciación de P. taxon Pgchlamydo y P. cambivora. La combinación C produjo la mejor discriminación entre P. taxon Pgchlamydo y $P$. cambivora. El ensayo RFLP fue además útil para distinguir un aislamiento reciente aún no identificado (AG246). La variabilidad intraespecífica del ensayo RFLP se determinó para varios aislamientos de las especies P. austrocedrae, P. gonapodyides, P. syringae y P. taxon Pgchlamydo. Únicamente $P$. syringae mostró variabilidad intraespecífica, sin embargo la misma no invalidó su diferenciación de las restantes especies.

La especificidad del método de detección de $P$. austrocedrae en lesiones necróticas fue verificada mediante secuenciación de los fragmentos amplificados. Ensayos de suplementación realizados en laboratorio señalan que $P$. gonapodyides podría dar amplificación cruzada con los primers específicos de P. austrocedrae. Sin embargo, esto no debería ser un problema en tanto que la especie no ha sido aislada desde lesiones necróticas. Por otra parte, como el método RFLP fue aplicado con éxito a muestras de lesiones necróticas, podría ser empleado en la diferenciación de especies en forma complementaria al método de detección específica. 
Los métodos moleculares desarrollados proporcionan herramientas útiles, sensibles y rápidas para la detección e identificación de especies de Phytophthora en bosques de A. chilensis, y una metodología eficiente para comparar diversos métodos de concentración de inóculo en muestras de suelo y agua que están siendo actualmente evaluados. La detección molecular de $P$. austrocedrae permitirá un rápido análisis de la distribución de la especie y ayudará a clarificar la relación entre la presencia de $P$. austrocedrae y los nuevos síntomas aéreos reportados en bosques de $A$. chilensis.

\section{5.-BIBLIOGRAFÍA}

Altschul SF, Madden TL, Schäffer AA, Zhang J, Miller W, Lipman DJ, 1997. Gapped-BLAST and PSI-BLAST: a new generation of protein database search programs. Nucleic Acids Res 25: 3389-3402.

Bekesiova I, Jan-Peter N, Amlynarova L. 1999. Isolation of High Quality DNA and RNA from Leaves of the Carnivorous Plant Drosera rotundifolia. Plant Molecular Biology Reporter 17: 269-277.

Brasier CM, Cooke DEL, Duncan JM, Hansen E, 2003. Multiple new phenotypic taxa from trees and riparian ecosystems in Phytophthora gonapodyides-P.megasperma ITS Clade 6, which tend to be high-temperature tolerant and either inbreeding or sterile. Mycological Research 107: 277-290.

Calí S, 1996. Austrocedrus chilensis: Estudio de los anillos de crecimiento y su relación con la dinámica del "mal del ciprés" en el Parque Nacional Nahuel Huapi, Argentina. Tesis de Licenciatura en Ciencias Biológicas. Universidad Nacional del Comahue. Argentina. 143 pp.

Cooke DEL, Drenth A, Duncan JM, Wagels G, Brasier CM, 2000a. A Molecular Phylogeny of Phytophthora and Related Oomyecetes. Fungal Genetics and Biology 30: 17-32.

Cooke DEL, Duncan JM, Williams NA, Hagenaar de Weerdt M, Bonants PJM, 2000b. Identification of Phytophthora species on the basis of restriction enzyme fragment analysis of the Internal Transcribed Spacer regions of ribosomal RNA OEPP/EPPO Bulletin 20: 519-523.

El Mujtar V, Andenmatten E, 2007a. "Mal del ciprés": búsqueda de la causa más probable de daño mediante un análisis deductivo y comparativo. Bosque 28(1): 3-9.

El Mujtar V, Andenmatten E, 2007b. Análisis del "Mal del ciprés" mediante un "Modelo de Enfermedad": Vacíos de información y perspectivas. Revista de la Facultad de Agronomía de La Plata. 106(2): 119-133. 
Filip G, 1995: Comparison of forest diseases in Andean Patagonian and Oregon Cascade forest ecosystems. A report to the OSU Research Council. 19 pp.

Filip GM, Rosso PH, 1999. Cypress mortality (mal del ciprés) in the Patagonian Andes: comparisons with similar forest diseases and declines in North America. European Journal of Forest Pathology. 29: 89-96.

Greslebin AG, Hansen EM, Winton LM, Rajchenberg M, 2005. Phytophthora species from declining Austrocedrus chilensis forests in Patagonia, Argentina. Mycologia 97(1): 218228.

Greslebin AG, Hansen EM, Sutton W, 2007. Phytophthora austrocedrae sp. nov., a new species associated with Austrocedrus chilensis mortality in Patagonia (Argentina). Mycological Research III: 308-316.

Greslebin AG, Hansen EM, 2006. Novedades sobre el mal del ciprés. CIEFAP Patagonia Forestal XII(1): 11-14.

Greslebin AG, Hansen EM, 2007a. La causa del "mal del ciprés". CIEFAP Patagonia Forestal XIII(1): 5-8.

Greslebin, AG, Hansen EM, 2007b. The Decline of Austrocedrus Forests in Patagonia (Mal del Ciprés): Another Phytophthora-Caused Forest Disease. Proceedings of the 4th IUFRO meeting on Phytophthora in forests and natural ecosystems (Monterey, CA, USA).

Grote D, Olmos A, Kofoet A, Tuset JJ, Bertolini E, Cambra M, 2002. Specific and sensitive detection of Phytophthora nicotianae by simple and nested-PCR. European Journal of Plant Pathology 108: 197-207.

Hall TA, 1999. BioEdit: a user-friendly biological sequence alignment editor and analysis program for Windows 95/98/NT. Nucleic Acids Symposium Series 41: 95-98.

Hansen EM, 2000. Phytophthora in the Americas. 23-27 pp. En: Hansen EM, Sutton W. First International Meeting on Phytophthoras in Forest and Wildland Ecosystems, Phytophthora Disease of Forest tree (Grant Pass, Oregon, USA).

Hayden KJ, Rizzo D, Tse J, Garbelotto M, 2004. Detection and quantification of Phytophthora ramorum from California forests using a real-time polymerase chain reaction assay. Phytopathology 94(10): 1075-1083.

Hennon PE, Rajchenberg M, 2000. El "mal del ciprés". Algunas observaciones, comparaciones e ideas. CIEFAP Patagonia Forestal VI(2): 4-6.

La Manna L, 2004. La declinación de los bosques de Austrocedrus chilensis: relación entre el "Mal del ciprés" y el sitio. Tesis para optar al título de Doctora en Ciencias Biológicas. Universidad de Buenos Aires. Argentina. 291 pp. 
La Manna L, Carabelli F, Gómez M, Matteucci S, 2008b. Disposición espacial de parches de Austrocedrus chilensis con síntomas de defoliación y mortalidad en el Valle 16 de Octubre (Chubut, Argentina). Bosque 29(1): 23-32.

La Manna L, Rajchenberg M, 2004a. The decline of Austrocedrus chilensis forests in Patagonia, Argentina: soil features as predisponsing factors. Forest Ecology and Management 190, 345-357.

Lee SB, Taylor JW, 1992. Phylogeny of five fungus-like protoctistan Phytophthora species, inferred from the internal transcribed spacers of ribosomal DNA. Molecular Biology and Evolution 9: 636-653.

Loguercio GA, Urretavizcaya F, Rey M, Andenmatten E, 1998. El "mal del cipres" como condicionante de la silvicultura del ciprés de la cordillera Austrocedrus chilensis (D. Don) Florin et Boutelje en el norte de la Patagonia Argentina. I Congreso Latinoamericano IUFRO (Valdivia, Chile). 22 pp.

Loguercio GA, Rajchenberg M, Rodriguez N, Pantaenius P, 1999a. Curso-Taller de actualización en silvicultura de los bosques de ciprés de la cordillera (El Bolsón). 60 pp.

Martin FN, Tooley PW, 2003. Phylogenetic relationships among Phytophthora species inferred from sequence analysis of mitochondrially encoded cytochrome oxidase I and II genes. Mycologia 95: 269-284.

Martin FN, Tooley PW, 2004. Identification of Phytophthora Isolates to Species Level Using Restriction Fragment Length Polymorphism Analysis of a Polymerase Chain ReactionAmplified Region of Mitochondrial DNA. Phytopathology 94: 983-991.

Nechwatal J, Mendgen K, 2006. Widespread detection of Phytophthora taxon Salixsoil in the littoral zone of Lake Constance, Germany. European Journal of Plant Pathology 114: 261264.

Rajchenberg M, Barroetaveña C, Cwielong PP, Rossini M, Cabral D, Sivori A, 1997. Fungal species associated with the decline of Austrocedrus chilensis in Patagonia, Argentina: preliminary results. Root and Butt Rots of Forest Trees (Carcans-Maubuisson, France). Les Colloques 89: 235-244.

Rosso PH, Baccalá N, Havrylenko M, Fontenla S, 1994. Spatial pattern of Austrocedrus chilensis wilting and the scope of autocorrelation analysis in natural forests. Forest Ecology and Management 67: 273-279.

Thompson JD, Gibson TJ, Plewniak F, Jeanmougin F, Higgins DG, 1997. The ClustalX windows interface: flexible strategies for multiple sequence alignment aided by quality analysis tools. Nucleic Acids Research 24: 4876-4882.

White TJ, Bruns T, Lee S, Taylor J, 1990. Amplification and direct sequencing of fungal ribosomal RNA genes for phylogenetics. 315-321 pp. En: Innis MA, Gelfand DH, Sninsky 
JJ, White TJ, eds. PCR Protocols: a Guide to Methods and Applications. Academic Press, San Diego.

Winton LM, Hansen EM, 2001. Molecular diagnosis of Phytophthora lateralis in trees, water, and foliage baits using multiplex polymerase chain reaction. Forest Pathology 31: 275283. 


\section{ANEXO 8}

AMPLIFICACIÓN DEL GEN 16S rRNA

\begin{tabular}{|c|c|c|c|c|c|c|c|c|}
\hline Sitio & Arbol & PCR 16S rRNA & Arbol & PCR 16S rRNA & Arbol & PCR 16S rRNA & Arbol & PCR 16S rRNA \\
\hline \multirow{5}{*}{ L5y6 } & $11 \mathrm{~A}$ & positiva & $11 \mathrm{~S}$ & positiva $^{a}$ & $36 \mathrm{~A}$ & positiva & $36 S$ & positiva \\
\hline & $12 \mathrm{~A}$ & positiva & $12 S$ & positiva $^{\mathrm{a}}$ & $37 A$ & positiva & $37 S$ & positiva \\
\hline & $13 \mathrm{~A}$ & positiva & $13 S$ & positiva & $38 \mathrm{~A}$ & positiva & $38 S$ & positiva \\
\hline & $14 \mathrm{~A}$ & positiva & $14 S$ & positiva & $39 A$ & positiva & $39 S$ & positiva \\
\hline & $15 \mathrm{~A}$ & positiva & $15 S$ & positiva & $40 \mathrm{~A}$ & positiva & $40 S$ & positiva \\
\hline \multirow{5}{*}{ R11 } & $1 \mathrm{~A}$ & negativa & $1 \mathrm{~S}$ & positiva & $26 \mathrm{~A}$ & positiva & $26 S$ & positiva \\
\hline & $2 \mathrm{~A}$ & positiva & $2 S$ & positiva $^{a, b}$ & $27 \mathrm{~A}$ & positiva & $27 S$ & positiva $^{b}$ \\
\hline & $3 \mathrm{~A}$ & positiva & $3 S$ & positiva & $28 \mathrm{~A}$ & positiva & $28 S$ & positiva $^{b}$ \\
\hline & $4 \mathrm{~A}$ & positiva & $4 S$ & positiva & $29 A$ & positiva & $29 S$ & positiva \\
\hline & $5 \mathrm{~A}$ & positiva & $5 S$ & positiva & $30 \mathrm{~A}$ & positiva & $30 S$ & positiva \\
\hline \multirow{5}{*}{ R18 } & $16 \mathrm{~A}$ & positiva & $16 S$ & positiva & $41 \mathrm{~A}$ & positiva $^{a, b}$ & $41 S$ & positiva \\
\hline & $17 \mathrm{~A}$ & positiva & $17 S$ & positiva $^{a, b}$ & $42 \mathrm{~A}$ & positiva & $42 S$ & positiva \\
\hline & $18 \mathrm{~A}$ & positiva & $18 \mathrm{~S}$ & positiva & $43 A$ & positiva & $43 S$ & positiva \\
\hline & $19 \mathrm{~A}$ & positiva & $19 S$ & positiva & $44 \mathrm{~A}$ & positiva & $44 S$ & positiva \\
\hline & $20 \mathrm{~A}$ & positiva & $20 S$ & positiva & $45 \mathrm{~A}$ & positiva & $45 S$ & positiva \\
\hline \multirow{5}{*}{ R81 } & $21 \mathrm{~A}$ & positiva $^{b}$ & $21 S$ & positiva & $46 \mathrm{~A}$ & positiva & $46 S$ & positiva \\
\hline & $22 \mathrm{~A}$ & positiva & $22 S$ & positiva & $47 \mathrm{~A}$ & positiva & $47 S$ & positiva \\
\hline & $23 \mathrm{~A}$ & positiva & $23 S$ & positiva & $48 \mathrm{~A}$ & positiva $^{\mathrm{d}, \mathrm{b}}$ & $48 S$ & positiva $^{a, b}$ \\
\hline & $24 \mathrm{~A}$ & positiva & $24 S$ & positiva & $49 A$ & positiva & $49 S$ & positiva \\
\hline & $25 \mathrm{~A}$ & positiva & $25 S$ & positiva & $50 \mathrm{~A}$ & positiva $^{\mathrm{d}, \mathrm{b}}$ & $50 S$ & positiva $^{b}$ \\
\hline \multirow{5}{*}{ L9y15 } & $6 A$ & positiva & $6 S$ & positiva & $31 \mathrm{~A}$ & positiva & $31 S$ & positiva \\
\hline & $7 \mathrm{~A}$ & positiva & $7 S$ & positiva $^{a}$ & $32 \mathrm{~A}$ & positiva & $32 S$ & positiva \\
\hline & $8 \mathrm{~A}$ & positiva & $8 S$ & positiva & $33 A$ & positiva & $33 S$ & positiva \\
\hline & $9 A$ & positiva & 9S & positiva & $34 \mathrm{~A}$ & positiva & $34 S$ & positiva \\
\hline & $10 \mathrm{~A}$ & positiva & $10 S$ & positiva & $35 \mathrm{~A}$ & positiva & $35 S$ & positiva \\
\hline
\end{tabular}

Tabla A8-1: Resultado de la amplificación del gen 16S rRNA desde muestras de DNA total obtenidas a partir de xilema de individuos de la especie $A$. chilensis. d, a, b: condición del DNA total utilizado como molde en la reacción de PCR. d: directo. a: dilución 1/100. b: dilución 1/10. Los resultados reportados sin referencias fueron realizados sobre DNA total directo. A la izquierda se indica el área de origen de los individuos empleados en el análisis. 



\section{ANEXO 9}

\section{SIGNIFICACIÓN DEL DENDROGRAMA DERIVADO DEL ANÁLISIS DE DGGE A NIVEL DE INDIVIDUO}

\begin{tabular}{|c|c|c|c|c|}
\hline Nodo & $\begin{array}{l}\text { Similitud } \\
\text { Promedio }\end{array}$ & $\begin{array}{l}\text { Desvío } \\
\text { Estándar }\end{array}$ & $\begin{array}{l}\text { Coeficiente } \\
\text { Cofenético }\end{array}$ & $\begin{array}{l}\text { Valor de } \\
\text { Bootstrap }\end{array}$ \\
\hline 1 & 37,5 & 0,00 & 100 & 16 \\
\hline 2 & 43,5 & 0,00 & 100 & 28 \\
\hline 3 & 31,0 & 6,71 & 50 & 5 \\
\hline 4 & 54,5 & 0,00 & 100 & 54 \\
\hline 5 & 25,5 & 6,98 & 72 & 1 \\
\hline 6 & 66,7 & 0,00 & 100 & 67 \\
\hline 7 & 31,4 & 10,42 & 81 & 14 \\
\hline 8 & 18,2 & 8,08 & 79 & 0 \\
\hline 9 & 60,0 & 0,00 & 100 & 54 \\
\hline 10 & 42,3 & 3,85 & 94 & 25 \\
\hline 11 & 28,7 & 13,84 & 75 & 1 \\
\hline 12 & 27,5 & 7,06 & 75 & 0 \\
\hline 13 & 90,0 & 0,00 & 100 & 81 \\
\hline 14 & 73,9 & 3,89 & 92 & 30 \\
\hline 15 & 71,4 & 3,31 & 90 & 49 \\
\hline 16 & 62,6 & 3,07 & 93 & 36 \\
\hline 17 & 59,9 & 2,97 & 93 & 49 \\
\hline 18 & 44,7 & 7,51 & 93 & 42 \\
\hline 19 & 20,4 & 13,99 & 87 & 0 \\
\hline 20 & 57,1 & 0,00 & 100 & 63 \\
\hline 21 & 31,0 & 2,38 & 99 & 22 \\
\hline 22 & 18,5 & 11,44 & 85 & 1 \\
\hline 23 & 14,0 & 10,31 & 80 & 0 \\
\hline 24 & 42,9 & 0,00 & 100 & 30 \\
\hline 25 & 23,6 & 1,39 & 99 & 6 \\
\hline 26 & 16,8 & 16,93 & 61 & 1 \\
\hline 27 & 9,1 & 10,60 & 78 & 26 \\
\hline \multirow[t]{2}{*}{28} & 5,5 & 6,99 & 78 & 33 \\
\hline & 2,7 & 5,97 & 79 & \\
\hline
\end{tabular}

Tabla A9-1: Valores de significación del dendrograma obtenido para el análisis de la diversidad de la región V3 del gen 16S rRNA entre individuos de A. chilensis (Figura VI-6, Capitulo VI). Nodos según orden derecha izquierda y arriba abajo. 


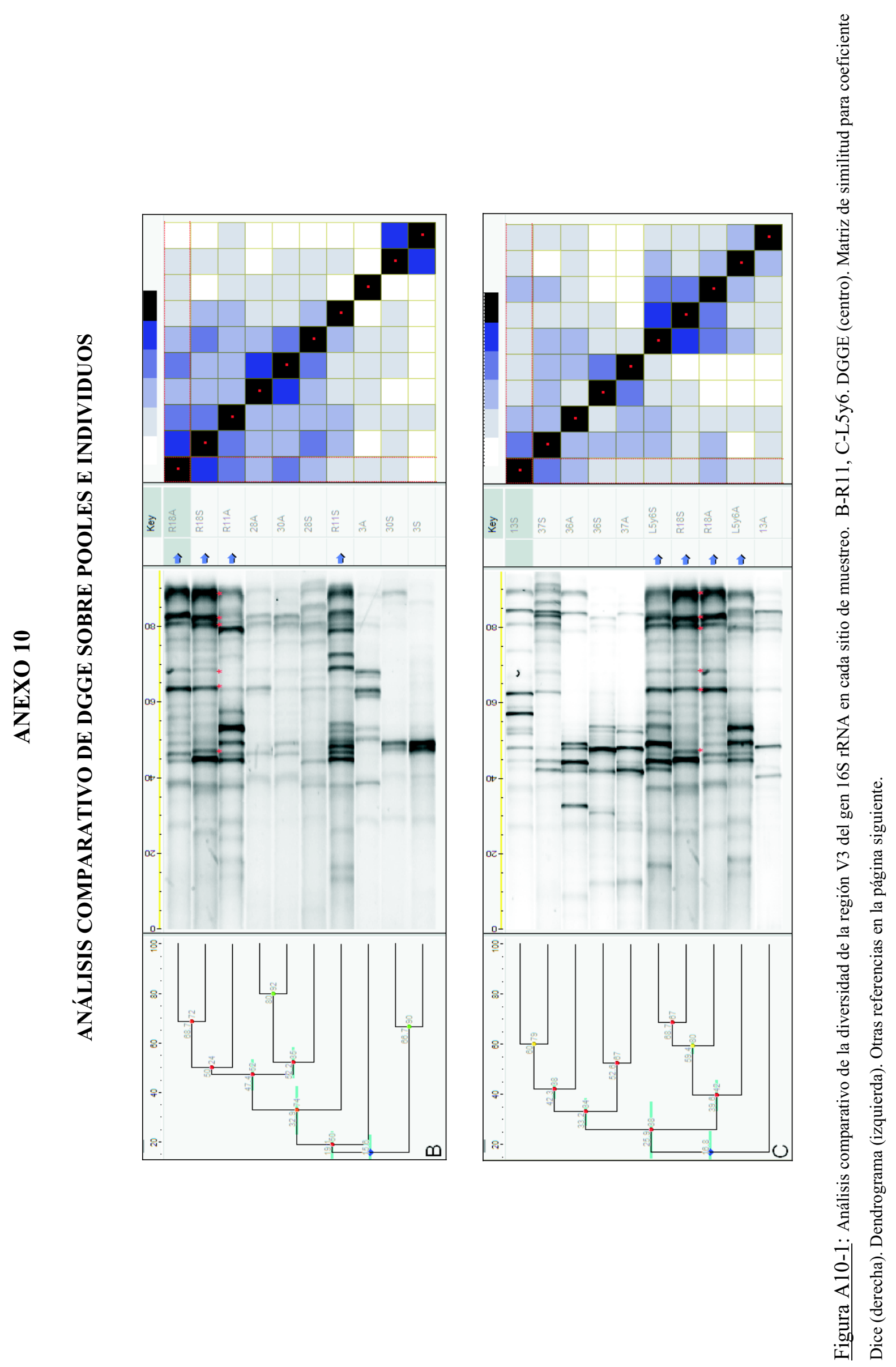

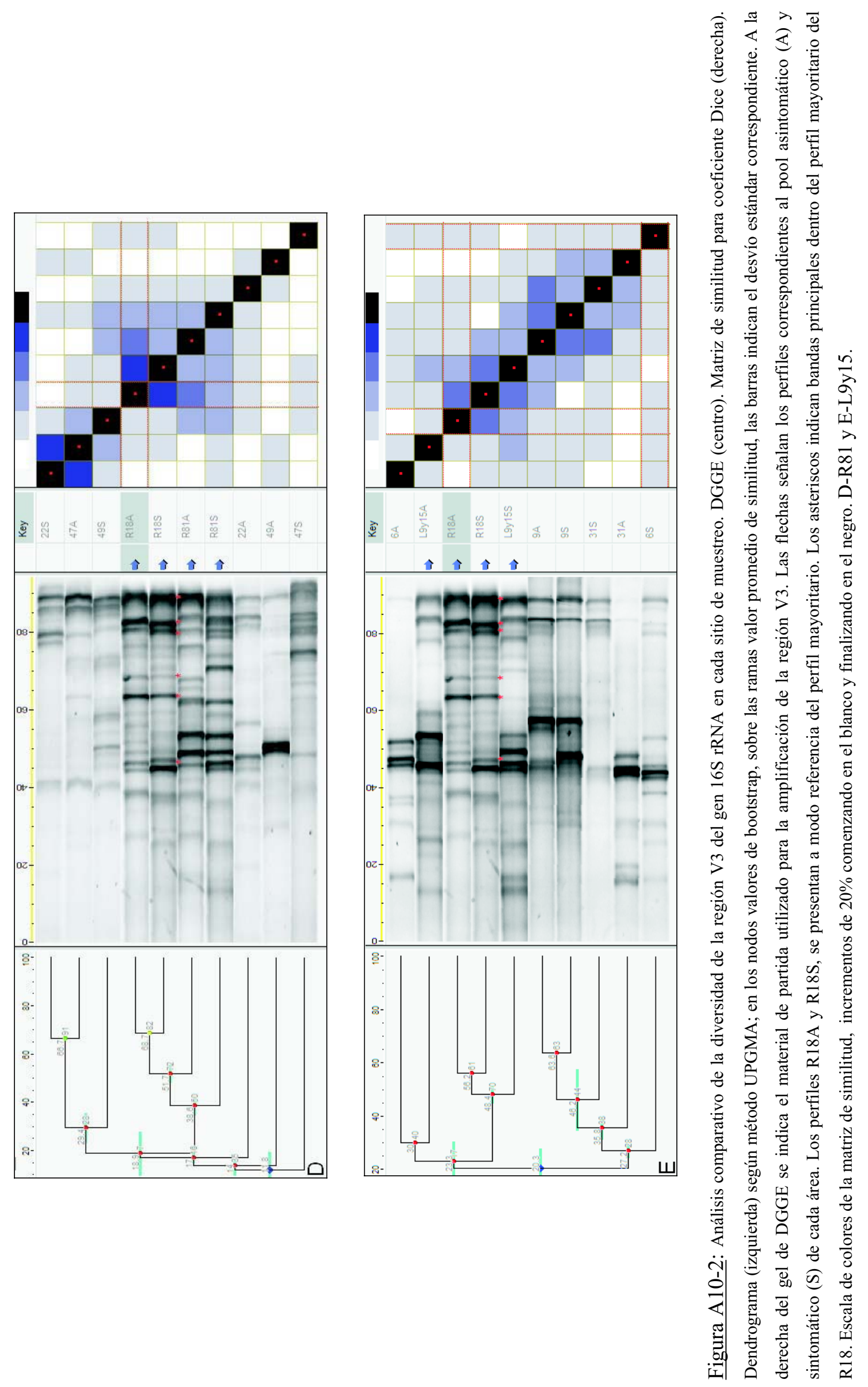


\section{ANEXO 11}

PUBLICACIONES EN EL MARCO DE LA TESIS 



\title{
OPINIONES
}

\section{"Mal del ciprés": búsqueda de la causa más probable de daño mediante un análisis deductivo y comparativo}

\author{
"Cypress Mortality": search the more probably damage cause by means of \\ deductive and comparative analysis
}

\author{
Verónica Andrea El Mujtar ${ }^{a *}$ y Ernesto Andenmattenb \\ *Autor de correspondencia: a Universidad Nacional de La Plata, Facultad de Ciencias Exactas, Instituto de Bioquímica y \\ Biología Molecular (IBBM), Calle 49 y 115 s/n (1900), La Plata, Buenos Aires, Argentina, Tel./Fax: 54-221 4259223, \\ verel@biol.unlp.edu.ar. \\ b Instituto Nacional de Tecnología Agropecuaria (INTA)-EEA, Bariloche, Argentina.
}

\section{SUMMARY}

The "cypress mortality" ("mal del ciprés") is a disease of unknown causes, which affects cordillera cypress (Austrocedrus chilensis) in Argentina. In this work a basic guide to diagnosing plant diseases and to compare the cypress mortality with other forest diseases is shown for its application, in order to identify the most probable cause of damage. The systematic management of the information permitted to establish that the dates are not sufficient to discriminate between different damage agents. The association between the cypress mortality and others forest diseases allowed us to verify that there are several difficulties to diagnose and manage this pathologies. We detected several key points of the disease that should be considered in future investigations: absence of specific symptoms, absence of signs, subjective assignment of the degree of defoliation and the associated sanitary state, absence of an analysis model for disturbance.

Key words: Austrocedrus chilensis, guide to diagnosing, deductive steps, propagation study, analysis models.

\section{RESUMEN}

El "mal del ciprés" es un disturbio de origen desconocido que afecta a ciprés de la cordillera (Austrocedrus chilensis) en Argentina. En este trabajo se plantea la aplicación de una guía básica para el diagnóstico de enfermedades de plantas con el fin de identificar la causa más probable de daño. Por otra parte, se compara el "mal del ciprés" con algunas enfermedades de especies forestales. El manejo sistemático de la información, logrado al aplicar la guía de diagnóstico, permitió establecer que los datos existentes son insuficientes para discriminar entre los diferentes grupos de agentes de daño. La comparación entre el "mal del ciprés" y diferentes enfermedades de especies forestales permitió comprobar que son muchas las dificultades que encierra el diagnóstico y el manejo de tales patologías. De la implementación de ambos enfoques surgieron algunos puntos claves de la afección que deberían ser considerados en investigaciones futuras: falta de especificidad de síntomas, falta de estudios de propagación, ausencia de signos de la afección, subjetividad en la asignación del grado de defoliación y el estado sanitario asociado, falta de un modelo de análisis para el disturbio.

Palabras clave: Austrocedrus chilensis, guía de diagnóstico, pasos deductivos, estudios de propagación, modelo de análisis.

\section{INTRODUCCIÓN}

Austrocedrus chilensis (D. Don) Pic. Ser et Bizzarri (ciprés de la cordillera) se distribuye en una franja de no más de $50 \mathrm{~km}$ de ancho, formada por una serie de parches de bosque de tamaño variable. En Chile se encuentra entre los límites $32^{\circ} 39^{\prime} \mathrm{S}$ y $44^{\circ} \mathrm{S}$, mientras que en Argentina lo hace entre los $39^{\circ} 30^{\prime} \mathrm{S}$ y $43^{\circ} 44^{\prime} \mathrm{S}$ (Gallo et al. 2004). La especie está adaptada a un amplio rango de condiciones ambientales y sus bosques se localizan en un marcado gradiente de precipitación. Los bosques de ciprés de la cordillera forman el denominado "Cinturón de Frontera" entre los bosques húmedos de Nothofagus spp. al oeste y la estepa patagónica al este (Dezzotti y Sancholuz 1991).

Un disturbio de origen desconocido, denominado "mal del ciprés", afecta a esta especie en Argentina. De acuerdo a los datos históricos, los primeros registros se 
localizan en Puerto Piedras Blancas (Isla Victoria, Provincia de Neuquén) en el año 1948 (Varsavsky et al. 1975) y en cipresales adyacentes al Vivero Forestal General San Martín (Lote 12, Sección Golondrinas, Colonia Mixta; Epuyén al NO de la Provincia de Chubut) en el año 1953 (Hranilovich 1988). En la actualidad, la afección está presente en casi toda el área de distribución del ciprés de la cordillera y el número de árboles afectados es cada vez mayor (Havrylenko et al. 1989).

Havrylenko et al. (1989) señalan una sintomatología con características identificables y constantes en todos los bosques afectados, sin signos visibles y con un patrón de síntomas sin relación aparente con afecciones conocidas. Concluyen que la afección responde a una misma causa independientemente de los bosques estudiados, con inicio aparente en la zona radical, existiendo factores de sitio que favorecen el desarrollo y sin incidencia preferencial según edad de los árboles. Indican, además, que los hongos xilófagos asociados a las pudriciones radiculares no son responsables principales de la mortalidad del ciprés, sino que atacan un sistema ya debilitado por otro agente.

Rosso et al. (1989) indican la existencia de segregación mutua entre los individuos sanos y afectados, postulando que la mortalidad se dispondría en forma agregada debido a un proceso de contagio. En un trabajo posterior señalan que la mortalidad del ciprés de la cordillera se presenta en forma de manchones cuando la incidencia de la afección es baja, y que las condiciones del ambiente en cada parcela influyen en forma directa sobre el grado de agregación cambiando el patrón espacial (Rosso et al. 1994).

El estudio desarrollado por Baccalá et al. (1998) establece la existencia de un patrón ecológico en el disturbio según el cual los bosques más propensos a desarrollar síntomas serían los que se ubican en sitios con mayores precipitaciones y peor drenaje. Calí (1996) indica que la manifestación externa de la afección se correlaciona con una caída del crecimiento radial y que el inicio de dicha caída se da, por lo general, varios años antes que la sintomatología externa en la copa. También indica afección asociada a sitios húmedos y pequeños cursos de agua y con menor grado de correlación a la actividad humana y la pendiente del terreno.

Rajchenberg y Cwielong (1993) sostienen que las pudriciones cúbicas presentes en la albura están fuertemente relacionadas con el "mal del ciprés". Indican a las especies Coniophora arida y Postia dissecta como causantes de estas pudriciones y postulan que se comportarían como parásitos oportunistas. Establecen, además, que las condiciones del sitio jugarían un rol principal en el establecimiento de la afección. Y concluyen que suelos con un horizonte "A" poco profundo, seguido de un horizonte arcilloso impermeable al paso del agua, y terrenos con poca pendiente, estarían asociados con una mayor incidencia del disturbio.
La Manna et al. (2001) mencionan la presencia de lesiones necróticas en raíces de árboles afectados, probablemente producidas por hongos de los géneros Phytophthora y Pythium. Y establecen que la naturaleza del suelo condiciona la forma más o menos agregada en que se presenta la afección. Existe también un importante trabajo de aislamiento y caracterización de especies del género Phytophthora en bosques de ciprés de la cordillera y cursos de agua asociados (Greslebin et al. 2005).

Hasta la fecha se ha logrado:

caracterizar la sintomatología: marchitamiento y amarillamiento progresivo de las hojas, defoliación del árbol, disminución del crecimiento, pudrición intensa de las raíces principales, pudrición en tronco (proveniente de las raíces y con escasa extensión) y muerte en pie.

comprobar que son afectados individuos de distintas edades, tamaños y posiciones sociológicas.

○ establecer que la afección aparece como manchones más o menos extendidos (aunque la presentación dentro de cada manchón es más difícil de definir y depende en gran parte de las características del sitio y de la incidencia de la misma).

O establecer la relación entre las condiciones del sitio y la aparición del disturbio.

demostrar la utilidad de las técnicas dendrocronológicas para determinar el inicio de alteraciones en la planta en forma previa a la aparición de síntomas externos.

A pesar de toda la investigación desarrollada, la etiología del disturbio es aún desconocida. La probabilidad de un diagnóstico correcto basado sólo en unos pocos indicios o síntomas es baja, ya que síntomas similares pueden ser producidos por diferentes agentes de daño en una misma planta. El uso exclusivo de la sintomatología como elemento de diagnóstico es inadecuado, ya que la presencia de signos y el patrón de presentación y propagación del daño deben también ser utilizados para discernir entre diferentes agentes.

En este trabajo se aplicó una "guía básica para el diagnóstico de enfermedades de plantas" con el fin de manejar la información existente de un modo sistemático, intentando discriminar entre los probables agentes etiológicos o estableciendo los aspectos que falta investigar para poder lograrlo. De las distintas guías de diagnóstico encontradas, se utilizó la presentada por Green et al. (2003). Esta guía fue seleccionada por la claridad en el desarrollo, por ser aplicable a diversos sistemas y por ajustarse a modelos generales de análisis de enfermedades de plantas, y será seguida sin modificación. Los pasos principales son indicados a continuación (la guía completa puede consultarse en la referencia bibliográfica): definir el problema, búsqueda de patrones, delinear el tiempo de desarrollo del patrón de daño, determinar 
las causas de daño a la planta y sintetizar la información para determinar las posibles causas.

El "mal del ciprés" fue comparado con enfermedades de otras especies forestales en un intento de establecer las dificultades generales que encierra el diagnóstico y el manejo de la investigación de estos disturbios.

\section{APLICACIÓN DE LA GUÍA BÁSICA DE DIAGNÓSTICO AL "MAL DEL CIPRÉS"}

Definir el problema. La existencia del problema ha sido ya establecida. La identificación de plantas afectadas puede hacerse a través de síntomas externos (amarillamiento, defoliación) o internos (caída en la tasa de crecimiento). En el trabajo de Havrylenko et al. (1989) se definen los síntomas de la afección, se indica la ausencia de signos visibles y se postula a la zona radical como punto de inicio del daño, con factores de sitio favoreciendo el desarrollo. El inicio en la zona radical y el efecto de las características del sitio han sido también planteados por Rajchenberg y Cwielong (1993), La Manna et al. (2001) y La Manna y Rajchenberg (2004ab). El amarillamiento y la caída de hojas son más intensos que lo esperable para la especie y los patrones de defoliación observados son característicos e identificables (Havrylenko et al. 1989, Rajchenberg y Cwielong 1993). La disminución de la tasa de crecimiento, determinada por dendrocronología (Calí 1996), permite establecer diferencias entre individuos con y sin síntomas aéreos y verificar que la caída del crecimiento radial se inicia varios años antes que la sintomatología externa.

Es importante mencionar que, además de la sintomatología definida como característica para el "mal del ciprés", se observa otro patrón de afección. En este último caso, la coloración de las hojas pasa de clorótica a roja y el árbol muere rápidamente reteniendo aún el follaje (Filip y Rosso 1999). No se sabe si éstas son diferentes manifestaciones de la misma afección o si corresponden a disturbios distintos.

No se ha encontrado bibliografía en la que se relacione el "mal del ciprés" con afecciones simultáneas de otras especies forestales, arbustivas o herbáceas. Este análisis podría ser de mucha utilidad al evaluar el efecto de agentes abióticos en el proceso (sequía, anegamiento, radiación, ozono) y ayudaría a discriminar entre daño producido por agentes bióticos o abióticos.

Búsqueda de patrones de daño. La distinción entre factores de daño bióticos o abióticos se inicia con la caracterización del patrón de afección, aunque no siempre sea esto suficiente. En el "mal del ciprés" se observa un amarillamiento y marchitamiento progresivo, seguido por pérdida de hojas. La defoliación ocurre, en general, de abajo hacia arriba y de adentro hacia afuera de la copa. Havrylenko et al. (1989) establecen que la distribución y el avance de la defoliación responden a seis patrones diferentes: follaje completo, defoliación proximal en ramas inferiores, defoliación total en ramas inferiores, defoliación proximal generalizada, defoliación lateral, defoliación total. Rajchenberg y Cwielong (1993) plantean una tabla de asignación de tipos de vitalidad, según el porcentaje de defoliación (0-10, 10-25, 25-60, 60-99, $100 \%$ ) y las características del árbol (copa, aspecto y coloración de hojas, aspecto de la corteza). Dichos sistemas no son exactamente iguales y la interpretación de los resultados de los trabajos de investigación podría variar al cambiar el sistema de asignación de patrones y tipos de vitalidad.

La investigación desarrollada hasta la fecha indica que las pudriciones de raíz no son responsables principales de la afección. El origen de las lesiones necróticas que se encuentran en las raíces de los árboles está siendo investigado. De la misma forma, la asociación con factores de sitio es difícil de interpretar. Si bien se demuestra que el drenaje pobre del suelo es una característica de gran importancia para el desarrollo de la afección, no se ha podido establecer el fundamento básico de esta asociación. Diferenciar el origen primario o secundario de la defoliación, parece ser un punto de gran importancia.

Delinear el tiempo de desarrollo del patrón de daño. Observar el desarrollo del patrón de daño en el tiempo, es otro elemento clave para distinguir entre factores bióticos y abióticos. Por lo general, los organismos bióticos se multiplican con el tiempo, de forma tal que el daño se propaga en la planta o en grupos de plantas de manera progresiva. Los factores abióticos, generalmente, producen daño en un momento dado y no se propagan en el tiempo. Para el "mal del ciprés" se han realizado algunos estudios de asociación espacial entre individuos sanos y afectados y se ha determinado la forma de presentación de la afección (Rosso et al. 1989, 1994). Sin embargo, no se cuenta con estudios de propagación del disturbio. De acuerdo a los datos históricos, el problema se registró inicialmente en la zona de Isla Victoria (Río Negro), luego en el noroeste de la provincia de Chubut y posteriormente en el resto del área de distribución del ciprés de la cordillera. Estos son datos de registros de aparición del problema y no deben ser considerados como estudios epidemiológicos o de propagación.

Determinar las causas de daño a la planta y sintetizar la información. Los puntos anteriores del modelo deberían permitir la discriminación entre dos grandes grupos de agentes de daño: bióticos y abióticos. Una vez hecha esta distinción se podría avanzar tratando de identificar un agente específico dentro del grupo de agentes de daño seleccionado. En el caso del "mal del ciprés", la información recabada no permite hacer la discriminación entre grupos de agentes. De acuerdo a los datos aportados, los síntomas mejor conocidos del "mal del ciprés" son la caída en la tasa de crecimiento, el amarillamiento y la 
defoliación. La caída en la tasa de crecimiento ha sido determinada por medio de técnicas dendrocronológicas, pero aún falta establecer la causa o las causas que la provocan y evaluar cada una de las hipótesis que han sido planteadas. El amarillamiento y la defoliación son síntomas muy inespecíficos y diversas causas podrían originarlos. El estudio o análisis del patrón de defoliación permitirá una mejor definición del síndrome y posiblemente ayudará a discriminar entre los probables agentes de daño. No se han señalado aún signos de la enfermedad. La investigación mediante técnicas de microscopía óptica y electrónica de diversos tejidos de plantas con y sin síntomas aéreos podría revelar signos que se relacionen con agentes o grupos de agentes específicos.

No es posible, por tanto, definir el tipo de agentes que se asocian con el disturbio. Aún falta información para establecer si el origen de la afección es biótico o abiótico, o si más de un agente (del mismo o de distinto origen) está participando en el desarrollo de la afección.

\section{EL “MAL DEL CIPRÉS” Y OTRAS ENFERMEDADES FORESTALES}

El número de enfermedades que afectan a especies forestales es muy elevado, como lo es también el número de causas o factores que las originan. En este apartado se pretende mencionar y relacionar con el "mal del ciprés" algunas enfermedades forestales que tienen etiología desconocida o que han sido muy difíciles de abordar por las características de su presentación.

Filip y Rosso (1999) comparan el "mal del ciprés" con declinamientos y enfermedades de bosques en América del Norte, discuten algunas hipótesis que han sido planteadas e indican algunos de los estudios que deberían ser conducidos en la investigación. La mortalidad y el declinamiento de Chamaecyparis nootkatensis (D. Don) Spach es una de las primeras enfermedades que ha sido relacionada con el "mal del ciprés". Hennon y Rajchenberg (2000) realizan una interesante comparación entre ambas. La etiología del declinamiento de C. nootkatensis es aún desconocida. Según Hennon et al. (1990ab, 1994) el declinamiento se presenta en bosques prístinos, puede ocurrir rápidamente (2-3 años) o lentamente en el tiempo (15 años o más) y las áreas afectadas varían en tamaño. Independientemente de cuán rápido se produzca el declinamiento de la copa, el sistema de raíces siempre está afectado al manifestarse los síntomas aéreos. La asociación entre estas dos enfermedades se ha ido acentuando en el tiempo y, en cierta forma, la investigación realizada en $C$. nootkatensis ha servido de base para direccionar los estudios en el "mal del ciprés".

Beever et al. (1996) realizan una interesante revisión sobre la búsqueda de la causa del declinamiento de Cordyline australis (Forster) Endl., detallando sintomatolo- gía, distribución, epidemiología, hipótesis y búsqueda de posibles patógenos. El esquema de trabajo planteado es amplio y complejo, con una gran variedad de técnicas y experimentos utilizados en la investigación. La complejidad en el diseño de actividades deriva de la poca especificidad de los síntomas observados y de la necesidad de evaluar una gran cantidad de hipótesis. La semejanza con el "mal del ciprés" es evidente en este sentido, ya que la sintomatología es muy poco específica y diferentes agentes podrían dar origen a los mismos síntomas.

Otras dos enfermedades que pueden ser relacionadas con el "mal del ciprés" son el declinamiento de Acer saccharum Marsh. y de Pinus taeda L.. La etiología es aún desconocida en ambos casos, aunque en el declinamiento de $P$. taeda se han hecho importantes avances. Hay disponible mucha información sobre ambas enfermedades, entre las que se seleccionaron las revisiones de Minorsky (2003) y Hess et al. (2002). Un punto de especial interés en el declinamiento de $P$. taeda es la aplicación de protocolos y estándares del Forest Health Monitoring (FHM) Program (Hess et al. 2002), y la comparación de la presencia de patógenos en suelo y raíces con indicadores FHM y de crecimiento de árboles. Parámetros como la relación de copa viva, la exposición de la copa a la luz, la densidad, dieback y transparencia de la copa son utilizados. En el declinamiento de $A$. saccharum se evalúa el efecto de insectos defoliadores en la enfermedad (Horsley et al. 2000). Fuertes correlaciones se obtienen entre el número de eventos o el índice de severidad de defoliación y el estado sanitario. Se establece que el efecto de la defoliación en los carbohidratos no estructurales de la planta (especialmente las reservas de almidón de las raíces) juega un rol crítico en el vigor del árbol. La defoliación y la sequía son asociadas con cambios bioquímicos que harían a la planta más susceptible al ataque por organismos secundarios. Importantes estudios son realizados para evaluar la relación entre la defoliación y la nutrición foliar. Algunas de estas evaluaciones o esquemas de trabajo deberían considerarse en el estudio del "mal del ciprés".

Otras enfermedades de especies forestales podrían ser comparadas y relacionadas con el "mal del ciprés" (Wargo et al. 1983, Sherald 1999, Ayres y Lombardero 2000, O'Brien et al. 2002, Roberts 2004). Una evaluación exhaustiva de estas comparaciones no puede ser incluida en este trabajo; sin embargo, sería interesante considerarlas ya que podrían surgir nuevas ideas o diseños experimentales con aplicación al "mal del ciprés".

\section{DISCUSIÓN Y CONCLUSIONES}

El manejo sistemático de la información, logrado al aplicar la guía de diagnóstico, permitió establecer que los datos existentes son aún insuficientes para discriminar entre los diferentes grupos de agentes de daño. Si 
bien es posible identificar una planta afectada, tanto por síntomas externos como internos, falta determinar la relación entre estos síntomas y los problemas a nivel de raíz. El patrón de defoliación que presentan las plantas está asociado a afección de las raíces. Sin embargo, aún no se ha establecido la causa de esta pérdida de hojas. ¿Está el origen de la defoliación en una afección inicial de raíces debida al efecto del anegamiento, a una necrosis crónica producida por hongos pitiáceos o algún otro agente? ¿El sistema radicular se ve afectado por un bloqueo de vasos floemáticos derivado de una infección viral o de bacterias fastidiosas de floema? ¿Cuál es la relación que existe entre la caída en la tasa de crecimiento, la afección de raíces, el amarillamiento y la defoliación? ¿Son todos estos procesos debidos a un mismo agente o diferentes agentes actúan en distintas etapas condicionando el patrón de desarrollo? La pérdida de hojas avanza, por lo general, de la base de la copa hacia arriba y desde el tronco hacia la periferia (Havrylenko et al. 1989, Rajchenberg y Cwielong 1993). ¿Cuáles son los procesos fisiológicos que determinan este patrón? ¿Por qué se produce un avance gradual que involucra inicialmente hojas maduras, reteniéndose en los períodos finales sólo hojas jóvenes? El análisis del patrón de defoliación es un requisito básico para definir la naturaleza del daño. Responder a las preguntas que surgen de la observación del mismo, sería clave para avanzar en el estudio.

Un sistema de asignación de patrones y tipos de vitalidad, común para todos los grupos de investigación, tendría que ser establecido. Dicho sistema no deberá basarse sólo en determinaciones visuales que pueden variar con el observador. La combinación de una serie de parámetros cuantificables en un índice parece una opción más objetiva. Un análisis sobre la utilidad de algunos de estos parámetros puede verse en Bussotti et al. (2002) o en Zarnoch et al. (2004). Es necesario, además, evaluar y determinar la relación que existe entre el patrón de marchitamiento progresivo y el patrón de afección rápida.

La falta de estudios sobre la propagación del disturbio limita la discriminación entre grupos de agentes de daño. La caída en la tasa de crecimiento radial es el síntoma más objetivo del inicio y avance del "mal del ciprés", y debería ser utilizada como base para los estudios de presentación y dispersión de la misma. Alternativamente, un estudio de propagación podría ser realizado en forma comparativa utilizando datos dendrocronológicos y datos de síntomas externos. Estudios complementarios, a través de fotos aéreas, permitirían analizar la propagación y ayudarían a definir si los síntomas internos y externos son o no debidos al mismo agente y cuál es la relación existente entre ellos. Todas estas evaluaciones serán fundamentales en el diseño de estrategias que permitan avanzar en la discriminación del origen biótico, abiótico o mixto del disturbio.

La comparación entre el "mal del ciprés" y otras enfermedades de especies forestales ha permitido compro- bar que son muchas las dificultades que encierra el diagnóstico y el manejo de tales patologías. Se han presentado ejemplos de enfermedades con sintomatología similar que son debidas a diferentes agentes de daño y que han requerido para su identificación la aplicación de técnicas y metodologías diversas. Holdenrieder et al. (2004) presentan una interesante revisión acerca de las enfermedades de especies forestales, haciendo hincapié en los desafíos que plantea la investigación de estas patologías cuando el problema se presenta a escala de bosques. Algunas herramientas cuantitativas y estrategias de investigación que podrían ser de utilidad son comentadas en dicho artículo.

La participación de agentes bióticos (distintos de los hongos) en la mortalidad de A. chilensis no está siendo investigada y debería ser tenida en cuenta. El efecto que la presencia del áfido Cinara tujafilina tiene sobre $A$. chilensis en Argentina y el papel que desempeña en el disturbio no han sido aún evaluados. El análisis de la química foliar y el estudio de los efectos que las condiciones de sitio tienen en la nutrición de la hoja y a su vez en los sistemas de defensa de la planta tampoco han sido desarrollados para el "mal del ciprés".

Los enfoques planteados en el trabajo han permitido identificar algunos puntos clave que deberían ser considerados en investigaciones futuras, entre los que se encuentran: falta de especificidad de síntomas y de estudios de propagación, ausencia de signos, subjetividad en la asignación del grado de defoliación y el estado sanitario asociado, falta de un modelo de análisis para el disturbio.

Es necesario, en síntesis, continuar la investigación del "mal del ciprés" teniendo en mente la complejidad del estudio de este tipo de disturbios forestales. La falta de signos, la falta de especificidad de los síntomas y la dificultad para establecer la asociación espacial y los patrones de dispersión o propagación de la afección obligan a considerar la participación de diferentes agentes de daño (bióticos, abióticos o mezcla de ambos) en el desarrollo del proceso y a diseñar ensayos o experimentos que sean lo suficientemente robustos como para responder a los complejos interrogantes planteados.

Es importante señalar que a la luz de la investigación realizada hasta la fecha la denominación "mal del ciprés" parece ser la más adecuada para el disturbio que afecta a la especie A. chilensis en Argentina. Esta denominación hace referencia a un síndrome complejo desde el cual, probablemente, sea posible discriminar diferentes disturbios. Cada uno de éstos, una vez definido, deberá ser nombrado de acuerdo con su agente causal.

\section{AGRADECIMIENTOS}

A la Dra. Alina Greslebin (CIEFAP, Centro de Investigación y Extensión Forestal Andino Patagónico) por el apoyo recibido y el constante intercambio de ideas. Al 
Dr. Leonardo Gallo (INTA, Instituto Nacional de Tecnología Agropecuaria) y al Dr. Mario Rajchenberg (CIEFAP) por la lectura y las recomendaciones sobre el manuscrito. A todos aquellos que anónimamente colaboraron con nuestro trabajo. La financiación del presente artículo corresponde al Proyecto Nacional 520405: Funciones y algoritmos dasométricos para manejo silvícola intenso, de aplicación en plantaciones forestales orientadas a producción de madera de alto valor agregado.

\section{REFERENCIAS}

Ayres M, M Lombardero. 2000. Assessing the consequences of global change for forest disturbance for herbivores and pathogens. Sci Total Environ. 262: 263-286.

Baccalá NB, PH Rosso, M Havrylenko. 1998. Austrocedrus chilensis mortality in the Nahuel Huapi National Park (Argentina). Forest Ecol. Manag. 109: 261-269.

Beever R, R Forster, J Rees-George, G Robertson, G Wood, C Winks. 1996. Sudden decline of cabbage tree (Cordyline australis): Search for the cause. New Zealand Journal of Ecology 20(1): 53-68.

Bussotti F, A Cozzi, M Ferretti, E Cenni, D Bettini, R Nibbi. 2002. Crown condition assessment at the CONECOFOR Permanent Monitoring Plots. Long-term ecological research in Italian forest ecosystems. J. Limnol. 61(1): 12-18.

Calí SG. 1996. Austrocedrus chilensis: Estudio de los anillos de crecimiento y su relación con la dinámica del "Mal del ciprés" en el Parque Nacional Nahuel Huapi, Argentina. Tesis Licenciado en Biología. Bariloche, Argentina. Universidad Nacional del Comahue. $143 \mathrm{p}$.

Dezzotti A, L Sancholuz. 1991. Los bosques de Austrocedrus chilensis en Argentina: ubicación, estructura y crecimiento. Bosque 12: 43-52.

Filip GM, PH Rosso. 1999. Cypress mortality (mal del ciprés) in the Patagonian Andes: comparisons with similar forest diseases and declines in North America. Eur. J. For. Path. 29: 89-96.

Gallo L, MJ Pastorino, C Donoso. 2004. Variación en Austrocedrus chilensis (D. Don) Pic. Ser et Bizzarri (Ciprés de la Cordillera). In Donoso C, R Ipinza, A Premoli, L Gallo. Variación intraespecífica en las especies arbóreas de los bosques templados de Chile y Argentina. Chile. Editorial Universitaria. p. 233-252.

Green J, O Maloy, J Capizzi. 2003. A systematic approach to diagnosing plant damage. Consultado marzo 2005. Disponible en http://oregonstate.edu/Dept/nurspest/ otherresources.htm

Greslebin AG, EM Hansen, LM Winton, M Rajchenberg. 2005. Phytophthora species from declining Austrocedrus chilensis forests in Patagonia, Argentina. Mycologia 97(1): 218-228

Havrylenko M, PH Rosso, SB Fontenla. 1989. Austrocedrus chilensis: contribución al estudio de su mortalidad en Argentina. Bosque 10(1): 29-36.

Hennon P, M Rajchenberg. 2000. El "mal del ciprés". Algunas observaciones, comparaciones e ideas. CIEFAP-Patagonia Forestal 2: 4-6.
Hennon P, E Hansen, C Shaw III. 1990a. Dynamics of decline and mortality in Chamaecyparis nootkatensis in southeast Alaska. Can. J. Bot. 68: 651-662.

Hennon P, C Shaw III, E Hansen. 1990b. Dating decline and mortality of Chamaecyparis nootkatensis in southeast Alaska. Forest Science 36: 502-515.

Hennon P, M Schultz, D Wittwer. 1994. Yellow-cedar decline. Consultado marzo 2005. Disponible en http://www.fs.fed.us/ r10/spf/fhp/sefhp/seycedar.htm

Hess N, W Otrosina, E Carter, J Steinman, J Jones, L Eckhardt, A Weber, C Walkinshaw. 2002. Assessment of loblolly pine decline in central Alabama. In Proceedings of the eleventh biennial southern silvicultural research conference. Gen. Tech. Rep. SRS-48. Asheville, NC: U.S. Department of Agriculture, Forest Service, Southern Research Station. p. 558-564.

Holdenrieder O, M Pautasso, P Weisberg, D Lonsdale. 2004. Tree diseases and landscape processes: the challenge of landscape pathology. Trends Ecol. and Evol. 19: 446-452.

Horsley S, R Long, S Bailey, R Hallett, T Hall. 2000. Factors associated with the decline disease of sugar maple on the Allegheny Plateau. Can. J. For. Res. 30: 1365-1378.

Hranilovich S. 1988. Informe Histórico sobre el "mal del ciprés" de la cordillera (Austrocedrus chilensis). Revista de la Asociación Forestal Argentina. Año XLII. 3: 58-62.

La Manna L, M Rajchenberg. 2004a. The decline of Austrocedrus chilensis forests in Patagonia, Argentina: soil features as predisposing factors. Forest Ecol. Manag. 190: 345-357.

La Manna L, M Rajchenberg. 2004b. Soil properties and Austrocedrus chilensis forests decline in Central Patagonia, Argentina. Plant and Soil 263: 29-41.

La Manna L, M Rajchenberg, L Taladiz. 2001. El "Mal del ciprés" en el Valle 16 de Octubre: ¿los suelos pueden decirnos algo? CIEFAP-Patagonia Forestal. 7: 11-12.

Minorsky P. 2003. The hot and the classic. The decline of sugar maples (Acer saccharum). Plant Physiol. 133: 441-442.

O’Brien J, M Mielke, S Oak, B Moltzan. 2002. Sudden oak death. Pest alert. United States Department of Agriculture, Forest Service. NA-PR-02-02. Consultado marzo 2005. Disponible en http://www.na.fs.fed.us/spfo/pubs/pest_al/ sodeast/sodeast.htm

Rajchenberg M, PP Cwielong. 1993. El mal del ciprés (Austrocedrus chilensis): su relación con las pudriciones radiculares y el sitio. CIEFAP, Anales Volumen 1. p. 96-108.

Roberts D. 2004. Ash tree decline. Michigan State University Extension. Consultado marzo 2005. Disponible en http:// web1.msue.msu.edu/reg_se/roberts/ash/decline.html\#what

Rosso PH, N Baccalá, M Havrylenko, S Fontenla. 1994. Spatial pattern of Austrocedrus chilensis wilting and the scope of autocorrelation analysis in natural forests. Forest Ecol. Manag. 67: 273-279.

Rosso PH, M Havrylenko, S Fontenla. 1989. Austrocedrus chilensis: asociación espacial entre individuos sanos y afectados por la mortalidad. Bosque 10(2): 85-88.

Sherald J. 1999. Elm yellows. Park Science 19 (2). Consultado marzo 2005. Disponible en http://www2.nature.nps.gov/ parksci/vol19/vol19(2)/10sherald.htm 
BOSQUE 28(1): 3-9, 2007

Varsavsky E, L Bettuci, D Rodríguez García, C Gómez. 1975. Observaciones preliminares sobre la mortalidad del ciprés (Austrocedrus chilensis) en los bosques patagónicos. Fundación Bariloche, publicación $\mathrm{N}^{\circ} 19.11 \mathrm{p}$.

Wargo P, D Houston, L LaMadeleine. 1983. Oak decline. Forest insect and disease leaflet 165. Department of Agri- culture, Forest Service. Consultado marzo 2005. Disponible en http://www.na.fs.fed.us/spfo/pubs/fidls/ oakdecline/oakdecline.htm

Zarnoch S, W Bechtold, K Stoke. 2004. Using crown condition variables as indicators of forest health. Can. J. For. Res. 34: 1057-1070.

Recibido: 26.07 .05

Aceptado: 12.01.07 

Revista de la Facultad de Agronomía, La Plata 106 (2), 2007

ISSN 0041-8676, Facultad de Ciencias Agrarias y Forestales, UNLP, Argentina.

\title{
Análisis del "Mal del Ciprés" mediante un "Modelo de Enfermedad": Vacíos de información y Perspectivas
}

\author{
V. A. El Mujtar \& E. Andenmatten \\ Instituto de Bioquímica y Biología Molecular (IBBM), Facultad de Ciencias Exactas, \\ Universidad Nacional de La Plata. \\ Ernesto Andenmatten, INTA - EEA Bariloche, Campo Forestal Gral. San Martín. \\ C.C. 26, 8430. El Bolsón. Río Negro. Argentina. \\ Email:verel@biol.unlp.edu.ar
}

\begin{abstract}
El Mujtar, V. A \& E. Andenmatten. 2007. Análisis del "Mal del Ciprés" mediante un "Modelo de Enfermedad": Vacíos de información y Perspectivas. Rev. Fac. Agron. Vol 106 (2):119-133.

El «Mal del Ciprés» afecta a la especie Austrocedrus chilensis (D.Don) Pic. Ser et Bizzarri (Ciprés de la Cordillera) en Argentina. A pesar de la importante investigación desarrollada, la etiología no ha podido ser establecida. Este trabajo presenta una revisión de la investigación sobre el tema y analiza el problema desde una perspectiva general, utilizando un modelo de enfermedad como marco referencial para el análisis y la interrelación de la información disponible.

El análisis del «Mal del Ciprés» bajo este modelo permitió identificar vacíos de información y algunas líneas de investigación que deberían ser iniciadas. Entre ellas encontramos: estudio de agentes bióticos (virus, bacterias vasculares o fitoplasmas) asociados con la enfermedad, estudios tendientes a identificar y caracterizar las especies de áfidos que colonizan $A$. chilensis, estudios microscópicos comparativos (sobre plantas con y sin síntomas), búsqueda y caracterización de plantas con resistencia o tolerancia a la enfermedad, evaluaciones sobre el papel que el anegamiento y la sequía tienen en el proceso, determinación de la existencia de estrés hídrico en plantas afectadas y desarrollo de modelos hidrológicos específicos, estudio del impacto del aumento de la radiación ultravioleta B, el ozono troposférico y el cambio climático en el proceso.
\end{abstract}

Palabras clave: Austrocedrus chilensis, hospedante, agente, ambiente, triángulo de enfermedad.

El Mujtar, V. A \& E. Andenmatten. 2007. Analysis of "Cypress Mortality» by means of «Disease Model»: Information gaps and Perspectives. Rev. Fac. Agron. Vol 106 (2):119-133.

\begin{abstract}
Austrocedrus chilensis (D.Don) Pic. Ser et Bizzarri (Ciprés de la Cordillera) is affected by Cypress Mortality (Mal del Ciprés) in Argentina. Despite that important investigation was developed, the etiology is unknown. This work present a review about the disease and analyse the problem from a general perspective. A disease model was used as referential framework.

This analysis we permitted to identify information gaps and research lines that should be initiated We mentioned only the following: to study biotic agents (virus, vascular bacterial or phytoplasmas) associated with the disease, to identify and to characterize aphids that colonized $A$. chilensis, to make comparatives microscopy studies, search resistance or tolerance to the disease, to evaluate about flooding and drought into the process, to determine if exist hydric stress in affected plants and to develop specific hydrological models, to study the impact the increase of UV-B radiation, tropospheric ozone and climatic change into the process.
\end{abstract}

Keywords: Austrocedrus chilensis, host, agent, environment, disease triangle.

Recibido: 06/07/05. Aceptado: 26/05/06 


\section{INTRODUCCIÓN}

Austrocedrus chilensis (D.Don) Pic. Ser et Bizzarri (Ciprés de la Cordillera) crece naturalmente en un área restringida, cubriendo cerca de 160.000 ha. Se distribuye a lo largo de una franja discontinua, de no más de 50 $\mathrm{Km}$ de ancho, paralela a la cordillera de los Andes. Los extremos de la distribución para Argentina $\left(39^{\circ} 30^{\prime} \mathrm{S}-43^{\circ} 44^{\prime} \mathrm{S}\right)$ y Chile $\left(32^{\circ}\right.$ $\left.39^{\prime} \mathrm{S}-44^{\circ} \mathrm{S}\right)$ han sido recientemente revisados (Gallo et al., 2004).

Una enfermedad de origen desconocido, denominada «Mal del Ciprés», afecta a esta especie en la Argentina. De acuerdo a los datos históricos, los primeros registros de la enfermedad se localizan en Puerto Piedras Blancas, Isla Victoria (Pcia. de Neuquén) en el año 1948 (Varsavsky et al., 1975), y en cipresales adyacentes al Vivero Forestal Gral. San Martín (Lote 12, Sección Golondrinas, Colonia Mixta; Epuyén al NO de la Pcia. de Chubut) en el año 1953 (Hranilovich, 1988). En la actualidad, la enfermedad está presente en casi toda el área de distribución del ciprés de la cordillera y el número de árboles afectados es cada vez mayor (Havrylenko et al., 1989). Estos datos han sido interpretados, algunas veces, como evidencia de la dispersión de la enfermedad. Sin embargo, es importante señalar que sólo son datos de registro de aparición del problema, y no constituyen evaluaciones epidemiológicas o de propagación.

Los estudios realizados han generado mucha información y han permitido que diferentes aspectos de la enfermedad sean conocidos y en cierta medida estandarizados. La importancia económica, ecológica, social y paisajística de los bosques de $A$. chilensis, la aparente expansión que la enfermedad ha tenido en los últimos tiempos y el impacto que la misma tiene en cada uno de los aspectos mencionados determinan la necesidad de continuar con la investigación a fin de identificar la etiología de la enfermedad.

Nuestro objetivo es presentar un marco referencial en el cual pueda analizarse e interrelacionarse la información disponible y definir líneas de investigación que será necesario abordar para lograr un conocimiento completo de la enfermedad, considerando sus implicancias en los ecosistemas forestales y sus posibilidades de manejo o control.

Analizaremos el "Mal del Ciprés» con un modelo general procurando contemplar la mayor cantidad de aspectos posibles. El modelo de «triángulo de enfermedad» (Francl, 2001), reúne las características deseadas. Este modelo establece que el desarrollo de la enfermedad requiere la interacción entre hospedante, agente y ambiente. El hospedante debe ser susceptible al agente de daño, el cual debe ser a su vez capaz de afectar al hospedante. El ambiente puede condicionar la acción del agente o la susceptibilidad del hospedante. Por tanto, de la interacción entre estos factores resulta el estado enfermedad y la misma no se establece si alguno de ellos es modificado. Según Franc (1998) las enfermedades en plantas se presentan cuando un agente específico, tal como una condición ambiental desfavorable persistente o la actividad de un patógeno, alteran funciones fisiológicas en la planta afectando su normal desarrollo. El término «persistente» permite distinguir entre enfermedad (la cual se desarrolla en el tiempo) e injuria (la cual ocurre más o menos en forma instantánea).

Este modelo ha sido utilizado con distintas adaptaciones en las que se incorporan el factor "tiempo", u otros factores tales como la participación del hombre o de insectos vectores (Francl, 2001).

\section{MODELO «TRIANGULO DE ENFERMEDAD»: Criterios básicos y marco de aplicación}

En esta revisión adoptaremos el modelo más simple con hospedante, agente y ambiente, en cada uno de los vértices del triángulo. La acción del hombre y la presencia de vectores serán consideradas dentro del ambiente. El efecto del anegamiento del suelo y la se- 
quía serán considerados dentro de los agentes abióticos. Dentro del ambiente consideraremos, principalmente, aspectos relacionados con condiciones de sitio. El cambio climático y su efecto sobre el sistema de estudio será desdoblado de la siguiente forma. El aumento de la frecuencia de sequías, de la radiación ultravioleta B (UV-B) y del ozono $\left(\mathrm{O}_{3}\right)$ troposférico será considerado dentro de los agentes abióticos. La influencia del cambio climático en los disturbios que afectan a los bosques (como epidemias de insectos y patógenos) será considerada dentro del ambiente. Esta distribución, en cierta forma arbitraria, es necesaria para un mejor análisis de la información recabada.

Cada uno de los vértices de este triángulo será desglosado en una serie de factores con el objeto de organizar la información disponible y analizar el aporte de cada uno al conocimiento de la enfermedad, como así también evaluar el papel que juegan en el desarrollo de la misma.

Este análisis, aún intentando abarcar una gran cantidad de aspectos, no pretende ser exhaustivo. Por el contrario, está orientado a establecer un marco de trabajo en el que otros factores puedan ser incorporados y analizados.

\section{Hospedante}

Austrocedrus chilensis es una especie forestal siempreverde. Sus individuos pueden alcanzar 30-35 m de altura, presentan copa piramidal, corteza grisácea, ligeramente rugosa y ramitas comprimidas. Tiene hojas opuestas, decusadas y escuamiformes, desiguales, siendo las laterales notablemente más grandes, anquiladas y curvadas que las faciales. A menudo se observan bandas estomáticas blanquecinas. Según Dimitri (1989) su madera tiene un peso específico de 0.5 , la albura es blanco-amarillenta y el duramen castañoocráceo claro. Las características de la copa son variables. En general es cónica y puntiaguda, pero cuando crece en lugares con alta exposición al viento, a menudo forma una copa unilateralmente desarrollada. El fuste, en general recto, rara vez está libre de ramas. Los árboles aislados poseen ramas verdes, vivas, que llegan incluso cerca del suelo. Dentro del bosque las ramas inferiores se secan, generalmente, hasta dos tercios de la altura total. Las ramas secas se pierden con dificultad (Hueck, 1978). Según Dezzoti \& Sancholuz (1991) tres tipos de bosque pueden ser identificados para A. chilensis de este a oeste: Bosque Marginal (seco), Bosque Compacto (puro), Bosque Mixto (húmedo). Sólo en algunos casos existen relaciones lineales significativas entre la edad y el diámetro de los árboles; y por tanto, la distribución de las frecuencias de las clases de tamaño no puede ser usada para inferir la estructura de edades del ciprés.

De acuerdo a la revisión presentada por Veblen et al., (1995) los principales disturbios naturales que afectan a la especie en el noroeste de la Patagonia, son el viento, los terremotos y especialmente el fuego. Los fuertes vientos de la Patagonia afectan el establecimiento de plantines y el vigor y la forma de los árboles adultos. Fuertes terremotos pueden, ocasionalmente, resultar en episodios de mortalidad y afectar la tasa de crecimiento de los árboles que sobreviven. El fuego es el disturbio más importante y en dicha revisión se analiza el efecto que tiene sobre diferentes tipos de bosque de $A$. chilensis: mésicos mixtos, puros en sitios relativamente mésicos y abiertos en laderas xéricas o hacia la estepa.

Veblen et al., (1995) obtuvieron mediante un análisis de componentes principales (PCA) los patrones más importantes en la variación del crecimiento de la especie. En la cronología, los tres primeros componentes principales (PCs) dan cuenta del $70 \%$ de la variancia total. Las relaciones, entre patrones de crecimiento y variables climáticas regionales, fueron establecidas utilizando funciones de correlación para comparar las amplitudes de los componentes principales más importantes con registros de temperatura y precipitación. Los 
autores concluyen que el crecimiento de $A$. chilensis entre los $38^{\circ}$ a $43^{\circ} \mathrm{S}$ al este de Los Andes, está fuertemente influenciado por la precipitación de noviembre y diciembre durante la estación de crecimiento. Para los árboles que crecen entre los $32^{\circ}$ y los $34^{\circ} \mathrm{S}$ al oeste de Los Andes los datos muestran una relación positiva fuerte entre la variación del ancho de anillo y la precipitación de abril a noviembre. Para los árboles que crecen entre $36^{\circ}$ a $38^{\circ}$ $\mathrm{S}$, a ambos lados de Los Andes la relación entre el crecimiento y las variables climáticas tiene poca consistencia.

Gallo et al., (2004) presentan información sobre la variación de la distribución ecológica de la especie (suelo, requerimientos hídricos, altitud, exposición), los tipos forestales asociados con $A$. chilensis, la variación genecológica (hojas, copa, semillas) y la variación genética de la especie (isoenzimas y otros marcadores génicos); e indican que $A$. chilensis es una especie con alta plasticidad (evidenciada en la variación fenotípica y genética detectadas) y por tanto con capacidad de adaptación a condiciones ambientales extremas a través de modificaciones fenotípicas. Señalan además, la posible existencia de adaptaciones de tipo evolutivo.

\section{Agentes bióticos}

\section{Hongos}

Entre los diferentes grupos de agentes bióticos, el de los hongos, es el único que ha sido ampliamente estudiado en relación con el «Mal del Ciprés» (Rajchenberg \& Cwielong, 1993; Rajchenberg et al., 1998; Barroetaveña \& Rajchenberg, 1996). Sin embargo, hasta el momento no ha sido posible establecer a ninguna especie como agente causal de la enfermedad. Las especies Coniophora arida y Postia dissecta, son responsables de las pudriciones cúbicas que se presentan en la albura y actuarían como agentes oportunistas. Diferentes especies de Phytophthora sp. han sido aisladas e identificadas en muestras de suelo y agua. Estas especies no serían patogénicas y su papel en el desarrollo de la enfermedad está aún siendo evaluado (Greslebin et al., 2005).

\section{Nemátodos}

Gobbi \& Brugni (1991), estudiaron los criconemátidos asociados a bosques de ciprés. Dos picos de abundancia en todo el gradiente, uno mayor en verano y otro en invierno, fueron establecidos. Las especies reportadas son Hemicycliophora n. sp., en sitio seco; Ogma (Seriespínula) n. sp., con la distribución más amplia, tanto en sitio como en profundidad; y Nothocriconemella mutabile, presente en bosques puros, y en verano también en bosque mixto. En un estudio sobre la fluctuación estacional de grupos tróficos de nemátodos en un bosque marginal de ciprés en la estepa arbustiva, se registraron 17 familias con 20 géneros (Gobbi \& Brugni, 1996). Los grupos tróficos más importantes mencionados son: fitoparásitos $(32 \%)$, omnívoros $(26,5 \%)$, microbiófagos (26\%), micófagos $(13,5 \%)$ y depredadores $(0,1 \%$,). La profundidad del suelo y la época del año determinarían variaciones en la abundancia de cada grupo trófico.

\section{Insectos}

Gomez \& Klasmer (1997) estudiaron un microlepidóptero que ataca frutos y semillas de Ciprés de la Cordillera. El organismo pertenece a la familia Agonoxenidae, es miembro del género Nanodacna, presenta una generación anual y un ciclo biológico sincronizado con el estado fenológico de la especie hospedante. El daño producido por este agente sobre las semillas de $A$. chilensis es importante. Ninguna asociación entre su presencia y la aparición del «Mal del Ciprés» es mencionada.

Los áfidos representan un grupo de agentes bióticos fuertemente asociados a enfermedades de plantas. La acción de los mismos puede ser directa, por remoción de savia o producción de lesiones; o indirecta, actuando como vectores de otros patógenos. El género 
Cinara Curtis contiene un gran número de especies que viven sobre coniferales, principalmente Pinaceae y Cupressaceae (Delfino, 2002). Cinara cupressi ha sido reportada en Europa, Oriente Medio, Canadá, Estados Unidos y África, viviendo sobre Juniperus, Cupressus, Thuja, Chamaecyparis, Widdringtonia, y otras coníferas. En África, produce secado de cipreses que se extiende de abajo hacia arriba y de adentro hacia fuera de la copa; y se ha instrumentado un manejo integrado de plagas que contempla prácticas silvícolas, y estrategias genéticas y biológicas (Cielsa, 1991). C. cupressi ha sido detectada en Brasil sobre Cupressus Iusitanica (Sousa-Silva \& Ilharco, 2000), en Chile afectando Austrocedrus, Cupressus, Chamaecyparis, Juniperus, Thuja, y el híbrido Cupressocyparis (Quiroz, 2004) y recientemente en Argentina atacando Cupressus. Hasta la fecha, no hemos encontrado publicaciones que registren a $C$. cupressi atacando a $A$. chilensis en Argentina. Sin embargo, desde 1926 se conoce en nuestro país la presencia de Cinara tujafilina, que tiene como hospedante a $A$. chilensis (Delfino, com. pers., 2004). Watson et al., (1999) establecieron que los áfidos comúnmente identificados como $C$. cupressi, constituyen un complejo de especies y que la especie C. tujafilina formaría parte del mismo.

\section{Agentes abióticos}

Anegamiento del suelo

Hay mucha información disponible sobre el anegamiento del suelo y los efectos que éste tiene en el desarrollo de las plantas. Una revisión exhaustiva ha sido realizada por Kozlowski (1997) sobre la respuesta de plantas leñosas al anegamiento y la salinidad. A continuación se indican los tópicos más sobresalientes de la misma, que podrían ser relevantes para la especie y/o la enfermedad que analizamos.

El anegamiento del suelo pone en marcha una variedad de procesos biológicos, quí- micos y físicos que alteran la capacidad de los suelos para soportar el crecimiento de las plantas. Los principales cambios químicos incluyen disminución o eliminación completa del $\mathrm{O}_{2}$, acumulación de $\mathrm{CO}_{2}$, aumento de la solubilidad de minerales, reducción de $\mathrm{Fe}$ y $\mathrm{Mn}$, descomposición anaeróbica de la materia orgánica, y formación de compuestos tóxicos. Los organismos aerobios, son reemplazados por anaerobios que causan desnitrificación y reducción de $\mathrm{Mn}$, Fe y S. Muchos compuestos tóxicos se acumulan en suelos anegados. Algunos son producidos en el suelo, otros son producidos por las raíces.

La tolerancia al anegamiento del suelo, varía ampliamente con la especie y el genotipo, la edad de la planta, el tiempo y la duración del proceso, y las condiciones del agua de anegamiento. En general, las angiospermas son más tolerantes que las gimnospermas. La sensibilidad varía, incluso, entre especies leñosas estrechamente relacionadas. El anegamiento durante la estación de crecimiento, afecta negativamente todas las etapas de desarrollo en plantas intolerantes a la inundación del suelo; mientras que el efecto durante la estación de dormancia tiene poco efecto a corto plazo. Las respuestas al anegamiento durante la estación de crecimiento incluyen inhibición de la germinación de semillas y del crecimiento reproductivo y vegetativo, cambios en la anatomía de la planta, senescencia temprana y mortalidad. Las respuestas específicas varían dependiendo de cada caso.

La inundación de los suelos reduce el crecimiento de raíces de la mayoría de las plantas leñosas. Debido a que el crecimiento de la raíz es más inhibido que el crecimiento de los tallos, la relación raíz/tallo disminuye. Cuando el agua drena, las plantas previamente inundadas pueden ser menos tolerantes a la sequía, ya que la absorción de agua por sus pequeños sistemas de raíces no puede cubrir adecuadamente las pérdidas por transpiración.

Los hongos micorríticos son fuertemente 
aeróbicos, por eso son raros en suelos anegados. La inundación reduce el número de hongos alrededor de las raíces del árbol y suprime la formación de nuevas poblaciones de micorrizas. Sin embargo, la sensibilidad varía entre diferentes especies de hongos micorríticos.

De acuerdo a las condiciones, los suelos inundados pueden conducir el desarrollo de pudriciones de raíz. El decaimiento de los sistemas de raíces en los suelos anegados ocurre principalmente a través del aumento de actividad de Phytophthora sp. La severidad de la afección depende de la especie de planta atacada, la especie de hongo, la duración del anegamiento, y la predisposición de la planta (derivada de la acción de distintas formas de estrés ambiental).

El daño y la inhibición del crecimiento que se observa en plantas que crecen en suelo anegados, han sido atribuidas a múltiples disfunciones fisiológicas. Entre ellas se encuentra la alteración de la relación entre hormonas, carbohidratos, minerales y agua. Bajo condiciones anaeróbicas la actividad de varias vías metabólicas es reducida o alterada. El anegamiento del suelo generalmente es seguido por una disminución relativamente rápida en la tasa de fotosíntesis en muchas angiospermas y gimnospermas (mayoritariamente por el cierre de estomas). Cuando el anegamiento se mantiene en el tiempo, la tasa de fotosíntesis sigue cayendo, por efectos inhibitorios que pueden incluir cambios en enzimas de carboxilación y pérdida de clorofila. El anegamiento del suelo disminuye la absorción de macronutrientes (especialmente $\mathrm{N}, \mathrm{P}, \mathrm{y} \mathrm{K}$ ) en plantas intolerantes a la inundación.

En el caso del «Mal del Ciprés», la asociación entre la aparición de la enfermedad y suelos con características de pobre drenaje ha sido establecida; sin embargo, el anegamiento no ha sido profundamente estudiado. Trabajos orientados a determinar la existencia de anegamiento a lo largo del año, la presencia o ausencia de compuestos tóxicos en el suelo, la alteración de procesos fisiológicos normales (caída en la tasa de fotosíntesis, deficiencias nutricionales) deberían ser tenidos en cuenta. Ellos podrían aportar datos de gran valor, que serían muy útiles para intentar determinar cuál es el papel que el anegamiento tiene en la aparición de la enfermedad.

La presencia de micorrizas en $A$. chilensis ha sido establecida por Godoy \& Mayr (1989) y Fontenla et al., (1991). Sin embargo, no existe información disponible sobre evaluaciones cuantitativas de la presencia de micorrizas en árboles afectados o no afectados. Del mismo modo, no se han realizado estudios para determinar cambios en el número de micorrizas entre sitios con y sin características de pobre drenaje.

\section{Sequía}

Según Kramer (1983) una definición del término sequía es «la ausencia de precipitación por un período de tiempo lo suficientemente largo como para generar la depleción del agua del suelo y producir daño o lesión en las plantas».

De la gran cantidad de publicaciones disponibles sobre este tema, hemos seleccionado una revisión de Hanson \& Weltzin (2000). En la misma se analizan, en el contexto del cambio climático, el efecto de la sequía y los aspectos que condicionan la respuesta de las plantas. Se indica que las especies leñosas varían ampliamente en su respuesta dependiendo, entre otras cosas, de la genética de la especie, del tipo de planta afectada (latifoliadas o coníferas), de la forma de crecimiento, y del momento en que se presenta la sequía. También se señala el efecto que ésta tiene en una comunidad de plantas, y de que forma el estrés hídrico puede condicionar el establecimiento de plantines y las interacciones planta-planta y planta-suelo. Se menciona la necesidad de analizar la interacción entre la sequía y otros factores ambientales.

Para la especie $A$. chilensis Kitzberger et al., (1995) señalan que sequías severas, o la presentación de un terremoto durante un pe- 
ríodo prolongado de sequía, llevan a una importante mortalidad de árboles. Con base en sus resultados establecen que la respuesta de un rodal al efecto de un terremoto está condicionada principalmente por factores predisponentes o sinérgicos (características del sitio, estructura del rodal, condiciones climáticas). En el mismo trabajo indican que sequías severas, en ausencia de terremotos, pueden producir idéntico efecto; poniendo énfasis en que la relación sinérgica de ambos fenómenos debe ser tenida siempre en cuenta. Villalba \& Veblen (1998) establecen que los episodios de mortalidad masiva de la especie coinciden con primaveras y veranos especialmente secos. Indican, que si bien existe una sincronicidad general a nivel regional en esta asociación, las variaciones intra-regionales en la intensidad de la sequía son reflejadas por la variación norte-sur de los patrones de mortalidad. Los mismos autores señalan que la influencia de las condiciones del sitio, en la respuesta del crecimiento a las variaciones climáticas, es importante y debe ser siempre tenida en cuenta

Calí (1996) realizó un estudio dendrocronológico en bosques de $A$. chilensis con presencia de "Mal del Ciprés». Entre sus resultados y conclusiones indica que hay diferencias significativas de crecimiento de anillos, cuali y cuantitativas, entre individuos sanos y afectados; que los disturbios climáticos cálidos-secos y/o movimientos sísmicos, pueden ser considerados como disparadores y contribuyentes al decaimiento de los árboles; que podría existir otra causa no climática que determinara el decaimiento y que las características de sitio estarían determinando el grado de asociación espacial entre los individuos afectados y sanos.

La información presentada, en este apartado y en "Hospedante» permitiría predecir que las sequías que se desarrollen durante la época de crecimiento, afectarán negativamente el crecimiento de $A$. chilensis en la zona que se extiende entre $38^{\circ}$ y $42^{\circ} \mathrm{S}$ (gran parte del área en que se desarrolla el «Mal del Ciprés»). La confirmación de dichas predicciones y el análisis del efecto que la sequía tiene sobre el crecimiento de la especie a mayores latitudes, aportarán datos de gran importancia en el entendimiento de la enfermedad.

Por otro lado, existen algunas hipótesis que relacionan la sequía con el «Mal del Ciprés» e hipótesis de estrés hídrico que deberían confirmarse (Calí, 1996; Havrylenko et al., 1989; Rajchenberg \& Cwielong, 1993). Relevamientos climatológicos y estudios con aplicación de modelos hidrológicos, serían de gran utilidad para establecer la existencia real de sequía, y la posible relación entre ésta y la enfermedad.

Una gran cantidad de modelos hidrológicos y sus aplicaciones están disponibles. Granier et al., (1999) presentan un modelo de balance de agua que permite cuantificar la duración y la intensidad de sequía en los bosques y computar índices de estrés. Zierl (2001) describe el desarrollo, la validación y la aplicación del modelo hidrológico WAWAHAMO, diseñado para simular el balance de agua y que permite predecir el contenido de humedad del suelo, la transpiración, la evaporación, la intercepción y establecer un índice de sequía anual. Correlaciones estadísticas entre estimaciones de sequía específicas de sitio y la defoliación de la copa en los árboles han sido realizadas por Zierl (2004). Martinez-Vilalta et al., (2002) presentan un modelo para predecir la mortalidad inducida por sequía en plantas leñosas. El modelo tiene una base fisiológica y asume que la mortalidad de las plantas es controlada por el balance de carbono.

Algunos de estos modelos podrían ser aplicados a los bosques de $A$. chilensis para establecer correlaciones entre los índices de estrés o sequía y la aparición de la enfermedad, la defoliación de la copa, o la disminución en la tasa de crecimiento; o podrían servir como sistemas de base para el desarrollo de modelos específicos para la especie. 


\section{Ambiente}

\section{Condiciones de Sitio}

La relación entre condiciones de sitio y aparición de la enfermedad ha sido analizada casi desde sus inicios. Las hipótesis que derivan de estos estudios, no siempre coinciden entre los distintos grupos de investigación, e incluso el papel que las condiciones de sitio cumplen en el desarrollo de la enfermedad, ha ido variando en el tiempo.

Havrylenko et al., (1989) establecen que los bosques afectados del Parque Nacional Nahuel Huapi (PNNH) están en áreas con precipitación superior a $900 \mathrm{~mm} / \mathrm{año}$, que la presencia de la mortalidad se asocia a mayor densidad y diversidad de especies arbóreas, pendiente poco pronunciada, suelos de tipo ándico con porcentajes de materia orgánica superiores en los dos primeros estratos y con $\mathrm{pH}$ ligeramente ácido. Indican que las condiciones son apropiadas para el desarrollo de microorganismos de suelo, y que podría existir un condicionamiento ambiental para el desarrollo del agente causal. Con base en estos resultados y en la caracterización de la sintomatología, infieren que un agente biótico presente en la rizosfera podría ser el agente causal de la enfermedad.

Rajchenberg \& Cwielong (1993) determinaron que los sitios con un horizonte «A» relativamente poco profundo, seguido de un horizonte arcilloso impermeable al paso del agua proporcionan las condiciones para la muerte o debilitamiento de raíces. Estas raíces serían colonizadas por hongos xilófagos, que provocarían pudrición progresiva y generarían estrés hídrico y nutritivo.

Baccalá et al., (1998) indican que los bosques que se desarrollan en sitios con altas precipitaciones y altitudes relativamente bajas, son los más proclives a presentar síntomas. Señalan, sin embargo, que no es fácil definir si la elevada humedad del suelo afecta las raíces directamente o si genera un ambiente más favorable para el desarrollo de pa- tógenos de raíz.

La Manna \& Rajchenberg (2004a) establecen que ciertas propiedades del suelo relacionadas con pobre drenaje (proximidad a cursos de agua, suelos de textura fina no alofanizados, y características redoximórficas) actúan como factores predisponentes para el desarrollo del «Mal del Ciprés». Indican que el pobre drenaje del suelo, se asocia fuertemente no sólo con la presencia de enfermedad, sino también con su patrón espacial (clasificados como agregados o desagregados). Y plantean que árboles asintomáticos presentes en áreas con un patrón desagregado de la enfermedad, deberían ser considerados como propensos a desarrollar el mal.

De acuerdo a los resultados de todos los trabajos se puede concluir que el pobre drenaje del suelo es una característica muy importante para que se desarrolle la enfermedad. Sin embargo hasta el momento, no se ha podido determinar si esta relación deriva de una alteración directa de las raíces o de una acción indirecta a través de la generación de un ambiente propicio para el desarrollo o la vehiculización de patógenos.

\section{MODELO «TRIANGULO DE ENFERMEDAD»: Vacíos de información}

Al ser el «Mal del Ciprés» una enfermedad de origen desconocido, nos propusimos encuadrar los datos de la investigación en el contexto del modelo «triángulo de enfermedad». Para ello, consideramos no sólo la información que proviene de estudios sobre el «Mal del Ciprés», sino también la información derivada de trabajos de caracterización de la especie y el ambiente. El análisis de la enfermedad bajo este modelo nos permitió identificar vacíos de información en cada uno de los vértices del triángulo (hospedante, agente, ambiente). A continuación detallamos algunos aspectos sobre los cuales falta información y destacamos la importancia del desarrollo de estudios de investigación sobre los mismos. 


\section{Hospedante}

No hemos encontrado estudios que evalúen la existencia de tolerancia o resistencia al «Mal del Ciprés». Sin embargo, la presentación de la enfermedad en el bosque sugiere que podrían encontrarse árboles con estas características. Actualmente, se pueden observar sectores donde coexisten plantas sintomáticas y asintomáticas que incluyen individuos de edades, tamaños y posiciones sociológicas similares, dentro de un ambiente que puede considerarse uniforme y con similar exposición a un posible agente de daño (GaIlo, com. pers., 2003). Estos sectores de bosque deberían ser utilizados para caracterizar la variabilidad genética existente. El hallazgo y la caracterización de plantas con resistencia o tolerancia a la enfermedad serían de gran valor, ya que permitiría contar con una herramienta muy útil en el desarrollo de estrategias de conservación.

\section{Agentes bióticos}

Algunos autores postulan la hipótesis que describe al «Mal del Ciprés» como una enfermedad de declinamiento (Filip \& Rosso, 1999; La Manna \& Rajchenberg 2004a; La Manna \& Rajchenberg 2004b). Sin embargo, la participación de nemátodos, virus, bacterias y fitoplasmas (entre otros agentes biológicos) como factores desencadenantes, predisponentes o causales no ha sido considerada hasta el momento. Estos agentes están implicados en muchas enfermedades de plantas. Aquellas producidas en cultivos y herbáceas han sido profundamente estudiadas (Agrios, 1991). El conocimiento, respecto de las enfermedades generadas en plantas forestales es más limitado. Mucho más aún en el caso de las coníferas, básicamente por la dificultad de aislar y demostrar la presencia dichos patógenos (Nienhaus, 1985).

Los datos de sintomatología del «Mal del Ciprés» podrían orientar hacia dichos agentes. Algunas enfermedades producidas por virus, bacterias fastidiosas $u$ organismos que semejan micoplasmas (MLO, micoplasma-like organisms) generan síntomas similares (Agrios, 1991; Davis, 2001; Hopkins, 2001). El patrón de agregación y la relación con factores de sitio, podrían estar relacionados con la forma de transmisión de dichos agentes (transmisión de virus por hongos o nemátodos) (Agrios, 1991).

Algunas enfermedades en Olmo (Ulmus sp.), Fresno (Fraxinus sp.), Abedul (Betula sp.), Álamo (Populus sp.), Roble (Quercus sp.) y Haya (Fagus sp.) han sido asociadas con virus. En estos casos, la asociación fue establecida por microscopía electrónica o por ensayos de transmisión (mecánica, por polen, semillas, áfidos, nemátodos, injerto) (Nienhaus, 1985). A diferencia de los virus presentes en sistemas agrícolas, que requieren de un vector biótico para su dispersión, algunos de los virus más estables (Potexviruses, Tombusviruses, Tobamoviruses) detectados en sistemas forestales se dispersan sin la ayuda de un vector biótico (Fillhart et al., 1997). Algunos virus han sido detectados en suelos y en agua (Fillhart et al., 1998). Existen pocos reportes que relacionen la infección viral con la sintomatología, el crecimiento y el desarrollo de especies forestales. En este tipo de plantas, las infecciones virales pueden producir síntomas y/o afectar negativamente el crecimiento. Los síntomas foliares, por sí solos, no son buenos indicadores de infección viral (Bachand, 1996).

Los fitoplasmas y los espiroplasmas son organismos procariotes que carecen de una pared celular verdadera. En plantas, están asociados con enfermedades de amarillamiento (yellows diseases) y varios desórdenes (alteraciones en el crecimiento, escobas de brujas). Estos patógenos están limitados a floema (Lee et al., 2001). El amarillamiento del Olmo (Sherald, 1999) y el amarillamiento del Fresno (Roberts, 2004) son enfermedades producidas por fitoplasmas. Para el primero de ellos, los síntomas pueden presentarse en todo el árbol o inicialmente sólo en una parte, 
y destacan el amarillamiento y la caída de hojas. Cuando los síntomas en las hojas se observan, las raíces finas ya han sido destruidas, y el árbol muere muy rápidamente o durante el siguiente año. Para el segundo, los síntomas son también inespecíficos (pérdida de dominancia apical, dieback, escobas de brujas) y difíciles de diferenciar de los presentes en declinamientos causados por factores ambientales adversos. Actualmente se considera a esta enfermedad de amarillamiento, como parte importante de los complejos procesos de interacción que derivan en la enfermedad de declinamiento (Pokorny \& Sinclair, 1994). El estudio de estas patologías se dificulta por la falta de relación entre el inicio del declinamiento y la detección de MLO (Sinclair et al., 1993). La falta de sincronización podría ser debida a la dificultad que existe para detectar MLO, ya sea por el bajo título presente como por la distribución errática en los tejidos. MLO han sido reportados además en Haya (Fagus sp.) y en Alerce (Larix sp.) (Nienhaus, 1985).

Según Worral (2005) los patógenos bacterianos más importantes en especies forestales son los que producen amarillamientos y marchitamientos. Los marchitamientos vasculares son enfermedades que se producen cuando las bacterias se multiplican dentro de un lugar restringido (vasos del xilema o floema) causando muerte a distancia en las partes aéreas de la planta, al interferir el movimiento de agua y nutrientes. Si la bacteria ocupa el xilema la enfermedad recibe el nombre de marchitamiento vascular, mientras que si ocupa el floema se denomina amarillamiento. Originalmente se utilizó para estas bacterias el término "fastidiosas» por la dificultad para cultivarlas en laboratorio. En la actualidad han sido desarrollados medios especiales y algunas de ellas pueden cultivarse.

La enfermedad denominada "Bacterial Scorch» o "Bacterial Leaf Scorch» es producida por bacterias fastidiosas limitadas a xilema. La más conocida de estas bacterias es
Xylella fastidiosa. Produce decoloración, marchitamiento, quemado y curvado de las hojas, y posiblemente defoliación. La enfermedad es observada con frecuencia después que el árbol sufre un estrés, por ejemplo luego de una sequía. Ulmus, Quercus, Acer y Morus son algunos de los géneros afectados por $X$. fastidiosa. Más información sobre éstas y otras enfermedades pueden encontrarse en Gould (1998), Hopkins \& Purcell (2002) y Schaad et al., (2001).

\section{Agentes abióticos}

El anegamiento del suelo y la sequía han sido relacionados, directa o indirectamente, con la enfermedad. Sin embargo, aún resta evaluar la participación de otros agentes abióticos entre los que podemos mencionar el efecto del aumento de la radiación UV- $\mathrm{B}$ y del $\mathrm{O}_{3}$ troposférico.

Caldwell et al., (1998) establecen que la radiación puede ejercer efectos directos e indirectos, ya sea sobre los organismos vivos o el ambiente abiótico. Entre los efectos indirectos incluyen los cambios en la susceptibilidad de las plantas al ataque por insectos y patógenos, cambios en el balance competitivo de las plantas y en los ciclos de nutrientes. Entre las consecuencias del efecto directo de la radiación en las plantas incluyen cambios en la forma y el funcionamiento (a través de la modificación de la actividad de los genes más que de daño en los mismos) y cambios en el rendimiento y la productividad.

Karnosky et al., (2000) presentan una interesante revisión y consideran el efecto y/o las consecuencias producidas por la radiación a nivel genético, de célula, especie, procedencia y comunidad. Establecen la necesidad de considerar la interacción de varios agentes de estrés (aumento de radiación, $\mathrm{CO}_{2}$ y $\mathrm{O}_{3}$ troposférico). Entre los efectos que mencionan figuran, cambios fisicoquímicos en la superficie de las hojas, alteraciones en la fotosíntesis, aumento de compuestos que absorben UV-B en la epidermis y los tricomas, y cam- 
bios en la expansión y morfología de las hojas. La capacidad de diferentes especies para realizar fotoreparación de los dímeros de pirimidinas o modificar el contenido de pigmentos que absorben radiación, determinaría la mayor o menor sensibilidad al UV-B. Mencionan la posibilidad de que los efectos sean acumulativos y se transmitan a la descendencia.

En nuestra búsqueda no ha surgido ningún trabajo que evalúe el efecto del aumento de la radiación UV-B sobre la especie $A$. chilensis, o que lo relacione con el «Mal del Ciprés». Sin embargo, de acuerdo a la zona geográfica en que se encuentran los bosques afectados, éste parecería ser un tópico de especial interés.

Worral (2005) indica que el $\mathrm{O}_{3}$ es un agente de polución secundario, generado a partir de agentes de polución primarios bajo la influencia de la luz ultravioleta. Entre los efectos del $\mathrm{O}_{3}$ sobre las plantas latifoliadas, indica diferentes formas de presentación de manchas de color púrpura o blanco, coalescencia y decoloración de partes de la hoja. Para las coníferas, indica moteado clorótico, alteraciones del crecimiento y a veces necrosis de las puntas de las hojas. Por último, señala que los síntomas de daño por oxidación son comunes, especialmente en las plantas del sotobosque, $y$ al final del verano.

Karnosky et al., (2000) indican que el $\mathrm{O}_{3}$ troposférico es un compuesto altamente fitotóxico. Los efectos del mismo en los árboles incluirían disminución de la fotosíntesis, aceleración de la senescencia foliar y de ramas, e inhibición del crecimiento. Los autores presentan ejemplos de la acción del $\mathrm{O}_{3}$ sobre bosques y señalan el efecto indirecto que puede tener el $\mathrm{O}_{3}$ sobre las especies y las características del sotobosque.

Rudnitski (1997) indica que el $\mathrm{O}_{3}$ puede difundir con facilidad a través de los estomas y generar radicales libres en la célula. Dichos radicales oxidan grupos activos importantes en sistemas enzimáticos de cloroplastos, llevando a una reducción de la fotosíntesis y del cre- cimiento, y producen la oxidación de componentes de membranas biológicas. La susceptibilidad del árbol a otro tipo de estrés (insectos, hongos, etc) aumenta en estas condiciones. Por último, señala que el daño por $\mathrm{O}_{3}$ tiene características acumulativas y que los síntomas son más aparentes luego de múltiples exposiciones. Dizengremel (2001) presenta una muy completa revisión sobre los efectos del $\mathrm{O}_{3}$ en el metabolismo de compuestos carbonados en especies forestales, señala que la exposición al $\mathrm{O}_{3}$ resulta en una modificación general del metabolismo primario y secundario de carbohidratos para detoxificación, protección y reparación, a expensas del crecimiento; y que la interacción del $\mathrm{O}_{3}$ con otros factores de estrés puede modificar la respuesta de la planta.

Zierl (2002) establece que el $\mathrm{O}_{3}$ troposférico contribuye a la defoliación de la copa, aunque existirían diferencias regionales y anuales en la sensibilidad de los bosques debido a diferencias en las condiciones ambientales que determinan el nivel de apertura de los estomas; y que la humedad del suelo es el factor más importante en el control de la respuesta de los estomas al ambiente durante la estación de crecimiento. La combinación más perjudicial estaría dada por concentraciones no muy altas de $\mathrm{O}_{3}$, y sequía moderada o ausente; ya que en esta situación la apertura de los estomas no está condicionada y permite que el $\mathrm{O}_{3}$ ingrese sin restricciones.

No hemos encontrado ninguna publicación sobre el efecto del $\mathrm{O}_{3}$ en la especie $A$. chilensis, o su participación en el «Mal del Ciprés». Al ser el $\mathrm{O}_{3}$ un producto secundario de la contaminación ambiental, y teniendo en cuenta la ubicación geográfica de los bosques y el escaso desarrollo industrial de la zona, parecería poco probable que este agente esté afectando la especie. Sin embargo, considerando la relación entre la incidencia de la enfermedad y las condiciones de sitio y entre la concentración de $\mathrm{O}_{3}$ en la atmósfera y el nivel de apertura de estomas, no parece acertado 
descartar totalmente la participación del $\mathrm{O}_{3}$ en el proceso.

\section{Ambiente}

Si bien se han formulado algunas hipótesis que relacionan el aumento de las sequías o las precipitaciones con la enfermedad, ningún estudio sobre el efecto del cambio climático ha sido iniciado. La información disponible sobre cambio climático es muy amplia, por lo que sólo mencionaremos algunas publicaciones que relacionan el cambio climático con la presentación de disturbios en los bosques. Aspectos relacionados con la sequía, el aumento de los niveles de $\mathrm{O}_{3}$ troposférico o la disminución de $\mathrm{O}_{3}$ estratosférico, ya han sido mencionados.

Dale et al., (2000) establecen que los disturbios son parte del ecosistema de los bosques y que el cambio climático puede alterar sus interacciones llevando a cambios extremos en la estructura y la función del bosque. Indican que el conocimiento del efecto del cambio climático en los mismos no puede ser obtenido solamente de la información del impacto de la temperatura y la precipitación, sino que es necesario entender como afecta los disturbios y como éstos afectan a los bosques. Entre los disturbios que pueden ser alterados mencionan el fuego, la sequía, las epidemias de insectos y patógenos.

Ayres \& Lombardero (2000) establecen que el cambio climático puede alterar los patrones de disturbio a través de efectos directos e indirectos y que cualquier impacto en el régimen de disturbios puede tener consecuencias ecológicas importantes (reducción de la biodiversidad, alteración de la biogeoquímica del bosque, etc.). La acción de estos disturbios en los bosques puede afectar procesos del ecosistema (evapotranspiración, flujo de $\mathrm{CO}_{2}$ y transferencia de calor) que a su vez influyen en el clima.

Schwalm \& Ek (2001) teniendo en cuenta la relación entre efectos primarios del cambio climático (alteraciones de la temperatura, aumento de $\mathrm{CO}_{2} \mathrm{y} \mathrm{O}_{3}$ ), efectos secundarios (incremento en la temperatura del suelo, actividad microbiana, cambio en el patrón de precipitación) y efectos terciarios (cambios en fenología y fotosíntesis) proponen mecanismos y entidades relacionados al sitio que deben ser incluidos en los modelos. Esta información podría ser considerada como base para el desarrollo de modelos que evalúen la influencia del cambio climático en los bosques de $A$. chilensis o en los disturbios que lo afectan.

\section{MODELO «TRIANGULO DE ENFERMEDAD»:} Conclusiones y Perspectivas

La sintomatología del «Mal del Ciprés» es inespecífica y podría ser causada por diferentes tipos de agentes o combinaciones de ellos. A diferencia de lo que ocurre con los hongos, la investigación de otros agentes bióticos no ha sido desarrollada para la enfermedad. El estudio de estos agentes debería ser iniciado, a pesar de la complejidad que presenta este tipo de trabajo en el caso de especies forestales. Estudios microscópicos comparativos, realizados en plantas de $A$. chilensis con y sin síntomas, permitirán establecer características diferenciales a nivel celular, o detectar signos que puedan ser asociados con agentes específicos. En el caso de los áfidos, la información disponible justifica el inicio de estudios tendientes a identificar y caracterizar las especies que colonizan $A$. chilensis y a establecer su asociación con la enfermedad.

Deberían iniciarse trabajos orientados a determinar cuál es el papel que el anegamiento tiene en la aparición de la enfermedad y cuál es el efecto que la sequía tiene en el proceso. Del mismo modo, las hipótesis que plantean la existencia de estrés hídrico en plantas afectadas deberían ser confirmadas. Hemos presentado en esta revisión algunos modelos hidrológicos que podrían ser aplicados al «Mal del Ciprés» para establecer correlaciones entre índices de estrés o sequía y algunos de 
los síntomas de la enfermedad; o bien podrían servir de base para el desarrollo de modelos específicos. El aumento de la radiación UV-B en la región en que se encuentran los bosques de $A$. chilensis y el efecto que el $\mathrm{O}_{3}$ tiene sobre la especie y/o su participación en el «Mal del Ciprés» deberían ser evaluados.

Hemos presentado una gran cantidad de información sobre la relación existente entre las condiciones de sitio y la aparición de la enfermedad. El pobre drenaje del suelo parece ser una característica muy importante y condicionaría en cierta forma el desarrollo del proceso. Sin embargo, la causa de dicha asociación no ha podido aún ser establecida. Las hipótesis que intentan explicar esta asociación deberían ser confirmadas.

Por último, ningún estudio sobre el efecto del cambio climático ha sido iniciado. Sin embargo, existen algunos interrogantes que merecen ser analizados, y por tanto la influencia del cambio climático en los bosques de $A$. chilensis o en los disturbios que lo afectan debería ser evaluada.

\section{AGRADECIMIENTOS}

Al Dr. Iván Quiróz Marchant (INFOR, Instituto de Investigación Forestal) y al Ingeniero Forestal Angelo Sartori (CONAF, Corporación Nacional Forestal) por toda la información aportada. A Leonardo Gallo (INTA, Instituto Nacional de Tecnología Agropecuaria) y a Mario Rajchenberg (CIEFAP, Centro de Investigación y Extensión Forestal Andino Patagónico) por la revisión y corrección del manuscrito. A Alina Greslebin (CIEFAP) y a todos aquellos que anónimamente colaboraron con nosotros.

La financiación del presente trabajo corresponde al Proyecto Nacional 520405: Funciones y algoritmos dasométricos para manejo silvícola intenso, de aplicación en plantaciones forestales orientadas a producción de madera de alto valor agregado.

\section{BIBLIOGRAFÍA}

Agrios, G. N. 1991. Fitopatología. Editorial Limusa. México. 756 pp.

Ayres, M. \& M. Lombardero. 2000. Assesing the consequences of global change for forest disturbance form herbivores and pathogens. Science of The Total Environment 262: 263-286.

Baccalá, N. B., P. H. Rosso \& M. Havrylenko 1998. Austrocedrus chilensis mortality in the Nahuel Huapi National Park (Argentina). Forest Ecology and Management 109: 261-269

Bachand, G., J. Castello, M. Schaedle, S. Stehman \& W. Livingston. 1996. Effects of tomato mosaic Tobamovirus infection on red spruce seedlings. Canadian Journal of Forest Research 26: 973-981.

Barroetaveña, C. \& M. Rajchenberg. 1996. Hongos Aphyllophorales (Basidiomycetes) que causan pudriciones en Austrocedrus chilensis en pie. Boletín Sociedad Argentina de Botánica 31: 201-216.

Caldwell, M., L. Björn, J. Bornman, S. Flint, G. Kulandaivelu, A. Teramura \& M. Tevini. 1998. Efects of increased solar ultraviolet radiation on terrestrial ecosystems. Journal of Photochemistry and Photobiology B: Biology 46: 40-52.

Calí, S. G. 1996. Austrocedrus chilensis: Estudio de los anillos de crecimiento y su relación con la dinámica del «Mal del ciprés» en el Parque Nacional Nahuel Huapi, Argentina. Trabajo para optar al Grado de Licenciado en Biología. Biblioteca C.R.U.B., U.N.Comahue, Argentina. $143 \mathrm{pp}$.

Ciesla, W. 1991. El pulgón de los cipreses amenaza de muerte a los bosques africanos. Disponible en http://www.fao.org/documents/ show_cdr.asp?url_file=/docrep/u4200s/ u4200s09.htm. Ultimo acceso Marzo 2005.

Dale, V., L. Joyce, S. McNulty \& R. Neilson. 2000. The interplay between climate change, forests, and disturbances. Science of The Total Environment 262: 201-204

Davis, M. 2001. Fastidious Phloem-Limited Bacteria. En «Laboratory Guide for Identification of Plant Pathogenic Bacteria». Schaad N., J. Jones \& W. Chun. APS Press. The American Phytopathological Society. St. Paul, Minnesota. pp: 275-282.

Delfino, M. A. \& A. Binazzi. 2002. Áfidos en Coníferas en la Argentina (Hemiptera: Aphididae). Revista de la Sociedad Entomológica Argentina, 61: 27-36.

Dezzotti, A. \& L. Sancholuz. 1991. Los bosques de Austrocedrus chilensis en Argentina: ubicación, estructura y crecimiento. Bosque 12 : 43-52.

Dimitri, M. 1989. Iconografía dendrológica: Ár- 
boles exóticos e indígenas de la Argentina. Consejo profesional de Ingeniería Agronómica. Orientación Gráfica Editora. Buenos Aires. 188 pp.

Dizengremel, P. 2001. Effects of ozone on the carbon metabolism of forest trees. Plant Physiology and Biochemistry. 39: 729-742.

Filip, G. M. \& P. H. Rosso. 1999. Cypress mortality (mal del ciprés) in the Patagonian Andes: comparisons with similar forest diseases and declines in North America. Forest Pathology 29: 89-96.

Fillhart, R., G. Bachand \& J. Castello. 1997. Airborne transmission of tomato mosaic Tobamovirus and its occurrence in red spruce in the northeastern United States. Canadian Journal of Forest Research 27: 1176-1181.

Fillhart, R., G. Bachand \& J. Castello. 1998 Detection of Infectious Tobamoviruses in Forest Soils. Applied and Environmental Microbiology. 64: 1430-1435.

Fontenla, S., M. Havrylenko \& P. H. Rosso. 1991. Micorrizas vesículo-arbusculares en Austrocedrus chilensis. Suelo y Planta 1: 251-255.

Franc, G. D. 1998. An introduction to plant pathology and plant disease management. University of Wyoming. Cooperative Extension. Service College of Agriculture. Disponible en: http:// www.uwyo.edu/plants/wyopest/TrainingManuals/ Plantpat.pdf Ultimo acceso: Abril 2005.

Francl, L. J. 2001. The Disease Triangle: A plant pathological paradigm revisited. The Plant Health Instructor. Disponible en http://www.apsnet.org/ education/InstructorCommunication/TeachingArticles/Francl/Top.html. Ultimo acceso Marzo 2005.

Gallo, L., M. J. Pastorino \& C. Donoso. 2004 Variación en Austrocedrus chilensis (D.Don) Pic. Ser et Bizzarri (Ciprés de la Cordillera). En: Variación intraespecífica en las especies arbóreas de los bosques templados de Chile y Argentina. C. Donoso, R. Ipinza, A. Premoli \& L. Gallo. Eds. Editorial Universitaria, Chile. pp: 233-252.

Gobbi, M. \& N. Brugni. 1991. Criconemátidos asociados a bosques de ciprés (Austrocedrus chilensis), Argentina. II Congreso Nacional de Fitopatología. Valdivia. Chile.

Gobbi, M. \& N. Brugni. 1996. Fluctuación estacional de grupos tróficos de nemátodos en un bosque central de Austrocedrus chilensis en Argentina. Bosque 17: 21-27.

Godoy, R. \& R. Mayr. 1989. Caracterización morfológica de micorrizas vesículo-arbusculares en coníferas endémicas del sur de Chile. Bosque 10(2): 89-98.

Gómez C. \& P. Klasmer. 1997. Ciclo biológico de un microlepidóptero que ataca los frutos y semillas del ciprés de la cordillera Austrocedrus chilensis (D. Don) Fl. et Bout. Bosque 18: 31-37.
Gould, A. 1998. Plant Disease Control. Oak Lea Scorch. Fact sheet FS875. Rutgers cooperative extensión. N. J. Agricultural Experiment Station Rutgers, The State University of New Jersey. Disponible en http://www.rce.rutgers.edu. Ultimo acceso Marzo 2005.

Granier, A., N. Bréda, P. Biron \& S. Villette. 1999. A lumped water balance model to evaluate duration and intensity of drought constraints in forest stands. Ecological Modelling 116: 269-283.

Greslebin, A. G., E.M. Hansen, L.M. Winton \& M. Rajchenberg. 2005. Phytophthora species from declining Austrocedrus chilensis forests in Patagonia, Argentina. Mycologia 97(1):218-228.

Hanson, P. \& J. Weltzin. 2000. Drought disturbance from climate change: response of United States forests. Science of The Total Environment 262: 205-220.

Havrylenko, M., P. H. Rosso \& S. B. Fontenla. 1989. Austrocedrus chilensis: contribución al estudio de su mortalidad en Argentina. Bosque 10: 29-36.

Hopkins, D. 2001. Xylella fastidiosa. En «Laboratory Guide for Identification of Plant Pathogenic Bacteria». Schaad N., J. Jones \& W. Chun. APS Press. The American Phytopathological Society. St. Paul, Minnesota. pp: 201-213.

Hopkins, D. \& A. Purcell. 2002. Xylella fastidiosa: Cause of Pierce's Disease of Grapevine and Other Emergent Diseases. Plant Disease. 86: 1066-1056.

Hranilovich, S. 1988. Informe Histórico sobre el «mal del Ciprés» de la Cordillera (Austrocedrus chilensis). Revista de la Asociación Forestal Argentina. Año XLII, 3:58-62.

Hueck, K. 1978. Los bosques de Sudamérica. Ecología, composición e importancia económica. Sociedad Alemana de cooperación técnica (GTZ). Alemania. 476 pp.

Karnosky, D., K. Percy, B. Mankovska, R. Dickson, J. Isebrands \& G. Podila. 2000 Genetic implications for forest trees of increasing levels of greenhouse gases and UV-B radiation. En: Forest genetics and sustainability. Matyas, C., ed. The Netherlands: Kluwer Academis Publishers.pp:111-124.

Kitzberger, T., T. Veblen \& R. Villalba. 1995 Tectonic influences on tree growth in northern Patagonia, Argentina: the roles of substrate stability and climatic variation. Canadian Journal of Forest Research 25: 1684-1696.

Kozlowski, T. 1997. Responses of woody plants to flooding and salinity. Tree Physiology Disponible en http://heronpublishing.com/tp/ monograph/kozlowski.pdf Ultimo acceso Marzo 2005

Kramer, P. J. 1983. Water relations of plants. New York: Academic Press, 489. 
La Manna, L. \& M. Rajchenberg. 2004a. The decline of Austrocedrus chilensis forests in Patagonia, Argentina: soil features as predisposing factors. Forest Ecology and Managment 190: 345-357.

La Manna, L. \& M. Rajchenberg. 2004b. Soil properties and Austrocedrus chilensis forests decline in Central Patagonia, Argentina. Plant and Soil 263: 29-41.

Lee, I., R. Davis \& J. Fletcher. 2001. Spiroplasmas and Phytoplasmas. En «Laboratory Guide for Identification of Plant Pathogenic Bacteria». Schaad N., J. Jones \& W. Chun. APS Press. The American Phytopathological Society. St. Paul, Minnesota. pp: 283-320.

Martinez-Vilalta, J., J. Piñol \& K. Beven. 2002. A hydraulic model to predict drought-induced mortality in woody plants: an application to climate change in the Mediterranean. Ecological Modelling 155: 127-147.

Nienhaus, F. 1985. Infectious diseases in forest trees caused by viruses, mycoplasma-like organisms and primitive bacteria. Experiencia 41 , Birkhäuser Verlag. CH-4010 Basel Switzerland.

Pokorny, J. \& W. Sinclair. 1994. Identify and Manage Ash Yellows in Forest Stands and Home Landscapes. Disponible en http:// www.na.fs.fed.us/spfo/pubs/howtos/ht ash/ ht_ash.htm Ultimo acceso Marzo 2005.

Quiroz, I. 2004. Proyecto «Manejo Integrado: Técnica para la recuperación del crecimiento de Austrocedrus chilensis. Disponible en http: // www.infor.cl. Ultimo acceso Marzo 2005.

Rajchenberg, M. \& P. P. Cwielong. 1993. El mal del ciprés (Austrocedrus chilensis): su relación con las pudriciones radiculares y el sitio. Actas Congreso Forestal Argentino y Latinoamericano. Paraná, Entre Ríos, Argentina.

Rajchenberg, M., C. Barroetaveña, P. Cwielong, M. Rossini, D. Cabral \& A. Sivori. 1998. Fungal species associated with the decline of Austrocedrus chilensis in Patagonia, Argentina: preliminary results. En: Root and Butt Rots of Forest Trees. (9 $9^{\text {th }}$ Int. Conf. Root and Butt Rots, Carcans-Maubuisson). Ed. by Delatour, C. Guillaumin, H., Lung-Escarmant, B., Marçais, B. (France), Les Colloques no 89. INRA Editions. pp: 235-244

Roberts, D. 2004. Ash tree decline. Michigan State University Extension. Disponible en http:// web1.msue.msu.edu/reg_se/roberts/ash/ decline.html\#what Ultimo acceso Marzo 2005.

Rudnitski, K. 1997. Recent tree decline in Europe. Climate and Pollution, University of Stirling. Disponible en http://www.crle.uoguelph.ca/ past $\% 20$ users/kris/education/TreeDecline.htm
Ultimo acceso Marzo 2005.

Schaad, N., J. Jones \& W. Chun. 2001. Laboratory Guide for Identification of Plant Pathogenic Bacteria. APS Press. The American Phytopathological Society. St. Paul, Minnesota. 373 pp.

Schwalm, C. \& A. Ek. 2001. Climate change and site: relevant mechanisms and modeling techniques. Forest Ecology and Management 150: 241-257.

Sherald, J. 1999. Elm yellows. Park Science 19 (2). Disponible en http://www2.nature.nps.gov/ parksci/vol19/vol19(2)/10sherald.htm Ultimo acceso Marzo 2005.

Sinclair, W., H. Griffths \& M. Treshow. 1993. Impacto of ash yellows mycoplasmalike organisms on radial growth of naturally infect white, green, and velvet ash. Canadian Journal of Forest Research. 23: 2467-2472.

Sousa-Silva, C. \& F. Ilharco. 2000. First report of Cinara cupressi (Hemiptera: Aphidoidea) in Brazil. Revista de Biología Tropical 49-2.

Varsavsky, E., L. Bettuci, D. Rodríguez García \& C. Gómez. 1975. Observaciones preliminares sobre la mortalidad del ciprés (Austrocedrus chilensis) en los Bosques Patagónicos. Fundación Bariloche, publicación $N^{\circ} 19,11 \mathrm{pp}$.

Veblen, T., B. Burns, T. Kitzberger, A. Lara \& R. Villalba. 1995. The Ecology of the Conifers of Southern South America. En «Ecology of the Southern Conifers». Enright \& Hill (Ed.) Mellbourne University Press. Australian Systematic Botany Society. pp: 120-155

Villalba, R. \& T. Veblen. 1998. Influencies of large-scale climatic variability on episodic tree mortality in northern patagonia. Ecology 79 : 2624-2640.

Watson, G. W., D.J. Voegtlin, S. T. Murphy \& R. G. Foottit. 1999. Biogeography of the Cinara cupresssi complex (Hemiptera: Aphididae) on Cupressaceae, with description of a pest species introduced into Africa. Bulletin of Entomological Research 89: 271-283.

Worral, J. 2005. Forest \& Shade Tree Pathology Disponible en www.forestpathology.org Ultimo acceso Marzo 2005.

Zierl, B. 2001. A water balance model to simulate drought in forested ecosystems and its application to the entire forested area in Switzerland. Journal of Hydrology 242: 115-136.

Zierl, B. 2002. Relations between crown condition and ozone and its dependence on environmental factors. Environmental Pollution 119: 55-68.

Zierl, B. 2004. A simulation study to analyse the relations between crown condition and drought in Switzerland. Forest Ecology and Management 188: 25-38. 



\title{
Molecular Identification of Cinara cupressi and Cinara tujafilina (Hemiptera, Aphididae)
}

\author{
VERÓNICA EL MUJTAR, ${ }^{1,2}$ JULIETA COVELLI, ${ }^{1}$ MIGUEL ANGEL DELFINO, ${ }^{3}$ AND OSCAR GRAU ${ }^{1}$
}

Environ. Entomol. 38(2): 505-512 (2009)

\begin{abstract}
A condition called "cypress mortality" affects forest of Austrocedrus chilensis (D. Don) Pic. Ser et Bizarri in Argentina. Their classic groups of symptoms has been described as a slow process of defoliation that culminating in death of the tree; nevertheless, dying and recently dead trees with abundant foliage are frequently observed in which foliage changes to red. Cinara (Cupressobium) cupressi (Buckton) is considered the agent responsible for reddening this indigenous conifer in Chile. Therefore, the relationship between the presence of C. cupressi and the new aerial symptoms in $A$. chilensis from Argentina required evaluation. However, Cinara (Cupressobium) tujafilina (del Guercio) also has been reported from this host, and the differentiation of both species of Cinara is time consuming and requires a great expertise because they share many morphologic and microscopic characters. A rapid molecular method of identification of C. cupressi and C. tujafilina is desirable to detect and differentiate them. We report the development and evaluation of a polymerase chain reaction-restriction fragment length polymorphism method based on the mitochrondial cytochrome oxidase I gene to identify C. cupressi and C. tujafilina in colonies of aphids. The first detection of $C$. cupressi from A. chilensis in Argentina, is reported based on the new method.
\end{abstract}

KEY WORDS Cinara cupressi, Cinara tujafilina, Austrocedrus chilensis, polymerase chain reactionrestriction fragment length polymorphism, cytochrome oxidase I

\begin{abstract}
Austrocedrus chilensis (ciprés de la cordillera) is an indigenous Cupressaceae of the Patagonian Andes forests of southern Argentina and Chile. In Argentina, A. chilensis forests are afflicted by what has been called "cypress mortality" (mal del ciprés). Symptoms include progressive or rapid defoliation, chlorosis, resin exudation, and brown rot in the sapwood (Varsavsky et al. 1975; Hranilovich 1988; Havrylenko et al. 1989; Rajchenberg and Cwielong 1993; Filip and Rosso 1999; El Mujtar and Andenmatten 2007a, b). The classic symptomology of the disorder has been described as a slow process of defoliation that culminates with the death of the tree; nevertheless, dying and recently dead trees with abundant foliage are now frequently observed in which case foliage changes from chlorotic to red. Because Cinara (Cupressobium) cupressi (Buckton) is considered the responsible agent for reddening of this conifer in Chile (Silva et al. 2005), the relationship between the presence of C. cupressi and the new aerial symptoms in A. chilensis in Argentina must be evaluated to distinguish cypress mortality (mal del ciprés) from other pathologies; furthermore, uncontrolled propagation of aggressive species of $\mathrm{Ci}$ -
\end{abstract}

\footnotetext{
${ }^{1}$ Instituto de Biotecnología y Biología Molecular (IBBM), CCT La Plata CONICET Facultad de Ciencias Exactas, Universidad Nacional de La Plata, Calle 49 y 115 s/n, 1900 La Plata, Buenos Aires, Argentina. ${ }^{2}$ Corresponding author, e-mail: verel@biol.unlp.edu.ar.

${ }^{3}$ Cátedra de Entomología, Facultad de Ciencias Exactas, Físicas y Naturales, Universidad Nacional de Córdoba, Comisión Nacional de Investigaciones Científicas y Tecnológicas, Córdoba, Argentina.
}

nara could produce considerable damage in Argentine forests.

Many plant diseases are vectored by aphids. They can damage the host either directly, by removal of sap and producing lesions or indirectly as vectors of pathogens. Approximately 200 species of aphids from the genus Cinara Curtis attack conifers, primarily Pinaceae and Cupressaceae, and the relationships between aphids and conifers (native or exotic) in Argentina have been described (Delfino and Binazzi 2002).

Cinara (Cupressobium) tujafilina (del Guercio) is a cosmopolitan species, more frequently present in warm and arid regions, which has been reported living on Thuja, Callitris, Chamaecyparis, Libocedrus, and Widdringtonia. Although considered strictly anholocyclic, an oviparous female has been reported (Remaudière and Binazzi 2003). C. tujafilina colonizes well-lignified twigs of its host plants, produces copious honeydew, and is attended by ants. Sooty mold fungi develop on the honeydew, causing withering, and alteration of growth can be observed. In Argentina, $C$. tujafilina was reported in 1926 as Dilachnus juniperi (de Geer) on Thuja occidentalis (Blanchard 1926). In 1990, it was detected colonizing Thuja orientalis and the native A. chilensis in El Bolsón, province of Río Negro (Delfino and Binazzi 2002). C. tujafilina is an introduced aphid but is not considered a pest in this country.

Cinara cupressi is a native species of the western Palaeartic and has been reported in Europe, North 
America, and Africa living on Juniperus, Cupressus, Thuja, Chamaecyparis, Widdringtonia, and other conifers. The life cycle is holocyclic, but in warmer and drier areas, C. cupressi shows an anholocyclic way of life (Delfino and Binazzi 2005). Although it produces a huge amount of honeydew, it is scarcely attended by ants. Watson et al. (1999) proposed that the aphids usually identified as C. cupressi constitute a species complex with C. cupressi s.l. and a new species named Cinara (Cupressobium) cupressivora Watson and Voetglin sp. n. However, Remaudière and Binazzi (2003) rejected the proposal of C. cupressivora as a new species because the criteria applied were not satisfactory. As many as $25 \%$ of the specimens could not be identified using the discrimination function proposed by Watson et al. (1999). To date, the status of $C$. cupressivora as a species remains controversial.

Stands of cypresses and junipers in many countries have been seriously damaged by C. cupressi, and outbreaks have been reported (Ciesla 1991, Watson et al. 1999). In Africa, C. cupressi causes leaf drying that progresses from bottom to top and inside out in the crown. In Chile, C. cupressi was first reported in 2003 (Silva et al. 2005) in exotic cypresses, but in 2004, it affected many species of trees (Cupressus, Chamaecyparis, Juniperus, Thuja, and hybrid Cupressocyparis) including the native conifer A. chilensis; thus exhibiting an important capacity for dispersion, climate adaptability, and use of several possible host species. On A. chilensis, it produces reddening of foliage and regressive mortality of twigs, which become blackish inside from growth by the developing of sooty mold fungi (Silva et al. 2005). C. cupressi is considered an important pest in Chile, and silvicultural, chemical, and biological controls have been implemented (Silva et al. 2005). In Argentina, Delfino and Binazzi (2005) reported the first certain detection of $C$. cupressi in 2001 in exotic cypresses used as ornamental trees in Córdoba province (center of the country) and later in 2003 in Santa Cruz province (southeastern part of the country), showing a wide distribution of this aphid. $C$. cupressi was not reported from southwestern Argentina, but in a collection carried out during springsummer 2006-2007 from El Bolsón province of Río Negro, we detected this species colonizing Cupressus sp. (ornamental trees) and the indigenous conifer $A$ chilensis. However, because the last previous survey for this region was conducted in 1990, it is not possible to define the date of entry of C. cupressi.

Only C. cupressi and C. tujafilina have been reported from A. chilensis forests among the Cinara species. Other species of the Cinara genus reported from southwestern region of Argentina are introduced and colonize exotic species of trees used in plantations or as ornamental. Cinara (Cupressobium) juniperi (de Geer), colonize Juniperus communis L.; Cinara maritimae (Dufour) colonize Pinus contorta, Cinara piceae (Panzer) colonize Picea sp. and Cinara pilicornis (Hartig), and Cinara costata (Zetterstedt) colonize Picea abies L. Karst. (Delfino and Binazzi 2002).

Traditional differentiation among species in the genus Cinara requires microscopic observations and morphometric analyses of the specimens. The differentiation between C. cupressi and C. tujafilina is time consuming and requires great expertise because they share many morphological and microscopic characters. Both have spinopleural sclerifications on the thorax and first to second abdominal tergites; their tibiae are pale except at the distal end, but C. cupressi also has a dark basal end. Femora pigmentation is useful in the identification because apterous C. tujafilina always have pale femora whereas C. cupressi has a more or less darker distal half. Nevertheless, this character is highly variable on C. cupressi. An evaluation of supplementary characters such as hairs on rostral segment III and hairs on antennal segment VIb are needed to differentiate C. tujafilina from $C$. cupressi with very pale femora. A key to the 12 species of the subgenus $\mathrm{Cu}$ pressobium thus far known in the world (C. smolandiae, C. dahurica, C. lalazarica $\mathrm{n}$. sp., C. petersoni, C. mordvilkoi, C. juniperi, C. oxycedri, C. louisianensis, $C$. pseudosabinae, C. tujafilina, C.cupressi, and C. fresai) has been presented by Remaudière and Binazzi (2003).

Taxonomic and phylogenetic research on insects has used many molecular markers for diagnostics of various entomological groups. Mitochondrial DNA (mtDNA) is useful as a molecular marker because of the uniform and simple organization of the genome, the lack of recombination, higher mutation rate than coding nuclear DNA, and high ratio of mitochondria to nuclei per cell (Loxdale and Lushai 1998). Universal primers have been developed for conserved mtDNA sequences flanking regions useful for phylogenetic and population studies (Simon et al. 1994, Folmer et al. 1994, Lunt et al. 1996). Taxonomic and phylogenetic studies have used mitochondrial or nuclear genes as cytochrome oxidase I and II (CO-I and COII), nuclear elongation factor $1 \alpha$, and leucine tRNA (Loxdale and Lushai 1998, Normark 2000). DNAbased approaches targeting the mitochondrial gene encoding for CO-I have been largely used for the identification of insects from several orders (Otranto et al. 2003, Asokan et al. 2007, Lozier et al. 2008) and of immature stages (Harvey et al. 2003, Chen et al. 2004, Thyssen et al. 2005). One approach is to use restriction fragment length polymorphisms (RFLP) from mtDNA to distinguish, for example, lineages of honey bee subspecies (Hall and Smith 1991), species of noctuids (Lepidoptera) morphologically indistinguishable at the early larval stage (Roehrdanz 1997), aphid biotypes (Sunnucks et al. 1997, Shufran 2003), aphid taxa (Valenzuela et al. 2007), and Phortica species (Cantacessi et al. 2008, Otranto et al. 2008).

The Cinara Curtis genus was studied by Normark (2000), who used molecular systematics to reconstruct evolution of the aphid family Lachnidae based on sequences of nuclear elongation factor $1 \alpha$ and CO-II. Favret and Voegtlin (2004) provided an important molecular phylogenetic analysis of Cinara species, associated with pinyon pines in the southwestern United States, using CO-I and nuclear elongation factor $1 \alpha$ DNA sequences. 

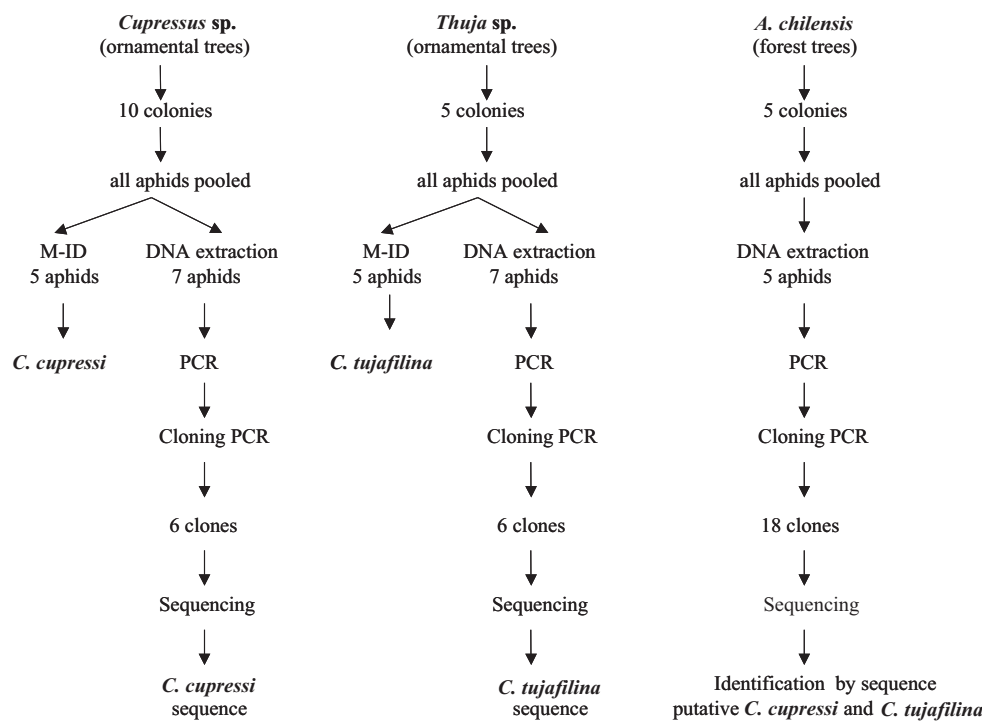

Fig. 1. Flow chart of processing of Cinara aphid samples for each host, including morphological identification (M-ID), molecular identification, DNA extraction, PCR, and sequencing.

Nevertheless, a diagnostic molecular identification tool for C. cupressi and C. tujafilina was not available. A rapid diagnostic method is needed to establish if $C$. cupressi is responsible for the observed reddening of foliage in A. chilensis from Argentina. Thus, the aim of this work was the development and evaluation of a PCR-RFLP method based on the CO-I gene to identify C. cupressi and C. tujafilina in colonies of aphids from A. chilensis.

\section{Materials and Methods}

Sample Collection and Morphological Identification. Representative colonies of aphids were collected from Cupressus sp., Thuja sp., and A. chilensis in El Bolsón, Río Negro province, Argentina (Fig. 1). Aphids were preserved for morphological examination in $65 \%$ ethanol. Later, aphids were prepared following the method for mounting small insects in Canada balsam proposed by Remaudière (1992). The criteria proposed by Watson et al. (1999), Remaudière and Binazzi (2003), and Delfino and Binazzi (2005) were used for the morphological identification of the species.

PCR Amplification and Sequencing. The development of a molecular identification method requires specimens of each species under study. The special preparations of adult specimens for morphological identification under microscopic observation invalidates those specimens for later use in molecular analysis. The alternative method proposed by Favret and Voegtlin (2004) that involves extracting embryos from the adults used for the morphological identification and using those embryos for molecular procedures was not possible because of the long distances among the sample area in Patagonia and the laboratories in Córdoba and in La Plata.
Our preliminary observations in the study area showed that ornamental trees of Cupressus sp. are colonized by C. cupressi and that ornamental trees of Thuja sp. are colonized by C. tujafilina. In contrast, surveys from A. chilensis forests showed that C. $\mathrm{cu}$ pressi and C. tujafilina both live on this host and that the pigmentation of legs of these aphids is highly variable. For this reason, representative colonies of aphids were collected from Cupressus sp. and Thuja sp. to determine the nucleotide sequences of C. cupressi and C. tujafilina, respectively. Because aphids reproduce parthenogenetically during summer and often form colonies of genetically similar individuals (Loxdale and Lushai 2003), several colonies (at least five) of each species were collected from different twigs or branches for use in detecting intraspecific genetic diversity. Aphids used for DNA extraction were preserved in $96 \%$ ethanol. DNA was extracted from pools of seven individuals of $C . \mathrm{cu}$ pressi or C. tujafilina from colonies that had been morphologically identified and from pools of five unidentified aphids collected from A. chilensis (Fig. 1). The DNA extraction method reported by Hammond et al. (1996) was used.

The universal primers COIS, 5'-GGAGGATTTGGAAATTGATTAGTTCC-3' (Cl-J-1718; Simon et al. 1994) and COIA, 5'-GCTAATCATCTAAAAATTTTAATTCCTGTTGG-3' (C1-J-2441; modified from Simon et al. 1994) were used to amplify a fragment of CO-I ( $\approx 690$ bp excluding primers sequences). Reactions were done in $25 \mu \mathrm{l}$ in $1 \times$ TaqDNA polymerase buffer, $200 \mu \mathrm{M}$ each dNTPs, $0.5 \mu \mathrm{M}$ forward and reverse primers, $2 \mathrm{mM} \mathrm{MgCl}_{2}$, and $0.02 \mathrm{U} / \mu \mathrm{l}$ of TaqDNA polymerase (Invitrogen Life Technologies). A GeneAmp PCR System 9700 thermocycler (Applied Biosystems) was used. The thermal cycling parameters were initial denaturation at $94^{\circ} \mathrm{C}$ for 6 min followed by 
Table 1. Host, morphological, and molecular identification of Cinara aphid species, haplotype sequences, and GenBank accession no. of the sequenced clones

\begin{tabular}{|c|c|c|c|c|c|}
\hline Host & $\begin{array}{l}\text { Morphological } \\
\text { identification }\end{array}$ & $\begin{array}{l}\text { No. of } \\
\text { clones }\end{array}$ & Haplotype & Accession no. & $\begin{array}{c}\text { Molecular } \\
\text { identification }\end{array}$ \\
\hline \multicolumn{6}{|c|}{ A. Ornamental trees } \\
\hline Thuja sp. & C. tujafilina & 5 & 1 & EU881684 $4^{a}$ & C. tujafilina \\
\hline Thuja sp. & C. tujafilina & 1 & 2 & EU881683 & C. tujafilina \\
\hline Cupressus sp. & C. cupressi & 6 & 4 & EU $881687^{b}$ & C. cupressi \\
\hline \multicolumn{6}{|l|}{ B. Forest trees } \\
\hline A. chilensis & Unidentified & 2 & 1 & EU881685 $5^{a}$ & Putative C. tujafilina \\
\hline A. chilensis & Unidentified & 1 & 3 & EU881686 & Putative C. tujafilina \\
\hline A. chilensis & Unidentified & 10 & 4 & EU881688 ${ }^{b}$ & Putative C. cupressi \\
\hline A. chilensis & Unidentified & 1 & 5 & EU881689 & Putative C. cupressi \\
\hline A. chilensis & Unidentified & 1 & 6 & EU881690 & Putative C. cupressi \\
\hline A. chilensis & Unidentified & 1 & 7 & EU881692 & Putative C. cupressi \\
\hline A. chilensis & Unidentified & 2 & 8 & EU881691 & Putative C. cupressi \\
\hline
\end{tabular}

Sequences ${ }^{a}$ or ${ }^{b}$ were respectively identical but they were submitted with different accession numbers because EU881684 and EU881687 were obtained from morphologically identified aphids.

35 cycles consisting of denaturation at $94^{\circ} \mathrm{C}$ for $1 \mathrm{~min}$ annealing at $50^{\circ} \mathrm{C}$ for $90 \mathrm{~s}$, and extension at $72^{\circ} \mathrm{C}$ for $90 \mathrm{~s}$, and final extension at $72^{\circ} \mathrm{C}$ for $5 \mathrm{~min}$. All amplifications were electrophoresed in $2.0 \%$ agarose gel $(1 \times \mathrm{TAE})$. Amplicons of the expected size were sliced from the gel, purified with the GENECLEAN Kit (QbioGene; MP Biomedicals), and cloned in pCR 2.1-TOPO vector (Invitrogen Life Technologies). Plasmid DNA was prepared using a modified Alkaline Lysis/PEG method (P/N 4305080; Applied Biosystems). At least six positive clones were sequenced (MACROGEN) from both directions using BigDyeTM terminator cycling conditions and an Automatic Sequencer (3730xl; Applied Biosystems). Sequences were compared with those of the known species available at GenBank with the BLASTN search utility (Altschul et al. 1997). All unique haplotype sequences have been deposited in GenBank (Table 1). DnaSP (Rozas et al. 2003) was used to analyze monomorphic and polymorphic sites.

Molecular Identification by PCR-RFLP. Sequences of C. cupressi and C. tujafilina were aligned using ClustalX (Thompson et al. 1997), edited with Bioedit (Hall 1999), and analyzed with Clone Manager (Scientific and Educational Software 1995) to find and select one restriction enzyme useful to differentiate these species.

To test the effectiveness of the single restriction site to differentiate the species, plasmid preparations of positive clones were quantified with Qubit Fluorometer using Quant-iT dsDNA BR Assay Kit (Molecular Probes; Invitrogen Detection Technologies), and dilutions of $100 \mathrm{ng} / \mu \mathrm{l}$ were amplified with the COIS and COIA primer pair using the same conditions as the original PCR. Seven microliters of each PCR product was digested with $1.0 \mathrm{U}$ of endonuclease HaeIII (New England Biolabs) in a total volume of $10 \mu \mathrm{l}$ (containing the appropriate buffer and water) at $37^{\circ} \mathrm{C}$ for $1 \mathrm{~h}$. Digestions were electrophoresed in a $2 \%$ agarose gel ( $1 \times \mathrm{TAE})$, and the product was visualized by ethidium bromide staining. To test the PCR-RFLP method for differentiating field-collected aphids, DNA extracted from seven individuals of C. cupressi or
C. tujafilina (from morphologically identified colonies) were amplified with the COIS and COIA primer pair and the amplicons were digested with HaeIII, using the same conditions mentioned above. Digestions were electrophoresed and visualized as described above in $2 \%$ agarose gel ( $1 \times$ TAE).

\section{Results}

Morphological Identification. Morphological identification of species was performed as indicated in the Materials and Methods section on representative individuals collected from Cupressus sp. and Thuja sp. Under microscopic observation, aphids collected from Cupressus sp. were C. cupressi and those collected from Thuja sp. were C. tujafilina. These results agree with our preliminary observations in the study area. Individuals collected from A. chilensis were not used for morphological identification.

PCR Amplification and Sequencing. DNA extracted from individuals from colonies that had been morphologically identified (C. cupressi from Cupressus sp. or C. tujafilina from Thuja sp.) were amplified, cloned, and sequenced. Sequences of six clones from C. $\mathrm{cu}$ pressi and C. tujafilina were used to query sequences available in GenBank through BLAST searches. Sequences from C. tujafilina had $99 \%$ nucleotide identity to sequences of CO-I from C. tujafilina reported in Europe by Durak et al. (2008). Sequences from $C$. cupressi showed 91-92\% nucleotide identity with $C$. tujafilina. The sequences of $C$. cupressi reported here are the only ones available in the databases. This difference in sequences provided the basis for a molecular identification method. All unique haplotype sequences deposited in GenBank are shown in Fig. 2. Codon positions are indicated with alternating triplets of capital and small letters in the first sequence. DNA extracted from unidentified aphids collected from $A$. chilensis was also amplified, cloned, and sequenced as indicated above. Sequences of 18 positive clones were blasted and grouped in two sets, based on 99 (3 clones) and $91 \%$ ( 15 clones) nucleotide identity to sequences from C. tujafilina reported by Durak et al. (2008). The 

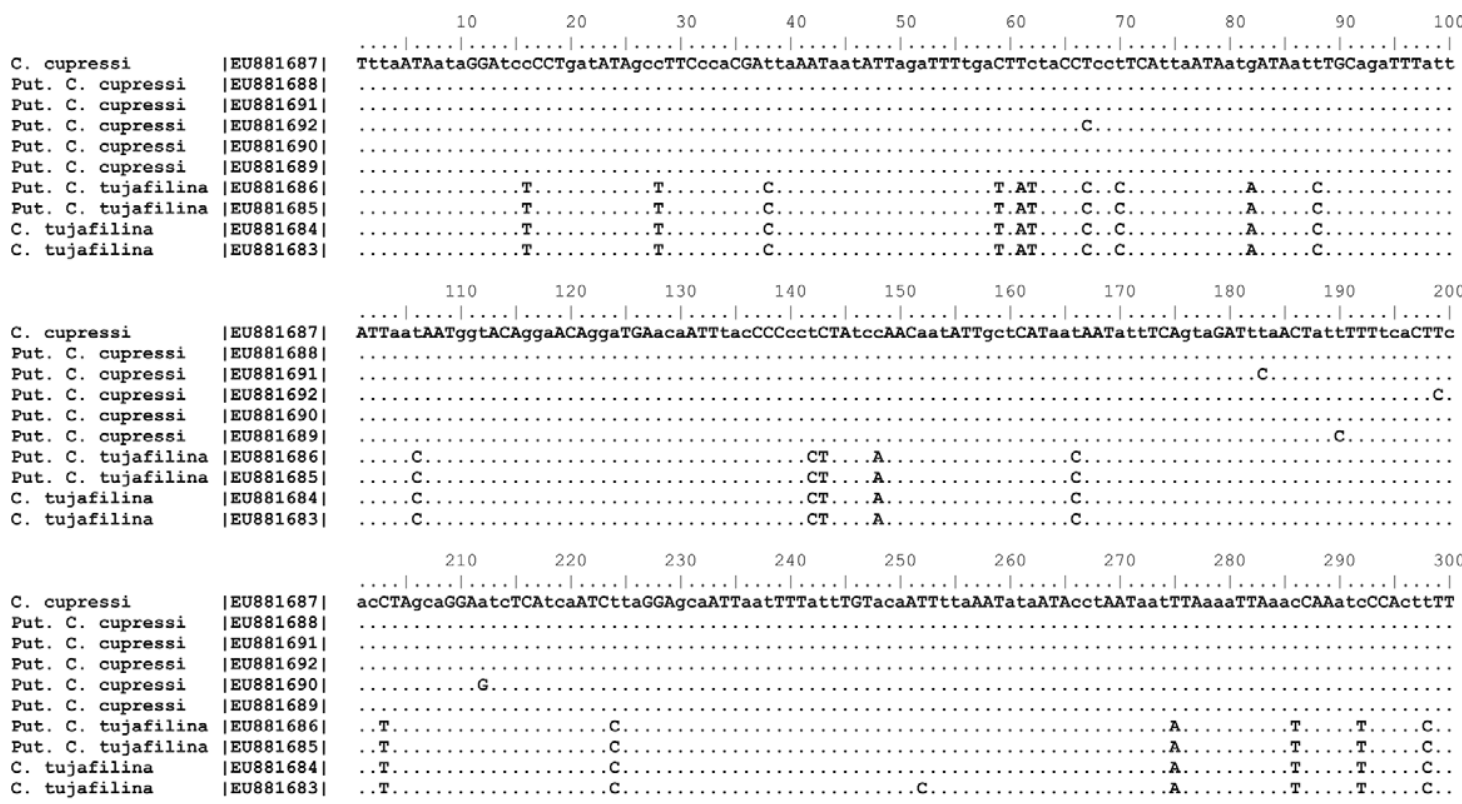

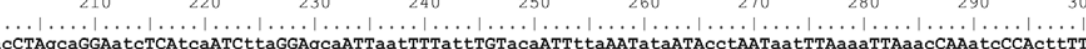

acCTAgCaGGAatcTCAtcaATCttaGGAgcaATTaatTTTattTGTacaATT taAATa taATACCTAATaatTTAaaaTTAaacCAAatcCCActtTT

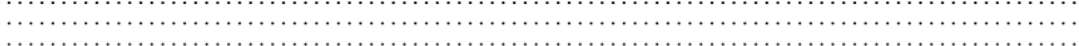

...........

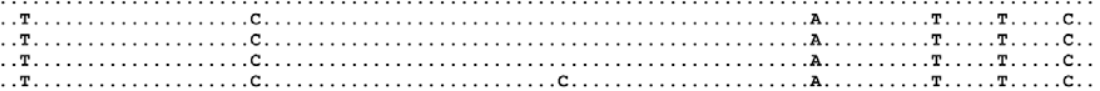

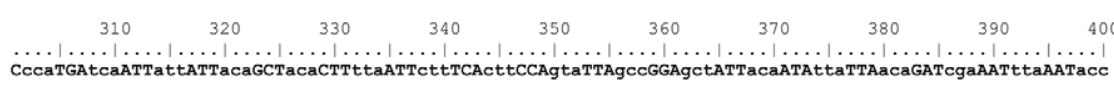

$\begin{array}{ll}\text { C. cupressi } & \text { |EU881687| } \\ \text { Put. C. cupressi } & \mid \text { EU881688| }\end{array}$

Put. C. cupressi cupressi

Put. C. cupressi |EU881690|

Put. C. cupressi |EU881689|

Put. C. tujafilina |EU881686|

put. C. tujafilina |EU881685|

c. tujafilina |EU881684|

c. tujafilina |EU881683|

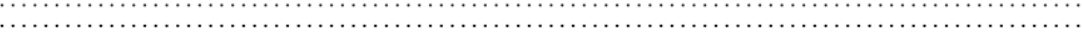

T..............

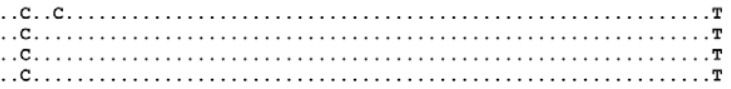

$\begin{array}{ll}\text { C. cupressi } & \text { |EU881687| } \\ \text { Put. C. cupressi } & \mid \text { EU881688| } \\ \text { Put. C. cupressi } & \text { |EU881691| } \\ \text { Put. C. cupressi } & \text { |EU881692| }\end{array}$

Put. C. cupressi |EU881692

Put. C. cupressi |EU881689|

Put. C. tujafilina |EU881686

Put. C. tujafilina |EU881685|

c. tujafilina |EU881684

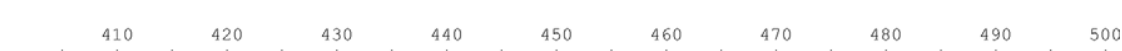

TCAtttTTTgacCAACaGGAggaGGAgatCCAattTTA ta

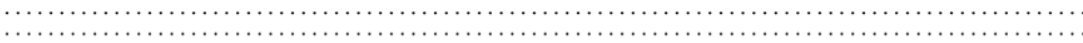

acc.

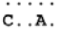

C. A.
C..A.
C.A.

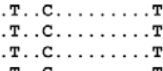

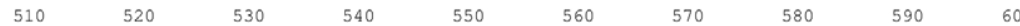

$\begin{array}{ll}\text { C. cupressi } & |\mathrm{EU} 881687| \\ \text { Put. C. cupressi } & |\mathrm{EU} 881688|\end{array}$

Put. C. cupress

|EU881692

Put. C. cupressi |EU881690|

Put. C. cupressi |EU881689|

Put. c. tujafilina |EU881686

\begin{tabular}{l|l} 
Put. C. tujafilina |EU881685| \\
C. tujafilina & $|\mathrm{EU} 881684|$
\end{tabular}

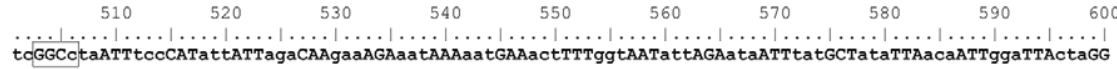

G...

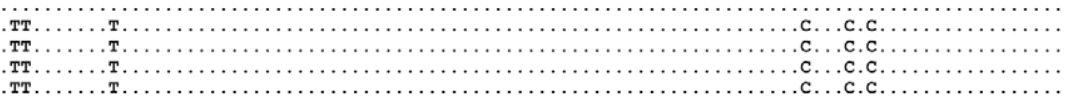

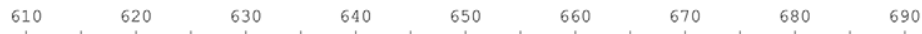

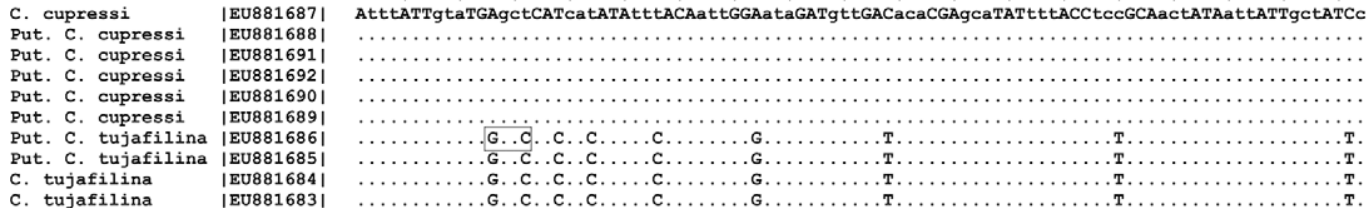

Fig. 2. Alignment of unique CO-I haplotype sequences for Cinara aphid species deposited in GenBank blocks indicate diagnostic HaeIII restriction sites (GGCC). Alternating triplets of capital and small letters in topmost sequence indicate codon positions. Dots indicate identical nucleotides as the topmost sequence.

group with lower identity had the same nucleotide sequences as those obtained from aphids collected from Cupressus sp. All unique haplotype sequences deposited in GenBank were aligned (Fig. 2) and easily classified in this way as putative C. tujafilina and putative C. cupressi. 


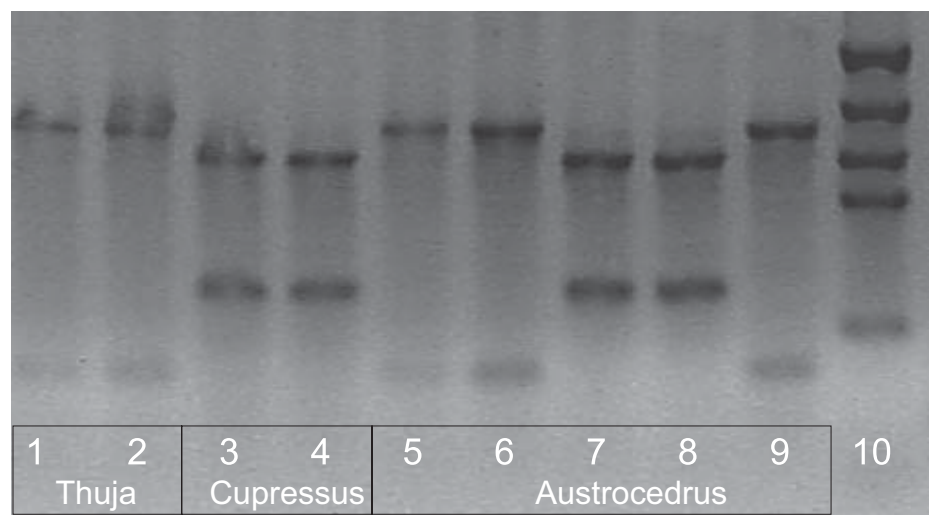

Fig. 3. Patterns of clones amplified with COIS and COIA primers, digested with $\mathrm{Hae} \mathrm{III}$ and electrophoresed in $2 \%$ agarose gel in $1 \times$ TAE. Clones of C. tujafilina collected from Thuja sp. (lanes 1 and 2); clones of C. cupressi collected from Cupressus sp. (lanes 3 and 4), and clones from aphids collected from A. chilensis (lanes 5-9). Molecular marker (lane 10): pcDNAII digested with $D d e \mathrm{I} / \mathrm{XhoI}(1,140,758,540,409$, and $166 \mathrm{bp})$.

Forty-four polymorphic sites were detected at the interspecific level. Minimal intraspecific nucleotide diversity was detected in C. tujafilina, and all sequences of C. cupressi were identical (Fig. 2; Table 1). The more frequent haplotype sequences of C. cupressi and C. tujafilina were also present in aphids collected from A. chilensis (putative C. cupressi and putative $C$. tujafilina); nevertheless, a higher nucleotide diversity was detected among these clones (Fig. 2; Table 1). More sequences will be needed to define precisely the frequency and the distribution of polymorphic sites by species and hosts, because that could be a result of a higher number of clones used from A. chilensis.

PCR-RFLP Method. C. cupressi and C. tujafilina sequences were compared, and HaeIII was selected from the possible restriction enzymes because it produces patterns of bands that can be easily differentiated in a $2 \%$ agarose gel. The differential restriction sites for HaeIII are shown in Fig. 2. A pattern with two bands of 530 and $220 \mathrm{bp}$ is expected for C. cupressi and a pattern with two bands of 640 and $110 \mathrm{bp}$ is expected for C. tujafilina.

Plasmid preparations of clones from C. cupressi and C. tujafilina were quantified, amplified, and digested with HaeIII. The banding patterns of two different clones from each species are shown in Fig. 3: C. tujafilina (lanes 1 and 2) and C. cupressi (lanes 3 and 4). The fragments had the expected size and both species can be easily discriminated.

DNA extracted from unidentified aphids collected from A. chilensis was quantified, amplified, and cloned. Five clones were digested to evaluate the performance of the PCR-RFLP method. The resulting patterns are shown in Fig. 3 (lanes 5-9): three of these five clones showed the pattern of C. tujafilina (lanes 5, 6, and 9) and two showed the pattern of C. cupressi (lanes 7 and 8).

DNA extracted from aphids collected from Thuja sp. and Cupressus sp. were also amplified by PCR, digested, and electrophoresed without cloning. Patterns predicted for C. tujafilina and C. cupressi were observed (Fig. 4).

\section{Discussion}

A rapid and easy method for distinguishing C. $\mathrm{cu}$ pressi and C. tujafilina is urgently needed because of recent reports of C. cupressi, a dangerous pest of cypresses, colonizing several host species in Brazil, Chile, and Argentina (Sousa-Silva and Ilharco 2001, Delfino and Binazzi 2005, Silva et al. 2005, Ortego 2006). Morphological differentiation between C. cupressi and C. tujafilina is possible, but complex and time consuming. A molecular identification method

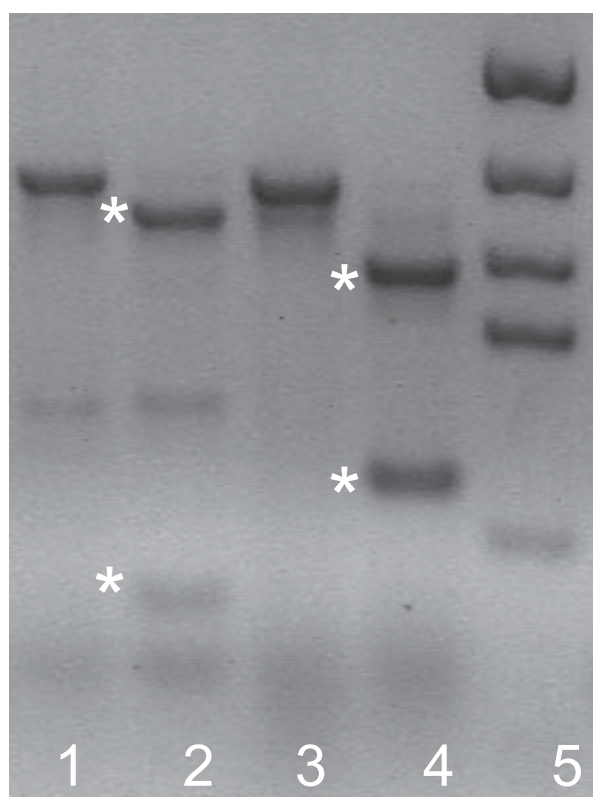

Fig. 4. Patterns of amplicons obtained by PCR (lanes 1 and 3 ) and those by PCR-RFLP (lanes 2 and 4) electrophoresed in $2 \%$ agarose gel in $1 \times$ TAE. Lanes 1 and 2 , from $C$. tujafilina collected from Thuja sp; lanes 3 and 4, from $C$ cupressi collected from Cupressus sp. Molecular marker (lane 5): pcDNAII digested with $D d e I / X h o I ~(1,140,758,540,409$, and $166 \mathrm{bp}$ ). *Expected bands for C. cupressi and C. tujafilina. 
seemed desirable for this task. In this work, we described the utility of a region in the mitochondrial CO-I gene as containing enough sequence variation between $C$. cupressi and C. tujafilina to be used for diagnostics. Based on this information, we developed a PCR-RFLP method to discriminate these species. The molecular identification method relies on a single restriction enzyme (HaeIII), but other endonucleases such as ApoI or PstI could be used as well. While intraspecific variation could confuse species identification, we found only a little intraspecific variation in our samples, which does not affect the HaeIII restriction sites or those of the proposed alternative enzymes (ApoI or PstI).

Samples from A. chilensis were easily classified in this way as putative C. tujafilina and putative C. $\mathrm{cu}$ pressi according to our preliminary observations of both species on A. chilensis, and this confirm the first detection of $C$. cupressi in this indigenous conifer in Argentina. However, the ratio of $15 / 3$ (putative $C$. cupressi/putative C. tujafilina) clones cannot be taken as the ratio of both species in the population. More samples are needed to determine this relative frequency.

This method promises to be a valuable tool for analyzing seasonal variation in occurrence distribution among regions and hosts, and distribution within individual trees for both species. However, more populations from both species should be tested to validate the application of this PCR-RFLP method in different geographic regions.

Foottit et al. (2008), using a region of the CO-I gene from 300 species from $>130$ genera of aphids, detected low intraspecific variation and showed that molecular methods are useful for identification of aphid species. Reported sequences of the mitochondrial CO-I gene have been amplified using different primer combinations (Favret and Voegtlin 2004, Durak et al. 2008, Foottit et al. 2008), and some intraspecific variation can be detected in the overlapping regions [e.g., $C$. pergandei (Wilson), C. coloradensis (Gillette), Eulachnus rileyi (Williams)]. We initially assayed the specific primers reported by Favret and Voegtlin (2004); however, the amplification level was lower than that obtained with the COIS and COIA primer pair that we used in our work.

The developed PCR-RFLP method probably can be extended to other Cinara species that live in the native and exotic conifers in Argentina by combining several restriction enzymes. A similar method has been used by Valenzuela et al. (2007) to identify 25 aphid species commonly found in southern Australia. Analysis of available sequences in GenBank predict that $\mathrm{C}$. $\mathrm{Cu}$ pressi and C. tujafilina could be separated from all species of the Cinara genus reported by Favret and Voegtlin (2004) using the PCR-RFLP method based on HaeIII

\section{References Cited}

Altschul, S. F., T. L. Madden, A. A. Schäffer, J. Zhang, W. Miller, and D. J. Lipman. 1997. Gapped-BLAST and
PSI-BLAST: a new generation of protein database search programs. Nucleic Acids Res. 25: 3389-3402.

Asokan, R., K. Kumar, and A. Verghese. 2007. Molecular identification of fruit flies, Bactrocera spp. (Diptera Tephtitidae) using mitochondrial cytochrome oxidase I. Curr. Sci. 93: 1668-1669.

Blanchard, E. E. 1926. Aphid notes. Part VI: Argentine species of the subtribes Callipterina, Pterochlorina, Lachnina and of the tribes Eriosamtini and Phemphigini. Physis 8: $324-327$.

Cantacessi, C., D. Traversa, G. Testini, R. P. Lia, C. Carfachia, J. Máca, and D. Otranto. 2008. Molecular identification of Phortica variegata and Phortica semivirgo (Drosophilidae, Steganinae) by PCR-RFLP of the mitochondrial cytochrome oxidase c subunit I gene. Parasitol. Res. 103 $727-730$.

Chen, W. Y., T. H. Hung, and S. F. Shiao. 2004. Molecular identification of forensically important blow fly species (Diptera: Calliphoridae) in Taiwan. J. Med. Entomol. 41: $47-57$.

Ciesla, W. 1991. Cypress aphid, Cinara cupressi, a new pest of conifers in easter and southern Africa. FAO Plant Protect. Bull. 39: 82-93.

Delfino, M., and A. Binazzi. 2002. Áfidos en Coníferas en la Argentina (Hemiptera: Aphididae). Rev. Soc. Entomol. Argent. 61: 27-36.

Delfino, M., and A. Binazzi. 2005. Further data on conifer aphids from Argentina (Aphididae Lachninae Eulachinini). REDIA 88: 3-7.

Durak, R., I. Sadowska-Woda, A. Machordom, and B. Borowiak-Sobkowiak. 2008. Biological and genetic studies of Polish populations of Cinara tujafilina. Bull. Insectol. 61: $159-160$.

El Mujtar, V and E. Andenmatten. 2007a. Análisis del "Mal del ciprés" mediante un "Modelo de Enfermedad": Vacíos de información y perspectivas. Rev. Fac. Agron. La Plata 106: $119-133$

El Mujtar, V., and E. Andenmatten. 2007b. Mal del ciprés: Búsqueda de la causa más probable de daño mediante un análisis deductivo y comparativo. Bosque 28: 3-9.

Favret, C., and J. Voegtlin. 2004. Speciation by host-switching in pinyon Cinara (Insecta:Hemiptera:Aphididae). Mol. Phylogenet. Evol. 32: 139-151.

Filip, G. M., and P. H. Rosso. 1999. Cypress mortality (mal del ciprés) in the Patagonian Andes: comparisons with similar forest diseases and declines in North America. Eur. J. For. Path. 29: 89-96,

Folmer, O., M. Black, W. Hoeh, R. Lutz, and R. Vrijenhoek. 1994. DNA primers for amplification of mitochondrial cytochrome c oxidase subunit I from diverse metazoan invertebrates. Mol. Mar. Biol. Biotechnol. 3: 294-299.

Foottit, R. G., H.E.L. Maw, C. D. Von Dohlen, and P.D.N. Hebert. 2008. Species identification of aphids (Insecta: Hemiptera: Aphididae) through DNA barcodes. Mol. Ecol. Res. 8: 1189-1201.

Hall, H. G., and D. R. Smith. 1991. Distinguishing African and European honeybee matrilines using amplified mitochondrial DNA. Proc. Nati. Acad. Sci. U.S.A. 88: 4548 4552.

Hall, T. A. 1999. BioEdit: a user-friendly biological sequence alignment, and analysis program for Windows 95/98/NT. Nucleic Acids Symp. Ser. 41: 95-98.

Hammond, J.B.W., G. Spanswick, and J. A. Mawn. 1996. Extraction of DNA from preserved animal specimens for use in ramdomly amplified polymorphic DNA analysis. Anal. Biochem. 240: 298-300.

Harvey, M. L., I. R. Dadour, and S. Gaudieri. 2003. Mitochondrial DNA cytochrome oxidase I gene: potential for 
distinction between immature stages of some forensically important fly species (Diptera) in western Australia. Forensic Sci. Int. 131: 134-139.

Havrylenko, M., P. H. Rosso, and S. B. Fontenla. 1989. Austrocedrus chilensis: contribución al estudio de su mortalidad en Argentina. Bosque 10: 29-36.

Hranilovich, S. 1988. Informe Histórico sobre el $\ll$ mal del Ciprés $\gg$ de la Cordillera (Austrocedrus chilensis). Rev. Asoc. Ftal. Arg. XLII 3: 58-62.

Loxdale, H., and G. Lushai. 1998. Molecular markers in entomology. Bull. Entomol. Res. 88: 577-600.

Loxdale, H. D., and G. Lushai. 2003. Rapid changes in clonal lines: the death of a "sacred cow". Biol. J. Linn. Soc. 79: $3-16$.

Lozier, J. D., R. G. Foottit, G. L. Miller, N. J. Mills, and G. K. Roderick. 2008. Molecular and morphological evaluation of the aphid genus Hyalopterus Koch (Insecta Hemiptera: Aphididae), with a description of a new species. Zootaxa 1688: 1-19.

Lunt, D. H., D. X. Zhang, J. M. Szymura, and G. M. Hewitt. 1996. The insect cytochrome oxidase I gene: evolutionary patterns and conserved primers for phylogenetics studies. Insect Mol. Biol. 5: 153-165.

Normark, B. 2000. Molecular systematics and evolution of the aphid family Lachnidae. Mol. Phylogenet. Evol. 14: 131-140.

Ortego, J. 2006. Actualización de la lista de Pulgones (Hemiptera: Aphididae) de Jujuy y Salta. Registro de Cinara cupressi (BUCKTON). Revista de Investigaciones Agropecuarias 35: 107-120.

Otranto, D., D. Traversa, B. Guida, E. Tarsitano, P. Fiorente, and J. R. Stevens. 2003. Molecular characterization of the mitochondrial cytochrome oxidase I gene of Oestridae species causing obligate myiasis. Med. Vet. Entomol. 17: $307-315$

Otranto, D., J. R. Stevens, G. Testini, C. Cantacessi, and J. Máca. 2008. Molecular characterization and phylogenesis of Steganinae (Diptera, Drosophilidae) inferred by the mitochondrial cytochrome c oxidase subunit I. Med. Vet. Entomol. 22: 37-47.

Rajchenberg, M., and P. P. Cwielong. 1993. El mal del ciprés (Austrocedrus chilensis): su relación con las pudriciones radiculares y el sitio. CIEFAP Anal. I: 96-108.

Remaudière, G. 1992. A simplified method for mounting aphids and other small insects in Canada balsam. Rev. Fr. Entomol. 14: 185-186.

Remaudière, G., and A. Binazzi. 2003. Les Cinara du Pakistan. II. Le sous-genre Cupressobium (Hemiptera, Aphididae, Lachninae). Rev. Fr. Entomol. 25: 85-96.

Roehrdanz, R. L. 1997. Identification of tobacco budworm and corn earworm (Lepidoptera: Noctuidae) during early developmental stages by polymerase chain reaction and restriction fragment length polymorphism. Ann. Entomol. Soc. Am. 9: 329-332

Rozas, J., J. C. Sánchez-del Barrio, X. Messeguer, and R. Rozas. 2003. DnaSP, DNA polymorphism analyses by coalescent and other methods. Bioinformatics 19: 2496 2497.

Shufran, K. A. 2003. Polymerase chain reaction-restriction fragment length polymorphisms identity mtDNA haplotypes of greenbug (Hemiptera: Aphididae). J. Kans. Entomol. Soc. 76: 551-556.

Silva, J., A. Ruilova, and A. Urrutia. 2005. El Complejo Cinara cupressi (Hemiptera: Aphididae): una amenaza para las cupresáceas nativas de Chile. CONAF 23: 1-7.

Simon, C., R. Frati, A. Beckenbach, B. Crespi, and H. Liu. 1994. Evolution, weighting, and phylogenetic utility of mitochondrial gene sequences and a compilation of conserved poymerase chain reaction primers. Ann. Entomol. Soc. Am. 87: 651-701.

Sousa-Silva, C., and F. Ilharco. 2001. First report of Cinara cupressi (Lachninae: Cinarini) in Brazil. Rev. Biol. Trop. 49: 768 .

Sunnucks, P., F. Driver, W. V. Brown, M. Carver, D. F. Hales, and W. M. Milne. 1997. Biological and genetic characterization of morphologically similar Therioaphis trifoli (Hemiptera: Aphididae) with different host utilization. Bull. Entomol. Res. 87: 425-436.

Thompson, J. D., T. J. Gibson, F. Plewniak, F. Jeanmougin, and D. G. Higgins. 1997. The ClustalX windows interface: flexible strategies for multiple sequence alignment aided by quality analysis tools. Nucleic Acids Res. 24: $4876-4882$.

Thyssen, P. J., A. C. Lessinger, A.M.L. Azeredo-Espin, and A. X. Linhares. 2005. The value of PCR-RFLP molecular markers for the differentiation of immature stages of two necrophagous flies (Diptera: Calliphoridae) of potential forensic importance. Neotrop. Entomol. 34: 777-783.

Valenzuela, I., A. A. Hoffman, M. B. Malipatil, P. M. Ridland, and A. R. Weeks. 2007. Identification of aphid species (Hemiptera: Aphididae: Aphidinae) using a rapid polymerase chain reaction restriction fragment length polymorphism method based on the cytochrome oxidase subunit I gen. Aust. J. Entomol. 46: 305-312.

Varsavsky, E., L. Bettuci, D. Rodríguez García, and C. Gómez. 1975. Observaciones preliminares sobre la mortalidad del ciprés (Austrocedrus chilensis) en los Bosques Patagónicos. Fund. Bariloche 19: 1-11.

Watson, G., D. Voegtlin, S. Murphy, and R. Foottit. 1999 Biogeography of the Cinara cupresssi complex (Hemiptera: Aphididae) on Cupressaceae, with description of a pest species introduced into Africa. Bull. Entomol. Res. 89: 271-283.

Received 16 July 2008; accepted 22 December 2008. 
Ignacio A. Mundo a,b; Verónica A. El Mujtar'; Marcelo H. Perdomo ${ }^{\mathrm{d}}$; Leonardo A.

2 Gallo $^{\mathrm{e}}$; Ricardo Villalba ${ }^{\mathrm{a}}$; Marcelo D. Barrera ${ }^{\mathrm{b}}$

4 Austrocedrus chilensis growth decline in 5 relation to drought events in northern 6 Patagonia, Argentina.

8 a. Departamento de Dendrocronología e Historia Ambiental. IANIGLA. CCT

9 CONICET-Mendoza. CC 330 - M5502IRA Mendoza, Prov. de Mendoza,

10 Argentina

11 b. LISEA - Facultad de Ciencias Agrarias y Forestales, Universidad Nacional de

12 La Plata.1900 La Plata, Prov. de Buenos Aires, Argentina

13 c. Instituto de Biotecnología y Biología Molecular (IBBM). CCT CONICET La

14 Plata-Facultad de Ciencias Exactas, Universidad Nacional de La Plata. 1900, La

15 Plata. Prov. de Buenos Aires. Argentina.

16 d. Campo Forestal Gral. San Martín, EEA Bariloche, Instituto Nacional de

17 Tecnología Agropecuaria (INTA), CC26 - 8430 El Bolsón, Prov. de Río Negro,

18 Argentina

19 e. Unidad de Genética Ecológica y Mejoramiento Forestal, INTA EEA Bariloche.

20 CC 277 - 8400 San Carlos de Bariloche. Prov. de Río Negro. Argentina.

\section{Corresponding author:}

Ignacio A. Mundo; Phone +54-261-5244207; Fax +54-261-5244201; e-mail: 
Abstract

Significant mortality of the Austrocedrus chilensis (D. Don) Pic. Ser. et Bizarri forests, locally known as "Mal del Ciprés", has been reported since 1945 for most sites across its distribution in Argentina. However, the cause of this mortality is still a topic of discussion. In this study, radial growth patterns from symptomatic and asymptomatic $A$. chilensis trees were analyzed to determine the influence of drought events on tree growth. Fifty pairs of symptomatic and asymptomatic trees with similar DBH, competition, and microsite conditions were cored at five pure A. chilensis stands near El Bolsón, Río Negro, Argentina. A reference chronology from non-affected trees was used to cross-date all cores and to determine the relationship between A. chilensis radial growth and climate. The growth of $A$. chilensis is favored by above-average precipitation in late spring early summer (November and December). A strong relationship was also observed between radial growth patterns and the Palmer Drought Severity Index (PDSI), a measure of the regional water deficit. Significant differences in growth patterns were recorded between symptomatic and asymptomatic trees. Following extreme drought events, the growth of symptomatic trees is consistently lower than in asymptomatic trees. Based on the larger number of droughts recorded during the past decades and on future climatic predictions suggesting increasing trends in the frequency and intensity of drought events in northern Patagonia, a gradual increase in the number of trees affected by "Mal del Ciprés" along the 21 st century is likely expected.

Keywords: Tree rings, Dendroecology, Mal del ciprés, discriminant analysis, $P D S I$ 


\section{Introduction}

Growth rates, a measure of tree vigor, reflect the integrated response of individuals to current and past environmental stresses (Kozlowski et al. 1991, Pedersen 1998). Stem growth has relatively low priority for resource allocation within trees, and consequently, is a good indicator of environmental stress (Waring and Pitman 1985). In consequence, interannual variations in ring widths provide an indirect record of temporal changes in tree stress (Pedersen, 1998). The integration of multiple stresses over time leads, in most cases, to a decline in growth, the onset of tree weakening, and a larger sensitivity to subsequent stress (Monserud 1976; Pedersen 1998). Manion's dieback model (1981) predicts that previous droughts or insect attacks lead to decline, which in turn make trees more susceptible to death from other environmental factors such as recurrent droughts.

The Austrocedrus chilensis (D. Don) Pic. Ser. et Bizarri mortality (sensu Filip and Rosso 1999), locally called "Mal del Ciprés", is characterized by progressive withering, yellowing of the crowns and the gradual defoliation of trees (Havrylenko et al. 1989; Filip and Rosso 1999). Trees of all size classes growing in forests with different structures are affected by "Mal del Ciprés" (Havrylenko et al. 1989; La Manna et al. 2006). Root rot and decay, and internal bark necrosis at the root, root collar and lower part of the stem, have also been observed in affected trees (Rajchenberg and Cwielong 1993; Greslebin et al. 2005).

The first massive mortality of $A$. chilensis stands were recorded in the year 1945 in the Nahuel Huapi National Park (Varsavsky et al. 1975). Presently, dispersed and aggregated mortality patterns are observed in most $A$. chilensis stands along its natural distribution in Argentina (Havrylenko et al. 1989; La Manna and Rajchenberg 2004). Although several etiological models have been proposed to explain this mortality, including biotic, abiotic or a combination of both factors, the causes of "Mal del Ciprés" are still today a topic of discussion (El Mujtar and Andenmatten 2007).

The first attempt to compare radial growth patterns from symptomatic and asymptomatic $A$. chilensis trees was conducted by Calí (1996) in an area of the Nahuel Huapi National Park, near Bariloche, Argentina. According to Calí (1996), the "Mal del Ciprés" was associated with a decrease in radial growth, that in most cases, started several years before external crown dieback were evident. Drought events in northern Patagonia influence the structure of A. chilensisNothofagus dombeyi forests by affecting tree demography (Villalba and Veblen 1997a, 1998; Suarez et al. 2004). Episodes of mortality of A. chilensis over the past c. 100 years were related to exceptionally dry spring-summer events during the 1910s, in 1943-44 and in the 1950s (Villalba and Veblen 1997a, 1997b, 1998; Villalba et al. 1998). Calí (1996) proposed warm and dry climatic conditions as triggers of the "Mal del Ciprés" mortality.

The main objectives of this study are (1) to compare the radial growth patterns between pairs of trees with and without external symptoms of "Mal del Ciprés", and (2) to determine the influences of extreme drought events in $A$. chilensis growth decline near El Bolsón, Patagonia, Argentina. 


\section{Study area}

Five pure Austrocedrus chilensis stands were sampled along a north-south

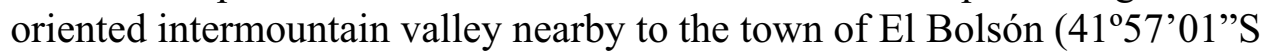
$71^{\circ} 31^{\prime} 54^{\prime \prime W}$ ), Río Negro province, Patagonia, Argentina (Fig. 1 and Table 1). The area has a mean annual temperature of $9.3^{\circ} \mathrm{C}$ and total annual precipitation of $904 \mathrm{~mm}$ concentrated in winter (Servicio Meteorológico Nacional 1981). Summers are characterized by high irradiance and extreme air dryness (Cordon et al. 1993). The Thornwaite's water balance indicates a surplus of winter precipitation $(445 \mathrm{~mm})$ and a deficit $(146 \mathrm{~mm})$ during the spring-summer growing season (Goya et al. 1995). Soils are Udivitrand type developed from Holocene volcanic ashes showing good effective depth and drainage (Buamscha et al. 1998).

The forest is dominated by pure, even age, and compact stands of $A$. chilensis (Dezzotti and Sancholuz 1991). Due to extensive fire events late in the 19th and beginning of the 20th centuries, individuals older than 100-120 years are rare (Willis 1914; Veblen et al. 1995).

\section{Field sampling and laboratory analysis}

In the summers of 2007 and 2008, 50 pairs of symptomatic and asymptomatic $A$. chilensis trees were cored. The sampling strategy corresponds to a matched-pair case-control study, which is widely used in epidemiology (Breslow and Day 1980; Woodward 1999; Bigler and Bugmann 2003). For each stand, 10 pairs of living trees were identified. For each pair, the selected individuals were similar in DBH $(>10 \mathrm{~cm})$, height, crown-class position, competition status, and microsite conditions. The average distance between pair of trees was lower than $15 \mathrm{~m}$. At least two cores were taken from each tree at c.a. 1.1 $\mathrm{m}$ height.

Twenty healthy, dominant trees from an A. chilensis stand in the northern part of the study area were cored for developing a reference chronology. Past events of "Mal del Ciprés" have not been documented for this stand (Chauchard and Barnaba 1986). All cores from the five stands were cross-dated against this reference chronology.

Cores were mounted, sanded and visually cross-dated following Stokes and Smiley (1968). Following the Schulman's (1956) convention for the Southern Hemisphere, annual rings are assigned to the year in which the ring formation starts. Ring widths were measured to the nearest $0.001 \mathrm{~mm}$, and the computer program COFECHA (Holmes 1983) was used to detect measurement and crossdating errors.

Two different standardization methods were used for developing the chronologies. The tree-ring series used to develop the chronology of reference were standardized using negative exponential functions. On the other hand, in the standardization of symptomatic and asymptomatic ring-width series, the observed data was adjusted to a horizontal line equal to the mean ring width of each series. This standardization method facilitates the detection of past disturbance events (such as insect outbreaks or fires), which are more difficult to identify when the individual series are standardized using polynomial or cubic spline functions 
(Veblen et al. 1991). The series standardization was conducted using the program ARSTAN (Cook 1985).

Standardized tree-ring series from symptomatic and asymptomatic trees were firstly averaged into individual mean series, then into symptomatic and asymptomatic local chronologies for each site, and finally in symptomatic and asymptomatic regional chronologies. In order to reduce the interannual variability in the tree-ring series, the local and regional chronologies from symptomatic and asymptomatic trees were filtered using a five-year running mean.

\section{Statistical analysis}

The quality of the reference chronology was assessed on the basis of the following statistics: mean sensitivity (MS), the average correlation between all series (RBAR), the expressed population signal (EPS), and the first-order autocorrelation, a measure of the association between growth rings in two consecutive years.

The MS represents a measure of the interannual variability in tree rings (Fritts 1976), whereas the RBAR is a measure of the common variance between the single series in a chronology (Wigley et al. 1984). Running RBARs illustrate changes in the strength of common forcings of tree growth over time. The EPS measures how well the finite-sample chronology compares with a theoretical population chronology based on an infinite number of trees (Wigley et al. 1984). It varies from 0.0 to 1.0. The cutoff point for accepting EPS suggested by Wigley et al. (1984) is around 0.85. The RBAR and EPS values were computed using a 20 -year moving window with a 10 -year overlap.

Correlation functions (Blasing et al. 1984) were used to determine the influence of climatic factors in the growth of $A$. chilensis. Interannual variations in the reference chronology were compared with temperature and precipitation records from the Bariloche meteorological station (Servicio Meterológico Nacional: $41^{\circ} 09^{\prime} \mathrm{S}-71^{\circ} 09.6^{\prime} \mathrm{W}$ ) and with the Palmer Drought Severity Index from Dai et al. (2004). The Palmer Drought Severity Index (PDSI) takes into account precipitation, evapotranspiration and soil moisture conditions, all of which are determinants of hydrologic droughts. The PDSI is a standardized measure, ranging from about -10 (dry) to +10 (wet), of surface moisture conditions that allow comparisons across regions and time.

The correlation function is the series of correlation coefficients between the tree ring chronology and each of several sequential climatic variables. The statistical relationship between ring width and each monthly climatic variable is examined over the period common to the chronology and the instrumental climatic record. In this study, the relationships between ring width and monthly climate were examined for a sequence of 16 months starting with January of the previous growing season and ending with April of the year in which the ring was formed (i.e., at the end of the current growing season). Correlation functions between temperature, precipitation and the tree-ring chronology were determined for the interval 1915-2005. For the PDSI, the period of comparison with the chronology extended from 1901 to 2005.

A Discriminant Analysis (DA) was conducted on the interannual variations in radial growth to determine the correspondence between tree growth patterns and external manifestations of the "Mal del Ciprés". The DA is mainly used to assess the adequacy of classification, given the group memberships of the 
trees under study (Anderson 1957; McLachlan 1992). The mean series per tree were used as the variables for the DA classification.

Crossing-curve events were assigned to years when the running-means from the symptomatic and asymptomatic growth indexes intercept, representing the onset of the period with persistent differences between groups. Student tpaired tests were performed between symptomatic and asymptomatic mean annual indexes, and the mean annual index differences calculated for each site.

Differences in the 10-year mean index before and after the crossing-curve events were analyzed using a two-way ANOVA test. Shapiro-Wilk tests were performed in order to evaluate the normality in the series. Significant differences between pairs of means in ANOVA were analyzed using the Tukey's HSD post test.

Running-t tests of 5-year contiguous intervals were conducted for regional chronology index differences. The recorded $t$ values were assigned to the last year of the first five-year group in the comparison. A Superposed Epoch Analysis (SEA) was performed in order to test the departures of PDSI during the 15 years with the most negative extreme values in the running-t tests. In all analyses, significant differences were considered for $\alpha=0.05$.

\section{Results}

\section{Reference chronology}

The tree-ring chronology of reference, with a mean ring width of 1.899 mm (SD: 0.365), covers the interval 1879-2006 (127 years; Fig. 2). The chronology statistics (MS $=0.160$, mean $\mathrm{RBAR}=0.429$, first-order autocorrelation $=0.602$ ) are within the ranges of $A$. chilensis tree-ring records in the region (Villalba and Veblen. 1997b). Stable EPS values exceed the cutoff value of 0.85 during the 20th century.

The correlation-function analysis over the interval 1915-2005 indicates that the radial growth of $A$. chilensis is positively associated with precipitation most of the year (Fig. 3). Statistically significant correlations between rainfall and tree growth are observed for April, May and June (autumn), and for November and December (spring) during the current growing season. In contrast to precipitation, tree growth is negatively related to temperature during growing seasons, being highly significant for November and December during the current growing season. Positive and significant relationships between the PDSI and radial growth occur for most months, except for August and September with positive, but not significant correlations (Fig. 3).

\section{Validation of tree classification}

Table 2 shows the classification, using discriminant analysis (DA), of the A. chilensis symptomatic and asymptomatic trees on the basis of their tree-ring width variations. A total of 89 mean individual series covering the interval 19402005 were included in the DA. Two asymptomatic trees from site 1 (13A and $37 \mathrm{~A}$ ) were incorrectly predicted as symptomatics. In contrast, $100 \%$ of the symptomatic trees were correctly classified. The overall classification accuracy of 
the DA model is $97.7 \%$, indicating a high degree of success for the classification of symptomatic and asymptomatic $A$. chilensis trees (Table 2).

The most recent ring in five symptomatic trees does not match with the sampling date. For example, the last ring formed in a radius from tree $17 \mathrm{~S}$ was dated to 1997, whereas the other two radii from the same tree dated to 2006. All trees were alive at the coring time in March 2007.

\section{Growth patterns for symptomatic and asymptomatic trees}

The development of tree-ring chronologies from both symptomatic and asymptomatic trees in each stand allows the identification of the years in which the radial growth from these groups starts to diverge (Fig. 4). Four divergence events were clearly detected: 1932, 1943, 1944 and 1963. Although the curves crossed over in the year 1932 at site 1, differences in tree growth between symptomatic and asymptomatic trees started to be consistently negative since 1943. Divergences in tree growth between symptomatic and asymptomatic trees started in 1943 and 1944 at stands 2 and 3, respectively; whereas in sites 4 and 5 persistent differences were recorded since 1963.

Differences between the chronologies from symptomatic and asymptomatic trees show a consistent pattern of positive followed by negative values since the dates when the chronologies intercept. This observation indicates that symptomatic trees show larger tree growth than asymptomatic trees before chronologies intercept. The t-paired tests showed significant differences in tree growth between symptomatic and asymptomatic trees before and after the chronologies interception dates.

The interval with significant negative differences in radial growth between symptomatic and asymptomatic trees varied between sites. These intervals range between 4 and 49 years in length for sites 4 and 3, respectively (Fig. 4). For all sites, however, significant differences were recorded in the most recent period of the records. Differences in radial growth between symptomatic and asymptomatic trees increased, particularly, after 1999.

Two-way ANOVAs were used to statistically validate the differences in tree growth for 10-year periods before and after the curve intersection dates (Fig. 5). Decreases in radial growth were recorded for sites 1, 2 and 3, however, differences were statistically significant just for symptomatic trees. Chronologies from sites 4 and 5 show increases in the 10-year mean growth after the intersection dates. However, symptomatic trees in sites 4 and 5 showed smaller increases in radial growth than asymptomatic trees.

\section{Regional analysis}

Symptomatic and asymptomatic trees from all sampling sites were grouped into regional chronologies. The 5-year running means for the regional chronologies intersected in the year 1944 (Fig.6). Differences between the regional indices have been persistently negative since 1944 and significantly different since 1963. An increasing negative trend in the index differences has been recorded since 1999 .

The 15 most negative $t$ values, based on 5-year contiguous means, were identified in the regional differences between symptomatic and asymptomatic trees (Fig. 7). The most significant values are lagged 1 year from the extreme 
drought events identified in the October-March PDSI series. The years 1943, 1944 and 1963 are coincident with the intersection dates registered at the local stand level.

A superposed epoch analysis was conducted for the whole area to determine the temporal evolution of the October-March PDSI for years in which the running-t test of the regional index difference reached the most negative values $(1909,1910,1928,1929,1930,1940,1941,1942,1943,1944,1956,1963$, 1990, 1999 and 2000). The October-March PDSI record exhibits significantly negative (droughts) departures for 1 year before the occurrence of extreme negative regional differences between chronologies (Fig 8).

\section{Discussion and conclusion}

The reference chronology of $A$. chilensis provides a reliable context for dating tree-ring series from symptomatic and asymptomatic trees and for evaluating the climate-tree growth relationships. In this region, the radial growth of $A$. chilensis is favored by above-average precipitation in late spring-early summer (November and December). Temperatures above the long-term mean during late spring-early summer increase evapotranspiration, reduce water supply, and diminish tree growth. Our results are consistent with previous studies for several A. chilensis stands along its distribution in Argentina (Villalba and Veblen, 1997b). The positive relationship between radial growth and precipitation in the previous and current growing season indicates that the growth of $A$. chilensis is extremely dependent on water supply. This observation is consistent with positive relationships between radial growth and the PDSI (Fig. 3B).

The DA model results, based on the growth pattern of individual trees, show an excellent agreement between field classification and tree-growth patterns for symptomatic vs. asymptomatic trees. Thus, tree-ring patterns from A. chilensis can be used in advance to assess future changes in tree health considering that symptomatic trees show a persistent decline in radial growth many years before the external symptoms (chlorosis and defolitation) are evident.

Cores with the outer-most ring dates prior to the sampling year indicate partial cambial mortality in sectors of the stem. Rajchenberg and Cwielong (1993), Calí (1996) and Amoroso (2009) have also reported partial cambial mortality in declining A. chilensis. In some individuals, almost 40 years of difference between radii were recorded. Rajchenberg and Cwielong (1993) observed that the sectors in the trees showing partial cambial mortality were also affected by root and stem rots. However, according to these authors, partial cambial mortality was localized in the lower $0.6 \mathrm{~m}$ of the stem. Only 5 from the 100 sampled trees in our study showed partial cambial mortality. However, as we sampled on average at $1.1 \mathrm{~m}$ height, many sectors with cambial mortality might have had missed.

Symptomatic and asymptomatic chronologies at local and regional scales show significantly differences in tree-growth patterns. Crossing-curve points, providing the dates when radial growth from symptomatic trees starts to be consistently lower than in asymptomatic trees, were identified in all sites and at regional level. However, the intersection dates vary between sites (Fig. 4). Crossing points in sites 2 and 3 occurred in 1944 and 1943, respectively, in response to extreme droughts in 1942 and 1943. In response to extremely dry conditions, extensive fires were recorded in northern Patagonia during the year 
1943 (Tortorelli 1947; Kitzberger et al. 1997; Veblen et al. 1999). Although the symptomatic and asymptomatic chronologies for sites 4 and 5 did not showed a decreased in the 10-year mean increments before and after the crossing-curve points as it was recorded in other sites, tree growth was consistently lower in symptomatic than asymptomatic trees. The increases in the 10-year mean growth at these two sites after the crossing points in 1962 should be related to the onset, in 1963, of a long-term cool and wet period (Villalba and Veblen, 1997a; 1998). Although the symptomatic trees responded to these cool and wet climatic conditions, the increase in radial growth was smaller in symptomatic than asymptomatic trees in both sites 4 and 5. Differences in radial growth between symptomatic and asymptomatic have increased in recent years. Indeed, the running- $t$ tests comparing the regional index differences reach the highest values since 1999.

Local and regional chronologies show larger radial growths of symptomatic than asymptomatic trees during early decades (before the crossingcurve points). We speculate that symptomatic individuals were more vigorous and had a denser crown during early stages of growth. In consequence, these trees were more affected by the extreme droughts due to their larger evapotranspiration leaf areas. Water stress associated with droughts affects tree vigor by inhibiting physiological processes such as photosynthesis, the movement of gases, the flow of latex and oleoresins, and the absorption of water and ions (Kozlowski 1982).

The fifteen most extreme negative values in the running-t test for the differences in regional chronology indexes are significantly related to negative anomalies in PDSI during the previous year. Based on PDSI (Dai et al. 2004), the number of severe droughts increased three times during the last 50 years in the record. Indeed, 10 severe droughts were recorded in the last 20 years in comparison with 6 in the previous 80 years. The mean drought interval for the period 1909-1983 was 12 years, but it dropped to 2 years during the most recent interval (1983-2003). In addition, the model simulations, recently released by IPCC in its Fourth Assessment Report, predict drier conditions along the southern Andes during the 21st century (Christensen et al. 2007). Continental climate simulations by Labraga (1998) also predict a decrease in summer precipitation (between 2 and $42 \%$ of present mean values) by 2070 for northwestern Patagonia. Taking in account these climate predictions and the sensitivity of $A$. chilensis to droughts, we expect that the number of $A$. chilensis stands affected by "Mal del Ciprés" increase in the next decades.

Acknowledgments. This research was supported by the Agencia Nacional de Promoción Científica y Tecnológica of Argentina (PICT 25518) and by a CONICET doctoral fellowship (National Council for Scientific and Technical Research of Argentina). We are grateful to Mariano S. Morales, María Laura Suarez, Alberto Ripalta and Andrés Manceñido for research assistance.

\section{References}

Amoroso MM (2009) Stand development patterns as a consequence of the decline in Austrocedrus chilensis forests. PhD Dissertation, University of British Columbia.

Anderson TW (1957) An introduction to multivariate statistical analysis. John Wiley and Sons, New York, USA.

Bigler C, Bugmann H (2003) Growth-dependent tree mortality models based on tree rings. Can J For Res 33:210-221

Blasing TJ, Solomon AM, Duvick DN (1984) Response Functions Revisited. Tree Ring Bull 44: $1-15$ 
Breslow NE, Day NE (1980) Statistical Methods in Cancer Research, Vol.1: The analysis of casecontrol studies. International Agency for Research on Cancer, Lyon Buamscha G, Gobbi M, Mazzarino MJ, Laos F (1998) Indicators of nitrogen conservation in Austrocedrus chilensis forests along a moisture gradient in Argentina. For Ecol Manage 112: 253261

Calí SG (1996) Austrocedrus chilensis: estudio de los anillos de crecimiento y su relación con la dinámica del "Mal del Ciprés" en el Parque Nacional Nahuel Huapi, Argentina. Trabajo para optar al grado de Licenciado en Ciencias Biológicas. Universidad Nacional del Comahue. Bariloche Chauchard LM, Barnaba J (1986) Plan de Ordenación Forestal Cuartel Loma del Medio-Río Azul. Provincia de Río Negro. IFONA - Servicio Forestal Andino. Informe interno inédito Cook ER (1985) A time series analysis approach to tree-ring standardization. Ph.D. dissertation, University of Arizona, Tucson

Cordon V, Forquera JC, Gastiazoro J, Barros V, Schmidt I (1993) Estudio microclimático del área cordillerana del Sudoeste de la Pcia. de Río Negro. Cartas de precipitación. Facultad de Ciencias Agrarias, Cinco Saltos, Río Negro

451 Christensen JH, Hewitson B, Busuioc A, Chen A, Gao X, Held I, Jones R, Kolli RK, Kwon W-T, 452 Laprise R, Magaña Rueda V, Mearns L, Menéndez CG, Räisänen J, Rinke A, Sarr A, Whetton P (2007) Regional Climate Projections. In: Climate Change 2007: The Physical Science Basis. Contribution of Working Group I to the Fourth Assessment Report of the Intergovernmental Panel on Climate Change. Solomon S, Qin D, Manning M, Chen Z, Marquis M, Averyt KB, Tignor M, Miller HL (eds.). Cambridge University Press, Cambridge, United Kingdom and New York, NY, USA. 847-940

Dai A, Trenberth KE, Qian T (2004) A global dataset of Palmer drought severity index for 18702002: Relationship with soil moisture and effects of surface warming. J Hydromet 5:1117- 1130 Dezzotti A, Sancholuz L (1991) Los bosques de Austrocedrus chilensis en Argentina: ubicación, estructura y crecimiento. Bosques 12:43-47

El Mujtar VA, Andenmatten, E (2007) "Mal del ciprés": búsqueda de la causa más probable de daño mediante un análisis deductivo y comparativo. Bosque 28: 3-9

Filip GM, Rosso PH (1999) Cypress mortality (mal del ciprés) in the Patagonian Andes: comparison with similar forest diseases and declines in North America. Eur J Forest Pathol 29:8996

Fritts HC (1976) Tree rings and climate. Academic Press, New York, USA.

Goya JF, Ferrando JJ, Bocos D, Yapura P (1995) Estructura y desarrollo de un rodal coetáneo de Austrocedrus chilensis en El Bolsón, Río Negro, Argentina. Rev Fac Agron. La Plata 71:165-171 Greslebin AG, Hansen EM, Winton LM, Rajchenberg M (2005) Phytophthora species from declining Austrocedrus chilensis forests in Patagonia, Argentina. Mycologia 97: 218-228.

Havrylenko M, Rosso PH, Fontenla SB (1989) Austrocedrus chilensis: contribución al estudio de su mortalidad en Argentina. Bosque 10:29-36

Holmes R (1983) Computer-assisted quality control in tree-ring dating and measurement. TreeRing Bull 43:69-75

Kitzberger T, Veblen TT, Villalba R (1997) Climatic influences on fire regimes along a rain forest-to-xeric woodland gradient in northern Patagonia, Argentina. J Biogeog 24:35-47

Kozlowski TT (1982) Water supply and tree growth: part I water deficits. For. Abs. 43: 57-95

Kozlowski TT, Kramer PJ, Pallardy SG (1991) The physiological ecology of woody plants.

Academic Press, San Diego, California, USA.

La Manna L, Bava J, Collantes M, Rajchenberg M (2006) Características estructurales de los bosques de Austrocedrus chilensis afectados por "mal del ciprés" en Patagonia, Argentina. Bosque 27:135-145

La Manna L, Rajchenberg M (2004) The decline of Austrocedrus chilensis forests in Patagonia, Argentina: soil features as predisposing factors. For Ecol Manage 190:345-357

Labraga JC (1998) Escenario de Cambio Climático para la Argentina. Ciencia Hoy 8: 18-25

Manion PD (1981) Tree Disease Concepts. Prentice Hall, New Jersey, USA.

McLachlan GJ (1992) Discriminant analysis and statistical pattern recognition. John Wiley \& Sons, Inc., New York, USA

Monserud RA (1976) Simulation of forest tree mortality. For Sci 22: 438-444

Mooney CZ, Duval RD (1993) Bootstrapping: a nonparametric approach to statistical inference. Sage University Paper Series on Quantitative Applications in the Social Sciences, series no. 07095. Newbury Park, California, USA 
Rajchenberg M, Cwielong PP (1993) El Mal del Ciprés (Austrocedrus chilensis): su relación con las pudriciones radiculares y el sitio. Congreso Forestal Argentino y Latinoamericano. Paraná,

Servicio Meteorológico Nacional (1981) Estadísticas climatológicas 1971-1980. Serie B. N³5.

501 Servicio Meteorológico Nacional. Buenos Aires

502 Suarez M, Ghermandi L, Kitzberger T (2004) Factors predisposing episodic drought-induced tree mortality in Nothofagus-site, climatic sensitivity and growth trends. J Ecol 92:954-966. Schulman E (1956) Dendroclimatic Change in Semiarid America. University of Arizona Press, Tucson

Stokes MA, Smiley TL (1968) An Introduction to Tree-Ring Dating. University of Chicago Press, Chicago Tortorelli LA (1947) Los incendios de bosques en la Argentina. Ministerio de Agricultura de la Nación, Buenos Aires

Varsavsky E, Bettuci L, Rodríguez García D, Gómez C (1975) Observaciones preliminares sobre la mortalidad del ciprés (Austrocedrus chilensis) en los bosques patagónicos. Fundación Bariloche, publicación $\mathrm{N}^{\circ} 19$ Veblen TT, Burns BR, Kitzberger T, Lara A, Villalba R (1995) The Ecology of the Conifers of Southern America. In: Enright NJ, Hill RS (eds) Ecology of the Southern Conifers. Melbourne University Press, Melbourne, pp: 120-155.

\section{$537 \quad$ Legends of figures} Veblen TT, Hadley KS, Reid MS, Rebertus AJ (1991) Methods of detecting past spruce beetle outbreaks in Rocky Mountain subalpine forests. Can J For Res 21:242-254

Veblen TT, Kitzberger T, Villalba R, Donnegan, J (1999) Fire history in northern Patagonia: the roles of humans and climatic variation. Ecol Monog 69(1):47-67

Villalba R, Cook ER, Jacoby GC, D'Arrigo RD, Veblen TT, Jones PD (1998) Tree-ring based reconstruction of northern Patagonia precipitation since AD 1600. The Holocene 8: 659-674. Villalba R, Veblen TT (1997a) Regional patterns of tree population age structures in northern Patagonia: climatic and disturbance influences. J Ecol 85: 113-124.

Villalba R, Veblen TT (1997b) Spatial and temporal variation in Austrocedrus growth along the forest-steppe ecotone in northern Patagonia. Can J For Res 27:580-597

Villalba R, Veblen TT (1998) Influences of Large-Scale Climatic Variability on Episodic Tree Mortality in Northern Patagonia. Ecology 79(8):2624-2640.

Waring RH, Pitman GB (1985) Modifying lodgepole pine stands to change susceptibility to mountain pine beetle attack. Ecology 66:889-897.

Wigley TML, Briffa KR, Jones PD (1984) On the value of correlated time series, with applications in dendroclimatology and hydrometeorology. J Clim Appl Meteorol 23:201-213

Willis B (1914) El norte de la Patagonia, naturaleza y riquezas. Tomo I. Ministerios de Obras Públicas, Buenos Aires

Woodward M (1999) Epidemiology: study design and data analysis. Chapman and Hall/CRC, Boca Ratón, Florida

Fig. 1 Location of the sampling sites (triangles) along the El Bolsón inter-mountain valley. The interstate boundary between Río Negro and Chubut is indicated. Contour interval between isolines is $100 \mathrm{~m}$

Fig. 2 Reference chronology of Austrocedrus chilensis. Tree-ring indices (A) and sample size (B) are shown for the interval 1879-2006. The Expressed Population Signal (EPS, C) and the running mean correlations between series (RBAR, D) were estimated over 20-year windows with 10-year overlaps (with standard error bars). The cutoff point for accepting EPS is 0.85 (dashed line).

Fig. 3 Correlation functions for the reference chronology of Austrocedrus chilensis. (A) Correlation coefficients between ring-width indices and monthly temperature and precipitation from Bariloche during the interval 1915-2005. (B) Correlation coefficients between ring-width indices and monthly PDSI for the interval 1901-2005. In both graphs, the shaded areas represent the current growing season (October-April) and the dashed lines the $95 \%$ confidence limits. 
Fig. 4 Symptomatic (grey) and asymptomatic (black) tree-ring chronologies for each stand (left) and their corresponding index differences (right). To emphasize the long-term oscillations in the records, the chronologies are shown as 5-year running mean curves. Arrows indicate the intersection dates for the 5-years running mean curves. On the right plots, segments capped with asterisk correspond to intervals with index differences statistically different $(p<0.05)$ from the long-term mean based on $t$-paired tests. The sample depth of each chronology is also shown at the bottom of each pair of chronologies. Sites are indicated on the upper-right corner of each plot.

Fig. 5 Mean 10-year radial increments before and after the intersection dates for the asymptomatic (black bars) and symptomatic (grey bars) chronologies for each sampling site. Site codes and intersection dates are indicated in the upper-right corner of each plot. Means with the same letter are not significantly different at $\mathrm{p}<0.05$ based on ANOVA and Tukey's HSD post tests.

Fig. 6 Regional tree-ring chronologies from symptomatic (grey) and asymptomatic (black) trees (A). To emphasize the long-term oscillations in the records, the chronologies are also shown as 5year running mean curves. The intersection of the 5-years running mean curves is indicated by white arrows. Years with reduced growth related to drought events in both chronologies are indicated by small black arrows. The sample depth of each chronology is also shown at the bottom of (A). Regional index differences between chronologies (B). Segments capped with asterisk correspond to index differences statistically significant $(\mathrm{p}<0.05)$ from the long-term mean determined by $t$-paired tests.

Fig. 7 Running- $t$ values for the regional index difference (grey curve) and October-March PDSI (black curve) for the area according to Dai et al. (2004). Intersection dates from Fig. 4 are shown by triangles. Arrows at the bottom indicate the 15 most negative values in the $t$ values. The PDSI mean (black solid line), moderate drought (PDSI $<-1.0$; black dotted line), and severe drought (PDSI $<-1.5$; black dashed line) are also shown. Drought definitions follow Palmer (1965). The grey short dashed lines represent the $95 \%$ confidence limits of the $t$-paired tests

Fig. 8 October-March PDSI departures over the interval 1904 to 2003 for the 15 years with the most extreme negative running $t$-values from the differences between indexes in the symptomatic and asymptomatic regional chronologies. A 10-year time-window, starting six years prior and ending four year after the events was used for the SEA estimation. The October-March PDSI during one year prior to the events is statistically different $(\mathrm{p}<0.05)$ from the mean based on 1000 Monte Carlo simulations (Mooney and Duval 1993). Dashed lines represent the $95 \%$ confidence limits.

\section{Tables}

Table 1 Site characteristics of the Austrocedrus chilensis stands. (BA: basal area; HD: mean dominant height)

\begin{tabular}{cccccc}
\hline Stand & $\begin{array}{c}\text { Altitude } \\
(\mathrm{m} \text { a.s.1.) }\end{array}$ & Aspect & $\begin{array}{c}\text { Slope } \\
\left({ }^{\circ}\right)\end{array}$ & $\begin{array}{c}\text { BA } \\
\left(\mathrm{m}^{2} / \mathrm{ha}\right)\end{array}$ & $\begin{array}{c}\text { HD } \\
(\mathrm{m})\end{array}$ \\
\hline 1 & 491 & $\mathrm{~S}\left(159^{\circ}\right)$ & 2 & 25 & 25 \\
2 & 398 & $\mathrm{~W}\left(267^{\circ}\right)$ & 20 & 35 & 25 \\
3 & 311 & $\mathrm{~W}\left(266^{\circ}\right)$ & 9 & 31 & 26 \\
4 & 401 & $\mathrm{~W}\left(248^{\circ}\right)$ & 1 & 35 & 21 \\
5 & 467 & $\mathrm{E}\left(100^{\circ}\right)$ & 14 & 40 & 25 \\
\hline
\end{tabular}

595 Table 2 Classification of the Austrocedrus chilensis symptomatic and asymptomatic trees on the 


\begin{tabular}{cccc}
\hline Observed & \multicolumn{2}{c}{ Predicted } & Percentage \\
& Asymptomatic (A) & Symptomatic (S) & correct \\
\hline Asymptomatic (A) & 41 & 2 & 95.3 \\
Symptomatic (S) & 0 & 46 & 100 \\
\hline Total & 41 & 48 & 97.7 \\
\hline
\end{tabular}

597

598 Figures

$599 \quad$ Fig. 1

600

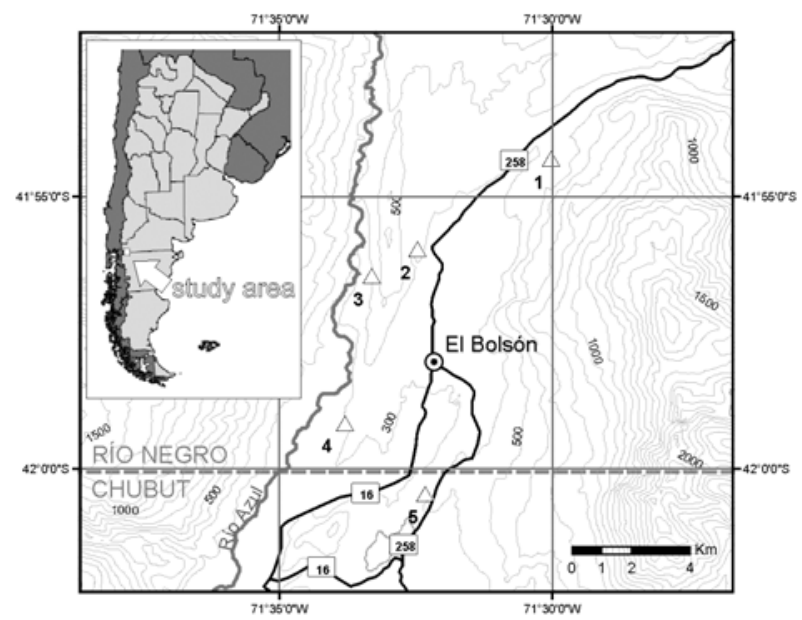

601

602

Fig. 2

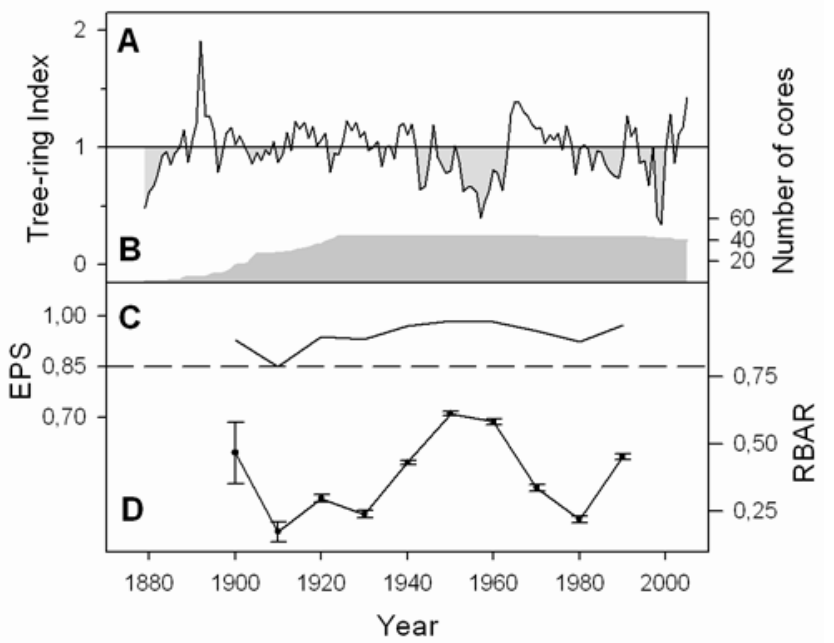

603

604

605

606

607

608

609

610

611

612 
$613 \quad$ Fig 3
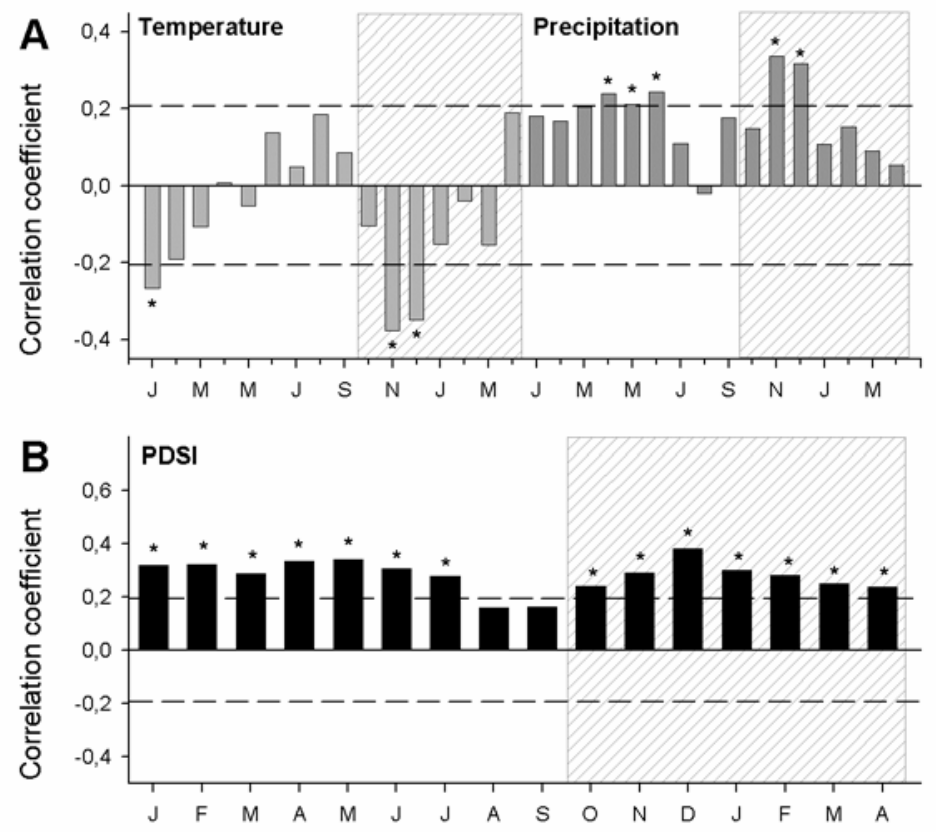

614

615

616

617

618

619

620

621

622

623

624

625

626

627

628

629

630

631

632

633

634

635

636

637

638

639

640

641

642

643

644 

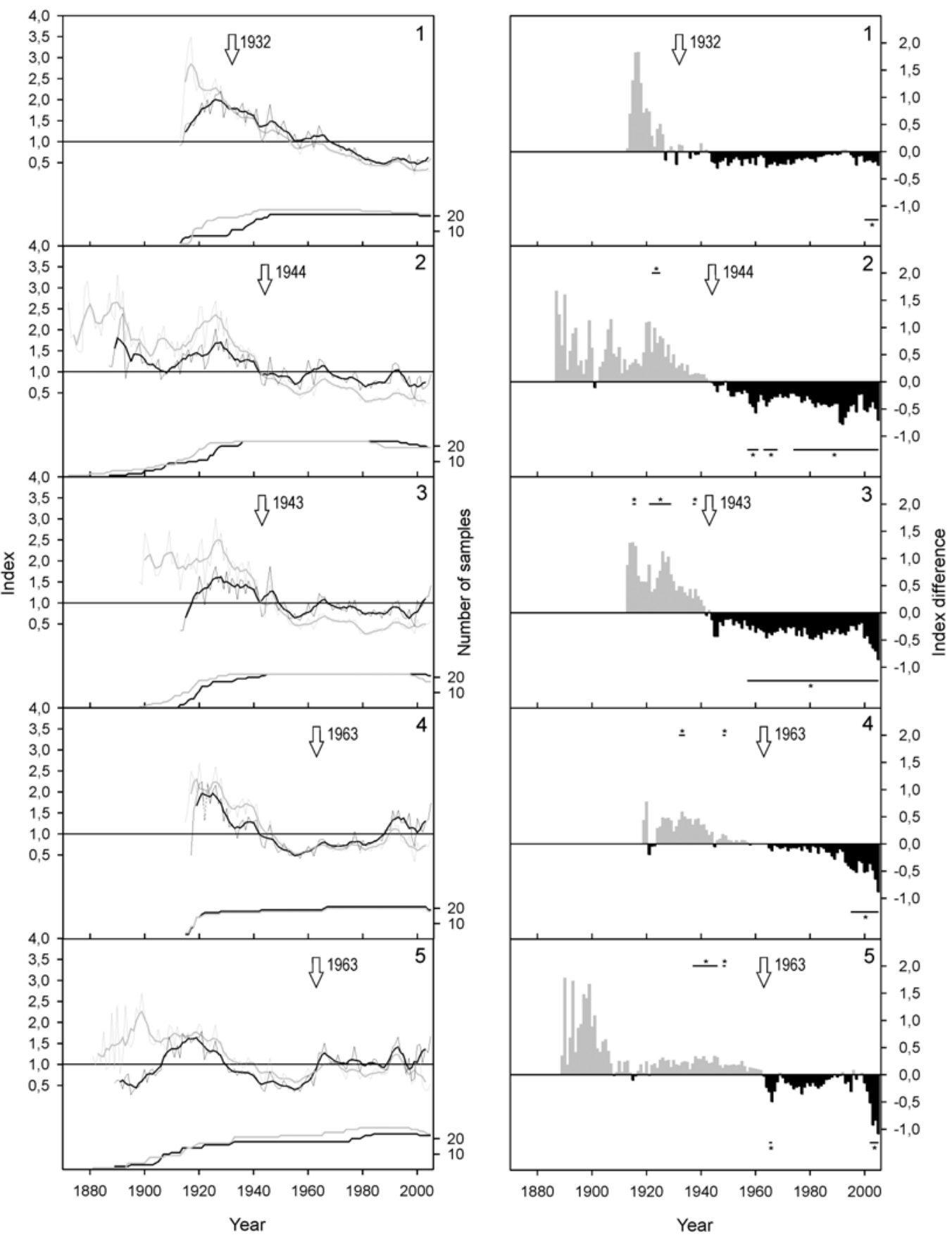

646

647

648

649

650

651

652

653

654

655

656

657

658

659 
Fig 5

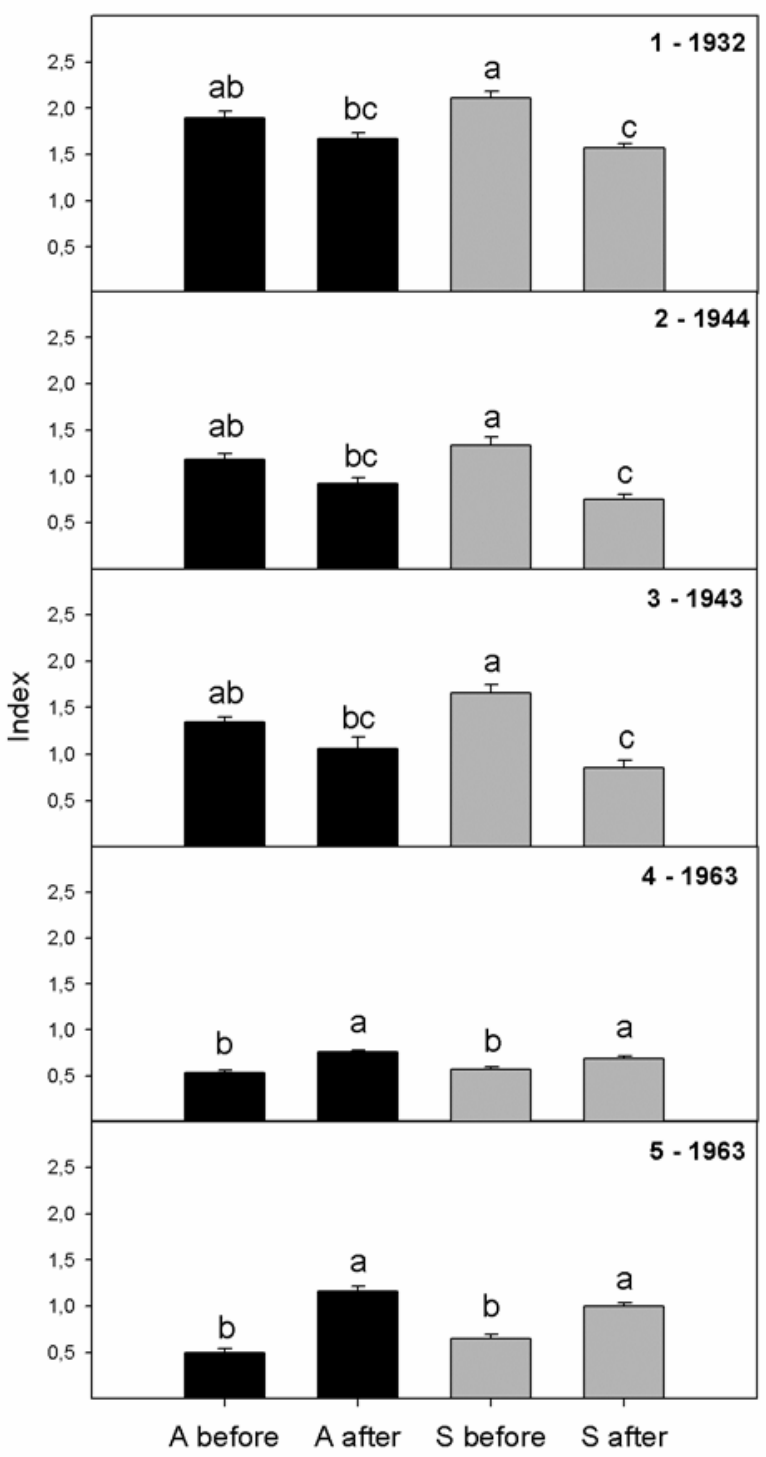

661

662

663

664

665

666

667

668

669

670

671

672

673

674

675

676

677

678

679 


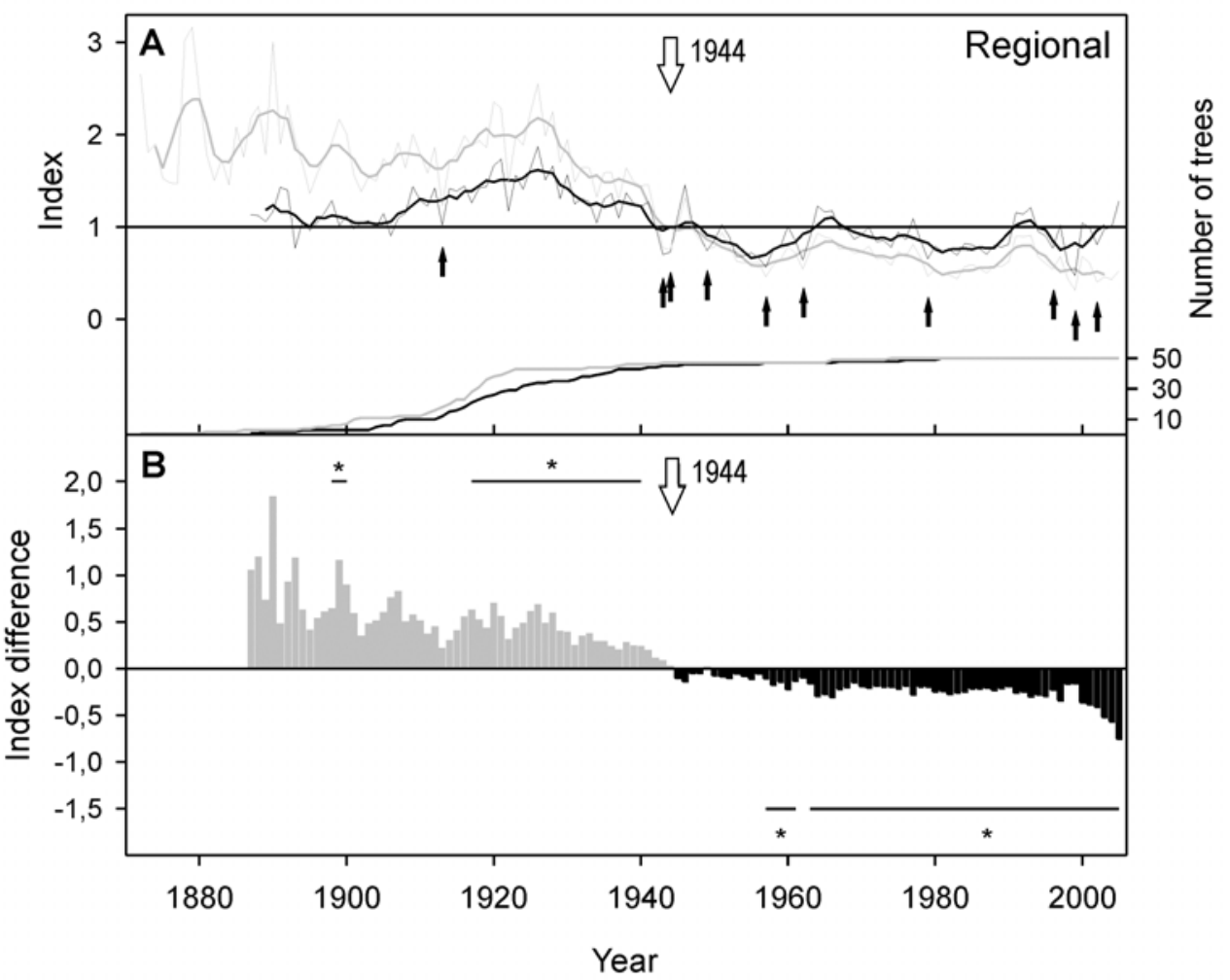

681

682

683

684

685

686

687

688

689

690

691

692

693

694

695

696

697

698

Fig 7

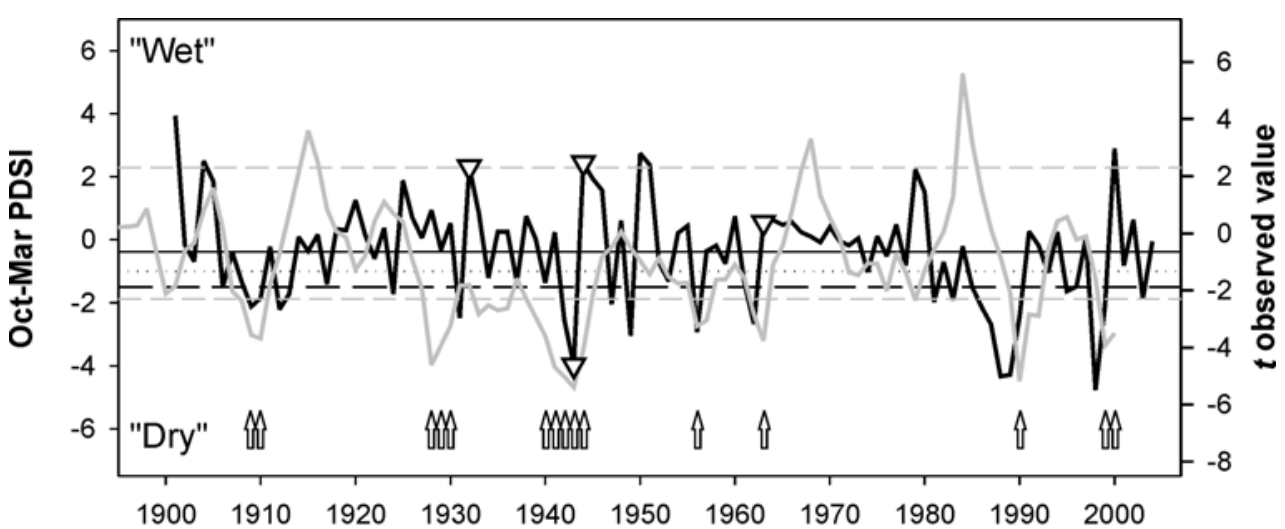

Year 
Fig 8

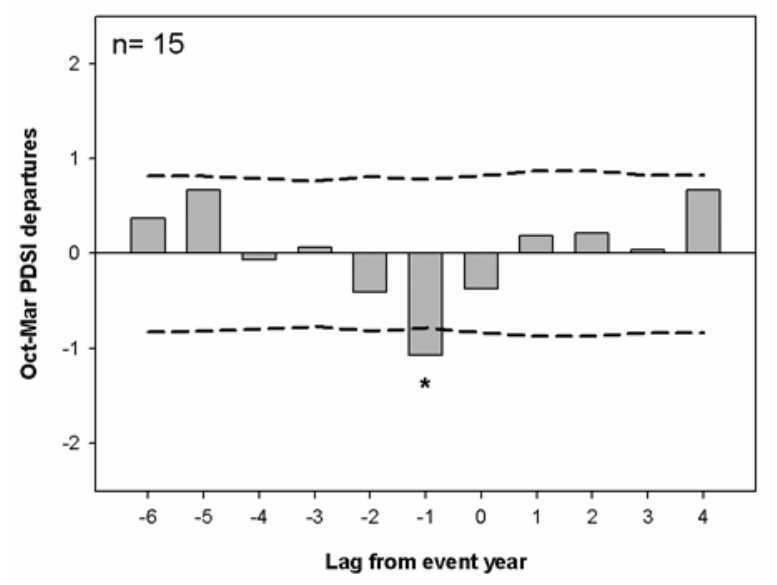

700 

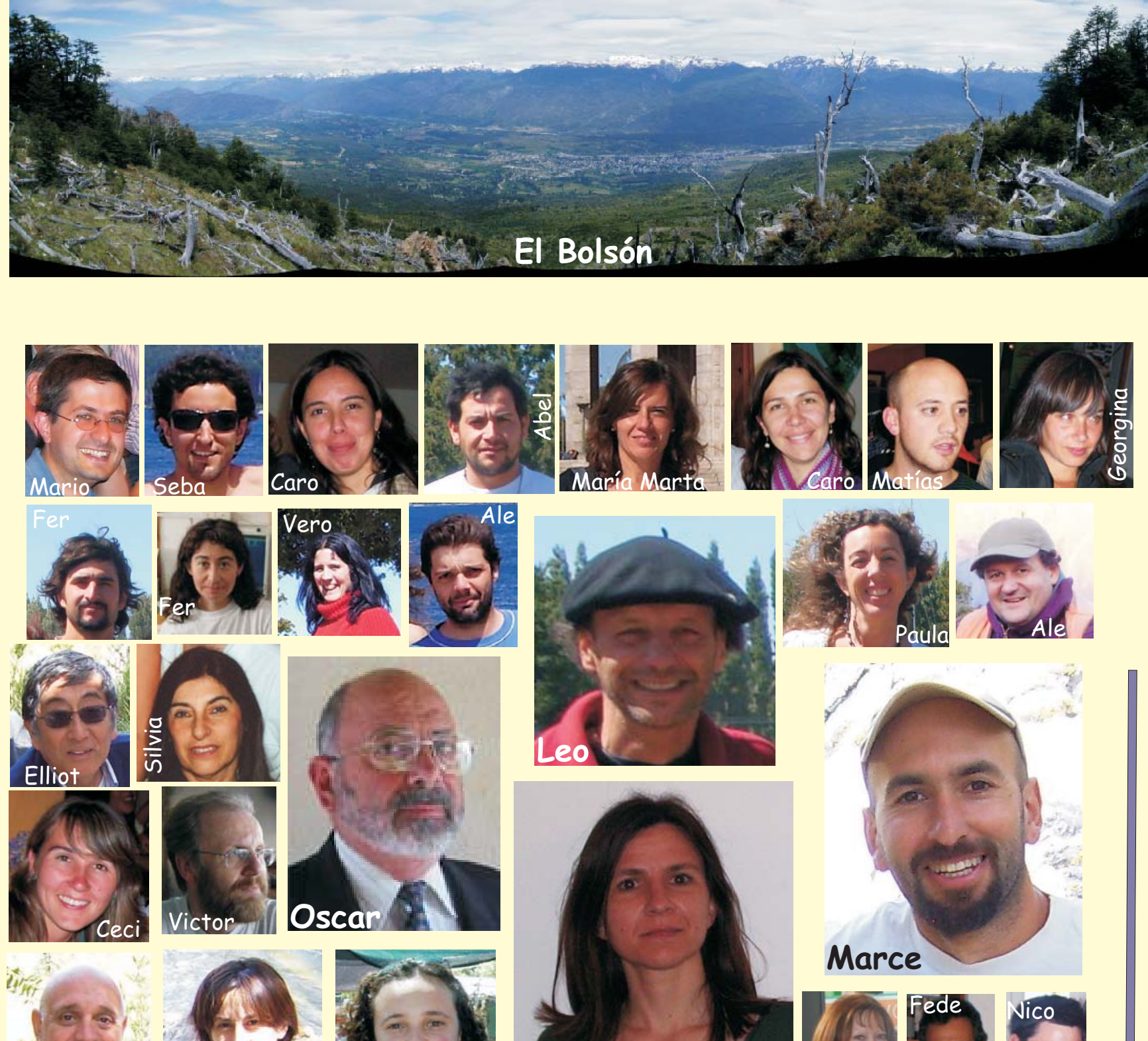

0 단

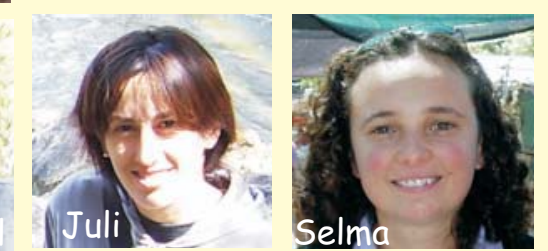

Miguel Angel IJulit Selma is
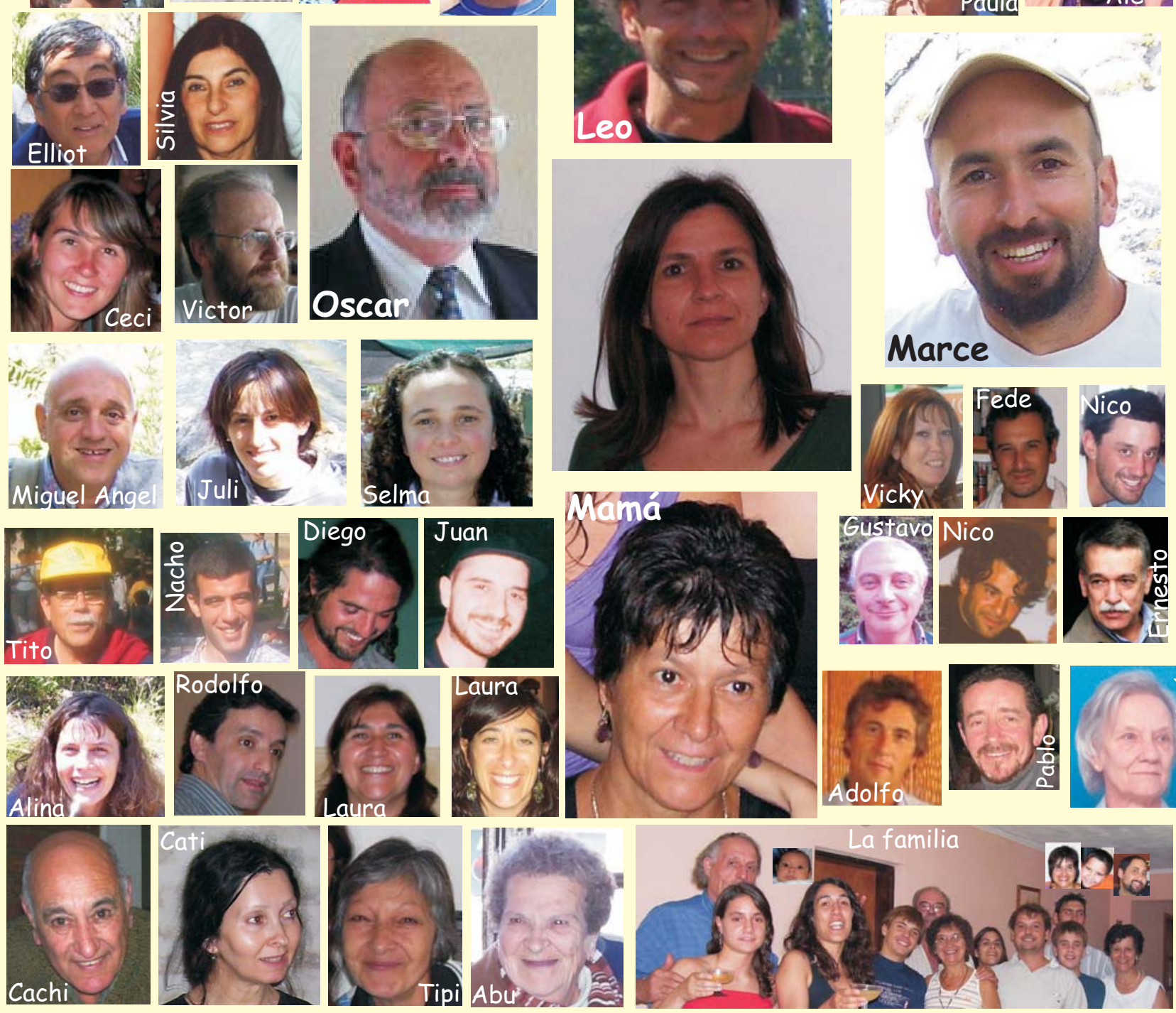
Gustavo Nico
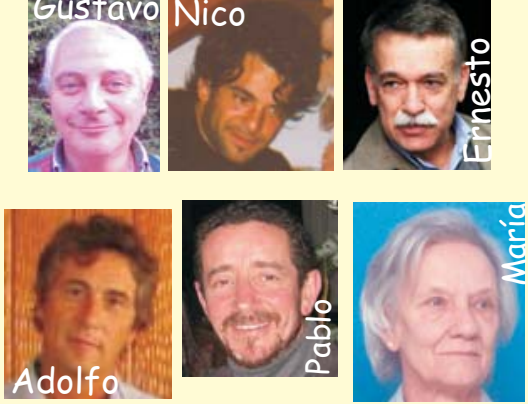